\title{
De buitengerechtelijke afdoening van strafbare feiten door het openbaar ministerie
}

Citation for published version (APA):

van den Biggelaar, G. J. M. (1994). De buitengerechtelijke afdoening van strafbare feiten door het openbaar ministerie. [Doctoral Thesis, Maastricht University]. Gouda Quint. https://doi.org/10.26481/dis.19941103gb

Document status and date:

Published: 01/01/1994

DOI:

10.26481/dis.19941103gb

Document Version:

Publisher's PDF, also known as Version of record

\section{Please check the document version of this publication:}

- A submitted manuscript is the version of the article upon submission and before peer-review. There can be important differences between the submitted version and the official published version of record.

People interested in the research are advised to contact the author for the final version of the publication, or visit the DOI to the publisher's website.

- The final author version and the galley proof are versions of the publication after peer review.

- The final published version features the final layout of the paper including the volume, issue and page numbers.

Link to publication

\footnotetext{
General rights rights.

- You may freely distribute the URL identifying the publication in the public portal. please follow below link for the End User Agreement:

www.umlib.nl/taverne-license

Take down policy

If you believe that this document breaches copyright please contact us at:

repository@maastrichtuniversity.nl

providing details and we will investigate your claim.
}

Copyright and moral rights for the publications made accessible in the public portal are retained by the authors and/or other copyright owners and it is a condition of accessing publications that users recognise and abide by the legal requirements associated with these

- Users may download and print one copy of any publication from the public portal for the purpose of private study or research.

- You may not further distribute the material or use it for any profit-making activity or commercial gain

If the publication is distributed under the terms of Article $25 \mathrm{fa}$ of the Dutch Copyright Act, indicated by the "Taverne" license above, 
De buitengerechtelijke afdoening van strafbare feiten door het openbaar ministerie 
. 


\section{De buitengerechtelijke afdoening van strafbare feiten door het openbaar ministerie}

\section{PROEFSCHRIFT}

ter verkrijging van de graad van doctor

aan de Rijksuniversiteit Limburg te Maastricht, op gezag van de Rector Magnificus, Prof.dr. H. Philipsen, volgens het besluit van het College van Dekanen, in het openbaar te verdedigingen op donderdag 3 november 1994 om 16.00 uur

door

Gabriëlle Johanna Maria van den Biggelaar

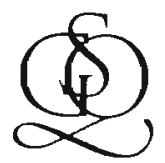

Gouda Quint bv

(S. Gouda Quint - D. Brouwer en Zoon)

Arnhem 
Promotoren:

Prof.mr. G.P.M.F. Mols

Prof.mr. A.Q.C. Tak

Beoordelingscommissie:

Prof.mr. Th.A. de Roos (voorzitter)

Prof.mr. M.S. Groenhuijsen (Katholieke Universiteit Brabant)

Prof.mr. F.A.M. Stroink 


\section{Voorwoord}

Wat heeft de kerk van Wouw, een plattelandsgemeente in West-Brabant met het schrijven van dit proefschrift te maken?

Een zeefdruk ervan hangt thuis boven mijn bureau waarachter ik vele uren heb doorgebracht. De kerkklok (het is 9.35 uur) was richtpunt wanneer ik, achteroverleunend, in gepeins of gedachten was verzonken.

De omstandigheden waaronder dit proefschrift is geschreven, zijn in de loop der jaren gewijzigd. Ik begon, pas afgestudeerd, als wetenschappelijk assistent bij de vakgroep Strafrecht en Criminologie van de Rijksuniversiteit Limburg. Deze wetenschappelijke omgeving werd na vijf jaar, toen ons eerste kind zich aankondigde, ingewisseld voor de studeerkamer thuis.

De combinatie van de verzorging van de kinderen en het schrijven van dit proefschrift leidde voor mij tot een gezonde relativering van beide. Het ontbreken van een wetenschappelijke omgeving moest wel zoveel mogelijk worden opgevangen.

Hoewel ik zelf uiteraard het meeste werk heb verricht, besef ik dat het schrijven van dit proefschrift niet mogelijk was geweest zonder de hulp en steun van velen. Enkelen wil ik speciaal noemen en bedanken.

Allereerst mijn promotoren, Prof.mr G.P.M.F. Mols en Prof.mr A.Q.C. Tak. Gerard Mols droeg ertoe bij dat het onderzoek, na een wat moeizame start, toch op de rails kwam. Met zijn kritische opmerkingen zaaide hij soms verwarring, met zijn praktische kijk zorgde hij voor verheldering. Het is mede de verdienste van Twan Tak dat mijn kennis van het bestuursrecht is uitgebreid en verdiept. Uit de inhoudelijke gesprekken die wij voerden putte ik inspiratie en zelfvertrouwen. Ik zal er met plezier aan terug. denken.

Het schrijven van een proefschrift op afstand van de universiteit schept speciale problemen, zoals de verwerving van actuele literatuur en tijdschriftartikelen. Op Jan Klifman kon ik altijd een beroep doen wanneer ik dringend iets nodig had. Bij hem en vele anderen kon ik terecht om te eten of te overnachten als de afstand tussen Maastricht en Eindhoven te groot was. Bedankt hiervoor!

Toen de tekst van dit boek vastlag werd het tijd aandacht te schenken aan de lay-out. Dankzij de grote vakkennis en dito inzet van Josta Mommertz en Margot de Boer, 
secretaresses van de vakgroep Strafrecht en Criminologie, ligt het boek in deze vorm voor de lezer. Daarvoor ben ik hen dank verschuldigd. Dit geldt ook voor Wies Rayar die de vertaling van de samenvatting heeft verzorgd.

Veel dank komt toe aan degenen die zorgden voor de opvang van de kinderen en de continuïteit van het huishouden als dat nodig was: mijn ouders, mijn schoonouders, Jeanne en Kitty. Het was fijn van jullie diensten gebruik te kunnen maken, al weet ik vrijwel zeker dat het genoegen wederzijds was.

Ik ben me ervan bewust dat het schrijven van dit boek niet mogelijk was geweest zonder een gezonde thuisbasis. Hiervoor zorgden mijn drie mannen: Erik, Hidde en Tijmen. Hidde en Tijmen droegen ertoe bij dat ik ontspannen kon werken. Door hun vrolijke en vaak ontwapenende gedrag had ik geen tijd om me onnodig druk te maken. Erik was de grote stimulator. Hij haalde mij na de geboorte van de kinderen van mijn roze wolk met de mededeling dat het zwangerschapsverlof voorbij was. Hij zorgde er samen met mij voor dat de omstandigheden waaronder ik werkte optimaal waren. Hij steunde en hielp mij als dat nodig was. Mede door hem is dit boek voltooid. Daarom draag ik het aan hem op.

Met het afronden van dit boek is een periode afgesloten. Het is tijd voor een nieuwe uitdaging.

En de kerk van Wouw? Die zal ik missen!

Gaby van den Biggelaar

Eindhoven 19 juli 1994 


\section{Inhoudsopgave}

Lijst van gebruikte afkortingen

XVII

Hoofdstuk $1 \quad$ Inleiding en probleemstelling 1

Rolverdeling in het strafproces

1

$2 \quad$ Normering van de afdoening buiten het geding

door het OM

4

3

Probleemstelling

Plan van aanpak

Historische ontwikkeling van het vervolgingsrecht van het $\mathrm{OM}$

Onvoorwaardelijk sepot

Wettelijke regeling

3.2.2 Negatieve en positieve uitleg van het opportuniteitsbeginsel

3.2.3.1 Termijn voor de vervolgingsbeslissing na het opsporingsonderzoek

3.2.3.2 Termijn voor de vervolgingsheslissing tijdens en na het gerechtelijk vooronderzoek

3.2.3.3 Termijn voor de vervolgingsbeslissing na voorlopige hechtenis 
$4.4 \quad$ Verhouding tussen $\mathrm{OM}$ en politie bij de toepassing van het politiesepot

Inleiding

Zestiende eeuw: submissie en compositie

De huidige wettelijke regeling, ingevoerd in 1983 
Wet inzake de uitbreiding van de politietransactie voor eenvoudige misdrijven

\section{Hoofdstuk 4 Administratiefrechtelijke handhaving van} verkeersvoorschriften

Ontwerp van de Commissie partiële herziening strafvordering en het Voorontwerp van wet tot herziening van wettelijke voorschriften betreffende de tenuitvoerlegging van vermogensstraffen en van voorwaarden ter voorkoming van strafvervolging

Wetenschappelijke discussie $\quad 111$

Voorontwerp $17.478 \quad 115$

Voorstellen van de Commissie Vereenvoudigde afdoening lichte overtredingen van verkeersvoorschriften (Commissie Mulder)

Commentaar bij het Rapport Mulder

Het Rapport Mulder en de internationaalrechtelijke bepalingen

Wet Administratiefrechtelijke afdoening van inbreuken op bepaalde verkeersovertredingen (Wet Administratiefrechtelijke handhaving verkeersvoorschriften) $\quad 136$ 
De WAHV en het EVRM, met name art. 6 lid 2

8.4.2 Jurisprudentie van de Hoge Raad en de Europese instanties

Ervaringen met de WAHV

Centraal Justitieel Incassobureau

Executie van de administratieve sanctie

De WAHV en de Algemene wet bestuursrecht

Criterium voor toedeling van gedragingen aan strafrecht of bestuursrecht 
Voordelen en bezwaren van het officiers- respectievelijk het rechtersmodel

Wet Aanvulling van het Wetboek van Strafrecht met de straf van onbetaalde arbeid

Inleiding en begripsbepaling

Rechtsgrond van de voeging ad informandum

De positie van het slachtoffer van het ad informandum gevoegde feit

Hoofdstuk 7 Openbaar ministerie: rechterlijke macht of bestuursorgaan?

Inleiding

Constitutioneel aspect

Inhoudelijke aspecten

Verschillende standpunten

Wet op de Zamenstelling der Regterlijke Magt en het Beleid der Justitie, 1827 Jaarvergadering Nederlandse Juristenvereniging, 1968, en de reacties daarop

Het politieke debat naar aanleiding van concrete gebeurtenissen

Voorbereiding grondwetswijziging 
3.1.11 Dissertatie Van de Bunt, 1984

3.1.12 Oratie De Doelder, $1988 \quad 245$

3.1.13 Rede minister van Justitie Korthals Altes, 1988

3.1.14 Jaarverslag OM $1988 \quad 247$

3.1.15 Voorjaarsvergadering NVvR 1991 en verdere discussie 248

3.2 Jurisprudentie Europese instanties 254

3.2.1 Beslissingen van Hof en Commissie 254

3.2.2 Toepassing van de in de Europese jurisprudentie ontwikkelde criteria op de Nederlandse officier van justitie bij de inverzekeringstelling 257

Commentaar

258

Algemene opmerkingen 258

$\begin{array}{lll}\text { 3.3.2 Beoordeling van enkele inhoudelijke argumenten } & 260\end{array}$

$\begin{array}{lll}\text { 3.3.2.1 Zelfstandigheid } & 260\end{array}$

3.3.2.2 Onafhankelijkheid 264

$\begin{array}{lll}3.3 .2 .3 & \text { Objectiviteit } & 267\end{array}$

3.3.2.4 Inhoud van de beslissing 268

$\begin{array}{lll}\text { 3.3.2.5 Recente ontwikkelingen } & 270\end{array}$

3.3.2.6 Conclusie op grond van inhoudelijke kenmerken 271

$4 \quad$ Administratiefrechtelijke bepalingen 271

4.1 Wet Beroep tegen Administratieve Beschikkingen 272

4.2 Wet Administratieve Rechtspraak Overheidsbeschikkingen 273

$\begin{array}{lll}4.3 & \text { Algemene wet bestuursrecht } & 274\end{array}$

$5 \quad$ Algehele conclusie 277

$\begin{array}{lll}\text { Hoofdstuk } 8 & \text { Karakter van de OM-beslissing } & 279\end{array}$

$\begin{array}{lll}1 & \text { Inleiding } & 279\end{array}$

$2 \quad$ Besluit en beschikking 279

3 Uitzonderingen 283

4 Toepassing op de OM-beslissing tot buitengerechtelijke afdoening

Hoofdstuk 9 Bestuursrechtelijke normen

Inleiding

Bestuursrechtelijke normen 
Verkeer tussen burgers en bestuursorganen

Zorgvuldigheidsbeginsel

Verbod van détournement de pouvoir

Verbod van willekeur

Motiveringsbeginsel

Andere -niet gecodificeerde- beginselen van behoorlijk bestuur

Rechtszekerheidsbeginsel

Vertrouwensbeginsel

Gelijkheidsbeginsel

De aanvraag en voorbereiding van de beschikking

Hoofdstuk 10 Vergelijking van de methoden tot buitengerechtelijke afdoening door het openbaar ministerie met bestuursrechtelijke normen

Verkeer tussen burgers en bestuursorganen 

van verkeersvoorschriften aan de Algemene wet bestuursrecht

Toedeling van gedragingen aan strafrecht of administratief recht

2.2.3 Gemeenschappelijke regeling transactie en voorwaardelijk sepot

2.2.3.2 Feiten die door middel van afdoening onder voorwaarden kunnen worden afgedaan 
Lijst van de geraadpleegde en verkort aangehaalde literatuur 


\section{Lijst van gebruikte afkortingen}

AA

aant.

$\mathrm{AB}$

ABAR

abbb

A-G

AIDP

Ambt. wet

AMvB

APK

ARBO

AR RVS

art.

artt.

a.w.

Awb

AWDA

AWR

BAS

BNB

$\mathrm{tB} / \mathrm{S}$

BW

$\mathrm{B} \& \mathrm{~W}$

CBB

CDWO

Cie.

CJIB

Compas

$\mathrm{CPN}$

c.q.
Ars Aequi

aantekening

Administratiefrechtelijke Beslissingen

Algemene bepalingen van administratief recht

algemene beginselen van behoorlijk bestuur

Advocaat-Generaal

Association Internationale de Droit Pénal

Ambtenarenwet 1929

Algemene Maatregel van Bestuur

Algemene politie keuring

Wet administratieve rechtspraak Bedrijfsorganisatie

Afdeling Rechtspraak Raad van State

artikel

artikelen

aangehaald werk

Algemene wet bestuursrecht

Algemene wet inzake de Douane en de Accijnzen

Algemene wet inzake Rijksbelastingen

Bekeuringen afhandeling systeem

Beslissingen in Belastingzaken, Nederlandse Belastingrechtspraak

J.B.J.M. ten Berge en F.A.M. Stroink, losbladige Arobjurisprudentie (Samson, Alphen aan den Rijn)

Burgerlijk Wetboek

Burgemeester en Wethouders

College van beroep voor het Bedrijfsleven

Centrale Directie Wetenschapsbeleid en Ontwikkeling commissie

Centraal Justitieel Incasso-Bureau

Communicatiesysteem openbaar ministerie - Parket administratie systeem

Communistische Partij van Nederland

casu quo 
CRvB

c.s.

D66

DD

d.d.

diss.

e.a.

\section{ECRM}

e.d.

EK

e.v.

EHRM

etc.

EVRM

F

FED

FIOD

Gem. st.

GW

Handelingen I

Handelingen II

HNJV

Hof

HR

i.c.

IVBP

jo.

JV

$\mathrm{KB}$

$\mathrm{Ktr}$

KVP

$\mathrm{LAB}$

$\mathrm{M}$ en $\mathrm{R}$

m.n.

m.nt.

MvA

MvT

NJ

NJB
Centrale Raad van Beroep

cum suis

Democraten 66

Delikt en Delinkwent

de dato

dissertatie

en andere(n)

Europese Commissie voor de rechten van de mens en dergelijke

Bijlagen Handelingen Eerste Kamer der Staten-Generaal en volgende(n)

Europees Hof voor de bescherming van de rechten van de mens

etcetera

Europees verdrag tot bescherming van de rechten van de mens en de fundamentele vrijheden

Faillissementswet

Fed's Fiscaal Weekblad

Fiscale Inlichtingen- en Opsporingsdienst

Gemeentestem

Grondwet

Handelingen der Eerste Kamer der Staten-Generaal

Handelingen der Tweede Kamer der Staten-Generaal

Handelingen der Nederlandse Juristen Vereniging

Gerechtshof

Hoge Raad der Nederlanden

in casu

Internationaal verdrag inzake burgerrechten en politieke rechten

juncto

Justitiële Verkenningen

Koninklijk Besluit

Kantonrechter

Katholieke Volkspartij

Leidraad administratieve boeten (1984)

Nederlands tijdschrift voor milieu en recht

met name

met noot

Memorie van Antwoord

Memorie van Toelichting

Nederlandse Jurisprudentie, uitspraken in burgerlijke en strafzaken

Nederlands Juristenblad 
NJCM

NJV

NO

$\mathrm{nr}(\mathrm{s})$.

NTB

NVvR

OM

o.a.

ORO

Owi

pag.

par.

P-G('s)

Publ. ECRM

PSP

PvdA

$\mathrm{Rb}$.

RDW

red.

$\mathrm{R}$ en $\mathrm{K}$

resp.

RM Themis

RO

r.o.

RvdW

Rv

RvS

RVV

SEW

SGP

Stb.

StPO

Stb.

Stcrt.

TAR

TBS

TK

Trema

TvdP

TvS

TwK

UCV

VAR
Nederlands Juristen Comité voor de Mensenrechten

Nederlandse Juristen Vereniging

Nationale Ombudsman

nummer(s)

Nederlands Tijdschrift voor bestuursrecht

Nederlandse Vereniging voor Rechtspraak

openbaar ministerie

onder andere

Oorspronkelijk regeringsontwerp

Ordnungswidrigkeit

pagina

paragraaf

Procureur(s)-Generaal

Publications of the European Court of Human Rights

Pacifistisch-Socialistische Partij

Partij van de Arbeid

rechtbank

Rijksdienst voor het Wegverkeer

redactie

Recht en Kritiek

respectievelijk

Rechtsgeleerd Magazijn Themis

Wet op de rechterlijke organisatie

rechtsoverweging

Rechtspraak van de Week

Wetboek van Burgerlijke Rechtsvordering

Raad van State

Reglement verkeersregels en verkeerstekens

Sociaal-economische wetgeving

Staatkundig Gereformeerde Partij

Staatsblad van het Koninkrijk der Nederlanden

Strafprozessordnung

Staatsblad

Staatscourant

Tijdschrift voor Ambtenarenrecht

terbeschikkingstelling

Bijlagen Handelingen Tweede Kamer der Staten-Generatal

Tijdschrift voor de rechterlijke macht

Tijdschrift voor de politie

Tijdschrift voor strafrecht

Tijdelijke wet Kroongeschillen

Uitgebreide Commissievergadering

Vereniging voor Administratief Recht 
VED

vgl.

VR

vs

VVD

(Vz.)AGRvS

(Vz.)ARRvS

W.

WAHV

WED

Wet $A B$

Wet AROB

Wet BAB

WFR

WMB

WMSr

WO

WODC

WVR

(Wv)Sr

(Wv)Sv

WVW

$\mathrm{zg}$.

ZGStW
Voorbereidingsgroep Experimenten Dienstverlening vergelijk

Verkeersrecht, juridisch maandblad betreffende het wegverkeer voorwaardelijk sepot

Volkspartij voor Vrijheid en Democratie

(Voorzitter van de) Afdeling geschillen van bestuur van de Raad van State

(Voorzitter van de) Afdeling rechtspraak van de Raad van State

Weekblad van het recht

Wet Administratiefrechtelijke handhaving van verkeersovertredingen

Wet op de economische delicten

Wet algemene bepalingen

Wet Administratieve Rechtspraak Overheidsbeschikkingen

Wet Beroep tegen Administratieve Beschikkingen

Weekblad voor fiscaal recht

Wet Motorrijtuigenbelasting

Wet militaire strafrechtspraak

wetsontwerp

Wetenschappelijk onderzoek- en

documentatiecentrum van het ministerie

van justitie

Wegenverkeersreglement

Wetboek van Strafrecht

Wetboek van Strafvordering

Wegenverkeerswet

zogenaamd(e)

Zeitschrift für die gesamte Strafrechtswissenschaft 


\section{Inleiding en probleemstelling}

\section{Rolverdeling in het strafproces}

Het Wetboek van Strafvordering van 1926 gaf iedere deelnemer aan het strafproces zijn eigen rol. Grof geschetst kwam dit neer op de volgende rolverdeling: de politie werd belast met de opsporing van strafbare feiten en kreeg daartoe bepaalde dwangmiddelen. Het Openbaar Ministerie (voortaan aangeduid als: OM) had de leiding over de opsporing. Aan het $\mathrm{OM}$ was de vervolging van het strafhaar feit opgedragen. Daartoe dagvaardde het de verdachte ter terechtzitting en vorderde daar een strat: De taak van berechting van de verdachte werd toebedeeld aan onafhankelijke rechters, die tijdens de rechtszitting van de meervoudige strafkamer, na de beoordeling van het bewijs, tot een uitspraak kwamen met (eventueel) een strafoplegging. Voor de uitvoering van de straf droeg het OM zorg.

Het strafrechtelijk onderzoek was verdeeld in twee fasen: het vooronderzoek en het eindonderzoek.

In het vooronderzoek had het belang van de waarheidsvinding prioriteit. De verdachte was voorwerp van onderzoek en had weinig rechten. Wel was er een belangrijke rol weggelegd voor de rechter-commissaris, als waarborg dat het onderzoek rekening hield zowel met het belang van de maatschappij als met het belang van de verdachte. De wetgever voelde er niets voor het gehele onderzoek in handen van het OM te leggen, vanwege de kans dat het daar niet zou blijven, maar in handen van de politie zou overgaan. ${ }^{1}$ Door de heerschappij van het legaliteitsbeginsel kwam in iedere strafzaak een rechter-commissaris, of een rechter ter zitting, te pas.

Het eindonderzoek, waarmee wordt bedoeld het onderzoek ter terechtzitting, had een ander karakter. De verdachte was procespartij tegenover het OM. In dit gedeelte van het onderzoek prevaleerde de waarborgfunctie en had de verdachte allerlei rechten.

De nadruk van het strafproces kwam te liggen op dit eindonderzoek. Samenvattend: Dit systeem van strafvordering gaat uit van een klassieke triasverdeling, waarbij de kern wordt gevormd door het geding voor de rechter. 
Hoewel deze taakverdeling tussen de procesdeelnemers op papier weliswaar nog bestaat, is de strafvorderlijke werkelijkheid veranderd. In dit kader is van belang dat door allerlei oorzaken het accent van het strafproces steeds meer verschoven is in de richting van het vooronderzoek. ${ }^{2}$

Eén van de aspecten die hiermee samenhangen is de gewijzigde rol van het $\mathrm{OM}$ in het strafproces, onder meer onder invloed van een andere opvatting over het opportuniteitsbeginsel. Hierop wordt in hoofdstuk 2 uitvoerig ingegaan. Het OM is geworden van een louter vervolgend orgaan tot een meer beleidvoerend orgaan. Op grond van het opportuniteitsbeginsel (van vervolging kan worden afgezien op gronden aan het algemeen belang ontleend) is het OM niet verplicht ieder opgespoord strafbitar feit te vervolgen, maar kan het een selectie maken. In de toepassing van dit opportuniteitsbeginsel heeft zich een verandering voorgedaan van "vervolgen, tenzij..." naar "nict vervolgen, tenzij... "Ongetwijfeld heeft de toegenomen werkdruk hierbij een rol gespeeld. In plaats dus van de situatie waarin in beginsel ieder strafbaar feit tot een vervolging leidde, kennen we nu de toestand dat een overgroot gedeelte niet wordt vervolgd, tenzij daar redenen toe zijn. Het $O M$ heeft meer zeggenschap gekregen over de vervolging en daarmee over de vraag of er een rechter bij de strafzaak betrokken wordt en de strafzaak überhaupt tot een eindonderzoek komt. ${ }^{3}$ Het is daardoor de spil van de strafvordering. Naast onderzoeker is het $O M$ nu ook beslisser geworden.

Deze ontwikkeling heeft ertoe geleid dat momenteel meer zaken niet din wel door de rechter binnen het strafgeding worden afgedaan. De klassieke manier van afduening van misdrijven door middel van een strafrechtelijk geding voor de meervoudige kamer van de rechtbank is uitzondering geworden." Voor overtredingen is berechting door de rechter uitzondering. Hierdoor is de kern van het Wetboek van Strafvordering, namelijk het geding, voor een groot aantal strafzaken verdrongen door de afdoening van het $\mathrm{OM}$ buiten het geding.

2 Zie hierover onder andere W.P.J. Pompe, Vooronderzoek of eindonderzoek beslissend? TuS 1959, pag. 141-151; tevens in: Vijf opstellen van Willem Pompe, pag. 14-32, Zwolle (zonder jaartal); G.P.M.F. Mols, Staande de zitting: een beschouwing over het onmiddellijkheidsbeginsel, oratic RL, Arnhem 1989; D.M.H.R. Gare, Het onmiddellijkheidsbeginsel in het Ncderlandse strafproces, diss. RL, Arnhem 1994.

3 Hierbij moet gewezen worden op het recht van iedere belanghebbende beklag te doen over niet of niet verdere vervolging door het openbaar ministerie (art. $12 \mathrm{~Sv}$ ).

4 Het Jaarverslag OM over 1992 geeft de volgende cijfers: van de door de rechtbanken te berechten misdrijven (ruim 87.000 ) werd ruim $8 \%$ door de meervoudige kamer en ruim $90 \%$ door de politierechter afgedaan.

Van het totaal aantal door de rechtbank en het $\mathrm{OM}$ afgedane misdrijven werd ca. $50 \%$ door het OM afgedaan: ruim $13 \%$ door technisch sepot, bijna $15 \%$ door beleidssepot en ruim $22 \%$ door transactie. Globale trend: minder sepots, meer transacties. Doelstelling voor 1995: een derde van vervolgbare zaken afdoen door transactic. Bron: Jaarverslag OM 1992, OM en politie, pag. 54-55. 
Bij deze afdoening buiten het geding bestaat de mogelijkheid dat wel wordt gesanctioneerd, namelijk door het OM. Onder 'sanctie' zou ik, in navolging van Duk, willen verstaan: een door het recht toegelaten reactie op onrechtmatig gedrag, die ertoe strekt de overtreder rechtstreeks in zijn belang te treffen. ${ }^{5}$ Voor de duidelijkheid: het begrip 'sanctie' is ruimer dan het strafrechtelijk begrip 'straf. Onder 'straf versta ik de sancties die in de verschillende strafwetten zijn opgenomen, als mogelijke reacties op een strafrechtelijk gedraging en op te leggen door een onafhankelijke strafrechter, zoals de straffen opgenomen in art. 9 e.v. Sr, de jeugdstraffen van art. $77 \mathrm{~g}$ e.v. $\mathrm{Sr}$, de straffen in de WED art. 6 e.v. en de strafbepalingen in bijzondere wetten en verordeningen, ${ }^{\circ}$ die door de rechter na een strafrechtelijk geding worden opgelegd.

Zoals ik hiervoor stelde wordt in een toenemend aantal gevallen een strafzaak zelfstandig door het $\mathrm{OM}$ of door de politie afgedaan.

Dit kan gebeuren door middel van een onvoorwaardelijk sepot, waarbij de verdachte verder geen gevolgen in de vorm van een sanctie ondervindt van het door hem gepleegde strafbaar feit.

Het OM kan zich daarnaast ook bedienen van methoden van afdoening wararbij wel een sanctie, als een reactie op het plegen van een strafbaar feit, opgelegd wordt. Hierbij kan worden gedacht aan een voorwaardelijk sepot, een transactie, een berisping of (voorheen) een alternatieve sanctie in de vorm van het officiersmodel.? Een afdoeningsmethode die tussen sepot en vervolging ligt is de voeging ad informandum. $^{8}$

Als verzamelterm voor alle door het $\mathrm{OM}$ gehanteerde afdoeningsmodaliteiten gebruik ik: de buitengerechtelijke afdoening van strafbare feiten door het $\mathrm{OM}$.

Deze ontwikkeling houdt in dat relatief minder strafzaken door een rechter behlindeld worden en dat er meer door het OM worden afgedaan. We mogen verwachten dat er in de toekomst, onder andere door een groei van het aantal dalarvoor in aanmerking komende strafbare feiten, gerelateerd aan een verdere beperking van budgettaire mogelijkheden, een toenemend gebruik zal zijn waar te nemen van de bevoegdheid van het $\mathrm{OM}$ om strafzaken buitengerechtelijk af te doen, bij voorkeur met oplegging

5 W. Duk, Handhaving van bestuursrecht, NTB 1988/4, pag. 105-110.

6 Zie voor verdere beschrijving onder meer; L.J.J. Rogier, Strafsancties, administraticve sancties en het una via-beginsel, diss. EUR Arnhem 1992, Hoofdstuk 4, pag. 43-71.

7 Het verschil tussen het officiersmodel en het rechtersmodel wordt uitgelegd in hoofdstuk 5.

8 Door het opportuniteitsbeginsel is het $\mathrm{OM}$ bijvoorbeeld ook in staat om een minder zwaar delict ten laste te leggen, of om een verdachte te dagvaarden voor de politierechter in plaats van voor de meervoudige kamer. Omdat het hier echter niet 'afdoening buiten het geding' betreft, wordt hierop nu niet verder ingegaan.

9 Hiermee wordt de afdoening van een strafbaar feit door middel van dading tussen verdachte en benadeelde van dit onderzoek uitgesloten. Zie hierover: P. Ingelse, Dading in plaats van strafrecht, NJB 1991, pag. 963-967. 
van een sanctie. Ook de invoering van de politietransactie ten aanzien van eenvoudige misdrijven (zie paragraaf 3.6) en de uitbreiding van de administratieve handhaving van overtredingen (zie Hoofdstuk 4) zullen aan deze ontwikkeling bijdragen.

Een aanzet daarvoor werd gegeven in het Beleidsplan Samenleving en Criminaliteit. ${ }^{10}$ Uitgangspunt was dat het aantal onvoorwaardelijke beleidssepots (beslissing om van vervolging af te zien op grond van beleidsmatige overwegingen ${ }^{11}$ ), zou worden teruggedrongen ten gunste van de transactie en het voorwaardelijk sepot. Uit de daaropvolgende jaarverslagen van het $\mathrm{OM}$ blijkt dat dit streven is gerealiseerd en het aantal transacties is toegenomen ten koste van het sepot. ${ }^{12}{ }^{13}$ Het Beleidsplan Strafrecht met beleid wil deze lijn doorzetten. Als beleidsuitgangspunt geldt dat een transactievoorstel nog vaker kan worden gedaan, indien de officier van justitie een boete acceptabel acht. ${ }^{14}$ Het Jaarverslag OM 1992 spreekt over het streven in 1995 een derde van de vervolgbare zaken door transactie af te doen.

\section{Normering van de afdoening buiten het geding door het $\mathrm{OM}$}

Veelal is deze afdoening en/of sanctionering door het OM niet of onvoldoende genormeerd. Zoals we hierboven constateerden is de rechtsbescherming bij sanctionering binnen het geding uitgebreid geregeld, terwijl de zaken die tot zo een geding leiden, getalsmatig, een minderheid vormen. Doordat het OM een grote mate van beslissingsbevoegdheid heeft verworven, wordt de behoefte aan rechtsbescherming in deze fase groter. Deze noodzaak wordt nog groter indien men bedenkt dat een rechter, evenals dit in het bestuursrecht het geval is, terughoudend zal zijn in het toetsen van het beleid van het OM. Het doel van deze studie is te komen tot een verbetering van de normering van de afdoening van strafzaken buiten het geding door het OM.

Op deze plaats wil ik met nadruk stellen dat aan de buitengerechtelijke afdoening van strafbare feiten door het $\mathrm{OM}$ niet slechts nadelen verbonden zijn en dat daarop alleen maar kritiek mogelijk zou zijn. Natuurlijk heeft een dergelijke afdoening ook voordelen vergeleken met de afdoening binnen het geding. Zo is het $\mathrm{OM}$ bij de keuze uit een aantal verschillende modaliteiten redelijk flexibel. Het heeft niet slechts de keuze uit wel of niet vervolgen, maar het staat een breed scala van mogelijkheden

10 Beleidsplan Samenleving en Criminaliteit, Tweede Kamer 1984-1985, 18995, 1-2.

11 Zie daarover uitgebreider Hoofdstuk 2, par. 1.

12 Jaarverslagen OM 1986, pag. 63; 1987, pag. 66; 1988, pag. 57; 1989, pag. 121.

13 Ik publiceerde daarover eerder: Justitie miskent uitgangspunten transacticbuvoegdheid, NJB 1)90, pag. 1281-1282. Zie verder onder meer N.F. van Manen, Automatisering binnen het openbaar ministerie, JV 1992, nr. 5, met name pag. 44-45.

14 Beleidsplan Strafrecht met beleid, beleidsplan openbaar ministerie 1990-1995, OM 1990, met name pag. 46-47. 
ter beschikking. Het is mogelijk de strafrechtelijke reactie meer toe te spitsen op de persoon van de verdachte. Dit is vanzelfsprekend ook in veel gevallen in het voordeel van de verdachte. Daarnaast volgt er door de mogelijkheid van buitengerechtelijke afdoening (met sanctie) doorgaans een snellere reactie na het begaan van het delict, hetgeen op zijn beurt van positieve invloed kan zijn op het algemeen niveau van rechtshandhaving.

Tegen de beschreven modaliteiten is echter ook een aantal bezwaren aan te voeren. Deze worden hier puntsgewijs gememoreerd. Bij de betreffende hoofdstukken zullen zij uitgebreider aan de orde komen.

- Onoverzichtelijkheid, doordat verschillende modaliteiten op verschillende plaatsen in de wet zijn geregeld;

- voor een aantal modaliteiten geldt dat de rechtsgevolgen niet goed geregeld zijn, hetgeen van nadelige invloed is op de rechtszekerheid;

- voor een aantal afdoeningsmodaliteiten bestaat er geen of slechts een gebrekkige wettelijke regeling;

- een aantal methoden biedt te weinig rechtsbescherming; (OM-besluit wordt niet getoetst, dwangpositie verdachte);

- rechtsongelijkheid.

De optimale situatie zou zijn dat de bezwaren van de bestaande afdoeningsmodaliteiten zouden kunnen worden ondervangen, zonder de voordelen ervan te verliezen.

Ter verbetering van de nomering van de afdoening van strafzaken buiten het geding door het $\mathrm{OM}$ doen zich verschillende mogelijkheden voor:

1. gezocht wordt naar een vereenvoudigde afdoening binnen het strafrecht;

2. er wordt aansluiting gezocht bij het bestuursrecht.

Aanvankelijk gingen mijn gedachten (slechts) in de richting van de eerste optie. Logisch eigenlijk, voor een strafrechtelijk georiënteerd jurist. De bestudering van de ontwikkeling van de transactie droeg aan deze gedachtengang bij. Ook bij deze afdoeningsmethode was aanvankelijk steeds gezocht naar een vereenvoudigde afdoening binnen het strafrecht.

Later groeide het idee dat voor oplossingen aansluiting gezocht moest worden bij het bestuursrecht.

Deze 'ommezwaai' naar het bestuursrecht werd ingegeven door een aantal ontwikkelingen:

a. de sanctionering door het OM kan vergeleken worden met sanctionering in het bestuursrecht, bijvoorbeeld met de fiscale of socialrechtelijke boete. Het OM legt in eerste instantie de sanctie op. Pas wanneer de verdachte hiermee niet 
akkoord gaat komt de rechter eraan te pas. De rechter treedt dan op als toetser van het beleid van het $O M$.

In zijn noot onder het zogenaamde Tuindersfraude-arrest ${ }^{15}$ stelt 't Hart de vraag aan de orde of de toetsing door de strafrechter van het vervolgingsbeleid van het $\mathrm{OM}$ zich laat vergelijken met toetsing door een administratieve rechter van het beleid van een bestuursorgaan. En, in het vervolg daarop, of de algemene beginselen van behoorlijk bestuur zonder meer kunnen worden overgeplant en toegepast in het strafrecht. Weliswaar komt hij tot een negatieve beantwoording van deze vraag, maar dat neemt zijns inziens niet weg dat het heel nuttig is dat het strafrecht en bestuursrecht in elkaars tuin kijken.

Dit onderzoek wil hieraan in ieder geval een bijdrage leveren;

b. in de loop der tijd zijn er veel strafbaarstellingen opgenomen in het ordeningsrecht. Deze strafbaarstellingen zijn van een ander type dan de klassieke strafbaarstellingen. Zij laten zich naar mijn idee meer vergelijken met administratiefrechtelijke regelingen. Aan de strafbaarstelling ligt niet zozeer een afkeuring van bepaald gedrag ten grondslag, maar het strafrecht wordt ingezet als instrument voor de beheersing of sturing van bepaalde maatschappelijke gedragingen of ontwikkelingen. ${ }^{16}$

Veel overtredingen van dit soort strafbaarstellingen worden door het OM buiten het geding afgedaan;

c. het $\mathrm{OM}$ is, weliswaar daartoe genoodzaakt, ${ }^{17}$ steeds meer gaan functioneren als een bestuursorgaan en bedient zich ook van bestuursrechtelijke methoden of middelen. Ook het OM vaardigt bijvoorbeeld, evenals bestuursorganen dit doen, richtlijnen (in bestuursrechtelijk jargon: beleidsregels) uit, waarvan de werking niet slechts intern is. Het vervolgingsbeleid van het OM staat voorts niet los van het algemene overheidsbeleid. Het OM treedt dan ook veelvuldig in overleg met andere overheidsinstanties;

d. de wetgever heeft het $\mathrm{OM}$ bij de handhaving van een groot aantal verkeersovertredingen dezelfde rol toebedeeld als de rol die andere bestuursorganen vervullen, namelijk die van administratiefrechtelijk beroepsorgaan. In de WAHV namelijk is het OM de instantie waar betrokkenen in beroep kunnen gaan van een beschikking waarbij door de politie een administratieve sanctie is opgelegd ter zake van overtreding van een verkeersvoorschrift. De procedure ter handlaving van de betreffende groep verkeersvoorschriften is in haar geheel overgeheveld van het strafrecht naar het bestuursrecht;

e. in de jurisprudentie is een verschuiving van het-strafrecht in de richting van het bestuursrecht waar te nemen. Reeds geruime tijd wordt het strafrechtelijk optreden, in navolging van het optreden van andere bestuursorganen, onder meer

15 HR 22 oktober 1991, NJ 1992, 282 m.nt. 'iH.

16 Zie daarover: Y. Buruma, De strafrechtelijke handhaving van bestuurswetten, diss. RUL, Arnhem 1993.

17 Zie hierover Hoofdstuk 2, par. 3.5. 
getoetst aan algemene beginselen van behoorlijke procesorde of ook genoemd algemene beginselen van behoorlijke strafrechtspleging. Een naar mijn mening nog verdere verschuiving naar het bestuursrecht vond plaats toen de Hoge Raad aannam dat het strafrechtelijk optreden niet slechts getoetst wordt aan de strafwet, maar, evenals dit in het bestuursrecht kort tevoren was aangenomen, ook aan de beleidsregels (HR 19 juni 1990, NJ 1991, 119 m.nt. ThWvV en MS);

f. het nieuwe bestuursprocesrecht pretendeert een procedure te zijn met een behoorlijk juridisch gehalte met als uitgangspunten rechtsbescherming en proceseconomie. ${ }^{18}$ Reden om dit bestuursprocesrecht als mogelijk alternatief te onderzoeken.

\section{Probleemstelling}

$\mathrm{Na}$ bestudering van de verschillende afdoeningsmodaliteiten van het $\mathrm{OM}$ ontstond bij mij de vraag of het functioneren van het $\mathrm{OM}$ wat betreft deze buitengerechtelijke afdoening vergelijkbaar is of zelfs gelijkgesteld mag worden met het functioneren van ieder ander bestuursorgaan. En, doorredenerend, of, ter aanvulling of wijziging van de regelingen betreffende de afdoeningsmethoden van het $O M$, gebruik gemaakt zou kunnen worden van de (wettelijke) regeling ter zake van het bestuursrechtelijke besluit. Met andere woorden: of, naast het overbrengen van de handhaving van verkeersovertredingen naar het bestuursrecht, ook de andere door het OM gehanteerde afdoeningsmethoden gemodelleerd moeten of kunnen worden naar de procedures van het bestuursrecht.

Een ondersteuning van deze gedachtengang wordt naar mijn idee gegeven in de toelichting bij de nieuwe Algemene wet bestuursrecht. Daarin immers wordt gestreefd naar unificatie: eenheid op het gebied van alle bestuursrechtelijke regelingen en procedures. Door deze Algemene wet bestuursrecht wordt het OM ook als een bestuursorgaan beschouwd. Echter: art. 1:6 van deze wet sluit (onder andere) de opsporing en vervolging van strafbare feiten van de werking van de wet uit. Hierdoor komt de hiervoor geformuleerde probleemstelling in een ander licht te staan, namelijk: in hoeverre moeten of kunnen de zelfstandige besluiten van het OM tot afdoening van strafzaken buiten het geding buiten de uitzondering van art. 1:6 Awb worden gelaten?

De werkhypothese luidt: het zelfstandige besluit van het $O M$ tot afdoening van een strafzaak buiten het geding is een bestuursbesluit in de zin van art. 1:6 Awb en dient buiten de uitzondering van art. 1:6 Awb te worden gelaten. 
Toelichting: het $O M$ heeft de mogelijkheid in een bepaalde strafzaak te vervolgen c.q. straf te vorderen bij de rechter. Indien van vervolging of verdere vervolging wordt afgezien (sepotbeslissing) impliceert dit letterlijk 'afzien van strafvordering'. Ook indien aan een sepotbesluit voorwarden worden verbonden, wordt er geen straf gevorderd. Buitengerechtelijk afdoen is dus letterlijk 'niet strafvorderen' maar afzien daarvan.

Nadat geconstateerd is dat een zelfstandig besluit van het $\mathrm{OM}$ tot afdoening van een strafzaak huiten het geding niet betreft vervolging of strafvordering, komt de vraag op wat het dan wel betreft. Antwoord: een bestuursbesluit.

Na een beschrijving van de afdoeningsmethoden en een analyse van het karakter van het $\mathrm{OM}$ en het OM-besluit tot buitengerechtelijke afdoening moet blijken of deze hypothese houdbaar is. Indien dit het geval zal blijken te zijn, zullen de consequenties daarvan onderzocht dienen te worden.

\section{Plan van aanpak}

In het eerste deel van dit boek zullen de verschillende buitengerechtelijk afdoeningsmethoden die door het OM worden gehanteerd of waarbij het OM een rol speelt, respectievelijk het sepot, walaronder het voorwaardelijk sepot en het politiesepot (hoofdstuk 2), de transactie (hoofdstuk 3), de administratiefrechtelijke handhaving van verkeersvoorschriften (hoofdstuk 4), de voeging ad informandum (hoofdstuk 5) en de dienstverlening (hoofdstuk 6), worden besproken. De administratiefrechtelijke handhaving van verkeersvoorschriften is na het hoofdstuk over de transactie geplaatst, omdat de ontwikkeling van deze wijze van handhaving aansluit op de ontwikkeling van de transactie. Beide vormen zochten naar een vereenvoudiging met betrekking tot de handhaving. Beschrijving van de dienstverlening als afdoeningsmodaliteit van het $O M$ heeft nog slechts historische waarde, daar de dienstverlening als straf is ingevoerd. De argumenten die in de loop der tijd zijn gehanteerd ter ondersteuning van zowel het officiers- als het rechtersmodel behouden naar mijn mening actualiteit. Om die reden wordt daaraan, zij het kort, aandacht besteed.

Bekeken zal worden hoe de regelgeving met betrekking tot de afdoeningsmethoden zich heeft ontwikkeld, wat de achtergrond van deze ontwikkeling is, hoe de regeling zich verhoudt met internationaalrechtelijke bepalingen en hoe de praktische hantering van de verschillende wijzen van afdoen in haar werk gaat.

Een beperkingwordt hierbij noodzakelijkerwijs aangebracht: het onderzoek zal zich beperken tot delicten, gepleegd door strafrechtelijk meerderjarigen. Het minderjarigenstrafrecht zou voor het onderwerp erg interessant zijn vanwege de 'voorlopersfunctie' van verschillende afdoeningsmethoden, met name de dienstverlening, inclusief de HALT-aanpak. Omdat er met betrekking tot het minderjarigenstrafrecht sprake 
is van een eigen problematiek en deze aanleiding is tot beschouwingen die mijn onderwerp te buiten gaan, blijft bespreking ervan hier achterwege..$^{10}$

Naar aanleiding van de theoretische beschouwing van de verschillende afdoeningsmodaliteiten worden standpunten ingenomen over de toereikendheid van de formele regelgeving.

Alvorens tot een antwoord te kunnen komen op de geformuleerde probleemstelling is het noodzakelijk dat aandacht wordt geschonken aan het karakter van het OM als orgaan. Eerder in deze inleiding stelde ik de vraag of het orgaan OM vergeleken zou kunnen worden met andere bestuursorganen. Willen we het OM-besluit tot buitengerechtelijke afdoening kunnen vergelijken of gelijkstellen net een bestuursbesluit dan moet het OM zich laten vergelijken of wellicht laten gelijkstellen met een bestuursorgaan. Dit zal dan eerst moeten worden onderzocht, hetgeen in Hoofdstuk $7 \mathrm{zal}$ gebeuren aan de hand van een drietal aspecten, te weten het constitutionele, het inhoudelijke en het administratiefrechtelijke aspect. Met name met betrekking tot het tweede aandachtspunt zal blijken dat hierover in bestuursrechtelijke en in strafrechtelijke kring verschillend wordt gedacht.

Vervolgens wordt in Hoofdstuk 8 het karakter van de beslissing tot buitengerechtelijke afdoening onder de loep genomen. Laat deze vervolgingsbeslissing zich met een bestuursbesluit in algemene zin vergelijken? Bekeken wordt welke eisen het bestuursrecht stelt aan een bestuursbesluit, om vervolgens de OM beslissing tot buitengerechtelijke afdoening aan deze eisen te toetsen, teneinde tot een antwoord te komen op de vraag die aan mijn werkhypothese ten grondslag ligt, namelijk: is het besluit van het $\mathrm{OM}$ tot buitengerechtelijke afdoening een bestuursbesluit?

Indien blijkt dat deze vraag positief beantwoord wordt, moeten de consequenties daarvan worden bekeken. De consequentie zou dan moeten zijn dat de normen c.q. bepalingen die gelden voor bestuursbesluiten in het algemeen ook van toepassing zouden moeten zijn op de individuele besluiten van het $\mathrm{OM}$ tot afdoening buiten het geding.

In het daarop volgende Hoofdstuk 9 wordt weergegeven welke normen gelden voor bestuursbesluiten. Voor een strafrechtelijk georiënteerd jurist geen eenvoudige opgave. Tot voor kort was deze opgave echter nog moeilijker, omdat er toen nog niet zoiets was als 'het' bestuursrecht of 'éen' bestuurswet. Er bestond een veelvoud van administratieve (beroeps)procedures, die weliswaar overeenkomstenvertoonden, maar die toch moeilijk als één geheel te bestuderen waren. De ontwikkeling van de Algemene wet bestuursrecht bracht hierin verandering. In deze wet zijn veel van de bestuursrechtelijke regels gecodificeerd, waarbij gestreefd is naar unificatie.

19 Zie hierover onder andere de dissertatie van P.H van der Laan, Alternatieve sancties voor jeugdigen, Arnhem 1991. 
Voor bestuursjuristen zal dit hoofdstuk wellicht overbodige informatie bevatiten. Toch meen ik een dergelijke gedetailleerde weergave te moeten opnemen, omdat de gevolgen van de invoering van de Algemene wet bestuursrecht wellicht nog miet bij iedereen bekend zijn. Bovendien lijkt het mij verstandig dit hoofdstuk als een soort referentiekader te beschouwen voor het volgende hoofdstuk.

In hoofdstuk 10 vindt vergelijking plaats. In dat hoofdstuk wordt namelijk onderzocht in hoeverre de procedures van de door het OM gehanteerde afdoeningsmethoden reeds overeenkomen met de wettelijke regeling van het bestuursbesluit en op welke punten er afwijkingen bestaan. Bij constatering van verschillen zal een afweging dienen plaats te vinden of hier een verandering is aangewezen of het onderscheid moet blijven bestaan. Indien overwogen wordt de regeling op het betreffende piunt te wijzigen, moet worden bezien of dit volgens het bestuursrechtelijk model dient te gebeuren.

Uiteindelijk zal een antwoord worden geformuleerd op de vraag of de beslui ten van het $\mathrm{OM}$ tot buitengerechtelijke afdoening moeten worden uitgesloten van de uitzondering die art. 1:6 Awb maakt voor de vervolgingsbeslissing in het strafproces.

Tenslotte worden in Hoofdstuk 11 voorstellen gedaan ter verbetering van de procerdures van de door het $\mathrm{OM}$ gehanteerde afdoeningsmethoden. Deze voorstellen zijn gegoten in de vorm van een wettelijke regeling en voorzien van een toelichting. 


\section{Sepot}

\section{Inleiding}

In het Nederlandse strafproces ligt de bevoegdheid om strafbare feiten te vervolgen bij uitsluiting in handen van het OM. Geen andere instantie is hiertoe bevoegd. We noemen dit het vervolgingsmonopolie van het $\mathrm{OM}$. Dit vervolgingsrecht van het $\mathrm{OM}$ is neergelegd in art. $4 \mathrm{RO}$.

Het OM heeft echter niet de plicht om ieder geconstateerd strafbaar feit te vervolgen. Het kan om verschillende redenen besluiten van vervolging af te zien. Dit niet-vervolgen wordt seponeren genoemd. Er wordt dan geen rechter bij de zaak betrokken. Ook kan het zo zijn dat een vervolging die reeds is aangevangen, bijvoorbeeld door het instellen van een gerechtelijk vooronderzoek of de toepassing van voorlopige hechtenis, wordt beëindigd. Gesproken wordt dan over niet verdere vervolging. Hiervoor worden ook de termen informeel respectievelijk formeel sepot gehanteerd. Een officier van justitie kan verschillende redenen hebben om een strafzaak niet (verder) te vervolgen. Voor een goed begrip is het van belang duidelijk onderscheid te maken tussen een technisch sepot en een beleidssepot. Van een technisch sepot of haalbaarheidssepot is sprake indien de officier van justitie, vooruitlopend op de einduitspraak van de rechter, de kans groot acht dat deze niet tot een veroordeling zal komen, bijvoorbeeld omdat het feit niet bewijsbaar en/of de dader niet strafbaar is en daarom de zaak niet (verder) vervolgt. Een beleidssepot wordt gehanteerd vanwege, het woord zegt het al, beleidsmatige overwegingen. Het op grond van beleidsoverwegingen afzien van vervolging is gebaseerd op het opportuniteitsbeginsel, dat wettelijk is vastgelegd in de artt. 167 lid 2 en 242 lid 2 Sv. Dit beginsel staat tegenover het legaliteitsbeginsel, ${ }^{20}$ dat inhoudt dat in theorie ieder strafbar feit vervolgd dient te worden indien er voldoende redenen zijn om aan te nemen dat er een veroordeling door de rechter zal volgen. Dit systeem geldt bijvoorbeeld in

20 In het oog dient te worden gehouden dat het begrip 'legaliteitsbeginsel' in verband met de vervolging een beperkter betekenis heeft dan het legaliteitsbeginsel zoals dat is neergelegd in art. 1 Sv. Dit laatste houdt in dat strafvordering slechts mag plaatsvinden bij in de wet voorziene wijze en niet naar willekeur. Die wet zegt dat het opportuniteitsheginsel geldt. Vgl. G.J.M. Corstens, Het Nederlands strafprocesrecht, Arnhem 1993, pag. 54-55. 
Duitsland. Indien ik in verband met het opportuniteitsbeginsel spreek over een sepot, moet dit opgevat worden in de zin van een beleidssepot.

Een beleidssepot kan zich voordoen in twee vormen; het onvoorwaardelijk en het voorwaardelijk sepot. ${ }^{21}$ De officier van justitie kan beslissen de verdachte niet (verder) te vervolgen zonder daar verdere consequenties aan te verbinden, onvoorwaardelijk. Daarnaast bestaat de mogelijkheid dat de officier van justitie de zaak niet (verder) vervolgt, waarbij hij de verdachte aan een bepaalde voorwaarde bindt. Deze twee vormen van een sepot zullen hieronder worden besproken.

In beginsel is het de officier van justitie die de beslissing neemt om van vervolging af te zien. In de praktijk heeft zich de situatie ontwikkeld, dat de politie, vooruitlopend op een sepot door de officier van justitie en in samenspraak met het OM, de sepotbeslissing neemt, het politiesepot.

Alvorens het sepot in zijn verschillende vormen te bespreken, zal een schets gegeven worden van de historische ontwikkeling van het vervolgingsrecht van het OM.

\section{Historische ontwikkeling van het vervolgingsrecht van het $O M$}

Artikel 4 Wet op de Rechterlijke Organisatie noemt als één der taken waarmee het $\mathrm{OM}$ is belast de vervolging van alle strafbare feiten. Het Nederlands strafproces kent niet de vervolging door private personen, maar enkel de vervolging van overheidswege. ${ }^{2}$ Het $\mathrm{OM}$ is de instantie die namens de overheid de vervolging instelt. Deze situatie heeft niet altijd bestaan, maar is in de loop der tijden gegroeid. ${ }^{23}$

Oorspronkelijk droeg het strafproces een privaatrechtelijk karakter: de beledigde partij was klager, de belediger de aangeklaagde. In beginsel bleef vervolging vanwege de overheid achterwege (geen klager, geen rechter). De rechtspraak berustte bij vertegenwoordigers van het volk. De rechter had als taak de behandeling te leiden (accusatoir proces). Vanaf het begin van de middeleeuwen gaat de overheid zich steeds meer met de vervolging en berechting van strafbare feiten bemoeien, ${ }^{24}$ waardoor de inbreng van het slachtoffer wordt teruggedrongen. In het inquisitoir proces

21 Het Jaarverslag OM 1986 noemt nog een derde vorm van een beleidssepot: het onvoorwaardelijk scpot, met een schriftelijke waarschuwing of een berisping ten parkette. Jaarverslag OM 1986, pag. 6. Deze methoden zie ik als verschijningsvormen van het voorwaardelijk sepot.

22. Zie voor een uitgebreidere beschrijving van de positie van de beledigde partij: J.M. van Bemmelen, De positie van de beledigde partij in het strafproces, TvS 1942, pag. 1-25 en 115-138.

23 Zie over de ontwikkeling van het OM uitgebreider: R. Pieterman, De plaats van de rechter in Nederland, 1813-1920, Arnhem 1990; A.G. Bosch, De ontwikkeling van het openbaar ministerie. Uit: Magistraat met beleid: de officier van justitic en zijn omgeving (red. T.M. Schalken e.a.), Arnhem 1992, pag. 15-31.

24 Van Bemmelen geeft hiervoor drie redenen; het accusatoire proces schoot tekort ter bestrijding van de misdaad, de "opbrengsten" waren niet onaanzienlijk en de over heid was vaak zelf beledigde partij. J.M. van Bemmelen, a.w., pag. 3-4. 
heeft de inbreng van de gelaedeerde bij de vervolging nog slechts weinig betekenis. Vervolging en berechting zijn vaak in handen van dezelfde persoon, die zich doorgaans ook nog met de opsporing heeft beziggehouden.

De invoering van de Franse Code d'Instruction Criminelle (1811) bracht met zich mee dat er éen openbaar ministerie kwam. De oorprong van het openbaar ministerie schijnt te liggen in de Germaanse en Frankische rechtspleging. ${ }^{25}$ Binnen dit openbaar ministerie waren een uitvoerende en een rechterlijke macht te onderscheiden. De eerste werd uitgeoefend door de vorst of door legerhoofden, die de vergaderingen samenriepen, bestuurden en het vonnis deden uitvoeren. Het vonnis werd geveld door het volk.

Deze taken werden later overgenomen door de baljuw, respectievelijk de schepenen. $\mathrm{Bij}$ uitbreiding van het inquisitoir proces spoorden de vorstelijke ambtenaren de misdaden zelf op en vervolgden deze.

Door staatkundige ontwikkelingen heeft dit systeem zich niet overal op dezelfde wijze ontwikkeld. In Frankrijk breidde de monarchale macht zich zodanig uit dat de verschillende vertegenwoordigers van de koning tot één lichaam werden gevormd. In ons land stonden de stedelijke en gewestelijke belangen op de voorgrond. Oprichting van één openbaar ministerie was onmogelijk. De openbare aanklagers waren niet afhankelijk van het centrale gezag.

De Bataafse omwenteling van 1795 bracht hierin geen verandering. Pas door de inlijving bij Frankrijk (1810-1813) kregen we ook in ons land één vervolgingsinstantie. Onder de werking van de Code (1811-1838) lag de verantwoordelijkheid voor de vervolging van strafbare feiten nog bij de rechter. De rol van het openbaar ministerie . was beperkt tot het de rechter op de hoogte stellen van mogelijk gepleegde strafbare feiten. De rechter bepaalde of en wat er vervolgd moest worden.

Bij de Wet op de Rechterlijke Organisatie van 1827 werd, in navolging van de Franse inrichting van het openbaar ministerie, als uitgangspunt genomen dat er éñ openbaar ministerie zou zijn. Alle openhare aanklagers bij de verschillende rechtbanken moesten één geheel vormen. Al deze ambtenaren waren verplicht de bevelen van de koning op te volgen. Bij de behandeling van deze wet gaf de minister van justitie de taken van het openbaar ministerie als volgt aan:

"Het openbaar ministerie beslist niets; het zorgt alleen voor de belangen der regering en de behoorlijke toepassing en opvolging der wetten, door de juiste ontwikkeling der beginselen, welke daarmede in verband staan, en door in dien zin zijne requisitoren te doen of conclusiën te nemen, welke nogtans den regter, die geheel onafhankelijk blijft, tot niets verbinden. Het openbaar ministerie is dus niet eene eigenlijke regterlijke authoriteit, maar de tolk, de zaakwaarnemer der hooge regeering; het is eene van het eigenlijk gezegde regter-

25 Zic hierover uitgebreider: J.MJ. de Bosch Kemper, Het Wetboek van Strafvordering, Amsterdam 1838, pag. 143-148. 
ambt geheel afgescheiden magistratuur, verpligt, om ten nutte der algemeene burgerlijke en maatschappelijke gemeenschap te zorgen, dat hare belangen en regten niet verachterd worden, en daaromtrent niets verzuimd worde" ${ }^{26}$

Door de invoering van het Wetboek van Strafvordering in $1838 \mathrm{kwam}$ het initiatief tot vervolgen in principe bij het $O M$ te liggen, maar de rol van de rechter bleef aanzienlijk. Zo kon het gerechtshof, indien het van mening was dat het OM verzuimd had een misdaad of wanbedrijf te vervolgen, de procureur-generaal gelasten vervolging te laten instellen. ${ }^{27}$ Verder moest de rechter in veel gevallen het $\mathrm{OM}$ rechtsingang verlenen, waarbij de rechter, tijdens de instructie, bekeek of er voldoende bewijsmateriaal aanwezig was dat de vervolging rechtvaardigde. Het instituut van de rechtsingang gaf burgers een waarborg dat niet te spoedig een procedure tegen hen zou worden gevoerd. Een lichtvaardige vervolging zou een onschuldige te zeer bezwaren, ook al werd later de onschuld of de niet-strafbaarheid aangetoond. Het OM behoefde echter niet ieder strafbaar feit aan de rechter voor te leggen. Bij misdaden moest altijd rechtsingang worden verleend. Bij wanbedrijven vond dat slechts plaats indien het OM zulks vorderde. Het werd aan de onpartijdigheid en voorzichtigheid van het OM toevertrouwd dat men niet te voorbarig zou zijn met dagvaarden. Wanneer het OM twijfelde of een dergelijke strafzaak bewezen kon worden, behoorde het om instructie en rechtsingang te verzoeken. Wanbedrijven die zo eenvoudig van aard waren dat zij zonder instructie dadelijk op de terechtzitting konden worden behandeld, betroffen meestal feiten van zo'n geringe strafwaardigheid, dat bij een vrijspraak van deze feiten de verdachte door de terechtzitting geen nadeel werd bezorgd. Dit nadeel moest het openbaar ministerie zien te voorkomen. Bij politieovertredingen vond geen gerechtelijke instructie platats en behoefde er geen rechtsingang te worden verleend. ${ }^{28}$

Om nu te voorkomen dat het OM van zijn bevoegdheid zonder rechtsingang iemand te vervolgen een te ruim gebruik zou maken, werd een artikel opgenomen waarin bepaald werd dat de rechtbank, indien zij, "op klagte van den belanghebbende, of op eene andere voldoende wijze" van mening is dat het openbaar ministeric verzuimd heeft een strafbaar feit te vervolgen, vervolging kon bevelen.

Het Wetboek van Strafvordering van 1926 legt het vervolgingsrecht in handen van het OM. Aan private personen komt geen recht toe tot het instellen van een strafvervolging. Het instituut van de rechtsingang is vervallen. Het argument hiervoor is dat de vraag of een gerechtelijk onderzoek nodig is, behoort te worden beslist door het met vervolging belaste $O M$; de rechter moet niet de gelegenheid tot dat onderzoek kunnen afsnijden, op misschien voorbarige, feitelijke of op rechtskundige overwegingen. Om de weegschaal niet helemaal ten nadele van de verdachte te doen door- 
slaan, is aan de rechter-commissaris de leiding van het gerechtelijk vooronderzoek opgedragen. Slechts wanneer de rechter-commissaris oordeelt dat tot het onderzoek generlei grond bestaat, moet hij dit, behoudens beroep op de rechtbank, kunnen weigeren. ${ }^{2}$ Een beklagregeling voor degene die door het strafbaar feit is benadeeld (zie hierboven), is gehandhaafd in art. 14 (later 12) Sv. Dit toezicht op het vervolgingsrecht van het $\mathrm{OM}$ is ondergebracht bij het gerechtshof, teneinde iedere vooringenomenheid bij de latere berechting (door de rechtbank) te vermijden. ${ }^{30}$

\section{Onvoorwaardelijk sepot}

\subsection{Inleiding}

Het $O M$ heeft dus, als vertegenwoordiger van de overheid, het vervolgingsmonopolie. ${ }^{31}$ Op grond van art. $4 \mathrm{RO}$ zou geconcludeerd kunnen worden dat het OM verplicht is alle bekend geworden en bewijsbare strafbare feiten te vervolgen. Dit is echter niet het geval. Op grond van het opportuniteitsbeginsel, een centraal begrip bij de strafvordering, kan het $O M$ van vervolging afzien.

Het Wetboek van Strafvordering van 1838 bevatte geen bepaling waarin het opportuniteitsbeginsel uitdrukkelijk was neergelegd. Er bestond dan ook bij de schrijvers verschil van mening over de vraag of dit heginsel wel of niet uit de wet af te leiden was. Op grond van dezelfde artikelen, art. 2 Sv (oud), art. 22 Sv (oud) en art. 4 R(), betoogde de ene auteur dat daaruit het opportuniteitsbeginsel kon worden afgeleid, terwijl een ander van mening was dat in dat artikel het legaliteitsprincipe was neergelegd. ${ }^{32}$

In het algemeen kan worden gezegd dat zij. die van mening waren dat het opportuniteitsbeginsel zou moeten worden toegepast, wel inzagen dat dit principe niet uitdrukkelijk in de wet stond. Een wetshepaling werd gemist. Maar nict viel in te zien dat de wetgever het opportuniteitsheginsel, afkomstig uit het Franse recht, had willen uitsluiten. Als de wetgever daarvan had willen afwijken had hij dat in de wet tot uitdrukking moeten brengen.

Ondanks onenigheid over de vraag of het beginsel wel of niet een wettelijke basis had, hanteerde het OM in praktijk wel degelijk het opportuniteitsbeginsel. Uit het viij recente onderzoek van Faber blijkt zelfs dat al vóór 1838 op de parketten gesepo-

29 MvT Wetboek van Strafvordering 1926, pag. 61.

30 MvT Wetboek van Strafvordering 1926, pag. 66.

31. Hierop bestaan enkele uitzonderingen, bijwoorbeeld art. $293 \mathrm{~Sv}$, artt. 493 en $499 \mathrm{~Sv}$ :

32 Zic over deze discussie uitgebreider: Gr.J.M. Corstens, Waamborgen rondom het vervolgingsbeleid, diss. UvA, IJmuiden 1974, pag. 10-12. 
neerd werd en dat in 1847 dergelijke sepotbeslissingen voor het eerst opgetekend zijn."

Het opportuniteitsbeginsel heeft eerst in het Wethoek van Stralvordering van 1926 een wettelijke grondslag gekregen en wel in art. 167 lid 2 en art. 242 lid 2 Sv. Volgens de MvT werd hiermee aangesloten bij een reeds geruime tijd bestaande praktijk. Het $O M$ had de bevoegdheid van vervolging van een strafbaar feit, waarvan een veroordeling zeer onwaarschijnlijk was, achterwege te laten wanneer dit, rekening houdend met het algemeen belang, wenselijk voorkwam. Toepassing van deze bepaling leidde in de praktijk, behoudens enkele uitzonderingen, niet tot misbruik. Over afschaffing of beperking van deze afdoening werd in ons land, in tegenstelling tot bijvoorbeeld Duitsland, niet gesproken. Daardoor bestond er voor de wetgever voldoende aanjeiding dit beginsel te handhaven, maar dan moest dat wel in een wettelijk kader gegoten worden, zodat de bestaande twijfel, waartoe de tot dan toe geldende wet aanleiding had gegeven, zou verdwijnen. ${ }^{\text {H }}$

\subsection{Wettelijke regeling}

Zoals vermeld kreeg het opportuniteitsbeginsel in het wetboek van 1926 een wettelijke basis en wel in de artikelen 167 lid 2 respectievelijk 242 lid 2 : van vervolging respectievelijk verdere vervolging kan worden afgezien op gronden aan het algemeen belang ontleend. Art. 167 Sv handelt over de overgang van de opsporingsfase naar de vervolgingsfase. Een herhaling volgt in art. $242 \mathrm{~Sv}$, dat van toepassing is na een gerechtelijk vooronderzoek of na toepassing van voorlopige hechtenis. Tot het moment van aanvang der zitting (het onderzoek vangt aan door het doen uitroepen van de zaak door de rechter, art. $278 \mathrm{~Sv}$ ) kan de officier van justitie een strafzaak seponeren (art. 266 $\mathrm{Sv}$ ).

$\mathrm{Bij}$ de bespreking van de wettelijke regeling van het onvoorwaardelijk sepot zal ik de nadruk leggen op twee zaken, namelijk de term 'algemeen belang' en de termijnen waarbinnen de vervolgingsbeslissing moet worden genomen.

De wettelijke formulering van het opportuniteitsbeginsel is vrij open. Met name de betekenis van de term 'algemeen belang' geeft aanleiding tot onduidelijkheid. De redactie van de artt. 167 lid 2 en 242 lid 2 Sv is sinds 1926 ongewijzigd gebleven. De hantering ervan heeft in de loop der jaren een verandering ondergaan. Dit hangt onder meer samen met de vraag of het opportuniteitsbeginsel negatief dan wel positief geïnterpreteerd dient te worden.

Volgens de MvT moet de verdachte zo spoedig mogelijk intormatie worden verschaft over de resultaten van het reeds gepleegde onderzock, hetgeen bijvoorbeeld van

33 S. Faber, OM-richtlijnen: geen nieuw verschijnsel. Uit: H.G. van de Bunt, J.F.L. Roording en MJ.M. Verpalen (red.), Richtlijnen van het Openbaar Ministerie, Nijmegen 1993, pag. 5-23.

34 MvT Oorspronkelijk Regerings Ontwerp, TK 1913-1914, 286, pag. 8. 
belang kan zijn voor het bepalen van zijn procesrechtelijk positie, en over het vervolg van de verdere strafprocedure. ${ }^{35}$ De ratio hiervan ligt in de rechtsbescherming van de verdachte. Voor de sepotmededeling zou dit inhouden dat de wet een termijn geeft waarbinnen deze genomen en aan de verdachte medegedeeld zou worden. Hieronder zal bekeken worden in hoeverre dit het geval is.

\subsubsection{Algemeen belang}

In de MvT staat niet omschreven wat verstaan moet worden onder 'algemeen bolang'. Dit gaf aanleiding tot onduidelijkheid.

Minister van Justitie Ort hanteerde de term 'algemeen belang' tegenover 'particulier belang', om aan te geven dat het vervolgingsrecht niet in handen ligt van particulieren maar een zaak is van het $\mathrm{OM}$, om te voorkomen dat op overtre ding van bepaalde delicten te vaak een beroep zou worden gedaan en om te bewerkstelligen dat het OM een evenwichtig beleid zou voeren. ${ }^{36} \mathrm{Bij}$ de behandeling van het wetsontwerp stelde de minister dat een individueel belang grond kan zijn voor niet-vervolging, indien dit samenvalt met het algemeen belang. ${ }^{37}$ Van afzien van vervolging louter gebaseerd op particuliere belangen mocht geen sprake zijn. Bij hantering van het opportuniteitsbeginsel moet het OM willekeur voorkomen.

Hiermee worden twee grenzen aangegeven, maar de inhoud van het begrip blijft vaag. De discussie spitste zich toe op de verhouding algemeen-particulier belang. Blok en Besier betogen dat het belang der gemeenschap, beschermingsobject van het strafrecht, niet in alle gevallen waarin een vervolging zou kunnen slagen, het instellen daarvan vordert. Er zijn gevallen waarin de voordelen van een vervolging niet in verhouding staan tot de daaruit voor de verdachte en de maatschappij voortvloeiende nadelen. Het algemeen belang lijdt schade wanneer de pleger van een strafbaar feit nodeloos hard getroffen wordt door de vervolging daarvan."

Noyon, ervan uitgaand dat op de voorgrond blijft staan dat in het algemeen verwolging van strafbare feiten noodzakelijk is, is van mening dat gekeken moet worden naar de gevolgen van het wel of niet vervolgen in een bepaald concreet geval. 'Algemeen belang' zal in verband gebracht moeten worden met de bijzondere belangen die in een concreet geval een vervolging onwenselijk maken. Beslissend zal zijn dat de vervolging van een concreet strafbaar feit, rekening houdend met de omstandigheden waaronder het begaan is, praktisch tot onbillijkheid of onrechtvaardigheid kan leiden of een onwenselijke toestand kan scheppen."

35 MvT Wet tot vastsielling van een Wetbock van Strafvordering, TK. 1913-1914, 286, pag. 112.

36 MvT Wet tot vaststelling van cen Wetboek van Strafvordering, TK 1913-1914, 286, par. 3.

37 EK 1920-1921, 286, pag. 56.

38 A.J. Blok en L.Ch. Besier, Het Nederlands strafproces, deel I, II en III, Haarlem 1925, pag. 71-72 en 477.

39 T.J. Noyon, Het Weiboek van Strafrecht, 1926, pag. 275. 
Tot de zeventiger jaren heeft het $\mathrm{OM}$ uit opportuniteitsoverwegingen betrekkelijk weinig gebruik gemaakt van zijn seponeringsbevoegdheid. Door omstandigheden, die in de volgende paragraaf aan de orde zullen komen, is hierin verandering opgetreden en is het aantal beleidssepots sterk gegroeid. Bij de hantering van het opportuniteitsbeginsel blijkt de officier van justitie rekening te houden met meerdere belangen. Tak maakt hierbij bijvoorheeld een onderscheid in: staatsbelang, maatschappelijk belang en particuliere belangen (slachtoffer, derde, dader). ${ }^{\text {s0 }}$

Sinds 1980 werken de officieren van justitie met een landelijke lijst van gronden voor een sepot. ${ }^{.1}$ Hierin worden genoemd als gronden voor een technisch sepot: ten onrechte als verdachte aangemerkt, geen wettig bewijs, OM niet ontvankelijk, burgerlijke rechter niet bevoegd, feit niet strafbaar en dader niet strafbaar. Gronden voor een beleidssepot zijn: gronden die samenhangen met de algemene rechtsorde, gronden die samen hangen met het gepleegde feit, gronden die samenhangen met de persoon van de verdachte, gronden die samenhangen met de verhouding tussen verdachte en slachtoffer.

Uit deze (standaard)sepotgronden die de officieren van justitie hanteren bij hun vervolgingsbeslissing (een OvJ moet, voor de interne administratie, bij een sepotheslissing op een speciaal daartoe dienend formulier aangeven welke specifieke grond hij aanwezig acht, zie par. 3.4), blijkt dat de term 'algemeen belang' sinds de wettelijke fundering van het opportuniteitsbeginsel in 1926 een meer genuanceerde interpretatie heeft gekregen.

\subsubsection{Negatieve en positieve uitleg van het opportuniteitsbeginsel}

De interpretatie van 'algemeen belang' in de artikelen 167 lid 2 en 242 lid 2 Sv, met andere woorden het bepalen van de grenzen waarbinnen het opportuniteitsbeginsel kan of mag worden toegepast, hangt samen met de vraag of het seponeren gezien moet worden als een uitzondering op de regel dat alle strafbare feiten vervolgd dienen te worden (negatieve uitleg) of dat vervolging alleen geïndiceerd is indien het algemeen belang dit noodzakelijk maakt (positieve uitleg).

De wetgever lijkt, in navolging van de voorstellen van de staatscommissie Ort, te kiezen voor de negatieve opvatting: Indien naar aanleiding van het ingestelde opsporingsonderzoek, respectievelijk voorhereidend onderzoek, vervolging respectievelijk verdere vervolging moet plaatshebhen, gaat het $O M$ ten spoedigste daartoe over. Van vervolging, respectievelijk verdere vervolging kan worden afgezien op gronden aan het algemeen belang ontleend. Op de voorgrond staat de gedachte dat als algeme-

41 Zie daarvoor Melai c.s., aant. 5 bij art. $167 \mathrm{~Sv}$ (suppl. 75). 
ne regel vervolging van strafbare feiten noodzakelijk is, maar dat van deze algemene regel mag worden afgeweken op gronden aan het algemeen belang ontleend. ${ }^{42}$ De MvT neemt deze motivering over. Het opportuniteitsbeginsel heeft geen ander doel aan het legaliteitsbeginsel zijn scherpte te ontnemen. ${ }^{43}$

In een gewijzigd ontwerp werd, op initiatief van de commissie van voorbereiding van de Tweede Kamer een meer positieve versie opgenomen: Indien naar aanleiding van het ingestelde opsporingsonderzoek, respectievelijk gerechtelijk vooronderzoek het OM van oordeel is dat strafvervolging moet plaatsvinden, gdat het daartoe onverwijld over. In het tweede lid werd de negatieve visie er echter weer bijgehaald: van vervolging kan worden afgezien op gronden aan het algemeen belang ontleend. Bij de behandeling van het wetsontwerp in de Tweede Kamer bestond geen eenstemmigheid over de handhaving van het tweede lid. ${ }^{\text {H }}$

Noyon, zoals reeds hierboven aangehaald, gaat, op basis van het tweede lid, uit van een negatieve opvatting van het beginsel. ${ }^{45}$

Volgens Moons bestond er echter ten tijde van de legalisering van het opportuniteitsbeginsel een gezaghebbende stroming die aan dit principe een ruimere (positieve) toepassing wilde geven. Hij refereert hierbij onder andere aan een aanbeveling van de minister van Justitie aan het OM in 1893 slechts vervolging in te stellen indien het gepleegde feit de openbare orde of het algemeen belang had geschaad. Achtergrond hiervan was een toename van het aantal vervolgingen als gevolg van een uitbreiding van het aantal politiekorpsen." Moons is van mening dat de wetgever niet persé een slechts negatief opportuniteitsbeginsel heeft willen toelaten, maar veeleer het beginsel, zoals daarover werd gedacht en zoals dat werd toegepast, wilde legaliseren. ${ }^{47}$

Voor zowel de stelling dat aan de wet (artt. 167 en 242 Sv) een negatieve als voor de stelling dat daaraan een positieve visie op het opportuniteitsbeginsel ten grondslag ligt, worden aan de wetshistorie argumenten ontleend.

Het lijkt mij van belang te bekijken hoe de theorie van het opportuniteitsbeginsel zich door de praktijk heeft ontwikkeld en hoe het beginsel daadwerkelijk wordt toegepast. Daarin heeft zich onder invloed van bepaalde omstandigheden een ontwikkeling voorgedaan van een meer negatieve naar een meer positieve hantering. Een belangrijke factor speelt daarbij de vraag welke rol aan het strafrecht toegekend wordt binnen het gehele maatschappelijke gebeuren (ideologie van het strafrecht).

Staktscommissic Ort, Ontwerp tot vaststelling van een Wetboekvan Strafvordering,'s-Gravenhage 1913, pag. 12-13.

47 J.M.A.V. Moons, Het opportuniteitsbeginsel. Enige notities over zijn inhoud en omvang, N.JB 1969, pag. 491-495 en 521-529. 
Een andere belangrijke factor is de capaciteit van het strafrechtelijk apparaat: kan überhaupt ieder geconstateerd en bewijsbaar delict vervolgd worden (economie van het strafrecht)? Deze vragen hebben de concrete invulling van het opportuniteitsbeginsel sterk beïnvloed, zoals in het nu volgende in een grove schets zal worden beschreven.

Tot de zestiger jaren leverde de toepassing van het opportuniteitsbeginsel weinig problemen op. In wetten was neergelegd welk gedrag als strafbaar gedrag moest worden aangemerkt. Het $\mathrm{OM}$, dat als taak had de handhaving der wetten, stelde, indien bepaald gedrag onder een strafbepaling viel, strafvervolging in. Van belang is te vermelden dat het dit ook kon doen, omdat het strafrechtelijk apparaat over voldoende capaciteit beschikte. Alleen in uitzonderingsgevallen mocht van vervolging worden afgezien. Het OM had geen eigen discretionaire bevoegdheid om van vervolging af te zien. Daar was ook geen reden toe.

In de zestiger jaren verandert dit beeld ${ }^{48}$ Als gevolg van bepaalde gebeurtenissen in die jaren ondergaat het denken over strafrechtstoepassing een wijziging. ${ }^{\text {t9 }} \mathrm{Het}$ strafrechtelijk optreden tegen allerlei vormen van sociaal protest in die tijd (bezettingen, ordeverstoringen) blijkt onvoldoende te functioneren. Door een groot deel van de bevolking wordt dit justitieel optreden niet geaccepteerd en dit maakt de problemen alleen maar groter. De wet alleen blijkt onvoldoende rechtvaardigingsgrond te zijn voor strafrechtelijk optreden. Strafrechtshandhaving is geen doel op zichzelf. Een ander referentiepunt hiervoor is noodzakelijk. Dit wordt gevonden in de te verwachten maatschappelijke effecten van strafrechtelijk optreden. Een officier van justitie moet zich voortaan bij een te nemen vervolgingsbeslissing afvragen of vervolging hier in het algemeen belang is. Het feit dat een bepaalde gedraging in een strafwet is opgenomen is niet meer de enige voorwaarde voor vervolging; het algemeen belang, waaronder dan naar mijn mening verstaan kan worden het belang van de rechtsorde maar ook het belang van de maatschappelijke orde, wordt medeuitgangspunt voor strafrechtelijk optreden. Dit houdt onder meer in dat nagegaan dient te worden of als reactie op een bepaalde strafbaar gestelde gedraging persé een strafrechtelijke weg bewandeld moet worden of dat andere wegen openstalan. Het meest doeltreffend middel dient ingezet te worden om het gestelde doel te bereiken. Strafrechtelijk ingrijpen is niet immer gewenst. ${ }^{\text {so }}$

Volgens A. Patijn is het niet vreemd dat dit niet veel later na de wetswijziging van 20-6-1963, Stb. 272 valt, waarbij de in art. 99 RO genoemde cassatiegrond 'verkeerde tocpassing of schending van de wet' vervangen wordt door 'schending van het recht'. A. Patijn, De strafrechtelijke handhaving van de wetgeving. Uit: Kracht van wet. 1984, pag. 147-164.

49 Zie onder andere J.M. Broekman en A.C. 't Hart, Normverleggend gedrag en justitiecl beleid. Leuven 1980, pag. 65 c.v; A.C. ' $t$ Hart, Criminal law policy in the Netherlands. Uit: J. van Dijk e.a. (red.), Criminal law in action, Arnhem 1986, pag. 73-99.

50 Zie ook: D.H. de Jong, Rechtsbescherming in een beslissende fase, oratic RUG, Arnhem 1985. 


\section{Deze opinie vinden we terug in de jaarverslagen van het $O M^{s t}$}

"Justitiële repressie, met de opsporing als inleiding daarop, vormt voor de staande magistratuur geen doel op zichzelf. Het beschouwt de repressie slechts als middel, en dan nog maar als een van de middelen die kunnen worden aangewend om het doel dat die middelen gemeen hebben, te bereiken: aangepast gedrag in de samenleving, dit is gedrag overeenkomstig het geldend recht" en "bij gelijkblijven van de wettekst - de artikelen 167 lid 2 en 242 lid 2 Sv - valt de laatste decenniën een ontwikkeling te constateren, waarbij meer het 'waarom vervolgen?' dan het 'waarom niet vervolgen?' normatief is"..$^{2}$

"Men zou ...... onderscheid kunnen maken tussen delicten waarbij het bereiken van een matschappelijk effect primair is en delicten waarbij het individuele aspect van de daad of van de dader het zwaarst weegt. Met name ten aanzien van delicten van de eerste groep geldt dat het openbaar ministerie zijn strafrechtelijke taak vervult in nauw overleg met andere bestuurlijke instanties. Opsporing en vervolging worden gehanteerd om het ongewenste gedrag binnen aanvaardbare marges te houden. Opsporing van alle delicten van deze groep blijkt niet mogelijk en is, gezien de doelstelling, ook niet nodig".5.

Uit het voorgaande kan worden geconcludeerd dat er op basis van ideologische argumenten een accentverschuiving heeft plaatsgevonden van een meer negatieve naar een meer positieve uitleg van het opportuniteitsbeginsel.

Deze ontwikkeling is in de zeventiger en tachtiger jaren nog versterkt door de capaciteitsproblematick, zoals die bij de strafrechtelijke organen (politie, OM, rechters, gevangeniswezen) ontstaan is, onder andere ten gevolge van bezuinigingsoperaties bij de overheid, een flinke toename van het aantal strafbepalingen (zie bijvoorbeeld art. 1 WED) en door een groeiend aantal overtredingen van de strafbepalingen, de toename van de criminaliteit. ${ }^{\mathrm{s}}$ Dit betekent dat een groot aantal gepleegde delic-

51 Sedert 1972 (waarin het verslag van 1970 verscheen) brengen de procureurs-generaal bij de gerechtshoven jaarlijks een verslag uit waarin een beeld geschetst wordt van de wijze waarop het $O M$ in de uitvoering van zijn taken heeft gefunctioneerd. Dit verslag werd aanvankelijk gepresenteerd bij de justitiebegroting. Later werd met deze lijn gebroken en werd het jaarverslag OM in zelfstandige vorm gepresenteerd, te beginnen met het jaarverslag over 1986. Deze vernieuwde vorm zou beter passen bij actuele ontwikkelingen met betrckking tot het $O M$ als een organisatie met cigen taken en bevoegdheden en verantwoordelijkheden op het gebied van de criminalitcitsbestrijding (voorwoord Jaarverslag OM 1986).

52 Jaarverslag OM 1970. Tweede Kamer, Rijksbegroting 1971-1972, hoofdstuk VI, no. 3, bijlage IV, pag. 8.

53 Jaarverslag OM 1972. Tweede Kamer, Rijksbegroting 1973-1974, Hoofdstuk VI, no. 3, bijlage IV, pag. 9-13.

54 Zic onder andere: A.C. 't Hart, Criminal law policy in the Netherlands. Uit: Criminal law in aclion, Arnhem 1986; D.H. de Jong, Rechtsbescherming in een beslissende fase, Arnhem 1985; A. Patijn, Strafrechtelijke handhaving van de wetgeving. Uit: Kracht van wet, 1984. 
ten niet strafrechtelijk aangepakt kan worden vanwege een overbelasting van het strafrechtelijk apparaatt. ${ }^{s}$

Ook de jaarverslagen van het OM signaleren deze problematiek..$^{\mathrm{s}_{1}}$

Het niet langer min of meer 'automatisch' vervolgen heeft dan niet enkel meer te maken met een bepaalde ideologische reden waarom vervolging niet op zijn plaats zou zijn. Vanwege puur praktische, economische omstandigheden is het $\mathrm{OM}$ niet bij machte alle strafbare feiten, waarvan het vervolging wenselijk acht, op die manier te behandelen. Dit vereist het stellen van prioriteiten. Het gevolg hiervan is geweest dat het OM, meer dan voorheen, beleid is gaan voeren. Overleg (intern en extern) en het opstellen van vervolgings- en transactierichtlijnen zijn hiervan belangrijke consequenties.

In het Beleidsplan Samenleving en Criminaliteit $(1985)^{57}$ ligt de nadruk op het bestrijden van veelvoorkomende criminaliteit. Eén van de doe]stellingen was het aantal kale beleidssepots sterk terug te dringen door een meer frequente toepassing van het voorwaardelijk sepot met bijzondere voorwaarden en de transactie. Het OM krijgt hierbij een centrale rol. Het OM dient zo adequaat mogelijk te reageren op elke strafzaak.

Ondertussen verandert ook de alard van de criminaliteit. $\mathrm{Na}$ de opkomst van de veelvoorkomende criminaliteit kent onze maatschappij tegenwoordig ernstige vormen van zware criminaliteit, zoals handel in verdovende middelen, milieucriminaliteit en vormen van fraude. Deze vormen van criminaliteit krijgen een steeds professioneler karakter en worden vaak gepleegd in internationaal verband. Het niet (tijdig) reageren op strafbaar gedrag maakt de geloofwaardigheid van het strafrecht er natuurlijk niet groter op. In het Beleidsplan Strafrecht met beleid (1990), ${ }^{58}$ wordt dan ook gesteld dat het niveau van opsporing en vervolging verhoogd dient te worden. Hierop moet het beleid worden afgesteld. Onderdeel daarvan is het streven het aantal kale beleidssepots en het aantal technische sepots verder terug te dringen." Eén van de aanbevelingen is dat het aantal kale beleidssepots moet worden teruggedrongen, totdat het in 1995 niet meer dan 5 procent van het totaal vervolgbare zaken uitmaakt. ${ }^{\infty}$ Dit gaat dus terug in de richting van een negatieve uitleg van het opportuniteitsbeginsel.

55 De Jong noemt dit de ongewenste onontkoombaarheid om vervolging achterwege te laten. D.H. de Jong, a.w., pag. 15.

56 Zie onder andere Jaarverslag OM 1970, pag. 8; Jaarverslag OM 1972, pag. 10; Jaarverslag OM 1977, pag. 41; Jaarverslag OM 1981, pag. 56 e.v.; Jaarverslag OM 1984, pag. 70-71.

57 Beleidsplan Samenleving en Criminaliteit, TK 1984-1985 (en verder), 18995.

58 Beleidsplan Strafrecht met beleid, Beleidsplan openbaar ministerie 1990-1995, OM 1990.

59 Om de meer ernstiger vormen van criminaliteit aan te kunnen pakken zijn ingrijpende veranderingen binnen het $\mathrm{OM}$ noodzakelijk, zoals veranderingen in cultuur, organisatie, werkwijze, informatievoorziening en in personele en materiële voorzieningen. Zie hierover uitgebreider: Themanummer Justitiēle Verkenningen, $1992 \mathrm{nr}$. 5, Het openbaar ministerie in ontwikkeling.

60 Beleidsplan Strafrecht met belcid, pag. 46. 
Conclusie: het opportuniteitsbeginsel is in 1926 wettelijk vastgelegd. Ongeacht of de redactie van de artikelen 167 lid 2 en 242 lid 2 van het Wetboek van Strafvordering nu de negatieve dan wel de positieve visie weergeeft, feit is dat de praktische hantering ervan sinds 1926 gewijzigd is. Het gegeven, dat een bepaalde gedraging onder de wettelijke omschrijving van een delict valt, is onvoldoende legitimatie om tot vervolging over te gaan. Het algemeen belang, het belang van de rechtsorde, moet vervolging noodzakelijk maken, waarbij bedacht moet worden dat het strafrecht slechts één van de middelen is om op strafbaar gedrag te reageren. Hiertoe is door het OM beleid ontwikkeld.

Daarnaast moet gekomen worden tot het stellen var, prioriteiten vanwege de omstandigheid dat het OM (en andere strafrechtsorganen) niet in staat is, vanwege capaciteitsproblemen, alle strafbare feiten, waarvan vervolging wenselijk zou zijn, aan te pakken.

In een tijd van toenemende (zware) criminaliteit wordt vermindering van het auntal kale beleidssepots weer ingezet als wapen in de strijd.

Samengevat: zowel ideologische als economische als crimineel-politieke overwegingen zijn van invloed geweest op de hantering van het opportuniteitsbeginsel.

Voor een duidelijke voorstelling van zaken dient (nogmaals) te worden vermeld dat het $\mathrm{OM}$ bij de hantering van het opportuniteitsheginsel niet slechts de keuze heeft tussen of vervolgen of seponeren. Het kan bijvoorbeeld ook ter zake van een mildere variant van het gepleegde delict vervolgen of dagvaarden voor de politierechter in plaats van voor de meervoudige strafkamer. Daarnaast kan het gebruik maken van andere afdoeningsmethoden die tussen vervolging en sepot liggen. Hierbij volgt er dan, in tegenstelling tot het sepot, een strafrechtelijke reactie vanwege het OM ten opzichte van de verdachte, zoals een voorwaardelijk sepot of een transactie. De voeging ad informandum neemt hierbij een aparte plaats in. In de volgende hoofdstukken komen deze afdoeningsmethoden achtereenvolgens aan de orde.

Uiteindelijk gaat het in de strafrechtshandhaving bij het nemen van de vervolgingsbeslissing door het OM mijns inziens niet meer om de pure toepassing van het opportuniteitsbeginsel met overwegingen als wel vervolgen of niet vervolgen, maar wordt er na de constatering van een strathaar feit een keuze gemalakt uit een groot aantal mogelijke afdoeningsmethoden, waarvan vervolgen ${ }^{61}$ of niet vervolgen de uitersten zijn. ${ }^{2}$

61 Ook ten aanzien van de beslissing $10 t$ vervolgen moct worden bedacht dat er keuzemügelijkheden voor het $\mathrm{OM}$ bestaan: dagvaarding, vordering gerechtelijk vooronderzoek of vordering voorlopige hechtenis.

62 Vgl. Jaarverslag OM 1986, pag. 13: "Dat hoeft nict direct een dagvaarding of transactie te zijn, maar kan ook een voorwaardelijk sepot of waarschuwing zijn: een dergelijke reactic kan zodanig effectief zijn, dat het algemeen belang de vervolging zelf niet meer verlangt. In zoverre kan worden gesproken van een verderc nuancering van het opportunitcitsbeginsel doordat de ter beschikking 


\subsubsection{Termijnen}

Het vervolgingsmonopolie van het OM is uitgewerkt in art. 167 lid 2 Sv en, in geval een gerechtelijk vooronderzoek of voorlopige hechtenis is toegepast, in art. 242 lid 2 Sv. Op grond van deze artikelen heeft de officier van justitie de bevoegdheid van (verdere) vervolging af te zien.

Zoals ik hiervoor reeds vermeldde, achtte de wetgever het van belang dat een verdachte zo snel mogelijk op de hoogte zou worden gebracht van het vervolg van de strafprocedure, zodat hij zijn procespositie kon bepalen. Door het opnemen van termijnen waarbinnen de vervolgingsbeslissing moest worden genomen, kon hieraan worden tegemoetgekomen.

Ook het slachtoffer van een delict kan belang hebben bij een spoedige beslissing.

\subsubsection{Termijn voor de vervolgingsbeslissing na het opsporingsonderzoek}

Bij de vervolgingsbeslissing, welke genomen wordt na het opsporingsonderzoek (waarbij er geen gerechtelijk vooronderzoek heeft plaatsgevonden en geen voorlopige hechtenis is toegepast), wordt de officier van justitie door de wet niet aan een termijn gebonden. Ook verplicht de wet de officier van justitie niet van zijn beslissing mededeling te doen aan de verdachte.

Wordt echter door de bevoegde autoriteiten aan de verdachte uitdrukkelijk meegedeeld dat hij ter zake van een strafbaar feit niet vervolgd zal worden, dan mag de verdachte er, blijkens de jurisprudentie, op vertrouwen dat geen vervolging zal plaatsvinden, tenzij zwaarwichtiger belangen zich hiertegen verzetten. Vervolging kan in een dergelijk geval leiden tot niet-ontvankelijkheid van het $\mathrm{OM}$ op grond van het vertrouwensbeginsel ${ }^{k 3}$ (zie par. 2.2.4 en 2.4 .2 en hoofdstuk 10 over het vertrouwensbeginsel).

Dit betekent dat een verdachte, die van een tegen hem bestaande verdenking op de hoogte is, maar waarbij er ten aanzien van het feit waarvan hij wordt verdacht geen gerechtelijk vooronderzoek is ingesteld, of een verdachte die niet in voorlopige hechtenis is genomen en aan wie geen sepotmededeling is gedaan, in een groot aantal gevallen in onzekerheid blijft verkeren over de vraag of hij wel of niet vervolgd zal worden. Om aan deze onzekerheid een einde te maken kan de verdachte, of diens raadsman, telefonisch contact opnemen met de administratie van het betreffende

staande instrumenten meer en beler worden hinut."

63 Zie voor de werking van het vertrouwensbeginsel onder andere HR 29 mei 1978, NJ 1978, 358; HR 22 mei 1979, NJ 1979, 301; HR 13 september 1983, NJ 1984, 151; In het arrest van HR 26 juni 1984, NJ 1985, 41 is de werking van het vertrouwensbeginsel met betrekking tot een sepotbeslissing voortvloeiend uit art. 167 lid 2 Sv erkend. Ook indien de sepotmededeling gedaan is door een lagere opsporingsambtenaar mag de verdachte er op vertrouwen dat hij ter zake van dat feit. niet vervolgd zal worden, HR 19 september 1988, NJ 1989, 379 (parkeerwachter), zie hierover hoofdstuk 10. 
parket om, na opgave van het betreffende proces-verbaalnummer, te informeren naar de stand van zaken met betrekking tot zijn strafzaak. Onder het motto 'Men moet geen slapende honden wakker maken' is het wellicht niet zo verstandig om rechtstreeks bij de officier van justitie te informeren. Als de verdachte als antwoord krijgt dat er nog geen beslissing is genomen, schiet hij er niets mee op. In art. $36 \mathrm{~Sv}$ wordt de verdachte de mogelijkheid gegeven de rechter te verzoeken te verklaren dat de zaak is beëindigd. Dit kan echter slechts in het geval dat de vervolging niet wordt voortgezet. Aangezien wij hier nu praten over een situatie waarin van een vervolging nog geen sprake is, kan de verdachte van deze mogelijkheid geen gebruik maken.

Het feit, dat de wettelijke regeling van het informeel sepot (art. 167 lid $2 \mathrm{~Sv}$ ) geen termijn noemt waarbinnen de officier van justitie zijn vervolgingsbeslissing moet nemen, betekent nog niet dat de officier, indien hij tot vervolging overgaat, nooit aan een termijn gebonden is. Op grond van art. 6 lid 1 EVRM en art. 14 lid 3 onder c IVBP dient de berechting van een strafzaak plaats te vinden binnen een redelijke termijn, althans zonder onredelijke vertraging. Strekking hiervan is te voorkomen dat de verdachte onredelijk lang zou moeten leven onder dreiging van een vervolging. ${ }^{4}$

Het vereiste van de redelijke termijn heeft betrekking op de afzonderlijke stadia van de strafvervolging, alsook op de behandeling van de strafzaak in zijn geheel. ${ }^{.5}$ De Hoge Raad heeft in 1982 voor het eerst beslist dat het OM niet-ontvankelijk was wegens undue delay, onaanvaardbare traagheid bij de vervolging.".

Allereerst is van belang de vraag op welk moment de termijn begint te lopen, met andere woorden wanneer er voor het eerst sprake is van een 'criminal charge' in de zin van art. 6 lid 1 EVRM. Volgens de huidige jurisprudentie van de Hoge Raad ${ }^{\text {(z) }}$ is hiervoor beslissend het moment waarop jegens de verdachte vanwege de staat een handeling is verricht waaraan deze de verwachting heeft ontleend - en in redelijkheid ook de verwachting heeft kunnen ontlenen - dat het $O M$ het ernstige voornemen heeft hem ter zake van een strafbaar feit te vervolgen. ${ }^{68}$ Dit kan bijvoorbeeld het geval zijn op het moment van dagvaarden, ${ }^{\oplus}$ van een vordering tot het instellen van

64 HR 23 september 1980, NJ 1981, 116 m.nt. GEM.

65 HR 19 februari 1985, NJ 1985, $581 \mathrm{~m} . n t$. ThWvV.

66 HR 9 maari 1982, NJ 1982, 409 m.nt. ALM.

67 Volgens Lensing is de Hoge Raad voorzichtiger, zo niet terughoudender bij het bepalen van het moment waarop van een "charge" sprake is dan het Europese Hof van de Rechten van de Mens. J.A.W. Lensing, Aspecten van de invloed van art. 6 EVRM op onderdelen van het strafproces in Nederland. Preadvies voor de Vereniging voor de vergelijkende studie van het recht van Belgie en Nederland, Den Haag 1988, pag. 51.

68 Zie bijvoorbeeld HR 17 februari 1987, NJ 1987, 951; HR 2 juni 1987, NJ 1988, 266; HR 24 november 1987, NJ 1988, 563.

69 Zie bijvoorbeeld HR 6 mei 1986, NJ 1987, 26. 
een gerechtelijk vooronderzoek ${ }^{\pi}$ en van een vordering tot hewaring. De Hoge Raad heeft bepaald dat de aanhouding van de verdachte een handeling als hierboven hedoeld kan opleveren." Het politieverhoor kán als beginpunt van de redelijke termijn aangemerkt worden, namelijk indien de verdachte daaruit heeft opgemaakt en redelijkerwijs kon opmaken dat het $O M$ het ernstige voornemen heeft tegen hem strafvervolging in te stellen." Ook het moment van de inverzekeringstelling kan bepalend zijn. ${ }^{73}$ De Rechtbank Zutphen oordeelde dat er op het moment, dat de officier van justitie aan de verdachte meedeelt dat in verband met een andere zaak gewacht wordt met het doen uitgaan van de dagvaarding en dat verdachtes strafzaak geenszins is beëindigd, van een 'charge' in de zin van art. 6 lid 1 EVRM sprake is. ${ }^{74}$ Het oordeel van het Hof dat de verdachte aan de inbeslagneming (van de administratie), het schrijven van de FIOD (waarin hij als verdachte wordt aangemerkt) en het FIOD-proces-verbaal niet de verwachting kon ontlenen dat het $\mathrm{OM}$ een strafvervolging tegen hem zou instellen, doch dat daarvan pas sprake was toen de verdachte inverzekering was gesteld, acht de Hoge Raad evenwel niet onbegrijpelijk. ${ }^{75}$ Uit de jurisprudentie van de Hoge Raad blijkt tevens dat hij de kwestie, wanneer aan het gestelde criterium voldaan is, als van feitelijke aard beschouwt en in cassatie niet kan worden getoetst.

Wanneer is de vervolgingstermijn nu onredelijk?

In een arrest van 19 februari 1985 heeft de Hoge Raad als richtlijn genomen dat een normale strafzaak twee jaar na het begin van de vervolging in eerste aanleg moet kunnen worden afgerond. ${ }^{70}$ In navolging van het Europese Hof heeft de Hoge Raad een aantal criteria ontwikkeld aan de hand waarvan deze vraag beoordeeld dient te worden. Volgens de rechtspraak van het Europese Hof moet worden gekeken naar de omstandigheden van het geval. Of een termijn onredelijk is hangt af van de ingewikkeldheid van de zaak, het gedrag van de betrokkene en de wijze waarop de zaak door de justitiële autoriteiten is hehandeld. De Hoge Raad hanteert naast deze criteria nog een ander, namelijk de aard en de ernst van het ten laste gelegde feit. ${ }^{n}$ Een ingewikkelde zaak is bijvoorbeeld een zaak die met een andere strafzaak samenhangt, ${ }^{78}$ of waarbij internationale aspecten een rol hebben gespeeld, waardoor het Nederlands justitiële apparaat zich geplaatst zag voor moeilijk begaanbare diplo-

Zie echter HR 24 november 1987, NJ 1988, 617 waarin bepaald werd dat dit niet \%onder mecr opgaat.

71 HR 23 juni 1987, DD 87.494.

72 HR 10 november 1985, NJ 1986, $494 \mathrm{m.nt}$. 'tH.

73 HR 23 juni 1987, DD 87.501; HR 19 april 1988, NJ 1988, 879.

74 Rechtbank Zutphen 1 juli 1987, NJ 1987, 942.

75 HR 15 maart 1988, DD 88.336.

76 HR 19 februari 1985, NJ 1985, 581 m.nt. ThWvV.

77 Zie onder anderc HR 17 maart 1987, DD 87.377; HR 19 mei 1987, DD 87.470; HR 2 juni 1987, NJ 1988, 180; HR 26 mei 1987, NJ 1988, 175; 23 juni 1987, DD 87.501.

Zie bijvoorbeeld HR 19 mei 1987, NJ 1988, 218. 
matieke kanalen. ${ }^{x}$ In het geval een verdachte er zelf (mede) oorzalak van is dat de zaak zolang op zich heeft laten wachten, bijvoorbeeld door het herhaaldelijk verzoeken om uitstel of het herhaaldelijk instellen van rechtsmiddelen ${ }^{\text {sin }}$ of door het niet-nakomen van afspraken in het kader van een psychiatrisch onderzoek, heeft het beroep op een onredelijke termijn geen succes. Overbelasting van het justitiële apparaat als zodanig is geen omstandigheid die het onredelijk tijdsverloop rechtvaardigt. $^{81}$

De beslissing of de termijn al dan niet is overschreden hangt zozeer af van de waardering van de feitelijke omstandigheden, dat zij als van overwegend feitelijke aard onttrokken is aan het oordeel van de cassatierechter en slechts op haar begrijpelijkheid kan worden getoetst. Vaak komt de Hoge Raad dan met de constatering dat het oordeel van het Hof in een bepaalde zaak niet onbegrijpelijk is. ${ }^{82}$

Het gevolg van overschrijding van de redelijke termijn was aanvankelijk dat het $O M$ niet-ontvankelijk was in zijn vervolging (art. 349 lid $1 \mathrm{~Sv}$ ). Door overschrijding van de termijn had het $O M$ het recht op strafvervolging verloren. In 1987 is hierin een wijziging opgetreden in die zin dat naast het genoemde gevolg het voortaan ook mogelijk is dat overschrijding van de redelijke termijn verdisconteerd wordt in de strafoplegging. ${ }^{\infty}$ De rechter dient daarbij de mate van schending in aanmerking te nemen en tevens aan te geven tot welke verlaging hij daarin aanleiding heeft gezien. ${ }^{84}$ In geval van zeer lange overschrijding wordt het OM niet-ontvankelijk verklaard..$^{\text {s5 }}$

3.2.3.2 Termijn voor de vervolgingsbeslissing tijdens en na het gerechtelijk vooronderzoek

Ook tijdens het gerechtelijk vooronderzoek kan de officier van justitie tot de beslissing komen dat hij van verdere vervolging afziet. Hij deelt dit schriftelijk mede aan de rechter-commissaris (art. 237 lid $1 \mathrm{~Sv}$ ), waarna deze laatste de beschikking tot sluiting van dit onderzoek aan de verdachte doet toekomen (art. 237 lid 2 Sv). Hij dient hierbij de reden tot sluiting, in casu de schriftelijke mededeling van de officier van justitie, te vermelden. Op grond van art. $243 \mathrm{~Sv}$ moet de officier van justitie de verdachte er onverwijld van in kennis stellen dat hij hem ter zake van het feit waarop het gerechtelijk vooronderzoek betrekking had, niet verder zal vervolgen.

79 Rechtbank Rotterdam 11 november 1987, NJ 1988, 616.

80 Zie bijvoorbeeld HR 22 september 1987, DD 88.039.

81 Zie bijvoorbeeld HR 26 mei 1987, NJ 1988, 175; HR 23 juni 1987, NJ 1988, 353.

82 Zie bijvoorbeeld HR 16 juni 1987, NJ 1988, 220.

83 Zie bijvoorbeeld HR 7 april 1987, NJ 1987, 587 m.nt. ThWvV.

84 Zie hierover uitgebreider: D.H. de Jong, Undue delay. lagere straf in plaats van niet-ontvankelijkheid OM, AA 1987, pag. 628-634.

85

HR 25 april 1989, NJ 1989, 705. 
Een duidelijke termijn voor deze kennisgeving van niet verdere vervolging stelt de wet niet. Kennelijk heeft de wetgever dat in deze fase nog niet van belang geacht. Een reden hiervoor zou misschien kunnen zijn dat de verdachte door middel van de mededeling van de beschikking tot sluiting van het gerechtelijk vooronderzoek door de rechter-commissaris (art. 237 lid 1 en $2 \mathrm{~Sv}$ ) toch al op de hoogte is van het feit dat de officier van justitie heeft besloten van verdere vervolging af te zien. De MvT vermeldt hieromtrent niets.

Toch is het van groot belang dat de verdachte zo spoedig mogelijk een dergelijke kennisgeving ontvangt, vanwege het belangrijke rechtsgevolg dat de wet hieraan verbindt. Door een kennisgeving van niet verdere vervolging eindigt namelijk de zaak (tenzij er sprake is van nieuwe bezwaren): art. 246 lid $1 \mathrm{~Sv}$ jo. art. 255 lid 1 Sv.

De situatie kan zich nu voordoen dat de verdachte enerzijds wel de mededeling van de beschikking door de rechter-commissaris heeft ontvangen, doch anderzijds verstoken is gebleven van de formele kennisgeving van de officier van justitie.

Art. $36 \mathrm{~Sv}$ biedt de verdachte de mogelijkheid de rechter te verzoeken te verklaren dat de zaak beëindigd is.

De vervolgingsbeslissing na beëindiging van het gerechtelijk vooronderzoek lijkt als enige aan een strikte termijn gebonden. De officier van justitie dient deze te nemen uiterlijk binnen twee maanden nadat de beschikking tot sluiting van het gerechtelijk vooronderzoek voor de verdachte onherroepelijk is geworden (art. 244 lid $1 \mathrm{~Sv}) .{ }^{8}$ Het moment echter waarop deze beschikking onherroepelijk voor de verdachte wordt is geen constant gegeven, maar varieert in verband met de termijnen die in art. 238 leden 2-5 genoemd worden en die samenhangen met het feit dat de verdachte al dan niet om heropening van het gerechtelijk vooronderzoek kan verzoeken. Startpunt voor deze laatstgenoemde termijnen is steeds de betekening van de beschikking tot sluiting van het gerechtelijk vooronderzoek door de officier van justitie aan de verdachte. Na deze betekening kan de verdachte terstond of binnen acht dagen om heropening verzoeken (art. 238 lid 2 Sv). Doet hij dit niet dan is na acht

86 Deze termijn bedroeg tot voor kort een maand. Na de inwerkingtreding op 1 mei 1992 van de Wet van 27 november 1991, houdende enkele wijzigingen van het Wetboek van Strafvordering en enige andere wetten in het bijzonder houdende termijnen (Tweede Kamer, 1988-1989, 21.241; Stb. 1991, 663), ook genoemd Termijnenwet, is hierin verandering gekomen. Volgens de MvT bij deze wet werden de tot dan toe bestaande termijnen als te krap bemeten ervaren, als gevolg van de sterk toegenomen werkbelasting van parketten en griffies, het feit dat een deugdelijke betekening van stukken veel tijd is gemocid en de omst andigheid dat de griffies cn parketten niet altijd in het\%clfde gehnuw gevestigd zijn waardoor tijdverlics optreed. Dat door verlenging van de termijn van art. 238 lid $1 \mathrm{~Sv}$ de verdachte langer in onzekerheid blijft verkeren omtrent de voortgang van het onderzoek, wordt door de minister erkend doch niet van doorslaggevende betekenis geacht. Hij acht het niet verantwoord, gezien de zwaarte van de sanctic op overschrijding (art. 255 lid 4: bec̈indiging van de zaak) de huidige regeling te handhaven. Verlenging van de termijn is voor de verdachte minder bezwarend dan het laten vervallen van deze sanctic, aldus de MvT. 
dagen de beschikking tot sluiting van het gerechtelijk vooronderzock voor hem onherroepelijk geworden. Ziet de verdachte terstond van heropening af of doet hij dat binnen acht dagen dan is de beschikking vanaf dat moment voor hem onherroepelijk. Verzoekt de verdachte om heropening van het gerechtelijk vooronderzoek en wijst de rechter-commissaris dit verzoek af dan wordt de beschikking tot sluiting van het gerechtelijk vooronderzoek onherroepelijk voor de verdachte op het moment waarop de beroepstermijn van veertien dagen, te rekenen vanaf het moment dat de beschikking tot afwijzing van het heropeningsverzoek aan de verdachte wordt betekend, waarbinnen de verdachte van de afwijzing in hoger beroep kan komen (art. 2.38 lid $5 \mathrm{~Sv}$ ) maar hij daarvan afziet, is verlopen. Gaat de verdachte van de beslissing van de rechter-commissaris in beroep (art. 238 lid $5 \mathrm{~Sv}$ ) dan wordt de beschikking tot sluiting van het gerechtelijk vooronderzoek onherroepelijk op het moment de rechtbank een negatieve beslissing neemt op het verzoek tot heropening van het gerechtelijk vooronderzoek door de verdachte. Samengevat: de termijn tussen het betekenen van de beschikking tot sluiting van het gerechtelijk vooronderzoek aan de verdachte en het onherroepelijk worden van deze beschikking voor de verdachte kan variëren van 0 tot 22 dagen, de tijd die de rechter-commissaris en de rechtbank ter behandeling behoeven niet meegerekend.

Het tijdstip, waarop de beschikking tot sluiting van het gerechtelijk vooronderzoek aan de verdachte wordt betekend, is evenmin een constant gegeven. Dit is afhankelijk van het moment waarop de officier deze beschikking doet betekenen (kan variëren van 1 dag tot twee maanden nadat de termijn van art. 237 lid 3 verlopen is, art. 238 lid $1 \mathrm{~Sv}$, eerste en tweede volzin) en van het feit of de officier van justitie al dan niet een verzoek tot heropening van het gerechtelijk vooronderzoek aan de rechtercommissaris richt (art. 237 lid $3 \mathrm{~Sv}$ ).

In lid 2 van art. $244 \mathrm{~Sv}$ is bepaald dat de in het eerste lid genoemde termijn op verzoek van de officier van justitie door de rechtbank kan worden verlengd. Door het stellen van een termijn kwam de wetgever tegemoet aan de belangen van de verdachte, doch dit kon er ook toe leiden dat er van ongewenste spoed sprake was, hetgeen niet in het belang was van het openbaar ministerie. ${ }^{g i}$

De situatie kan zich bijvoorbeeld voordoen dat het gerechtelijk vooronderzoek is beëindigd maar de officier van justitie nog niet tot dagvaarden kan overgaan, omdat een belangrijke getuige-deskundige zich in het buitenland bevindt.

Art. 244 lid 2 Sv spreekt over een verlenging voor een bepaalde tijd. Naar mijn mening dient deze verlenging zo kort mogelijk te zijn. Lid 2 moet steeds als een uitzondering gezien worden op lid 1 . Het woord 'telkens' in lid 2 doet vermoeden dat de officier van justitie meerdere malen een verzoek om verlenging kan doen. Naar mijn mening mag dit niet vaker gebeuren dan strikt noodzakelijk is. Hoewel de wet niet uitdrukkelijk bepaalt dat de verdachte gehoord dient te worden (art.

87 MvT, pag. 112 en meer in het algemeen pag. 55: er moet naar een verzoening tussen tegenstrijdige belangen worden gestreefd. 
23 e.v. Sv) moet dit naar mijn mening wel gebeuren, omdat een dergelijke verlenging als een uitzondering gezien kan worden op de grondgedachte van de wetgever dat de verdachte niet in onzekerheid gelaten moet worden. De verdachte kan zich laten bijstaan door een raadsman (art. $24 \mathrm{~Sv}$ ), die kritiek kan laten horen op de termijn en de frequentie van de verlenging.

Ook hier blijft de mogelijkheid bestaan voor de verdachte om de rechter om beëindiging van de strafzaak te verzoeken (art. $36 \mathrm{~Sv}$ ).

De sluitingsprocedure met de daarbij behorende termijnstellingen overziend, kan de conclusie geen andere zijn dan dat deze bijzonder ingewikkeld en onduidelijk is. Deze mening is ook de Commissie herijking Wethoek van Strafvordering (voortaan te noemen de Cie. Moons) toegedaan." De commissie stelt in haar rapport voor de sluitingsprocedure van het gerechtelijk vooronderzoek sterk te vereenvoudigen. Als grond hiervoor voert zij onder andere aan dat de thans aan de niet-inachtneming van enkele, met betrekking tot de sluitingsprocedure in de wet opgenomen, vormvoorschriften verbonden rechtsgevolgen niet meer in een redelijke verhouding staan tot het belang dat door de betreffende vormvoorschriften wordt beschermd. ${ }^{*}$ De commissie bepleit een wettelijke procedure die zo weinig mogelijk vormvoorschriften bevat. Haar voorstellen, voor zover hier van belang, komen op het volgende neer:

- de sluiting van het gerechtelijk vooronderzoek door de rechter-commissaris is zowel voor de officier van justitie als de verdachte onherroepelijk (art. 237 lid 1). Hij sluit het onderzoek bij een beschikking, waarin de reden tot sluiting is genoemd, en laat deze toekomen aan officier en verdachte (art. 2.37 lid 2).

Dit voorstel biedt duidelijkheid over de aanvang van de termijn waarbinnen de officier zijn vervolyingsheslissing moet nemen;

- deze termijn wordt, in navolging van de reeds genoemde Termijnenwet verlengd tot twee maanden (art. 244 lid 1).

De commissie verwijst hierbij naar de in de $\mathrm{Mv} T$ aangevoerde argumenten. De commissie verwerpt uitdrukkelijk het vanwege het $O M$ gedane voorstel om geen enkele termijn op te nemen...$^{\infty}$ Dit zou de verdachte te lang in onzekerheid laten omtrent de vervolgingsheslissing. Verder zou afschaffing van een termijn het risico hebben van een extra vertraging van het strafproces omdat het OM de mogelijkheid geeft zijn tijd aan zwaardere strafzaken te besteden. Ook een eventuele procedure betreffende termijnstelling door de verdachte doet het proces onnodig vertragen;

Rapport van de Commissie herijking Wetboek van Strafvordering. Arnhem 1990; rie voor dit onderwerp in het bijzonder par. 8.3.

89 Rapport Cie. Moons, pag. 73.

90 Herijking Wetboek van Strafvordering. Rapport van de vergadering van resac-voorzitters van 23 maart 1988. TK 1987-1988, 19774, no. 5. 
na de sluiting van het gerechtelijk vooronderzoek kunnen zowel de officier van justitie als de verdachte zich tot de rechter-commissaris wenden met het verzoek nog voor de aanvang van de terechtzitting een bepaalde onderzoekshandeling te verrichten (art. 241).

Deze bepaling biedt tegenwicht aan de onherroepelijkheid van de sluiting van het gerechtelijk vooronderzoek. ${ }^{92}$

\subsubsection{Termijn voor de vervolgingsbeslissing na voorlopige hechtenis}

In tegenstelling tot de vervolgingsbeslissing die genomen wordt na het gerechtelijk vooronderzoek stelt de wet voor een dergelijke beslissing na toepassing van voorlopige hechtenis (zonder dat er een gerechtelijk vooronderzoek heeft plaatsgehad) wederom geen duidelijke termijn. We moeten hierbij denken aan de situatie dat er voorlopige hechtenis is toegepast tijdens het opsporingsonderzoek. Niet noodzakelijk is dat de verdachte zich nog in voorlopige hechtenis bevindt, maar art. $245 \mathrm{~Sv}$ is ook van toepassing als de verdachte inmiddels daaruit, hetzij definitief, hetzij onder voorwaarden is ontslagen." Art. 245 lid 1 Sv bepaalt dat de vervolgingsbeslissing wordt genomen 'zodra de zaak tot klaarheid is gebracht'. In vergelijking met art. $244 \mathrm{~Sv}$ biedt dit artikel de verdachte nog minder houvast. Het moment waarop de zaak tot klaarheid is gebracht is voor hem moeilijker te bepalen dan het moment waarop de beschikking tot sluiting van het gerechtelijk vooronderzoek voor hem onherroepelijk is geworden. Bovendien stelt art. $245 \mathrm{~Sv}$ geen strikte termijn vanaf het moment waarop de zaak tot klaarheid wordt gebracht, waarbinnen de vervolgingsbeslissing genomen moet worden.

Dit verschil is verklaarbaar wegens het verschil tussen het gerechtelijk vooronderzoek en het opsporingsonderzoek." Dit laatste staat onder leiding van de officier van justitie en hij is degene die bepaalt of en wanneer de zaak tot voldoende duidelijkheid is gebracht.

Om aan de onzekere positie van de verdachte een einde te maken wordt hem in lid 2 van art. $245 \mathrm{~Sv}$ de gelegenheid gegeven de rechter te verzoeken aan de officier van justitie een termijn te stellen waarbinnen deze zijn vervolgingsbeslissing moet nemen. De officier van justitie wordt daartoe gehoord (art. 23 lid 2 Sv). Hieruit zal

92 Commentaar op deze voorstellen van de Cie. Moons komt van Harteveld. Hij is van mening dat het, in vergelijking tot het huidige wetboek, moeilijker wordt voor de officier van justitie op een zorgvuldige wijze zijn vervolgingsbeslissing te nemen en voor de verdachte, om invloed op die beslissing uit te oefenen. A.E. Harteveld, Het Wetboek van Strafvordering en hel (gerechtelijk) vooronderzoek. Uit: D.R. Doorenbos en R.J. Verweij (red.), Hercodificatic Wetboek van Strafvordering, Nijmegen 1991; A.E. Harteveld, Het stelsel van strafvordering en het rapport van de Commissie Moons, DD 1991, pag. 565-591.

93 MvT bij het oorspronkelijke art. 248 (nu 245) Sv, pag. 113.

94 Vgl. Blok-Besier I, a.w., pag. 113. 
de rechtbank blijken hoe ver het onderzoek gevorderd is en hoeveel tijd de officier redelijkerwijs nog nodig heeft.

Overeenkomstig de leden 2 en 3 van het vorige artikel kan de officier van justitie um verlenging van de gestelde termijn verzoeken of $k a n$ hij op verzoek van de verdachte een langere termijn nemen voor het nemen van zijn vervolgingsbeslissing. Wordt alsnog een gerechtelijk vooronderzoek ingesteld dan vervalt de gestelde termijn (lid 5). Na sluiting van dit gerechtelijk vooronderzoek wordt de vervolgingsbeslissing genomen op grond van art. 244 Sv.

Op dit punt zijn door de Cie. Moons geen voorstellen gedaan.

Zelfs nadat er reeds een dagvaarding is uitgebracht kan de officier van justitie zijn vervolgingsbeslissing wijzigen in die zin dat hij van verdere vervolging afziet. Hij kan dit namelijk doen zolang het onderzoek op de terechtzitting nog niet is aangevangen (art. 242 lid 2 Sv). Art. 266 lid 1 Sv geeft de officier van justitie de mogelijkheid de dagvaarding in te trekken tot aan de aanvang van het onderzoek op de terechtzitting. ${ }^{95}$ Dit moet hij schriftelijk aan de verdachte meedelen. Tegelijkertijd of later kan hij een sepotbeslissing nemen, waarna hij de verdachte moet kennisgeven van niet verdere vervolging, art. 266 lid $3 \mathrm{~Sv}$. De rechtbank op vordering van de verdachte een termijn stellen, waarbinnen de officier deze kennisgeving aan de verdachte moet richten.

Ook hier kan de verdachte op grond van art. $36 \mathrm{~Sv}$ een verklaring uitlokken dat de zaak beëindigd is.

Ten aanzien van zowel de vervolgingsheslissing tijdens het gerechtelijk vooronderzuek, als van die na het gerechtelijk vooronderzoek, als van die na toepassing van voorlopige hechtenis geldt dat een kennisgeving van niet verdere vervolging door de officier van justitie niet genomen mag worden indien een klacht op grond van art. $12 \mathrm{~Sv}$ is ingediend, tenzij in de kennisgeving door het gerechtshof is bewilligd, met andere woorden: tenzij het hof de klacht over het niet-vervolgen heeft verworpen (art. 240 lid 1 en art. 246 lid $3 \mathrm{~Sv}$ ). Als gevolg hiervan kan de termijn waarbinnen de vervolgingsbeslissing genomen dient te worden overschreden worden.

\subsubsection{Termijnoverschrijding}

De sanctie op het laten verlopen van de termijn waarbinnen de officier van justitie zijn vervolgingsbeslissing moet nemen, is ingrijpend. Deze staat gelijk met het rechtsgevolg dat de wet verbindt aan een buitenvervolgingstelling, een kennisgeving van niet verdere vervolging of een verklaring dat de zaak beëindigd is. De verdachte kan ten aanzien van hetzelfde feit niet opnieuw in rechte worden betrokken, tenzij nieuwe bezwaren bekend zijn geworden: art. 255 lid 4 Sv. In beginsel is de zaak hiermee beëindigd. Uit hetzelfde lid blijkt dat deze sanctie echter niet absoluut werkt,

95 Er kan niet meer worden geseponecrd na aanwang van de zitting, omdat de zaak dan in handen ligt van de rechter. 
herstel is mogelijk. Indien het algemeen belang dit dringend vraagt kan het gerecht, waarbij de zaak het laatst werd vervolgd, op vordering van de officier van justitie alsnog eénmaal een nieuwe termijn stellen. ${ }^{6}$ Achtergrond voor invoering van deze mogelijkheid tot herstel is geweest dat anders, als gevolg van een te ver doorgevoerd formalisme, een gevaarlijke misdadiger vrij zou kunnen blijven rondlopen. ${ }^{97}$ Ook de ernst van het feit, ten aanzien waarvan de verdenking bestaat, kan reden zijn tot het stellen van een nieuwe termijn." Het lijkt mij niet juist het algemeen belang, op grond waarvan het stellen van een nieuwe termijn dringend vereist is, alleen te laten bepalen door de zwaarte van het feit waarvan verdenking bestaat. Het tegendeel zou betekenen dat een officier van justitie bij de vervolging van bijvoorbeeld doodslag minder 'termijngebonden' is dan bij bijvoorbeeld diefstal, terwijl een verdachte van doodslag er wellicht meer behoefte aan heeft zo spoedig mogelijk op de hoogte te zijn van de resultaten en de verdere gang van het onderzoek.

De verdachte wordt naar aanleiding van de vordering van het $\mathrm{OM}$ tot een nieuwe termijn, in de gelegenheid gesteld te worden gehoord. Hij mag zich hierbij laten bijstaan door een raadsman (art. 24 lid 1 Sv) die de gelegenheid heeft de nodige opmerkingen te maken (art. 24 lid 3 Sv).

De termijnoverschrijding, zoals bedoeld in lid 4 van art. $255 \mathrm{~Sv}$ wordt niet aanwezig geacht indien de officier van justitie tijdig een dagvaarding om ter terechtzitting te verschijnen heeft uitgebracht (lid 5). Deze dagvaarding kan dan weer ingetrokken worden, waarbij ogenblikkelijk een kennisgeving van niet verdere vervolging moet volgen. Hiervoor zagen we reeds dat de officier van justitie een tijdslimiet gesteld kan worden voor het aan de verdachte kennis geven van niet verdere vervolging. Bij overschrijding is art. 255 Sv van toepassing, zodat ook hier in beginsel door overschrijding van de termijn de zaak beëindigd is.

De sanctie op termijnoverschrijding blijft in de voorstellen van de Cie. Moons dezelfde als in de huidige wet (art. $255 \mathrm{~Sv}$ ).

\subsection{Bekendmaking van de vervolgingsbeslissing}

Van een kennisgeving van niet verdere vervolging doet de officier van justitie de verdachte kennisgeven, art. 244 en 245 lid 1 Sv. Onduidelijk was of de wet ten aanzien van deze mededelingen betekening vereist. Uit art. 585 lid 1 en 2 zou kunnen worden afgeleid dat volstaan kan worden met toezending van een gewone of aangetekende

96 Dc officicr van justitie kan een dergelijke vordering nog doen na een buitenvervolgingstciling na een bezwaarschriftprocedure, HR 4 oktober 1988, NJ 1989, 392 m.nt. ThWvV.

97 Vgl. de eerste Nota van Wijzigingen, toclichting bij de nieuwe leden van art. 256 (nu 25.5) Sv.

98 HR 26 november 1974, NJ 1976, 36 m.nt. ALM. 
brief bij post. Lid 3 van datzelfde artikel bepaalt evenwel dat dagvaardingen en aanzeggingen die aan het $\mathrm{OM}$ zijn opgedragen steeds betekend worden.

In de reeds meerdere malen genoemde Termijnenwet wordt dit probleem opgelost in de vorm van een nieuw art. 245a Sv: Kennisgevingen van verdere vervolging en van niet verdere vervolging worden aan de verdachte betekend.

Verder zij hier vermeld dat betekening geschiedt door uitreiking van een gerechtelijk schrijven aan het huis van de verdachte (art. $586 \mathrm{~Sv}$ ). ${ }^{\infty}$

Ten aanzien van het informeel sepot is niet voorgeschreven dat dit aan de verdachte moet worden bekendgemaakt, laat staan hoe dat in zijn werk zou moeten gaan. Ten aanzien van een strafbaar feit, waarbij de betrokkene niet op de hoogte is van de tegen hem bestaande verdenking, lijkt mij dit ook niet zo noodzakelijk.

Deze noodzaak is volgens mij wel aanwezig indien de verdachte wel weet heeft van een verdenking jegens hem, bijvoorbeeld doordat er tegen hem proces-verbaal is opgemaakt, hij door de politie is verhoord of in verzekering is gesteld. Door het achterwege laten van een sepotmededeling blijft hij in onzekerheid verkeren omtrent een eventuele vervolging.

\subsection{Motivering van een sepot}

Indien de officier van justitie tot een technisch sepot komt na een gerechtelijk vooronderzoek of nadat voorlopige hechtenis is toegepast, dient hij de grond van niet verdere vervolging in de kennisgeving van niet verdere vervolging te vermelden. In art. 247 Sv worden achtereenvolgens genoemd:

a. onbevoegdheid van de rechtbank tot kennisneming van het feit;

b. vereniging met een strafzaak welke voor een andere rechtbank in onderzoek is;

c. niet-ontvankelijkheid van de officier van justitie;

d. niet-strafbaarheid van het feit of van de verdachte;

e. onvoldoende aanwijzing van schuld.

Ten aanzien van een beleidssepot bestaat er voor het OM geen motiveringsplicht. Wel wordt de grond voor het sepot intern geadministreerd. Om tot een grotere uniformiteit en inzichtelijkheid in het sepotbeleid te komen heeft men in 1980 binnen het $O M$ de sepotgronden gerubriceerd. Indien een officier van justitie in een bepaalde zaak van vervolging afziet, moet hij in het dossier, door het nummer van de betreffende sepotrubriek te vermelden, aangeven op welke grond hij dat doet. Hij wordt op die manier dus 'gedwongen' tot een hewuste sepotkeuze. ${ }^{100}$

99 Zie voor verdere formaliteiten art. 587 Sv e.v.

100 Vgl. Jaarverslag OM 1986, pag. 6-7. 
Gronden die leiden tot de niet-haalbaarheid van de vervolging zijn (tussen haakjes is het nummer van de betreffende sepotrubriek vermeld):

- iemand is ten onrechte als verdachte aangemerkt (01);

- er is geen of onvoldoende wettig hewijs (02);

- het OM is niet-ontvankelijk (03);

- de burgerlijke strafrechter is niet bevoegd (04);

- het feit is niet strafbaar (05);

- de dader is niet strafbaar (06).

Gronden die kunnen leiden tot een beleidssepot zijn:

- gronden die samenhangen met maatregelen genomen of nog te nemen door anderen dan de officier van justitie;

- ander dan strafrechtelijk ingrijpen prevaleert (20);

- civielrechtelijke jeugdmaatregel (21);

- strafrechtelijke jeugdmaatregel (22);

- TBS (23).

Gronden die samenhangen met de algemene rechtsorde:

- landsbelang (30);

- wetswijziging (31);

- onvoldoende nationaal belang (32).

Gronden die samenhangen met het gepleegde feit:

- gering feit (40);

- gering aandeel in feit (41);

- geringe strafwaardigheid van het livit;

- oud feit (43);

- maatschappelijk belangenconflict (44).

Gronden die samenhangen met de persoon van de verdachte:

- leeftijd (50);

- gezondheidstoestand (51);

- recente bestraffing (52);

- dader is zelf door het feit getroffen (53);

- reclasseringsbelang (54);

- gewijzigde omstandigheden (55);

- verdachte onvindbaar (56). 
- verhouding tot benadeelde geregeld (70);

- medeschuld benadeelde (71);

- vervolging is in strijd met het belang van de benadeelde (72);

- kring (waarin zich het strafbaar feit heeft voorgedaan is) gering (73);

- civielrecht (74).

Deze rubricering van sepotgronden geeft geen garantie dat, indien zich een van de genoemde omstandigheid voordoet, niet tot vervolging zal worden overgegaan. De officier van justitie mag er van afwijken. De lijst is bedoeld voor intern gebruik. De verdachte kan er geen rechten aan ontlenen. Wel kan hij (of zijn raadsman), wanneer hij vervolgd wordt, de officier van justitie op een informele manier nog eens nadrukkelijk wijzen op omstandigheden die naar zijn oordeel tot een sepot zouden moeten leiden.

Zoals vermeld heeft de registratie van de sepotgrond slechts de bedoeling van intern gebruik. Dat wil echter niet zeggen dat de betrokkene geen belang kan hebben bij een juiste registratie van de sepotgrond in zijn strafzaak. Een voorbeeld hiervan is een klacht bij de Nationale Ombudsman (rapport 88/229). Deze oordeelde dat de officier van justitie niet mag seponeren op grond van 'geen wettig bewijs' (sepotgrond 02 ) indien in werkelijkheid de verdachte 'ten onrechte als verdachte was aangemerkt' (sepotgrond 01).

\subsection{OM als beleidvoerend orgaan ${ }^{\text {101 }}$}

Als slot van deze paragraaf over het onvoorwaardelijk sepot wil ik enige opmerkingen maken over het $\mathrm{OM}$ als beleidvoerend orgaan, omdat dit van belang is voor een goed begrip van de nog te behandelen afdoeningsmethoden.

Door de beschreven wijziging in de hantering van het vervolgingsrecht is het OM in staat een gericht vervolgingsbeleid te voeren. ${ }^{102}$ Het is hiertoe trouwens ook gedwongen, omdat anders rechtsongelijkheid en willekeur de kop op zouden kunnen steken. Dit vervolgingsbeleid is gericht op de handhaving van het geldend recht,

101 Zie voor de ontwikkeling van het $\mathrm{OM}$ als belcidvoerend orgaan de verschillende jaarverslagen van het OM, met name het jaarverslag over 1988, dat als titel meckreeg: Het Openbaar Ministerie in zijn bestuurlijke omgeving. Zie voor cen uitgebreide weergave van de betreffende jaarverslagen: P. Osinga, Transactie in strafzaken, Arnhem 1992, Hoofdstuk 2.

102 In bet Jaarverslag OM 1968 zien we voor de eerste maal een kopje: vervolgingsbeleid. Hierbij wordt vermeld dat aandacht wordt geschonken aan de coürdinatie. Ook het jaarverslag OM 1970 meldt dat gestreefd is naar gerichte beleidswering, vooral op het terrein van de vervolging, pag. 41. 
waartoe de strafrechtshandhaving een van de middelen is. Kernbegrippen van het voeren van een vervolgingsbeleid zijn: coördinatie en eenheid in de uitvocring. Dit heeft onder meer gevolgen gehad voor de interne organisatie. Het beleid wordt besproken in parketvergaderingen, ressortvergaderingen en de vergadering van de procureurs-generaal. Deze laatsten vergaderen eens per veertien dagen, voorgezeten, namens de minister van Justitie, door de secretaris-generaal. In deze vergadering van de procureurs-generaal vindt de beleidsbepaling op landelijk niveau plaats, wairin de lijnen van de parketten en ressorts samenkomen. ${ }^{103}$ Naast deze verticale overlegstructuur bestaat er ook horizontaal overleg, bijvoorbeeld tussen milieu- of drugsofficieren. Daarnaast kent men binnen het $\mathrm{OM}$ allerlei adviescommissies en nemen leden van het $\mathrm{OM}$ deel aan commissies buiten het $\mathrm{OM}$.

Omdat vervolging niet meer de enig mogelijke reactie is op ongewenst gedrag, maar een van de middelen is die het OM (en anderen die belast zijn met ordehandhaving, bijvoorbeeld de burgemeester) ter beschikking staan om hierop te reageren, is tevens extern overleg noodzakelijk. Afstemming van de inzet van opsporingscapaciteit ten behoeve van de handhaving van de openbare orde, een taak van het bestuur, noopt ook tot overleg. Daarom wordt er regelmatig vergaderd met andere bestuursorganen, waarvan het zogenaamde driehoeksoverleg tussen (hoofd-)officier van justitie. burgemeester en korpschef van de politie wellicht het meest bekende voorbeeld is. Dit driehoeksoverleg vindt ook in regional verband plaats. ${ }^{104}$ In de loop der jaren heeft deze vorm van overleg aan importantie gewonnen, niet in de laatste plaats omdat de hehoefte is ontstaan de in het driehoeksoverleg gemaakte afspraken vast te leggen als beleidsafspraken. In de Politiewet heeft deze overlegvorm dan ook een wettelijke basis gekregen in art. $37 .{ }^{105}$ Verder bestaan er overlegvormen met andere ministeries en de daaronder ressorterende opsporingsdiensten, met de provincies en hun uitvoeringsorganen, met de gemeenten en met de regionale of interregionale bestuurlijke samenwerkingsverbanden. ${ }^{100}$

Hiervoor zagen we dat lang niet alle wetsovertredingen worden vervolgd. Een oorzalak hiervan is dat vervolging lang niet altijd meer gewenst is. Vervolging is bovendien feitelijk ook lang niet altijd mogelijk, gezien het grote aantal gepleegde stratbare feiten. Dit afzien van vervolging betreft vaak overtredingen. $0 \mathrm{~m}$ in de hantering van het vervolgingsrecht eenstemmigheid te krijgen en om opsporing en vervolging

103 Jaarverslag OM 1985, pag. 68.

104 Zie over de ontwikkeling en het functioneren van het driehoeksoverleg uitgebreider: Jaarverslag

OM 1988, Het Openbaar Ministeric in zijn bestuurlijke omgeving, pag. 18-22.

105 Wet van 14 december 1988, Stb. 576.

$106 \mathrm{Vgl}$. Jaarverslag OM over 1988, Het Openbaar Ministerie in zijn bestuurlijke omgeving, pag. 13. 
op elkaar af te stemmen ${ }^{107}$ is het noodzakelijk dat het te volgen beleid wordt vastgelegd.

Dit heeft voor het OM geleid tot het opstellen van tal van opsporings- vervolgingsen requireerrichtlijnen. ${ }^{108}$ Aanvankelijk waren deze richtlijnen in beginsel niet openhaar, omdat gevreesd werd dat bij de bevolking de indruk zou worden gewekt dat men straffeloos de betreffende bepalingen zou kunnen overtreden. ${ }^{100}$ Later worden de meeste richtlijnen door het OM zelf gepubliceerd. In een in 1990 gewezen arrest heeft de Hoge Raad de uitspraak gedaan dat een dergelijke vervolgingsrichtlijn gezien kan worden als recht in de zin van art. 99 RO, HR 19 juni 1990, NJ 1991, 119 m.nt. ThWvV en MS. Over de status van (gepubliceerde) richtlijnen en de gebondenheid eraan van het $O M, k o m$ ik later (Hoofdstuk 10 par. 2.3.9) nog uitgebreid te spreken.

\section{Politiesepot}

\subsection{Inleiding}

Hiervoor zagen we dat het OM niet ieder gepleegd delict vervolgt, maar dat het een vervolgingsbeleid voert waarbij wordt aangegeven welk feit en onder welke omstandigheden wel of niet vervolgd wordt. Dit beleid is geen vaststaand gegeven. Het kan naar tijd en plaats verschillen. Ook zagen we dat het vervolgingsbeleid van het $\mathrm{OM}$ belangrijke consequenties heeft voor de opsporingstaak van de politie. De opsporing en verbalisering van strafbare feiten zal afgestemd dienen te zijn op het vervolgingsbeleid van het $\mathrm{OM}$, hetgeen concreet inhoudt dat de politie bepaalde overtredingen niet opspoort en/of verbaliseert.

Door een toename van het aantal strafbare feiten en een beperking van de financiële middelen is de werkdruk van de politie enorm gestegen ${ }^{1{ }^{10}} \mathrm{Dit}$ heeft als gevolg gehad

107 Het zal duidelijk zijn dat er bij de opsporingsdiensten, voornamelijk de politie, ongenoegen en frustratie zal ontstaan als het OM steeds weer opgespoorde feiten seponeert (Jaarverslag OM 1975, pag 8), om nog maar niet te spreken over de geldverspilling die hiervan het gevolg is. Om dit te ondervangen moet veekuldig overleg plaatsvinden tussen het $\mathrm{OM}$ en de politie, om het opsporingsen verbaliseringsbeleid af te stemmen op het vervolgingsbeleid. Dit overleg vindt globaal plaats in het driehoeksoverleg (waar bijwoorbeeld ook gesproken kan worden over de inzet van mankracht), maar krijgt concreter vorm in opsporingsrichtlijnen. Het OM dient op encigerlei wijze vat te hebben op het opsporingsbeleid, om zo een sturende invloed te kunnen hebben op de instroom van strafbare feiten.

108 Zie uitgebreider over deze richtlijnen en de daarmee samenhangende onderwerpen: H.G. van de Bunt, J.F.L. Roording en MJ.M, Verpalen (red.), Richtlijnen van het Openbaar Ministerie, Nijmegen 1993.

109 Jaarverslag 1971 , pag. 8.

110 Zie het rapport over het project kwantificering politiewerk (PKP). Dit rapport vormt de neerslag van bij de politie uitgevoerde werkdrukmetingen. Zie uitgebreider: Jaarverslag OM 1988, pag. $22-23$. 
dat de politie eenvoudig niet meer in staat is alle strafbare feiten op te sporen en daarvan een proces-verbaal op te maken. Er dienen keuzes gemaakt te worden. Als gevolg van deze ontwikkelingen is onder andere het politiesepot ontstaan. Een ander gevolg was de praktijk van de politietransactie. Dit komt in het volgende hoofdstuk aan de orde.

In de literatuur en jurisprndentie wordt de vraag besproken of de politie deze bevoegdheid tot seponeren eigenlijk wel heeft en waarop deze gebaseerd zou zijn. De volgende vraag is hoe deze zich verhoudt tot die van het OM.

Alvorens hierop in te gaan is het belangrijk de inhoud van het hegrip te hepalen.

\subsection{Begripsbepaling}

Tot een duidelijke begripsbepaling te komen is niet eenvoudig. Door meerdere auteurs worden verschillende definities gegeven.

Peijster verstaat onder een politiesepot de beslissing tot het niet voortzetten van het opsporingsonderzoek, het niet opmaken van een proces-verbaal ofwel het opleggen van een proces-verbaal, steeds ter zake van een misdrijf."

De Doelder en 't Hart betrekken het politiesepot op de vraag in hoeverre van een opgespoord delict proces-verbaal moet worden opgemaakt en ten parkette ingestuurd. ${ }^{12}$

Schalken daarentegen vindt het typologisch onjuist de vraag of de politie sepotbevoegdheid heeft afhankelijk te stellen van de vraag of zij bevoegd is zelf te beslissen over het al dan niet opmaken van een proces-verbaal. Volgens hem bestaat het politiesepot uit het achterwege laten van opsporingshandelingen. Weliswaar wordt het verloop van opsporingsactiviteiten vastgelegd in een proces-verbaal, maar daarmee kan het opmaken daarvan niet als een opsporingshandeling worden aangemerkt. Het proces-verbaal is een middel om het $\mathrm{OM}$ in te lichten over strafbare feiten op grond waarvan het $\mathrm{OM}$ een vervolgingsbeslissing kan nemen. ${ }^{\text {II3 }}$

Volgens Van der Molen-Maesen is het politiesepot een ruim begrip. Zij ziet verschillende verschijningsvormen van het politiesepot:

1. de politie constateert een strafbaar feit, maar maakt daarvan geen proces-verbaal op. Dit kan betekenen dat de politie helemaal niet reageert of dat doet op een andere wijze dan het opmaken van een proces-verbaal, bijvoorbeeld door het geven van een waarschuwing;

111 C.N. Peijster, Het politic̈le sepot, TvdP 1964, pag. 97.

112 H. de Doelder en A.C. 't Hart, Verbaliseringsbeleid en opportuniteitsbeginsel, DD 1976, pag. 204.

113 T.M. Schalken, Het politiesepot en de mandaatsverhouding tussen openbaar ministerie en politie, Trema 1984, pag. 3. 
2. de politie neemt de aangifte op van een strafbaar feit maar onderneemt verder geen opsporingsactiviteiten;

3. een strafbaar feit wordt geconstateerd, na de aangifte volgt een summier opsporingsonderzoek en wordt een summier proces-verbaal opgemaakt. ${ }^{114}$

Het jaarverslag van het $O M$ van 1983 onderneemt een poging een invulling te geven aan het begrip 'politiesepot'. Geconstateerd wordt dat het moeilijk is het begrip af te bakenen, omdat er geen scherp onderscheid ligt tussen het handelen en niet-handelen van de politie. In veel gevallen zal de politie op strafbaar gedrag niet reageren of reageren op een andere manier dan het opmaken van een proces-verbaal, zoals het negeren van overtredingen of volstaan met het geven van een waarschuwing, het niet-verrichten van opsporingshandelingen in een vermoedelijke fraudezaak wegens capaciteitsproblemen of het niet-opnemen van aangiften op het politiebureau. Men noemt dit het "voorterrein" van het politiesepot. Van een eigenlijk politiesepot is pas sprake in het geval wel een aangifte wordt opgenomen of enige opsporingsactiviteiten worden verricht, doch verdere opsporingshandelingen achterwege blijven en het OM niet door middel van een proces-verbaal wordt geïnformeerd. ${ }^{115}$ In het Jaarverslag van het OM over 1986 wordt als een politiesepot aangemerkt het afzien van het opmaken van proces-verbaal. Dit wordt veelal vergezeld van een mondelinge of schriftelijke waarschuwing. In datzelfde jaarverslag wordt overigens vermeld dat deze vorm van afdoening in vrijwel het hele land ingang heeft gevonden. ${ }^{116}$

Van Rooyen-de Wit hanteert de begripsbepaling zoals die tot uitdrukking komt in de verschillende aanwijzingen aan de politie afkomstig van de arrondissementsparketten:

"de beslissing, door de politie genomen, om in een strafzaak tegen een strafrechtelijk meerderjarige, waarin een opsporingsonderzoek heeft plaatsgevonden, te volstaan met het summier vastleggen van het resultaat daarvan en het mededelen aan de verdachte dat geen strafvervolging zal worden ingesteld".177

Bij de verdere behandeling van dit onderwerp ga ik uit van een ruim begrip 'politiesepot'. Hieronder versta ik dan het niet verrichten van opsporingshandelingen wanneer er een vermoeden is van een strafbaar feit, het niet opmaken van een proces-verbaal bij de constatering van een strafbaar feit, en het niet doorsturen van een reeds opgemaakt proces-verbaal aan het OM. Dit begrip sluit naar mijn mening het best aan bij het begrip zoals dat in de jurisprudentie gehanteerd wordt.

114 P.M.H. van der Molen-Maesen, OM en politiesepot. TvdP 1984, pag. 1.

115 Jaarverslag OM 1983, TK 1984-1985, 18600, hoofdstuk VI, par. 3.

116 Jaarverslag OM 1986, pag. 6.

117 C.M. van Rooyen-de Wit, Wic is er eigenlijk nog bang voor het politiesepot? TvdP 1987, nr.1, pag. 6-13. Een zelfde betekenis wordt aan dit begrip gegeven door J.H.C. van Rijn, Politiesepot: een uitkomst woor het Openbaar Ministerie of voor de politic? TvdP 1983, pag, 621-625. 


\subsection{Rechtsgrond}

Een uitdrukkelijke wettelijke grondslag voor het politiesepot ontbreekt. Uit verschillende wettelijke bepalingen leiden sommige auteurs af dat met betrekking tot de politie het legaliteitsbeginsel van toepassing zou zijn: art. 141 Sv: opsporingsambtenaren zijn belast met de opsporing van strafbare feiten, art. $152 \mathrm{~Sv}$ : zij maken procesverbaal op, art. $155 \mathrm{~Sv}$ : de hulpofficieren doen de p-v's toekomen aan de officier van justitie. ${ }^{118}$ Begrijp ik het goed, dan bedoelen zij dat er, om in bestuursrechtelijke termen te spreken, geen sprake is van een vrije maar van een gebonden bevoegdheid. Er zou geen ruimte zijn voor een eigen invulling.

In de praktijk van de strafrechtspleging echter wordt het politiesepot toelaatbaar geacht en veelvuldig gehanteerd.

Reeds in het zogenaamde Broodjeswinkel-arrest (31 januari 1950, NJ 1950, 668 m.nt. Pompe) heeft de Hoge Raad het politiesepot gesanctioneerd.

Een agent van politie heeft overtreding geconstateerd van de Beschikking Broodjeswinkels 1946. De agent laat na van deze overtreding proces-verbaal op te maken, in ruil voor het ontvangen van een geldbedrag. De agent wordt vervolgd ter zake van overtreding van art. $363 \mathrm{Sr}$. Hij zou gehandeld hebben in strijd met zijn rechtsplicht die voortvloeit uit art. $152 \mathrm{~Sv}$ (het ten spoedigste opmaken van een procesverbaal na de constatering van een strafbaar feit). Namens verdachte wordt aangevoerd dat het nalaten van het opmaken van een proces-verbaal door een opsporingsambtenaar in gevallen van betrekkelijke betekenis, zoals in het onderhavige geval, niet in strijd is met de plicht van die ambtenaar. A-G Langemeyer beroept zich op de gangbare praktijk, op grond waarvan hij concludeert dat een rechtsplicht niet aan te nemen is. De opsporingsambtenaar dient zich volgens de $A-G$, wanneer hij overweegt het opmaken van een proces-verbaal na te laten, te richten naar het oordeel van de bevoegde organen van het $\mathrm{OM}$, zoals hij die kent of redelijkerwijs behoort te kennen. De Hoge Raad overweegt dat een proces-verbaal moet worden opgemaakt als dit de normale gang van zaken is, als dit tevens de normale gedragslijn van de opsporingsambtenaar in bovengenoemde situatie is en als deze gedragslijn bovendien overeenkomt met de opdrachten en visie van de corpsleiding en de officier van justitie. Opgemerkt moet worden dat de A-G criteria ontwikkelde met betrekking tot het nalaten van het opmaken van een proces-verbaal (meer negatief), terwijl de Hoge Raad criteria geeft voor het wel opmaken van een proces-verbaal (meer positief). Pompe prefereert, in zijn noot onder het arrest, de opvatting van de Hoge Raad. Het opmaken van een proces-verbaal na de constatering van een strafbaar feit is niet zonder meer als regel verplicht.

Ook na dit arrest blijft deze kwestie aanleiding tot discussie geven.

Melai c.s. zijn, in tegenstelling tot Pompe, van oordeel dat de door A-G Langemeyer gegeven maatstaf voor de toepassing van het opportuniteitsbeginsel met betrekking

118 Zie noot Pompe onder arrest Hoge Raad 31 januari 1950, NJ 1950, 668; Melai c.s., aant. 3 bij art. $141 \mathrm{~Sv}$. 
tot de opsporing voorkeur verdient boven het door de Hoge Raad ontwikkelde criterium, omdat de formulering van de A-G meer in overeenstemming is met het opportuniteitsbeginsel zoals neergelegd in artikel $167 \mathrm{~Sv} .{ }^{119}$ Overigens vinden zij het politiesepot alleen toelaatbaar, indien duidelijk is ten aanzien van welk feit van (verdere) opsporing wordt afgezien. Bij zodanige twijfel dat de aard en de ernst van het delict zich niet aannemelijk in de voorlopige gegevens aftekenen, zal afzien van (verdere) opsporing ontoelaatbaar zijn. ${ }^{120}$

Politiecommissaris Peijster ziet voor de praktijk niet veel verschil tussen de opvatting van A-G Langemeyer en die van de Hoge Raad naar aanleiding van het Broodjeswinkel-arrest. Het binden van de opsporingsambtenaar aan het - meestal veronderstelde oordeel van het openbaar ministerie (zoals Langemeyer doet) behoeft in zijn uitwerking niet veel anders te betekenen dan de 'krachtens opdracht gevolgde gedragslijn' van de Hoge Raad. Volgens Peijster is de bestaande praktijk van politieel sepot in strijd met de wet. Hieraan moet zo snel mogelijk een einde worden gemaakt door de feite-lijk bestaande bevoegdheid van de politie om te seponeren een wettelijke basis te verschaffen. Een dergelijke wettelijke erkenning zal naar zijn mening de problemen waarvoor de individuele politie-ambtenaar zich ziet gesteld niet verminderen. Van meer belang is het derhalve nadere instructies te ontvangen. Dit zou bovendien de uniformiteit van de rechtsbedeling bevorderen. ${ }^{121}$

De Doelder en 't Hart baseren een uitbreiding van het opportuniteitsbeginsel van de vervolgings- naar de opsporingsfase op zowel praktische als theoretische gronden. Doordat de politie niet in staat is alle strafbare feiten op te sporen, zullen hierbij prioriteiten moeten worden gesteld. Zowel bij het verbaliseren, na de opsporing, als bij de overgang van opsporings- naar vervolgingsfase bestaat ruimte voor opportuniteitsoverwegingen. Voor wat betreft de meer theoretische grond zoeken zij aansluiting bij de ontwikkeling van het opportuniteitsbeginsel van art. $167 \mathrm{~Sv}$. Niet meer van belang is of een gedraging juridisch kwalificeerbaar is, maar wat er met een eventuele juridische kwalificatie kan worden bereikt. Conclusie: het opportuniteitsbeginsel geldt zowel voor de vervolgings-als de opsporingsfase, het dient positief te worden uitgelegd en het betreft zowel misdrijven als overtredingen. ${ }^{12}$ Begrijp ik het goed, dan bedoelen zij dat de positieve invulling van het opportuniteitsbeginsel door het $\mathrm{OM}$ als het ware overgedragen wordt naar de politie.

Deze 'rechtvaardigingen' van het politiesepot komen mij eerlijk gezegd ietwat geforceerd over. Dit is naar mijn idee niet nodig indien we de mandaatfiguur uit het bestuursrecht op de verhouding OM-politiesepot toepassen. In het Wetsvoorstel Aiınvulling van de Algemene wet bestuursrecht (Derde tranche Algemene wet be-

119 Hierbij dient bedacht te worden dat over de wijze van uitleg van dit artikel verschillen van mening bestaan, zie vorige paragraat.

120 Melai c.s., Het Wetboek van Strafvordering, aant. 3 bij art. 141 Sv.

121 C.N. Peijster, Het politiële sepot. TvdP 1964, pag. 97-101.

122 H. de Doelder en A.C. 't Hart, Verbaliseringsbeleid en opportuniteitsbeginsel, DD 1976, pag. 206207. 
stuursrecht) ${ }^{12}$ is een regeling over het mandaat opgenomen..$^{12}$ Volgens de MvT bij dit voorstel kan de voorgestelde regeling in hoge mate worden beschouwd als neerslag van geldend recht. ${ }^{125}$ Onder mandaat wordt in het voorstel verstaan: de bevoegdheid om in naam van een bestuursorgaan besluiten te nemen, art. 1A.1.1.1. ${ }^{126}$ De mandaatverlener blijft derhalve de verantwoordelijkheid voor de bevoegdheidsuitoefening behouden. Dit blijkt ook uit art. 1A.1.1.6 waarin expliciet de bevoegdheid van de mandaatverlener staat om terzake van de uitoefening van de gemandateerde bevoegdheid zowel algemene als bijzondere aanwijzingen te geven. De mandaatgever zelf blijft bevoegd de gemandateerde bevoegdheid uit te oefenen, art. 1A.1.1.7. In tegenstelling tot de figuur van delegatie behoeft mandaat niet te berusten op een wettelijke grondslag.

Betoogd wordt wel dat de overdracht van de sepotbevoegdheid van het OM naar de politie in strijd komt met art. $1 \mathrm{~Sv}^{127}$ In deze wijze van afhandeling van strafbare feiten door de politie heeft de wet volgens deze theorie niet voorzien. Het politiesepot is immers een in de praktijk ontstane werkwijze.

Wanneer we er echter van uit gaan dat de uiteindelijke verantwoordelijkheid blijft liggen bij het $O M$, zoals dat in een mandaatsverhouding het geval is, zal van strijd met art. $1 \mathrm{~Sv}$ geen sprake zijn. Deze ondergeschiktheid aan het $O M$ is op zich niets bijzonders, daar deze ook in andere wettelijke bepalingen voorkomt. In de uitoefening van haar bevoegdheden is de politie ondergeschikt aan het OM, zoals blijkt uit de artt. 28 en 41 van de Politiewet en art. $148 \mathrm{~Sv}$. Het OM is bevoegd aan de politie algemene en bijzondere aanwijzingen te geven. Dit geldt ook voor het te volgen opsporings- en verbaliseringsbeleid. ${ }^{1.8}$ Het politiesepot kan dan beschouwd worden als een afgeleide van het beleidssepot door het $\mathrm{OM}$. Het $\mathrm{OM}$ blijft zelf verantwoordelijk voor de hantering van de sepotbevoegdheid. De politie oefent deze bevoegdheid uit in ondergeschiktheid aan het bevoegd gezag, het $\mathrm{OM} .{ }^{10}$ Een nadere theoretisch-

123 Ingediend op 29 april 1994, TK 1994-1995, 23.700.

124 Zie hierover onder andere: F.H. van der Burg, Mandaat en delegatic, NTB 1992, nr. 8, pag. 268-275;

125 Hoe dit geldend recht zich heeft ontwikkeld wordt door Van der Burg omschreven in het in de vorige noot genoemd artikel.

126 Zie voor commentaar op de tekst van het Voorontwerp: W. Konijnenbelt, Hoofdstuk 2 Attributie, delegatie en mandaat in de Algemene wet bestuursrecht. Uit: W. Konijnenbelt (red.) De derde tranche, Alphen aan den Rijn 1992, pag. 6-22, m.n. pag. 13.

127 Zie bijvoorbeeld S.R.B. Walther, Een wcttelijke regeling voor het politiesepot,127 TvdP 1987, nr. 6, pag. 264-270.

128 Schalken spreekt van een mandátswerhouding tussen OM en politic. Een orgatan (het OM) verleent machtiging een bevoegdhcid door een ander orgaan (de politic) te laten uitoefenen, waarbij het orgaan dat de machtiging verleent zelf verantwoordclijk bljft voor de hantering ervan. T.M. Schalken, Het politiesepot en de mandaatsverhouding tussen openbaar ministerie en politie, Trema 1984, pag. 3-13.

$129 \mathrm{Vgl}$. T.M. Schalken, Het politiesepot en de mandaatsverhouding tussen het openbaar ministeric en de politie, Trema 1984, afl. I/2, pag. 3-13. 
juridische onderbouwing in de vorm van een wettelijke regeling lijkt mij derhalve niet nodig.

Tot zover de theoretische fundering van het politiesepot. Hoe werkt dit door in de praktijk?

Hiermee zijn we beland op het vraagstuk over de verhouding tussen OM en politie bij de concrete toepassing van het politiesepot.

\subsection{Verhouding tussen $O M$ en politie bij de toepassing van het politiesepot ${ }^{130}$}

Nadat de Hoge Raad in het Broodjeswinkelarrest had beslist dat de politie een bepaalde vrijheid heeft om zelf te beslissen al dan niet een proces-verbaal op te maken, bleef de vraag bestaan welke voorwaarden hiervoor moesten worden ontwikkeld. Vanaf de zestiger jaren kwam de discussie over het politiesepot in een breder verband te staan: wie heeft de leiding over de opsporing van strafbare feiten, de politie of het $\mathrm{OM} ?^{131}$ Hierbij kan naar twee kanten toe worden geredeneerd. ${ }^{132}$ (1) Het politiesepot wordt wettelijk gefundeerd met wettelijke gegarandeerde beleidsruimte voor de politie; het OM speelt geen of een ondergeschikte rol bij de concrete opsporing en het opsporingsbeleid; (2) Het OM krijgt zeggenschap en/of leiding over het opsporingsbeleid.

Uiteindelijk is voor de tweede visie gekozen en is de bestaande gezagsverhouding in de nieuwe Politiewet (1988) gehandhaafd. Hiermee is de mandaatsverhouding tussen politie en OM bevestigd. Fijnaut is het hiermee niet eens. Hij toont zich voorstander van toekenning van de nodige autonomie aan de politie, waardoor deze verplicht is voortdurend de kwaliteit van haar optreden kritisch te bekijken en hierover rekenschap af te leggen aan de verantwoordelijke instanties. Bovendien denkt hij dat het OM niet in staat is de politie tot in detail te besturen, omdat het in de praktijk daar veel te ver vanaf staat. ${ }^{133} \mathrm{Ik}$ ben van mening dat een te grote zelfstandigheid van de politie niet past in ons staatkundig systeem. Een andere vraag is hoe een en ander moet worden geconcretiseerd.

Natuurlijk kan het OM zich niet tot in detail met elke opsporings- en verbaliseringsbeslissing bemoeien. De politie zal nadere instructies moeten krijgen van het $\mathrm{OM}$

130 Dit vraagstuk maakt deel uit van ecn groter thema, namelijk de verhouding tussen OM en politic in het algemeen. Zie daarover vitgebreider de Jaarverslag OM 1973 en 1992.

131 Zie hicrover uitgebreid: C. Fijnaut, E.G.M. Nuijten-Edelbroek en J.L.P. Spickenheuer, Politiële misdaadbestrijding. 's-Gravenhage Staatsuitgeverij 1985, pag. 81-85; Cyrille Fijnaut, De magistratelijke rol van de politic. Uit: Overheidsrechter gepasseerd, H.J. Snijders e.a. (red.), Arnhem 1988, pag. 321-330.

$132 \mathrm{Vgl}$. de preadviezen van de NJV 1968 van G. Duisterwinkel en P. Mostert.

133 Cyrille Fijnaut, De magistratelijke rol van de politie. Uit: De overheidsrechter gepasseerd, H.J. Snijders e.a. (red.), Arnhem 1988, pag. 327-328. 
betreffende het te volgen opsporings- en verbaliseringsbeleid teneinde te voorkomen dat de politie zaken opspoort en verbaliseert waarvan later blijkt dat het OM ze niet zal vervolgen vanwege beleidsoverwegingen. Deze instructies kunnen ook bijdragen aan een meer eerlijke vorm van rechtsbedeling. Hierdoor kunnen verschillen in afdoening tussen individuele agenten, tussen verschillende politiecorpsen in een arrondissement en wellicht tussen verschillende arrondissementen geminimaliseerd worden, afhankelijk van de reikwijdte van de richtlijn. Overigens wordt in het bestuursrecht aangenomen dat de mandaatverlener, die over de bevoegdheidsuitoefening blijft beschikken, ter zake van de uitoefening ervan beleidsregels kan vaststellen, art. 1A.1.1.6 lid 1 van het Ontwerp derde tranche $\mathrm{Awb}^{134}$. Gezien de gezagsverhouding zal de gemandateerde (i.c. de politie) deze regels in acht moeten nemen. ${ }^{135}$

Er hebben verschillende experimenten met betrekking tot het politiesepot plaatsgevonden. Reeds in 1971 werd een werkgroep geformeerd uit leden van het parket en van de politie in het zuiden van het land, onder leiding van Gonsalves. Deze werkgroep had als doel te zoeken naar vereenvoudiging van processen-verbaal en het daaraan gekoppelde opsporingsonderzoek. Resultaat: met betrekking tot bepaalde eenvoudige strafbare feiten met bekende dader(s), welke feiten op bepaalde gronden vermoedelijk tot een sepot door het $O M$ zouden leiden, kan worden volstaan met een beperkt opsporingsonderzoek en het opmaken van een verkort proces-verbaal. De lichte misdrijven waren: eenvoudige belediging, mishandeling, huisvredebreuk, vernieling en eenvoudige diefstal. Voor wat betreft de gronden moet vooropgesteld worden dat de betrokkene first-offender is. Het verkorte verbaal krijgt als naam sepotverbaal.

Dit rapport van de Werkgroep Gonsalves had niet als doel het politiesepot in te voeren, maar het is herhaaldelijk gebruikt voor werkafspraken tussen politie en justitie, betreffende het politiesepot.

Het verkorte verbaal is in 1972 in Den Bosch ingevoerd. Gebleken is dat er slechts sporadisch gebruik van werd gemaakt. In 1981 is het verkurt verbaal opnieuw ingevoerd, waarbij aansluiting is gezocht bij de "Rubricering sepotgronden" van het ministerie van justitie van 1979.

Het rapport van de werkgroep Gonsalves is gebruikt als basis voor een experiment betreffende de systematiek van het politiesepot van 1983 in het arrondissement Haarlem. ${ }^{136}$ Als definitie van 'politiesepot' is gehanteerd:

"de beslissing die door de politie genomen wordt om in een bepaalde strafzaak waarin een opsporingsonderzoek heeft plaatsgevonden te volstaan met het opmaken en inzenden van

134 Zie hierover uitgebreider: C.P.J. Goorden, Beleidsregels bij mandaat en delegatic, NTB 1992/5, pag. 163-168.

135 In deze zin ook de MvT Voorontwerp derde tranche Awb, pag. 127.

136 Zie J.H.C. van Rijn, Politiesepot: een uitkomst voor het Openbaar Ministerie of voor de politie? TvdP 1983, pag. 621-625. 
een summier proces-verbaal en een mededeling aan de meerderjarige verdachte dat de zaak strafrechtelijk niet zal worden vervolgd, tenzij mocht blijken dat de verdachte zich in de voorgaande drie jaren aan enig misdrijf heeft schuldig gemaakt of andere bijzondere omstandigheden aanleiding geven alsnog strafrechtelijke vervolging in te stellen".

Melding van een politiesepot aan het $\mathrm{OM}$ gebeurt door inzending van een procesverbaal, waarop de sepotbeslissing alsmede de grond en code zijn aangegeven die later door de officier van justitie wordt overgenomen voor de Justitiële Documentatie Registers. Voor het proces-verbaal wordt gebruik gemaakt van een zg. summier proces-verbaal, dat zeer kort alle elementen van een normaal proces-verbaal bevat. Bij de bepaling van delicten waarbij politiesepot mogelijk is, wordt gedacht aan: mishandeling, belediging, huisvredebreuk, vernieling, eenvoudige diefstal, verduistering en geringe vormen van heling. Van te voren zijn de volgende afspraken gemaakt: geen sepot in geval van recidive; geen sepot bij schade, tenzij deze gering is en volledig is vergoed; geen sepot bij mishandeling indien daarbij wapens zijn gebruikt; geen sepot bij een inverzekeringstelling; geen sepot indien de aangever op vervolging staat; geen sepot in politiek gevoelige zaken; geen sepot indien de politie zelf als benadeelde bij de zaak betrokken is; geen sepot bij een ontkennende verdachte, tenzij bij het onderzoek overduidelijk blijkt dat de verdachte ten onrechte voor dit strafbaar feit wordt aangezien.

Bij dit Haarlemse experiment is verder afgesproken dat alle sepotbeslissingen genomen worden door drie hogere ambtenaren van de justitiële politie. Na de sepotbeslissing wordt hiervan middels een brief namens de officier van justitie mededeling gedaan aan de verdachte.

Uit dit experiment blijkt dat het systeem werkbesparend werkt voor het OM; bij de politie vindt al een selectie plaats van zaken die wel of niet vervolgd moeten worden. Het politiesepot is daarentegen werkverzwarend voor de politie. Aanbevolen wordt desondanks door te gaan met het politiesepot, onder andere omdat de verwachting bestaat dat door de tijdsbesparing bij het OM meer aandacht kan worden besteed aan zwaardere vormen van criminaliteit. Voor lichte strafbare feiten moet een soepeler systeem van politiesepot worden gevonden.

Uit een onderzoek van Van Rooyen-de $W_{i t}{ }^{137}$ blijkt dat er in veel arrondissementsparketten ook met een richtlijn wordt gewerkt. Naast enkele verschillen vertonen de richtlijnen ook overeenkomsten: de verdachte is first-offender, de verdachte bekent en de verdachte is niet in verzekering gesteld. De richtlijnen van Alkmaar en Utrecht noemen vier limitatieve sepotgronden: gering teit, verhouding benadeelde geregeld, medeschuld benadeelde, beperkte kring. Ook voor wat betreft de strafbare feiten zijn er overeenkomsten. Zo worden in de richtlijnen genoemd: huisvredebreuk, eenvoudige belediging, mishandeling, eenvoudige winkeldiefstal en vernieling. In

137 C.M. van Rooyen-de Wit, Het politiesepot. Afstudeerscriptie Rijksuniversiteit Utrecht, 1986. Een uittrekscl staat in TrdP 1987, pag. (i-13. 
gevallen waarin tot een sepot wordt besloten zendt de politie een summier gestandaardiseerd proces-verbaal naar het $\mathrm{OM}$, waarin de sepot-beslissing wordt aangegeven. Tevens wordt aan de verdachte een standaardbrief gestuurd, waarin namens de officier van justitie mededeling wordt gedaan van de sepotbeslissing. ${ }^{138}$

De werkgroep Prioriteitenstelling OM (werkgroep Addens) heeft onderzocht of de richtlijn van het arrondissement Arnhem niet als landelijke richtlijn kan dienen. Men heeft echter besloten om arrondissementsgewijs het sepotbeleid gestalte te geven. Wanneer er geen richtlijn is, kan die van het arrondissement Arnhem als zodanig functioneren.

Het ontbreken van een landelijke regeling met betrekking tot het politiesepot heeft het risico dat er rechtsongelijkheid ontstaat. Hetzelfde delict kan in een bepaald arrondissement worden vervolgd, terwijl het in een ander arrondissement geseponeerd zou worden. Het is dus belangrijk dat de sepotregelingen van de verschillende gebieden zoveel mogelijk op elkaar worden afgestemd. Aan de andere kant moet worden bedacht dat vormen van strafwaardig gedrag per regio kunnen verschillen, waardoor derhalve een andere sepotrichtlijn noodzakelijk kan zijn.

Aanpassing of wijziging van een bestaande richtlijn, bijvoorbeeld als gevolg van veranderde omstandigheden op strafrechtelijk gebied of als gevolg van verhoogde werklast bij de politie, dienen naar mijn mening na overleg tussen politie en justitie plaats te vinden. Dit kan bijvoorbeeld gebeuren tussen een officier van justitie en de korpsleiding. Een geschikter forum lijkt mij het driehoeksoverleg, waarbij tevens het plaatselijk bestuur betrokken is. Kortom: het OM heeft uiteindelijk de zeggenschap over het opsporingsbeleid, maar de concretisering ervan is slechts optimaal bij een maximale inbreng van de betrokken instanties.

Het zal duidelijk zijn dat door het politiesepot de politie een grote macht gekregen heeft. Alhoewel er bepaalde afspraken gemaakt kunnen worden, zal het toch vaak de politie (of de individuele politie-ambtenaar) zijn die in een concreet geval bepaalt of de zaak naar het parket gestuurd zal worden. De mogelijkheid een strafzaak te seponeren draagt dan tevens de risico's van vriendjespolitiek en omkoping met zich mee. ${ }^{1.9}$ Daarnaast kan het gebruikt worden om buiten-wettelijk of onnodig grof politie-optreden uit de openbaarheid te houden.

Nu de Hoge Raad inmiddels beslist heeft dat een sepotmededeling van een parkerwachter tot gevolg kan hebben dat het vervolgingsrecht van het OM daarmee is vervallen (zie Hoofdstuk 10, par. 2.3.8), volgens mij een logisch gevolg van de mandaatsverhouding tussen $O M$ en politie, is mijns inziens de noodzalak voor een strak

138 Vgl. J.H.C. van Rijn, Politie-sepot: eert uitkomst voor het openbaar ministerie of voor de politic?

TvdP 1983, pag. 621-625.

139 J.M. van Bemmelen, Het politiesepot, DD 1976, pag. 527. 
toezicht vanuit het $\mathrm{OM}$ op de hantering van het opportuniteitsbeginsel door de politie vergroot. Deze hantering door de politie, waarbij aan de betrokkene meegedeeld wordt dat hij niet zal worden vervolgd, kan voortaan van rechtstreekse invloed zijn op de ontvankelijkheid van het $\mathrm{OM}$ bij de vervolging van het betrokken feit. ${ }^{140}$

\section{Voorwaardelijk sepot}

\subsection{Inleiding}

In 1926 aanvaardde de wetgever het opportuniteitsheginsel. Hierdoor had de officier van justitie voortaan een wettelijke grondslag om bij ten parkette ingekomen strafbare feiten vervolging achterwege te laten, ook al was het bewijs rond en een veroordeling wadarschijnlijk.

Hantering van dit beleidssepot (reeds voor wettelijke invoering), de op beleid gebaseerde beslissing van de officier van justitie dat niet tot vervolging zal worden overgegaan, had met zich mee gebracht dat het OM strafzaken nog op een andere wijze ging afdoen dan door te vervolgen of te seponeren. Gezocht werd naar een soort tussenweg. Zo ontstond in de praktijk het voorwaardelijk sepot. Het formeel voorwaardelijk sepot kreeg in 1926 een wettelijke basis, het informeel sepot ontbeert deze tot op heden.

De wettelijke regeling blinkt niet uit door duidelijkheid.

De juridisch theoretische rechtvaardiging van het voorwaardelijk sepot wordt gevonden in 'wie het meerdere mag, mag ook het mindere'.

\subsection{Historie}

Bijgebreke van een wettelijke grondslag ontwikkelde het voorwaardelijk sepot zich in de 'illegaliteit'. Waarschijnlijk werd deze wijze van afdoening van strafbare feiten voor het eerst in jeugdzaken toegepast. Rond $1896 \mathrm{kwam}$ deze afdoeningsmethode voor in Amsterdam. Rond 1907 werd het voorwaardelijk sepot ook voor volwassenen gebruikt. ${ }^{141}$ Doel hiervan was vrijwel altijd dat de delinquent zich gedurende een bepaalde periode zou richten naar aanwijzingen van een bepaalde, daarvoor aangewezen persoon (reclassering). ${ }^{142}$

In 1913 stelt de Commissie Ort in haar ontwerp tot vaststelling van een nieuw Wetboek van Strafvordering voor het voorwaardelijk sepot wettelijk te erkennen. Zij

140 Zie ook: T.M. Schalken, HR en politiesepot: De carrière van een parkeerwachter, NJB 1989, pag. 917-918.

141. Blok-Besier III, pag. 20.

142 Zie J. Rcijntjes, V(wonwaardelijk sepot. Uit: Liber Amicorum Th.W. van Vcen, pag. 297-298. 
beargumenteert dit door te stellen dat het in het belang van de verdachte kan zijn dat de officier van justitie wacht met het nemen van de definitieve vervolgingsheslissing. Door het stellen van bepaalde voorwaarden omtrent levenswijze en gedrag kan de officier van justitie informatie worden verschaft omtrent de levenswijze en het gedrag van de verdachte. ${ }^{43}$ Bij het nemen van de vervolgingsbeslissing is de officier op de hoogte van de nakoming van deze voorwaarden.

In 1922 krijgt het voorwaardelijk sepot, tegelijk met het opportuniteitsbeginsel, een wettelijke grondslag in het kinderstrafprocesrecht (art. 227r Sv, nu: art. $493 \mathrm{~Sv}$ ). ${ }^{1 .+4}$ In het strafprocesrecht voor volwassenen volgt wettelijke erkenning in 1926.

"Het kan in het belang van den verdachte zijn, dat de officier van justitie toeft met het nemen van eene beslissing aangaande de vervolging. Bepaalde voorwaarden voor levenswijze en gedrag kunnen gesteld worden, omtrent wier vervulling de officier voor zijne definitieve beslissing kan vergewissen". 145

Overeenkomstig de voorstellen van de Commissie Ort wordt het voorwaardelijk sepot enkel mogelijk in het geval een gerechtelijk vooronderzoek heeft plaatsgevonden (art. 244 lid 3 Sv) of voorlopige hechtenis is toegepast (art. 245 lid 4 Sv). Kennelijk heeft de toenmalige wetgever niet aan de mogelijkheid van een voorwaardelijk sepot buiten deze gevallen gedacht.

De rechtspraak (Hof Arnhem 27 mei 1930, W. 12414) heeft het voorwaardelijk sepot echter ook spoedig aanvaard in het geval geen voorlopige hechtenis of een gerechtelijk vooronderzoek heeft plaatsgevonden, dus bij een, zoals ik dat definieer, informeel sepot. Daarbij overwoog het Hof onder andere

"dat de straf is een uiterste maatregel tot handhaving der rechtsorde, die achterwege behoort te blijven, wanneer langs anderen weg het doel kan worden bereikt; dat onze wetgeving het OM vrijlaat om te beslissen of er al dan niet zal worden vervolgd, terwijl zij ook kent de voorwaardelijke veroordeling; waarbij dan toch, bij behoorlijke naleving der voorwaarden, geen straf wordt toegepast; dat niet is te voorspellen wat de rechter zoude doen, kwam deze zaak ter terechtzitting; dat gedacht kan worden aan veroordeling tot geldboete of aan eene voorwaardelijke veroordeling; dat echter ook ontslag van rechtsvervolging tot de mogelijkheden behoort, terwijl onvoorwaardelijke veroordeling tot gevangenissst raflijkt uitgesloten".

Dit soort overwegingen komt mijns inziens in strijd met de motivering van de wetgever bij invoering van art. 244 lid $3 \mathrm{~Sv}$. Gemakshalve wordt het voorwaardelijk sepot gelijk gesteld met de voorwaardelijke veroordeling. Indien de officier voorziet dat de rechter ter zitting tot een ontslag van rechtsvervolging kan komen, mag naar mijn

143 MvT ORO, art. $247 \mathrm{~Sv}$.

144 Wet van 5 juli 1922, Stb. 834, inwerkingtreding 1 november 1922.

145 MvT ORO bij art. 247 (nu art. 244), pag. 112. 
mening niet naar het middel van het voorwaardelijk sepot gegrepen worden om zo de verdachte via de achterdeur toch weer een 'straf' op te leggen.

Het is thans regel dat aan een informeel sepot (art. $167 \mathrm{lid} 2 \mathrm{~Sv}$ ) voorwaarden kunnen worden verbonden. Dit is mijns inziens niet te rijmen met de bedoeling van de wetgever welke aan invoering van het voorwaardelijk sepot ten grondslag lag, namelijk het voorwaardelijk sepot als voorlopige beslissing.

Het past echter in het 'plaatje' dat de officier bij het nemen van zijn vervolgingsbeslissing de keuze heeft uit een scala van mogelijkheden, begrenst door onvoorwaardelijk sepot en vervolging. Het voorwaardelijk sepot is dan meer een definitief besluit.

\subsection{Wettelijke regeling}

De wettelijke grondslag van het voorwaardelijk sepot moet worden gezocht in art. 244 lid 3 Sv. Zoals in de inleiding reeds is vermeld, beoordeel ik de wettelijk regeling van het voorwaardelijk sepot als niet sterk. In de eerste paragraaf zal dit nader gemotiveerd worden. Daarna zal aandacht worden geschonken aan de legitimering van het voorwaardelijk sepot. In de volgende paragrafen volgt een analyse van de wettelijke regeling van het voorwaardelijk sepot, waarbij aandacht geschonken wordt aan de vraag wie het initiatief tot een voorwaardelijk sepot dient te nemen en aan de voorwaarden die gesteld kunnen worden.

\subsubsection{Zwakke wettelijke regeling}

In art. 244 lid $3 \mathrm{~Sv}$ wordt vermeld dat de officier van justitie, op verzoek van de verdachte en al dan niet onder het stellen van bepaalde voorwaarden, voor het doen van een kennisgeving van (niet) verdere vervolging een bepaalde langere termijn kan nemen.

Naar mijn mening geeft dit artikel niet dé regeling van het voorwaardelijk sepot maar biedt het de officier de mogelijkheid om, al dan niet onder het stellen van bepaalde voorwaarden, een langere termijn te nemen voor zijn beslissing om wel of niet verder te vervolgen dan het eerste lid van art. $244 \mathrm{~Sv}$ aangeeft. Het geeft de officier de mogelijkheid zijn definitieve beslissing uit te stellen, zonodig onder het stellen van voorwaarden. Op grond van deze bepaling is het ook mogelijk dat de officier een langere termijn neemt voor zijn vervolgingsheslissing zonder daaraan voorwaarden te verbinden. De zaak blijft dan enige tijd liggen, wordt niet terstond definitief afgedaan.

De oorspronkelijke bedoeling achter Titel IV (Beslissingen omtrent verdere vervolging) is dat de verdachte zo snel mogelijk zekerheid gegeven wordt over zijn strafrechtelijk positie: 
"... niet zal, als thans bij voorloopige informatiën, de beklaagde zeer langen tijd in onzekerheid kunnen blijven of al dan niet eene vervolging tegen hem zal worden ingesteld. Zorg is gedragen dat hem spoedig zekerheid omtrent het resultaat van het onderzoek wordt verschaft, terwijl hij evenzeer zoodanige zekerheid binnen korten termijn kan erlangen in de gevallen, waarin geen gerechtelijk vooronderzoek heeft plaats gehad, doch voorloopige hechtenis is toegepast".

De verdachte behoort zo spoedig mogelijk te weten of die vervolging doorgezet wordt en zo ja, op welke wijze. Daarom is de officier van justitie bij het nemen van zijn beslissing aan een termijn, een maand, gebonden. Dit is de hoofdregel van art. 244 respectievelijk 245 Sv. Hierop wordt door lid 3 van art. 244 Sv (waarnaar in art. 245 lid $4 \mathrm{~Sv}$ verwezen wordt) een uitzondering gemaakt. Na bestudering van de bijlagen van deze wet en de kamerstukken meen ik te kunnen vaststellen dat de wetgever hier niet bedoeld heeft een definitief altematief te scheppen voor enerzijds vervolging, anderzijds sepot.

In art. $493 \mathrm{~Sv}$ is het voorwaardelijk sepot voor minderjarige verdachten daarentegen wel uitdrukkelijk gelegaliseerd.

Hierboven is reeds gesignaleerd dat volgens de wet een voorwaardelijk sepot slechts kan plaatsvinden nadat een gerechtelijk vooronderzoek heeft plaatsgevonden of voorlopige hechtenis is toegepast. De wetgever heeft zich deze beperking waarschijnlijk niet gerealiseerd. Dit is naar mijn mening wederom te verklaren uit het feit dat de hoofdzaak van het betreffende artikel was dat verdachten, ten opzichte van wie reeds een strafrechtelijke reactie had plaatsgevonden in de zin van een gerechtelijk vooronderzoek of in de vorm van voorlopige hechtenis, zo snel mogelijk op de hoogte dienden te worden gesteld van wat er verder zou gebeuren. De noodzaak zo snel mogelijk op de hoogte te zijn van de verdere stappen van justitie voor een verdachte die niet in voorlopige hechtenis heeft gezeten of ten opzichte van wie geen gerechtelijk onderzoek heeft plaatsgevonden is blijkbaar niet onderkend.

Zoals hiervoor al beschreven heeft de jurisprudentie dit gemis echter betrekkelijk snel onderkend en is het voorwaardelijk sepot ook buiten de gevallen van voorlopige hechtenis en gerechtelijk vooronderzoek ook van toepassing geworden. Als we de motivering van deze uitspraak van het Hof Arnhem bekijken, moet naar mijn mening worden vastgesteld dat deze niet overeenstemt met de motivering die de wetgever voor het voorwaardelijk sepot ex art. 244 lid 3 Sv gegeven heeft. Moet hieruit dan worden afgeleid dat ook reeds bij het invoeren van het voorwaardelijk sepot van art. 244 lid 3 Sv de gronden om tot een voorwaardelijk sepot te komen in praktijk al veranderd waren? 


\subsubsection{Legitimering}

De theoretische onderbouwing van het voorwaardelijk sepot wordt gevonden in: wie het meerdere mag (onvoorwaardelijk seponeren) mag ook het mindere (voorwaardelijk seponeren). ${ }^{147}$ Ook de motivering van het Hof bij de erkenning van het informeel voorwaardelijk sepot gaat in die richting.

De vraag is dan wat als meerdere en wat als mindere kan worden gekwalificeerd. Vanuit de verdachte geredeneerd is voorwaardelijk vervolgen het meerdere van onvoorwaardelijk vervolgen.

Vanuit de officier van justitie gezien, die rechtstreeks uit de wet de bevoegdheden heeft om onvoorwaardelijke te seponeren en om te vervolgen, is het voorwaardelijk sepot het mindere ten opzichte van vervolgen. Derhalve is de legitimering van wie het meerdere mag, mag ook het mindere te handhaven.

Groenhuijsen en Van Kalmthout zien in een voorwaardelijk sepot niet een 'minus' maar een 'aliud' van het onvoorwaardelijk sepot. ${ }^{1+8}$

De legitimering van het voorwaardelijk sepot wordt ook gezocht in het subsidiariteitsbeginsel. ${ }^{199}$ Op grond van dit beginsel moet met het hanteren van zwaardere maatregelen (i.c. vervolging met veroordeling) worden gewacht indien het gewenste effect ook met minder ingrijpende middelen kan worden bereikt. Dit beginsel gaat dan uit van de gedachte: wie het meerdere kan, moet daarmee wachten en eerst het mindere proberen.

Vanuit het perspectief van het OM dan is volgens mij te verdedigen dat het voorwaardelijk sepot minder is dan vervolgen.

\subsubsection{Initiatief tot een voorwaardelijk sepot}

In art. 244 lid $3 \mathrm{~Sv}$ is te lezen dat het initiatief tot een voorwaardelijk sepot moet uitgaan van de verdachte. Hij moet een verzoek richten tot de officier van justitie. Deze eis brengt tot uitdrukking dat een strafzaak op basis van vrijwilligheid op deze manier kan worden afgedaan. Indien de verdachte niet instemt met het voorwaardelijk sepot moet de rechter worden ingeschakeld.

147 Zie onder andere: J.M.A.V. Moons, Het opportuniteitsbeginsel. Enige notities over zijn inhoud en omvang, NJB 1966 pag. 486; Melai c.s., Het Wetbock van Strafvordering, aant. 8 bij art. 167 Sv, G.J.M. Corstens en P.J.P. Tak, Het openbaar ministerie, pag. 98-99.; J.M. Reijntjes: Voonwaardelijk sepot. Uit: Liber Amicorum Th.W. van Veen, 1985, pag. 295-316; G.J.M. Corstens, De Nederlandse strafvordering, Arnhem 1993, pag. 462.

148 Dat zou blijken uit de omstandigheid dat hett politiesepot aanvaard wordt, doch (nog) door niemand verdedigd wordt dat de zaak eveneens door de politie onder het stellen van voorwaarden wordt afgedaan. M.S. Groenhuijsen en A.M. van Kalmthout, Transactie en voorwaardelijk sepot: lood OM oud ijzer? DD 1983, pag. 475.

149 Vgl. John Blad, (Voorwaardelijk) seponeren als conflictoplossende activiteit buiten de rechter om. Uit: H.J. Snijders e.a. (red.), Overheidsrechter gepasseerd, Arnhem 1988, pag. 312. 
De eis dat het verzoek tot een voorwaardelijk sepot uit moet gaan van de verdachte veronderstelt dat de verdachte op de hoogte is van deze wijze van afdoening. Dit lijkt mij niet altijd het geval. Zijn raadsman zou hem van dit recht op de hoogte moeten stellen maar niet iedere verdachte heeft in deze fase van het strafproces bijstand van een raadsman, met name niet in geval van een informeel voorwaardelijk sepot (zonder gerechtelijk vooronderzoek of voorlopige hechtenis). In geval van een formeel voorwaardelijk sepot is er altijd een raadsman toegevoegd.

Met betrekking tot de transactie stelde art. 74 Sr tot 1983 ook als eis dat het initiaticf uit moest gaan van de verdachte. In praktijk kwam het er op neer dat de officier van justitie de voorwaarde(n) bekend maakte. Het voldoen aan die voorwaarden impliceerde een stilzwijgend verzoek van de kant van de verdachte. Mede omdat de wet op dit punt tot een dode letter was geworden, verviel bij de invoering van de Wet Vermogenssancties in 1983 het vereiste dat het initiatief tot de transactie van de verdachte moest komen.

Is er reden bij het voorwaardelijk sepot het vereiste dat de verdachte erom moet verzoeken te handhaven? Ik denk dat deze eis ook bij het voorwaardelijk sepot kan vervallen. Het is niet noodzakelijk dat de verdachte altijd het inititatief tot een voorwaardelijk sepot moet nemen. ${ }^{15 i} \mathrm{Hij}$ kan dit wel doen. Belangrijk is dat de verdachte vrijwillig de voorwaarden accepteert.

De vrijwilligheid van de verdachte zich te onderwerpen aan het voorwaardelijk sepot wordt in de huidige regeling niet geheel gegarandeerd door hem het initiatief te laten. Ook al gaat het initiatief van hem uit dan kan dat nog altijd tot gevolg hebben dat hij het met de door de officier gestelde voorwaarden niet eens is. De officier van justitie bevindt zich in een machtspositie, in die zin dat hij tot vervolging kan besluiten. Daarnaast zou handhaving van dit vereiste tot gevolg hebben dat een verdachte die van deze afdoeningsmethode op de hoogte is (bijvoorbeeld omdat hij rechtsbijstand heeft) bevoordeeld wordt ten opzichte van de verdachte die dat, zonder dat aan hemzelf te wijten is, niet is.

Van belang is het nog op te merken dat, indien het bovengenoemde vereiste dat de verdachte om een voorwaardelijk sepot moet verzoeken zou vervallen, de verdachte wel de mogelijkheid moet behouden de officier om een voorwaardelijk sepot te kunnen verzoeken.

\subsubsection{Voorwaarden en grenzen}

In tegenstelling tot de transactie zijn de voorwaarden waarop de officier van justitie van (verdere) vervolging kan afzien, niet in de wet opgenomen. De MvT bij de Wet 
Vaststelling van een Wetboek van Strafvordering spreekt van "voorwaarden voor levenswijze en gedrag", ${ }^{151}$ zonder nadere beschrijving.

Dit heeft als voordeel dat de officier van justitie de te stellen voorwaarde kan afstellen op of aanpassen aan de persoon en de positie van de individuele verdachte. De officier heeft een grote differentiatiemogelijkheid. Een nadeel is dat de verdachte van te voren niet weet welke voorwaarde(n) de officier kan stellen of zal stellen. De officier wordt daarin vrijgelaten en dit zou tot een zekere willekeur kunnen leiden. Ook vergroot het de machtspositie van de officier van justitie ten opzichte van de verdachte.

\subsubsection{Vereisten voor een voorwaardelijk sepot}

De officier van justitie kan mijns inziens niet bij ieder delict overgaan tot een voorwaardelijk sepot. In de eerste plaats is daarvoor vanzelfsprekend vereist dat de zaak tot een veroordeling door de rechter moet kunnen leiden (vgl. technisch sepot). De officier mag geen voorwaarden verbinden aan een sepot van een zaak die bewijsrechtelijk niet rond is of waarvan het bewijsmateriaal op onrechtmatige wijze verkregen is. In de meeste gevallen zal dit betekenen dat de verdachte het strafbaar feit bekend moet hebben en zelf weet dat hem een veroordeling boven het hoofd hangt. Het OM moet in de betreffende zaak ontvankelijk zijn in de vervolging. Door in een dergelijk geval toch over te gaan tot een voorwaardelijk sepot zouden bewijsproblemen verdoezeld kunnen worden. De controle van deze voorwaarde ligt bij de verdachte, die vrijwillig de voorwaarde moet accepteren. Zoals we reeds gezien hebben heeft echter niet iedere verdachte in dit stadium rechtsbijstand.

Voorwaarde voor opleggen, maar zeker voor het slagen van een voorwaardelijk sepot is, dat de verdachte instemt met de hem opgelegde voorwaarde.

\subsubsection{Grenzen aan het voorwaardelijk sepot}

Betekent het feit dat de wet de mogelijk op te leggen voorwaarden niet noemt dat de officier van justitie iedere willekeurige voorwaarde kan stellen? Deze consequentie mag hieraan niet worden verbonden. De officier is aan bepaalde grenzen gebonden. De volgende grenzen moeten, naar het mij voorkomt, in acht worden genomen:

- alleen die voorwaarde mag worden opgelegd, waarmee de verdachte akkoord gaat;

- er mag geen voorwaarde worden opgelegd die in het algemeen als zwaarder wordt ervaren dan een te verwachten veroordeling door de rechter ter zake van het 
gepleegde feit. Het $O M$ mag geen gebruik maken van de angst van de verdachte voor een openbare terechtzitting: ${ }^{132}$

- het voorwaardelijk sepot mag er niet toe strekken het gedrag van de verdachte indirect te beïnvloeden door het toedienen van opzettelijk leed. Opzettelijke leedtoevoeging is overgelaten aan de onafhankelijke rechter. ${ }^{153}$ De voorwatarde behoort dus in beginsel geen strafkarakter te dragen. Ik ben mij er hierbij van hewust dat een bepaalde voorwaarde, hoewel niet bedoeld als leedtoevoeging, door de verdachte wel als zodanig gevoeld kan worden;

- de te stellen voorwaarde mag niet een beperking van de grondrechten van de verdachte betreffen, zoals zijn persoonlijke vrijheid doordat hij zich bijvoorbeeld op bepaalde plaatsen niet meer vertoont of met bepaalde personen geen contact mag hebben. Deze voorwaarden maken een zodanige inbreuk op een belangrijk grondrecht (art. 15 GW) dat zij alleen door de rechter kunnen worden opgelegd, niet door het OM. ${ }^{154}$ Ook een voorwaarde als opneming in een ontwenningskliniek behoort tot deze categorie. ${ }^{155}$ Verder kunnen we denken aan het in art. $17 \mathrm{GW}$ neergelegde recht op toegang tot de rechter. Het Hof 's-Hertogenbosch achtte de voorwaarde dat een verdachte (in een fiscale zaak) niet zou worden vervolgd indien hij afzag van de rechtsgang (bezwaar-, beroep- en verzoekschriften) met betrekking tot andere fiscale zaken die nog liepen ontoelaatbaar wegens strijd met de algemene beginselen van behoorlijk bestuur en verklaarde de officier van justitie niet ontvankelijk (Hof's-Hertogenbosch 18 december 1991, NJ 1993, 60 ). De voor de voorwaardelijke veroordeling geldende grens dat de voorwaarde niet de vrijheid van godsdienst of levensovertuiging en staatkundige vrijheid van de verdachte mag beperken (art. $14 \mathrm{c}$ lid $3 \mathrm{Sr}$ ) is ook hier van toepassing;

- zoals uit de reeds aangehaalde passage uit de MvT blijkt moet de te stellen voorwaarde de levenswijze en het gedrag van de verdachte betreffen. De prestatie moet dus 'persoonsgebonden' zijn. De prestatie mag naar mijn mening niet slechts het vermogen van de verdachte treffen;

- de te stellen voorwaarde moet, zo mogelijk, verband houden met de persoonlijke en sociale factoren die het gedrag van de verdachte beïnvloeden en die mede hebben geleid tot het crimineel gedrag. Met andere woorden: de voorwaarde dient een positieve bijdrage te leveren aan het opheffen van bepaalde 'blokkades'.

152 Melai c.s., Het Wetbock van Strafvordering, aantckening 8a bij art. 167 Sv.

153 Vgl. J. Reijntjes, Voorwaardelijk scpot. Uit: Liber Amicorum Th.W. van Veen. Arnhem 1985, pag. 303-304. Hij is van mening dat indien de sanctie beperkt kan blijven tot een geldboete en er geen geschil bestaat tussen OM en verdachte het OM de zaak zelfstandig, door middel van transactie mag afdoen (Reijntjes ziet de transactie als een bijzondere verschijningsvorm van het vs).

154 In een dergelijk geval kan een kort geding voor een slachtoffer van een delict uitkomst brengen, omdat er voor hem haast geboden kan zịn bij de beperking van de bewegingsruimte van de verdachte.

$155 \mathrm{Bij}$ deze voorwaarde is het risico aanwezig dat de verdachte geen reële keuzevrijheid heeft. 
Hierbij valt te denken aan het leggen van contact met hulpverleningsinstanties of het volgen van een opleiding.

Het is weer de verdachte zelf die er op moet toezien dat deze grenzen niet overschreden worden. Maar in het geval van overschrijding zal de verdachte zich in een moeilijke positie bevinden: moet hij het voorwaardelijk sepot afwijzen met als gevolg dat hij ter zitting moet komen? Indien hij de voorwaarde accepteert impliceert dat dat de zaak niet meer beoordeeld kan worden door de rechter.

\subsubsection{Inhoud van de voorwaarde(n)}

Omdat de wet de mogelijk te stellen voorwaarden niet opsomt, wordt in de literaturur voor wat de inhoud van de voorwaarde hetreft, aansluiting gezocht bij de voorwaarden die verbonden kunnen worden aan een veroordeling (art. 14 a en c Sr). ${ }^{1.56}$ Aansluiting zoeken vind ik in dit verband eigenlijk een te groot woord, het gaat meer om 'inspiratie putten uit'. ${ }^{157}$ Het $\mathrm{OM}$ heeft immers geen veroordelingsbevoegdheid. Anders dan bij een voorwaardelijke veroordeling behoeft bij het voorwaardelijk sepot niet de algemene voorwaarde worden gesteld dat de verdachte zich binnen de proeftijd (meestal twee jaar) niet aan een nieuw strafbaar feit schuldig maakt (art. 14c lid 1). Deze voorwaarde mag worden gesteld en het gebeurt meestal ook. Andere voorwaarden die worden gesteld zijn dat de verdachte de schade, die door het strafbaar feit veroorzaakt is, vergoedt, dat hij zich laat begeleiden door de reclassering, dat hij zich laat opnemen in een kliniek voor ontwenning of afkicken, dat hij zich onder psychologische of psychiatrische behandeling stelt, dat hij zich op bepaalde plaatsen niet meer vertoont of dat hij met bepaalde personen geen contact meer zoekt of heeft. Hierboven heb ik reeds aangegeven dat enkele van de hier genoemde voorwaarden niet gesteld zouden mogen worden, zoals opneming in een kliniek voor ontwenning. Welke voorwaarden er feitelijk in de praktijk opgelegd worden, in welke mate dit gebeurt en welke overwegingen hieraan ten grondslag liggen is niet eenvoudig te achterhalen. Het OM behoeft hiervan geen statistieken bij te houden.

\subsubsection{Schadebriefje en berisping ten parkette}

Twee vormen van het voorwaardelijk sepot moeten hier nog genoemd worden: het schadebriefje en de berisping ten parkette. Dit laatste wordt ook wel het parketstandje of parketberisping genoemd.

De eerste vorm is formeel geen toepassing van het voorwaardelijk sepot, materieel valt deze er naar mijn mening wel onder, omdat de uitwerking ervan hetzelfde is.

156 Zie onder andere Van Overbeck, TvS 1958, pag. 199; Mulder en Schootstra, Preadvies NJV 1974; Melai c.s., Wetboek van Strafvordering, aant. 8a bij art. 167 en aant. 11 bij art. $244 \mathrm{~Sv}$.

157 Vgl. G.J.M. Corstens, De Nederlandse strafvordering, Arnhem 1993, pag, 463. 
De officier van justitie stuurt een bericht naar de verdachte dat deze gehouden is de schade te vergoeden welke de verdachte door middel van een strafbaar feit berokkend heeft. De officier verzoekt de verdachte hem te laten blijken dat de schade is vergoed, waarbij hij hem meedeelt daar bij de vervolgingsbeslissing mee te houden. In praktijk wordt na de vergoeding van de schade de zaak geseponeerd.

Nu sinds 1983 de schadevergoeding als voorwaarde bij de transactieregeling is opgenumen (art. 74 lid 2 sub e $\mathrm{Sr}$ ), is de betekenis van het schadebriefje afgenomen.

De officier van justitie kan een (beleids)sepot gepaard doen gaan met het geven van een waarschuwing of berisping. Dit gebeurt meestal mondeling. De officier van justitie stuurt een oproep aan de verdachte om op een bepaalde datum voor hem te verschijnen. Meestal heeft de officier zijn vervolgingsbeslissing dan al genomen, maar wil hij de verdachte er op wijzen dat hij dergelijk gedrag in het vervolg achterwege dient te laten. Indien de verdachte niet reageert op de oproep heeft dit doorgaans vervolging tot gevolg. De verdachte kan zich laten bijstaan door een raadsman (als hij die heeft) of door iemand van de reclassering. De officier behoeft dit niet toe te laten. Deze waarschuwing kan ook schriftelijk worden gegeven. In beide gevallen wordt aan verdachte meegedeeld dat van vervolging wordt afgezien, dat van het voorval aantekening wordt gemaakt in het Algemeen Documentatieregister en dat bij een eventuele herhaling met het betreffende feit rekening zal worden gehouden. In het door de minister van Justitie aan de Tweede Kamer aangeboden beleidsplan "Recht in beweging" wordt, in het kader van een evaluatie van het beleidsplan "Samenleving en Criminaliteit", waarin het streven was opgenomen het aantal kale beleidssepots terug te dringen, opgemerkt dat ten aanzien van misdrijven thans (1989) vaker een strafrechtelijke interventie volgt in de vorm van bijvoorbeeld een berisping, transactie, boete, dienstverlening of vrijheidsstraf in vergelijking met de periode 1980 $1985 .^{158}$

Deze parketberisping heeft geen wettelijke regeling. De vraag die dan gesteld kan worden is of de officier van justitie deze bevoegdheid tot berispen heeft. Deze vraag was voorwerp van onderzoek in een uitspraak van de Nationale Ombudsman, 20 december 1990, AB 1991, 158. De NO is van oordeel dat een onderscheid gemaakt dient te worden tussen een waarschuwing en een berisping. Van de eerste vorm is sprake indien wordt beoogd de verdachte informatie te verschaffen over de haalbaarheid van een eventuele strafvervolging en omtrent de gevolgen bij herhaling. Hiertegen bestaat volgens de NO geen bezwaar. Van een berisping kan worden gesproken indien de verdachte door de officier van justitie bestraffend wordt toe- of aangesproken, waarbij het woord 'berispen' wordt genoemd. Een dergelijke berisping stuit bij de NO op bezwaar omdat er dan sprake is van toepassing van een sanctie, waartoe de officier van justitie geen wettelijke bevoegdheid heeft. Bovendien acht hij een dergelijke handelswijze in strijd met art. 6 EVRM, daar op de verdachte een leedtoe- 
brengende sanctie wordt toege:past als reactie op een strafbaar feit, zonder dat daar een onafhankelijke en onpartijdige rechter aan te pas komt.

Allereerst wil ik hierbij de opmerking maken dat het in de praktijk moeilijk zal zijn de grens aan te geven tussen waarschuwing en berisping. Afgezien van deze complicatie ben ik het met de NO eens dat de berisping door de officier van justitie, die beschouwd kan worden als een straf ${ }^{15 s}$, een wettelijk toegekende bevoegdheid mist, waardoor deze bevoegdheid hem eigenlijk niet toekomt.

\subsection{Karakter van het voorwaardelijk sepot}

Uit lid 3 van art. 244 Sv en ook uit de MvT kan afgeleid worden dat het voorwaardelijk sepot in beginsel een voorlopige beslissing is. De officier van justitie stelt het nemen van de beslissing om wel of niet (verder) te vervolgen uit, al dan niet onder het stellen van bepaalde voorwaarden. Dit zou tot gevolg kunnen hebben dat pas op een later tijdstip, nadat de gestelde voorwaarde wel of niet nagekomen is, de definitieve vervolgingsbeslissing wordt genomen. Dit was volgens mij ook de bedoeling van de wetgever in 1926.

Het karakter een voorwaardelijk sepot heeft een wijziging ondergaan. In praktijk heeft het voorwaardelijk sepot zich ontwikkeld tot een definitieve afdoeningsmethode, die tussen het onvoorwaardelijk sepot en de transactie staat. ${ }^{160}$ Aan de verdachte wordt een schriftelijk stuk betekend waarin staat vermeld dat een bepaalde strafzaak wordt geseponeerd indien aan een bepaalde voorwaarde voldaan wordt.

Is het karakter van het voorwaardelijk sepot nu wezenlijk anders dan dat van het onvoorwaardelijk sepot of de transactie?

Te verdedigen is dat er geen wezenlijk verschil tussen het onvoorwaardelijk en het voorwaardelijk sepot bestaat, zeker wanneer we bedenken dat er in de praktijk na overtreding van de voorwaarde(n) zelden wordt overgegaan tot vervolging. Te betogen is dat het voorwaardelijk sepot naar mijn mening een 'major' vormt van het onvoorwaardelijk sepot. Een verdachte is beter af met een onvoorwaardelijk dan met een voorwaardelijk sepot en wel om de volgende redenen: de te stellen voorwaarden kunnen diep ingrijpen in het persoonlijke leven van de verdachte; de verdachte hangt de Jreiging van een vervolging boven het hoofd als hij niet voldoet aan de voorwaarden; het niet voldoen aan de voorwaarden kan doorwerken in een eventuele andere vervolging.

159 In het jeugdstrafrecht is de berisping als een straf opgenomen, art. $77 \mathrm{~g} \mathrm{Sr}$.

160 Groenhuijsen en Van Kalmthout betogen dat $\mathrm{cr}$, sinds de invoering van de Wet Vermogenssancties in 1983 waarbij de transactieregeling sterk uitgebreid werd, geen principieel verschil meer bestaat. Volgens hen kan art. $74 \mathrm{Sr}$ beschouwd worden als een basisregeling van het voorwaardelijk niet (verder) vervolgen. M.S. Grocnhuijsen en A.M. van Kalmthout, Transactie en voorwaardclijk sepot: lood OM oud ijzer? DD 1986, pag. 474 e.v. 
Reijntjes ziet de transactie met het $\mathrm{OM}$ als een bijzondere verschijningsvorm van het voorwaardelijk sepot. ${ }^{16 i}$ Zowel bij de transactie als bij het voorwaardelijk sepot beslist de officier van justitie dat niet tot vervolging zal worden overgegaan, mits binnen een zekere termijn aan de voorwaarden is voldaan. Volgens Groenhuijsen en Van Kalmthout bestaat er sinds de invoering van de Wet Vermogenssancties geen princieel verschil meer tussen het voorwaardelijk sepot en de transactie. ${ }^{162}$ Voor hen zijn er geen klemmende redenen die verhinderen art. $74 \mathrm{Sr}$ te beschouwen als een basisregeling omtrent het voorwaardelijk niet (verder) vervolgen. Art. 74 Sr moet dan wel uitgebouwd worden.

Ook ik ben van mening dat er thans tussen de transactie en de feitelijke hantering het voorwaardelijk sepot geen wezenlijk verschil meer bestaat. Het zou dan ook ten goede komen aan de rechtspositie van de verdachte indien de regeling van het voorwaardelijk sepot ondergebracht zou worden bij de transactie. Door het voonwaardelijk sepot te incorporeren bij de transactieregeling zou het rechtsgevolg van het voorwaardelijk sepot expliciet vast komen staan (art. 74 lid $1 \mathrm{Sr}$ : Door voldoening aan die voorwaarden vervalt het recht tot strafvordering).

Aan de oorspronkelijke bedoeling van art. 244 lid 3 bestaat derhalve geen behoefte meer.

\subsection{Slotopmerking}

Deze paragraaf overziende kan worden vastgesteld dat het OM door de hantering van het voorwaardelijk sepot ten opzichte van de verdachte een machtige positie inneemt. In beginsel moet de verdachte de voorwaarde vrijwillig accepteren. De vraag is of dit reëel is. Wat is namelijk het gevolg van weigering? De controlemogelijkheden van de verdachte op het OM zijn, indien aanwezig, niet erg reëel. Als middelen om tegen het voorwaardelijk sepot op te komen kunnen worden genoemd:

1. beklag doen bij de hoofdofficier van justitic en daarna eventueel hoger in de OM-hiërarchie;

2. beklag doen bij de Nationale Ombudsman. Zijn uitspraak is echter niet bindend;

3. het voorwaardelijk sepot afwijzen en in een bewaarschrift tegen de dagvaarding trachten duidelijk te maken dat het OM onjuist heeft gehandeld.

Controle van buitenaf is moeilijk, externe verantwoording is niet voorgeschreven.

161 J.M. Reijntjes, Voorwaardelijk sepot. Uit: Liber Amicurum Th.W. Van Veen, pag. 299 e.v. 162 M.S. Groenhuijsen en A.M. van Kalmthout, a.w. 
De officier van justitie kan zijn sepotbeslissing nemen op grond van art. 167 lid 2 Sv (informeel sepot) en art. 242 lid 2 Sv (formeel sepot). Met betrekking tot het formeel sepot regelt de wet het rechtsgevolg. Voor wat betreft het informeel sepot moeten we een onderscheid maken tussen de gevallen waarbij aan de verdachte wel en die waarbij de verdachte niet een uitdrukkelijke sepotmededeling is gedaan.

\subsection{Rechtsgevolgen van een formeel OM-sepot}

Het rechtsgevolg van een kennisgeving van niet verdere vervolging staat in art. 246 Sv en in art. 255 Sv. Door deze mededeling namelijk eindigt de zaak. De verdachte kan ter zake van het feit, waarvan de officier besloten heeft het te seponeren, niet opnieuw vervolgd worden, tenzij nieuwe bezwaren bekend zijn geworden. Lid 2 van art. $255 \mathrm{~Sv}$ geeft aan wat als nieuwe bezwaren kan worden aangemerkt: verklaringen van getuigen of van de verdachte en stukken, bescheiden en processen-verbaal, welke later zijn bekend geworden of niet zijn onderzocht. In de volgende leden van dit artikel wordt aangegeven aan welke voorwaarden voldaan moet zijn wil een nieuwe vervolging kunnen plaatsvinden.

\subsection{Rechtsgevolgen van een informecl OM-sepot}

In de wet zelf vinden we geen bepalingen, die het rechtsgevolg van het informeel sepot regelen. Een voor de hand liggende gedachte zou dan ook kunnen zijn dat er aan dit sepot geen rechtsgevolgen verbonden zijn en dat de officier altijd opnieuw mag vervolgen (die eventueel tot een niet-ontvankelijkheid leidt bij overschrijding van de redelijke termijn). Hierbij moet echter een nuancering gemaakt worden voor het geval de verdachte ervan op de hoogte is gesteld dat de zaak geseponeerd zal worden.

Een sepot ex art. 167 lid 2 Sv heeft geen consequenties indien aan de verdachte geen mededeling daarvan vanwege het $\mathrm{OM}$ is gedaan. De officier van justitie heeft altijd het recht om later alsnog een vervolging in te stellen.

Wanneer de verdachte wel in kennis is gesteld van het sepot rijst de vraag of de officier van justitie daarna alsnog tot vervolging kan overgaan. ${ }^{12}$ Geruime tijd heeft ten aanzien van dergelijke sepotmededelingen een arrest van HR 2 februari 1964, NJ 1964, 419 gegolden, waarin de Hoge Raad overwoog dat, nu blijkens de wet een sepotmededeling voortvloeiend uit art. 167 lid 2 Sv geen rechtsgevolgen heeft, een dergelijke mededeling niet aan latere vervolging in de weg staat. Nadat de Hoge

163 Zie ook: G.J.M. Corstens, Beginselen van behoorlijk procesrecht, Trema 1985, pag. 181-183. 
Raad in het Macintosh-arrest (HR 18 oktober 1977, NJ 1978, 128), in strijd met de conclusie van advocaat-generaal Remmelink, het bezwaar dat ondanks een aan de verdachte medegedeeld sepot toch was vervolgd, zonder verdere redengeving had verworpen, gaf het eerste Menten-arrest (HR 29 mei 1978, NJ 1978, 358; Menten I) een onverwachte standpuntsherziening. Menten beriep zich in casu op een in 1951 door de toenmalige minister van Justitie gedane mededeling hem niet te zullen vervolgen. Ten aanzien van de vraag of na een dergelijke toezegging alsnog tot vervolging kon worden overgegaan overwoog de Hoge Raad:

"Dat bij de beantwoording van de vraag of zulks mogelijk is, rekening moet worden gehouden met de beginselen van een goede procesorde, welke onder meer medebrengen dat de voor het justitiële beleid verantwoordelijke organen niet handelen naar willekeur doch-tenzij zwaarwichtiger belangen zich daartegen verzetten- in gebondenheid jegens de verdachte aan toezeggingen, welke bij laatstgenoemde gerechtvaardigde verwachtingen hebben opgewekt".

De Hoge Raad erkent in dit arrest derhalve dat, analoog aan het bestuursrecht, ook de overheid gebonden kan zijn aan eigen voorafgaand handelen, indien in een concreet geval bepaalde venwachtingen zijn gewekt. Voor het gerechtvaardigd zijn van de verwachtingen is blijkens het tweede Menten-arrest (HR 22 mei 1979, NJ 1979, 301; Menten II) in elk geval nodig dat dit vertrouwen zijn grondslag vindt in een uitdrukkelijke en onvoorwaardelijke toezegging van de minister van Justitie.

Een nadere beschouwing van de Menten-arresten leert dat de Hoge Raad niet echt is omgegaan. Hij maakt namelijk een duidelijk onderscheid tussen een door de minister gedane toezegging en die welke van leden van het $\mathrm{OM}$ afkomstig zijn. De Hoge Raad erkent de werking van het vertrouwensbeginsel alleen voor de ministeriële toezegging. Voor toezeggingen door leden van het OM blijft het sepotarrest uit 1964 van kracht. De toezeggingen van deze laatsten zijn, in verband met art. $5 \mathrm{RO}$, noodwendig van voorlopige aard, aldus de Hoge Raad in het Menten I-arrest.

In latere arresten wordt de werking van het vertrouwensbeginsel uitgebreid en erkent de Hoge Raad de werking van dit beginsel ook voor toezeggingen die de officier van justitie heeft gedaan. ${ }^{164}$

In een arrest van 26 juni 1984, NJ 1985, 41 heeft de Hoge Raad de werking van het vertrouwensbeginsel met betrekking tot een sepotmededeling voortvloeiend uit art. 167 lid 2 Sv erkend. Verdachte F. was op 5 juli 1981 aangehouden ter zake van misdrijven van art. $284 \mathrm{Sr}$ en art. 3 Vuurwapenwet. Ter zake van het eerste misdrijf werd hij in verzekering gesteld. Op 29 maart 1982 ontvangt de raadsman een brief van de officier van justitie met de mededeling dat hij de strafzaak tegen $F$. heeft

164 Zie HR 15 juni 1982, NJ 1983, 216 (voeging ad informandum); HR 13 september 1983, NJ 1984, 151; zie voorts lagere rechtspraak o.a. Rb. Dordrecht 27 februari 1981, NJ 1981, 609; Rb. Amsterdam 12 januari 1982, NJ 1982, 395; Hof Arnhem 25 augustus 1982, NJCM-bulletin 1983, pag. 44; Hof Amsterdam 21 maart 1983, NJ 1983, 301. 
geseponeerd. De brief droeg het kenmerk 14728-1 RM, het parketnummer van de bedreigingszaak. Het vuurwapendelict droeg een ander nummer. Daarvoor werd F. gedagvaard. De officier van justitie werd door het Hof 's-Hertogenbosch nietontvankelijk verklaard. De brief hield geen beperking in en bood daarvoor volgens het hof geen duidelijke aanwijzing. Het hof was van mening dat vervolging in casu niet verenigbaar was met de regels van behoorlijke procesvoering en met die van behoorlijk bestuur. De Hoge Raad achtte het oordeel van het hof niet onbegrijpelijk. Gezien dit arrest, waarin impliciet het vertrouwensbeginsel ten aanzien van een sepotmededeling ex art. $167 \mathrm{lid} 2 \mathrm{~Sv}$ is erkend, en analoog redenerend aan arresten waarin ten aanzien van andere toezeggingen van de officier van justitie toetsing expliciet geschiedde, meen ik het volgende te mogen concluderen: Een sepotmededeling ex art. 167 lid 2 Sv blokkeert weliswaar niet het recht op strafvervolging, doch een latere vervolging kan in strijd zijn met het vertrouwensbeginsel en daardoor leiden tot niet-ontvankelijkheid van het $\mathrm{OM}$, indien deze mededeling kan worden opgevat als een onvoorwaardelijke en uitdrukkelijke toezegging van de officier van justitie aan verdachte, welke bij deze laatste de gerechtvaardigde verwachting heeft gewekt dat hij niet verder in rechte zal worden betrokken, tenzij zwaardere belangen zich daartegen verzetten. Erkenning van het vertrouwensbeginsel ten aanzien van deze sepotmededeling betekent dat de officier van justitie niet in alle gevallen alsnog tot vervolging kan overgaan nadat hij een dergelijke toezegging aan verdachte heeft doen toekomen.

Desondanks ben ik van mening dat het vertrouwensbeginsel door zijn vaagheid onvoldoende rechtszekerheid biedt en dat een wettelijke regeling in deze gewenst is. Om tot een evenwichtige regeling te komen zou in belangrijke mate aangesloten kunnen worden bij de regeling van artt. 242 Sv e.v., inzake de beslissingen omtrent verdere vervolging.

\subsection{Rechtsgevolgen van een politiesepot}

Een sepotmededeling kan alleen binden als zij is uitgegaan van het bevoegde orgaan, het OM. Mag een burger, aan wie door de politie is meegedeeld dat een bepaald strafbaar feit niet vervolgd zal worden, hierop vertrouwen? Met andere woorden: is het $\mathrm{OM}$ gebonden aan door de politie gedane sepotmededelingen?

In twee arresten heeft de Hoge Raad hierover duidelijkheid verschaft, HR 13 september 1988, NJ 1989, 403 en HR 19 september, NJ 1989, 379). ${ }^{165}$ Over deze arresten zal ik uitgebreider spreken in hoofdstuk 10. Hierop vooruitlopend geef ik in het kort de strekking van beide uitspraken weer. De vraag of de door de politie-ambtenaar gedane mededeling dat niet zal worden vervolgd tot niet-ontvankelijkheid leidt, is van een aantal omstandigheden afhankelijk:

165 Zie voor commentaar bij dit laatste arrest: T.M. Schälken, HR en politiesepot: De carrière van een parkeerwachter, NJB 1989, pag. 917-918. 
1. valt het seponeren onder de eigen ${ }^{1 * x}$ bevoegdheid van de betreffende ambtenaar?

2. is de verdachte van de bevoegdheidsverdeling tussen politie en OM op de hoogte?

3. de aard van de overtreding en de omstandigheden waaronder het feit is begaan.

\subsection{Rechtsgevolgen van een voorwaardelijk sepot}

In vergelijking met een onvoorwaardelijk sepot is het bij een voorwaardelijk afzien van (verdere) vervolging nog van groter belang dat een verdachte erop mag afgaan dat hij niet alsnog vervolgd zal worden. Een dergelijk sepot rechtvaardigt de verwachting bij de verdachte dat er, na afloop van de gestelde termijn en zonder dat de eventueel gestelde voorwaarden zijn overtreden, geen vervolging zal plaatsvinden. Bovendien heeft de verdachte, aan wie voorwaarden waren gesteld, een 'tegenprestatie' geleverd.

Een dergelijk garantie biedt de wet echter niet. Met betrekking tot een intormeel sepot (sepot op grond van art. 167 lid $2 \mathrm{~Sv}$ ) regelt de wet al niets met betrekking tot het rechtsgevolg. Aangezien het informeel voorwaardelijk sepot geen echte wettelijke basis kent, zijn de rechtsgevolgen hiervan al helemaal onduidelijk. Verondersteld zou kunnen worden dat na een voorwaardelijk niet-verdere vervolging de verdachte op grond van art. $255 \mathrm{~Sv}$ niet opnieuw vervolgd kan worden. Dit artikel echter vooronderstelt dat er een kennisgeving van niet-verdere vervolging is vooraf gegaan. We hebben hiervoor reeds gezien dat een dergelijk kennisgeving doorgaans ontbreckt. Ook hier kunnen beginselen van een behoorlijke procesorde uitkomst brengen, ${ }^{10 i}$ met name het vertrouwensbeginsel. Ook hier geldt mijns inziens dat het vertrouwensbeginsel te weinig rechtszekerheid biedt. Met Reijntjes" ${ }^{\text {"* }}$ hen ik dan ook van mening dat het aanbeveling verdient de wettelijke regeling van de gevolgen van transactie (art. 74 lid $1 \mathrm{~Sv}$ : door voldoening aan die voorwaarden vervalt het recht tot strafvordering) ook op het voorwaardelijk sepot van toepassing te verklaren, zodat een verdachte die aan alle voorwaarden heeft voldaan ervan verzekerd kan zijn dat zijn zaak daarmee beëindigd is.

$166 \mathrm{Met}$ andere woorden: is hem mandaat verleend ten aanzien van deze bevoegdheid?

167 In een arrest van het Hof 's-Hertogenbosch, 2 december 1982, NJ 1983, 168, werd het alsnog dagvaarden van een verdachte na volbrenging van dienstverlening in strijd geacht met het beginsel dat iemand niet tweemaal terzake van hetzelfde feit mag worden bestraft, dit omdat het volbrengen van de alternatieve sanctie door de verdachte zal zijn ervaren als een straf.

168 J.M. Reijntjes, a.w., pag. 312-131. Zie ook: M.S. Groenhuijsen en A.M. van Kalmthout, Transactie en voorwaardelijk sepot: lood OM oud ijzer? DD 1983, pag. 483. 
Hetgeen in deze paragraaf tot nu toe is beschreven zou misschien een te 'rooskleurig' beeld voor de verdachte geven indien geen aandacht wordt besteed aan de beklagregeling van art. $12 \mathrm{~Sv}$. De vraag rijst of na een aan verdachte meegedeeld (voorwaardelijk) sepot of na een kennisgeving van (voorwaardelijke) niet verdere vervolging alsnog met succes door een belanghebbende over het niet-vervolgen kan worden geklaagd. Om met de laatste situatie te beginnen: Reeds in 1927 (HR 10 oktober 1927, NJ 1927, pag. 1433) besliste de Hoge Raad dat na een kennisgeving van niet verdere vervolging niet meer met goed gevolg kan worden geklaagd, gezien de bewoordingen van de wet (art. 246 lid 1) en de geschiedenis van haar totstandkoming. Het doel van deze wettelijke regeling was aan de verdachte zekerheid te bieden omtrent de beëindiging van de vervolging. Hiermee is niet te verenigen dat het hof nog jarenlang de vervolging zou kunnen bevelen.

Deze regeling benadeelde de positie van het slachtoffer van een strafbaar feit. Bij de herziening van de art. $12 \mathrm{~Sv}$-procedure is hierin dan ook een verandering aangebracht. De belanghebbende moet voortaan beklag doen voordat de kennisgeving van niet verdere vervolging naar de verdachte gaat. De wettelijke regeling hiervan is te vinden in het derde lid van art. $246 \mathrm{~Sv}$, waarin is bepaald dat, in het geval een bevel tot vervolgen is gevraagd, een kennisgeving van niet verdere vervolging achterwege blijft tenzij het hof daarin heeft bewilligd. Art. 244 lid 2 Sv geeft een verlenging van de termijn waarbinnen de officier van justitie deze kennisgeving aan de verdachte moet geven, wanneer de officier het hof om bewilliging in de kennisgeving van niet verdere vervolging heeft verzocht.

Klagen over een voorgenomen kennisgeving van niet verdere vervolging veronderstelt dat de klager met dit voornemen bekend is. Op grond van twee circulaires van de procureurs-generaal bij de gerechtshoven, die de taak van politie en OM regelen ten aanzien van slachtoffers van misdrijven, moet de politie het slachtoffer vragen of deze op de hoogte gehouden wil worden van het verdere verloop van de procedure. Wanneer het slachtoffer dit inderdaad wenst, komt daarvan een aantekening te staan op de omslag van het proces-verbaal. Als het proces-verbaal op het parket ingeschreven wordt, moet de verdachte nogmaals gevraagd worden of hij op de hoogte wil blijven van het verdere verloop. Bij een bevestigend antwoord moet hem meegedeeld worden dat de zaak, al dan niet voorwaardelijk, geseponeerd zal worden. Hij dient op de mogelijkheid van een beklag ex art. $12 \mathrm{~Sv}$ gewezen te worden. ${ }^{169}$

De officier van justitie behoeft bij het stellen van voorwaarden op grond van art. 244 lid 3 Sv niet te wachten op bewilliging van een beklag door het hof; hij geeft immers (nog) geen kennisgeving van niet verdere vervolging. Dit heeft het, naar mijn mening voor de verdachte nadelige, gevolg dat hij na vervulling van de voorwaarden na een klacht van de belanghebbende alsnog vervolgd kan worden. In vergelijking 
met de transactie (art. $12 \mathrm{~b}$ lid $2 \mathrm{~Sv}$ ) kan de door de verdachte geleverde prestatie doorgaans niet 'terugbetaald' worden. Het hof zal, beslissende over het beklag over niet-vervolgen, dit een rol kunnen laten spelen. Het zou naar mijn mening een verbetering zijn wanneer de officier van justitie, alvorens de voorwaarde(n) op te leggen, wacht tot het hof, na een ingediend beklag, in dit voorwaardelijk niet-vervolgen heeft bewilligd.

Hiervoor is reeds vermeld dat ook aan een informeel (voorwaardelijk) sepot rechtsgevolgen verbonden kunnen zijn als gevolg van beginselen van een goede procesorde, namelijk wanneer door toezeggingen door het $\mathrm{OM}$ bij de verdachte gerechtvaardigde verwachtingen zijn gewekt dat hij niet vervolgd zal worden. Hier rijst de vraag of na toezeggingen van het $O M$ dat niet vervolgd zal worden, alsnog met succes ex art. $12 \mathrm{~Sv}$ geklaagd kan worden. Met andere woorden: is het hof gebonden aan de door het OM gedane toezeggingen? Bij een bevestigend antwoord zou volgens Melai de hele beklagregeling op losse schroeven komen staan, omdat dan alleen nog met succes geklaagd zou kunnen worden in het geval de verdachte niet van de sepotbeslissing op de hoogte is gesteld. ${ }^{17}$ In het arrest van 2 juni 1987, NJ 1988, 266 overwoog de Hoge Raad

"dat een bij een verdachte door een mededeling dat geen vervolging zal worden ingesteld opgewekt vertrouwen dat hij niet zal worden vervolgd, niet kan worden gehonoreerd indien door het hof krachtens art. 12 Sv zoals dat ten tijde van de in deze zaak door het hof gegeven beschikking Juidde, wordt bevolen dat de vervolging zal worden ingesteld. Immers, het OM was ingevolge het bepaalde in art. 12 Sv zoals dat toen luidde, en is thans krachtens art. $12 \mathrm{k}$ Sv gehouden aan dit bevel gevolg te geven."

Ingevolge dit arrest kan derhalve een sepotmededeling ex art. 167 lid 2 Sv worden doorkruist door de beklagregeling van art. $12 \mathrm{~Sv}$. De rechtszekerheid van de verdachte is ondergeschikt aan het recht van de belanghebbende te klagen over niet-vervolging. Deze uitspraak houdt naar mijn mening niet in dat bij beoordeling van het beklag door het hof met de sepotmededeling van het $O M$ helemaal geen rekening behoeft te worden gehouden. Dit geldt in het bijzonder wanneer er onder bepaalde voorwaarden geseponeerd is. Het is een voldongen feit dat de verdachte dan al aan door het OM gestelde voorwaarden heeft voldaan.

170 Melai c.s., aant. 6 bij artt. 12-13a (suppl. 73, oktober 1990). 


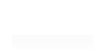




\section{Transactie}

\section{Historie ${ }^{17}$ \\ 1.1 Inleiding}

Het instituut van de transactie heeft reeds een lange geschiedenis achter zich. Deze gaat terug tot de tijd waarin de afdoening buiten proces, dat wil zeggen buiten het door de overheid gevoerde proces, als zelfstandig instituut voorkomt: de eerste helft van de zestiende eeuw.

In deze paragraaf zal een overzicht gegeven worden van de historische ontwikkeling van de transactie, waarbij als aanknopingspunt steeds is genomen een jaar waarin een belangrijke wijziging of aanvulling werd doorgevoerd.

\subsection{De zestiende eeuw: submissie en compositie}

De afdoening buiten proces deed zich in die tijd voor in twee vormen, de submissie en de compositie.

De procedure in die dagen was langdurig en ingewikkeld en droeg een sterk inquisitoir karakter. Voor de verdachte was het moeilijk zijn onschuld te bewijzen. In praktijk ontstond de submissie. De verdachte onderwierp zich bij voorbaat aan het oordeel van de rechter. Hij diende een request in bij het hof, waarbij hij alles kon aanvoeren wat zijn verontschuldiging kon dienen. Het hof kon, na raad en advies gevraagd te hebben aan de procureur-generaal, er op ingaan. Het legde een straf op, doorgaans een geldboete, en de openbare aanklager werd gelast de requestrant verder met rust te laten. De verdachte nam de zekerheid van een niet te zware straf en het openbaar ministerie werkte er graag aan mee als daardoor een langdurig en moeizaam onderzoek voorkomen kon worden.

En ander instituut was dat van de compositie, dat toegepast werd bij de lagere gerechten. Door betaling van een geldsom aan de openbare aanklager zag deze van vervolging af, waardoor alle aan het proces verbonden moeilijkheden omzeild konden

171 Zie voor een uitgebreide historische beschrijving van de transactie tot en met 1935: P. s'Jacub, Geschiedenis, theorie en practijk van artikel 74 Wetboek vãn Strafrecht, 's-Gravenhage 1936. 
worden. Was het de bedoeling dat dit onder rechterlijke controle geschiedde, de praktijk was een andere. Dit vond zijn oorzaak in de vrijwel onafhankelijke positie van de openbare aanklagers, de baljuwen en de officieren. Meestal waren zij voorzitter van het betrokken college en bovendien stonden zij aan het hoofd van de plaatselijke politie. De boetes kwamen aan hen toe en dat leidde ertoe dat zij zoveel mogelijk trachtten te innen. Het gevolg was misbruik op grote schaal. Personen, tegen wie ook maar de flauwste verdenking bestond, hoe ongegrond soms ook, werden zonder meer gearresteerd en opgesloten om vervolgens in de gelegenheid te worden gesteld te composeren. Van deze gelegenheid werd maar al te vaak gebruik gemaakt om zo een procedure te kunnen voorkomen, waaraan voor de verdachte hoge kosten verbonden waren en waarbij hij het risico liep met verbanning, lijfstraf of verbeurdverklaring van goederen gestraft te worden.

De overheid trachtte deze praktijken te bestrijden, onder andere door procedures tegen de baljuw (niet altijd met resultaat) en wettelijke regelingen. De Criminele Ordonnantiën van 1570 bevatten een scherp verbod van de compositie. In de praktijk echter bleef de compositie bestaan. De omwenteling van 1795 bracht slechts een tijdelijke verbetering: de nieuwe magistraten keerden spoedig tot de oude gebruiken terug. Verschillende ontwerpen van wettelijke regelingen bevatten regels over de compositie en de submissie. Deze werden echter niet ingevoerd. De Franse overheersing (1810-1813) bracht opheffing van de instituten, doch na 1813 werden zij in ere hersteld.

\subsection{8}

Inmiddels was ons land verenigd geweest met België (1813-18.30) en alle ontwerpen van nationale wetgeving moesten in handen worden gesteld van een Belgische Commissie die daarover advies moest uitbrengen. Het is waarschijnlijk de invloed van de Belgen geweest dat de oude vormen van submissie en compositie niet meer in de wet van 1838 opgenomen werden. In 1815 bracht de Belgische Commissie, in het kader van een Ontwerp Wetboek van Strafvordering, een negatief advies uit over de submissie: wanneer er geen bewijs was van het feit of van de schuld van de dader behoorde er geen veroordeling of straf te volgen, ook niet via een omweg. Aan de andere kant mocht de verdachte niet aan een rechtvaardige bestraffing ontkomen. De compositie had evenmin de instemming van de Belgen. Dit instituut gaf enerzijds het vervolgend orgaan de mogelijkheid vriendjespolitiek te voeren en zou anderzijds kunnen leiden tot represailles van machtige lieden aan wie een schikking zou zijn geweigerd.

Bij die zelfde wet van 1838 werd een nieuwe methode van afdoening geïntroduceerd: wanneer op bepaalde lichte overtredingen geen zwaardere straf was gesteld dan geldboete, kon de beklaagde vervolging voorkomen door vrijwillig het maximum van die boete te voldoen aan het OM (art. $254 \mathrm{~Sv}$ ). Waarschijnlijk om willekeur te vermijden en om te voorkomen dat iemand een geldboete voldeed terwijl hij anders 
zou worden vrijgesproken, werd een machtiging door de kintonrechter vereist. Het verschil met vroeger was dat de verdachte niet deemoedig een verzoek tot de rechter behoefde te richten. Het doen van een aanbod was nu een recht van de verdachte en het verplichtte het OM zijn medewerking te verlenen. De boete stond vast en was van te voren bij de beklaagde bekend, zodat ongerechtvaardigde bevoorrechting was uitgesloten.

Deze nieuwigheid had in de Tweede Kamer kritiek ontmoet. De regeling zou de rijkere verdachte een bevoorrechte positie geven in vergelijking met de armere. Een ander tegenargument was dat de vervolging op zich ook een deel van de straf vormt en dit effect zou dan verloren gaan. Bovendien was de kans aanwezig dat iemand zijn geldboete betaalde, terwijl hij vrijgesproken diende te worden. Hierop voegde de minister de rechterlijke machtiging toe aan het ontwerp. ${ }^{172}$

Deze wijze van afdoening werd aangeduid met submissie, historisch gezien een verkeerde term, want deze afdoeningswijze verschilde van de oude submissic.

De oude vormen van submissie en compositie verdwenen hiermee uit de strafwet. In andere wetten, bijvoorbeeld de Jachtwet, bleef de compositie bestaan in de vorm dat door in te gaan op de door de officier van justitie aangeboden transactie de verdachte strafvervolging kon voorkomen. Achtergrond hiervan was een enorme toename van het aantal overtredingen dat op de openbare terechtzitting zou moeten worden behandeld. ${ }^{13}$

\subsection{6}

In 1886 onderging de regeling opnieuw enkele wijzigingen. Met de invoering van het nieuwe Wetboek van Strafrecht werd een gedeelte naar dit wetboek gebracht (art. $74 \mathrm{Sr}$ ), met als argumentatie dat de regeling van het verval van het recht van strafvordering de vraag betreft of een strafvervolging kan worden ingesteld. Deze vraag werd geacht een vraag van materieel recht te zijn. De procedurele gang van zaken bleef in het Wetboek van Strafvordering staan.

Tevens bepaalde de wetgever dat de toepasselijkheid uitgebreid werd tot die gevallen, waarin naast geldboete verbeurdverklaring was bedreigd. Verder werd bepaald dat, in geval van strafverzwaring wegens herhaling, de afdoening buiten proces op de wijze als hier vermeld zou worden gelijkgesteld met een onherroepelijke veroordeling. De rechterlijke machtiging werd, op voorstel van de Raad van State, uiteindelijk in art. $74 \mathrm{Sr}$ niet opgenomen omdat de voorkoming van vervolging door betaling van een geldbedrag vergemakkelijkt diende te worden. Hierover bestond echter geen algemene overeenstemming. ${ }^{174}$ 
Bij de discussie over de vraag of teruggekeerd moest worden tot het transactiestelsel, waarbij de officier van justitie de hoogte van de boete bepaalde, toonde een meerderheid van de Tweede Kamer zich hiervan tegenstander, hoewel erkend werd dat vrijwillige betaling van het maximum der geldboete vrijwel niet meer zou plaatsvinden, doordat het ontwerp WvSr een grote speling liet tussen minima en maxima. De regel moest zijn dat de rechter de straf bepaalt en niet, ook niet indirect, het $\mathrm{OM}$. Alleen bij uitzondering moest worden toegelaten dat de beklaagde een rechterlijke uitspraak kon voorkomen, maar dan ook door het vrijwillig ondergaan van de hoogste straf.

\subsection{1}

Een voortdurende toename van het aantal strafzaken, met name van die welke tot de competentie van de kantonrechter behoorden, leidde op het einde van de negentiende eeuw tot capaciteitsproblemen bij de kantongerechten.

Art. $254 \mathrm{~Sv}$ was reeds in onbruik geraakt ten gevolge van steeds hoger geworden maxima. Bovendien stelden lagere overheden vaak naast geldboete hechtenis als straf op overtreding van hun verordeningen. Voor toepassing van art. $254 \mathrm{~Sv}$ kwamerr deze bepalingen niet in aanmerking. Het bleek onmogelijk alle zaken via de wettelijke weg binnen een redelijke termijn te behandelen. De meeste zaken waren echter eenvoudig van aard en de berechting leverde geen moeilijkheden op.

Het vraagstuk ontstond van de vereenvoudiging van rechtspleging in lichte strafzaken. Bij de oplossing hiervan manifesteerden zich twee denkrichtingen:

1. Naar buitenlands voorbeeld kon voor een bepaalde categorie van strafbare feiten een speciale, summiere procedure worden ingevoerd.

2. Naast de vereenvoudiging en bespoediging van de bestaande procedure kon de mogelijkheid van afdoening buiten proces worden uitgebreid, in die zin dat strafvervolging zou kunnen worden voorkomen door betaling van een bedray. minder dan de maximale boete.

De Nederlandse Juristenvereniging besteedde verschillende vergaderingen aan dit probleem.

In 1884 verklaarde Van Hamel zich voorstander van het eerste systeem. Als bezwaar tegen het tweede, de transactie, voerde hij aan dat er dan geen sprake was van rechtspraak. In plaats van de rechter zou het de vervolgend ambtenaar zijn die vervolg en de strafmaat vaststelt en Van Hamel vreesde dat misbruik, bevoorrechting en ongelijke bestraffing hiervan het gevolg zouden zijn. De verdachte zou de vrijheid kunnen kopen.

Van Swinderen zocht een tussenoplossing. Hij wilde in geval van overtreding, waarop alleen geldboete stond, al dan niet gecombineerd met verbeurdverklaring, de kantorrechter de bevoegdheid geven om, op requisitoir van het $\mathrm{OM}$, het door beklaagde in der minne te betalen bedrag vast te stellen. Nam het $\mathrm{OM}$ hiermee geen genoegen 
dan kon het de zaak ter zitting brengen. In beide gevallen zou het de rechter zijn die de boete vaststelt, welke geacht werd in verhouding te staan met de gepleegde overtreding. Beide schrijvers waren van mening dat de mogelijkheid tot vrijwillige betaling van het maximum van de gestelde boete moest worden gehandhaafd. Zowel het standpunt van Van Hamel als dat van Van Swinderen ontmoette kritiek. $\mathrm{Zij}$ werden door de vergadering afgewezen. Het systeem van de transactie werd verworpen, evenals de vrijwillige betaling van het maximum der gestelde boete. Tijdens de vergadering van de Nederlandse Juristenvereniging van 1892 sloot Van der Aa zich bij Van Swinderen aan. De vraag of het wenselijk was de gelegenheid open te stellen ook door betaling van minder dan het maximum der geldboete vervolging te voorkomen werd nu, in tegenstelling tot 1884 , door de vergadering bevestigend beantwoord. In 1895 pleitte Rethaan-Macaré voor terugkeer naar het oude submissiestelsel, waarbij de verdachte een verzoekschrift moest richten aan de rechter, waarin hij het strafbaar feit bekende en tevens alles aanvoerde wat tot zijn verontschuldiging kon leiden, met de bedoeling dat de rechter een milde(re) straf op zou leggen. Een openbaar proces kon hiermee voorkomen worden.

De preadviseurs in 1896, Van Geuns en Van Hamel, waren het erover eens dat geen nieuwe stelsels moesten worden ingevoerd, maar dat een oplossing gezocht moest worden in een vereenvoudiging en vooral bekorting van de bestaande procedure. Uitbreiding van art. $74 \mathrm{Sr}$ in die zin dat het $\mathrm{OM}$ het door de verdachte te betalen bedrag zou vaststellen, vond Van Geuns onjuist omdat het $\mathrm{OM}$ dan het terrein van de rechter zou betreden. Aan het systeem, waarbij de rechter het bedrag zou moeten vaststellen kleefden volgens hem praktische bezwaren. Of de rechter onderzoekt de zaak niet, maar dan kan hij het bedrag niet nauwkeurig vaststellen met de kans dat het te hoog wordt, of hij onderzoekt de zaak wel, maar dat zou er toe kunnen leiden dat een dubbele behandeling van de zaak zou plaatsvinden, namelijk als de beklaagde toch een openbare zitting wilde. Van Hamel keurde wederom het transactiestelsel af en vond het submissiestelsel niet in de tijd passen, omdat een verdachte zich bij voorbaat neerlegde bij een beslissing die hij later onbillijk kon vinden. Voor hem bleef als mogelijkheid open de vaststelling van het bedrag door de rechter. De vergadering, tenslotte, beantwoordde de vraag "Moet de gelegenheid worden gegeven tot voorkoming der strafvervolging, door vrijwillige betaling van een boetebedrag, door den rechter vast te stellen?" bevestigend.

Een eerste wetsvoorstel verscheen in 1907. Dit stond theoretisch op het standpunt van de Nederlandse Juristenvereniging van 1896 . Het zwaartepunt lag op de uitbreiding van de mogelijkheid van afdoening buiten proces. Art. $74 \mathrm{Sr}$ werd uitgebreid in die zin dat niet alleen maar betaling van de maximum boete mogelijk was. Bij overtredingen waarop geldboete, al dan niet naast hechtenis, was gesteld, verviel het recht op strafvordering door tijdige voldoening aan de voorwaarde, te stellen door een ambtenaar van het $\mathrm{OM}$ en goedgekeurd door de kantonrechter. Wanneer de kantonrechter zich tegen een zodanige afdoening verklaarde moest het $O M$ de zaak ter zitting aanbrengen. 
Het Voorlopig Verslag leek niet gunstig. De Commissie van Rapporteurs was van mening dat de voorstellen niet ver genoeg gingen en tot onvoldoende verbetering zouden leiden. De inmenging van de rechter diende te vervallen.

In 1913 werd dit ontwerp ingetrokken. ${ }^{175}$

Inmiddels was in 1910 een voorstel van de Staatscommissie Herziening Wetboek van Strafvordering verschenen. Dit ontwerp zocht in de eerste plaats naar mogelijkheden om het rechtsgeding te bespoedigen en te vereenvoudigen. Daarnaast kende het ontwerp de mogelijkheid van afdoening buiten proces door vrijwillige aanvaarding van een zekere straf, die zou bestaan uit betaling van een bedrag minder dan de maximum boete. Tussenkomst van de rechter werd uitgesloten.

Het wetsvoorstel luidde: Het recht tot strafvordering wegens overtreding waarop naar de wettelijke omschrijving geldboete, hetzij als enige hoofdstraf hetzij hechtenis is gesteld, vervalt door vrijwillige voldoening aan de voorwaarde welke de bevoegde ambtenaar van het $\mathrm{OM}$ op vóór de aanvang van de terechtzitting in te dienen verzoek van de verdachte ter voorkoming van strafvervolging mocht hebben gesteld. De voorwaarde bestaat uit de betaling van een geldsom binnen een door de ambtenaar te bepalen termijn, met of zonder uitlevering van aan verbeurdverklaring onderworpen voorwerpen of voldoening der geschatte waarde of afstand van reeds inbeslaggenomen voorwerpen. De te betalen geldsom bedraagt minimaal 50 cent en hoogstens het maximum van de boete naar wettelijke omschrijving op het feit gesteld. Als er op de overtreding geen andere hoofdstraf is gesteld dan geldboete en de verdachte biedt aan het maximum van deze boete te betalen binnen een door de ambtenaar van het $\mathrm{OM}$ te bepalen termijn dan zal deze ambtenaar dat niet mogen weigeren.

De behandeling van dit voorstel door de Tweede Kamer liet, door de oorlogstoestand, op zich wachten. In 1919 werd het ontwerp "Wet tot vereenvoudiging van de rechtspleging in lichte strafzaken" ingediend, waarin de voorstellen tot wijziging van art. 74 Sr van de Staatscommissie Strafvordering werden overgenomen.

In het Voorlopig Verslag werd als bezwaar naar voren gebracht dat de ambtenaren van het OM bij de kantongerechten de nodige ervaring zouden missen om de bepaling goed uit te voeren. Men vreesde dat zij een heel andere strafmaat zouden hanteren dan de kantonrechters. Bovendien zou de toepassing in de verschillende arrondissementen aanzienlijk kunnen verschillen. Er zou een schijn van willekeur kunnen ontstaan die vermeden diende te worden. Aangedrongen werd op (her)invoering van de rechterlijke toestemming, waardoor een juiste vaststelling van de transactiebedragen zou zijn gewaarborgd.

In de MvA bestreed de minister van Justitie deze bezwaren. De ambtenaar van he! OM stelt op verzoek van de verdachte de voorwaarde en door vrijwillige vervulling van die voorwaarde vervalt het recht tot strafvordering. De ambtenaren van het $\mathrm{OM}$ 
staan onder toezicht van de officier van justitie. De ambtenaren zullen zich aansluiten bij de strafmaat van de kantonrechter. Doch, wordt hiervan afgeweken ten nadele van de verdachte dan kan deze besluiten niet op de voorwaarde in te gaan. Zijn oordeel is allesbeslissend. Met betrekking tot de mogelijke verschillen in afdoening in verschillende arrondissementen antwoordde de minister dat hetzelfde geldt voor beslissingen van rechters. Daarnaast kunnen de procureur-generaal en de officieren van justitie de eenheid bevorderen. Voor rechterlijke toestemming voelt de minister niets, omdat daarvoor een proces van hoor en wederhoor noodzakelijk zou zijn terwijl men juist afdoening buiten proces wenst.

Bij wet van 5 juli 1921, Stb. $883^{176}$ werd de transactieregeling gewijzigd.

Art. $74 \mathrm{Sr}$ vermeldde niet hoe het bedrag werd vastgesteld. In een circulaire van 1922 bracht de minister naar voren dat dit moest overeenkomen met de straf die de verdachte vermoedelijk van de kantonrechter zou hebben gekregen. Doel van de afdoening buiten proces was een snellere en minder omslachtige strafprocedure voor de kantonrechter. Het zou niet de bedoeling zijn om de berechting van strafzaken, een aan de rechter opgedragen taak, over te brengen naar een ambtenaar van het $\mathrm{OM}$, een orgaan dat daarvoor door de Grondwet niet was aangewezen. Het resultaat moest hetzelfde zijn als wanneer de kantonrechter de straf zou hebben bepaald. Bij de verdachte mocht niet de indruk worden gewekt dat hij er door deze afdoeningswijze voordeliger zou afkomen. Hoe de ambtenaar van het $O M$ in de praktijk handelde was moeilijk te controleren. De verdachte kon aan de circulaire geen recht ontlenen en als hij eenmaal aan de gestelde voorwaarde voldaan had kon daarin geen verandering meer worden gebracht.

De tekst van art. $74 \mathrm{Sr}$ bleef ongewijzigd tot 1 mei 1983. De invulling ervan onderging echter, onder invloed van de crisis van de dertiger jaren, wel een verandering. Noodzakelijke bezuinigingen en een geweldige stijging van het aantal door de parketten te behandelen strafzaken vestigden opnieuw de aandacht op art. $74 \mathrm{Sr} .{ }^{1 \pi}$ De Staatscommissie voor de verlaging van de Rijksuitgaven ${ }^{178}$ wilde het aantal strafvonnissen zoveel mogelijk beperken. Afdoening buiten proces kon daartoe een doeltreffend middel zijn, mits het bedrag dat ter voorkoming van vervolging betaald moest worden lager zou zijn dan de boete die door de rechter zou worden opgelegd. De commissie hield hierbij zeer waarschijnlijk rekening met de bij meerdere parketten ontstane praktijk. In 1935 werd een aanvang gemaakt met dit systeem, waarbij aan verdachte ongevraagd, derhalve anders dan de wet lijkt te veronderstellen, de gelegenheid werd gegeven zijn zaak buiten proces af te doen door betaling van een bedrag dat iets

176 Wet tot vereenvoudiging van de rechtspleging in lichte strafzaken.

177 Zie s'Jacob, a.w., pag. 119-123.

178 Commissie Welter, 1932. 
lager werd gesteld dan de boete die de kantonrechter pleegde op te leggen. Dit ontlokte s'Jacob de opmerking:

"Hoe het zij, als de nood aan de man komt, is voor theoretische beschouwingen geen plaats meer. Crisis breekt wet, dat is ook in andere opzichten duidelijk gebleken. Trouwens, het moet worden toegegeven, uit een oogpunt van billijkheid en uit een oogpunt van bestrijding van de criminaliteit is het verschil of iemand voor een geringe overtreding door den rechter wordt veroordeeld tot een geldboete van drie gulden, dan wel door betaling van een bedrag van een rijksdaalder, practisch van geen betekenis".

Hij blijft echter van mening dat het transactiebedrag gelijk moet zijn aan het te verwachten rechterlijk vonnis maar vreest dat deze gedwongen wijziging niet van tijdelijke aard zal zijn. ${ }^{1 x}$ In de volgende paragraaf zal blijken dat deze vrees bewaarheid is geworden.

\subsection{De huidige wettelijke regeling, ingevoerd in 1983}

Op 1 mei 1983 werd de transactiebevoegdheid van het OM aanzienlijk uitgebreid. ${ }^{18}$ Van Veen sprak zelfs van een "aardverschuiving". ${ }^{181}$

Ter voorbereiding van deze wetswijziging verschenen twee rapporten van de Commissie Vermogensstraffen, waarin onder andere wijziging c.q. uitbreiding van de bestaande regeling werd bepleit. ${ }^{182}$

Inspiratiebron voor deze commissie was de Wet op de Economische Delicten, waarin een dergelijke uitbreiding reeds was gerealiseerd.

De commissie stelde voor de transactiebevoegdheid uit te breiden tot alle misdrijven, met als argumentatie dat wie het meerdere mag (seponeren) ook het mindere mag doen. Dit is een eenzijdige benadering van de meerdere-mindere optiek. Voor de verdachte betekent de transactie 'meer' dan een sepot. De commissie beoogde hiermee twee verbeteringen in het strafrecht aan te brengen:

1. Een humanere bejegening van de verdachte, vooral door terugdringing van de vrijheidsstraf maar ook door verruiming van de transactiemogelijkheid. De verdachte behoefde dan niet meer in het openbaar terecht te staan.

179 Zie s'Jacob, a.w., pag. 122-123.

180 Wet van 31 maart 1983, Stb. 153.

181 Th.W. van Veen, Het nieuwe art. $74 \mathrm{Sr}$, een aardverschuiving. DD 1983, pag. 539-543.

182 Commissic Vermogensstraffen, ingesteld bij besluit van de minister van Justitic van 9 mei 1966. Interimrapport Vermogensstraflen, Den Haatg 1969.

Eindrapport van de Commissic Vermogensstraffen, Den Haag 1972. 
2. Tijdsbesparing voor getuigen, deskundigen, raadsman, rechter en OM. Met name voor de twee laatstgenoemden gold dat zij zich dan met echt belangrijke zaken konden bezighouden.

Als eventueel bezwaar onderkende de commissie dat de voorgestelde regeling er in bepaalde gevallen toe zou kunnen leiden dat de verdachte onder druk wordt gezet of de zaak ten onrechte aan de openbaarheid wordt onttrokken.

De commissie zag echter als garanties tegen onverantwoord transactiebeleid de hiërarchische ordening binnen het $\mathrm{OM}$, waardoor een individuele officier aanwijzingen van bovenaf zou krijgen, de parlementaire verantwoordelijkheid van de minister van Justitie, die, indien dit wordt gewenst, verantwoording moet afleggen over het gevoerde beleid, en de vrije openbare meningsuiting.

Verder stelde de commissie voor het vereiste van een uitdrukkelijk verzoek om transactie van de verdachte te laten vervallen. De zogenaamde submissie zoals die was neergelegd in art. 74 lid $4 \mathrm{Sr}$ moest verdwijnen. Daarnaast wilde de commissie de beklagmogelijkheid voor de gelaedeerde (art. $12 \mathrm{~Sv}$ ) laten vervallen. ${ }^{133}$

De wetgever nam niet alle voorstellen van de commissie over. Zo werd de transactiebevoegdheid niet verruimd tot alle misdrijven, maar tot misdrijven, waarop niet meer dan 6 jaar gevangenisstraf is gesteld. ${ }^{1 \ll}$ De minister achtte de uitsluiting van transactie voor zeer zware misdrijven gewenst om de integriteit van het transactie-instituut te verzekeren: het zou immers wel een zeer vreemde indruk maken, indien bijvoorbeeld moord en doodslag bij wege van transactie in handen van het $\mathrm{OM}$ zouden kunnen worden afgedaan. ${ }^{125}$ Tevens gaf de minister van Justitie er de voorkeur aan de regeling van art. $12 \mathrm{~Sv}$ ook op gevallen van transactie wegens misdrijf mogelijk te maken. Verder prefereerde de minister de submissie te handhaven, omdat de verdachte er belang bij kan hebben om aan de onzekerheid of hij een transactievoorstel zal ontvangen, een einde te maken. ${ }^{186}$

Bij de uitbreiding van de transactiemogelijkheid stonden bij de minister vooral de doelmatigheidsoverwegingen voorop. De terechtzitting rondom de bestrijding van de kleine criminaliteit vond hij in het algemeen te zwaar in verhouding tot de feiten, waaraan men overigens niet wilde voorbijgaan. De transactiebevoegdheid voor misdrijven zou bijdragen aan de bevordering van de produktiviteit van de rechterlijke macht als geheel. Het moest hierbij gaan om zaken waarin tot dagvaarding werd overgegaan en ter terechtzitting werd volstaan met het eisen van een onvoorwaardelijke geldboete. Om te bereiken dat zoveel mogelijk zaken door middel van transactie zouden worden

183 Interimrapport pag. 79-81.

184 Dit gebeurde na een advies van de Commissie Partiêle Herziening Strafvordering (Commissie Duk), zoals mij gebleken is uit het Centraal Archief van het ministerie van justitie, Wetten 937. Zie hierover uitgebreid hoofdstuk 4.

185 MvA, TK 1981-1982, 15012, no. 5, pag. 35.

186 MvT, TK $1977-1978,15012$, no. 1-3, pag. 36. 
afgedaan, werd de verdachte, die weigerde op het transactie-aanbod in te gaan, ter terechtzitting een boete in het vooruitzicht gesteld die hoger zou zijn dan het transactiebedrag (ziehier de vrees van s'Jacob).

De andere doelstelling, een humanere bejegening van de verdachte, zo al ooit serieus gemeend, verdween geleidelijk naar de achtergrond.

In het algemeen werd het wetsvoorstel tot verruiming van de transactiebevoegdheid tot misdrijven, behalve die waarop meer dan zes jaar gevangenisstraf staat, in het parlement met instemming begroet. De transactie zou een doeltreffend middel zijn ter bestrijding van de kleine criminaliteit. De kwantiteit van de strafrechtspleging moest afgewogen worden tegen de kwaliteit. De verruiming van de transactie kon een bijdrage leveren aan een vermindering van de werklast van het justitieel apparaat en daardoor aan het terugdringen van de te lange wachttijden, alsmede aan het terugbrengen van de voorraad lopende vonnissen.

Er bestonden echter ook bezwaren tegen het voorstel tot wijziging van art. $74 \mathrm{Sr}$. In de Tweede Kamer werd door verschillende politieke partijen aan de orde gesteld of door de sterke uitbreiding van de transactie het gevaar niet zou ontstaan dat de officier van justitie op de stoel van de onafhankelijke rechter zou plaatsnemen. ${ }^{1 F}$ Tevens werd gewezen op de zwakker wordende positie van een verdachte tegenover een sterker wordend OM. . $^{\text {ss }}$

De minister stelde dat de verruiming van de transactiebevoegdheid was gebaseerd op doelmatigheidsoverwegingen. De transactie moest dan worden toegepast in die gevallen waarin de rechter zou hebben volstaan met het opleggen van een geldboete. De officier van justitie moet bij het aunbieden van een transactie het straftoemetingsbeleid van de rechter als uitgangspunt nemen. ${ }^{* *}$ De rechterlijke controle zit volgens de minister in de waarborg voor de verdachte dat hij geheel vrij is om het transactieaanbod te accepteren. Weigert hij dit, dat kan hij de zaak aan het oordeel van de rechter onderwerpen. ${ }^{20}$ Door het opstellen van richtlijnen zal getracht worden rechtsongelijkheid te voorkomen.

Naast de reeds door de Tweede Kamer opgeworpen bezwaren signaleerde de Eerste Kamer nog andere. Allereerst werd de vraag aan de orde gesteld waarom de grens tussen wel of niet voor transactie vatbare delicten lag bij misdrijven met een gevangenisstraf van zes jaar. Verschillende senatoren vonden dit enigszins onlogisch. Hierdoor zou middelzware criminaliteit vatbaar worden voor transactie en tevens zouden lichte

187 Zie bijvoorbeeld het Voorlopig Verslag, TK 1978-1979, 15012, no. 4, pag. 12, en Handelingen Il 18-5-1982, pag. 3362.

188 Handelingen II 18-5-1982, pag. 3367 en pag. 3370.

189 MvA, TK 1981-1982, 15012, no. 5, pag. 23.

MvA pag. 24; Handelingen II 19-5-1982, pag. 3381. 
vormen van zwaar bedreigde feiten niet, en zware vormen van minder bedreigde feiten, wél transigabel zijn. ${ }^{21}$

De minister kwam met het (mijns inziens zwakke) antwoord, dat deze grens inderdaad wat arbitrair is, maar dat het wetsontwerp, afkomstig van zijn voorganger, er nu eenmaal zo ligt. ${ }^{22}$

Daarnaast wordt door de Senaat geconstateerd dat de weg naar de rechter steeds smaller zal worden. De rechtsbescherming van de verdachte zal verminderen. Hij komt tegenover een machtig OM te staan. Een verdachte is formeel dan wel vrij in zijn keuze de transactie wel of niet te aanvaarden, materieel is hij dat niet. ${ }^{23}$ Gesuggereerd wordt om, ter toetsing van de billijkheid van een transactievorsstel, een rechterlijke beslissing mogelijk te maken. Hiertegen voert de minister aan dat dit zou leiden tot een werklastverzwaring voor de rechterlijke macht en het was nu juist de bedoeling deze te verlichten. ${ }^{24}$

De belangrijkste verschillen tussen de oude en de nieuwe regeling zijn:

1. De mogelijkheid strafvervolging door middel van transactie te voorkomen is niet meer beperkt tot overtredingen, maar is uitgebreid tot misdrijven, behalve die waarop een gevangenisstraf staat van meer dan zes jaar;

2. De officier van justitie is degene die het transactie-aanbod doet. De vorige tekst ging er van uit dat de verdachte een verzoek moest richten aan de ambtenaar van het $\mathrm{OM}$, ofschoon de praktijk was geworden dat het $\mathrm{OM}$ in daarvoor in aanmerking komende gevallen dadelijk meedeelde onder welke voorwaarden het bereid was van vervolging af te zien;

3. Het aantal te stellen voorwaarden is uitgebreid.

\section{Samenvatting:}

Tijdens haar geschiedenis is de transactie steeds met argwaan bekeken. Tegenstanders van dit instituut hebben er door de jaren heen op gewezen dat misbruik en rechtsongelijkheid er het gevolg van konden zijn. Een ander steeds terugkerend argument tegen was de te zelfstandige positie van het $\mathrm{OM}$ ten opzichte van de onafhankelijke rechter. Het straffen van plegers van strafbare feiten, zeker die van misdrijven, diende aan de rechter overgelaten te worden.

Uitbreiding van de transactieregeling werd vrijwel steeds gebaseerd op praktische, proces-economische overwegingen, met name de werklast bij de rechterlijke macht speelde een rol.

Wanneer we de ontwikkeling van de transactieregeling bekijken kan gesteld worden dat:

21 Handelingen I 29-3-1983, pag. 488.

22 Handelingen I 19-3-1983, pag. 495.

23 Handelingen I 29-3-1983, pag. 487 en pag. 492.

24 Handelingen I 29-3-1983, pag. 494. 
1. Het aantal strafbare feiten, waarbij vervolging voorkomen kan worden door middel van transactie, aanzienlijk is uitgebreid;

2. De voorwaarden die bij transactie kunnen worden gesteld zijn uitgebreid;

De oorspronkelijke gedachte: het omzeilen van aan het strafproces verbonden moeilijkheden voor beide partijen bij lichte overtredingen, is door de huidige regeling veranderd in: het zo snel mogelijk afdoen van de meerderheid der misdrijven.

\section{Analyse van art. $74 \mathrm{Sr}$}

\subsection{Het initiatief tot de transactie}

In tegenstelling tot het oude art. $74 \mathrm{Sr}$ vermeldt de huidige wettelijke regeling dat het initiatief tot de transactie uitgaat van de officier van justitie. De vorige redactie wees de verdachte als initiatiefnemer aan.

De Commissie Vermogensstraffen was van oordeel dat het vereiste van een uitdrukkelijk verzoek van de verdachte als onnodig kon vervallen. Het zou de verdachte immen toch vrij staan de hem aangeboden transactie te accepteren.

De minister nam dit voorstel over.

Het was reeds praktijk dat het transactie-aanbod in feite van de zijde van het OM kwam. Dit kon op twee manieren gebeuren. In het ene geval werd door de verbalisant of de verhorend ambtenaar aan de verdachte gevraagd of hij wenste te transigeren. Het antwoord van de verdachte werd vermeld in het proces-verbaal en daarmee had dan het uitdrukkelijk verzoek van de verdachte, zoals het toenmalige art. 74 Sr vereiste, plaatsgehad.

In het andere geval werd aan de verdachte een acceptgirokaart of een postwisselformulier gezonden. Door betaling van het daarop vermelde, door het $\mathrm{OM}$ vastgestelde bedrag, kon de verdachte vervolging voorkomen. In de betaling zelf lag het verzoek van de verdachte opgesloten. ${ }^{26}$

De wetswijziging op dit punt past dus in deze ontwikkeling.

Hierbij is echter uit het oog verloren dat het, zeker nu het aantal transigabele delicten sterk is uitgebreid, voor een verdachte van belang kan zijn zelf een schikking te vragen.

De minister sluit deze mogelijkheid niet uit. ${ }^{27}$ 
Het zou naar mijn mening vollediger zijn geweest indien de mogelijkheid dat de verdachte verzoekt om een transactie naast de huidige regeling was blijven bestaan. ${ }^{2 s}$

In art. 74a Sr is een uitzondering op de regel, dat de transactie uit dient te gaan van de officier van justitie, neergelegd. Indien iemand wordt verdacht van een strafbaar feit, waarop naar wettelijke omschrijving geen andere hoofdstraf is gesteld dan geldboete en hij biedt aan het maximum der geldboete te betalen, alsmede aan andere door de officier te stellen voorwaarden (zie lid 2 van art. $74 \mathrm{Sr}$ ) te voldoen, dan mag de officier van justitie dit niet weigeren (dit noemt men submissie, hetgeen, historisch gezien, een verkeerde benaming is).

Zoals reeds beschreven was dit voor 1921 was dit de enige afkoopmogelijkheid. De Commissie Vermogensstraffen gaf er de voorkeur aan deze regeling af te schaffen. ${ }^{20}$ De voorkeur van de minister ging uit naar handhaving ervan, omdat de verdachte er belang bij kon hebben om aan de onzekerheid of hij een transactievoorstel zou ontvangen, zelf een einde te maken. ${ }^{30}$

Door deze regeling wordt aan de officier van justitie de mogelijkheid gegeven voorwaarden te stellen die zwaarder zijn dan een mogelijke straf die de rechter zou hebben opgelegd, namelijk door een cumulatie van voorwaarden.

Wanneer een verdachte van de mogelijkheid die art. 74a Sr hem biedt gebruikt maakt, behoeft dit nog niet te betekenen dat hij de maximum boete moet betalen. De officier van justitie stelt het bedrag vast. Dit leidt ertoe dat een verdachte niet langer het risico loopt een hoger bedrag te betalen dan wanneer het initiatief tot de transactie van de officier van justitie was uitgegaan. Wel blijft de kans bestaan dat hij meer voldoet dan waartoe de rechter hem zou hebben veroordeeld.

\subsection{Voor de aanvang van de terechtzitting}

Het eerste lid van art. $74 \mathrm{Sr}$ bepaalt dat de officier van justitie voor de aanvang van de terechtzitting een of meer voorwaarden kan stellen. In de praktijk verbindt de officier van justitie aan zijn voorstel een termijn, waarbinnen voldaan moet zijn. $\mathrm{Hij}$ is vrij in het bepalen van deze termijn.

In het arrest van 27 juni 1932, NJ 1933, pag. 27 bepaalde de Hoge Raad dat de te stellen termijn niet voor de aanvang van de terechtzitting behoeft af te lopen. De rechter mag, indien het OM de dagvaarding niet intrekt, het onderzoek niet sluiten, voordat de termijn verstreken is. Hiervoor kan de rechter geen vonnis wijzen omdat hij de ontvankelijkheid van het $\mathrm{OM}$ niet kan beoordelen. Wordt een vonnis gewezen nadat aan de voorwaarden is voldaan, dan is het vonnis nietig.

Vgl. M.S. Groenhuijsen en A.M. van Kalmthout: De wet vermogenssancties en de kwaliteit van de rechtshedeling. DD 1983, pag. 1.

29 Eindrapport Commissie Vermogensstraffen, pag. 58.

30 MvT Wet Vermogenssancties, TK 1977-1978, 15012, nr. 1-3, pag. 48. 
Het kan ook voorkomen dat het $\mathrm{OM}$ aan het transactievoorstel geen termijn verbindt. In dat geval moet worden aangenomen dat een verdachte, zolang het vonnis niet in kracht van gewijsde is gegaan, altijd nog de mogelijkheid heeft door middel van transactie de zaak af te doen. ${ }^{31}$

\subsection{Voorwaarden ${ }^{32}$}

Door de inwerkingtreding van de Wet Vermogenssancties is het aantal bij transactie te stellen voorwaarden uitgebreid. Het oude art. $74 \mathrm{Sr}$ kende als voorwaarde de betaling van een bepaalde geldsom met of zonder uitlevering van aan verbeurdverklaring onderworpen voorwerpen of afstand van reeds in beslag genomen voorwerpen, De te betalen geldsom bedroeg ten minste vijftig cent en ten hoogste het maximum der boete die op het strafbaar feit gesteld was.

Het nieuwe art. $74 \mathrm{Sr}$ vermeldt deze voorwaarden naast elkaar (lid 2 sub a, b, c). Het minimum van de te betalen geldsom is verhoogd naar vijf gulden. De officier van justitie kan één van de voorwaarden van art. $74 \mathrm{Sr}$ opleggen. Hij kan ze echter ook cumuleren.

Als nieuwe voorwaarden zijn opgenomen: de voldoening aan de Staat van een geldbedrag gelijk aan of lager dan het geschatte voordeel- met inbegrip van besparing vatn kosten- door de verdachte door middel van het strafbaar feit verkregen (art. 74 lid 2 sub d) en een gehele of gedeeltelijke vergoeding van de door het strafbaar feit veroorzaakte schade (art. 74 lid 2 sud e).

In de praktijk werd deze schadevergneding reeds gebruikt als een "voor-voorwaarde". Het $O M$ liet de transactiemogelijkheid afhangen van het overleggen van het bewijs dat de schade geregeld was. Door deze voorwaarde in art. 74 op te nemen wordt duidelijkheid geschapen over de vraag of deze handelswijze van het $\mathrm{OM}$ wel legitiem was. $^{33}$

Aangenomen wordt dat de opsomming van de voorwaarden limitatief is. ${ }^{34}$ De officier van justitie mag bij een transactievoorstel geen andere voorwaarde, bijvoorbeeld een ontzegging van de rijbevoegdheid, opleggen.

Hoge Raad 3 oktober 1972, NJ 1973, 18.

32 Voor een uitgebreide omschrijving van de inhoud van de voorwaarden verwijs ik naar $P$. Osinga, Transactic in misdrijfzaken, Arnhem 1992, pag. 225-242. 
De sterke uitbreiding van het aantal strafbare feiten waarbij transactie mogelijk is kan als een ingrijpende wijziging van art. $74 \mathrm{Sr}$ worden beschouwd.

In de oude transactieregeling kon een transactie slechts plaatsvinden in geval van een overtreding waarop geldboete, hetzij als enige hoofdstraf hetzij naast hechtenis, was gesteld.

Uit de geschiedenis van dit instituut kan worden opgemaakt dat steeds terughoudendheid is betracht met betrekking tot uitbreiding van de gevallen waarin een transactie regeling kon worden getroffen. De wettelijke regeling van 1921 was eigenlijk uitsluitend met praktische argumenten te verdedigen. De transactiemogelijkheid moest in ieder geval beperkt blijven tot lichtere strafbare feiten en dit bleef (zelfs) gedurende de crisis van de dertiger jaren vanzelfsprekend.

In contrast hiermee staat de wetswijziging van 1983, waarbij de transactie is uitgebreid tot misdrijven, behalve die waarop meer dan zes jaar gevangenisstraf staat. De Commissie Vermogensstraffen had nog verder willen gaan door de transactiebevoegdheid uit te breiden tot alle misdrijven. Zover wilde de minister niet gaan. Wel gaf hij een zekere bovengrens aan: de transactie kan alleen worden aangeboden indien de verwachting bestaat dat de rechter geen vrijheidsstraf zal opleggen.

Gedurende de parlementaire behandeling is de uitbreiding van de transactie meer en meer in het licht komen staan van de bestrijding van de "kleine" criminaliteit. ${ }^{3 .}$

Op deze enorme uitbreiding van gevallen die door transactie kunnen worden afgedaan, kwam veel kritiek, die zich voornamelijk richtte op de grens zoals die gelegd werd tussen de wel en niet voor transactie vatbare delicten.

Door de nieuwe wettelijke regeling zou het in feite mogelijk zijn dat circa $90 \%$ van alle misdrijven door transactie kan worden afgedaan. ${ }^{36}$ Gevreesd werd dat de normale procedure voor de rechter, met alle waarborgen voor de verdachte, van de normale tot een bijzondere zou worden. ${ }^{37}$

Bovendien zou de voorgestelde regeling kunnen leiden tot ongerechtvaardigde situaties. Misdrijven kunnen in allerlei vormen en gradaties voorkomen. Een lichte vorm van een misdrijf waarop meer dan zes jaar gevangenisstraf staat zou niet getransigeerd kunnen worden, terwijl die mogelijkheid wel bestaat indien zich een zwaardere vorm van een misdrijf, waarop minder dan zes jaar staat, heeft voorgedaan. ${ }^{38}$

Voorts kan gewezen worden op bijvoorbeeld de Slavenburg-zaak, waarin aan verschillende personen die van fraude verdacht werden een transactie-aanbod is gedaan, dat geaccepteerd werd. Het lijkt mij moeilijk vol te houden dat de transactiebevoegd-

MvA, TK 1981-1982, 15012, nr. 5, pag. 25, Eindverslag, nr. 7, pag. 1.

Vgl. D.H. de Jong, Rechtsbescherming in een beslissende fase, pag. 27.

Vgl. Th.W, van Veen, De geldbocte op de helling, NJB 1978, pag. 917.

38 Een voorbeeld hiervan geven Groenhuijsen en Van Kalmthout, a.w., pag. 19. 
heid hier gehanteerd is om redenen van humanisering of decriminalisering of vanwege een effectieve aanpak van de kleine criminaliteit. ${ }^{\text {s }}$

Voor de grens, zoals die zou kunnen liggen tussen de wel en niet transigabele delicten, zijn verschillende alternatieven geboden.

Betoogd is dat de wetgever deze, voor overtredingen in beginsel geschikte, afdoeningsmethode niet naar het grootste deel der misdrijven had moeten overbrengen, maar beter die misdrijven of vormen van misdrijven welke geschikt zouden zijn om op die manier te worden afgedaan, bij de overtredingengroep onder te brengen."

Delicten, die vaak gepleegd worden en waarvan de norm weinig morele waarde heeft maar die de wetgever toch nageleefd wil zien, zouden op een tariefmatige wijze afgedaan kunnen worden. ${ }^{41}$ De grens tussen wel of niet voor transactie in aanmerking komende delicten wordt gezocht in de inhoud van de norm die overtreden wordt. Groenhuijsen en Van Kalmthout zoeken de oplossing in de concrete ernst van het begane delict. Legde de wetgever als maatstaf aan het in de wet tegen het delict bedreigde strafmaximum, zij zijn van mening dat de zwaarte van de in een bepaald geval op te leggen sanctie als uitgangspunt dient te worden genomen. ${ }^{42}$

In diezelfde lijn ligt het alternatief van de CDA-tweedekamerfractie bij de behandeling van het wetsontwerp, om voor de grensbepaling uit te gaan van de indeling van een strafbaar feit in een bepaalde boetecategorie. ${ }^{43}$

\section{De positie van de verdachte}

De oude transactieregeling bevatte de zinsnede: "Het recht tot strafvordering ....... vervalt door vrijwillige voldoening aan de voorwaarde......". Het huidige artikel 74 Sr zegt: "Door voldoening aan die voorwaarden vervalt het recht tot strafvordering.". Is hiermee de vrijwilligheid verdwenen?

Veelvuldig is als bezwaar tegen de verruimde transactieregeling aangevoerd dat de macht van het $\mathrm{OM}$ aanzienlijk wordt vergroot. De officier van justitie stelt de hoogte van het transactiebedrag vast en zou daarmee op de stoel van de rechter gaan zitten. Een deel van de straftoemeting wordt aan de rechter onttrokken en daarmee ook aan de openbaarheid. Dit betekent dan dat de transactieregeling in strijd kan komen met art. 6 EVRM, dat in het eerste lid bepaalt dat bij het bepalen van de gegrondheid van een tegen hem ingestelde strafvervolging een ieder het recht heeft op een eerlijke en openbare behandeling van zijn zaak door een onafhankelijke en onpartijdige

39 Vgl. C. Brants, Slavenburg: een geslaagde transactie? Recht en Kritiek 1987, pag. 7 e.v.

40 Vgl. Th.W. van Veen, De geldboete op de helling, NJB 1978, pag. 918.

41 D. Schaffmeister, preadvies NJV 1984, pag. 243 e.v.

42 M.S. Groenhuijsen en A.M. van Kalmthout, De wet vermogenssancties en de kwaliteit van de rechtsbedeling, DD 1983, pag. 19-20.

Voorlopig Verslag, TK 1978-1979, 15012, nr. 4, pag. 17 en MvA, TK 1981-1982, nr. 5, pag. 34. 
rechterlijke instantie welke bij wet is ingesteld. Eenzelfde bepaling wordt gevonden in art. 14 IVBP.

De minister bestrijdt dit met het argument dat het de verdachte altijd vrij staat de transactie te weigeren en zodoende zijn zaak aan het rechterlijk oordeel kan onderwerpen. De verdachte heeft een vrije toegang tot de rechter.

In de Deweer-zaak ${ }^{\text {t4 }}$ (klager werd betrapt op overtreding van prijsvoorschriften met betrekking tot vlees. De vervolger gelastte sluiting van de winkel tot de datum waarop een rechterlijke beslissing zou zijn genomen, of tot de dag waarop klager, bij wijze van minnelijke schikking, een som geld betaald zou hebben. Klager betaalde de schikking en zag daarmee af van een verdere procedure) besliste het Europese Hof dat een transactieregeling op zich niet in strijd is met art. 6 EVRM. Van belang is of de concrete toepassing in strijd is met art. 6: in hoeverre is de verdachte gedwongen aan de schikking te voldoen? "Absence of constraint is at all events one of the conditions to be satisfied". Het Hof bepaalde dat het voor de rechter moeten verschijnen als zodanig niet als dwang gezien kan worden. De beslissing van klager om in casu af te zien van een eerlijk proces met al zijn waarborgen door betaling van een geldbedrag, om winkelsluiting te voorkomen, was wél onder druk genomen en dus in strijd met art. 6 EVRM.

Formeel mag de redenering van de minister dus juist zijn, aan de materiële uitwerking ervan blijft naar mijn mening bezwaar verbonden. Formeel, volgens de letter van de wet, kan de verdachte vrij zijn in zijn beslissing het transactie-aanbod te accepteren, in feite bevindt hij zich vaak in een dwangpositie.

In de eerste plaats veronderstelt een keuzevrijheid gelijkwaardigheid van partijen. Het OM mag alleen een transactie aanbieden wanneer het strafbaar feit vast staat en de schuld van de verdachte aannemelijk is. Voor een verdachte, met name diegene zonder raadsman, is dit niet altijd goed te beoordelen. Daarnaast moet de officier van justitie zich richten naar het straftoemetingsbeleid van de rechter en alleen in dí gevallen een transactie-aanbod doen walarin de rechter een geldboete zou hebben opgelegd. Ook dit is voor een verdachte doorgaans niet goed te beoordelen. Hij beschikt in deze fase meestal niet over rechtsbijstand, zodat er sprake is van een ongelijke positie van de verdachte ten opzichte van het $O M$.

Maar bovendien: wat zijn de gevolgen voor de verdachte wanneer hij niet op de transactie ingaat? Hij zal in het openbaar moeten terechtstaan ter zake van het gepleegde strafbaar feit, hetgeen op zichzelf geen pretje is. Door het strafvorderingsbeleid van het OM loopt hij de kans door de rechter veroordeeld te worden tot een hogere geldboete of zelfs tot een vrijheidsstraf. Verder wordt een veroordeling door de rechter, in tegenstelling tot een aanvaarde transactie, op het strafblad vermeld. 
Kortom: genoeg redenen voor een verdachte om af te zien van het strafproces met al zijn rechtsbescherming.

Naar mijn mening behoort de tekst zoals die thans vermeld staat op een schikkingsvoorstel gewijzigd cq aangevuld te worden. De huidige tekst luidt:

" $U$ wordt verdacht van het plegen van een strafbaar feit, wairvan de gegevens onderaan deze brief zijn vermeld.

Ik ben bereid van verdere vervolging af te zien, indien u vớr (datum) het op aangehechte acceptgiro genoemde bedrag hetaalt.

Indien in verband met het door u geplecgde strafbare feit een of meer voorwerpen in beslag genomen zijn, geeft u door het voldoen atan deze voorwaarde(n) tevens aan dat u van het inbeslaggenome afstand doet.

Wanneer u niet of te laat betaalt en/of niet aan de overige voorwaarde(n) voldoet, zal ik uw strafzaak ter beoordeling voorleggen aan de rechter.

Betaling in termijnen is niet toegestaan.

De geldboete die ik ter terechtzitting zal vorderen is in de regel hoger dan het bedrag dat u thans als schikking wordt voorgesteld."

De zinsnede: "Ik ben bereid van verdere vervolging af te zien, indien..." moet verdwijnen, omdat daaruit van een zekere goedheid, gulheid, maar ook een zekere afhankelijkheid blijkt die er eigenlijk niet is. Beter zou zijn: "Van verdere vervolging wordt afgezien, indien...".

Een groter bezwaar vind ik het feit dat op dit formulier nergens gesproken wordt over het recht dat de verdachte zelf heeft, namelijk het recht om zijn zaak door de rechter te laten beoordelen. I $k$ ben van mening dat de verdachte er (actief) op gewezen dient te worden dat hij, indien hij gegronde bezwaren heeft tegen de beschuldiging of tegen de hoogte van het schikkingsbedrag, van zijn recht op toegang tot de onafhankelijke rechter gebruik kan maken en wat zijn rechten dan zijn. De huidige tekst is zo eenzijdig opgesteld, dat het lijkt alsof het de bedoeling is de verdachte ervan te weerhouden van dit recht gebruik te maken. De dreiging met een hogere boete is hier natuurlijk debet aan. Deze laatste regel is onaanvaardbaar en dient derhalve te verdwijnen.

De openbaarheid van de terechtzitting is bezwarend voor de verdachte. Aan de andere kant dient deze openbaarheid ter bescherming van de kwaliteit van de rechtspleging en daarmee ook ter bescherming van de verdachte. Dit gaat zwaarder wegen naar mate het om een ernstiger delict gaat. Maar juist in deze zaken is de kans groot dat de verdachte eerder bereid is om in te gaan op het transactie-aanbod van het OM.

Samenvattend kunnen we zeggen dat hier een evenwichtige machtenverdeling tussen de uitvoerende en de rechtcrlijke macht ter wille van de vrijheid van de burger en 
de onafhankelijkheid van de rechterlijke macht in zijn toetsende functie in het geding is.

Het vervolgingsbeleid van het $O M$ gaat er van uit dat, indien een verdachte het transactie-aanbod weigert, ter zitting een boete gevorderd zal worden die hoger is dan het oorspronkelijk transactiebedrag. Deze afweging kan een verdachte ook in een dergelijke dwangpositie brengen, waarvan gezegd zou kunnen worden dat dit in strijd is met art. 6 EVRM. De grens tussen het nemen van een beslissing in vrijheid of onder druk is moeilijk te bepalen.

\section{Uitwerking van art. $74 \mathrm{Sr}$ : transactiebeleid en richtlijnen}

Bij de voorbereiding van de Wet Vermogenssancties van 1983 is meerdere malen gesteld dat de verruimde transactiebevoegdheid gebruikt moet worden voor die gevallen waarin voorheen een onvoorwaardelijke geldboete werd opgelegd. Het resultaat van de transactie, betaling van een geldsom, zal uiteindelijk hetzelfde zijn en een strafproces kan daardoor vermeden worden. De officier van justitie dient zich bij een transactie-aanbod te richten naar hetgeen de rechter in dat geval zou hebben opgelegd. Mede ter bevordering van een gelijke rechtsbedeling zullen gedetailleerde richtlijnen over de toepassing van de verruimde transactiebevoegdheid worden gegeven. ${ }^{45}$ De minister is van mening dat het opstellen van richtlijnen eigenlijk alleen zin heeft bij delicten die relatief frequent voorkomen. Een bijkomend voordeel van richtlijnen is dat openbaarmaking ervan een controle-element in zich draagt. In de MvA aan de Tweede Kamer op de Wet Vermogenssancties stelt de minister:

"..zou ik de bedoelde richtlijnen... vooral willen zien als een middel om binnen het openbaar ministerie een uniform optreden te bevorderen en daarmee ook een gelijkheid van bedeling". ${ }^{46}$ En in de MvA aan de Eerste Kamer: "Het openbaar ministerie is bij de toepassing van de transactiebevoegdheid gebonden aan de wet en aan de in onze rechtsorde erkende beginselen die het optreden van het bestuur tegenover de burger beheersen. Naarmate de toepassing van de transactiebevoegdheid verder in naar buiten kenbare beleidsafspraken of in een bestendige praktijk is geobjectiveerd, zal de officier van justitie daaraan feitelijk en juridisch meer gebonden zijn"."

Op 27 april 1983 hebben de procureurs-generaal bij de gerechtshoven richtlijnen voor het transactie- en strafvorderingsbeleid van het OM vastgesteld. ${ }^{\text {ss }}$ Deze transac15012, nr. 4, pag. 23; Handelingen II 19-5-1982, pag. 3381.

46

47

MvA, TK 1981-1982, 15012, nr. 5.

MvA, EK 1982-1983, 15012, nr. 31 a.

Gepubliceerd in de Stcrt. van 28 april $19 \times 3$. 
tierichtlijnen geven voor een aantal misdrijven (enkele commune misdrijven zoals eenvoudige diefstal, winkeldiefstal, fietsendiefstal, mishandeling, gering verzet bij aanhouding, vernieling, niet voldoen aan een ambtelijk bevel, eenvoudige belediging en enkele bijzondere misdrijven zoals misdrijven uit de Telegraaf- en Telefoonwet 1904 en uit de Vuurwapenwet, alsmede het verbreken van de verzegeling van radioen televisietoestellen (art. $199 \mathrm{Sr}$ ) de te stellen voorwaarden aan. Dit betekent niet dat andere misdrijven niet in aanmerking komen en evenmin dat voor de genoemde misdrijven het aanbieden van een transactie altijd is aangewezen. Er kunnen redenen zijn die een behandeling ter terechtzitting rechtvaardigen. De vraag die zich dan voordoet is of het $\mathrm{OM}$, door geen transactie-aanbod te doen in een geval waarin volgens de, openbaar gemaakte, richtlijn een transactie-aanbod geïndiceerd is, daarmee in strijd gehandeld heeft met algemene beginselen van behoorlijk procesrecht, met name het vertrouwensbeginsel, en wat de gevolgen daarvan zijn. In een arrest van HR 13 september 1988, NJ 1989, 285 m.nt. ALM (een zaak met betrekking tot overtreding van art. 26 WVW) wordt de vraag aan de orde gesteld of er, indien er geen aanwijsbare redenen zijn om de zaak ter zitting te doen behandelen, voor het $\mathrm{OM}$ een verplichting bestaat om aan een verdachte die volgens de richtlijnen voor een transactie in aanmerking komt zo'n transactie aan te bieden op straffe van niet-ontvankelijkheid in geval van verdere vervolging bij gebreke van een dergelijk aanbod. Zowel de politierechter als het Hof gingen er van uit dat de officier inderdaad in strijd met de richtlijnen geen transactie had aangeboden. In geen van beide instanties volgde er een niet-ontvankelijk verklaring. De politierechter gaf de officier alsnog de gelegenheid een transactie-aanbod te doen en schorste de zitting. Toen de verdachte vervolgens niet op het transactie-aanbod inging, verklaarde de politierechter de officier ontvankelijk en veroordeelde de verdachte. Het Hof, na opgemerkt te hebben dat een transactie-aanbod niet meer gedaan kan worden nadat de behandeling ter zitting is aangevangen, betoogde dat voor de verdachte de mogelijkheid heeft opengestaan om tussen het ontvangen van de dagvaarding en de terechtzitting een verzoek te doen om alsnog een transactie aan te bieden en hem in elk geval de wettelijke mogelijkheid opengestaan had een bezwaarschrift tegen de dagvaarding in te dienen. Omdat hij dat niet gedaan heeft, staat hem ter zitting het verweer tegen het verzuim (een beroep op de niet-ontvankelijkheid) van de officier niet meer open. De Hoge Raad is van oordeel dat het feit dat de verdachte na ontvangst van de dagvaarding niet alsnog verzocht heeft om een transactie-aanbod en evenmin een bezwaarschrift heeft ingediend, hem niet de mogelijkheid ontneemt alsnog een verweer met genoemde inhoud te voeren en het ontslait de rechter niet van de plicht hierop een gemotiveerde beslissing te geven.

Indien een verdachte het transactie-aanbod niet accepteert, zal hij ter zitting worden gedagvaard. Dagvaarding mag volgens de richtlijn in geen geval achterwege blijven. Om een vlotte afdoening van veelvoorkomende misdrijven te bevorderen, is het transactiebedrag $\pm 20 \%$ lager gesteld dan het bedrag dat ter zitting geëist zal worden. 
Een officier van justitie kan van de transactievoorwaarden afwijken, zowel ten voordele als ten nadele van de verdachte, indien omstandigheden daartoe aanleiding geven.

Speciale aandacht verdient de positie van de gelaedeerde. Zoveel mogelijk dient de voorwaarde 'gehele of gedeeltelijke vergoeding van de door het strafbare feit veroorzaakte schade' (art. 74 lid 2 sub e $\mathrm{Sr}$ ) te worden gesteld. De richtlijnen gelden in principe voor strafrechtelijk meerderjarigen.

Verder zijn ingevoerd richtlijnen voor het strafvorderingsbeleid inzake rijden onder invloed en het weigeren van een bloedproef. Deze richtlijn bestond reeds sinds 1 november 1977; in verband met de verruimde transactieregeling is zij aangepast. De richtlijn heeft een tweeledig doel: bevorderen van rechtsgelijkheid en vergroten van de efficiency bij de afdoening. Dit delict leent zich hier bij uitstek voor, omdat een beperkt aantal feiten doorslaggevend is voor de strafvervolging en berechting. Uitgangspunt is dat in die gevallen waarin uitsluitend een vermogenssanctie wordt overwogen, een transactie kan en dient te worden aangeboden. Ook hier geldt hetgeen hiervoor voor de transactie in het algemeen opgemerkt is, dat niet in alle gevallen het aanbieden van een transactie is aangewezen. Indien er redenen zijn voor behandeling van de zaak ter terechtzitting (die redenen kunnen bijvoorbeeld zijn de geschonden rechtsorde of de belangen van de benadeelde) blijft een transactie-aanbod achterwege.

De richtlijn hanteert een schijventarief, waarbij rekening gehouden kan worden met de draagkracht van de verdachte. Tevens worden strafverzwarende omstandigheden meegewogen.

Het WODC heeft in 1986 een onderzoek verricht naar de toepassing van de transactie in misdrijfzaken. ${ }^{\text {t9 }}$ De belangrijkste uitkomsten van dit onderzoek zijn:

de mate waarin van de transactiebevoegdheid gebruik wordt gemaakt loopt zowel tussen de betrokken delicten als tussen de meewerkende arrondissementen vrij sterk uiteen;

- voor wat betreft de hoogte van de transactiebedragen zijn tussen de arrondissementen forse verschillen waarneembaar;

- de inhoud van een transactie-aanbod verschilt nogal tussen de delicten;

- in vrij weinig gevallen wordt de voorwaarde van schadevergoeding aan de gelaedeerde toegepast;

- de bereidheid om op een transactie-aanbod in te gaan is in het algemeen groot $(76 \%)$;

49 M.M. Kommer, J J.A. Essers en W.A.F. Damen, De transactic in misdrijfzaken; Een beleidsevaluatie. Den Haag 1986, WODC-recks no. 68. 
- wanneer niet op het transactie-aanbod werd ingegaan volgde vrijwel steeds dagvaarding. Wanneer de verdachte principieel verweer voerde werd zelden een boete gevorderd die hoger was dan het transactie-aanbod;

- hoewel het de bedoeling was dat een transactie zou plaatsvinden in die gevallen waarin een vermogenssanctie zou zijn opgelegd, is het waarschijnlijk zo dat de regeling ook wordt toegepast in gevallen waarin voorheen geseponeerd zou zijn;

- criteria voor het al dan niet aanbieden van een transactie blijken niet eenvoudig te kunnen worden geformuleerd. Vrij algemeen is de opvatting dat alleen relatief niet ernstige delicten in aanmerking komen. Voor wat betreft de ondergrens speelt het voorheen geldende sepotbeleid een rol. Tevens wordt rekening gehouden met de persoon van de verdachte. Het inkomen van de verdachte wordt nauwelijks als criterium gehanteerd. Wel wordt zijn betalingsbereidheid bekeken;

- voor het bepalen van de hoogte van het transactiebedrag wordt vooral uitgegaan op wat ter zitting zou worden gevorderd;

- in praktijk blijkt dat van de transactiebevoegdheid met omzichtigheid gebruik wordt gemaakt. Daarvan wordt slechts in 'lichte gevallen' gebruik gemaakt en dan alleen bij een bekennende verdachte. Het idee dat een verdachte zich in een dwangpositie bevindt is nauwelijks te handhaven, zij het dat het verschil tussen een transactie en een boete voor velen niet duidelijk is;

- de vraag of meer en/of gedetailleerde (landelijke) richtlijnen tot (nog) grotere rechtsgelijkheid zouden kunnen bijdragen, wordt niet eensluidend beantwoord. Bij verkeersdelicten kan dit zeker het geval zijn. Voor wat betreft commune delicten bestaan hiertegen bij de ondervraagde officieren van justitie bezwaren. de verruimde transactiebevoegdheid heeft geleid tot een aanzienlijke vermindering van de door de rechtbank afgedane zaken. De zittingen zijn daarentegen wel zwaarder geworden, omdat eenvoudige, korte zaken van de rol zijn verdwenen. De transactie heeft gezorgd voor minder werk voor de officier van justitie, de administratieve afdelingen van het parket hebben er alleen maar werk bijgekregen.

Uit het onderzoek blijkt dat het transactie-instituut een rol is gaan spelen bij de bestrijding van de kleine criminaliteit. Er is een verschuiving waarneembaar van sepot naar transactie, met als doel meer op te treden tegen deze vorm van criminaliteit. De transactie heeft zich ontwikkeld tot een zelfstandig afdoeningsmodaliteit tussen dagvaarden en seponeren. Enerzijds behoeft hiertegen geen bezwaar te bestaan omdat oneigenlijke sepots niet meer behoeven voor te komen, anderzijds kan door deze aanzuigende werking de doelstelling van werkdrukvermindering in gevaar komen. In de nota 'Samenleving en Criminaliteit' wordt deze ontwikkeling gestimuleerd. Hierin is een nieuwe beleidslijn uiteengezet. welke inhoudt dat het aantal onvoorwaardelijke beleidssepots in 1990 met 50\% dient te worden teruggebracht, (gedeeltelijk) 
via vervanging door transactie. ${ }^{50}$ De verhouding tussen de ernst van het feit en de hoogte van het transactiebedrag dient zodanig te zijn dat zoveel mogelijk verdachten een transactie-aanbod aanvaarden. Hierbij denkt men aan het gebruik van een 'indicatielijstje'.

Ik acht het van belang er op te wijzen dat deze gang van zaken afwijkt van hetgeen de ontwerpers van de Wet Vermogenssancties voor ogen stond: de transactie moest komen voor die gevallen die voorheen leidden tot een korte vrijheidsstraf en was uitdrukkelijk niet bedoeld voor gevallen die voorheen werden geseponeerd. ${ }^{\text {s1 }}$

Als gevolg hiervan hebben de procureurs-generaal bij de gerechtshoven de tekst van de uitgangspunten van transactiebeleid bij misdrijven opnieuw vastgesteld. ${ }^{22}$ De transactiebedragen zijn daarbij opnieuw bezien en zonodig scherper gesteld. Daarnaast hebben de procureurs-generaal beleidsuitgangspunten vastgesteld voor hoge transacties in misdrijfzaken. Het gaat hierbij om misdrijven van ernstige aard, welke publieke verontrusting hebben veroorzaakt, zoals fraude en milieuverontreiniging. Het belang van de rechtsorde moet tegen dat van de verdachte worden afgewogen. Het betreft hier ernstige misdrijven die echter wel met een vermogenssanctie kunnen worden afgedaan, hetzij omdat de ernst geen (voorwaardelijke) vrijheidsstraf noodzakelijk maakt, hetzij omdat deze niet kan worden opgelegd (rechtspersoon). Het kan wenselijk zijn dat de schikking openbaar wordt gemaakt vanwege de normbevestigende werking. Bijzondere aandacht moet worden geschonken aan de in art. 74 lid 2 Sr genoemde voorwaarden van ontneming van het wederrechtelijk verkregen voordeel en/of vergoeding van de schade.

Een officier van justitie die een hoge transactie overweegt wordt aanbevolen overleg te plegen met de hoofdofficier.

Het Jaarverslag OM over 1992 maakt melding van het streven naar afdoening door middel van transactie voor een derde van alle vervolgbare strafzaken."

\section{Praktijk van de transactie}

Bekeken wordt nu de praktische gang van zaken van een transactie, vanaf het moment dat er op het parket een procesverbaal binnenkomt tot en met het moment van (niet-) betaling.

50 Beleidsplan Samenleving en Criminaliteit, op 22 mei 1985 aangeboden aan de Tweede Kamer, TK 1984-1985, 18995, no. 2, pag. 44-45.

51 G.J.M. van den Biggelaar, Justitie miskent uitgangspunten transactiebevocgdheid, NJB 1991, pag. 1281-1282.

52 Stcrt. 23 juni 1987, no. 117.

53 Jaarverslag OM 1992, pag. 54-55. 
We beperken ons hierbij tot de "gewone" strafzaken en laten economische strafzaken, minderjarigen, onbekende daders en rampen en ongelukken buiten beschouwing. Waar nodig zal een onderscheid gemaakt dienen te worden tussen rechtbank- en kantongerechtzaken.

Tot 1989 gebeurde dit op de volgende manier. De processenverbaal kwamen binnen op de afdeling registratie. Van de rechtbankzaken werd documentatie opgevraagd bij de griffie. Dit werd ook gedaan met betrekking tot bepaalde categorieën kantongerechtszaken (zie Wet op de justitielle documentatie en de verklaring omtrent het gedrag). Daarna stuurde de afdeling registratie het procesverbaal met de documentatiestaat naar een parketsecretaris. Deze nam, met behulp van de bepaalde richtlijn en naar aanleiding van gemaakte interne afspraken, doorgaans zelfstandig een beslissing over de gewenste afdoening van het gepleegde strafbaar feit. Deze beslissing kwam op de kaft van het dossier te staan en dit werd teruggestuurd naar de registratie. Een enkele keer twijfelde een secretaris over de te nemen strafrechtelijke stappen. In dat geval deed hij een voorstel aan de officier van justitie die het wel of niet voor akkoord tekende. Ook dit ging dan weer richting registratie.

Op deze procedure bestonden enkele uitzonderingen. In bepaalde zeer eenvoudige kantongerechtszaken werd, om officieren en secretarissen te ontlasten, de beslissing tot een transactie genomen door iemand van de registratie. Dit was vanzelfsprekend niet dezelfde persoon als degene die de binnengekomen processenverbaal registreerde. Voorgeleidingszaken werden in het algemeen niet door een parketsecretaris maar door de officier van justitie zelf afgedaan. Zijn beslissing werd weer doorgestuurd nalar de registratie.

Stel dat de beslissing luidde: transactie, met als voorwaarde de betaling van een geldbedrag. Op de registratie werd een acceptgirokaart verzonden. Daarop stond het te betalen bedrag en de termijn waarbinnen betaald moest zijn, meestal een maand. Het dossier werd dan opgeborgen.

Betaling kon geschieden per giro of bank, storting op het postkantoor of kontant op de griffie. Wanneer iemand bij de griffie protest aantekende tegen het bedrag of de termijn werd hij doorverwezen naar de parketregistratie. Daar werd (vanzelfsprekend) nooit het transactiebedrag veranderd of gespreide betaling verleend. Wel verleende men een enkele keer uitstel van betaling. Voerde de verdachte een meer inhoudelijk verweer dan werd hem aangeraden een briefje te schrijven naar de betreffende officier.

Weigerde een verdachte betaling, dan werd hij, in geval van een rechtbankzaak, gedagvaard. Bij een kantongerechtzaak volgde eerst nog een aanmaning, welke geen verhoging van het bedrag inhield.

Deze gang van zaken overziend kunnen we stellen dat de officier van justitie zich niet of nauwelijks bemoeide met de bulk van overtredingen en lichtere misdrijven. Deze werden voornamelijk afgedaan door medewerkers van het parket en de parketsecretarissen. 
Vanaf 1989 werkt men binnen het OM met een geautomatiseerd afhandelingssysteem: het Communicatiesysteem openbaar ministerie - Parket administratie systeem, afgekort Compas. ${ }^{54}$ De overdracht van overtredingen door de politie vindt nu voor het grootste deel plaats op magneetband ${ }^{55}$, waardoor inschrijving bij de administratie van het parket geautomatiseerd kan gebeuren. Er vindt een marginale controle van de gegevens plaats, waarna de overtreding geheel binnen Compas wordt afgewerkt. Zo doet Compas de suggestie dat transactie mogelijk is. Wordt tot transactie besloten dan gebeurt dit binnen Compas, met inbegrip van betalingen en bewaking van termijnen. Bij afwijzing van de transactie wordt met behulp van Compas de (standaard)dagvaarding opgesteld en een eventueel rechterlijk vonnis geëxecuteerd. In de toekomst wil men ook de afdoening van misdrijven op een dergelijke wijze laten verlopen. Omdat Compas betrekking heeft op strafzaken waarmee de officier van justitie doorgaans geen bemoeienis heeft, brengt dit automatiseringssysteem vooral voordelen mee voor de parketmedewerkers en parketsecretarissen.

Voordeel van dit systeem is onmiskenbaar de enorme werkbesparing op het parket en de snellere afhandeling van de daarvoor geschikte strafzaken. Daarnaast kunnen veel meer zaken door middel van een transactie worden afgedaan. ${ }^{56}$ Naast deze voordelen zijn er echter ook bezwaren. ${ }^{57} \mathrm{De}$ administratieve medewerkers komen aan een inhoudelijke beoordeling (beoordeling bewijs, verjaringstermijnen, strafuitsluitingsgronden) niet meer toe. Op zich is dit al bezwaarlijk, maar het heeft als bijkomend effect dat er ook niet meer gekeken wordt naar omstandigheden die voorheen leidden tot een technisch sepot. Men gaat er blijkbaar van uit dat de verdachte zelf wel actie zal ondernemen als hij het met het transactie-aanbod niet eens is. Hiervoor heb ik reeds betoogd dat de verdachte in deze fase doorgaans geen rechtsbijstand geniet, waardoor hij de juridische kant van de zaak meestal niet geheel kan overzien. Van Manen spreekt in dit verband zelfs van 'arrogantie van de technologische macht' die afbreuk doet aan de geloofwaardigheid. ${ }^{58}$

\section{Politietransactie}

\subsection{Historie}

In 1959 kregen opsporingsambtenaren op grond van art. 74bis $\mathrm{Sr}$ (nu art. 74c Sr) de bevoegdheid om enkele, voor normale transactie door het $\mathrm{OM}$ in aanmerking

54 Zie over Compas uitgebreider: N.F, van Manen, Automatisering binnen het OM, JV 1992, ar. 5, pag. 39-54.

55 Sommige politiediensten kunnen niet met het systeem werken en sommige gecompliceerde overtredingen zijn niet geschikt voor geautomatisecrde afhandeling. N.F. van Manen, a.w., pag. 40-41.

Zie voor de gegevens daarover: N.F. van Manen, a.w., pag. 42-46.

57 Vgl. N.F. van Manen, a.w., pag. 46-48.

N.F. van Manen, a.w., pag. 53. 
komende, overtredingen met de verdachte af te doen door middel van een politietransactie. ${ }^{.7}$ Achtergrond van invoering van deze regeling was een groeiend aantal verkeersovertredingen. Dit zorgde voor een toenemende belasting voor politie, de parketten en de kantonrechters. De wetswijziging strekte ertoe de mogelijkheid te scheppen dat verkeersovertredingen en ook andere strafbare feiten van betrekkelijk geringe ernst en van eenvoudige aard door simpele betaling van een gefixeerd bedrag aan een opsporingsambtenaar konden worden afgedaan. ${ }^{\infty}$

De bevoegdheid van een opsporingsambtenaar moest gezien worden als een afgeleide van die van het $O M$. Deze laatste werd geacht leiding te geven aan het optreden van opsporingsambtenaren. De bevoegdheid tot transigeren van de ambtenaar van het $\mathrm{OM}$ bleef onverlet: indien een beklaagde niet had voldaan aan de voorwaarde die een opsporingsambtenaar had gesteld, behield het $\mathrm{OM}$ het recht alsnog voorwaarden te stellen ter voorkoming van vervolging. ${ }^{{ }^{11}}$ Deze bevoegdheidsgrondslag, een afgeleide van de OM-transactie, is een verkeerde. Er is namelijk geen sprake van mandaat, maar van attributie van bevoegdheden. De politietransactie berust rechtstreeks op de wet.

Tijdens de parlementaire behandeling van deze wetswijziging werden naast praktische vragen (hoe en waar dient de betaling te geschieden? wie controleert de opsporingsambtenaar met betrekking tot de door hem geïnde gelden?) meer principiële vragen naar voren gebracht. Door verschillende kamerleden werd gewezen op het element van willekeur: wie krijgt er wel of niet een boete en hoe hoog is deze? Belangrijker was de discussie over de vraag of de opsporingsambtenaar hier feitelijk niet als rechter optrad. Het publiek zou een schikkingsbedrag als boete aanvoelen. Daardoor zouden de opsporing, de constatering van een strafbaar feit, de vervolgingsbeslissing, het uitspreken van een vonnis en de executie daarvan in één hand komen liggen. ${ }^{2}$ Met betrekking tot het willekeursargument erkende de minister dat de opsporingsambteniar inderdaad de mogelijkheid tot differentiatie had. De grens lag echter in handen van de verdachte, die de transactie achterwege kon laten indien hij op goede gronden van mening is dat door omstandigheden de rechter geen of een lagere straf zal opleggen. Daarnaast wees de minister op de redelijkheid van het toezichthoudend politiepersoneel. Het tweede principiële bezwaar, de politie als rechter, bestreed de minister met het argument dat de opsporingsambtenaar niet vervolgt en berecht, maar dat een politietransactie juist strafvervolging voorkomt."

De minister betrachtte behoedzaamheid bij de invoering van de politietransactie door hier geleidelijk toe over te gaan. Eerst werd een proef genomen in één grote stad, twee middelgrote, twee kleine steden en enige plattelandsgemeenten. Het

59 Wet van 9 januari 1958, Stb. 7, in werking getreden op 1 mei 1959.

60 MvT, TK 1956,4415 , nr. 1-2, pag. 3.

61. idem vorige noot.

62 Handelingen II 1957-1958, pag. 2012-2018.

63 Handelingen II 1957-1958, pag. 2020. 
experiment werd als geslaagd beschouwd, waarna de politietransactie in 1962 in het gehele land is ingevoerd. ${ }^{\text {st }}$

In 1969 is het wetsartikel gedeeltelijk gewijzigd. ${ }^{a s}$ Daarbij is de beperking dat het overtredingen moest betreffen die tot de competentie van de kantonrechter vielen, vervallen. Tevens werd de leeftijd van degenen die voor een politietransactie in aanmerking kwamen verlaagd van 18 (strafrechtelijk meerderjarigen) naar 16 jaar. Toen ook heeft de vernummering plaatsgevonden van art. 74bis naar art. $74 \mathrm{c} \mathrm{Sr}$.

In 1993 is de politietransactie voor eenvoudige misdrijven ingevoerd. ${ }^{\star}$ Door deze uitbreiding van de transactiebevoegdheid van de politie worden volgens de MvT zowel de efficiëntie als de effectiviteit van de handhaving van de betreffende feiten gediend. ${ }^{67}$ Hierna $(\$ 6.3)$ zal op de verschillende aspecten van deze wet afzonderlijk worden ingegaan.

\subsection{Analyse art. $74 \mathrm{c} \mathrm{Sr}$}

De uitwerking van de politietransactie is neergelegd in het Besluit politietransactie (KB 18 april 1978, Stb. 192) en het Besluit transacties Koninklijke Marechaussee (KB 18 april 1978, Stb. 193, opnieuw gepubliceerd in Stb. 537 van 1985 en naar aanleiding van de wijziging van art. 74c Sr gewijzigd (Besluit van 21 maart 1993, Stb. 1994, nr. 223, inwerkingtredingsbesluit van 29 maart 1994, Stb. 228). Daarin wordt geregeld de aanwijzing van tot de politietransactie bevoegde opsporingsambtenaren alsmede het toezicht op hen en de intrekking van de aanwijzing, de zaken die voor een politietransactie in aanmerking komen, de wijze van betaling en de termijn waarbinnen dit moet gebeuren en de verantwoording van de betaalde geldbedragen. Enkele zaken worden hieronder nader belicht.

\subsubsection{Bevoegde opsporingsambtenaren}

In het eerste lid van art. $74 \mathrm{c}$ Sr staat dat de tot transactie gerechtigde opsporingsambtenaren aangewezen worden bij algemene maatregel van bestuur. Sindsdien zijn aangewezen alle in uniform optredende met de opsporing van strafbare feiten belaste bezoldigde ambtenaren van het Korps Rijkspolitie en van de gemeentepolitie, waaraan zijn toegevoegd parkeer- en reinigingspolitie, werkzaam op het hun betreffende

65 Wet van 8 mei 1969, Stb. 191.

66 Wetsvoorstel Wijziging van bet Wetboek van Strafrecht en het Wetboek van Strafvordering inzake politictransactie voor eenvoudige misdrijven. Tweede Kamer 1991-1992, 22.523.

67 TK 1991-1992, 22.523, nr. 3, pag. 3. 
terrein, de in uniform optredende militairen van het Wapen der Koninklijke Marechaussee, voor zover zij met opsporing zijn belast en de Rijksdienst voor het wegverkeer met betrekking tot enkele technische verkeersovertredingen. ${ }^{\sharp}$

In art. 2 van het Besluit Politietransactie staat vermeld dat de hoofdofficier van justitie een opsporingsambtenaar zjjn transactiebevoegdheid kan ontnemen, indien de taakvervulling dit vordert.

\subsubsection{In aanmerking komende strafbare feiten}

Uit lid 1 van art. $74 \mathrm{c} \mathrm{Sr}$ blijkt dat alleen overtredingen in aanmerking komen voor een politietransactie. Welke overtredingen dat zijn stond vroeger vermeld in een bijlage van het Besluit Politietransactie. Thans zijn deze verwerkt in de Richtlijnen voor het transactie- en strafvorderingsbeleid van het Openbaar Ministerie. ${ }^{ø}$ Blijkens de inleiding van deze Richtlijnen is de Bijlage als bedoeld in art. 3 van het Besluit Politietransactie (voor het laatst gewijzigd per 1 mei 1988, Stb. 1988, 178) in de richtlijn opgenomen. De overtredingen die niet door de politie met een transactie mogen worden afgedaan, zijn in de richtlijn met een * aangegeven.

Het betreft, globaal, bepaalde overtredingen betreffende gebreken aan voertuigen (WVW en WVR), bepaalde overtredingen betreffende het rijgedrag (RVV), bepaalde overtredingen betreffende het verkeer te water (Vaarreglement), bepaalde overtredingen betreffende het milieu (Natuurbeschermingswet, Afvalstoffenwet en Afvalstoffenverordeningen), bepaalde overtredingen van plaatselijke verordeningen en overtreding van art. 460 Sr. Art. 3 van het Besluit Politietransactie bepaalt dat een politietransactie slechts kan plaatsvinden bij een ontdekking op heterdaad (art. $128 \mathrm{~Sv}$ ). De limitatieve opsomming van transigabele strafbare feiten en het vereiste van betrapping op heterdaad verkleinen de beoordelingsruimte van de betreffende opsporingsambtenaar.

In een aantal gevallen mag geen politietransactie worden aangeboden ${ }^{\text {T}}$ :

- wanneer de opsporingsambtenaar of een van zijn naaste familieleden bij het feit of de gevolgen daarvan betrokken is;

- wanneer verschil van inzicht bestaat tussen de opsporingsambtenaar en de verdachte omtrent de feiten en/ of de strafbaarheid;

- wanneer het feit schade ten gevolge heeft gehad of overigens te ernstig van aard is;

- wanneer het feit onder verzwarende omstandigheden gepleegd is;

68 Besluit van 2 juli 1987, Stb. 332.

69 Richtlijn OM van 10 juli 1987, Bijlage Stcrt. 1978, 169, inwerkinggetreden op 15 september 1987, geratificeerd in Stert. 1987, 181, vervangen door Richlijnen voor transactie- en strafvorderingsbeleid van het OM van 29 juni 1988, Stcrt. 1988, 185.

70 Richtlijn OM 12 mei 1982, Stcrt. 1982, 121, in werking getreden op 1 juli 1982. 
- wanneer inbeslagneming plaatsvindt, dan wel van enig voorwerp vrijwillig afstand wordt gedaan;

- wanneer het feit wordt geconstateerd tezamen met een of ander(e) feiten, waarvoor geen politietransactie mag worden aangeboden; wanneer de militaire rechter uitsluitend bevoegd is.

Daarnaast is het mogelijk dat de hoofdofficier van justitie voor zijn arrondissement nog andere gevallen aanwijst, waarin geen transactie mag worden aangeboden (art. 9 Besluit Politietransactie).

Eind tachtiger jaren zijn nieuwe voorstellen gedaan met betrekking tot de politietransactie. Deze vorm van afdoening moest niet langer beperkt blijven tot overtredingen, maar diende uitgebreid te worden met bepaalde misdrijven. ${ }^{n}$ Deze ontwikkeling moeten we plaatsen in de discussie die toen plaatsvond inzake de bestrijding der kleine, of veelvoorkomende, criminaliteit in het kader van het beleidsplan Samenleving en Criminaliteit.

Met name betreft het hier de bestrijding van winkeldiefstal. Een overweging waardoor de wetgever zich onder andere heeft laten leiden is dat in de sfeer van politie en justitie de thans geldende procedures in de weg staan aan de verwerking van een fors groter aantal zaken. ${ }^{72}$ Voorkomen moet echter worden dat de situatie waarin de verdachte zich bevindt een zodanige, oneigenlijke, druk met zich meebrengt dat hij zich gedwongen voelt in te gaan op het transactie-aanbod, zonder daartoe zonder die druk bereid te zijn geweest. ${ }^{3}$

Per 1 oktober 1987 werden er in vier steden (Dordrecht, Eindhoven, Zaanstad en Anhem) experimenten gestart met betrekking tot de politietransactie bij winkeldiefstal, de zogenaamde lik-op-stuk-reactie. In Haarlem, Leiden en Delft is geëxperimenteerd met politietransactie bij andere misdrijven dan rijden onder invloed en winkeldiefstal, zoals geringe vermogensmisdrijven, vernieling, rijden met een valse APKsticker, rijden met een vals kentekenbewijs en doorrijden na een aanrijding. De juridische constructie waarin deze politietransactie bij misdrijven plaatsvond was krachtens mandaat van het OM. De resultaten van deze experimenten ${ }^{24}$ hebben onder andere geleid tot de wet inzake uitbreiding van de politietransactie voor eenvoudige misdrijven, die besproken zal worden in de volgende paragraaf.

Vooruitlopend op Hoofdstuk 4 betreffende de administratiefrechtelijke handhaving van verkeersvoorschriften wil ik er nu reeds op wijzen dat na invoering van de WAHV een groot aantal verkeersovertredingen voortaan op administratieve wijze wordt

Zie o.a. TK 1986-1987, 18995, nrs. 19-20, pag. 20-25.

72 TK 1986-1987, 18995, nrs. 19-20, pag. 21.

73 Brief van de minister van Justitie aan de Tweede Kamer, TK 1986-1987, 18995, no. 26 , pag. 1.

74 L.J.M. Koolen, C.J. Wiebrens, E.A.I.M. van den Berg, Geschikt of nict geschikt? Een evaluatie van de lik-op-stuk experimenten. WODC 1989. 
afgedaan in plaats van door een politietransactie. De politie treedt op als een bestuursorgaan en legt na de constatering van een verkeersovertreding een sanctie op door middel van een beschikking.

\subsubsection{Betaling van een bepaalde geldsom}

De te stellen voorwaarde bestaat uit in de betaling van een bepaalde geldsom, aldus lid 2 van art. 74c Sr. Dit roept twee vragen op: wie bepaalt de hoogte van de te betalen geldsom en hoe vindt de betaling plaats?

In de reeds eerder genoemde richtlijn van het OM van 10 juli 1987 wordt per overtreding en per soort overtreder met behulp van tariefgroepen een vast tarief voor politietransactie vastgesteld. In tegenstelling tot de tarieven van een OM-transactie of de bedragen die het $\mathrm{OM}$ ter zitting moet vorderen met betrekking tot overtredingen (ook aangegeven in deze richtlijn) liggen de bedragen van de politietransactie vast. Het staat de politie niet vrij ook andere voorwaarden te stellen. ${ }^{75}$ De tarieven van de politietransactie variëren van f 10,- tot f 140,-. In de hierboven reeds genoemde wet inzake de politietransactie bij misdrijven wordt dit bedrag verhoogd tot $f 500,-$, om op deze manier aan te sluiten bij de eerste boetecategorie en het maximum bedrag van de sanctie van WAHV. ${ }^{76}$

Het is dus van de soort overtreding en van de soort dader (bijvoorbeeld bestuurders van motorvoertuigen op meer dan twee wielen, voetgangers, schippers, eenieder) afhankelijk welk transactiebedrag gesteld zal worden.

Voorheen bevatte lid 2 van art. 74c Sr de bepaling dat betaling onmiddellijk kon geschieden aan de opsporingsambtenaar of, de dag na de ontdekking van het feit, op een door die ambtenaar aan te wijzen plaats, doorgaans het politiebureau. Deze betalingswijze kwam echter niet meer overeen met ontwikkelingen in het betalingsverkeer. Bij een ministeriële circulaire van 15 april $1982^{n}$ werd girale betaling van de politietransactie ingevoerd. Op 1 oktober 1983 is lid 2 van art. $74 \mathrm{c} \mathrm{Sr}$ aangepast, in die zin dat daarin met betrekking tot de wijze van betaling verwezen wordt naar een algemene maatregel van bestuur, waarin voorschriften gegeven worden betreffende de wijze van betaling en de termijn waarbinnen betaald moet zijn. Deze materie is geregeld in het Besluit Politietransactie (artt. 4 en 5), het Besluit transactie Koninklijke Marechaussee (artt. 4 en 5) en in het Besluit transactie Rijksdienst wegverkeer (art. 4).

De gang van zaken na betrapping op heterdaad van een daarvoor in aanmerking komende overtreding is als volgt: door de opsporingsambtenaar wordt aan verdachte de voorwaarde ter voorkoming van strafvervolging mondeling meegedeeld ("Dit gaat

art. 7 Besluit Politietransactic.

MvT, TK 1991-1992, 22.523, nr. 3, pag. 7.

Zie Stert. 29 juni 1982, 121, inwerkinggetreden op 1 juli 1982. 
U f..,- kosten" of iets dergelijks). Ter bevestiging wordt hem een formulier 'kennisgeving van bekeuring' uitgereikt (de bon), waarop het bedrag vermeld staat. De betaling van het bedrag geschiedt door storting of overschrijving op een daartoe bestemde postrekening of contant op een door de ambtenaar aan te wijzen plaats, doorgaans een politiebureau. Deze contante betaling moet binnen veertien dagen na de dag van de overtreding geschieden. De girale betaling moet binnen zes weken na de dag der overtreding zijn ontvangen. De opsporingsambtenaren houden aantekening van elke zaak waarin zij voorwaarden hebben gesteld, alsmede van de voldoening daarvan. Deze aantekeningen moeten desverlangd aan ambtenaren van het $O M$ worden getoond. Periodiek moet hiervan verslag worden gedaan aan de hoofdofficier van justitie. Wanneer hij het nodig acht dat in bepaalde gebieden of in bepaalde zaken geen gebruik van de politietransactie wordt gemaakt bericht hij dat, na overleg, aan de korpsleiding of aan de burgemeester.

\subsection{Wet inzake de uitbreiding van politietransactie voor eenvoudige misdrijven}

Inmiddels hebben onder andere de in de vorige paragraaf vermelde experimenten geleid tot een wet inzake de uitbreiding van de politietransactie voor eenvoudige misdrijven. ${ }^{78}$

Ik zal nu eerst enkele resultaten van de experimenten weergeven en daarna ingaan op deze nieuwe wet.

Bij de experimenten ter zake van winkeldiefstal werd de toepassing van de politietransactie aan een aantal voorwaarden verbonden ${ }^{n}$ :

- het moest gaan om een meerderjarige verdachte;

- er mocht geen sprake zijn van specifieke recidive binnen twee jaar;

- de verdachte mocht het feit niet ontkennen;

- de waarde van het gestolene moest duidelijk omschreven zijn en niet hoger zijn dan $f 250,-;$

- het moest gaan om eenvoudige diefstal;

- het gestolen goed moest zijn teruggegeven of de waarde ervan zijn vergoed.

Later werden deze voorwaarden aangescherpt. De voorwaarde van specifieke recidive werd verzwakt in die zin dat ook andere vormen van diefstal en heling eronder vielen. Tevens werd winkelverduistering toegevoegd. Het moest voortaan een bekennende

78 Wet Wijziging van het Wetboek van Strafrecht en het Wetboek van Strafvordering inzake politietransactie voor eenvoudige misdrijven. TK 1991-1992, 22.523. Wet van 16 september 1993, Stb. 1993, nr. 516. Inwerkingtreding 15 oktober 1993.

L.J.M. Koolen, LJ. Wiebrens, E.A.I.M. van den Berg, a.w., pag. 1. 
verdachte betreffen, zodat de verdachte die zijn zwijgrecht gebruikte niet in aanmerking kwam.

Uit het onderzoek bleek dat de andere delicten waarmee is geëxperimenteerd, zich niet voor deze afdoening leenden. ${ }^{\mathrm{x}}$ In geval van mishandeling bestonden er vaak tegengestelde verklaringen, zodat voor de politie niet duidelijk was wie als slachtoffer en wie als verdachte moest worden gezien. Vernieling kwam niet in aanmerking vanwege het vereiste dat de schade moet zijn vergoed voordat een transactie kon worden aangeboden. In zaken betreffende het rijden met een valse APK-sticker dan wel met een vals kentekenbewijs bleek dat relatief weinig transactie was aangeboden. Verder kwam uit de experimenten naar voren dat deze afdoeningsmethode geen effect heeft gehad op de aangiftebereidheid. Werklastverlichting vond met name plaats op het OM. De bereidheid om in te gaan op een transactie-aanbod was hoog. De experimenten leidden tot een afname van het aantal sepots.

Zich aansluitend bij de uitkomsten van de experimenten dient volgens de nieuwe wet de afdoening door middel van een politietransactie slechts open te staan voor misdrijven "die zich naar hun aard daarvoor lenen en onder voorwaarden die zulks verantwoord doen zijn". ${ }^{81}$ Het gaat dan om eenvoudige misdrijven die vaak voorkomen, die eenvoudig zijn op te sporen, die weinig bewijsproblemen opleveren en waarvan de besluitvorming met betrekking tot de afdoening gestandaardiseerd is. De wet betreft concreet de lichtere gevallen van rijden onder invloed en eenvoudige winkeldiefstallen, maar houdt de mogelijkheid open om het aantal lichte misdrijfcategorieën uit te breiden. ${ }^{2}$

Deze uitbreiding van de politietransactie wordt gemotiveerd met het argument dat het zowel de efficiëntie als de effectiviteit van de handhaving zal vergroten. De weg tussen constatering van een strafbaar feit en de strafrechtelijke reactie wordt één stap korter. De snelheid van de justitiële reactie heeft een preventief effect. Dit effect neemt eveneens toe doordat in een groter aantal gevallen van wetsovertreding een strafrechtelijke reactie volgt, namelijk in die gevallen waarin voorheen werd geseponeerd. ${ }^{2}$

De politie krijgt in deze wet transactiebevoegdheid tot een boetebedrag van $f 500$,Dit bedrag komt overeen met het bedrag van de eerste boetecategorie en met het maximum van de administratieve sanctie in de WAHV.

Bij de uitvoering van de experimenten was er sprake van een mandaatsconstructie. Volgens de MvT acht de minister het niet aantrekkelijk dit in de wet over te nemen, omdat dat er toe zou leiden dat de politietransactie ter zake van misdrijven met

81 MvT, TK 1991-1992, 22523, nr. 3, pag. 5.

82 MvT, pag. 6.

83 MvT, pag. 3. 
minder waarborgen is omkleed dan die ter zake van overtredingen, waarvoor immers een zelfstandige regeling geldt. ${ }^{\mathrm{BS}}$

Aangesloten wordt derhalve bij de regeling van de politietransactie in art. 74c Sr., die volgens de MvT zijn waarde in de loop der jaren heeft bewezen. ${ }^{\star}$ De feitelijke toekenning van transactiebevoegdheid aan opsporingsambtenaren ${ }^{\text {क }}$ en de aanwijzing van zaken zullen plaatsvinden bij $\mathrm{AMvB}$. Gedacht wordt aan aanvulling van het Besluit Politietransactie, zowel voor de feiten als de bedragen. Ook voor het toezicht op de politie wordt aansluiting gezocht bij de huidige regeling van de artt. 2, 8,9 Besluit Politietransactie. ${ }^{86}$

Hoewel ik in grote lijnen met de wet kan instemmen, wil ik een enkele kanttekening plaatsen. In de wet en de toelichting vind ik niets omtrent het recht van de verdachte om het transactie-aanbod te verwerpen. ${ }^{\circledast 2}$ Het risico is aanwezig dat iemand ingaat op een transactie-aanbod terwijl hij niet schuldig is of het bewijs nog niet vaststaat. Volgens de minister wordt dit bezwaar gedeeltelijk ondervangen door de omstandigheid dat het voorstel zich beperkt tot feiten die gemakkelijk zijn te constateren en die geen bewijsproblemen opleveren en de zorgvuldigheid die de opsporingsambtenaren in acht moeten nemen. Bovendien acht de minister het een in de samenleving een algemeen bekend feit dat men een transactie-aanbod kan weigeren. ${ }^{.0}$ Reeds vaker heb ik betoogd dat hiervan niet mag worden uitgegaan.

Het bezwaar kan worden ondervangen door voor te schrijven dat een opsporingsambtenaar het transactie-aanbod pas mag doen indien de verdachte reeds bekend heeft en, voor wat betreft het rijden onder invloed, als de uitslag van de ademanalyse vaststaat. ${ }^{\circ 1}$ Op deze manier wordt voorkomen dat een bekentenis wordt afgelegd onder druk van het transactie-aanbod.

Deze regeling overziend kan worden geconstateerd dat het wordt gehanteerd in het streven naar een meer efficiënte strafrechtelijke handhaving, hetgeen op haar beurt weer past in de historie van het instituut van de transactie, waarbij de afdoening van strafbare feiten door middel van transactie op weer grotere afstand van de rechter wordt gebracht.

In de historie van dit instituut past eveneens dat na introductie van een uitbreiding van de transactiebevoegdheid vaak een 'oneigenlijke' uitbreiding volgt, dat wil zeggen

MvT, pag. 7.

MvT, pag. 6-7.

87 Ter zake van winkeldiefstal zal de catcgorie opsporingsambtenaren worden beperkt tot hulpofficieren, MvA 22523, nr. 5, pag. 6.

88 MvT, pag. 7-8.

$89 \mathrm{Vgl}$. de vragen van de SGP-fractic in het Voorlopig Verslag, 22523, nr. 4.

90 MvA 22523, nr. 5, pag. 7.

91 Vgl. P. Osinga, Politictransactie bij misdrijven, DD 1993, pag. 410. 
een uitbreiding die bij de totstandkoming van de regeling eigenlijk niet bedoeld is. Wij wachten af.

\section{Transactie in andere wetten}

Niet alleen het Wetboek van Strafrecht kent een transactieregeling. Ook in een aantal bijzondere strafwetten is een transactieregeling opgenomen. Deze bijzondere regeling kan afwijken van de algemene. Ook kan het tot transactie bevoegde orgaan een ander zijn dan het OM. Het is met name het laatste aspect wat voor dit onderzoek van belang is en waar mijn belangstelling dan ook naar uitgaat. Voor de overige verschillen zou ik willen verwijzen naar de beschrijving van Osinga. ${ }^{92}$

Hierna zullen de revue passeren: de transactie ter zake van economische delicten, de transactie in belastingwetten en de transactie in de militaire strafwet.

\subsection{Transactiebevoegdheid in het economische strafrecht}

In art. 36 WED worden de voorwaarden die aan de transactie kunnen worden verbonden genoemd. In vergelijking met art. $74 \mathrm{Sr}$ worden enkele voorwaarden toegevoegd. Op basis van art. 37 WED kunnen andere organen dan het OM transactiebevoegdheid krijgen. Zij oefenen deze hevoegdheid zelfstandig uit, zij het onder toezicht van het OM.

Krachtens het Besluit transactiebevoegdheid Nederlandsche Bank en de Directeuren 's Rijksbelastingen ${ }^{93}$ wordt transactiebevoegdheid gegeven aan de Nederlandsche Bank en aan de directeuren van de verschillende belastingdiensten. Deze bevoegdheid betreft een klein aantal feiten.

\subsection{Transactiebevoegdheid in het fiscaal recht}

Het bestuur (de directeur) der rijksbelastingen heeft een zelfstandige transactiebevoegdheid, gebaseerd op art. 76 Algemene wet inzake Rijksbelastingen (AWR). Ook in de Algemene wet douane en accijnzen (AWDA) wordt hem een dergelijke bevoegdheid toegekend, art. 197. Deze transactiebevoegdheid komt in de plaats van de transactiebevoegdheid op grond van art. $74 \mathrm{Sr}$. De voorwaarden die kunnen worden gesteld zijn, in vergelijking met art. 74 Sr met één uitgebreid, namelijk 'het alsnog volduen aan een bij de belastingwet gestelde verplichting' en de voorwaarde van art. $74 \mathrm{Sr}$ met betrckking tot het betalen van schadevergoeding is niet opgenomen.

93 KB van 1951, Stcrt. 1951, 90, gewijgigd bij KB 24 januari 1963, Stcrt. 1964, 19. 
Deze zelfstandige bevoegdheid past in het systeem van het fiscale strafprocesrecht, waarin het bestuur der Rijksbelastingen een belangrijke rol vervuld bij de afdoening van strafbare feiten. Hierbij moet worden bedacht dat, voordat een zaak in het strafrechtelijk circuit belandt, binnen de belastingdienst reeds de keuze is gemaakt tussen administratieve of strafrechtelijke afdoening."

Zogeschiedt de opsporing van bij de belastingwet strafbaar gestelde feiten de belastingdienst door belastingambtenaren, art. 80 lid $1 \mathrm{AWR}$. De processen-verbaal worden niet gezonden aan de officier van justitie, maar aan het bestuur der Rijksbelastingen. In gevallen waarin inverzekeringstelling of voorlopige hechtenis is toegepast danwel de woning tegen de wil van de bewoner is betreden stuurt het bestuur de processenverbaal onverwijld door aan de officier van justitie. In de andere gevallen wordt de vervolgingsbeslissing in feite genomen door het bestuur. Wanneer zij vervolging wenselijk acht, wordt het betreffende proces-verbaal aan de officier van justitie gezonden, art. 80 lid 2 AWR. Indien de officier van justitie van mening is dat de zaak door middel van een transactie kan worden afgedaan, doet hij het proces-verbaal weer toekomen aan het bestuur.

Door een aantal ontwikkelingen moet deze zelfstandigheid in de afdoening van fiscale delicten van de belastingdienst ten opzichte van het $O M$ worden gerelativeerd. (1) Als gevolg van een uitspraak van de Hoge Raad 23 februari 1982, NJ 1982, 647 m.nt. ALM, waarin de verdachte werd vervolgd voor overtreding van zowel art. 68 AWR als art. $225 \mathrm{Sr}$ (valsheid in geschrifte), kan het OM, nadat de directeur der Rijksbelastingen een beslissing heeft genomen, alsnog een zelfstandige beslissing nemen, bijvoorbeeld vervolging of transactie ter zake van art. $225 \mathrm{Sr} .{ }^{95}$ In een arrest van HR 19 juni 1987, NJ 1988, 583 bepaalde de Hoge Raad dat het OM ook zelfstandig de beslissing kan nemen om in een fiscale strafzaak vervolging in te stellen. (2) Om overeenstemming te krijgen tussen de instanties die zich met fiscale delicten bezighouden is onderling overleg noodzakelijk. Dit overleg vindt plaats tussen belastingdienst en OM en binnen het OM in de ressortsfraudecornmissie (REFRAUCOM). Als gevolg van deze overlegvormen is door de procureurs-generaal en de directeurgeneraal der belastingen opgesteld met betrekking tot opsporing en vervolging bij belastingfraude. ${ }^{96}$ Hierin wordt aangegeven wanneer overgegaan zal worden tot vervolging of tot fiscale transactie.

In hoeverre een betrokkene c.q. verdachte zich op deze richtlijn kan beroepen wordt behandeld bij bespreking van het vertrouwensbeginsel (Hoofdstuk $10 \S 2.3 .8$ ). Wel kunnen we er hier reeds op wijzen dat het juist ten aanzien van deze richtlijn was

Zie hierover uitgebreider: P.J. Wattel, Fiscaal straf-en strafprocesrecht, Deventer 1989, pag. 241. e.v. Overigens wijst hij erop dat de hierna beschreven fasen in de praktijk door elkaar kunnen lopen.

96 Richtlijn van 13 december 1990, Stcrt. 1990, 243, in werking getreden 1 januari 1991. 
dat de Hoge Raad bepaalde dat zij gezien moest worden als 'recht' in de zin van art. 99 RO (HR 19 juni 1990, NJ 1991, 119, m.nt. ThWvV en MS).

\subsection{Transactiebevoegdheid in het militair strafrecht}

De transactiebevoegdheid inzake verkeersovertredingen ${ }^{97}$ wijkt niet af van de politietransactie.

Voor de overige militaire delicten geldt de regeling van art. $74 \mathrm{Sr}$. Volgens de Wet militaire strafrechtspraak neemt de fiscaal of de auditeur-militair de vervolgingsbeslissing, de officier van justitie is echter dominis litis.

Hierop bestaat één uitzondering. In art. $59 \mathrm{WMSr}$ is een regeling neergelegd die transactiebevoegdheid toekent aan bepaalde daarvoor aangewezen commandanten voor specifieke situaties (indien het onderdeel zich niet in Nederland bevindt) en voor een beperkt aantal gevallen. Deze bevoegdheidsuitoefening wordt aan voorwaarden onderworpen. Bovendien zijn er ter uitvoering richtlijnen opgesteld door het $\mathrm{OM}$.

97 Besluit transactie koninklijke marechaussee, 18 april 1978, Stb. 193. 


\section{Administratiefrechtelijke handhaving van verkeersvoorschriften}

\section{Inleiding}

Proceseconomische overwegingen hebben vaak (mede) ten grondslag gelegen aan veranderingen die ons strafprocesrecht de laatste jaren ondergaan heeft. Als voorbeeld kunnen we noemen: de wettelijke invoering van de politietransactie (1978), uitbreiding van de transactiemogelijkheid in misdrijfzaken (1983) en het invoeren van een alleensprekende rechter in hoger beroep (1987).

De Wet Administratiefrechtelijke afdoening van inbreuken op bepaalde verkeersvoorschriften (Wet administratiefrechtelijke handhaving verkeersvoorschriften, voortaan te noemen: WAHV) ${ }^{98}$ misstaat in dit tijdsbeeld niet. Eén van de uitgangspunten van deze wet is steeds geweest dat de werklast van politie, OM en rechterlijke macht teruggedrongen moest worden. ${ }^{\infty}$ Kort gezegd wil men bereiken dat de tijdsduur tussen het begaan van een verkeersovertreding en de uiteindelijke executie van de geldboete wordt teruggedrongen. Vergeleken met het traditionele strafproces is het strafproces met betrekking tot verkeersovertredingen al sterk vereenvoudigd, onder andere door de wettelijke invoering van de politietransactie (art. 74c Sr) en door een uitbreiding van de gevallen waarbij een transactie-aanbod door het OM kan worden gedaan (art. $74 \mathrm{Sr}$ ). Deze mogelijkheden tot het afdoen van strafzaken buiten de rechter om waren echter afhankelijk van de medewerking van de verdachte. Het stond hem vrij niet in te gaan op een transactievoorstel. Blijkbaar hebben deze buitengerechtelijke afdoeningsmethoden het justitiële apparaat niet voldoende ontlast. Het tijdsverloop ontstaat doordat cen verkeersovertreder niet ingaat op de politieen OM-transactie, daarna in twee instanties verstek laat gaan en, na een eventuele cassatieprocedure, vervolgens de opgelegde boete niet voldoet. Het gaat hier om ongeveer $10 \%$ van het aantal verkeersovertreders.

De WAHV ${ }^{\text {ia }}$ is in 1990 in werking getreden in het arrondissement Utrecht. Vervolgens is de wet gedurende een periode van twee jaren ressortsgewijs ingevoerd. De

98 TK 1987-1988, 20329.

99 TK 1981-1982, 17.478, nr. 1, pag. 1-2; TK 1987-1988, 20329, nr. 3, pag. 8-13.

100 Staatsblad $1989,300$. 
ervaringen $^{101}$ met, alsmede de verschenen jurisprudentie over deze wet zijn in de tekst verwerkt.

De regeling ziet er, kort gezegd, als volgt uit: degene die een bepaald verkeersvoorschrift overtreedt, krijgt door de politie een administratieve sanctie opgelegd. Deze sanctie bestaat uit het betalen van een geldsom. De administratieve sanctie wordt opgelegd bij beschikking van de politie. De betrokkene betaalt deze sanctie door middel van een per post door het Centraal Justitieel Incasso-Bureau (CJB) toegezonden acceptgirokaart. De betrokkene kan schriftelijk beroep instellen bij de officier van justitie. De officier van justitie kan de beschikking vernietigen, een lager bedrag vaststellen of de strafbare gedraging wijzigen en de sanctie hieraan aanpassen. De betrokkene kan tegen de beslissing van de officier van justitie beroep instellen bij het kantongerecht. Het beroep is pas ontvankelijk, nadat de betrokkene zekerheid heeft gesteld door middel van "beschikbaarstelling van geldswaarden tot het beloop van de administratieve sanctie" (art. 11 lid 1). Indien de kantonrechter van mening is dat de beslissing van de officier niet ten volle gehandhaafd kan worden, verklaart hij het beroep geheel of gedeeltelijk gegrond en vernietigt of wijzigt hij daarbij de bestreden beslissing. De betrokkene of de officier van justitie kunnen tegen de beslissing van de kantonrechter cassatie instellen bij de Hoge Raad. Indien degene aan wie de administratieve sanctie is opgelegd het bedrag niet voldoet binnen veertien dagen nadat de beschikking onherroepelijk is geworden, wordt het van rechtswege verhoogd. Wanneer dan nog niet wordt betaald volgt wederom een verhoging en kan de officier van justitie verhaal halen op de goederen, inkomsten en vermogen van de betrokkene. In het geval niet of onvoldoende verhaal heeft plaatsgevonden kan de officier van justitie op zijn verzoek door de kantonrechter gemachtigd worden de volgende dwangmiddelen uit te oefenen: huitengebruikstelling van het voertuig waarmee de gedraging heeft plaatsgevonden, inname van het rijbewijs of gijzeling van de betrokkene voor maximaal één week.

Deze figuur valt strikt genomen niet (geheel) onder 'buitengerechtelijke afdoening' (de titel van dit onderzoek), omdat de rechter wel degelijk in het stuk kan voorkomen. Overigens is deze rechter geen strafrechter maar een administratieve rechter. Behandeling van dit onderwerp in het kilder van dit onderzoek lijkt mij echter gepast. gezien de mogelijkheid van afdoening buiten rechte. De rechter wordt slechts bij de zaak betrokken nadat de verdachte in beroep is gegaan van de beslissing van de officier van justitie. Hierbij moeten we bedenken dat een grote groep van betrokkenen geer: beroep bij de officier van justitie of eventueel bij de rechter zal instellen (dat is althans de bedoeling van de wet) watırdoor de afdoening plaatsvindt door politie of eventueel de officier van justitie.

101 Tijdens het eerste jaar is ondereoek verricht naar de werking van deze wet. Zie hierover: M. Konmer, S. Eschen, E. van der Heijden, Eindrapport evaluatie invoering Wet Mulder. Den Hags oktober 1991. 
Bovendien is bespreking hier geboden, omdat deze wet aansluit bij de discussie over vereenvoudigde afdoening van strafzaken zoals deze gevoerd is ter zake van de transactie. Met de invoering van de WAHV is waarschijnlijk een begin gemalakt met de overheveling van voorschriften uit het strafrecht naar het administraticf recht. Het is de bedoeling dat ook andere voorschriften zullen volgen.

In het navolgende zal een overzicht worden gegeven van de ontwikkeling van het denken over de administratieve afdoening zoals die de laatste decennia heeft plaatsgevonden. Het vraagstuk betreffende de vereenvoudiging van de strafrechtspleging inzake (lichtere) overtredingen vormt sinds het begin van deze eeuw een bron van discussie (zie de ontwikkeling van de transactie, hoofdstuk 3 \$ 1 ). De "historie" van de administratieve afdoening sluit dan ook naadloos aan op die van de transactie. Dit is de reden waarom de administratieve afdoening hier behandeld wordt direct na de transactie.

Toespitsing van de discussie op verkeersovertredingen stamt uit de zeventiger en tachtiger jaren. Aanvankelijk zocht men de vereenvoudiging binnen het strafrechtelijk systeem. Later werd gekozen voor een administratiefrechtelijke weg.

Een van de meest in het oog springende problemen betrof de vraag in hoeverre een dergelijke regeling in overeenstemming is met bepalingen van internationale verdragen. Deze vraag heeft voortdurend een rol gespeeld. Hieraan wordt dan ook ruim aandacht besteed.

Slechts die facetten van de administratiefrechtelijke handhaving zullen besproken worden die voor het onderwerp van deze studie van belang zijn. Hoewel interessant, blijft bespreking van onderwerpen zoals de te verwachten werkbesparing, de automatische afhandeling (Bekeurings Afhandelings Systeem, BAS), bekeuring op kenteken, verkeersveiligheid etc. achterwege. ${ }^{102}$

Het gaat mij voornamelijk om de rechtspositie van de betrokkene bij het opleggen van de sanctie. De nadruk zal komen liggen op de procedures bij de politie, officier van justitie en rechter.

$\mathrm{Na}$ de invoering van de WAHV zijn verschillende wijzigingen voorgesteld die noodzakelijk waren geworden in verband met een grootscheepse actie binnen het administratieve recht: de invoering van de Algemene wet bestuursrecht (voortaan te noemen: Awb). ${ }^{109}$ Eén van de doelstellingen van deze wet is een grotere uniformiteit aan

102 Zie daarvoor onder meer Handelingen II, 14 resp. 15 februari 1989, TK 4857-4870 resp. 4945-4963; A.H.W. van Velzen, Het rapport van de commissie Mulder: cen vercenvoudiging voor de praktijk? uit: G.J.M. Corstens e.a. (red.), Administratieve afdoening verkeersovertredingen, Zwolle 1986, pag. 65-89.

103 Deze invoering van de Awb geschiedt in verschillende gedeelten (tranches). De eerste tranche (Wet van 4 juni 1992, Stb. 1992, 31.5) en de tweede tranche, voornamelijk administraticf procesrecht, (TK 1991-1992, 22495) zjn op 1 januari 1994 in werking getreden (Stb. 1993, 650). De derde tranche 
te brengen op het terrein van de bestuursrechtelijke wetgeving. ${ }^{104}$ Dit betekent dat in beginsel de Awb geldt voor alle administratieve wetten, waaronder de WAHV. Daarom is de WAHV op een aantal punten aan de eerste tranche Awb aangepast, middels twee aanpassingswetten (Wet van 4 juni 1992, Stb. 1992, 422 ${ }^{105}$ en Wet van 23 december 1993, Stb. 1993,690\%).

Deze aanpassingen zullen uitgebreid worden besproken in een aparte paragraaf, 9. Ook een andere aanpak was hierbij mogelijk geweest. Ik had kunnen uitgaan van de huidige tekst (dus na de wijzigingen) en daarbij kunnen aangeven hoe de oude tekst eruit zag. Voor de gebruikte aanpak is gekozen, omdat hierbij duidelijker kan worden gemaakt welke gevolgen de Awb voor de WAHV heeft gehad, mede met het oog op de toetsing van andere afdoeningsmethoden aan bestuursrechtelijke normen.

\section{Ontwerp van de Commissie partiële herziening strafvordering en het Voorontwerp} van wet tot herziening van wettelijke voorschriften betreffende de tenuitvoerlegging van vermogensstraffen en van voorwaarden ter voorkoming van strafvervolging ${ }^{107}$

In 1973 komt de Commissie Partiële Herziening Strafvordering (Cie. Duk) met een voorstel tot invoering van de tenuitvoerlegging van rechtswege van de inhoud van schikkingsvoorstellen waarop niet is gereageerd. Dit voorstel dient als aanvulling van de voorstellen van de Commissie Vermogensstraffen.

Uitgangspunt van het voorstel is gelegen in de omstandigheid dat het toenemend aantal strafzaken in het bijzonder wegens verkeersdelicten en het relatief geringe aanbod van nieuwe leden voor het $\mathrm{OM}$ een verdere vereenvoudiging en bespoediging van de behandeling van strafbare feiten noodzakelijk maken. ${ }^{\text {in }}$

In tegenstelling tot de Commissie Vermogensstraffen, die pleit voor een uitbreiding van de transactiebevoegdheid tot alle misdrijven ${ }^{100}$, wil de Commissie Duk de schikkingsbevoegdheid slechts uitbreiden tot die misdrijven waarop een maximale gevangenisstraf van zes jaar of minder is gesteld. De ernstige delicten vergen volgens de Commissie Duk een berechting door een onafhankelijke rechter. Bovendien zou een schikkingshevoegdheid bij alle misdrijven het van het bestuur niet onafhankelijke

is als wetsvoorstel op 29 april 1994 ingediend bij de Tweede Kamer (TK 1994-1995, 23.700) Hierin worden verschillende "losse" onderwerpen behandeld, waaronder delegatie en mandaat, beleidsregels, subsidicverlening en handhaving.

104 Zie daarover uitgebreider: Hoofdstuk 10 Bestuursrechtelijke normen.

105 De volledige titel: Wet van 4 juni 1992, houdende aanpassing van een aantal wetten aan de eerste tranche van de Algemene wet bestuursrecht. Zie voor de behandeling TK 1990-1991, 22061.

106 Wet tot wijziging van de Algemene wet bestuursrecht (Aanpassingswet III).

107 Deze beide ontwerpen zijn niet gepubliceerd. Voor bestudering werd gebruik gemaakt van het

Centraal Archief van het ministerie van justitie, Wetten 937.

108 Toelichting bij het voorstel, pag. 1.

109 Zie hiervoor uitgebreider Hoofdstuk $3 \$ 1.6$. 
OM in een kwetsbare positie plaatsen doordat, gezien het feit dat door een transactie het vervolgingsrecht vervalt, het $O M$ een ingrijpend instrument heeft om de wijze van repressie van strafbaar gedrag te bepalen. ${ }^{110}$

De Commissie is verder van mening dat de door haar voorgestelde uitbreiding van het transactiestelsel niet de definitieve oplossing zal brengen voor de afdoening van de toenemende stroom strafzaken, onder andere vanwege het toegenomen aantal verkeersovertredingen. Volgens de Commissie kunnen de voordelen van het transactiesysteem slechts dan worden benut, als de wet de mogelijkheid biedt om bij uitblijven van enige reactie vanwege de verdachte de zaak toch op een eenvoudige manier te beëindigen. ${ }^{\text {"I }} \mathrm{Zij}$ biedt de minister van justitie een voorstel aan tot wijziging van de wetboeken van strafrecht en strafvordering, strekkende tot de invoering van de tenuitvoerlegging van rechtswege van de inhoud van transactievoorstellen waarop niet gereageerd is. Volgens dit voorstel is de inhoud van een transactie-aanbod van rechtswege vatbaar geworden voor tenuitvoerlegging, tenzij de verdachte binnen veertien dagen bezwaar maakt tegen de voorgenomen executie. In dit laatste geval komt de zaak alsnog op zitting of wordt geseponeerd. De tenuitvoerlegging zal plaatsvinden met overeenkomstige toepassing van de artikelen uit het Wetboek van Strafvordering die de executie van de geldboete regelen. Indien verhaal op bank- of girosaldi niet mogelijk is of grote bezwaren oplevert kan door de rechter, voor wie de zaak had moeten dienen, vervangende hechtenis worden opgelegd.

De Commissie was er zich van bewust dat door vaststelling van de "executoirverklaring-ex-lege" een nieuw element in het bestaande strafrechtelijke sanctiesysteem zou worden geïntroduceerd. ${ }^{112}$

Zij verwachtte dat een regeling volgens dit voorstel werkbesparing zou opleveren voor degenen die bij het strafproces betrokken zijn, inclusief de verdachte. Het aantal zittingsdagen ten behoeve van de betreffende feiten voor de rechterlijke macht zou verminderen, zodat meer tijd aan zaken van wezenlijk belang zou kunnen worden besteed.

De Commissie wees er op dat het voorstel een nieuwe dimensie toevoegt aan het vervolgingsbeleid van het $\mathrm{OM}$ : het gaat beschikken over een instrument waardoor zaken die anders geseponeerd zouden zijn nu leiden tot een resultaat dat op één lijn staat met een veroordeling. ${ }^{13}$

Ter voorkoming van rechtsongelijkheid pleitte de Commissie voor landelijk of zonodig regionaal overleg.

De Commissie besteedde aandacht aan een aantal aspecten van art. 6 EVRM namelijk het recht op een openbare behandeling door een onafhankelijke en onpartijdige rechterlijke instantie (art. 6 lid 1 EVRM) en het recht op de hoogte te worden gesteld

110 Toelichting bij het voorstel, pag. 2.

111 Toclichting bij het voorstel, pag. 3.

112 Toelichting bij het voorstel, pag. 3 .

113 Toelichting bij het voorstel, pag. 4 . 
van de aard en de reden van de tegen hem ingebrachte beschuldiging (art. 6 lid 3 EVRM). ${ }^{114}$

Het eerstgenoemde recht wordt volgens de Commissie door het voorstel gewaarborgd doordat in verschillende stadia van de schikkingsprocedure de mogelijkheid aanwezig is dat een verdachte zijn zaak alsnog voor de rechter brengt. De verdachte kan onmiddellijk na ontvangst van het voorstel te kennen geven dat hij niet wil schikken en de zaak aan de rechter wil voorleggen. Deze bevoegdheid van de verdachte kan op het schikkingsformulier worden vermeld. Ook wanneer de verdachte niet gereageerd heeft binnen de gestelde termijn heeft hij de mogelijkheid bezwaar te maken tegen de tenuitvoerlegging. Het OM kan hem dan dagvaarden (art. 398b lid 5). Mocht de mededeling van het $\mathrm{OM}$ met betrekking tot de voorgenomen tenuitvoerlegging de verdachte niet in persoon zijn betekend dan kan deze door het doen van bezwaar zijn zaak aan de rechter voorleggen (art. 398b lid 6). Deze mogelijkheid heeft de verdachte aan wie de mededeling in persoon is betekend doch die hierop niet reageerde, niet.

Hoewel het derde lid van art. 6 EVRM betrekking heeft op een verdachte die wegens een strafbaar feit wordt vervolgd en een transactievoorstel juist het instellen van een strafvervolging beoogt te voorkomen, is de bepaling naar het oordeel van de Commissie niet zonder betekenis. Zowel het schikkingsvoorstel waaraan is voldaan als het voorstel waaraan niet wordt voldaan en waarvan de inhoud dus ten uitvoer kan worden gelegd, kunnen op één lijn worden gesteld met een onherroepelijke veroordeling. Doordat het schikkingsvoorstel de verdachte op summiere wijze duidelijk malakt op welk feit het voorstel betrekking heeft voldoet het naar de mening van de Commissie aan de eis die het Verdrag stelt. De mededeling die de verdachte ontvangt bij niet-voldoening van het schikkingsvoorstel geeft hem nadere informatie. Indien het een buitenlandse verdachte betreft moet deze informatie in een voor hem begrijpelijke taal zijn gesteld.

In een op het departement ontworpen, uit 1973 daterend voorontwerp van wet tot herziening van wettelijke voorschriften betreffende de tenuitvoerlegging van vermogensstraften en van voorwaarden ter voorkoming van strafvervolging ${ }^{115}$ werd dit voorstel van de commissie niet overgenomen. Gesteld werd dat een bevel tot het ondergaan van vervangende hechtenis alleen behoort te worden gegeven indien op

114 Toelichting bij het voorstel, pag. 4-6.

115 Dit ontwerp maakte aanvankelijk deel uit van het concept-wetsontwerp dat heeft geleid tot de wet van 8 september 1976, Stb. 484. Ook dit ontwerp is niet gepubliceerd. Voor een meer uitgebreide beschrijving van het voorontwerp wordt wederom gebruik gemaakt van het archief van het ministerie van justitie. Zie verder: L.A.R.J. de Beaufort, Strafbevel of strafvoorstel? Een onderzoek naar een vereenvoudigde strafrechtspleging. Preadvies opgesteld ter gelegenheid van het congres van de Vereniging voor de vergelijkende studie van het recht van Nederland en België, te houden te Antwerpen, 23 en 24 november 1979, 's-Gravenhage 1979, pag. 49-54; L.A.RJ. de Beaufort, Tien jaar op weg naar een wettelijke regeling van de executoir verklaring van transacties, Trema 1978, pag. 167-170; 
een openbare terechtzitting het wettig en overtuigend bewijs van de schuld van de verdachte aan het hem tenlastegelegde feit is geleverd.

Het departementale voorontwerp beoogt de afdoening van lichte strafzaken (waarbij aan geen andere sanctie wordt gedacht dan betaling van een kleine geldboete eventueel met verbeurdverklaring van inbeslaggenomen goederen) te vereenvoudigen door het executoir verklaren van transacties. Het ontwerp komt in dit opzicht in grote lijnen overeen met het ontwerp-Duk. Op schriftelijke vordering van de officier van justitie zou de rechter de inhoud van de bij transactie gestelde voorwaarde executoir kunnen verklaren.

Zoals gezegd sloot dit ontwerp in grote lijnen aan bij het ontwerp van de Commissie Duk, met uitzondering van de vervangende hechtenis. Bewust is geen aansluiting gezocht bij het in de Bondsrepubliek Duitsland geldende systeem van de Strafbefehle. Volgens dit systeem kan de rechter, op vordering van het OM, na kennisneming van de stukken, tegen een verdachte een Strafbefehl geven. Bij een dergelijk bevel kan een vrijheidsstraf van ten hoogste drie maanden, geldboete of ontzegging van de rijbevoegdheid worden opgelegd. Heeft de rechter bedenkingen dan wordt de strafzaak ter terechtzitting aanhangig gemaakt. Binnen een week nadat het Strafbefehl aan de verdachte betekend is kan deze hiertegen bezwaar maken, waardoor de zaak eveneens ter zitting komt. Verschijnt de verdachte daar dan niet en laat hij zich ook niet vertegenwoordigen, dan worden de bezwaren zonder onderzoek verworpen. Indien tegen het Strafbefehl niet tijdig bezwaar wordt gemaakt, krijgt het de kracht van een rechterlijk vonnis.

Het is niet onmogelijk dat een door de rechter gegeven betalingshevel door de justitiabelen eerder zal worden geaccepteerd dan een van rechtswege verhindend geworden voorstel waarin de rechter niet is gekend. Dit resultaat zou dan echter worden hereikt via een procedure die leidt tot een rechterlijke beslissing buiten de terechtzitting om, zonder behoorlijke procedurele waarborgen. Daardour zou het rechterlijk oordeel worden gedevalueerd. ${ }^{136}$ Het ontwerp gaat er dan ook vanuit dat, in het geval de rechter er aan te pas moet komen om de boete executabel te maken, zijn oordeel slechts gebaseerd kan worden op een onderzoek ter terechtzitting. Verschillen met het door de Commissie Duk gemaakte ontwerp waren ${ }^{\mathrm{nt}}$ :

1. De regeling heeft alleen betrekking op schikkingsvoorstellen, watarbij geen andere voorwaarde is gesteld dan de betaling van een bepaalde geldsom.

2. De regeling slaat niet op gevallen waarin ter zake van een (economisch) misdrijf of een fiscaal delict een schikkingsvoorstel is gedaan.

3. De mogelijkheid voor de werdachte de strafzaak, indien hij dit wenst, alsnog op de zitting te doen behandelen, is verruimd. De verdachte kan tenuitvoerlegging 
voorkomen niet slechts door bezwaar daartegen te maken binnen veertien dagen na de mededeling dat het voorstel voor tenuitvoerlegging vatbaar wordt, maar ook gedurende dertig dagen nadat het voorstel voor tenuitvoerlegging vatbaar is geworden.

4. Het voorstel van de Commissie om, indien aan het voor tenuitvoerlegging vatbaar geworden schikkingsvoorstel niet wordt voldaan en verhaal bezwaren heeft, vervangende hechtenis mogelijk te maken door de rechter daartoe op vordering van het $O M$ een bevel te doen geven, wordt in het ontwerp niet overgenomen. Men is van mening dat een voor de verdachte ingrijpend bevel als het ondergaan van subsidiaire hechtenisstraf alleen behoort te worden gegeven indien op een openbare terechtzitting het wettig en overtuigend bewijs van de schuld van de verdachte aan het hem tenlastegelegde feit is geleverd. In het wetsvoorstel wordt er dan ook vanuit gegaan dat, indien de verdachte weigert aan het schikkingsvoorstel te voldoen en het OM van oordeel is dat aan verhaal overwegende bezwaren verbonden zijn, de zaak alsnog bij gewone dagvaarding of oproeping op de terechtzitting wordt gebracht.

Het belangrijkste verschil tussen de twee ontwerpen is dus dat in het laatste ontwerp de rechter de voorwaarde tot voorkoming van strafvervolging executoir verklaart, terwijl in het eerste ontwerp de rechter er slechts aan te pas komt wanneer de verdachte niet aan het van rechtswege executoir geworden transactievoorstel voldoet.

Samengevat zag de voorgestelde regeling er als volgt uit:

Indien als enige voorwaarde ter voorkoming van strafvervolging is gesteld de betaling van een bepaalde geldsom en aan deze voorwaarde niet binnen een daarvoor door het $\mathrm{OM}$ gestelde termijn is voldaan kan de officier van justitie de verdachte schriftelijk in kennis stellen dat tenzij alsnog aan de voorwaarde wordt voldaan, deze op de veertiende dag nadat de kennisgeving is verzonden voor tenuitvoerlegging vatbaar wordt (Een kennisgeving mag alleen worden verzonden indien de verdachte in het geheel niet aan de voorwaarde heeft voldaan). De kennisgeving welke een korte aanduiding van het feit bevat wordt aan de verdachte betekend. Hij zal hierbij worden ingelicht over de manier waarop hij tegen de voorgenomen tenuitvoerlegging bezwaar kan maken. Blijft ook dan betaling achterwege, dan zal, nadat tenminste dertig dagen zijn verstreken sedert de voorwaarde ter voorkoming van de strafvervolging voor tenuitvoerlegging vatbaar is geworden en na nog een schriftelijke waarschuwing, verhaal op goederen van de verdachte kunnen plaatsvinden. Gedurende de periode van dertig dagen nadat de voorwaarde voor tenuitvoerlegging vatbaar is geworden kan de verdachte de wens te kennen geven de strafzaak alsnog bij gewone dagvaarding of oproeping op de zitting te brengen. Hij moet daartoe mondeling of schriftelijk (per aangetekende brief) een daartoe strekkende verklaring op het parket afleggen. Was de kennisgeving niet aan de verdachte in persoon betekend, dan behoudt hij de bevoegdheid tot uiterlijk veertien dagen na het tijdstip waarop zich een omstandigheid heeft voorgedaan waaruit blijkt dat hij kennis; heeft genomen van de voorgeno- 
men tenuitvoerlegging. Indien het $\mathrm{OM}$ van oordeel is dat aan verhaal op goederen of inkomsten van de verdachte overwegende bezwaren zijn verbonden, blijft tenuitvoerlegging achterwege. In dat geval zal het $O M$ de zaak langs gewone weg op de zitting kunnen brengen. Hij gaat dan zo spoedig mogelijk tot vervolging over.

Met de discussie over de executie van het transactiebedrag kunnen we een parallel trekken met de discussie over de invoering van de transactie, zoals die in het begin van deze eeuw gevoerd werd: wel of geen rechterlijke inmenging?

Tegen dit voorontwerp zijn, vooral van de kant van de rechterlijke macht, bezwaren gerezen omdat het te weinig werkbesparing zou opleveren. ${ }^{118}$ Men stelde dat zaken, waarin aangeboden schikkingen niet zijn betaald thans in grote getalen op één zitting komen. Deze worden als verstekzaken in feite na de zitting 'binnenskamers' door de kantonrechter behandeld (een soort stempelvonnis). Men voorziet dat het aantal administratieve handelingen in de nieuwe regeling niet minder zal zijn. Van verschillende kanten wordt een voorkeur uitgesproken voor het ontwerp van de Commissie Duk. Daarop heeft de minister dit gedeelte van het ontwerp, behorende bij het concept-ontwerp dat heeft geleid tot de wet van 8 september 1976, Stb 484, ingetrokken.

\section{Wetenschappelijke discussie}

In 1979 wordt een congres van de Vereniging voor de vergelijkende studie van het recht van België en Nederland gewijd aan de vereenvoudiging van de strafrechtspleging. Door De Beaufort en De Wilde worden preadviezen uitgehracht, getiteld "Strafbevel of strafvoorstel?" respectievelijk "Het strafbevel"."19

De Beaufort stelt dat er bij een oplossing van de massaliteit van kantongerechtsovertredingen, waarvan verkeersovertredingen een groot deel uitmaken, een keuze gemaakt moet worden:

"Of wij hechten eraan de verdachte in een bagatelzaak zoveel als mogelijk het volle pond te geven, maar overwegen dan hoe de toepassing van de verstekprocedure tot aanvaardbare proporties wordt teruggebracht. Of wij hechten aan een adequate reactie op het verschijnsel der kleine criminaliteit, maar doen dan niet net alsof een effectieve afdoening daarvan te rijmen is met de wijze waarop thans de belangen van de verdachte van rechtswege tot ontwikkeling komen". ${ }^{n} 20$

118 Een overzicht van het op het ontwerp geleverde commentaar is eveneens te vinden in het Centraal Archief van het ministeric van justitie, Wetten 937.

119 L.A.R.J. de Bcaufort, Strafbevel of strafvoorstel? 's-Gravenhage 1979; L. de Wilde, Het strafbevel, 's-Gravenhage 1979.

120 Preadvies De Beaufort, pag. 3. 
Volgens hem moet er een grens aangegeven worden. Aan de ene kant is er de behandeling door de meervoudige kamer met uitspraak over veertien dagen, aan de andere kant de via de computer vastgestelde boete, waaraan nauwelijks een rechter te pas komt. Voor hem ligt de grens voorbij het midden, niet aan de kant van de meervoudge kamer. ${ }^{121} \mathrm{Na}$ een uitvoerige beschouwing over de transactie, de administratieve boete en het strafbevel (het OM dient een schriftelijk requisitoir in waarin een bepaalde straf wordt geëist; de rechter kan de vordering afwijzen op grond van bewijsproblemen of op grond van de geëiste straf; het bevelschrift geeft, naast het feit, wetsartikelen en bewijsmiddelen de straf aan; de straf wordt uitvoerbaar indien de veroordeelde niet binnen een bepaalde termijn verzet doet) komt De Beaufort tot het voorstel van een betalingsbevel. Het strafbevel wijst hij af omdat van de strafrechter niet gevraagd kan worden bevelen uit te vaardigen zonder dat hem tevens de gelegenheid wordt geboden voordien de verdachte te horen. ${ }^{122}$ In de door hem gekozen variant vaardigt het $\mathrm{OM}$ zelf een betalingsbevel uit, dat executabel wordt tenzij de verdachte beroep op de strafrechter instelt. Hieronder valt ook het model te brengen waarin een door het OM gedaan transactieaanbod van rechtswege executoir wordt, wanneer de beroepstermijn is verstreken. Volgens De Beaufort moet een door het $\mathrm{OM}$ uit te vaardigen betalingsbevel worden aangemerkt als een bestuurshandeling die de overheid doet afzien van een vordering tot toepassen van strafrechtelijke middelen. Zo is het betalingsbevel dan ook eerder te vergelijken met een administratieve boete dan met een civielrechtelijke vordering. In het geval de rechter ingeroepen wordt treedt hij niet zozeer op als straftoemeter maar als administraticve rechter die bestuurlijk beleid toetst. ${ }^{123}$

We kunnen hier reeds constateren dat de discussie over de vereenvoudiging van de strafrechtspleging zich niet meer beperkt tot alleen het strafrecht, maar dat ook het administratieve recht ten tonele verschijnt.

In de literatuur en in de toelichting bij de gedane voorstellen wordt wel aangehaakt bij de Duitse Strafbefehlsprocedure, een afdoening buiten geding van lichte misdrijven. Om daarin meer inzicht te krijgen volgt hier een overzicht van de regeling van de Strafbefehlsprocedure en de Bussgeldprocedure (voor overtredingen) in het Duitse strafprocesrecht. ${ }^{124}$ Het Strafbefehl kan worden toegepast bij een Vergehen waarvoor de Strafrichter of het Schöffengericht in eerste aanleg bevoegd is (hieronder vallen alle verkeersmisdrijven) en waarbij naar het eensluidend oordeel van de officier van justitie en de rechter voor de bestraffing volstaan kan worden met het opleggen van een (voorwaardelijke) geldboete en/of de bijkomende straf van ontzegging van

121 Preadvies De Beaufort, pag. 4.

122 Preadvies De Beaufort, pag. 70.

123 Preadvies Dc Beaufort, pag. 57-58.

124 Zie hierover uitgebreider P.J.P. Tak, Strafbefehls- en Bussgeldverfahren; wijzen van afdoening van verkecrsmisdrijven en verkeersordnungswidrigkeiten. Ministerie van justitic, Den Haag 1980; D. Schaffmeister, Politiële en justitiële delicten. Preadvies NJV 1984, pag. 182-206. 
de rijbevoegdheid, ongeldigverklaring van het rijbewijs, verbeurdverklaring, onttrekking aan het verkeer, vernietiging, onbruikbaarmaking en openbaarmaking van het vonnis. De procedure loopt als volgt: de officier van justitie neemt de beslissing tot vervolgen. ${ }^{125}$ Kan het feit via de Strafbefehlsprocedure afgehandeld worden dan doet de officier de strafrechter een vordering (Strafbefehl) toekomen. Dit Strafbefehl moet inhouden de tenlastelegging, de bewijsmiddelen en de straf. Na toetsing van dit Strafbefehl aan de materiële en formele vereisten, wordt het door de rechter ondertekend. Na ondertekening wordt het aan de verdachte betekend. Indien deze niet binnen een bepaalde tijd verzet aantekent, wordt het Strafbefehl voor tenuitvorerlegging vatbaar. Door verzet aan te tekenen kan de verdachte een openbare terechtzitting afdwingen. Laat hij op die zitting verstek gaan dan herleeft het Strafbefehl en krijgt het kracht van gewijsde. Volgens schattingen (exacte cijfers over de omvang van het Strafbefehl zijn niet bekend) wordt 80 tot 90 procent van de verkeersmisdrijven op deze manier afgedaan. ${ }^{12}$

Het Bussgeldverfahren is de gebruikelijke procedure voor afdoening van Ordnungswidrigkeiten (de vroegere overtredingen). Alle verkeersovertredingen vallen onder de Ordnungswidrigkeiten (Owi's). De administratie waaraan de uitvoering van wettelijke regelingen en de controle dalarop is opgedragen, is belast met de vervolging en afdoening van Owi's. Bij een lichte Owi kan de politie of administratie volstaan met een waarschuwing of een transactie. Wanneer het feit niet voor transactie in aanmerking komt of de betrokkene niet tijdig betaalt, wordt een Owi-Anzeige aan de administratie gestuurd. Na bestudering van de stukken en na het horen van de betrokkene, die zich door een raadsman kan doen bijstaan, wordt een geldboete vastgesteld en een Bussgeldbescheid uitgevaardigd. Instemming of uitblijven van verzet (binnen een bepaalde termijn) doet de betekening in kracht van gewijscle gaan en makt het voor executie vatbaar. Indien de administratie, na verzet van de betrokkene, bij haar standpunt blijft wordt de zaak aan het OM overgedragen die deze behandelt als ware het een strafzaak. De zaak wordt aangebracht bij een Amtsrichter. Het aanhangig zijn van de zaak bij de rechter schorst de tenuitvoerlegging van de boete niet. Deze Amtsrichter kan de zaak schriftelijk afdoen als het OM en de betrokkene daartegen geen bezwaar aantekenen. In de meeste gevallen wordt beslist naar aanleiding van een onderzoek ter terechtzitting, waarbij het $O M$ en de betrokkene niet tot aanwezigheid verplicht zijn. De rechter is niet aan het Bussgeldbescheid gebonden. Hij kan dus ook een hogere boete opleggen. Tegen de beslissing van de Amtsrichter staat in een beperkt aantal gevallen het rechtsmiddel van Rechtsbeschwerde open

125 Anders dan het Nederlandse strafproces kent het Duitse het opportuniteitsbeginsel in beginsel niet. Seponeren geschiedt slechts op technische gronden. Uitzonderingen op dit legaliteitsbeginsel kunnen worden gemaakt op grond van art. 153 StPO (geldt voor Vergehen: feiten met een minimum straf lager dan 1 jaar), art. 153 a S(PO (te vergelijken met een voorwaardelijk sepot) en art. 154 StPO (bij onbelangrijke 'Ncbentaten').

126 PJ.P. Tak, a.w., pag. 26. 
(cassatie). Dit is een schriftelijke procedure. Er is geen behandeling door een tweede feitelijke instantie.

Over de aard van een Ordnungswidrigkeit vermeldt Tak dat oorspronkelijk een Owi, anders dan een strafbaar feit, niet gezien werd als een ethisch verwijtbare inbreuk op een rechtsgoed, maar als een ethisch indifferente ongehoorzaamheid aan administratieve voorschriften, die dan ook geen (morele) afkeuring in de vorm van een straf behoefde, maar slechts een sanctie die een opwekking inhield tot gehoorzaamheid. Met name door de omvorming van verkeersovertredingen in Ordnungswidrigkeiten (1968) wordt verdedigd dat er geen materieel verschil, maar slechts een formeel onderscheid te maken is. ${ }^{17}$

De grote voortrekker van een administratiefrechtelijke afdoening van de massaliteit van verkeersovertredingen in Nederland is A. Mulder (toenmalig lid van de Raad van State) geweest. ${ }^{128}$ Mulder is van mening "dat de regeling van de transactie, zowel voor overtredingen als voor de in de toekomst aangewezen misdrijven moet worden uitgebouwd". Het OM moet de bevoegdheid krijgen "om terzake van overtredingen en van die misdrijven, die zich daarvoor lenen, geldboeten op te leggen met, eventueel, verbeurdverklaring van inbeslaggenomen goederen en intrekking van de bevoegdheid motorrijtuigen te besturen". ${ }^{128}$ Mulder bepleit het volgende systeem ${ }^{130}$ :

1. de regeling van de (vrijwillige) transactie in handen der politie blijft gehandhaafd;

2. buiten de sub.1 genoemde gevallen beslist het $O M$ (als bestuursorgaan) of er gronden zijn om terzake van de geconstateerde overtreding een vermogenssanctie op te leggen (geldboete, ontzegging van de rijbevoegdheid, verbeurdverklaring van het voertuig);

3. zo ja, dan bepaalt het de op te leggen sanctie en de omvang ervan;

4. indien de overtreder daartegen bezwaar maakt beslist het OM gemotiveerd op het bezwaarschrift;

5. tegen deze beslissing kan de overtreder beroep instellen bij de strafkamer van de rechtbank op één of meer van de volgende gronden:
a. het feit is niet verboden;
b. de overtreder treft geen enkele schuld;

127 P.J.P.Tak, a.w., pag. 28-29. Uitgebreider in: D. Schaffmeister, Politiële en justitiele delicten. Preadvies NJV 1984, pag. 138-142.

128 Zie onder andere A. Mulder, Strafrechtspolitiek, DD 1980, pag. 331-341; A. Mulder, De functie van het strafrecht in de verzorgingsstaat, AA 1981, pag. 225-231; A. Mulder, Overvraging van rechtsbescherming, in: Strafrechtspleging onder spanning, Arnhem 1981, pag. 53-72; A. Mulder, Massaliteit van verkeersovertredingen, VR februari 1982, pag. 25-28.

129 A. Mulder, AA 1981, pag. 230.

130 A. Mulder, Inleiding gehouden op een bijeenkomst van de Centrale Politie Verkeerscommissie met als onderwerp: De massaliteit van verkeersovertredingen, d.d. 10 november 1981, afgedrukt in VR 1982, pag. 27. 
c. bij het onderzoek en het nemen van de beslissing is enig in het algemeen rechtsbewustzijn levend beginsel van behoorlijk bestuur geschonden;

d. de sanctie is niet evenredig aan de aard van het feit of de omstandigheden waaronder het is begaan;

6. de als administratieve rechter optredende strafkamer van de rechtbank kan de beslissing van het OM vernietigen en, zo nodig, zelf in de zaak voorzien;

7. van de beslissing van de rechter staat slechts beroep in cassatie open.

Dit systeem heeft volgens Mulder de volgende voordelen:

a. de overtreder is tot medewerking verplicht;

b. het proces voor de rechter is niet inquisitoir, partijen staan op gelijke voet (het $\mathrm{OM}$ is als zodanig procespartij);

c. de procedure is niet gebonden aan een strikte procesorde;

d. het politie-rapport kan summier zijn en is niet gebonden aan de eisen van een tenlastelegging;

e. als de overtreder in de sanctie, die het OM oplegt, berust, is de beslissing onherroepelijk;

f. één rechterlijke instantie wordt uitgespaard.

Indien er afstand wordt gedaan van de bijzondere bevoegdheden van strafvordering en van de subsidiaire hechtenis, is er geen wezenlijk obstakel meer voor administratieve afdoening van de massaliteit van verkeersovertredingen.

\section{Voorontwerp 17.478}

Naar aanleiding van het betoog van Mulder wordt er tijdens de behandeling van de begroting van het departement van justitie in de Tweede Kamer een motie ingediend, waarin de regering wordt verzocht nadere studie te verrichten naar mogelijkheden om eenvoudige verkeersovertredingen op andere dan strafrechtelijke wijze af te doen en de Kamer daarvan verslag uit te brengen. ${ }^{131}$ Bij bespreking van deze motie zegt de minister toe aan het verzoek gevolg te geven. ${ }^{132}$ De motie wordt op 15 december 1981 aanvaard. ${ }^{133}$

131 Motic Nijpels c.s, voorgesteld op 25 november 1981, TK 1981-1982, 17.100, hoofdstukken VI en VII, nr. 17.

132 Handelingen II 25 november 1981, pag. 588-589.

133 Handelingen II 15 december 1981, pag. 1076. 
Bij brief van 17 juni 1982 aan de Voorzitter van de Tweede Kamer wordt door de minister gevolg gegeven aan zijn toezegging. ${ }^{134}$ In deze nota plaatst de minister kanttekeningen bij het voorstel van Mulder.

Ten aanzien van de procedure als zodanig wordt gesteld dat de scheidslijn tussen administratiefrechtelijke en strafrechtelijke handhaving niet in alle opzichten even scherp is getrokken. Zo blijft de vrijwillige politietransactie bestaan, een typisch strafrechtelijk orgaan als het $\mathrm{OM}$ wordt belast met het nemen van de administratieve beslissing en ook de sanctie is aan het strafrecht ontleend, in het bijzonder de verbeurdverklaring van een voertuig. Doordat de voorschriften van de wetboeken van strafrecht en strafvordering niet meer zouden gelden wordt de rechtspositie van de overtreder er niet duidelijker op. In het voorstel van Mulder zouden bepaalde leerstukken, zoals die van de wederrechtelijkheid, straf- en schulduitsluitingsgronden, verjaring en ne-bis-in-idem niet langer meer rechtsgeldig zijn voor verkeersovertredingen. Het blijft de vraag of uitdrukkelijke bepalingen met betrekking tot deze onderwerpen kunnen worden gemist. ${ }^{135}$

Tevens vraagt de minister zich af hoe de voorgestelde procedure zich verhoudt tot het Europees Verdrag. Met betrekking tot dit onderwerp is een advies van de Utrechtse hoogleraar Internationaal recht Van Dijk als bijlage gevoegd. ${ }^{13137}$ (Hier lijkt mij de vraag gerechtvaardigd waarom niet ook advies is ingewonnen bij een hoogleraar bestuursrecht). Gesteld wordt dat het formele karakter dat een procedure naar nationaal recht heeft, niet bepalend is voor toepasbaarheid van art. 6 EVRM, omdat op deze manier verdragstaten verplichtingen die art. 6 EVRM impliceert, zouden kunnen ontduiken door een andere dan strafrechtelijke procedure te scheppen voor de behandeling van overtredingen die deel uitmaken van het strafrecht vanwege hun aard, karakter en sanctie. De minister komt tot de conclusie dat in een systeem van administratieve afdoening alleen een (kleine) geldboete, zonder dat vervangende hechtenis wordt toegepast, in aanmerking komt. ${ }^{136}$

Tenslotte worden vraagtekens geplaatst bij de praktische uitvoerbaarheid van het stelsel van Mulder. ${ }^{199}$

Mede in afwachting van de ontwikkeling van de Europese jurisprudentie geeft de minister de voorkeur aan het zoeken naar verdere vereenvoudigingen in de strafrechtelijke sfeer. Het gaat er hem om dat gestreefd wordt naar een zekere evenredigheid tussen het gewicht van een afzonderlijke strafzaak en de zwaarte van het toepasselijke procesrecht. Dit zou dan kunnen leiden tot bepaalde vereenvoudigingen van de

134 TK 1981-1982, 17.478, nr. 1.

135 TK 1981-1982, 17.478, nr. 1, pag. 5-6.

136. TK 1981-1982, 17.478, nr. 1, pag. 12-35.

137 Reeds in een eerdere publicatie had Van Dijk de woorstellen van Mulder in verband gebracht met art. 6 EVRM. P. van Dijk, Massaliteit van verkeersovertredingen en het recht op behandeling door de rechter, Trema 1982, pag. 3-13.

138 TK 1981-1982, 17.478, nr. 1, pag. 6-7.

139 TK 1981-1982, 17.478, nr. 1, pag. 7-9. 
procedure die overigens uiteraard zal moeten blijven voldoen aan een aantal minimum rechtswaarborgen voor de verdachte binnen de grenzen die het Europees Verdrag en het Internationaal Verdrag inzake burger- en politieke rechten op dit punt inhouden. Dit standpunt wordt geconcretiseerd in een voorontwerp van wet, welke als bijlage bij de brief is gevoegd. ${ }^{140}$ Samengevat komt dit voorontwerp op het volgende neer:

In verkeersstrafzaken die naar het oordeel van het OM met geen andere straf of matregel moeten worden afgedaan dan een geldboete met een maximum van $f$ 500 ,- kan het $\mathrm{OM}$ een beslissing tot vereenvoudigde afdoening nemen. Voordat de officier van justitie die beslissing neemt moet de verdachte in staat zijn gesteld daaromtrent bezwaren en opmerkingen te maken. Een afschrift van de beslissing wordt aan de verdachte toegezonden. Gedurende een maand na dagtekening van de beslissing tot vereenvoudigde afdoening kan de verdachte alsnog schriftelijk verzoeken dat door dagvaarding een rechtsgeding bij het kantongerecht aanhangig wordt gemaakt. Indien de verdachte niets van zich laat horen moet de officier van justitie een vordering indienen ter bevestiging van zijn beslissing tot vereenvoudigde afdoening en aanvulling daarvan met vervangende hechtenis. De kantonrechter roept de verdachte op om op een openbare terechtzitting te verschijnen om, indien gewenst, verweer te voeren. Bijstand door een raadsman is mogelijk. De kantonrechter kan de beslissing van de officier bevestigen. Hij kan de te betalen geldsom op een lager bedrag vaststellen. Tevens bepaalt de kantonrechter het aantal dagen van de vervangende hechtenis. Indien de beslissing van de officier niet wordt bevestigd kan de zaak alsnog door het $\mathrm{OM}$ bij de kantonrechter via een normale strafprocedure aanhangig worden gemaakt. Tegen de beslissing van de kantonrechter staat geen rechtsmiddel open.

Volgens Van Dijk zou deze voorgestelde procedure niet in strijd zijn met art. 6 EVRM, daarentegen wel met art. 14 lid 5 IVBP in verband met het recht op een hogere voorziening. ${ }^{131}$ Verder is hij van mening dat de vereenvoudiging zeer bescheiden van aard is. Het lijkt hem niet noodzakelijk dat aan de verdachte, nadat het $\mathrm{OM}$ tot vereenvoudigde afdoening heeft beslist, de gelegenheid wordt geboden binnen een maand alsnog schriftelijk te verzoeken dat door dagvaarding het rechtsgeding op de normale manier bij het kantongerecht wordt gevoerd. Het OM zou volgens hem onmiddellijk een vordering bij de kantonrechter ter bevestiging van zijn heslissing en tot aanvulling met voorlopige hechtenis kunnen eisen.

Door de minister was aan Van Dijk tevens advies gevraagd over de constructie waarbij de beslissing van het $O M$ tot vereenvoudigde afdoening voor de verdachte verbindend wordt, wanneer deze niet binnen de gestelde termijn bezwaar heeft aangetekend tegen deze beslissing. Door geen bezwaar aan te tekenen zou de verdachte zijn recht 
om de beslissing van het OM aan te vechten verspeeld hebben. Van Dijk is tegen een dergelijke constructie omdat het recht op toegang tot de rechter een primair recht is en niet een recht dat afhankelijk kan worden gemaakt van de verdachte door verzet aan te tekenen of beroep in te stellen tegen de bepaling van de gegrondheid van de tegen hem ingestelde strafvervolging die niet door een rechter of althans niet volgens de in art. 6 EVRM voorgeschreven procedure is geschied. ${ }^{142}$

Vervangende hechtenis kan volgens Van Dijk slechts opgelegd worden krachtens een rechterlijk vonnis dat tot stand is gekomen op grond van een eerlijk en openbaar proces. Hij is dan ook van mening dat, indien men zou aanvaarden dat de beslissing van het $\mathrm{OM}$ tot vereenvoudigde afdoening, mits daartegen geen verzet is aangetekend, verbindend wordt, de rechter, wanneer het OM hem vraagt vervangende hechtenis te bevelen, de verdachte alsnog ter openbare zitting zal moeten oproepen en zich een zelfstandig oordeel zal moeten vormen over wederrechtelijkheid en schuld. ${ }^{143}$ Ook gijzeling als middel om tenuitvoerlegging van de beslissing van het OM te verzekeren op grond van art. 5 EVRM wijst hij af. Art. 5 EVRM geeft twee rechtvaardigingsgronden voor een dergelijke maatregel: vrijheidsberoving wegens weigering een rechterlijk bevel op te volgen, of vrijheidsberoving ten einde de nakoming van een wettelijke verplichting te verzekeren. En gijzeling ter handhaving van het wegenverkeersrecht zal volgens Van Dijk onvoldoende rechtvaardigingsgrond opleveren.

In tegenstelling tot de opsteller van het voorontwerp, minister De Ruiter, voelt zijn opvolger op het departement van justitie, Korthals Altes, zoals hij tijdens de Uitgebreide Commissievergadering van Justitie bij bespreking van de brief van de minister duidelijk laat blijken, wel voor een administratiefrechtelijke handhaving van verkeersovertredingen. De meeste leden van de commissie staan ook niet afwijzend ten opzichte van administratieve elementen. ${ }^{144} \mathrm{Naar}$ aanleiding hiervan besluit de minister van Justitie de Commissie vereenvoudigde afdoening lichte verkeersovertredingen in te stellen, onder voorzitterschap van (wie anders?) A. Mulder. ${ }^{\text {is }}$

\section{Preadviezen Nederlandse Juristen-Vereniging}

In 1984 worden er ten behoeve van de Nederlandse Juristen-Vereniging twee preadviezen uitgebracht (door Corstens en Schaffmeister) over de vraagstelling: "Is het wenselijk om het terrein waarover de strafrechtspleging zich uitstrekt te beperken door het creëren van een wettelijke regeling volgens welke misdragingen binnen het kader van het "ordeningsrecht" welke slechts tot het opleggen van vermogenssancties aanleiding behoeven te geven, op andere wijze(n) kunnen worden afgedaan

142 TK 1981-1982, 17.478, nr. 1, pag. 30.

143 TK 1981-1982, 17.478, nr. 1, pag. 31.

144 UIC.V 1983-1984, 14 maart 1983, nr. 23.

145 Instellingsbesluit van 30 november 1983, Stafafdeling Wetgeving Publickrecht, nr. 646/692. 
dan door strafbedreiging en strafvervolging volgens de thans geldende regels? Zo $\mathrm{ja}$, dient deze regeling dan te voorzien in de mogelijkheid dat door (nader te bepalen) overheidsinstanties vermogenssancties worden opgelegd waartegen beroep op de rechter openstaat, of dient aan een andere regeling de voorkeur te worden gegeven?" met als titel: 'Civielrechtelijke, administratieve of strafrechtelijke rechtshandhaving?' respectievelijk 'Politiële en justitiële delicten'. ${ }^{146}$ Om doublures te voorkomen is het preadvies van Corstens toegespitst op de verkeersovertredingen en dat van Schaffmeister op het ordeningsrecht in het algemeen. Beiden nemen als uitgangspunt de overbelasting van het strafrechtelijk apparaat. Dit capaciteitsprobleem kan zich uiten in uitstel, slechte afhandeling, het niet in behandeling nemen van zaken en de lange tijdsduur van procedures. Bezuinigingen op overheidsuitgaven verhinderen personeelsuitbreiding en betere materiële voorzieningen ${ }^{147}$ Eén van de mogelijke middelen waarmee de capaciteitscrisis kan worden opgelost is de terugdringing van het strafrecht (decriminalisatie). Na een analyse van de verschillende handhavingsstelsels formuleert Corstens zestien criteria aan de hand waarvan 'toedeling' van onrecht aan het ene of het andere stelsel kan geschieden. ${ }^{15 k}$ Een eventuele overheveling vanuit het strafrecht naar het administratieve recht is echter aan juridische beperkingen gebonden (de gevolgen van het rechtsstaatsidee, de eisen die de Grondwet stelt en de bepalingen van het EVRM met name art. 6). ${ }^{1+4}$ Met betrekking tot de massaal gepleegde verkeersovertredingen (waarbij geen slachtoffers vallen) komt Corstens, na toetsing aan de gestelde criteria, tot de conclusie dat, gezien de zwaarte van de daarbij op te leggen sanctie de verplicht te volgen rechterlijke procedure teneinde tot een executabele boete te komen, kostbaar en bepaald niet nodig is. Volstaan zou kunnen worden met een administratieve afdoening met de mogelijkheid van beroep op de rechter. Door deze zeef zou de rechter de zaken wel meer individueel kunnen behandelen en zouden alleen zaken waarmee 'echt iets mis is' voor de rechter komen omdat de overtreder zelf initiatief moet ontplooien. Ook is in dit kader van groot belang dat in het huidige stelsel bij het achterwege blijven van een schikking de verplicht te volgen rechterlijke procedure tijd kost. Want volgens Vellinga blijkt uit onderzoek dat strafrechtelijke handhaving van verkeersvoorschriften alleen resultaat afwerpt, wanneer de politie frequent controleert én de opsporing wordt gevolgd door snelle justitiële actie. ${ }^{150}$ Vervolgens komt Corstens met een ontwerp voor een wettelijke regeling. ${ }^{{ }^{51}} \mathrm{Hij}$ beperkt de werkingssfeer van de administratieve afdoening vooralsnog tot een drietal categorieën van verkeersovertredingen, namelijk regelen betreffende de snelheid, de verkeerslichten en het stilstaan en parkeren. De politietransactie blijft in deze zaken mogelijk. Ook de mogelijkheid van transactie met

146 Handelingen 1984 der Nederlandse Juristen-Vereniging, deel I, cerste stuk. Zwolle 1984.

147 Corsiens, preadvies NJV, pag. 6-7.

148 Corstens, preadvies NJV, pag. 51-53.

149 Corstens, preadvies NJV, pag. 54-76.

150 Corstens, preadvies NJV, pag. 103-105.

151 Corstens, preadvies NJV, pag. 110-126. 
het $\mathrm{OM}$ wordt gehandhaafd. Wanneer de overtreder daarop niet ingaat en besloten wordt tot verder administratief optreden, legt de officier van justitie of de verkeersschout bij beschikking een boete op, welke beschikking dadelijk uitvoerbaar is (een eventueel beroep heeft geen schorsende werking). De overtreder kan binnen veertien dagen beroep instellen bij de kantonrechter, welk beroep niet in behandeling wordt genomen als niet aan de beschikking is voldaan. De zwaarte van de op te leggen sancties rechtvaardigt niet een tweede behandeling in feitelijke instantie. Wel is het wenselijk de mogelijkheid van cassatie voor overtreder en OM open te stellen.

In zijn preadvies zoekt Schaffmeister naar een nieuw criterium tussen misdrijven en overtredingen. Na bestudering van andere Europese systemen meent hij dat onder de overtredingen zouden zijn te rangschikken de strafbare feiten, die normen betreffen welke geen hoge feitelijke 'gedragsgelding' hebben, maar die volgens de wetgever wel nageleefd moeten worden. $\mathrm{Er}$ is een relatief lage onrechtsdrempel. Personen die doorgaans wetsgetrouw zijn, begaan wel eens dergelijke strafbare feiten. Hij legt hierbij een 'frequentiecriterium' aan: de verdeling van een feit in de ene of de andere categorie hangt af van de frequentie van de (te verwachten) normschendingen. ${ }^{15115}$. Schaffmeister, hierbij geïnspireerd door het Oostenrijkse systeem, wil deze categorie van overtredingen laten afwikkelen door nader te bepalen politiële diensten, hetgeen inhoudt dat de afdoening niet alleen plaatsvindt buiten de rechter, maar ook buiten het $\mathrm{OM} \mathrm{om}$. Het is volgens hem wenselijk het takenpakket van het $O M$ te herzien, om zo het OM te ontlasten..$^{1.4}$ Als mogelijke oplossing voor een te grote toeloop tot de rechter ziet Schaffmeister een bijdrage van de in het ongelijk gestelde "verdachte" in de kosten van het geding.

\section{Voorstellen van de Commissie Vereenvoudigde afdoening lichte overtredingen van verkeersvoorschriften (Commissie Mulder) ${ }^{1 \text { is }}$}

De Commissie krijgt als opdracht voorstellen te doen aan de minister van Justitie met betrekking tot de wettelijke regeling van de vereenvoudigde afdoening van lichte overtredingen van verkeersvoorschriften. Daarbij denkt de minister allereerst aan een administratieve afdoening. In zijn installatiere de houdt de minister van Justitie

152 Schaffmeister, preadvies NIV, pag. 226.

153 Schaffmeister merkt hierbij naar mijn mening terecht op dat de uitbreiding van de transactie tot bepaalde misdrijven in 1983 een 'osmose in de verkeerde richting' was. In plaats van overheveling van de voor de afgesplitste categorie kenmerkende en doelgerichte afdoening door middel van transactic, hadden de veelvoorkomende delicten toebedeeld moeten worden aan de daarvoor bestaande rubriek (van overtredingen gvdb). Schaffmeister, a.w., pag. 242-243.

154 Schaffmeister, preadvies NJV, pag. 270.

155 Deze voorstellen zijn neergelegd in het Rapport van de Commissie vereenvoudigde afdoening lichte overtredingen van verkecrsvoorschriften, Den Haag 1985. Voortaan te noemen: Rapport Mulder. 
(Korthals Altes) de mogelijkheid open dat van een voorstel tot administratieve afdoening van lichte verkeersovertredingen een precedentenwerking zal uitgian naar andere categorieën strafbare feiten. Door verschillende soorten lichte vergrijpen uit het strafrecht te halen wordt tegemoet gekomen aan de gedachte van decriminalisering is. De mogelijkheid van een vereenvoudigde strafrechtelijke afdoening wordt echter opengelaten, mocht onverhoopt blijken dat een administratiefrechtelijke afdoening in verband met het Europees Verdrag niet mogelijk is. ${ }^{157}$

De commissie hanteert een tweetal doelstellingen:

1. de verkeersvoorschriften dienen effectiever te worden gehandhaafd dan thans het geval is. De aan de overtreding verbonden sanctie dient zo snel mogelijk geëffectueerd te worden;

2. de werklast voor het politiële en justitiële apparaat, met inbegrip van de executiewerkzaamheden, moet zoveel mogelijk -namelijk als in het kader van een verantwoorde rechtspleging aanvaardbaar is- worden verminderd. De capaciteit van het strafrechtelijk apparaat is beperkt, zodat er zowel op het vlak van de regelgeving als ook op het vlak van de handhaving prioriteiten moeten worden gesteld.

Toelichting: De Commissie gaat uit van de door Corstens gepubliceerde cijfers. ${ }^{153}$ Daaruit blijkt dat in 1982 verkeersovertredingen bijna $94 \%$ besloegen van het aantal opgemaakte processen-verbaal en gedane transacties inzake overtredingen door de politie. Van alle verkeersovertredingen werd $50,7 \%$ via een poltietransactie afgedaan en $35,1 \%$ via een OM-transactie. Bijna 300.000 strafzaken (12,5\%) kwamen op de terechtzitting van de kantonrechter. Op een totaal van 376.777 eindvonnissen van de kantonrechter in 1982 betroffen er 294.572 verkeersovertredingen. In ruim $80 \%$ van de door de kantonrechter berechte zaken liet de verdachte verstek gaan (hicrbij is geen uitsplitsing gemaakt van verkeersovertredingen en andere overtredingen). De overbelasting van het strafrechtelijk apparaat en het streven naar een effectiever handhavingssysteem deed de vraag rijzen of het niet mogelijk was een bepaalde groep van overtredingen anders dan strafrechtelijk af te doen (decriminalisering). Dat de vraag naar vereenvoudiging van de handhaving zich juist voordoet bij verkeersovertredingen lag volgens de commissie voor de hand. Het plegen van dergelijke overtredingen werpt als zodanig geen morele blaam op de overtreder, want het gaat niet zozeer om "rechtsdelicten" maar om "wetsdelicten". Daamaast is in verschillende buitenlandse stelsels het merendeel van de verkeersovertredingen reeds aan het strafrecht onttrokken. De commissie gaf nog een derde reden waarom de vraag naar vereenvoudiging zich juist voordeed bij verkeersvoorschriften, namelijk dat ons recht al vertrouwd is met vormen van administratiefrechtelijke handhaving. Ik zie niet in dat dit een

156 Installaticrede minister van Justitic, als bijlage F opgenomen in het Rapport Mulder, pag. 118-119.

157 Installatierede minister van Justitic, Rapport Mulder, pag. 118.

158 GJ.M. Corstens, Civielrechtelijke, administratiefrechtelijke of strafrechtelijke rechtshandhaving? Preadvies NJV 1984. 
argument is om juist de handhaving van verkeersovertredingen te vereenvoudigen. Het is wel een argument om te zoeken naar een mogelijkheid van administratieve handhaving.

De hoofdlijn van het ontwerp van wet, zoals dit door de Commissie Mulder is opgesteld, is dat voor de afdoening van bepaalde lichte verkeersovertredingen uitsluitend de administratiefrechtelijke weg openstaat. Ten aanzien van deze gedragingen wordt uitdrukkelijk bepaald dat zij geen strafbare feiten zijn. Het strafrecht en strafprocesrecht zijn dus niet van toepassing op de opsporing, de vervolging en de berechting van deze gedragingen. De commissie heeft hierbij gedacht aan de gedragingen die momenteel voor een politietransactie in aanmerking komen. Bij constatering van zo'n verkeersgedraging is de daartoe aangewezen politie-ambtenaar bevoegd de betrokkene staande te houden, te vorderen dat deze zijn personalia en het nummer van zijn bank- of girorekening opgeeft en (terstond) een administratieve boete op te leggen. Dit bedrag wordt vastgesteld aan de hand van in een bijlage bij de wet vermelde bedragen, waaraan een maximum van $f 300$,- is gesteld. De enige sanctie die het ontwerp kent is een administratieve boete, vervangende hechtenis is uitgesioten. Met de overhandiging van deze beschikking neemt een termijn van dertig dagen een aanvang. Binnen deze termijn kan een ieder die door de beschikking rechtstreeks in zijn belang wordt getroffen, schriftelijk beroep instellen bij de officier van justitie bij de rechtbank van het rechtsgebied waar de overtreding heeft plaatsgevonden. Wanneer geen beroep wordt ingesteld is de oplegging van de boete executabel. De officier van justitie bekijkt de zaak in zijn geheel opnieuw. Hij kan de gegeven beschikking vernietigen. Verklaart de officier van justitie het beroep ongegrond dan kan de betrokkene, wederom binnen dertig dagen, beroep instellen bij een administratieve kamer van de rechtbank, welke doorgaans zal bestaan uit een alleensprekende rechter. Dit beroep is niet ontvankelijk indien de betrokkene niet binnen veertien dagen nadat dienaangaande bericht heeft ontvangen, zekerheid heeft gesteld voor betaling van de boete door middel van beschikbaarstelling van geldswaarden tot het bedrag van de boete. Dit om te voorkomen dat beroep wordt ingesteld alleen met de bedoeling om op deze manier uitstel van betaling te krijgen. $\mathrm{Na}$ beslissing door de rechtbank kan er geen behandeling door een feitelijke rechterlijke instantie meer plaatsvinden. Wel staat nog de mogelijkheid van beroep in cassatie open bij een administratieve kamer van de Hoge Raad.

De officier van justitie is belast met de inning van het boetebedrag. Bij niet-tijdige betaling wordt dit bedrag met $25 \%$ verhoogd. Wordt het verhoogd bedrag niet voldaan, dan volgt wederom een verhoging en wel met $50 \%$ en kan verhaal gehaald worden op het giro- of banksaldo van de betrokkene. Ziet de officier van justitie af van dit verhaal dan kan hij de rechtbank verzoeken om toepassing van éen der volgende dwangmiddelen:

- buitengebruikstelling van het voertuig van de betrokkene voor een maand;

- invordering van het rijbewijs van de betrokkene voor een maand; en in het uiterste geval: 
Opmerkelijk (het ontwerp beoogt immers decriminalisering) is dat een nieuw strafbaar feit in het leven wordt geroepen: de betrokkene die zijn personalia niet of onjuist opgeeft, pleegt een strafbaar feit (art. 24 ontwerp). Dit feit wordt niet anders dan strafrechtelijk afgedaan.

De Commissie Mulder is van mening dat het ontworpen voorstel niet in strijd is met de Grondwet. Art. 113 lid $1 \mathrm{GW}$ bepaalt dat de berechting van strafbare feiten is opgedragen aan de rechterlijke macht. De commissie concludeert dat geen materieel criterium aan te geven is op grond waarvan sommige overtredingen als strafbare feiten en andere als administratiefrechtelijke gedragingen moeten worden beschouwd. De vraag wat als strafbaar feit moet worden gezien, staat ter beantwoording aan de wetgever. Het voorstel van de commissie heeft betrekking op afdoening van administratieve feiten, en niet op strafbare feiten, zodat art. 113 lid 1 GW niet van toepassing is.

Het voorstel is volgens de commissie evenmin in strijd met de internationaalrechtelijke bepalingen zoals die in de verschillende verdragen zijn neergelegd. Gezien de bestaande jurisprudentie van het Europese Hof, kan de afdoening niet als strafrechtelijk gekwalificeerd kan worden, zodat de regeling niet valt onder de werking van art. 6 EVRM (het is geen criminal charge in de zin van art. 6 EVRM). Ditarnaist is zij van oordeel dat ook indien de regeling wel als strafrechtelijk bestempeld zou worden, voldaan is aan de eisen die art. 6 EVRM stelt doordat een volwaardige rechterlijke voorziening wordt geboden. De zekerheidstelling als voorwaarde voor ontvankelijkheid van het beroep op de rechter doet hieraan nict af. Het ontwerp is volgens de makers ervan evenmin in strijd met het beginsel van de presumptio innocentiae (art. 6 lid 2 EVRM en art. 14 lid 3 sub g IVBP). Totdat de rechtbank een beslissing over het beroepschrift heeft genomen, wordt de betrokkene voor onschuldig gehouden.

De ontworpen regeling voorziet in een berechting door slechts één feitelijke instantie. Naar het oordeel van de Commissie is dit niet in strijd met art. 14 lid 5 IVBP. ${ }^{195}$ Dit Verdrag van New York heeft betrekking op ernstige strafbare feiten en niet op de allerlichtste. De term "crime" in de oorspronkelijke Engelse tekst lijkt de commissie te ruim.

159 Rapport Mulder, par. 3.3.3, pag. 27. 


\section{Commentaar bij het Rapport Mulder}

\subsection{Inleiding}

Het rapport Mulder krijgt ruime aandacht in de (straf)rechtsliteratuur (opvallend genoeg niet in de bestuursrechtelijke). Daarbij staat centraal de toetsing van de voorgestelde regeling aan internationaalrechtelijke bepalingen, met name art. 6 EVRM en art. 14 IVBP. Alvorens deze toetsing te bespreken zal eerst een uiteenzetting gegeven worden van de betreffende internationaalrechtelijke bepalingen en de daarmee samenhangende jurisprudentie. Tot slot komen ook andere punten van kritiek op het rapport aan de orde.

\subsection{Intemationaalrechtelijke bepalingen}

Artikel 6 EVRM garandeert het recht op een eerlijke en openbare behandeling. De volledige tekst luidt:

1. In the determination of his civil rights and obligations or of any criminal charge against him, everyone is entitled to a fair and public hearing within a reasonable time by an independent and impartial tribunal established by law. Judgment shall be pronounced publicly but the press and public may be excluded from all or part of the trial in the interest of morals, public order or national security in a democratic society, where the interests of juveniles or the protection of the private life of the parties so require, or to the extent strictly necessary in the opinion of the court in special circumstances where publicity would prejudice the interest of justice.

2. Everyone charged with a criminal offence shall be presumed innocent until proved guilty according to law.

3. Everyone charged with a criminal offence has the following minimum rights:

a. to be informed promptly, in a language which he understands and in detail, of the nature and cause of the accusation against him;

b. to have adequate time and facilities for the preparation of his defence;

c. to defend himself in person or through legal assistance of his own choosing or, if he has not sufficient means to pay for legal assistance, to be given it free when the interest of justice so require;

d. to examine or have examined witnesses against him and to obtain the attendance and examination of witnesses on his behalf under the same conditions as witnesses against him;

e. to have the free assistance of an interpreter if he cannot understand or speak the language used in court.

Allereerst zal de vraag beantwoord moeten worden of de door de Cie. Mulder voorgestelde regeling valt onder de twee categorieën van procedures waaraan art. 6 lid 
1 EVRM bescherming biedt, namelijk procedures die leiden tot de determination of civil rights and obligations or of any criminal charge. Immers, bij een negatieve beantwoording van deze vraag is art. 6 lid 1 EVRM in het geheel niet van toepassing en behoeft de voorgestelde regeling niet aan de in art. 6 lid 1 EVRM neergelegde eisen te voldoen.

Wat bedoeld wordt met 'determination of civil rights and obligations' is door de opstellers van dit artikel niet nader aangegeven. ${ }^{100}$ De vraag of er sprake is van 'civil and obligations' levert met name problemen op bij procedures die volgens het nationale recht tot de administratiefrechtelijke gerekend worden. Uit de Delcourt-zaak vloeit voort dat de Europese instanties niets voelen voor een restrictieve interpretatie van deze term. ${ }^{161}$ In de Golder-zaak wordt door de Commissie en het Hof aangegeven dat aan de term een autonome betekenis moet worden toegekend, om te verhinderen dat verdragstaten, door bestaande of nieuwe procedures anders te kwalificeren, art. 6 uithollen. ${ }^{162}$ Niet beslissend is of de in het geding zijnde procedure naar nationaal recht een privaatrechtelijk karakter heeft, maar of op grond van objectieve beginselen dat karakter daaraan toe te kennen is. Bij een geschil tussen een particulier en een overheidsorgaan kan er sprake zijn van een procedure ter vaststelling van 'civil rights and obligations'. ${ }^{163}$ Niet van doorslaggevend belang is of de procedure gevoerd wordt voor de burgerlijke rechter of een andere instantie. ${ }^{164}$ Aan het begrip 'determination' is in de zaak Le Compte, Van Leuven en De Meyere een ruime interpretatie gegeven. De 'determination' van het bepaalde 'civil right' of 'civil obligation' behoeft niet de hoofdzaak van de procedure uit te maken. Voldoende is dat de uitkomst van de procedure mede bepalend is voor de vaststelling van zo'n recht. ${ }^{10 s}$ In de genoemde gevallen ging het om een procedure waarbij de administratie toezicht hield op handelingen tussen particulieren. Dit geeft nog geen uitsluitsel over de vraag of rechtsbetrekkingen tussen burger en overheid onder 'civil rights and obligations' van art. 6 lid 1 EVRM vallen. Volgens Van Dijk en Van Hoof laat dit artikel dit toe..$^{100}$ Bij de beoordeling van deze kwestie neemt de Europese Commissie echter een restrictief standpunt in. Procedures betreffende belastingen, premies van sociale verzekeringen en uitkeringen vallen er, gezien het publieke karakter, niet onder. In de Bethem-zaak (het betrof hier een weigering van een hinderwetvergunning voor de exploitatie van een benzinetank-station) meent de meerderheid van het Hof dat art. 6 lid 1 van toepassing is, gezien het directe verband dat er bestaat tussen de

160 Zie hierover: P. van Dijk en G.J.H. van Hoof, De Europese Conventie in theorie en praktijk. AA

Libri, Nijmegen, 1982, pag. 274-281.

161 Arrest Delcourt, 17 januari 1970, Publ, ECHR Series A. vol 11.

162 Arrest Golder, 21 fcbruari 1975, Publ. ECHR Scries A, vol. 18.

163 Arrest König, 28 juni 1978, Publ. ECHR Series A, vol. 27.

164 Arrest Ringeisen, 16 juli 1971, Publ. ECHR Series A, vol. 13.

165 Arrest Le Comptc, Van Leuven en De Meyere, 23 juni 1981, Publ. ECHR Series A, vol. 43. 166 P. van Dijk en G.J.H. van Hoof, a.w., pag. 27. 
verlening van de vergunning en de commerciële activiteiten van de klager ${ }^{16}$ In de zaak Feldbrugge heeft de meerderheid van het Hof voor de eerste keer een sociaal verzekeringsrecht, in casu een uitkering op grond van de Ziektewet, aangemerkt als een burgerlijk recht in de zin van art. $6 .{ }^{168}$ Vastgesteld wordt dat de Ziektewet zowel publiekrechtelijke als privaatrechtelijke aspecten heeft, maar dat laatstgenoemden overheersen en dat het recht op ziekengeld derhalve een burgerlijk recht is. Die privaatrechtelijke aspecten zijn: (1) het persoonlijke, economische en individuele karakter van het recht op ziekengeld; (2) het verband tussen de verzekering ingevolge de Ziekenwet en het arbeidskontrakt; (3) de overeenkomst tussen het systeem van de Ziektewet en de privaatrechtelijke arbeidsovereenkomst. Een minderheid van het Hof ziet de zwakte van deze redenering overigens in de omstandigheid dat tussen meerdere sociale verzekeringssystemen en zelfs binnen één systeem deze bepalende factoren kunnen verschillen. Deze minderheid acht het recht op ziekengeld derhalve geen burgerlijk recht.

In zijn reeds eerder genoemd preadvies stelt De Beaufort dat in een administratiefrechtelijke procedure ter afdoening van verkeersovertredingen, waarbij de executie van een betalingsbevel (of boete, gvdb) moet gebeuren door middel van verhaal op geld of goed, steeds burgerlijke rechten in het geding zijn. ${ }^{\text {(e) }}$ Van Dijk bestrijdt dit standpunt met het argument dat daarmee een te ruime uitleg aan art. 6 EVRM gegeven wordt. Rechterlijke inmenging is niet voorgeschreven in alle gevallen waarin burgerlijke rechten en verplichtingen in het geding zijn, maar slechts voor die procedures die leiden tot een vaststelling van dergelijke rechten en verplichtingen. ${ }^{10}$ In het licht van het Benthem-arrest moet er volgens het NJCM ernstig rekening mee worden gehouden dat art. 6 EVRM op de administratieve afdoening van verkeersovertredingen toegepast zal worden. ${ }^{71}$

Ik ben de mening toegedaan dat de administratiefrechtelijke afdoening een meer publiekrechtelijk karakter draagt. De betaling van een geldsom aan de staat of de verbeurdverklaring van een voertuig heeft weliswaar invloed op de vermogenspositie van de betrokkene, maar in tegenstelling tot de zaak Benthem is hier van beperking van eigendom of toezicht op het gebruik van eigendom in de zin van art. 1 Eerste Protocol geen sprake.

167 Arrest Benthem, 23 oktober 1983, Publ. ECHR Scries A, vol. 97; NJ 1986, 2 m.nt. Alkema; AB 1986, 1 m.nt. Hirsch Ballin.

168 Arrest Feldbrugge, 29 mei 1986, Publ. ECHR Series A, vol. 99; NJCM bulletin 1986, pag. 452 c.v.

169 L.A.R.J. de Beaufort, a.w., pag. 64.

170 P. van Dijk, Massaliteit van verkeersovertredingen en het recht op behandeling door de rechter, Trema jan./febr. 1982, pag. 5.

171 NJCM-commentaar op het rapport "Vercenvoudigde afdoening van lichte overtredingen van verkeersvoorschriften". NJCM-bulletin 1986, pag- 385. 
Gezien de nogal casuïstische benadering van het Hof blijft er onduidelijkheid en onzekerheid bestaan ten aanzien van de vraag of een bepaalde procedure de 'determination of civil rights and obligations' betreft. Ik ben het dan ook eens met Van Dijk wanneer hij pleit voor een verduidelijking door een verdragswijziging of door een gezaghebbende algemene definitie van het Hof. ${ }^{\text {in }}$

De interpretatie van 'determination of any criminal charge ${ }^{\mathrm{j}_{33}}$ levert al evenzeer moeilijkheden op. Ook hier moet naar een autonome uitleg worden gezocht. Het Europese Hof heeft in de Delcourt-zaak te kennen gegeven dat het niet voelt voor een restrictieve interpretatie, zodat bijvoorbeeld alleen de vervolging van strafbare feiten van een bepaalde zwaarte onder de bescherming van art. 6 EVRM zou vallen. ${ }^{174}$

In zijn beslissing in de zaak Engel e.a. vs Nederland ${ }^{175}$ hanteert het Hof drie criteria voor het antwoord op de vraag of er in casu (het ging hier om een tuchtrechtelijke procedure) sprake was geweest van het bepalen van de gegrondheid van een ingestelde strafvervolging:

a. de plaats van de omstreden regeling in het nationale recht;

b. de aard van de gedragsregel zelf;

c. de zwaarte van de sanctie die de overtreder met zijn gedraging riskeert.

ad a) Dit is slechts het vertrekpunt van de oordeelsvorming. omdat aan de classificatie die een gedraging in het nationale recht heeft, geen autonome betekenis toekomt.

ad b) Is het een norm die een zeer specifieke groep betreft, of heeft de norm een algemeen verbindend karakter?

ad c) Hierbij gaat het niet op de opgelegde straf, maar om de eventueel op te leggen straf. Het Hof is van oordeel dat sancties die een vrijheidsbeneming impliceren, tot de sfeer van het strafrecht gerekend worden, uitgezonderd die welke door hun karakter of wijze van tenuitvoerlegging voor de betrokkene niet 'appreciable detrimental' zijn.

In deze zaak lag de nadruk vooral op het laatste criterium.

172 P. van Dijk, Het doolhof van art. 6(1) ECRM; nieuwe openingen of doodlopende paden? NJCMbulletin 12-2, 1987, pag. 128-138.

$173 \mathrm{De}$ redactie van de leden 2 en 3 is in dit opzicht anders dan lid 1. Hierin wordt nl. gesproken van 'criminal charge' terwijl in lid 2 en 3 'charged with criminal offence' gebruikt wordt. Het Europese Hof ziet de twee termen als synoniemen. Arrust Oztürk, ECHR 21 februari 1484, Publ. ECHR Series A, vol 73 (lid 3); Arrest Lutz, ECHR 25 augustus 1987, Publ. ECHR Series A, vol. 123-A (lid 2).

174 Arrest Delcourt, 17 januari 1970, Publ. ECHR Serics A, vol. 11, pag. 15.

175 Arrest Engel e.a. vs. Nederland, 8 juni 1970, Publ. ECRM Series A, vol. 22, pag. 34. 
In de zaak Öztürk gaat het om de verenigbaarheid van het Duitse Ordnungswidrigkejtengesetz met het Europees Verdrag. ${ }^{176}$ Nog even enkele kenmerken van deze Duitse procedure: gedragingen in strijd met deze wet zijn geen strafbare feiten maar administratieve overtredingen en worden door een administratieve instantie afgedaan; de sanctie wordt niet gezien als straf; het opleggen van een vrijheidsstraf is niet mogelijk; OM en rechter behoeven niet te worden ingeschakeld; de betrokkene kan beroep instellen bij de strafrechter; dit beroep schorst de tenuitvoerlegging van de boete niet.

De feiten: Öztürk, een Turkse inwoner van Duitsland, raakt in Duitsland betrokken bij een aanrijding. Hem wordt een boete opgelegd (60 DM). Hiertegen tekent hij hezwaar aan. De rechter handhaaft de boete. Öztürk wordt tevens veroordeeld in de kosten van de procedure, waaronder een bedrag voor de kosten van een tolk. Tegen de veroordeling in de laatste kosten maakt Öztürk bezwaar, omdat dat volgens hem in strijd is met het recht op een eerlijk proces zoals art. 6 lid 1 EVRM dit garandeert.

De Duitse regering stelt zich op het standpunt dat het Ordnungswidrigkeitengesetz niet beschouwd kan worden als een vervolging en bestraffing van strafbare feiten waarop art. 6 EVRM van toepassing is.

Zowel de Europese Commissie als het Europese Hof komen tot de conclusie dat de beslissing van de Duitse strafrechter genomen is in strijd met art. 6 EVRM. In overweging 49 merkt het Hof (opnieuw) op dat het nationaal etiket dat aan de procedure hangt niet doorslaggevend is. Op basis van inhoudelijke criteria moet vastgesteld worden moet vastgesteld worden of er sprake is van een ingestelde strafvervolging.

In deze zaak worden wederom de drie criteria, zoals die in de zaak Engel zijn geformuleerd, gehanteerd (rechtsoverweging 50). De Europese Commissie heeft het accent op de zwaarte van de sancties gelegd, waarbij het dan niet gaat om de sanctie die concreet is opgelegd maar om die welke kan worden opgelegd. Deze kunnen grote invloed hebben op het leven van de betrokkene.

Voor het Hof is het tweede criterium beslissend: de aard van de gedragsregel zelf (rechtsoverweging 52). Naast de vraag tot wie de gedragsregel zich richt, blijkt de aard van de sanctie (het derde criterium zoals genoemd in de zaak Engel) hiervoor een belangrijke maatstaf te zijn. Het Hof hanteert drie argumenten om aan te tonen dat de Ordnungswidrigkeit een strafbaar feit betrof:

1. in het algemeen worden tot het strafrecht gerekend 'offences that make their prepetrator liable to penalties intended, to be deterrent and usually consisting of fines and of measures depriving the person of his liberty';

2. de overtreding wordt in het nationale recht van andere staten als strafrechtelijk aangemerkt; 
3. het punatieve karakter van de sanctie. De sanctie is (onder meer) gericht op afschrikking en bestraffing (rechtsoverweging 53).

Het Hof acht in dit arrest dus het tweede criterium beslissend. Ter motivering hiervan wordt mede het derde criterium gebruikt.

Opzich staat het Hof niet afwijzend tegenover het onderbrengen van overtredingen vanuit het strafrecht naar het administratief recht, maar dit mag er niet toe leiden dat de waarborgen van art. 6 EVRM ontkracht worden. Art. 6 EVRM behoeft niet in de weg te staan van een administratiefrechtelijke afdoening van lichte verkeersovertredingen wanneer er voor de betrokkene beroep openstaat bij een rechterlijke instantie in een beroepsgang waarbij de garanties van art. 6 EVRM nageleefd worden (overweging 56).

In de zaak Lutz heeft het Hof bepaald dat het tweede en het derde criterium, het karakter van de overtreden norm en de aard en zwaarte van de sanctie, afzonderlijk moeten worden bezien. De criteria gelden niet cumulatief maar alternatief. ${ }^{177}$

Nu de conclusie kan worden getrokken dat de administratiefrechtelijke afdoening van bepaalde overtredingen moet voldoen aan art. $6 \mathrm{EVRM}^{1781 x}$, is het van belang te bekijken welke garanties art. 6 EVRM biedt.

Art. 6 lid 1 EVRM garandeert een eerlijke berechting (fair hearing). Voorwaarde hiervoor is dat een zaak door een onafhankelijke rechter beoordeeld wordt. Verder impliceert een eerlijke berechting een zekere gelijkwaardigheid tussen de partijen (equality of arms), berechting binnen een redelijke termijn en het uitspreken van het vonnis in het openbaar.

In beginsel geldt art. 6 lid 1 EVRM niet alleen tijdens het onderzoek ter terechtzitting, maar ook tijdens het voorbereidend onderzoek, maar dan uitsluitend indien

177 Ariest Lutz, 25 augustus 1987, Publ. ECHR Series A, vol. 123-A.

178 Zic onder andere: E.A. Alkema, Het arrest Ötürk en de vereenvoudigde afdoening van (verkeers)overtredingen, VR november 1984, pag. 243; N. Jörg Administratiefrechtelijke afdoening van lichte verkeersovertredingen, Trema dec. 1985, pag. 6-8; D.H. de Jong, De afdoening van strafzaken buiten proces, preadvies, 1985, pag. 36 en later in: Het rapport van de commissie Mulder: een noodzakelijke wijziging? Uit: G.J.M. Corstens (red.), Administratieve afdoening verkeersovertredingen. Zwolle 1986, pag. 26-27; P.J. Baauw, Afdoening van verkeersovertredingen: afrekening met het strafrecht, NJB 1985, pag. 1226;

179 Hierbij moet vermeld worden dat er achter de Europese schermen door het Committee for the development of human rights gewerkt wordt aan een art. 6bis EVRM dat ertoe moet leiden dat, onder het mom van het creëren van speciale waarborgen voor administratieve procedures, zodanige nationale rechtsgangen van de werking van art. 6 uitgesloten worden, ook indien de uitkomst van zulke procedures beslissend kan zijn voor 'civil rights and obligations' of voor de 'determination of a criminal charge'. Redaktioneel NJCM 14-1, 1989, pag. 1-2. Bij de Raad van Europa bestaan nogal wat bezwaren hiertegen, omdat dat in feite inhoudt dat de jurisprudentie teruggedraaid wordt. 
het gaat om handelingen die direct verband houden met de gang van zaken op de terechtzitting.

In het Golder-arrest hebben de Europese Commissie en het Europese Hof het standpunt ingenomen dat art. 6 lid 1 EVRM niet alleen bepaalde garanties inhoudt voor het verloop van de rechterlijke procedure, maar ook een recht op een dergelijke procedure verleent. Art. 6 lid 1 EVRM waarborgt het recht op een beoordeling door een rechter. Deze uitspraak berust op de idee van de rechtsstaat. Het Europese Hof ziet in het rechterlijk toezicht een hoeksteen van de rechtsstaat. Zou art. 6 lid 1. EVRM slechts waarborgen bieden voor bestaande rechterlijke procedures, dan zouden deze illusoir gemaakt kunnen worden door de rechters hun rechtsmacht geheel of gedeeltelijk te ontnemen en deze procedures bijvoorbeeld te vervangen door administratieve. ${ }^{100}$

In de zaak Öztürk heeft het Europese Hof beslist dat een administratiefrechtelijke afdoening van bepaalde lichte overtredingen verenigbaar is met het verdrag, mits aan de betrokkene de gelegenheid wordt geboden de beslissing van de administratieve instantie voor te leggen aan de rechter.

In art. 6 lid 2 EVRM is de praesumptio innocentiae, ofwel het vermoeden van onschuld neergelegd. Volgens mij is het niet reëel te denken dat een beschuldigde werkelijk wordt vermoed onschuldig te zijn. In het algemeen zal er tegen hem een redelijke verdenking bestaan. Het vermoeden van onschuld moet dan ook veeleer worden beschouwd als een regel van procesrecht. ${ }^{181}$ De bewijsvoering is in handen van de rechter. De rechter kan slechts op grond van de aangevoerde wettelijke bewijsmiddelen en volgens de geldende bewijsregels tot een veroordeling komen. Enige vooringenomenheid mag hierbij geen rol spelen. De rechter moet zich onbevooroordeeld opstellen. Het bewijs dient door de vervolgende instantie te worden aangevoerd en de verdachte moet in de gelegenheid worden gesteld dit te weerleggen. Het is nict de taak van de verdachte om zijn onschuld aan te tonen, hij hoeft niet het overtuigende bewijs te leveren dat hij het tenlastegelegde feit niet begaan heeft.

Het recht op een eerlijk proces is tevens neergelegd in art. 14 IVBP. Deze bepaling vertoont veel overeenkomst met art. 6 EVRM $^{162}$ Op sommige punten biedt art. 14 IVBP meer bescherming dan art. 6 EVRM. In dit kader is dan vooral art. 14 lid 5 BUPO van belang, waarin bepaald wordt dat iemand die veroordeeld is wegens een strafbaar feit het recht heeft de schuldigverklaring en de veroordeling opnieuw te doen beoordelen door een hoger rechtscollege.

180 Arrest Golder, 21 februari 1975, Publ. ECHR Serics A, vol. 18.

$181 \mathrm{Vgl}$. N. Keijzer, Enkele opmerkingen over de presumptio innocentiae in strafizaken. Uit: Naar eer en gewetin - Liber Amicorum J. Remmelink, Arnhem 1987, pag. 235-253.

182 Zie verur een analyse hiervan A.H. Robertson, De Internationale bescherming van de rechten van de mins. Nederlandse bewerking: H.C. Dirkse-Bresters. Groningen 1974, pag. 120-123. 


\subsection{Het Rapport Mulder en de internationaalrechtelijke bepalingen}

Het oordeel van de commissie dat de voorgestelde regeling niet valt onder de werking van art. 6 EVRM, wordt in het algemeen niet gedeeld, waarbij trouwens de mate van stelligheid bij de verschillende auteurs enigszins varieert. ${ }^{180}$

Over de vraag of de voorgestelde regeling voldoet aan de eisen die de verdragsrechtelijke bepalingen stellen, lopen de meningen uiteen.

Het NJCM is enerzijds van mening dat de meeste elementen van het voorstel toetsing aan art. 6 EVRM kunnen doorstaan, maar denkt anderzijds dat het voorgestelde vrije bewijsstelsel, zoals dat in het administratieve procesrecht wordt gehanteerd de betrokkene minder garanties biedt dan de voorschriften omtrent het leveren van bewijs in strafzaken. ${ }^{184}$ De voorstellen zijn volgens het NJCM wel in strijd met art. 14 lid 5 IVBP. Tegen de uitspraak van de rechter in eerste aanleg moet beroep openstaan op een instantie die bevoegd is om het geschil in zijn volle omvang, dus zowel wat betreft feitelijke als rechtsvragen, te beoordelen. Het door de commissie voorgestelde cassatieberoep voldoet hieraan niet. ${ }^{1 k i}$

Om strijd met art. 6 EVRM te voorkomen heeft de commissie een beroepsmogelijkheid op de rechter ingebouwd. Deze werkwijze keurt Jörg af.

"Door feiten niet als strafbaar te verklaren en door zoveel mogelijk rechtswaarborgen uit te bannen die lijken op de waarborgen van een strafprocedure, en door de procedure als administratiefrechtelijk te kwalificeren, kan men aan de Europees-rechtelijke garanties ontkomen. En mocht het feit niettemin in essentie als strafbaar feit worden beschouwd door de Europees-rechtelijke organen, dan moet een rechter aan het eind van het traject alle eventueel voorafgaande strijd met art. $6 \mathrm{EV}$ goedmaken door een procedure met alle garanties van art. 6. Deze werkwijze houdt dus in dat de garanties van artikel 6 van het verdrag gebruikt worden als hefboom om zoveel mogelijk verdragsgaranties uit te sluiten. Dat is wel een heel bijzonder gebruik van het Europees Verdrag."

Door uiteindelijke tussenkomst van de rechter wordt het Europees Verdrag gebruikt voor het buiten de deur houden van de in de nationale wet gewaarborgde nationale

183 P.J. Baauw, Afdoening van verkeersovertredingen: afrekening met het strafrecht. NJB 1985, pag. 1225-1227, m.n. pag. 1226; N. Jörg, Administratiefrechtclijke afdocning lichte verkecrsovertredingen, Trema special 1985-1 pag. 8-9; D.H. de Jong. De afdocning van straf/aken buiten proces. Preadvies 1985 voor de Vereniging voor de vergelijkende studie van het recht van Belgic en Nederland, pag. 35; D.H. de Jong, Het rapport van de Commissie Mulder: een noodzakelijke wijziging? Uit: Administratieve afdoening verkeersovertredingen, onder redactie van G.J.M. Corstens, Zwolle 1986, pag. 21-41, m.n. pag. 27; NJCM-commentaar op het rapport "Vercenvoudigde afdoening van lichte overtrodingen van verkeersvoorschriften", NJCM-bulletin 1986, pag. 384-385.

184 Deze mening zien we ook bij Jörg terug: "De overheid hecft gelijk, tenzij blijkt van het tegendeel". N. Jörg, a.w., pag. 16.

185 NJCM-commentaar op het rapport "Vereenvoudigde afdoening van lichte overtredingen van verkeersvoorschriften". NJCM-bulletin 11-4, 1986, pag. 386. 
processuele waarborgen. Jörg noemt dit een bijzondere 'Umwertung' van het Europees Mensenrechtenverdrag. ${ }^{\text {is }}$

Naar het oordeel van Baauw staat het vereiste dat de verdachte zelf initiatief moet nemen om te voorkomen dat de door de politie opgelegde boete onherroepelijk wordt op gespannen voet met het recht op een eerlijk proces (art. 6 EVRM en art. 14 IVBP) en met name met de presumptie van onschuld. ${ }^{177} \mathrm{Jörg}$ bestrijdt dit laatste. Formeel gesproken is er geen sprake van dat beslissingen over de aard van de tenlastelegging ten uitvoer worden gelegd voordat zij kracht van gewijsde hebben gekregen. Er wordt geen straf bij voorbaat geëxecuteerd. De zekerheidstelling kan dienen tot verzekering van gerechtelijke verschijning van de verdachte. ${ }^{188}$

De Jong neemt als uitgangspunt de uitspraak van het Europese Hof in de Öztürkzaak. Daarin heeft het Hof bepaald dat de kansen om strafbare feiten uit de criminele sfeer te halen erg klein zijn. Daarnaast heeft het Hof beslist dat een administratieve afdoening van bepaalde lichte feiten verenigbaar is met het verdrag, mits de betrokkene de gelegenheid geboden wordt de beslissing van het administratieve orgaan voor te leggen aan een rechterlijke instantie. De Jong toetst vervolgens of met het door de commissie geconstrueerde beroep op de rechter aan de eisen van art. 6 voldaan wordt. Hij constateert dat het beroep op de rechter een 'vol beroep' inhoudt. Naar zijn oordeel wordt de vrije toegang tot de rechter niet aangetast door het feit dat de betrokkene zelf actie moet ondernemen en evenmin door de voorwaarde van zekerheidstelling, omdat het hier gaat om een betrekkelijk gering bedrag dat ook betaald moet worden indien geen beroep wordt ingesteld. De presumptie van onschuld wordt niet doorbroken indien de betrokkene zelf actie moet ondernemen. Wat betreft de zekerheidstelling is zijn twijfel op dit punt groter, maar ook hierdoor wordt volgens hem dit beginsel niet aangetast. De presumptie van onschuld richt zich volgens hem (in navolging van Corstens) tot de rechter: de rechter is verplicht tot een onbevooroordeelde opstelling. Of voldaan wordt aan de eis dat de betrokkene tijdig op de hoogte wordt gesteld van de aard en de reden van de tegen hem bestaande verdenking, zodat hij zich behoorlijk kan voorbereiden op zijn verdediging, is voor De Jong nog maar de vraag. Het lijkt hem verstandig te voorzien in een behoorlijke oproeping. In het voorstel wordt niet gesproken over openbare behandeling, recht op rechtsbijstand, kosteloze bijstand door een tolk en het recht op oproeping en ondervraging van getuigen. Dit hoeft ook niet, omdat art. 6 EVRM rechtstreeks van toepassing is. Het zou de duidelijkheid ten goede komen indien deze zaken wel in de wettelijke regeling opgenomen zouden worden. De Jong concludeert dat het voorstel van de commissie, eventueel met wat aanvullingen, verenigbaar is met het Europees Verdrag. ${ }^{180}$

186 N. Jörg, a.w., pag. 8-9.

187 P.J. Baauw, a.w., pag. 1227.

188 N. Jörg, a.w., pag. 32-33.

189 D.H. de Jong, De afdoening van strafzaken buiten proces. Preadvies voor de Vereniging voor de vergclijkende studic van het recht van België en Nederland, 1985, pag. 36-41. 


\subsection{Overig commentaar}

Door louter overheveling van voorschriften van het strafrecht naar het administratieve recht is er nog geen sprake van decriminalisering. Van 'decriminalisering' is volgens Jörg pas sprake "wanneer normen, die niet meer 'leven', niet meer gesanctioneerd worden, uitwassen daargelaten". Als voorbeelden noemt hij onder andere de openlijke verkoop van voorbehoedsmiddelen (art. 451ter oud Sr) en overspel (art. 241 sub $1 \mathrm{Sr}$ ). Men kan het voorstel volgens hem beter een vorm van depenalisering noemen in de betekenis van het vervangen van zware strafrechtelijke door lichtere strafrechtelijke sancties, of het vervangen van strafrechtelijke sancties door civielrechtelijke of administratiefrechtelijke sancties. In het voorstel worden de geldelijke sancties uit het strafrecht slechts van een ander etiket voorzien. ${ }^{190}$ Baauw spreekt over de 'vestzak-broekzak-theorie'. De voorgestelde regeling geeft bestaande organen nieuwe taken, vereist het instellen van nieuwe organen en kent als sluitstuk toch weer een nieuwe strafbepaling (art. 24).$^{191}$ Ook de kritiek van Van Veen gaat in deze richting. Door een verkeersovertreding door de politie te laten beboeten in plaats van door de rechter wordt niets gedecriminaliseerd. Het proces is volgens hem in wezen een strafproces. ${ }^{192}$

Volgens Van Veen is de procedure niet vereenvoudigd, maar eerder ingewikkelder geworden. Waarom moet de officier van justitie ingeschakeld worden als de betrokkene het met de opgelegde boete niet eens is? Het is een tussenstap die de betrokkene een rechtstreekse toegang tot de rechter ontzegt. Het wordt woor de officier moeilijker op de terechtzitting afstand te nemen van hetgeen door de opsporingsambtenaar is beslist, omdat hij zich reeds heeft vastgelegd in een beschikking." vindt de procedure nauwelijks eenvoudig: "Al met al een hink-stap-sprong-procedure, die zeker geen schoonheidsprijs verdient".

De vergrijpen die voortaan op een administratieve wijze afgedaan zullen worden, zijn opgenomen in een bijlage bij de wet. Bedoeld zijn de gedragingen die thans zijn opgenomen in de bijlage als bedoeld in art. 3 van het Besluit Politietransactie. Het criterium dat de commissie gehanteerd heeft voor de scheiding tussen strafbare feiten waarop een strafrechtelijke reactie volgt en een verboden gedraging die administratief afgedaan wordt, ligt in het feit of er wel of niet letsel of schade door de gedraging veroorzaakt is. Volgens Jörg is dit criterium niet altijd even duidelijk.

190 N. Jörg, Administratiefrechtelijke afdoening lichte verkeersovertredingen. Trema special '85-1, pag. 5-6;

191 P.J. Baauw, Afdoening van verkeersovertredingen: afrekening met het strafrecht. NJB 1985, pag. 1225.

192 Th.W. van Veen, Anders dan strafrechtelijk afdoen. VR 1985, pag. 360 e.v.

193 Th. W. van Veen, a.w., pag. 361.

194 PJ. Baauw, a.w., pag. 1226. 
De morele blaam kan bij verschillende overtredingen nogal eens verschillen van de omstandigheden waaronder zij begaan zijn. ${ }^{195}$ Ook naar de mening van De Jong is deze scheiding te geforceerd. ${ }^{196}$

Uitdrukkelijk wordt door de commissie gezegd dat de administratieve gedragingen geen strafbare feiten meer zullen zijn en dat voorzieningen van strafrechtelijke en strafvorderlijke aard zullen worden uitgesloten. Volgens De Jong gaat dit laatste, gezien de uitspraak van het Europese Hof in de Öztürk-zaak niet op. ${ }^{[\dot{\mid \omega}}$

Jörg stelt zich hierbij de vraag wat de gevolgen van de uitsluiting van voorzieningen van strafrechtelijke aard zijn voor bijvoorbeeld de deelnemingsvormen, samenloopbepalingen, het ne bis in idem-beginsel en de verjaring. Komen de strafuitsluitingsgronden noodtoestand, wettelijk voorschrift en ambtelijk bevel nog in aanmerking voor een verweer? Ook het uitsluiten van voorzieningen van strafvorderlijke aard stuit bij hem op bezwaren. De opsporingsambtenaar is bevoegd de betrokkene staande te houden, maar is deze verplicht hieraan gevolg te geven? De betrokkene is volgens het voorstel verplicht zijn personalia en zijn giro- of bankrekeningnummer op te geven. Is iedereen hierdoor verplicht zijn nummer te weten? Het zal moeilijk zijn hierbij vergissing en chicane te onderscheiden. De opsporingsambtenaar heeft geen bevoegdheid tot aanhouding, tot meenemen voor verhoor, tot foullering (uitgezonderd op grond van art. 24 ontwerp en art. $56 \mathrm{~Sv}$ ), geen bevoegdheid tot inbeslagname en geen bevoegdheid een onderzoek in de auto te verrichten. Volgens Jörg klinkt dit allemaal prachtig, maarvolgens hem zal de politie precies hetzelfde mogen doer als thans het geval is, namelijk via het leerstuk van de voortgezette toepassing. De buitengrens moet zijn dat het staande houden ter zake van een lichte verkeersovertreding geen vrijbrief is voor voortgezette opsporingshandelingen. ${ }^{198}$ Baauw vraagt zich af wat er moet gaan gebeuren met problemen rond de strafbaarheid, de vervolgbaarheid en uitvoerbaarheid nu deze overtredingen niet langer als strafbare feiten beschouwd zullen worden en daardoor algemene leerstukken niet meer van toepassing zullen zijn (art. $91 \mathrm{Sr}$ ). Het uitsluiten van voorzieningen van strafvorderlijke aard levert eveneens problemen op. Onduidelijk is de wijze waarop moet komen vast te staan dat de betrokkene de gedraging heeft verricht, nu de eis van een redelijk vermoeden (art. $27 \mathrm{~Sv}$ ) ontbreekt. De betrokkene is gehouden zijn personalia e.d. op te geven (art. 24). Het kan echter voorkomen dat pas later blijkt dat er sprake is van een strafbaar feit, zodat de cautie had moeten worden gegeven. De verdachte is dan gedwongen geworden aan zijn eigen veroordeling mee te werken. De rechtsbescherming van de verdachte wordt aangetast. ${ }^{193}$

195 N. Jörg, a.w., pag. 10.

196 D.H. de Jong, De afdoening van strafzaken buiten proces. Preadvies 1985 voor de Vereniging voor de vergelijkende studie van het recht van Belgiē en Nederland, pag. 35-36.

$197 \mathrm{Zie}$ vorige noot.

198 N. Jörg, a.w., pag. 11-15.

199 P.J. Baauw, a.w., pag. 1226-1227. 
Van Veen vraagt zich af waarom de berechting van deze bagatelzaken aan de enkelof meervoudige kamer van de rechtbank is opgedragen. Dit betekent dat de ernstige overtredingen door de kantonrechter worden berecht en de geringe verkeersovertredingen door de rechtbank. ${ }^{200}$ Voor De Jong doet de instelling van een enkelvoudige of meervoudige administratieve kamer bij de rechtbank vreemd aan. Volgens hem zal deze zich weinig onderscheiden van een strafkamer. ${ }^{201}$

\subsection{Altematieven}

Verschillende critici pleiten voor een vereenvoudigde strafrechtelijke afdoening van verkeersovertredingen, waardoor door betrekkelijk kleine veranderingen bevredigende resultaten kunnen worden bereikt zonder dat het huidige systeem van wetshandhaving van verkeersovertredingen op zijn kop wordt gezet. ${ }^{202}$ Zo stelt De Jong voor de door de commissie voorgestelde zekerheidstelling in het strafprocesrecht in te voeren. De verdachte die niet op het transactievoorstel ingaat en de zaak voor de rechter wil laten komen, moet zekerheid stellen dat hij, indien de rechter een geldboete zal opleggen, deze zal betalen. Reageert de verdachte niet op het transactievoorstel noch wordt zekerheid gesteld, dan kan het verschuldigde bedrag van de verdachte worden ingevorderd via verhaal op zijn tegoed op giro- of bankrekening. Het alternatief van Jörg komt er op neer dat door de verdachte vooraf, indien hij het oordeel van de rechter wil inroepen, zekerheid moet worden gesteld voor betaling van de eventuele boete. Voor het geval de verdachte niets doet -geen transactie en geen zekerheidstelling- bepleit Jörg een nieuwe procedure, waarbij de rechter beslist zonder voorafgaande terechtzitting. ${ }^{2 n}$

200 Th.W. van Veen, a.w., pag. 361.

201 Preadvies D.H. de Jong, pag. 41.

202 Zie o.a. Th.W. van Veen, a.w.; N. Jörg, a.w., pag. 31-34; D.H. de Jong, a.w., pag. 46 e.v. 203 N. Jörg, a.w., pag. 32-33. 
8 Wet Administratiefrechtelijke afdoening van inbreuken op bepaalde verkeersovertredingen (Wet Administratiefrechtelijke handhaving verkeersvoorschriften) ${ }^{2.4}$

\subsection{Inhoud van de wet}

De Wet administratiefrechtelijke handhaving verkeersvoorschriften (voortaan te noemen WAHV) is voor een zeer groot deel gebaseerd op het Ontwerp Mulder, vandaar dat ook gesproken wordt van de Lex Mulder. Alvorens we de verschillen tussen beide zullen bekijken, wordt eerst een overzicht gegeven van de inhoud, doelstellingen en achtergronden van de wet.

De regeling, zoals die oorspronkelijk (dat wil zeggen zonder aanpassingen in verband met de Awb en andere tussentijdse aanpassingen) is ingevoerd, ziet er als volgt uit ${ }^{25}$ :

- De daarvoor aangewezen opsporingsambtenaren zijn bevoegd bij een in een bijlage bedoelde overtreding een administratieve sanctie, bestaande uit het betalen van een geldsom van maximaal $f 500,-$ op te leggen. Dit wordt gedaan bij een schriftelijke beschikking. Art. 4 vermeldt de inhoud (lid 1) alsmede de procedure van oplegging (lid 2) van de beschikking. In hoofdlijnen komt dit erop neer dat, wanneer de beschikking niet kan worden overhandigd, deze binnen drie maanden nadat de gedraging heeft plaatsgevonden middels een gewone brief over de post wordt toegezonden aan het adres zoals dat blijkt uit het kentekenregister. Komt de brief onbestelbaar terug dan wordt deze per post gestuurd naar het adres zoals dat blijkt uit het bevolkingsregister. Lid 3 regelt de wijze waarop de sanctie moet worden voldaan en schrijft voor dat de beschikking melding moet maken van de mogelijkheid tot het indienen van beroep voor de betrokkene en verwijst naar art. 6 voor de vereisten waaraan het beroepschrift moet voldoen (termijn en inhoud).

- Degene tot wie de beschikking is gericht kan binnen zes weken na overhandiging van de beschikking schriftelijk beroep instellen bij de officier van justitie, art. 6 lid 1. Lid 2 regelt welke gegevens het beroepschrift moet bevatten (o.a. de gronden waarop het beroepschrift berust). Lid 3 geeft een regeling in het geval het beroepschrift te laat is ingediend.

204 TK 1987-1988, 20329. Ingediend op 23 november 1986. Bij de Tweede Kamer aanhangig genaakt op 23 november 1987; door de Tweede Kamer aangenomen op 21 februari 1989; door de Eerste Kamer aangenomen op 27 juni 1989; afgekondigd in het Staatsblad 1989, 300. De wet is in werking getreden per 1 september 1990 in het arrondissement Utrecht en vervolgens ressortsgewijs in het hele land. Per 1 juli 1992 was de wet overal in werking.

205 Zie voor een uitgebreide beschrijving van de WAHV voorzien van een artikelgewijs commentaar. L.JJ. Rogier, De wet Mulder, artikelgewijs commentaar op de Wet administratiefrechtelijke handhaving verkeersvoorschriften. Arnhem, eerste druk 1990, tweede druk 1992. 
- De officier van justitie beslist zo snel mogelijk op het beroep, volgens art. 7 WAHV. De betrokkene die daarom heeft verzocht wordt gehoord. De officier van justitie kan de beschikking vernietigen indien de gedraging niet is verricht of de betrokkene de gedraging niet heeft verricht (lid 1). Ook kan de officier een lager bedrag vaststellen indien de omstandigheden waarin de betrokkene verkeert daartoe aanleiding geven. Indien de gedraging niet juist is vermeld voorziet hij daarin en bepaalt hij de hoogte van de boete (deze kan dus hoger worden), lid 2. De beslissing van de officier van justitie wordt met redenen omkleed schriftelijk aan de betrokkene meegedeeld, waarbij deze gewezen moet worden op de mogelijkheid binnen zes weken beroep in te stellen bij de kantonrechter en op de verplichting tot zekerheidstelling, lid 3 .

Art. 9 regelt het beroep op het kantongerecht. Tegen de beslissing van de officier van justitie kan de betrokkene, binnen dertig dagen na de dag van verzending, schriftelijk gemotiveerd beroep instellen bij het kantongerecht, ter zake dat:

1. de gedraging niet is verricht, of niet is verricht door degene tot wie de beschikking gericht is;

2. de officier van justitie had moeten beslissen dat de omstandigheden de sanctie niet billijken, dan wel aanleiding zijn een lager bedrag vast te stellen;

3. de officier van justitie de beschikking ten onrechte niet heeft vernietigd op grond van het feit dat de betrokkene, op wiens naam het kenteken staat, niet aannemelijk heeft kunnen maken dat het voertuig tegen zijn wil door een ander is gebruikt en dat hij dit gebruik redelijkerwijs niet heeft kunnen voorkomen. De kantonrechter geeft de officier van justitie de gelegenheid opmerkingen te maken over het beroepschrift door hem dit ter kennis te stellen, art. 10 WAHV. Bij zijn antwoord voegt de officier de op de zaak betrekking hebbende stukken. Het beroepschrift wordt slechts in behandeling genomen nadat de betrokkene binnen twee weken na indiening van het beroepschrift zekerheid heeft gesteld voor de betaling van het geldbedrag, art. 11 lid 1. Dit lid vermeldt tevens hoe deze zekerheidstelling kan worden verricht. Blijft deze zekerheidstelling achterwege, dan wordt het beroep niet ontvankelijk verklaard.

Het tweede lid van art. 11 heeft betrekking op het inzagerecht. Degene die beroep heeft ingesteld kan kennis nemen van alle op het beroepschrift betrekking hebbende stukken.

Volgens art. 12 lid I worden degene die het beroep heeft ingesteld en de officier van justitie door de kantonrechter in de gelegenheid gesteld op een openbare zitting hun zienswijze nader toe te lichten. De betrokkene kan zich doen bijstaan door een raadsman of een door hem gemachtigde (lid 2). Getuigen en deskundigen kunnen worden meegebracht ten einde te kunnen worden gehoord (lid 3, 4 en 5).

- In art. 13 staan de beslissingsmogelijkheden van de kantonrechter vermeld. Hij kan het beroep geheel of ten dele gegrond verklaren en de beschikking vernietigen c.q. wijzigen. De beslissing van de kantonrechter is met redenen omkleed en wordt terstond of uiterlijk na veertien dagen op een openbare terechtzitting uitgesproken 
(lid 2). Volgens het derde lid wordt de beslissing in het proces-verbaal van de zitting aangetekend, alsmede de gronden waarop de beslissing is genomen. Hiervan wordt een afschrift gezonden aan de indiener van het beroep en aan de officier van justitie.

- Degene die bij de kantonrechter beroep had ingesteld en de officier van justitie kunnen binnen dertig dagen na de dag van toezending van het hiervoor vermelde afschrift tegen de beslissing van de kantonrechter beroep in cassatie instellen bij de Hoge Raad, art. 14. De partij die niet in cassatie ging wordt in de gelegenheid gesteld een vertoogschrift in te dienen.

- De artt. 15, 16 en 17 bevatten een aantal formele regels ten aanzien van de cassatieprocedure, zoals de doorzending van het beroepschrift, het inzenden van stukken naar de Hoge Raad, toezending van een afschrift van het beroepschrift aan degene die tot het instellen van beroep was gerechtigd, de indiening van een vertoogschrift en de doorzending daarvan en regels omtrent mondelinge toelichting van het beroepschrift,

- De Hoge Raad beslist in raadkamer, art. 18 lid 3. Wanneer de Hoge Raad de uitspraak van de kantonrechter vernietigt (hetzij op gronden aangevoerd in het beroepschrift, hetzij op andere gronden) beslist hij bij hetzelfde arrest de zaak, zoals het kantongerecht had behoren te doen. Indien de Hoge Raad de zaak niet zelf kan afdoen, kan hij, naar omstandigheden te beoordelen, de zaak terugverwijzen naar hetzelfde of een ander kantongerecht, art. 19.

- Nadat de beroepsprocedure voorbij is moet nog afwikkeling volgen van de zekerheidstelling. Dit is geregeld in art. 21.

De verplichting tot zekerheidstelling vervalt nadat een onherroepelijke beslissing is genomen. Indien deze beslissing inhoudt dat de opgelegde sanctie geheel of gedeeltelijk blijft gehandhaafd wordt de verschuldigde betaling van een geldsom op de zekerheidstelling verhaald. Wat er met het betaalde geldbedrag moet gebeuren indien de administratieve sanctie komt te vervallen, vermeldt de wet vreemd genoeg niet. Wellicht was het voor de wetgever vanzelfsprekend dat het betaalde bedrag in dat geval dient te worden teruggegeven.

De procedure zoals ik die tot nu toe heb omschreven, is van toepassing wanneer er beroep tegen de administratieve sanctie is ingesteld. Deze procedure komt, wanneer een dergelijk beroep achterwege blijft, niet aan de orde. Dit is een groot verschil met de tot dan toe geldende strafrechtelijke procedure, waarbij de verdachte die niets tegen de hem opgelegde transactie ondernam automatisch in de strafrechtelijke procedure rolde.

Voor degene die geen beroep heeft ingesteld wordt de sanctie in principe onherroepelijk en volgt inning van de boete. Hiervoor geldt onderstaande procedure.

- De administratieve sanctie moet zijn voldaan binnen twee weken nadat de beschikking onherroepelijk is geworden. Bij niet tijdige voldoening wordt de sanctie 
met $25 \%$ verhoogd, met een minimum van $f 10$,-. De betrokkene is verplicht binnen 4 weken na de aanmaning te betalen (artt. 22 en 23).

Blijft de betrokkene na de aanmaning in gebreke dan wordt het bedrag van rechtswege met $50 \%$ verhoogd, met een minimum van $f 25$,- en kan de officier verhaal halen op goederen, inkomsten uit arbeid, pensioenen en andere periodieke uitkeringen en het vermogen van de betrokkene. De executieverjaringstermijn bedraagt twee jaar nadat een onherroepelijke beslissing was genomen (art. 25). In de artt. 26 en 27 is geregeld op welke manieren het verhaal kan plaatsvinden, te weten met respectievelijk zonder dwangbevel door middel van derdenbeslag. Betrokkene kan bij de kantonrechter in verzet komen tegen de tenuitvoerlegging van het dwangbevel door indiening van een bezwaarschrift.

- Krachtens art. 28 kan, indien niet of niet volledig verhaal heeft plaatsgevonden, de officier van justitie tot uiterlijk drie jaar na een onherroepelijke beschikking bij de kantonrechter een vordering instellen te worden gemachtigd de volgende dwangmiddelen toe te passen:

1. buitengebruikstelling van het voertuig, voor maximaal een maand;

2. inneming van het rijbewijs, voor maximaal een maand;

3. gijzeling van de betrokkene, voor een week.

Toepassing van deze dwangmiddelen heft de verschuldigdheid van het geldbedrag niet op.

In de artt. 29, 30, 31, 32 en 33 wordt een nadere uitwerking gegeven van de toepassing van de in art. 28 genoemde dwangmiddelen.

- Aparte vermelding verdient art. 34. Dit artikel stelt strafbaar het niet voldoen aan eiders in de wet omschreven verplichtingen, zoals het niet of niet juist opgeven van de personalia.

Een wet die in eerste instantie beoogt ten zake van een aantal voorschriften het strafrecht buiten de deur te houden kan toch niet geheel zonder het strafrecht. Overigens is dit in het bestuursrecht niet nieuw. Ook in andere administratieve wetten zijn als handhavingsmogelijkheden strafsancties voor handen.

De doelstellingen van de wet zijn, blijkens de MvT, drieërlei:

1. Verbetering van de doelmatigheid van politioneel en justitieel optreden bij de afdoening van lichte verkeersovertredingen.

Toelichting: In $\pm 10 \%$ van de betreffende overtredingen is de tijdsduur tussen het plegen van het feit en de beslissing daarover ongewenst lang doordat het huidige strafrechtelijke systeem het mogelijk maakt dat de verdachte passief kan afwachten hoe de verdere behandeling van de zaak verloopt. Daarom wordt voorgesteld dat de betrokkene zelf het initiatief moet nemen wanneer hij de rechter ingeschakeld wil zien.

De huidige wijze van registratie van de overtredingen door de politie komt te vervallen. Het proces-verbaal wordt vervangen door een beschikking. Volgens het voorstel behoeft de opsporingsambtenaar slechts de geconstateerde gedraging 
en enkele persoonlijke gegevens van de overtreder vast te leggen. Dit systeem bespaart de politie veel werk.

De werkbesparing bij de parketten zal voor een deel wegvallen tegen de werklast die de administratieve rechtsgang met zich mee zal brengen. De verwachting is dat door de zekerheidstelling, bedoeld voor een zo verantwoordelijk mogelijk gebruik van de beroepsmogelijkheid op de kantonrechter, tot een beperking van het aantal beroepen zal leiden.

2. Rechtsbescherming van de verkeersovertreder.

Toelichting: De regeling moet voldoen aan de eisen die een moderne rechtsstaat stelt aan de rechtspleging en die onder andere zijn neergelegd in de Grondwet en in internationale mensenrechtenbepalingen. Voor wat betreft de toetsing aan de Grondwet verwijst het voorstel naar de door de Commissie Mulder getrokken conclusie.

De mening van de commissie dat art. 6 EVRM niet van toepassing zou zijn op het stelsel van administratiefrechtelijke afdoening (de uitspraak van het Europese Hof in de zaak Oztürk was toen nog niet bekend), wordt door de indieners van het wetsvoorstel, de bewindslieden van Justitie en van Verkeer en Waterstaat, niet gedeeld. Dit wordt gebaseerd op de inmiddels bekende uitspraak van het Europese Hof in het Arrest Öztürk en een arrest van HR 16 juni 1985, NJ 1986, 104. Het ging hier om de oplegging van een administratieve verhoging op grond van de Wet op de motorrijtuigenbelasting 1965. De Hoge Raad overwoog, met verwijzing naar het Öztürk-arrest, dat voor de beantwoording van de vraag of art. 6 EVRM op de betreffende verhoging van toepassing is, niet beslissend is dat het vergrijp waarvoor de verhoging is opgelegd naar het Nederlandse recht niet tot het strafrecht behoort. Het opleggen van deze verhoging is volgens de Hoge Raad onttrokken aan het strafrecht vanwege redenen van doelmatigheid. Zodoende moet het aangemerkt worden als een strafvervolging in de zin van art. 6 EVRM. ${ }^{206}$

Volgens de indieners van het voorstel biedt het een deugdelijke rechtsbescherming. Daarbij wordt gewezen op het feit dat de bezwaarschriftenprocedure reeds bestaat in andere wetten (Wet AROB en AWR). Is de betrokkene het met een beslissing niet eens dan zal hij zelf het initiatief moeten nemen en van de hem ter beschikking staande rechtsgang gebruik moeten maken.

Het beginsel van vermoeden van onschuld wordt door het voorstel niet opzij gezet. De ministers wijzen hierbij op de uitspraak van het Europese Hof in de Öztürzaak, waarbij het Hof overwoog dat een stelsel van administratieve afdoening in overeenstemming is met het recht op een eerlijk proces (art. 6 EVRM) mits de betrokkene in beroep kan gaan bij een rechterlijke instantie die voldoet aar art. 6. 
De voorgestelde zekerheidstelling is volgens de bewindslieden niet in strijd met het recht om een zaak bij een rechter aanhangig te maken. Dit recht is niet absoluut en laat beperkingen toe. De zekerheidstelling geschiedt slechts tot het beloop van de administratieve sanctie.

Zowel de officier van justitie als de kantonrechter kunnen de voorgaande beslissing van de opsporingsambtenaar respectievelijk de officier van justitie in haar volle omvang beoordelen. Gelet op de bestuurlijke functie van het $O M$ heeft men de mogelijkheid van de reformatio in peius voor de officier van justitie open gelaten (terwijl deze juist in de Awb is vervallen). Zowel de officier van justitie als de kantonrechter hebben een matigingsrecht.

Van de beschikking van de opsporingsambtenaar staat niet direct beroep open bij de rechter. Dit zou in strijd zijn met beginselen van administratieve rechtsbescherming volgens welke de beslissing eerst heroverwogen wordt door hetzelfde of een hoger administratief orgaan. Bovendien zou een dergelijke gang van zaken ondoelmatig zijn. De rechter zou dan allerlei voorwerk moeten verrichten dat beter door de officier van justitie kan worden gedaan. Op deze manier kan de officier ook nog beter toezicht houden op het optreden van de politie.

De ministers sluiten zich voor wat betreft art. 14 lid 5 IVBP aan bij hetgeen de Commissie Mulder heeft overwogen. Genoemd artikellid laat volgens hen berechting in één feitelijke instantie toe bij lichte vergrijpen.

Het gaat mij overigens te ver de rechtsbescherming van de burger een aparte doelstelling van een bepaalde regeling te noemen. Elke regeling moet voldoende rechtsbescherming bieden. In een democratische rechtsstaat moet de burger zich kunnen verweren tegen beslissingen die jegens hem door of namens de overheid genomen worden. Rechtsbescherming is derhalve geen doel op zich, maar een impliciet vereiste. Het geven van voidoende rechtsbescherming is naar mijn stellige overtuiging een randvoorwaarde waarbinnen de andere voorwaarden gerealiseerd moeten worden en geen voorwaarde naast de andere.

3. Verbetering van de tenuitvoerlegging van opgelegde boetes/administratieve sancties.

Toelichting: Het huidige executie-systeem van geldboeten, waarvan de verdachte door passief af te wachten de onherroepelijke veroordeling al behoorlijk kan traineren, schiet tekort. Nadat niet voldaan wordt aan twee aanmaningen die gestuurd worden na het onherroepelijk worden van de geldboete kan de officier overgaan tot verhaal. In de praktijk geheurt dit weinig. Daarna resteert de vervangende hechtenis. In praktijk wacht de verdachte de walarschuwing dat overgaan zal worden tot vervangende hechtenis af en betaalt pas dan de boete plus verhogingen. De vervangende hechtenis wordt pressiemiddel. Een probleem daarbij is het cellentekort.

De WAHV kent één sanctie, de administratieve geldboete. Wanneer de betrokkene geen beroep instelt wordt deze boete na zes weken onherroepelijk. De voorgestelde 
verhogingen moeten eerder prikkelen tot tijdige betaling. Ook wordt de mogelijkheid tot daadwerkelijk verhaal ruimer doordat de officier van justitie aan de kantonrechter een vordering tot het instellen van bepaalde dwangmiddelen kan doen.

Er wordt een strikte scheiding gemaakt tussen feiten die op een strafrechtelijke wijze afgedaan worden en gedragingen die de administratiefrechtelijke weg zullen volgen. Evenals de Commissie Mulder legt het wetsvoorstel het criterium voor feiten die op een administratiefrechtelijke wijze afgedaan kunnen worden bij het al of niet moreel verwerpelijk zijn van de gedraging (alsof verkeersovertredingen niet moreel verwerpelijk zouden kunnen zijn). De aansluiting bij de bestaande regeling van de politietransactie achten de ministers gewenst. Wanneer door bepaalde verkeersgedragingen letsel of schade is ontstaan, dient de opsporingsambtenaar de zaken via het strafrecht af te doen.

De wet voorziet in een constructie, waarbij de bijlage, welke de feiten bevat die op een administratieve manier kunnen worden afgedaan, bij algemene maatrege] van bestuur kan worden gewijzigd en aangevuld. Vooral dit laatste zal waarschijnlijk het geval zijn. De minister acht het nog te vroeg voor een definitieve aanwijzing van andere feiten, maar zijn gedachten gaan in de richting van het zwart en grijs rijden in het openbaar vervoer ${ }^{200}$, milieuwetgeving en algemene plaatselijke en provinciale verordeningen. ${ }^{208}$

\subsection{Verschillen met het Ontwerp Mulder}

Zoals gezegd is de WAHV grotendeels gebaseerd op het rapport en het wetsontwerp van de Commissie Mulder. Op een aantal punten bestaan er verschillen.

Anders dan in het ontwerp Mulder is de overtreder bij zijn aanhouding slechts verplicht zijn naam en adres op te geven en niet zijn giro- of bankrekeningnummer. Het niet of niet juist verstrekken van deze gegevens is strafbaar gesteld (art. 34). De overtreder behoeft slechts zijn bank- of gironummer op te geven wanneer hij administratief beroep instelt. Van degene die dus stilzit is het bank- of gironummer niet bekend bij het OM. Hierbij komt dan de vraag naar voren hoe de officier van justitie beslag kan leggen op tegoeden op bank- en girotegoeden wanneer hij niet op de hoogte is van het betreffende nummer. Volgens de MvT moet op deze vraag nog worden gestudeerd. ${ }^{20}$

In het Ontwerp Mulder bedroeg de maximale administratieve sanctie $f 300,-$ In de wet is dit bedrag verhoogd tot $f 500,-$. In de toelichting bij art. 2 wordt gezegd dat de commissie op niet nader aangegeven gronden uitging van haar maximum bedrag van $f 300,-$. Het bedrag wordt op $f 500$,- gesteld omdat dit bedrag gelijk is aan dat 
van de eerste geldboetecategorie. ${ }^{210}$ Waarom deze gelijkstelling dan noodzakelijk zou zijn wordt overigens ook niet nader aangegeven.

Bij niet-betaling had het $\mathrm{OM}$ in het Ontwerp Mulder verhaalsbevoegdheid op banken girotegoeden. In de wet is deze bevoegdheid uitgebreid met het verhaal op inkomsten in geld uit arbeid, op het pensioen, het wachtgeld of andere periodieke uitkeringen. Op deze wijze is de verhaalsbevoegdheid in overeenstemming gebracht met de verhaalsbevoegdheid die het OM thans op grond van art. 576 lid 1 Sv heeft. De minister zag geen reden een onderscheid te handhaven tussen de "normale" verhaalsbevoegdheid van het $\mathrm{OM}$ en die met betrekking tot administratieve sancties. ${ }^{211}$ De belangrijkste wijziging betreft de rechterlijke instantie die kennis neemt van de bedoelde inbreuken op verkeersvoorschriften. In het ontwerp Mulder was deze rol toebedacht aan een administratieve kamer (enkelvoudig dan wel meervoudig) van de rechtbank. In de wet ligt deze taak bij de kantongerechten, omdat deze instantie thans vertrouwd is met de afhandeling van lichte verkeersovertredingen. Tevens heeft hierbij een rol gespeeld dat deze instantie in de regel voor de burger beter bereikbaar zal zijn dan de rechtbank. ${ }^{212}$ Dit soort zaken zal naar verwachting weinig juridische problemen opleveren. Tevens wordt gewezen op de overeenkomst met het belastingrecht.

Voor het overige kunnen we constateren dat in de MvT duidelijk aandacht is besteed aan de kritiek op het Ontwerp Mulder. De bezwaren worden uitvoerig besproken doch hebben niet geleid tot aanpassingen.

\subsection{Parlementaire behandeling}

De Raad van State stemt, behoudens enkele opmerkingen die niet de opzet van het ontworpen stelsel raken, in met het wetsvoorstel. De Raad stemt bijvoorbeeld niet in met de uitleg die, in navolging van de Commissie Mulder, aan art. 113 Grondwet gegeven wordt. De Raad meent, in tegenstelling tot de makers van het wetsvoorstel, dat aan het begrip 'strafbaar feit' wel enige materiële betekenis toekomt. Ook wanneer bepaalde overtredingen betiteld worden als 'administratieve feiten' moeten

210 MvT, TK 1987-1988, 20329, nr. 3, pag. 37.

211 MvT, TK 1987-1988, 20329, nr. 3, pag. 49.

212 Hierbij moet worden opgemerkt dat dit argument niet overecnstemt met recenter gedane voorstellen van de minister van Justitie betreffende de wijziging van de rechterlijke organisatie, waarbij de kantongerechten opgeheven zullen worden. Notitie van de minister van Justitie aan de Tweede Kamer, TK 1988-1989, nr. 21206. Zie voor een samenvatting van de voorstellen NJB 1989, pag. 436-437 en 983-984; Zie voor commentaar op de voorstellen A. Mulder, Naar een nieuwe structuur van de rechterlijke macht, NJB 1989, pag. 1073-1080; H. van Breda, De rechter in het zicht van het jaar 2000, NJB 1989, pag. 1081-1084.

Inmiddels is een wet in werking getreden betreffende de herziening van de rechterlijke organisatie, Awb tweede tranche, TK 1991-1992, 22495, in werking getreden per 1 januari 1994. 
die feiten toch tot de 'strafbare feiten' gerekend worden, die dan ook berecht moeten worden door de rechterlijke macht. Hieraan wordt volgens de Raad van State voldaan door bervep op de kantonrechter open te stellen. ${ }^{2.3}$

De Raad heeft geen overwegende bezwaren tegen de zekerheidstelling als drempel voor toegang tot de rechter. Wel vraagt hij zich af of bij een cumulatie van overtredingen, en daardoor een evenredige cumulatie van zekerheidstellingen, de drempel niet te hoog wordt. ${ }^{21}$

De Ratad maant tot voorzichtigheid. Technische mogelijkheden kunnen tot vergroving van afdoening leiden. Aangezien ook een administratiefrechtelijke handhaving bestaat uit het opleggen van sancties met als bedoeling het toevoegen van leed, is een vergroving slechts binnen beperkte grenzen toelaatbaar. "De raad is van oordeel dat het bestuursrecht wel andere, maar geen minder verfijnde waarborgen voor het overheidsoptreden tegenover de burgers kent dan het strafrecht. Daaraan zal niet mogen worden te kort gedaan". 215

Ook in de Tweede Kamer wordt het wetsvoorstel in hoofdlijnen met instemming begroet. De discussie heeft geen aanleiding gegeven tot ingrijpende wijzigingen." ${ }^{\text {Ih }}$ Hetzelfde beeld geeft de behandeling in de Eerste Kamer te zien. ${ }^{217}$

\subsection{De WAHV en het EVRM, met name art. 6 lid 2}

\subsubsection{Inleiding}

Tijdens de wordingsgeschiedenis van het stelsel van administratiefrechtelijke handhaving van bepaalde overtredingen is herhaalde malen, ter rechtvaardiging van het stelsel van administratieve afdoening, gewezen op het fiscale recht, waarin een dergelijk systeem van afdoening reeds bestond, dat, zo werd geredeneerd, zonder veel problemen functioneerde. In de jurisprudentie betreffende deze administratiefrechtelijke afdoening hebben zich echter belangrijke ontwikkelingen voorgedaan die de verhouding met art. 6 EVRM betreffen. ${ }^{1 / 8}$ Deze ontwikkeling zou ook wel eens van belang kunnen zijn voor andere vormen van administratiefrechtelijke handhaving, waaronder die van verkeersovertredingen.

Alvorens de ontwikkeling in de jurisprudentie te bespreken zullen eerst de hoofdlijnen van de betreffende regelingen uit het fiscaal procesrecht duidelijk gemaakt worden.

213 Advies Raad van State 22 september 1987, TK, 20329 B, pag. 3-4.

214 zie vorige noot, pag. 18-19.

215 zie vorige noot, pag. 2.

216 Handelingen II 21 februari 1989, 51-5073.

217 Handelingen I 27 juni 1989, 34-1246.

218 Zie hierover: M.W.C. Feteris, Belastingen en mensenrechten, NJCM-bulletin 1993, pag. 755-771;

M.W.C. Feteris, Fiscale administratieve sancties en het EVRM, dissertatie UvA, Deventer 1993. 
Belasting kan grofweg op twee manieren worden geheven ${ }^{21 *}$ : door aanslag (aanslagbelasting, art. $11 \mathrm{AWR}$ ) of door afdracht en voldoening op aangifte (aungiftebelasting, art. 19 AWR). Onder de eerste groep vallen bijvoorbeeld de inkomstenbelasting, vennootschapsbelasting, vermogensbelasting, successie- en schenkingsrechten. Onder de tweede vallen de loonbelasting, dividendbelasting, kansspelbelasting, omzetbelasting, motorrijtuigenbelasting en belastingen van rechtsverkeer. Bij de aanslagbelasting formaliseert de inspecteur de belastingschuld onder andere naar aanleiding van een aangifte bij de beschikking (de aanslag). Pas daarna ontstaat een betalingsplicht. De aangifte is hier een hulpmiddel voor de inspecteur. Bij de aangiftebelasting ontstaat de betalingsplicht direct vanuit de wet. De inhoudingsplichtige of de belastingplichtige moet zelf de belastingschuld formaliseren door het doen van aangifte en het afdragen respectievelijk betalen van de belastingschuld.

Indien bij een aanslagbelasting de belastingplichtige, na een aanmaning, geen of te laat aangifte doet dan wordt de aanslag verhoogd met vijf procent, doch met een minimum van $f 5$,- en een maximum van $f$ 1000,- (art. 9 lid 3 AWR). Hiertegen staat geen rechtsmiddel open. Indien de aanslag te laag was of ten onrechte niet is gedaan, wordt een navorderingsaanslag opgelegd. De in een navorderingsaanslag begrepen belasting wordt met $100 \%$ verhoogd, "behoudens voor zover het niet aan opzet of grove schuld van de belastingplichtige is te wijten dat te weinig belasting is geheven" (art. 18 lid 1 AWR). Volgens het tweede lid van dit artikel neemt de inspecteur bij het vaststellen van de navorderingsaanslag een besluit of en in hoeverre kwijtschelding van de verhoging wordt verleend. Dit gebeurt op basis van daarvoor bestaande richtlijnen (Leidraad administratieve boeten 1984, LAB $^{220}$ ). Binnen twee maanden kan men tegen de navorderingsaanslag en het kwijtscheldingsbesluit in beroep komen bij de belastingrechter (er is dus geen voorafgaande bezwaarschriftprocedure), artt. 26 lid 2 en 27 lid 1 AWR. Het beroep moet gebaseerd zijn op een van de art. 27 lid 2 AWR genoemde gronden: dat de inspecteur van de bevoegdheid tot het geheel of gedeeltelijk niet verlenen van kwijtschelding kennelijk tot een ander doel gebruik heeft gemaakt dan tot de doeleinden, waartoe die bevoegdheid is gegeven; dat de inspecteur bij afweging van de betrokken belangen niet in redelijkheid tot het besluit heeft kunnen komen; dat de inspecteur anderszins heeft besloten in strijd met enig in het algemeen rechtsbewustzijn levend beginsel van behoorlijk bestuur. Uit de wettelijke formulering van art. 18 lid 1 AWR vloeit voort dat de beboete moet bewijzen dat hij geen opzet had of schuld droeg. Hij moet dus zelf zijn onschuld bewijzen. ${ }^{22}$ Tegen de uitspraak staat cassatieberoep open. De verplichting tot betaling

219 Zie hierover uitgebreider: M.W.C. Feteris, Fiscale administraticve sancties en het recht op een cerlijk proces, dissertatie UvA, Deventer 1993, pag. 48-56.

220 Beschikking van 28-03-'84, gepubliceerd in de Stcrt. 65, gewijzigd bij beschikking van 28-02-'85, Stcrt. 50.

221 Deze bepaling is inmiddels door de Hoge Raad onverbindend verklaard wegens strijd met art. 6 lid 2 EVRM, HR 15 juli 1988, BNB 1988/270 m.nt. Van Dijck; FED 1988/708 m.nt. P.J. Wattèl. 
wordt door het instellen van beroep niet opgeschort. Wel kan de ontvanger uitstel van betaling verlenen.

Bij de aangiftebelasting wordt, in het geval de aangifte niet blijkt te kloppen of in het geheel niet gedaan is, een naheffingsaanslag opgelegd (art. $20 \mathrm{AWR}$ ). In een dergelijke aanslag wordt altijd een boete opgenomen. Deze boete houdt in $100 \%$ verhoging van de belasting, tenzij het niet aan opzet of grove schuld van de inhoudings- of belastingplichtige te wijten is dat te weinig betaald werd. In het laatste geval wordt de belasting echter toch met $10 \%$ verhoogd met een minimum van $f$ 5,- (art. 21 AWR). Tegen deze naheffingsaanslag kan binnen twee maanden bezwaar gemaakt worden bij de inspecteur (art. 23 AWR). In zijn uitspraak op het bezwaarschrift moet de inspecteur tevens aangeven of en zo ja, in hoeverre, kwijtschelding van de $100 \%$-verhoging verleend wordt (art. 25 lid 5 AWR). Tegen de verhoging van $10 \%$ (geen opzet of schuld) kan geen kwijtschelding worden verleend en staat volgens de wet geen rechtsmiddel open. ${ }^{22}$ Men kan binnen twee maanden in beroep komen van het kwijtscheldingsbesluit van de inspecteur bij de belastingkamer van het gerechtshof (art. 27 lid 1 AWR), waarbij men zich kan beroepen op de drie hierboven vermelde gronden van art. 27 lid 2 AWR. Indien de belastingplichtige geen bezwaar heeft tegen de naheffing, maar wel tegen de opgelegde verhoging moet hij toch eerst bezwaar maken bij de inspecteur om een kwijtscheldingsbesluit te krijgen waartegen hij in beruep kan gaan. Van de uitspraak van het hof kan men binnen twee maanden in cassatie gaan. Ook hier schorst het instellen van bezwaar en beroep de betaling niet. Ook hier volgt uit de formulering van art. 21 AWR dat de belastingplichtige moet bewijzen dat hij geen opzet of schuld had.

Feteris laat door middel van weergave van de parlementaire behandeling van de AWR zien dat het uitdrukkelijk de bedoeling van de wetgever was dat de verhogingen het karakter hebben van een administratieve boete, om leed toe te delen. ${ }^{23}$

\subsubsection{Jurisprudentie van de Hoge Raad en de Europese instanties}

In zijn arrest van 19 juni 1985, BNB 1986/29 m.nt. J.P. Scheltens, NJ 1986, 104, heeft de Hoge Raad beslist dat het opleggen van een verhoging ex art. 18 lid 1 AWR, art. 21 lid 1 AWR of art. 16 lid 1 sub a WMB aangemerkt moet worden als het instellen van strafvervolging in de zin van art. 6 lid 1 EVRM. De Hoge Raad beperkte zich tot het eerste lid van art. 6 EVRM omdat de belanghebbende zich slechts daarop (de openbaarheid) had beroepen. Ondanks deze beperking bracht de Hoge Raad met deze uitspraak veel pennen in beweging.

222 Volgens de LAB 1984, kan de inspecteur, naar gelang het een eerste of een tweede verzuim betreft, de verhoging echter ambtshalve geheel of gedeeltelijk kwijtschelden. Hoofdstuk III, $§ 12$.

223 M.W.C. Feteris, a.w., pag. 51-52. 
In een arrest van 17 september 1986, BNB 1988/20 heeft het Hof 's-Gravenhage vastgesteld dat een verhoging ex art. 18 lid 1 AWR moet worden aangemerkt als het instellen van strafvervolging. Het Hof laat hier "in de zin van art. 6 EVRM" achterwege. Dit zou er op kunnen duiden dat het Hof van mening is dat bepaalde waarborgen van het nationale strafrecht, die verder gaan dan art. 6 EVRM, van toepassing zouden moeten zijn.

In het arrest van 7 september 1988, FED 1988/715 m.nt. P.J. Wattèl, overweegt de Hoge Raad:

"De omstandigheid dat het opleggen van een verhoging moet worden aangemerkt als 'a criminal charge' in de zin van art. 6 eerste lid van het Europees Verdrag tot bescherming van de rechten van de mens en de fundamentele vrijheden, brengt niet mee dat op zodanige oplegging (verhoging wegens te laat betaalde loonbelasting. gvdb) de regels en/of beginselen van het nationale strafrecht van toepassing zijn".

Hiermee geeft de Hoge Raad aan dat regels van het nationale strafrecht, die verdere bescherming bieden dan art. 6 EVRM, niet van belang zijn in het kader van de fiscale administratieve boetes.

Op 15 juli 1988 (BNB 1988/270 m.nt. Van Dijck; FED 1988/708 m.nt. P.J. Wattèl) wijst de Hoge Raad een arrest waarin hij bepaalt dat de belanghebbende, aan wie een verhoging is opgelegd welke kan worden aangemerkt als 'a criminal charge', aanspraak heeft op eerbiediging van de door art. 6 EVRM gewaarborgde rechten, waaronder het in lid 2 toegekende recht om voor onschuldig gehouden te worden totdat zijn schuld volgens de wet is bewezen. De vervolgende instantie moet bewijzen dat aan alle bestanddelen van het tenlaste gelegde feit voldaan is en de verdachte mag niet worden belast met het bewijs van het tegendeel. De inspecteur moet hij het opleggen van een verhoging niet slechts bewijzen dat te weinig belasting is geheven, maar ook dat dit aan opzet of grove schuld van de belastingplichtige is te wijten. In een arrest van 26 oktober 1988, NJB 1988, pag. 1454 besliste de Hoge Raad dat het Hof op een verweer van de betrokkene (aan wie een verhoging van $100 \%$ was opgelegd wegens niet betaalde motorrijtuigenbelasting) dat de behandeling niet plaatsvond binnen een redelijke termijn, gemotiveerd had dienen te beslissen. Bij de beoordeling of het tijdsverloop sedert de oplegging van de verhoging nog als redelijke termijn aan te merken is, moct niet alleen rekening gohouden worden met de verschillende fasen van het proces afzonderlijk, maar ook op de procesgang in het geheel, waarbij mede van belang zijn het processuele gedrag van de betrokkene, de ingewikkeldheid van de zaak, de hoogte van de verhoging voor zover niet kwijtgescholden en de wijze walarop de zaak door de belastingadministratie respectievelijk de rechter is behandeld.

De ECRM heeft inmiddels art. 6 EVRM van toepassing verklaard op een fiscale administratieve boete (zaak Bendenoun, ECRM 10 december 1990, gepubliceerd in FED 1993/326 m.nt. M.W.C. Feteris). 
Samengevat: het boetestelsel van het fiscaal procesrecht moet voldoen aan alle strafrechtelijke waarborgen die neergelegd zijn in art. 6 EVRM. Voor wat betreft het vermoeden van onschuld is het stelsel volgens de Hoge Raad in strijd met het tweede lid van art. 6 EVRM.

Dit laatste, de presumptio innocentiae, verdient nog wat nadere aandacht, omdat ook in het stelsel van administratiefrechtelijke handhaving van verkeersvoorschriften de verkeersovertreder moet aantonen dat de beschikking onterecht is gegeven of dat de opgelegde boete ten onrechte niet verlaagd is.

Op 7 oktober 1988 deed het Europees Hof voor de Rechten van de Mens uitspraak in de Salabiaku-zaak. ${ }^{224}$ Salabiaku werd gearresteerd nadat hij op en vliegveld een koffer in ontvangst had genomen waarin cannabis bleek te zitten. In eerste instantie werd hij veroordeeld wegens het onrechtmatig invoeren van verdovende middelen en wegens het smokkelen van verboden goederen. In hoger beroep werd hij van het eerste feit vrijgesproken. Salabiaku werd wederom veroordeeld wegens het over de grens brengen van verboden goederen, art. 414 Codes des douanes. In cassatie werd het beroep van de verdachte verworpen, waarbij het Hof zich baseerde op art. 392 lid 1 van de Codes des douanes. Hierin staat dat "le déteneur de marchandises de fraude est réputé responsable de la fraude". Alleen wanneer de verdachte kan aantonen dat er sprake was van overmacht kan hij vrijuit gaan. Salabiaku kon zich niet op overmacht beroepen omdat hij, voordat hij de kist met goederen in bezit nam, gewaarschuwd was door douanepersoneel. Hij dient een klacht in bij de Europese Commissie wegens schending van art. 6 lid 1 en lid 2 EVRM. De Commissie acht deze artikelen niet geschonden. De zaak wordt voorgelegd aan het Hof. Ook het Hof is van mening dat van schending geen sprake is. De Commissie kan een omkering van de bewijslast accepteren indien dit in het belang is van een effectieve rechtshandhaving en indien het voor de verdachte mogelijk is zijn onschuld te bewijzen. Art. 6 lid 2 richt zich volgens de Commissie tot de rechter en heeft geen betrekking op de zaak zelf. Het Hof is een andere mening toegedaan. De nationale wetgever zou anders te gemakkelijk de werking van de presumptie van onschuld kunnen uithollen. Art. 6 EVRM geeft de nationale wetgever volgens het Hof wel een zekere beleidsruimte met betrekking tot het vermoeden van onschuld. Hij moet daarbij wel binnen zekere grenzen blijven: "It requires States to confine them within reasonable limits which take into account the importance of what is at stake and maintain the rights of the defence" (overweging 28).

Volgens verschillende schrijvers is de Hoge Raad in zijn arrest van 15 juli 1988 ongemotiveerd verder gegaan dan de Europese instanties. Waarom zou strafbaarheid behoudens bewijs van overmacht niet in strijd zijn met art. 6 lid 2 EVRM (Salabiaku) 
en strafbaarheid behoudens bewijs van afwezigheid van opzet of grove schuld wel? ${ }^{225}$ Spronken vraagt zich af of deze kritiek wel terecht is. Het Europees Hof toetst steeds het individuele geval, zo ook in de Salabiaku-zaak. Dit betekent niet dat het Hof de betreffende wettelijke bepaling in abstracto in overeenstemming acht met art. 6 lid 2 EVRM. Het Hof toetst dit niet, de Hoge Raad op grond van art. 94 GW wel. ${ }^{22 t}$

De regering is doende het stelsel van fiscale administratieve boeten en van het fiscale. strafrecht te herzien, teneinde dit stelsel in overeenstemming te brengen met het EVRM. Een eerste wetsvoorstel met betrekking tot administratieve fiscale boetes dateert van 1986. Dit voorstel was voomamelijk gericht op aanscherping van de boetes en niet zozeer op afstemming met art. 6 EVRM. ${ }^{227}$ Een tweede voorstel werd ingediend in 1989. ${ }^{\cdots}$ Hierin werd voorgesteld de boete niet langer, als automatische verhoging, deel uit te laten maken van de belastingaanslag maar op te leggen bij afzonderlijke beschikking. Verder bevatte het wetsvoorstel een regeling met betrekking tot de verdeling van de bewijslast. Voorgesteld werden nieuwe artikelen 18 en 22 AWR: Indien het aan de opzet of grove schuld van de belastingplichtige is te wijten dat te weinig belasting is geheven, respectievelijk indien het aan de opzet of grove schuld van degene van wie wordt nageheven is te wijten dat belasting die op aangifte behoort te worden voldaan of afgedragen, geheel of gedeeltelijk niet is betaald, legt de inspecteur bij het vaststellen van de navorderingsaanslag respectievelijk van de naheffingsaanslag een boete op. Hiermee werd de bewijslastverdeling gewijzigd. In het wetsvoorstel werd niet langer uitgegaan van een "automatische" boete, welke over het volle bedrag wordt opgelegd, behoudens tegenbewijs van de belastingplichtige. In het voorstel bepaalde de inspecteur de basis van de boete afhankelijk van de aanwezigheid van opzet of grove schuld, alsmede de hoogte ervan (deze elementen zouden nader uitgewerkt worden in een algemene maatregel van bestuur). Het voomemen een boete op te leggen, de aanleiding daartoe en de hoogte daarvan zouden worden gemotiveerd bij een schriftelijke kennisgeving. De motivering kon in het algemeen niet een volledig bewijs bevatten. De inspecteur kon slechts indiceren, door feiten of gebeurtenissen te noemen, dat er sprake is van hijvoorbeeld opzet. De belastingplichtige zou echter nok niet kunnen volstaan met een blote ontkenning van het door de inspecteur gestelde, maar zou dit moeten beargumenteren. De eerste stap moest echter door de inspecteur worden gezet. ${ }^{20}$

225 J. Lensing, De Hoge Raad en de presumptie van onschuld: ecn motiveringsklacht, NJB 1989, pag. 84-86; G.J.M. Corstens en P.M. Frielink, De Hoge Raad en de fiscale boete: twee maal in de pas, eenmaal uit de pas, WFR 1989, pag. 216-224.

226 Taru Spronken, Presumptie van onschuld: De Salabiaku zaak, NJCM-bullctin 1989, pag. 495-503.

227 TK 1986-1987, 19489.

228 TK 1988-1989, 12058.

229 MvT, TK $1988-1989,12058$, nr. 3, pag. 11. 
Omdat dit voorstel niet geheel bleek te voldoen aan de eisen van het EVRM, is, na adviezen van mensenrechtendeskundigen en van een adviescommissie (Cie. Van Slooten), een derde wetsvoorstel verschenen. ${ }^{20231}$ Dit voorstel komt, voor zover voor ons van belang, op het volgende neer:

(1) De administratieve boete krijgt een zelfstandige positie blijkens de concentratie van de bepalingen betreffende de boete in een apart nieuw hoofdstuk (VIIA);

(2) Er komt een aparte functionaris die zich bezig houdt met het opleggen van de boetes, de zogenaamde boete-inspecteur. Achtergrond hiervan is dat er beter rekening gehouden kan worden met de verdedigingsrechten van de betrokkene;

(3) Er wordt onderscheid gemaakt tussen lichtere en zwaardere boetes, die de naam krijgen "verzuimboete" respectievelijk "vergrijpboete";

(4) De volgende sanctiebepalingen worden voorgesteld:

a. een verzuimboete van maximaal $f 2500$ bij belastingen die bij wege van aanslag worden geheven, indien de belastingplichtige de aangifte, na aanmaning, niet of niet binnen de gestelde termijn heeft gedaan (art. 67a);

b. een verzuimboete van maximaal $f 250$ bij belastingen die op aangifte moeten worden gedaan of afgedragen, wanneer die aangifte niet of niet tijdig is gedaan (art. 67b);

c. een verzuimboete van maximaal $f 10000$ bij belastingen die op aangifte moeten worden gedaan of afgedragen, wanneer die belasting niet of niet tijdig is betaald, zonder dat er sprake is van opzet of schuld (art. 67c);

d. een vergrijpboete van maximaal $100 \%$ bij belastingen die bij wege van aanslag worden geheven, indien het aan opzet of grove schuld van de belastingplichtige is te wijten dat de aangifte niet, onjuist, of onvolledig is gedaan (art. 67d);

e. een vergrijpboete van maximaal $100 \%$ bij belastingen die bij wege van aanslag worden geheven, indien het aan opzet of grove schuld van de belastingplichtige is te wijten dat er te weinig belasting is geheven (art. 67e);

f. een boete van maximaal $100 \%$ bij belastingen die op aangifte moeten worden gedaan of afgedragen, wanneer het aan opzet of grove schuld van de belastingplichtige is te wijten dat de verschuldigde belasting niet (geheel) tijdig is betaald (art. 67f).

Bij betwisting van de vergrijpboetes zal de inspecteur de opzet of grove schuld, overeenkomstig het arrest van HR 15 juli 1988, BNB 1988/270 moeten bewijzen.

230 Ingediend op 2 november 1993, TK 1993-1994, 23470 Wetsvoorstel tot wijziging van de Algemene wet inzake rijksbelastingen en van de Invorderingswet 1990 in verband met de herziening van het stelsel van administratieve boeten en van het fiscale strafrecht. Dit heeft tot gevolg dat uit het nog aanhangige wetsvoorstel 21058 bij nota van wijziging alle bepalingen moeten worden verwijderd die betrekking hcbben op administratieve boeten.

231 Zie uitgebreid over dit laatste wetsvoorstcl: M.W.C. Feteris, Het derde wetsvoorstel tot aanpassing van de fiscale administratieve boctes, WFR 1994, pag. 4.3-59. 
(5) De rechter kan de strafmaat volledig toetsen; hij kan de boete in een beroepsprocedure verhogen (reformatio in peius);

(6) Er komt geen tweede feitelijke instantie;

(7) Er komt een aantal bepalingen die administratieve sancties en strafsancties op elkaar moeten afstemmen:

1. na het opleggen van een administratieve sanctie is strafvervolging ten aanzien van hetzelfde feit uitgesloten;

2. oplegging van een administratieve sanctie is niet meer mogelijk zodra een strafvervolging ten aanzien van hetzelfde feit geleid heeft tot een terechtzitting of tot een schikking;

Nu het er met betrekking tot het tot nu toe bestaande systeem van administratieve boeten in het fiscale recht op is gaan lijken, dat de thans geldende bewijslastverdeling in strijd is met de onschuldpresumptie zoals deze is neergelegd in art. 6 lid 2 EVRM, lijkt de vraag gewettigd of het systeem van bewijslastverderdeling zoals dat is neergelegd in de WAHV niet in strijd zal blijken te zijn met deze verdragsbepaling. Van belang is dus de discussie rond de administratieve boete, met name die rond de fiscale administratieve boete in het oog te houden.

Tot zover de "historie" van de totstandkoming van en het parlementaire en wetenschappelijke debat over de WAHV. Na de invoering ervan zijn enkele meer of minder ingrijpende wijzigingen noodzakelijk geworden door (invoering van) de Awb.

Hieronder zal worden ingegaan op de wijzigingen die de WAHV reeds ondergaan heeft of door invoering van de Awb dient te ondergaan.

Daarnaast zal bekeken worden wat de eerste ervaringen zijn met de WAHV. Hierbij zal worden gebruik gemaakt van de uitkomsten van een evaluatie-onderzoek zoals dat is uitgevoerd in opdracht van het ministerie van justitie. Vanzelfsprekend zal ook de reeds verschenen jurisprudentie worden geanalyseerd en becommentarieerd. Als laatste wil ik ingaan op enkele specifieke onderwerpen die met de WAHV samenhangen, waarbij de kwestie van de keuze tussen strafrechtelijke of bestuursrechtelijke handhaving een belangrijke plaats inneemt.

\section{Ervaringen met de WAHV}

\subsection{Inleiding}

De WAHV draait nu een aantal jaren, zodat een voorzichtig oordeel kan worden gevormd over de werking en de resultaten ervan. Vooraf bestonden en tussentijds ontstonden er twijfels over bepaalde onderdelen van de wet. Jurisprudentie moest hierin duidelijkheid verschaffen. Daarnaast was een aantal zaken niet of in onvoldoende mate in de WAHV geregeld. Ook hier moest de rechter uitkomst brengen. Er zijn voorstellen gedaan om de WAHV te veranderen of aan te vullen. 
Ilet ministerie van justitie heeft onderzoek laten doen naar de werking van het systeem van de WAHV. In 1991 verschenen twee evaluatierapporten. ${ }^{212}$ Een nadeel bij deze vroege rapportage was, dat, ruim een jaar na de invoering van de WAHV, het verhaal- en dwangtraject niet was voltooid en ook de fase van het beroep op de Hoge Raad nog niet was doorlopen. Dit heeft consequenties op zaken als snelheid van de executie en effectiviteit van de inning, omdat deze pas goed kunnen worden beoordeeld na de executie. Een andere beperking van dit onderzoek was, dat deze evaluatie plaatsvond terwijl de WAHV nog niet overal was ingevoerd. Met name de grote steden deden nog niet mee. In december 1992 verscheen een belangrijk rapport over een onderzoek naar de juridische aspecten van de invoering van de WAHV. ${ }^{23}$ In dit onderzoek is gebruik gemaakt van documentenonderzoek (correctieformulieren van het CJIB, dossieronderzoek OM bij beroepschriften), is een aantal uitspraken van kantonrechters ter zake van beroepen van betrokkenen tegen de beslissing van de officier van justitie en op verzetschriften tegen de tenuitvoerlegging van dwangbevelen geanalyseerd, hebben observaties bij verschillende betrokken instellingen plaatsgevonden en zijn interviews gehouden met degenen die betrokken zijn bij de uitvoering van de wet. In dit rapport is een schat aan gegevens verzameld. Deze gegevens zijn op een gemakkelijk toegankelijke manier weergegeven, waardoor het mijns inziens een goed inzicht geeft in het functioneren van de WAHV. Afzonderlijke bespreking verdienen de aanpassingen van de WAHV aan de inmiddels wet geworden Awb. Hieraan zal een aparte paragraaf worden gewijd.

Aanvankelijk was het mijn bedoeling jurisprudentie en evaluatie van de WAHV los van elkaar weer te geven. Al spoedig bleek mij dit niet de juiste werkwijze, omdat de juridische evaluatie niet los gezien kan worden van de rechterlijke uitspraken zoals die intussen over de WAHV gedaan zijn. Afzonderlijke bespreking zou zeker een aantal doublures opleveren, hetgeen de leesbaarheid niet ten goede komt. Daarom is gekozen voor een geïntegreerde bespreking van juridische evaluatie en jurisprudentie. Dit betekent (vanzelfsprekend) niet dat voor bespreking van de jurisprudentie uitsluitend gebruik is gemaakt van het evaluatierapport. De rechtspraak zal meer uitgebreid worden weergegeven en ook zullen uitspraken worden geanalyseerd die in het evaluatie rapport niet worden genoemd, bijvoorbeeld omdat ze van latere datum zijn.

232 S. Eschen en M. Kommer, Evaluatie invocring Wet Mulder; interimrapportage. Den Haag 1991, Ministerie van Justitie/CDWO; M. Kommer, S. Eschen en E. van der Heijden, Eindrapport evaluatie invoering Wet Mulder. Den Haag 1991, Ministerie van Justitie/CDWO. Zie hierover ook: M. Kommer, Mulder vs Murphy, paper voor het symposium De Wet Mulder in bedrijf. Rotterdam, 1 september 1992.

233 P.M. van Russen Groen, Eindrapport van het juridisch deelonderzoek van het Evaluatieproject Wet Mulder. Deel I en II. Erasmus Universiteit Rolterdam, 1992. 


\subsubsection{Onderzoeksresultaten}

Het ministerie van justitie heeft onderzoek laten doen naar de werking van het systeem van de WAHV. In 1991 verschenen twee evaluatierapporten (interim- en eindonderzoek).

Uit het interimonderzoek blijkt onder meer:

- de snelheid van de executie is niet verhoogd. Hierbij wordt aangetekend dat de vertraging bij het CJIB gedeeltelijk is toe te schrijven aan procedures die binnenkort veranderd zullen worden. Daarnaast speelt waarschijnlijk een rol dat het verhaal- en dwangtraject nog niet is ingegaan. Afwachten dus.

- de effectiviteit van de inning ligt ongeveer gelijk met die van de politietransactie (was ruim $85 \% \%^{24}$ ): ongeveer $84 \%$ van de sancties wordt betaald. Van belang is erop te wijzen dat de verwachte winst van de inning ten opzichte van de strafprocedure (incasso van door de rechter opgelegde boete) vooral moet liggen in het verhaal- en dwangtraject. Afwachten dus.

- de werklast bij politie en OM is aanzienlijk verminderd. Echter, ook hier moet het verhaal- en dwangtraject worden afgewacht voordat een definitief oordeel kan worden gegeven.

- met betrekking tot de rechtsbescherming van de betrokkene blijkt dat slechts $3 \%$ van de betrokkenen beroep bij de officier van justitie instelt, het grootste gedeelte van de beroepen werd verworpen en dat zeer weinig beroep op de kantonrechter werd ingesteld.

De uitkomsten van het eindonderzoek waren:

- de effectiviteit van de WAHV is groot, in die zin dat $\pm 94 \%$ van de geconstateerde gedragingen gesanctioneerd wordt. De totale doorlooptijd ten opzichte van het strafrechtelijk systeem is aanzienlijk bekort: het interventieniveau dat onder het strafrecht na ruim 2,5 jaar wordt gerealiseerd, is onder de WAHV na minder dan 1 jaar bereikt. Wel is het zo dat de interventiesnelheid voor het merendeel der zaken iets is afgenomen: onder het strafrecht werd het merendecl van de boetes door middel van een politietransactie voldaan en dat ging sneller dan door een beschikking via het CJIB.

- bij alle betrokken onderdelen blijkt de werklast aanmerkelijk verminderd te zijn, hetgeen een kostenbesparing met zich meebrengt.

234 Zie de cijfers zoals door Corsiens weergegeven in zijn preadvies NJV 194. 
- er zijn geen ernstige problemen met de rechtsbescherming. Het percentage beroepen op de officier van justitie blijft achter bij de prognoses. Reële verweren (verhuur voertuig, verkeerd kenteken) worden gehonoreerd. De gang van zaken bij de kantonrechter geeft geen aanleiding tot zorg over de rechtspositie van de betrokkene. (hierbij moet in het oog worden gehouden dat het cassatietraject nog niet in het onderzoek was betrokken. Het is de Hoge Raad die de rechtspositie uiteindelijk beoordeelt. Dit komt uitgebreider aan de orde bij de bespreking van de jurisprudentie.

- over de vraag of deze ingrijpende systeemwijziging noodzakelijk was voor de bereikte resultaten viel nog weinig te zeggen.

Deze resultaten waren, zoals vaker gezegd, voorlopig, zodat nadere gegevens moesten worden afgewacht.

\subsubsection{Eindrapport juridisch onderzoek en jurisprudentie}

In december 1992 verscheen het Eindrapport van het juridisch onderzoek als onderdeel van het Evaluatieproject Wet Mulder. Dit rapport zal voortaan aangeduid worden als: Eindrapport. Hierna zullen de voornaamste bevindingen van het Eindrapport gecombineerd met jurisprudentie worden besproken. Hierbij wordt zoveel mogelijk de volgorde van de opeenvolgende stadia van de procedure gevolgd.

\subsubsection{Politie}

De ervaringen bij de politie met de WAHV waren tamelijk positief. Als belangrijke verbeteringen werden onder andere gezien de vermindering van de werklast (vooral na het opleggen van de sanctie) en het hoge inningspercentage van opgelegde sancties. Als een belangrijk nadeel werd gezien dat het een breuk betekende met de mogelijkheid tot meer informele wijzen van afdoening zoals die in de strafrechtelijke procedure wel bestonden. De autonomie van de individuele politieagent werd beperkt. Dit uitte zich bijvoorbeeld in een strakkere regeling van de correctieprocedure, dat wil zeggen de mogelijkheid om een beschikking te herzien op verzoek van de betrokkene, hetgeen zich voornamelijk voordoet indien door de politie een fout is gemaakt. De WAHV kent deze mogelijkheid niet, terwijl daar in de praktijk zeer duidelijk behoefte aan was. Het CJIB hanteerde, indien aan de voorwaarde dat indiening van een dergelijk verzoek was gedaan voordat de beroepstermijn op de officier van justitie was verlopen (de sanctie is dan immers onherroepelijk geworden), een aantal strakke criteria waaraan een correctieverzoek moest voldoen. Bij de politie bestond hierover ontevredenheid, omdat men van mening was dat degene die de beschikking oplegde (de politie) ook zelf de verantwoordelijkheid had deze ongedaan te maken indien hij de daarvoor aangevoerde reden acceptabel achtte. De vraag die hier speelt luidt: moet de correctiemogelijkheid worden beschouwd als een discretionaire bevoegdheid 
van de politieambtenaar die de sanctie heeft opgelegd? Ik ben geneigd tot een positieve beantwoording hiervan. De WAHV zal in deze zin moeten worden aangevuld. In de praktijk bleek het voor te komen dat door politieambtenaren geen kennisgeving van beschikking werd gegeven in situaties waarin zij volgens de WAHV daartoe bevoegd waren. Ook kwam het voor dat bij snelheidsovertredingen een aantal te hard gereden kilometers werd gepardonneerd, teneinde de overtreding onder de WAHV te laten vallen.

Vermeldenswaard is het gegeven dat bij de meeste politieambtenaren geen richtlijnen of uitvoeringsregelingen van het $\mathrm{OM}$ of het ministerie van justitie bekend waren. Er bleken problemen te bestaan bij de toekenning van sanctiebevoegdheid aan bepaalde ambtenaren, zoals reservepolitie, parkeerpolitie en spoorwegpolitie. Dit is inmiddels opgelost door aanpassing van het Besluit AHV. ${ }^{225}$

\subsubsection{Centraal Justitieel Incassobureau}

Het Centraal Justitieel Incassobureau (CJIB) neemt in de hele procedure, waarin de boetes op een gecentraliseerde en geautomatiseerde wijze worden afgehandeld, een centrale positie in. Het verstuurt namens de politieambtenaren de beschikking en is namens de officier van justitie belast met de inning van de sanctie. De wettelijke grondslag hiervan is te vinden in $\S 4$ van het Besluit administratiefrechtelijke handhaving verkeersvoorschriften. ${ }^{236}$

Over het incassotraject zal ik later afzonderlijk spreken. Nu zal aandacht worden geschonken aan de eerst genoemde taak, te weten de verzending van de beschikkingen.

Op de tekst van de beschikkingen werden drie punten van kritiek geuit: op de beschikkingen stond als afzender het CJIB vermeld, zodat het voor betrokkenen niet duidelijk was dat de beschikking afkomstig was van de politie, respectievelijk de officier van justitie; de formulieren waren erg ingewikkeld als gevolg van een onduidelijke lay-out en de vermelding van een grote hoeveelheid gegevens (zie ook HR 26 mei 1992, NJ 1992, 697); de beschikking vermeldde de uiterste beroepsdatum, hetgeen sommige kantonrechters niet de taak vonden van het CJIB.

Uit het eindrapport blijkt dat het CJIB in zijn algemeenheid door politie, OM en zelfs de rechterlijke macht als ambtelijk en vormelijk werd ervaren. Naar mijn mening is dit een risico van het werken met geautomatiseerde afhandeling door één centrale instantie. Een dergelijk systeem laat doorgaans niet allerlei uitzonderingen toe.

235 Besluit van 29 augustus 1990, houdende regels ter uitvoering van de artikelen 3, eerstc en derde lid, 22, tweede lid en 35 van de Wet administratiefrechtelijke handhaving verkcersvoorschriften, Stb. 1990, 437, gewijzigd bij Besluiten van 21 november 1991, Stb. 1991, 643 en van 14 augustus 1992, Stb. 1992, 431.

236 Besluit van 29 augustus 1990, Stb. $1990,437$. 


\subsubsection{Officier van justitie}

De officier van justitie speelt in de WAHV onder meer een rol als bestuursorgaan dat optreedt als beroepsinstantie, die een beslissing moet nemen over de juistheid van de beschikking zoals die is opgelegd door een daartoe bevoegde ambtenaar indien daartegen door de betrokkene bezwaar is aangetekend (over zijn andere rol, nl, die in het verhaalstraject kom ik nog te spreken).

Uit het Eindrapport blijkt dat in 1991 ten aanzien van bijna 3\% (10.819 van de 369.230) van de opgelegde beschikkingen beroep op de officier van justitie werd ingesteld. In het Eindrapport is naar deze beroepsfase onderzoek verricht bij het parket Utrecht. Daaruit blijkt dat het overgrote deel van de beroepschriften betrekking had op overtredingen die op kenteken waren geconstateerd. De meeste beschikkingen werden na behandeling van het beroep vernietigd $(50,4 \%)$. De meest aangevoerde beroepsgronden, naast inhoudelijke verweren, waren: verhuur van het voertuig en ontkenning van de gedraging. Juridische verweren kwamen nauwelijks voor, evenals verzoeken tot matiging van het sanctiebedrag in verband met persoonlijke omstandigheden van de betrokkene. Door de Hoge Raad werden uitspraken gedaan omtrent het matigingsrecht van de officier van justitie (art. 7 lid 2 jo. art. 9 lid 2 sub b). Hij kan volgens de wet een lager bedrag van de administratieve sanctie vaststellen in verband met de omstandigheden waarin de betrokkene verkeert. In het arrest van HR 29 september 1992, NJ 1993, 32 was de kantonrechter ervan uitgegaan dat gelet moest worden op de persoonlijke omstandigheden van de betrokkene. De Hoge Riad acht deze opvatting te beperkt. Hij geeft aan dat het matigingsrecht slechts bij uitzondering kan worden toegepast, maar sluit, op grond van de wetshistorie, niet uit dat ook de omstandigheden waaronder de gedraging plaatsvond aanleiding kunnen zijn voor matiging van het sanctiebedrag. Eenzelfde uitspraak volgt in HR 2 februari 1993, NJB-katern 1993, pag. 179, nr. 71 en HR 15 juli 1993, NJB-katern 1994, pag. 179, nr. 8. Art. 7 WAHV is inmiddels gewijzigd.

Van de inhoudelijke verweren (de betrokkene voert omstandigheden aan waaronder de gedraging is verricht) werd ongeveer twee derde verworpen. De beroepsgronden dat er een foutief kenteken was ingevoerd en dat het motorvoertuig was verkocht leiden het meest tot vernietiging. Relatief vaak werd aangevoerd dat men de gedraging niet had begaan omdat men zich op het betreffende tijdstip niet op de vermelde plaats had bevonden. Het gaat er dan om of er wellicht een data-entry fout was gemaakt, of dat er sprake was van een voertuig met een vals kenteken. Hier doet zich een interessant probleem voor: welke bewijsregels worden gehanteerd? ${ }^{237}$ Uit de onderzochte zaken blijkt dat de officier van justitie veel waarde hechtte aan schriftelijk bewijsmateriaal. In HR 20 april 1993, NJB-katern 1993, pag. 326, nr. 145, ontkende betrokkene de gedraging niet, maar bestond er tussen hem en het $\mathrm{OM}$

237 Het administratief recht kent immers een andere bewijsleer dan het strafrecht, waarin het feit wettig en overtuigend moet worden bewezen. In het bestuursrecht gaat men uit van het vermoeden van rechtmatigheid van de beschikking. 
verschil van mening over de datum van het plegen van de overtreding. Het was dus geen kwestie van "even de datum veranderen". De Hoge Raad is van mening, verwijzend naar de MvT WAHV pag. 40, dat de vermelding van gegevens in de beschikking ertoe dient om de betrokkene in staat te stellen om zelf na te gaan op welke gedraging de beschikking betrekking had. Daarover bestaat in dit geval geen onduidelijkheid.

Met betrekking tot het verweer verhuur van het voertuig deed zich het probleem voor wat aangemerkt moest worden als een geldige huurovereenkomst (zie bijvoorbeeld HR 18 mei 1993, NJB-katern 1993, pag. 358, nr. 158; HR 18 mei 1993, NJBkatern 1993, pag. 418, nr. 180). In HR 18 mei 1993, NJ 1994, 1 oordeelde de Hoge Raad dat met huurovereenkomst in de zin van art. 8 WAHV niet uitsluitend is bedoeld een bedrijfsmatige overeenkomst.

Zeer weinig betrokkenen werden door de officier van justitie niet-ontvankelijk verklaard. Zoals in het bestuursrecht gebruikelijk is, werden betrokkenen in de gelegenheid gesteld aanvullende informatie te verschaffen.

Bij alle bezochte parketten bleek dat er zeer weinig betrokkenen door de officier van justitie waren gehoord (art. 7 lid 2 WAHV vereiste aanvankelijk een uitdrukkelijk verzoek daartoe).

Volgens art. 7 WAHV beslist de officier van justitie zo spoedig mogelijk op het beroep. In praktijk bleek dat de officier van justitie gemiddeld vier weken nodig had om tot een beslissing te komen. In een aantal gevallen werd de beschikking vernietigd, omdat de officier te veel tijd nodig had (dit varieerde tot 4 11⁄2 á 5 maanden).

Op de beschikking waarin de officier van justitie zijn beslissing op het beroep geeft, is niet duidelijk vermeld de datum waarop deze beschikking is verzonden. Vermelding van deze datum is juist van belang, omdat dat het moment is waarop de beroepstermijn voor het beroep op de rechter aanvangt. De Hoge Raad heeft dit gebrek inmiddels vastgesteld, HR 3 maart 1992, NJ 1992, 696 (m.nt. C. onder NJ 1992, 692).

\subsubsection{Kantonrechter}

De kantonrechter heeft in de WAHV verschillende functies. Hij treedt op als rechter indien de betrokkene het niet eens is met de beslissing van de officier van justitie, betrokkenen kunnen bij de kantonrechter verzet aantekenen tegen de tenuitvoerlegging van een dwangbevel of tegen het verhaal en betrokkenen kunnen bij de kantonrechter een bezwaarschrift indienen tegen de inbewaringstelling van hun voertuig. Daarnaast kan de officier van justitie bij de kantonrechter een vordering instellen om te worden gemachtigd één of meer dwangmiddelen in te stellen. Nu zal worden ingegaan op de eerst genoemde functie.

Een belangrijk gegeven uit het Eindrapport is, dat in zeer weinig gevallen beroep bij de kantonrechter wordt ingesteld. Van de betrokkenen die in 1991 beroep hadden ingesteld bij de officier van justitie gingen er $692(6,4 \%)$ bij de kantonrechter in beroep. Zoals we hiervoor zagen was ook het aantal beroepen op de officier van 
justitie al beperkt (bijna 3\%, in 10.819 van de 369.230 opgelegde beschikkingen). Voor dit lage aantal worden vier mogelijke oorzaken genoemd: de betrokkene heeft geen reden in beroep te gaan, de betrokkene heeft geen zin of belangstelling in beroep te gaan, het administratief beroep op de officier van justitie was voor de betrokkene voldoende of de drempels werden te hoog bevonden. Bij dit laatste argument gaan de gedachten in de eerste plaats naar het vereiste van de zekerheidstelling.

In een relatief groot aantal gevallen werd het beroep van betrokkene op de rechter niet-ontvankelijk verklaard wegens het ontbreken van de vereiste zekerheidstelling, gemiddeld ruim $46 \%{ }^{23}$ Daarom zullen we dit vereiste nader bekijken. Daarna komen andere oorzaken van niet-ontvankelijkheid, namelijk het overschrijden van de beroepstermijn en het door de verkeerde persoon instellen van beroep aan de orde.

\subsection{Niet-ontvankelijkheid}

Art. 11 lid 1 WAHV schrijft voor dat zekerheid moet worden gesteld voor de betaling van de sanctie, omdat anders de kantonrechter de zaak niet in behandeling neemt. De zekerheid wordt gesteld ter griffie van het kantongerecht door overgifte van contant geld of cheques tot het beloop van de sanctie. De zekerheidstelling dient plaats te vinden binnen veertien dagen na de dag van ontvangst van het beroepschrift. Nadrukkelijk wordt vermeld dat, indien dit niet gebeurd is, het beroep, in afwijking van art. 6:6 Awb $\mathrm{Am}^{200}$, aanstonds niet ontvankelijk wordt verklaard.

Al bij de totstandkoming van de WAHV is herhaaldelijk de vraag opgeworpen of deze zekerheidstelling zich verdraagt met art. 6 EVRM, in die zin of het verenigbaar is met het recht op toegang tot de rechter. De algemene opvatting was toen dat deze verplichting niet met dit recht in strijd was. ${ }^{2+0}$

Niet verwonderlijk is derhalve dat de eerste jurisprudentie van de WAHV zich onder andere rond dit thema concentreert. In HR 11 februari 1992, NJ 1992, 692, m.nt. C., HR 11 februari 1992, NJ 1992, 693, HR 25 februari 1992, NJ 1992, 694 en HR 26 mei 1992, NJ 1992, 697 werd de Hoge Raad gevraagd een uitspraak te doen op dit terrein.

In de eerste zaak die de Hoge Raad over de WAHV kreeg voorgelegd (HR 11 februari 1992, NJ 1992, 692), was niet voldaan aan de verplichting tot het stellen van zekerheid, ook niet nadat de griffier appellant in de gelegenheid had gesteld

238 De verschillen tussen de onder/ochte kantongerechten Utrecht, Lecuwarden en Groningen waren echter zeer groot: resp. 92, $52 \mathrm{en} 18 \%$.

239 Deze toevocging was noodzakelijk in verband met (de invoering van) de Awb, die in art. 6:6 ecn herstelregeling biedt indien nict is voldaan aan art. 6:5 of aan enig ander bij de wet gesteld vereiste voor het in behandeling nemen van het bezwaar en beroep, bijvoorbecld de storting van griffierecht.

240 Zie bijvoorbecld N. Jörg. Themanummer Trema 1985-1, pag. 33; de bijdrage van D.H. de Jong in: Administratieve afdoening van verkeersovertredingen (1986), pag. 29. 
dit verzuim te herstellen. De Hoge Raad is van oordeel dat de kantonrechter de betrokkene terecht niet ontvankelijk heeft verklaard in zijn beroep.

In zijn conclusie bij dit arrest stelt A-G Meijers dat uit de Straatsburgse jurisprudentie kan worden afgeleid dat het stellen van zekerheid niet in strijd is met het in art. 6 lid 1 besloten liggende recht op toegang tot de rechter, voor zover het gaat om een bedrag van matige, in het geding zijnde belang en het daadwerkelijk financieel nadeel gerelateerde. Hij komt tot de conclusie dat het stellen van zekerheid tot een bedrag van maximaal $f$ 140,- (toen de maximale hoogte van de administratieve sanctie) niet in strijd komt met het betreffende mensenrecht. Wel werpt hij de vraag op of, indien deze maximum sanctie zal zijn verhoogd (hetgeen intussen is gebeurd en wel tot $\left.f 500,-^{241}\right)$, dit bedrag nog zal voldoen aan de door de Europese Commissie gehanteerde maatstaf van evenredigheid. Hij dringt erop aan dat de Hoge Raad aanleiding zal zien aan te geven waar (hij bedoelt: bij welke hongte van het bedrag van de sanctie, dus de hoogte van de zekerheidstelling) deze procedure niet meer aan het vereiste van evenredigheid voldoet.

Annotator Corstens deelt dit bezwaar van de A-G niet. Hij ziet een andere bedreiging voor het recht op toegang tot de rechter, namelijk in de omstandigheid dat de betrokkene in een dwangpositie kan komen te verkeren doordat de rechter de sanctie kan verhogen, de zg. reformatio in peius. Daardoor kan de betrokkene meer verliezen dan slechts het bedrag van de zekerheidstelling. Hierbij zou ik willen opmerken er dat in het administratieve recht voor toepassing van reformatio in peius in het algemeen een uitdrukkelijke wettelijke bepaling noodzakelijk is. Deze wordt in de Awb in het algemeen verboden, art. 7:11. 242

Ook in HR 11 februari 1992, NJ 1992, 693 (m.nt. C. onder NJ 1992, 692) had betrokkene geen zekerheid gesteld, terwijl ook hier de griffier hem de gelegenheid had gegeven dit verzuim te herstellen. De kantonrechter had de betrokkene niet ontvankelijk verklaard. De Hoge Raad constateert echter dat er een fout is gemaakt in de procedure. Art. 7 lid 3 WAHV schrijft voor dat de officier van justitie de betrokkene schriftelijk dient te wijzen op het bepaalde in art. 9 WAHV (beroepsmogelijkheid bij kantonrechter, beroepstermijn en welke gegevens vermeld moeten worden). De strekking van deze bepaling is dat degene die tegen de beslissing van de officier van justitie wil opkomen daarin niet wordt belemmerd door onbekendheid met de eisen die aan dit beroep worden gesteld. Annotator Corstens benadrukt het belang hiervan omdat de omstandigheid, dat de betrokkene zelf in actie moet komen wanneer hij het niet eens is met de sanctie en niet kan gaan zitten afwachten, juist het

241 Besluit van 23 augustus 1991, Stb 1991, 427 (vervanging van de bijlage bedoeld in art. 2 lid 1 WAHV, Stb. 1990, 534).

242 Bedoeld is dat de positie van de indiener van een bezwaarschrift niet slechter mag zijn dan zonder de bewaarschriftprocedure mogelijk was geweest. Met andere woorden: indien ook zonder bezwaarschriftprocedure het bestuursorgaan bevoegd zou zijn geweest het bestreden besluit ten nadele van de betrokkene te wijzigen verzet art. 7:11 zich niet hiertegen. A.Q.C. Tak, De algemene wet bestuursrecht, het nieuwe bestuursprocesrecht, Zwolle 1993, pag. 85-86. 
verschil vormt met de strafrechtelijke procedure. Een dergelijke mededeling bevindt zich niet bij de stukken van het geding.

Daarnaast creëert de Hoge Raad een nieuw vereiste. De WAHV eist niet dat betrokkene wordt geïnformeerd omtrent de zekerheidstelling. In de praktijk geven de griffiers van het kantongerecht, indien zekerheidstelling binnen de daarvoor gestelde termijn achterwege blijft, betrokkene de mogelijkheid dit alsnog te doen. De Hoge Raad vindt dit niet genoeg. Volgens de Hoge Raad brengen beginselen van behoorlijke procesorde met zich mee dat betrokkene tijdig mededeling wordt gedaan dat, tot welk bedrag en binnen welke termijn op straffe van niet ontvankelijkheid van het beroep zekerheid dient te worden gesteld voor de betaling van de sanctie. De kantonrechter, constaterende dat geen zekerheid is gesteld, moet onderzoeken of deze mededeling (door de officier van justitie) is gedaan. Blijkt dit niet het geval te zijn, dan moet betrokkene alsnog in de gelegenheid worden gesteld binnen een door de kantonrechter gestelde termijn aan het vereiste van zekerheidstelling te voldoen. Hiermee nuanceert de Hoge Raad het absolute gevolg dat art. 11 lid 1 WAHV, namelijk niet ontvankelijkheid van het beroep, aan het achterwege blijven van zekerheidstelling verbindt en stelt een nieuwvereiste, nl. het geven van gelegenheid om het verzuim te herstellen. Hiermee brengt de Hoge Raad de WAHV op dit punt in overeenstemming met art. 6:6 Awb: Indien niet is voldaan aan art. 6:5 of aan enig ander bij de wet gesteld vereiste voor het in behandeling nemen van het bezwaar of beroep, kan dit niet-ontvankelijk worden verklaard, mits de indiener de gelegenheid heeft gehad het vernum te herstellen binnen een hem daartoe gestelde termijn.

In zijn arrest van 26 mei 1992, NJ 1992, 697 (m.nt. C. onder NJ 1992, 692), eveneens een zaak waarin geen zekerheid was gesteld en de kantonrechter het beroep van betrokkene niet ontvankelijk had verklaard, scherpt de Hoge Raad het vereiste, zoals hij dat in het hiervoor genoemde arrest had geformuleerd, aan. Aan betrokkene was, na ongegrondhevinding van het beroep bij de officier van justitie, meegedeeld dat, binnen welke termijn en voor welk bedrag zekerheid moest worden gesteld, omdat anders het beroepschrift door de kantonrechter niet in behandeling zou worden genomen. Toch is de Hoge Raad ook in dit geval van mening dat betrokkene de gelegenheid moet worden geboden dit verzuim ter herstellen. Hij acht het niet onbegrijpelijk dat betrokkene de bedoelde informatie niet heeft begrepen, "gezien de voor betrokkenen geheel nieuwe wijze van afdoening van verkeersovertredingen, de complexiteit van de regeling, de hoeveelheid op het formulier bijeengebrachte informatie en de bewoordingen waarin die informatie is vervat" (r.o. 5.2.1). Het is de Hoge Raad, blijkens r.o. 5.2.2, ambtshalve gebleken dat het verzuim placht voort te komen uit onvoldoende begrip van het bepaalde in art. 11 lid 1 WAHV (zekerheidstelling). Vervolgens overweegt de Hoge Raad dat degene die bij de kantonrechter wil opkomen tegen de beslissing van de officier van justitie hierin niet mag worden belemmerd door onbekendheid met de eisen die aan dit beroep zijn gesteld. Dit zou in strijd zijn met de aan de wet ten grondslag liggende doelstelling van het waarborgen van een deugdelijke rechtsbescherming van de betrokkenen. In dit verband 
wordt gewezen op administratieve rechtsgangen, waar in het algemeen geldt dat niet-ontvankelijkheid wegens het niet betalen van griffierechten eerst kan worden uitgesproken nadat de betrokkene op zijn verzuim is gewezen en in de gelegenheid is gesteld dit verzuim binnen een bepaalde termijn te herstellen (r.o. 5.3.4). Na deze overwegingen komt de Hoge Raad tot de slotsom dat beginselen van behoorlijk procesrecht met zich mee brengen dat de kantonrechter, die vaststelt dat niet aan de voorwaarde van zekerheidstelling is voldaan, de betrokkene wijst op zijn verzuim en de gevolgen daarvan en hem alsnog een termijn stelt tot voldoening van de vereiste zekerheid (r.o. 5.3.5). Eenzelfde uitspraak volgde in HR 15 juli 1993, NJB-katern 1994, pag. 50, nr. 8. Gelet op andere administratieve procedures kan deze termijn worden gesteld op dertig dagen na de dag van verzending van de in r.o. 5.3 .5 bedoelde mededeling.

In het vorig vermelde arrest (NJ 1992, 693) eiste de Hoge Raad dat de kantonrechter een termijn voor herstel van het verzuim van de zekerheidstelling moest geven indien hem was gebleken dat de betrokkene daarover geen mededeling door de officier van justitie was gedaan. In de laatste uitspraak eist de Hoge Raad dat steeds wanneer de betrokkene geen zekerheid heeft gesteld, een termijn van dertig dagen voor herstel dient te worden gegeven door de kantonrechter.

In twee latere arresten (HR 16 maart 1993, NJB-katern 1993, pag. 279-280, nr. 116 en HR 25 mei 1993, NJB-katern 1993, pag. 376, nr. 162) bepaalt de Hoge Raad dat de termijn tot zekerheidstelling van dertig dagen pas begint te lopen nadat de termijn van veertien dagen uit het eerste lid van art. 11 WAHV is verlopen, ongeacht of reeds eerder enige mededeling aan betrokkene is gedaan.

Hnewel de zekerheidstelling in de WAHV en het betalen van griffierechten in andere administratieve procedures niet helemaal te vergelijken $z i j n^{243}$, is het naar mijn mening toe te juichen dat de Hoge Raad de WAHV op dit punt heeft aangepast aan andere administratieve procedures. Het doel van de zekerheidstelling komt wel overeen met dat van het betalen van griffierecht: het opwerpen van een dam voor lichtvaardig beroep. De rechtspositie van betrokkenen stemt eveneens overeen. De Awb geeft een hersteltermijn van vier weken, art. 8:41 lid 2. Het ware mijns inziens beter geweest indien de Hoge Raad ook voor het herstel van het verzuim van de zekerheidstelling een termijn van vier weken, in plaats van dertig dagen, had gesteld, mede gelet op de andere 'termijnaanpassingen' in de WAHV aan de Awb (zie $\S$ 10.2).

Opgemerkt moet nog worden dat men bij deze arresten moet bedenken dat art. 7 WAHV nadien is veranderd (zie hierna $\$ 10$ ). Van art. 7 is 'slechts' de bepaling overgebleven dat de officier van justitie zo spoedig mogelijk op het beroep beslist. Voor de rest gelden de bepalingen van de Awb, waarbij het hier gaat om art. 6:23.

243 Zie daarover onder andere de conclusie van A-G Meijers bij HR 11 februari 1992, NJ 1992, 692; LJJ. Rogier, a.w., aant. 4 bij art. 11 WAHV. 
In HR 26 oktober 1993, NJB-katern 1994, pag. 97, nr. 33 stelde betrokkene dat het vereiste tot zekerheidstelling in strijd was zowel met art. 6 lid 1 EVRM (art. 14 lid 1 IVBP) als met art. 6 lid 2 EVRM (art. 14 lid 2 IVBP). De Hoge Raad nam voor wat betreft het eerste lid de redenering van de kantonrechter over. Deze oordeelde dat van strijd met het eerste lid geen sprake was omdat de wet de zekerheidstelling limiteert tot de hoogte van de in het betreffende geval opgelegde sanctie, terwijl bovendien de sanctie, ingevolge art. 2 lid 3 WAHV, de sanctie per gedraging nimmer op een hoger bedrag kan worden vastgesteld $\operatorname{dan} f 500$, zodat niet gesproken kan worden van een met genoemde verdragsbepalingen onverenigbare inbreuk op het recht op toegang tot de rechter. De Hoge Raad achtte evenmin strijd aanwezig met art. 6 lid 2 EVRM waarbij hij in aanmerking nam:

(a) dat de WAHV voorziet in een volledige toetsing van de beslissing van de officier van justitie door de kantonrechter, waarin begrepen is een onderzoek of de gedraging ter zake waarvan de administratieve sanctie is opgelegd, is verricht;

(b) dat daarbij aannemelijk moet worden gemaakt dat die gedraging ook daadwerkelijk heeft plaatsgevonden;

(c) dat in het geval de kantonrechter het beroep gegrond verklaart, het bedrag van de zekerheidstelling wordt terugbetaald.

In een uitspraak van HR 9 november 1993, NJB-katern 1994, pag. 97-98, nr. 35 bepaalde de Hoge Raad dat het vereiste tot stellen van zekerheid niet in strijd is met het vermoeden van onschuld zoals neergelegd in art. 6 lid 2 EVRM, omdat deze verplichting tot het stellen van zekerheid niet vooruit loopt op de door de rechter te beantwoorden vraag of een betrokkene een gedraging in de zin van de WAHV heeft verricht en beperkt evenmin de verdedigingsmogelijkheden waarover een betrokkene kan beschikken.

De zekerheidstelling is ingevoerd om lichtvaardig beroep op de kantonrechter te voorkomen. Echter, betrokkene dient wel een reële mogelijkheid te hebben om zekerheid te stellen. Uit het Eindrapport blijkt dat dit vanwege een aantal redenen niet het geval is. Het gaat dan om de termijn waarbinnen en de plaats waar zekerheid dient te worden gesteld. De termijn is door art. 11 lid 1 WAHV gesteld op 14 dagen па ontvangst van het beroepschrift. Deze wordt in het algemeen als onnodig kort beschouwd. Als plaats waar de zekerheid moet worden gesteld wijst de wet aan de griffie van het kantongerecht, art. 11 lid 1. Daar dient overgifte plaats te vinden. Dit kan problemen opleveren indien de betrokkene ver van die griffie woont. Het zou veel gemakkelijker zijn als de betrokkene het geld naar de betreffende griffie zou kunnen overmaken, hetgeen in een arrest van HR 16 maart 1993, NJB-katern 1993, pag. 288, nr. 119, gezien werd als een juiste wijze van zekerheidstelling. Zijn ter zekerheidstelling cheques aangeboden, dan mogen deze aanstonds worden verzilverd (HR 2 november 1993, NJB-katern 1994, pag. 97, nr. 34). De Hoge Raad heeft inmiddels bepaald dat aan de zekerheidstelling ook is voldaan door middel van 
betaling van de sanctie aan het CJIB. In de zaak van HR 25 februari 1992, NJ 1992, 694 (m.nt. C. onder NJ 1992, 692) was betrokkene door de kantonrechter niet ontvankelijk verklaard in zijn beroep, omdat geen zekerheid was gesteld binnen de termijn van art. 11 lid 1 WAHV. Wel had betrokkene inmiddels de sanctie voldaan. Hij voerde als bezwaar aan dat de overtreding ten onrechte op zijn naam bleef staan, daar zijn zoon (die op hetzelfde adres woont) de overtreding heeft begaan. Volgens de Hoge Raad brengt redelijke wetstoepassing mee dat is aan te nemen dat, door betaling binnen de termijn van art. 11 lid 1 WAHV van het volledige bedrag van de sanctie, aan de verplichting tot zekerheidstelling is voldaan. Dit impliceert dus dat door betaling van de sanctie het recht op beroep niet verloren is gegaan.

Een andere omstandigheid die tot niet-ontvankelijkheid kan leiden is het te laat instellen van beroep op de kantonrechter. In het arrest van HR 3 maart 1992, NJ 1992, 696 (m.nt. C. onder NJ 1992, 692) was betrokkene door de kantonrechter niet ontvankelijk verklaard in zijn beroep omdat het beroep niet was ingesteld binnen dertig dagen na de dag van verzending van de beslissing van de officier van justitie. De Hoge Raad merkt op dat de aanvangsdatum van deze termijn niet is vast te stellen. De beslissing van de officier van justitie wordt vermeld op het CJB-formulier, terwijl op dit formulier een datum van verzending ontbreekt. Dit formulier zal in deze zin moeten worden aangepast.

De Hoge Raad casseert de uitspraak van de kantonrechter echter om een andere reden. Uit de artt. 11 lid 1 en 2, 12 lid 1 en 13 lid 1 WAHV volgt dat de vraag of het beroep op de kantonrechter ontvankelijk is, moet worden beoordeeld naar aanleiding van een onderzoek ter terechtzitting, behalve als de niet-ontvankelijkheid voortvloeit uit het niet tijdig stellen van zekerheid. De betrokkene moet ten aanzien van de voorvragen ter zitting verweer kunnen voeren. Niet was gebleken of er wel een zitting had plaatsgevonden, daar de stukken daaromtrent ontbraken zodat het er in cassatie voor werd gehouden dat deze stukken niet bestaan. Deze uitspraak komt er dus op neer dat de kantonrechter ter zitting moet onderzoeken waarom het beroep te laat is ingesteld. Dit kan heel vervelend zijn voor de betrokkene die ter zitting verschijnt en voornemens is daar zijn inhoudelijk verweer te voeren. Voordat hij zijn voornemen ten uitvoer kan leggen wordt hij niet-ontvankelijk verklaard omdat hij geen disculpatie heeft voor de termijnoverschrijding.

Volgens art. 9 lid 1 WAHV kan degene die beroep heeft ingesteld bij de officier van justitie beroep instellen bij de kantonrechter. Soms echter ging iemand anders in beroep bij de kantonrechter dan degene tot wie de oorspronkelijke beschikking of de beschikking van de officier van justitie was gericht. Dit speelde voornamelijk in de bedrijfsmatige sfeer. Dit was het geval in het arrest van HR 25 februari 1992, NJ 1992, 695 (m.nt. C. onder NJ 1992, 692). De sanctie is opgelegd aan een leasemaatschappij. Het beroep op de officier van justitie, het kantongerecht en de Hoge Raad wordt ingesteld door S. De officier van justitie verklaart het beroep ongegrond. De kantonrechter verklaart het beroep niet ontvankelijk omdat $S$. niet degene is 
tegen wie de beslissing van de officier van justitie is gericht. Deze uitspraak is volgens de Hoge Raad onjuist. Tot $\mathbf{S}$. was wel de beslissing van de officier van justitie gericht, maar deze had op grond van art. 6 WAHV geen beroep op de officier kunnen instellen, omdat dat alleen maar kan door degene tot wie de beschikking is gericht, i.c. de leasemaatschappij. De Hoge Raad redeneert nu als volgt: de beslissing van de officier van justitie, gegeven op het beroep van een ander dan degene tot wie de beschikking zich richt, is niet een beslissing als bedoeld in art. 9 WAHV waartegen beroep is opengesteld bij de kantonrechter. Hieruit volgt dat $\mathrm{S}$. terecht niet ontvankelijk is verklaard in zijn beroep op de kantonrechter. Hiermee blijft een probleem bestaan. Stel: sanctie opgelegd aan bedrijf $Y$ voor een gedraging gepleegd door $X$, werknemer. Kenteken staat op naam van bedrijf $Y$. Bedrijf $Y$ houdt sanctie in op loon werknemer $\mathrm{X}^{2+4}$ en gaat zelf niet in beroep. Werknemer kan niet in beroep, omdat hij niet degene is aan wie de sanctie is opgelegd.

Ik meen dat dit probleem zou kunnen worden opgelost door het 'belanghebbendecriterium', zoals de Awb dit kent in art. 8:1245, ook in de WAHV te hanteren. Als belanghebbende kan worden aangemerkt degene die rechtstreeks bij een besluit is betrokken, art. 1:2 lid 1 Awb. Volgens Tak gaat het hierbij om een persoonlijk, individueel, rechtstreeks belang van betrokkene. ${ }^{2+6}$

In een arrest van HR 20 april 1993, NJB-katern 1993, pag. 326, nr. 146, was de zaak, na het instellen van beroep bij de officier van justitie, bij de kantonrechter terecht gekomen. Deze verklaarde betrokkene niet-ontvankelijk omdat de officier van justitie nog niet had beslist. Volgens de Hoge Raad had de kantonrechter, in plaats van de niet-ontvankelijkheid, moeten bevelen de stukken door te sturen aan de officier van justitie. Deze uitspraak illustreert dat ook op dit punt er overeenstemming dient te bestaan met het bestuursrecht (art. 6:15 Awb).

\subsection{Gronden voor beroep}

In art. 9 WAHV worden de gronden genoemd waarop beroep op de kantonrechter kan worden ingesteld.

In het Eindrapport werd de vraag gesteld, of de in art. 9 genoemde beroeps- c.q. toetsingsgronden niet zouden kunnen vervallen, daar de MvT uitging van een volledige toetsing door de rechter. In de praktijk bleken de kantonrechters verschillend met de beroepsgronden om te gaan. Sommigen hielden zich er strikt aan, anderen waren soepeler.

Als een gebrek van de WAHV werd genoemd het ontbreken van een beruepsmogelijkheid van een betrokkene indien hij door de officier van justitie niet-ontvankelijk

244 Het Eindrapport vermeldt twee maal abusicvelijk 'werkgevers', pag. 86 (deel I) en 185 (deel II). 245 Art. 8:1 Awb is op nict op de kantonrechter in de WAHV van toepassing, omdat art. 8:1 uitsluitend spreckt over berocp bij de rechtbank.

246 A.Q.C. Tak, Algemene wet bestuursrecht, het nieuwe bestuursprocesrecht, Zwolle 1093, pag. 113. 
werd verklaard. Kan de kantonrechter deze beslissing van het OM toetsen? Uit het Eindrapport blijkt dat verschillende kantonrechters dit deden.

Mijns inziens is deze werkwijze terecht en moet zij geformaliseerd worden. Het gevolg hiervan moet zijn dat de beschikking van de officier van justitie waanin de betrokkene niet-ontvankelijk wordt verklaard, deze moet wijzen op zijn beroepsmogelijkheid op de kantonrechter.

\subsection{Zitting en uitspraak van de kantonrechter}

Tussen de zittingen van de verschillende kantongerechten bleken verschillen in sfeer te bestaan. Ging het er in het ene kantongerecht tamelijk informeel aan toe, in een andere zittingsplaats was de gang van zaken formeler.

Op grond van art. 6 EVRM moet iedere terechtzitting openbaar zijn. Art. 12 lid 1 WAHV resp. art. 13 lid 3 WAHV bepalen dat in het proces-verbaal van de zitting aantekening wordt gemaakt van de beslissing respectievelijk de gronden waarop de beslissing rust. Volgens de Hoge Raad betekent dit van iedere zitting een procesverbaal dient te worden opgemaakt. Wanneer dit niet gebeurt of er blijkt niet uit dat de terechtzitting in het openbaar plaatsvond leidt dit tot nietigheid van de uitspraak van de kantonrechter (HR 29 september 1992, NJ 1993, 31; HR 9 februari 1993, NJB-katern 1993, pag.179, nr. 72; HR 18 mei 1993, NJB-katern 1993, pag. 359, nr. 159).

De ene kantonrechter deed meteen uitspraak, terwijl anderen dat na veertien dagen deden.

Vermeldenswaard is het gegeven dat twee maal een uitspraak is gedaan waarbij een voorwaardelijke sanctie werd opgelegd, hetgeen door de WAHV is uitgesloten (art. 2 lid 1).

Ten aanzien van de terugbetaling van de zekerheidstelling bleek bij de in het gelijk gestelde betrokkenen soms onzekerheid te bestaan. Sommigen vonden dat ze te lang daarop moesten wachten. Men eiste middels een brief het bedrag terug bij de griffie van het kantongerecht waar men de zekerheid immers ook had betaald. In praktijk werd de terugbetaling echter verzorgd door het CJIB. Een verwarrende situatie.

Tot zover de onderzoeksresultaten van de 'eerste fase' van de WAHV. Daarmee bedoel ik de fase voor de executie. Deze is dus in het overgrote deel van de zaken kort en eindigt, wanneer geen beroep wordt ingesteld, na het verlopen van de beroepstermijn op de officier van justitie. In de zaken waarin wel beroep wordt ingesteld eindigt de eerste fase na het onherroepelijk worden van de beslissing c.q. uitspraak van de beroepsinstanties. Hiermee zijn we beland bij de executie van de administratieve sanctie. 


\subsubsection{Executie van de administratieve sanctie}

Indien de betrokkene niet heeft betaald binnen de daarvoor gestelde termijn van acht weken wordt de sanctie van rechtswege met $25 \%$ verhoogd. Deze betalingsverplichting ontstaat nadat de officier van justitie (namens hem het CJBB) een aanmaning heeft verzonden. Een termijn hiervoor noemt de wet niet. In de praktijk houdt het CJIB aan 7 dagen na het verlopen van de acht weken-termijn. De Nationale Ombudsman vindt dit te kort en acht 20 dagen acceptabel, NO 4 september 1992, AB 1992, 620 m.nt. P.J. Stolk.

De betrokkene heeft dan dertig dagen om de boete plus verhoging te betalen, te rekenen vanaf het moment van verzending van de aanmaning. Betaalt de betrokkene dan nog niet, dan ontstaan er twee rechtsgevolgen: het sanctiebedrag wordt verhoogd met $50 \%$ en de officier van justitie krijgt de mogelijkheid tot het nemen van verhaal. Wordt de boete te laat betaald, maar wel binnen de in de aanmaning genoemde termijn $n^{247}$ dan zou dat bij strikte naleving van de wet betekenen dat de tweede verhoging berekend wordt over het hele bedrag (sanctiebedrag plus verhoging). De Hoge Raad ging dit te ver en was van mening dat de tweede verhoging berekend moest worden over het bedrag dat nog open stond, dus niet over het reeds betaalde bedrag, HR 18 mei 1993, NJ 1993, 698.

Het verhaal kan worden genomen op goederen, inkomsten of vermogen van de betrokkene, al of niet met een dwangbevel. Bij verhaal op goederen is een dwangbevel vereist, bij verhaal op inkomsten en tegoeden niet. Het verhaal op goederen verloopt via de deurwaarder. Uit het Eindrapport blijkt dat uitsluitend gebruik wordt gemaakt van verhaal via het dwangbevel met inschakeling van de deurwaarder. Hiervoor is gekozen omdat dit een vast omschreven incassotraject is, dat de minste kosten opleverde. Verhaal zonder dwangbevel was duurder en bovendien beschikt men niet over de rekeningnummers van alle betrokkenen. Het toepassen van de twee verhaalsvormen naast elkaar werd onwenselijk geacht. Het CJIB verzond de dwangbevelen aan de gerechtsdeurwaarders.

Uit het Eindrapport bleek dat mensen zich tot het Bureau voor rechtshulp wenden uitsluitend voor problemen die betrekking hebben op dit incassotraject: het innen van de sanctie, het nemen van verhaal en het leggen van beslag. Het kwam voor dat mensen door de komst van de deurwaarder voor het eerst werden geconfronteerd met een betalingsverplichting. Ook waren er betrokkenen die reeds betaald hadden, maar dit te laat gedaan hadden. Op zich is het volgens mij niet zo verbazingwekkend dat mensen, die niet in beroep zijn gegaan, pas wanneer het op betalen aankomt in aktie komen. Ook in de strafprocedure was er een groep die alle fasen aan zich 
voorbij liet gaan en pas wanneer tot executie werd overgegaan met de sanctie werden geconfronteerd. 248

Tegen de tenuitvoerlegging van het dwangbevel kan de betrokkene in verzet komen bijde kantonrechter middels indiening van een bezwaarschrift. Uit het Eindrapport blijkt de verzetprocedure tegen de tenuitvoerlegging van het dwangbevel ex art. 26 WAHV met betrekking tot de werklastvermindering voor veel kantonrechters een grote tegenvaller te zijn (pag. 103). Het aantal bezwaarschriften was groter dan verwacht en de verzetzaken brachten veel werk met zich mee, meer dan de beroepszaken. In de voorbereiding van de WAHV was volgens de kantonrechters aan deze procedure veel minder aandacht geschonken. Ik denk dat gesteld mag worden dat in de hele discussie rond de totstandkoming van de WAHV de meeste aandacht is uitgegaan naar de eerste fase (beroep op officier van justitie en kantonrechter) en niet naar het incassotraject. Wellicht was de reden daarvoor dat dit laatste niet echt 'nieuw' was ten opzichte van de strafrechtelijke afdoening, de regeling werd immers bijna letterlijk overgenomen uit het WvSv, artt. 575 en 576 . Nieuw ten opzichte van de strafrechtelijke procedure is wel, dat in de WAHV van deze verhaalsmogelijkheid waarschijnlijk meer gebruik zal (moeten) worden gemaakt, omdat het strafproces uiteindelijk nog het dwangmiddel van vervangende hechtenis achter de hand had. Uit onderzoek blijkt dat het dreigen met deze vervangende hechtenis de betrokkene tot betaling van de boete deed overgaan. ${ }^{2+9}$

De vraag die zich volgens het Eindrapport in de praktijk voordeed was, waartegen het verzet zich precies kan richten. De wet noemt namelijk geen toetsingsgronden. In het algemeen werd aangenomen dat het verzet zich niet kon richten tegen de oorspronkelijke beschikking waarbij de sanctie werd opgelegd, aldus art. 26 lid 3 WAHV en art. 27 lid 6 WAHV. Dit heeft als uiterste consequentie dat iemand die in het geheel niet betrokken is geweest bij een overtreding een aanzienlijk bedrag moet betalen. De WAHV gaat ervan uit dat degene die onterecht een sanctie kreeg opgelegd de kans heeft gehad daartegen zelf in beroep te gaan. Dit kan echter vanwege een aantal redenen niet gebeurd zijn, bijvoorbeeld als de betrokkenen door de komst van de deurwaarder voor het eerst geconfronteerd waren met een betalingsverplichting van hetzij het sanctiebedrag, hetzij de verhogingen, hetzij de incassokosten. Het kan dan onder meer gaan over de vraag wie er moet zorgen voor een juiste adresvermelding in het kentekenregister, de burger of de overheid (HR 15 juli 1993, NJB-katern 1994, pag. 75-76, nr. 16 en HR 26 oktober 1993, NJB-katern 1994, pag. 76-77, nr. 18: betrokkene is niet verplicht zijn adreswijziging door te geven aan de Rijksdienst voor het Wegverkeer, hierdoor kan hij niet op de grond dat hij de adreswijziging niet heeft doorgegeven het risico dragen van de omstandigheid dat een

248 Vgl. C. Cozijn, De executie van de geldboete, Een onderzoek onder wanbetalers, WODC Den Haag, 1987.

249 Vgl. C. Cozijn, De executie van de geldboete, Een onderzock onder wanbetalers, WODC Den Haag, 1987. 
beschikking hem niet heeft bereikt) en over de vraag op wie het bewijs rust dat de beschikking niet is ontvangen. Volgens het Eindrapport werd hierover zeer verschillend geoordeeld (pag. 112 e.v.). Sommige kantonrechters hadden hier moeite mee. Men zag twee oplossingen: aangenomen kan worden dat de officier van justitie de mogelijkheid heeft de sanctie alsnog in te trekken door de betrokkene in beroep te laten gaan bij de officier van justitie die dan het beroep op de hardheidsclausule, art. 6 lid 1 WAHV (betrokkene kon niet eerder in beroep) moest honoreren, of: het creëren van een wettelijke bevoegdheid voor de officier van justitie om in apent onredelijke zaken alsnog te kunnen ingrijpen om executie van de sanctie te voorkomen. Van dit laatste ben ik geen voorstander, omdat volgens mij niet in het systeem van de wet past. De opzet was juist dit soort zaken te voorkomen. Bovendien zal iedereen zijn sanctie 'apert onredelijk' vinden. De eerste optie lijkt mij zo slecht nog niet. In de praktijk blijkt het bijvoorbeeld voor te komen dat een politie-ambtenaar zegt de sanctie te zullen intrekken, dit gebeurt vervolgens om onduidelijke reden niet, de betrokkene ontvangt de beschikking van het CJIB maar denkt dat de toezegging van de politie-ambtenaar hem ontheft van de verplichting om te betalen of in beroep te gaan. Hij denkt dat de zaak is afgehandeld, totdat hij met de deurwaarder wordt geconfronteerd.

De Hoge Raad heeft zich hierover inmiddels uitgelaten. In HR 10 november 1992, NJ 1993, 181 m.nt. MS (RvdW 1992, 251) was (onder meer) de vraag op wie (het bestuursorgaan dat de sanctie oplegt of de betrokkene) de bewijslast rust, indien de betrokkene stelt dat hij de beschikking waarbij de sanctie was opgelegd niet heeft ontvangen. Pas door middel van het dwanghevel werd hij, naar zijn zeggen, met het bestaan van de hem opgelegde sanctie geconfronteerd. Tegen dit dwangbevel tekende betrokkene verzet aan bij de kantonrechter (art. 26 WAHV), die dit verzet gegrond verklaarde, daarbij onder meer overwegende dat van een betrokkene niet kan worden gevergd aannemelijk te maken dat hij de beschikking niet heeft ontvangen. Van de zijde van het $O M$ werd het zaakoverzicht van het CJIB getoond met de aantekening "Initiële beschikking: Datum actief 30 oktober 1990". Dit achtte de kantonrechter onvoldoende rechtvaardiging voor toezending van de beschikking aan de betrokkene. De Hoge Raad overweegt dat op de aan betrokkene toekomende waarborgen van art. 6 EVRM een ontoelaatbare inbreuk zou worden gemaakt, evenals aan de strekking van art. 6 lid 3 WAHV zou worden tekort gedaan, indien, in geval de betrokkene stelt dat hij de inleidende beschikking niet heeft ontvangen omdat de per post toegezonden beschikking hem niet heeft bereikt en hem daarvan geen verwijt kan worden gemaakt, de last die stelling aannemelijk te maken op de betrokkene wordt gelegd. In een zodanig geval zal, indien geen zekerheid valt te verkrijgen omtrent de onjuistheid van hetgeen door de betrokkene is gesteld, van de juistheid daarvan moeten worden uitgegaan (r.o. 5.5). Dit had in deze zaak tot gevolg dat de beschikking niet onherroepelijk was geworden en dat betrokkene alsnog beroep op de officier van justitie openstaat tegen de inleidende beschikking.

De A-G Meijers en annotator Scheltema wijzen er in hun conclusie, respectievelijk noot op dat in het bestuursrecht meestal geldt dat het risico van het niet aankomen 
van niet-aangetekende stukken voor rekening van de afzender komt. Dit gaat in ieder geval op wanneer het om sanctie-oplegging gaat. In die richting gaat ook de jurisprudentie van de belastingkamer van de Hoge Raad. Ware dit namelijk niet zo, dan zou er strijd ontstaan met art. 6 EVRM. ${ }^{20}$ Scheltema merkt op dat dit, gezien de doelstellingen van de WAHV, geen ideaal systeem is, maar dat, indien gekozen wordt voor de administratieve weg, ook aangesloten moet worden bij regels die op dat gebied gelden. Een stelling die ik reeds vaker heb verdedigd. Uit het arrest volgt dat de rechter nader onderzoek moet instellen indien gesteld wordt dat de beschikking niet is aangekomen. Deze stelling zal moet worden verworpen indien blijkt dat de beschikking wel is aangekomen of het niet-aankomen het gevolg is van omstandigheden die te wijten zijn aan gedrag van betrokkene. Zoals hierboven is vermeld, is het niet doorgeven van een adreswijziging aan de Rijksdienst voor het Wegverkeer niet als een dergelijke omstandigheid te beschouwen.

In een later arrest wordt gesteld dat de betrokkene om zijn verweer aannemelijk te maken ook zelf gegevens moet aandragen. De Hoge Raad vindt de enkele ontkenning dat hij niets heeft ontvangen niet voldoende, HR 15 juli 1993, DD 94.002 en HR 26 oktober 1993, DD 94.074.

Art. 6:11 Awb gaat naar mijn idee verder dan de Hoge Raad. Het artikel bepaalt dat niet-ontvankelijkheid slechts achterwege blijft indien redelijkerwijs niet kan worden geoordeeld dat de indiener in verzuim is geweest. Ik kan me voorstellen dat het niet doorgeven van een adreswijziging aan de Rijksdienst voor het Wegverkeer binnen een dergelijke als een verzuim van betrokkene zou worden beschouwd. ${ }^{2 n}$

Aan deze problematiek kan een einde worden gemaakt door in de WAHV op te nemen dat beschikkingen via aangetekende post worden verstuurd. ${ }^{252}$

In de meeste uitspraken waarbij het verzet gegrond werd bevonden werd het dwangbevel vernietigd.

Kantonrechters gingen verschillend om met de vraag of een oordeel over de rechtmatigheid van de tenuitvoerlegging van het dwangbevel ook inhield dat een oordeel kon worden gegeven over de rechtmatigheid van de opgelegde verhogingen. Met

250 HR 22 juni 1988, BNB 1988/292. De Hoge Raad overwong dat toepassing van de hezwaar- en beroepstermijnen uit de AWR in strijd komt met art. 6 EVRM wanneer een termijnoverschrijding veroorzaakt wordt door een omstandigheid die de belastingplichtige niet kan worden toegerekend.

251 De oorspronkelijke tekst van art. 6:11 was overeenkomstig de jurisprudentie. Deze is gewijzigd bij de ecrste Nota van Wijzigingen, TK 1990-1992, 21221, nr. 6. Zie voor de toelichting hierbij pag. 6-7.

252 Zie over deze problematiek in het belastingrecht: J.W.C. Feteris, Fiscalc administratieve sancties en het recht op ecn eerlijk proces. Dissertatic UvA. Deventer 1993, pag. 371-374. 
betrekking tot deze verhogingen werd verschillend gedacht over de kwestie of betrokkene al dan niet tijdig had betaald.

De beslissing van de officier van justitie om verhaal met dwangbevel toe te passen met inschakeling van de deurwaarder in plaats van verhaal zonder dwangbevel is volgens verschillende kantonrechters toetsbaar. Een voorbeeld van een dergelijke uitspraak: Kantongerecht Zwolle van 1 april 1992, NJ 1992, 807. Voor het nemen van verhaal beschikt het OM over twee middelen te weten het dwangbevel (art. 26 WAHV) en het derdenbeslag (art. 27 WAHV). De kantonrechter overwoog dat de keuze voor de een of andere wijze van verhaal een beschikking is die in het kader van het administratief beroep door de rechter kan worden getoetst. In HR 26 oktober 1993, NJB-katern 1994, pag. 76, nr. 17 gaf de Hoge Raad als zijn oordeel dat de vraag of de inning van de administratieve boete wel of niet krachtens dwangbevel in het algemeen aan de officier van justitie is voorbehouden. Deze beleidsvrijheid brengt met zich mee, zo vervolgt de Hoge Raad, dat de juistheid van een zodanige beslissing in het algemeen niet door de rechter kan worden getoetst, behoudens in het geval dat zich strijd voordoet met beginselen van behoorlijk bestuur. In casu was dit het geval. Het ging om een niet betaalde tweede verhoging van $f 25$ (de oorspronkelijke sanctie en de eerste verhoging waren wel voldaan). De omstandigheid dat betrokkene de oorspronkelijke sanctie plus de eerste verhoging wel had voldaan en het geringe bedrag waarvoor verhaal krachtens dwangbevel was genomen in samenhang met de hoge kosten die daaraan voor de betrokkene zijn verbonden, wijst op een onredelijke belangenafweging.

Een probleem deed zich voor met betrekking tot de incassokosten. Uit het Eindrapport kwam naar voren dat de meeste kantonrechters van mening waren dat de op het dwangbevel vermelde $15 \%$ incassokosten niet door betrokkenen betaald behoefden te worden.

In het arrest van HR 8 juli 1992, NJ 1993, 180 m.nt. MS (RvdW 1992, 191) speelden er twee kwesties: het verhaal van invorderingskosten en de regeling van het griffierecht, waaraan hierna aandacht zal worden besteed. In het kort even de feiten. Betrokkene heeft een opgelegde sanctie, waartegen hij geen beroep had ingesteld, niet tijdig betaald, walrna twee keer een verhoging volgt. Uiteindelijk betaalt hij de eerste sanctie plus de eerste verhoging. De tweede verhoging blijft onbetaald, zodat de officier van justitie een dwangbevel uitvaardigt. In het dwangbevel wordt bevolen dat zal worden verhaald het sanctiebedrag, de kosten van betekening alsmede de invorderingskosten. Tegen dit laatste werd door betrokkene verzet ingesteld bij de kantonrechter. De Hoge Raad overweegt: met de kosten van verhaal krachtens art. 26 lid 5 WAHV kan alleen zijn bedoeld de kosten van de eigenlijke tenuitvoerlegging van het dwangbevel, dat wil zeggen de kosten verbonden aan toepassing van art. $430 \mathrm{Rv}$ (r.o. 5.1.2). De gevolgen van niet- betaling zijn geregeld in art. 23 en art. 25 lid 1 WAHV. Noch aan art. 26 noch aan enige andere bepaling kan de officier 
van justitie de bevoegdheid ontlenen een dwangbevel uit te vaardigen voor een hoger bedrag dan wordt gevormd door de som van de oorspronkelijke sanctie en de daarop toegepaste verhogingen (r.o. 5.1.3).

Deze uitspraak van de Hoge Raad zal aan betekenis verliezen na invoering van een wijziging van art. 26 lid 5, waaraan zal worden toegevoegd dat alle kosten van de invordering, alsmede een redelijk deel van de door de gerechtsdeurwaarder ter maken incassokosten, onder de kosten van het verhaal mogen worden begrepen.

In hetzelfde arrest werd uitspraak gedaan over de terugbetaling van het griffierecht. De kantonrechter, het verzet gegrond verklarende, bepaalt dat het voldane griffierecht door de griffier van het kantongerecht zal worden terugbetaald. De Hoge Raad gaat ervan uit dat uit art. 36 WAHV volgt dat bij indiening van een verzetschrift de betrokkene griffierecht is verschuldigd. Verder regelt de WAHV omtrent de griffierechten niets. Daarvoor verwijst de Hoge Raad naar het bestuursrecht (hij verwijst naar de Wet AROB, terwijl volgens annotator Scheltema de regels omtrent het griffierecht te vinden zijn in de Wet RvS) en past de daar geldende regels over griffierecht toe op de WAHV. Dit betekent onder meer dat de verschuldigdheid van griffierecht vervalt indien het verzet geheel of gedeeltelijk (zoals in deze zaak het geval is) wordt gegrond verklaard. Scheltema wijst erop dat het in het bestuursrecht thans niet meer $z 0$ is dat het griffierecht in bepaalde gevallen wordt teruggegeven: het moet door het in het ongelijk gestelde bestuursorgaan worden vergoed. Voor de WAHV zou dit dan als consequentie hebben dat de officier van justitie het griffierecht aan betrokkene moet vergoeden. De kantonrechter had dit ook al gesignaleerd, maar wilde, gezien de door de WAHV gestelde doeleinden van eenvoud en doelmatigheid, dit gevolg er niet aan verbinden.

$\mathrm{lk}$ zie niet in waarom voor het $\mathrm{OM}$ in deze een andere regeling zou gelden dan voor andere bestuursorganen. Ik kan mij er goed in vinden dat de Hoge Raad aansluit bij bestuursrechtelijke regels. Als de handhaving van verkeersvoorschriften voortaan op een bestuursrechtelijke wijze verloopt, zal ook de executie van de sancties op die manier moeten geschieden.

Wanneer aanmaningen en verhaal niet tot volledige betaling hebben geleid, staat de officier van justitie de mogelijkheid open de kantonrechter machtiging te vragen dwangmiddelen toe te passen.

Jurisprudentie over dwangmiddelen is (nog) niet gepubliceerd. Recent verscheen een onderzoeksverslag, maar hieruit kunnen nog geen definitieve conclusies worden getrokken, omdat het nog voorlopig was. ${ }^{23}$

253 Zie over dit onderzoek: L.J.J. Rogier en N.M. Dame, De vitoefening van bevoegdheden in het dwangtraject van de Wet Mulder, Trema, februari 1994. 
In het juridisch deelonderzoek is niet specifiek gevraagd naar de mening van de betrokkene (degene die de sanctie krijgt opgelegd) over het functioneren. Wel zijn een paar knelpunten gesignaleerd met betrekking tot de positie van de betrokkene in de uitvoering van de WAHV.

In het algemeen werden er weinig principiële bezwaren naar voren gebracht. Op een aantal specifieke punten was men ontevreden. Dit was met name het geval met betrekking tot de zekerheidstelling (van de zaken die voorgelegd werden aan de Hoge Raad maakten de bezwaren over de zekerheidstelling een relatief groot aantal uit). Verder was er een aantal betrokkenen dat zich schikte in het oordeel van de officier van justitie of rechter maar die het (op onderdelen) niet eens waren met de gang van zaken.

Sommige verhuurbedrijven bleken nog niet goed op de hoogte van de veranderingen. Sommige betrokkenen waren het niet eens met de aansprakelijkheid op grond van registratie in het kentekenregister (zie bijvoorbeeld HR 2 maart 1993, NJB-katern 13 mei 1993, pag. 248, nr. 98; HR 26 oktober 1993, NJB-katern 1994, pag. 77, nr. 20).

\section{De WAHV en de Algemene wet bestuursrecht}

\subsection{Inleiding}

Tijdens en na de totstandkoming van de WAHV vonden er grote ontwikkelingen plaats in het bestuursrecht. Getracht werd (en wordt nog steeds) te komen tot codificatie en unificatie van het bestuursrecht en bestuursprocesrecht in een Algemene wet bestuursrecht (Awb). ${ }^{24}$ De eerste tranche van de Awb is ingevoerd op 1 januari 1994. Deze invoering was eerder gepland, maar was afhankelijk van invoering van de tweede tranche, die men tegelijkertijd wilde laten plaatsvinden. ${ }^{255} \mathrm{De} A w b$ is afgekondigd in het Stb. 1993, 650.

De afdoening van een aantal verkeersvoorschriften vindt, na invoering van de WAHV, op een administratiefrechtelijke wijze plaats. In deze wet treedt het $\mathrm{OM}$ op als een bestuursorgaan. Ook in de toelichting bij art. 1:6 Awb worden opsporingsambtenaren, OM en minister van Justitie uitdrukkelijk als bestuursorgaan gekwalificeerd. ${ }^{2 \star}$ Dit

254 Zie daarover uitgebreider: Hoofdstuk 9 Bestuursrechtelijke normen.

255 De tweede tranche bevat Wijziging van de gerechtelijke organisatie, de Algemene wet bestuursrecht, de Wet op de Raad van State, de Beroepswet, de Ambtenarenwet $1929 \mathrm{cn}$ andere wetten, alsmede de intrekking van de Wet administratieve rechtspraak overheidsbeschikkingen (voltooiing eerste fase herziening rechterlijke organisatie) TK 1991-1992, 22495). Zie over gelijktijdige invoering: TK 1991-1992, 22495, nr. 3, pag. 12.

256 MvT Awb 21221, pag. 42. 
impliceert voor de WAHV dat de procedure ter administratieve afdoening in beginsel moet voldoen aan de voorschriften die de Awb aan administratieve handhaving stelt. $^{25}$

Dit bleek niet steeds het geval te zijn, zodat aanpassingen noodzakelijk waren. Deze zijn in aparte aanpassingswetten opgenomen. ${ }^{28}$ Deze wetten zijn tegelijkertijd met de eerste tranche van de Awb in werking getreden.

Zoals gezegd is intussen is ook de wet Voltooiing eerste fase herziening rechterlijke organisatie (de tweede tranche van de Awb) ingevoerd. Deze wet bevat onder andere een regeling voor geïntegreerde bestuursrechtspraak en de eigenlijke procesregeling van de nieuw gevormde administratieve kamers van de rechtbanken. Deze tweede tranche heeft vooralsnog geen gevolgen voor de WAHV in die zin dat de rechtbank de bevoegde instantie zou worden. ${ }^{250}$ Het is wel de bedoeling dat dit uiteindelijk, na de integratie van de kantongerechten en de rechtbanken, het geval zal zijn. ${ }^{20}$ Deze wet is overigens niet helemaal zonder betekenis voor de WAHV. In hoofdstuk 2(het hoofdstuk betreffende de Awb) wordt namelijk bepaald dat art. 1:4 lid 2 Awb wordt aangevuld in die zin dat de kantonrechter, rechtsprekende instantie in de WAHV, als administratieve rechter wordt aangemerkt. Hierop kom ik nog terug bij de bespreking van de wijziging van art. 9 WAHV.

Hieronder zal ik ingaan op de belangrijkste veranderingen die de Awb met zich heeft meegebracht voor de WAHV. Hierbij beperk ik mij tot aanpassingen die verband houden met de rechtspositie van de betrokkene. ${ }^{201}$

257 Deze kwestie behandelde ik in mijn bijdrage Toelsing van de Wet administratiefrechtelijke handhaving verkeersvoorschriften aan het wetsvoorstel Algemene wel bestuursrecht, NTB 1990/afl. 5, pag. 139-145. Zie verder: D. Allewijn, De bestuursrechtelijke toetsing in de Wet Mulder, in: De Wet Mulder in perspectief: van strafrecht naar bestuursrecht/ red. H. de Doelder, LJ J. Rogier, P.M. van Russen Groen, Arnhem 1990, pag. 67-76; L.J J. Rogier, Administratiefrechtelijk beroep op de kantonrechter, NJB 1990, afl. 12, pag. 452-455; Hugo Pennarts, Lex Mulder: van strafrecht naar bestuursrecht, Rechtshulp 1990, no.6/7, pag. 11-14; de noten van M. Scheltema onder HR 8 juli 1992, NJ 1993, 180 en HR 10 november 1992, NJ 1993, 181.

258 Wet van 4 juni 1992 houdende aanpassing van een aantal wetten aan de eerste tranche van de Algemene wet bestuursrecht, Stb. 1992, 422. Wet van 23 december 1993 tot wijziging van de Algemene wet bestuursrecht alsmede nadere aanpassing van een aantal wetten aan de Algemene wet bestuursrecht (Aanpassingswet Awb III), Stb. 1993, 690.

259 Zie art. 8.1.1.6 en Bijlage bij de Awb, onderdeel A.2.

260 TK 1991-1992, 22495, nr. 3, pag. 13.

261 Aanpassing bijvoorbecld van art. 3 lid 3 ter zake van het toezicht van de officier van justitie op de wijze waarop de bevoegde ambtenaren van hun bevoegdheid gebruik maken, blijft hier buiten bespreking. Zie daarover : LJJ. Rogier, De Wet Mulder, Artikelgewijs commentaar op de Wet administratiefrechtelijke handhaving verkeersvoorschriften, tweede druk, Arnhem 1992, pag. 34. 


\subsection{Aanpassing van de WAHV aan de Awb}

In art. 4 lid 1 WAHV vervalt het vereiste van de schriftelijkheid van de beschikking. Volgens de MvT bij Aanpassingswet I kan de vermelding van het schriftelijkheidsvereiste vervallen, gezien de begripsbepaling in de Awb. ${ }^{202}$ Bedoeld wordt dat de Awb de beschikking omschrijft als een besluit dat niet van algemene strekking is, terwijl het besluit wordt omschreven als een schriftelijke beslissing van een bestuursorgaan. Handhaving in de WAHV van het schriftelijkheidsvereiste van de beschikking zou dubbelop zijn. Met andere woorden: de term 'beschikking' impliceert reeds het vereiste van schriftelijkheid.

De belangrijkste wijziging van art. 4 betreft lid 2 inzake de aankondiging en bekendmaking van de beschikking. De gedetailleerde regeling van art. 4 lid 2 (oud) wordt in overeenstemming gebracht met de terminologie van de Awb. Tevens wordt aangegeven wanneer en op welke wijze de bekendmaking van de beschikking moet geschieden.

In de artt. 6 en 7 WAHV staan de procedureregels voor het administratief beroep op de officier van justitie. Deze regels kwamen niet geheel overeen met de procedureregels voor het administratief beroep zoals de Awb deze stelt. ${ }^{203}$

Art. 6 lid 3 WAHV bevatte een hardheidsclausule met betrekking tot overschrijding van de beroepstermijn, in tegenstelling tot art. 9 met betrekking tot het beroep op de kantonrechter, hetgeen niet automatisch betekent dat de hardheidsclausule dan geldt. Art. 6:11 Awb kent een algemene hardheidsclausule, wat inhoudt dat bij overschrijding van de termijn voor het indienen van bezwaar en beroep niet-ontvankelijkheid achterwege blijft indien de indiener redelijkerwijs niet geoordeeld kan worden in verzuim te zijn geweest. Bij Aanpassingswet I is het derde lid van art. 6 WAHV vervallen en is in art. 9 WAHV art. 6:11 Awb van toepassing verklaard. Beide fasen kennen nu een hardheidsclausule.

Een ander verschil betreft de regeling van het horen van belanghebbende. Het horen volgens de WAHV gebeurt alleen als daartoe door de betrokkene een verzoek is gedaan. Het initiatief moet derhalve uitgaan van degene die het beroep heeft ingesteld. In de Awb is het precies andersom. Degenen, van wie te verwachten is dat zij bezwaar zullen hebben tegen al dan niet inwilliging van het beroep (in lid 2 worden de indiener van het beroep en het bestuursorgaan dat het besluit nam met name genoemd) moeten door het bestuursorgaan op de hoogte worden gesteld van de hoormogelijkheid. Het initiatief ligt hier dus bij het beroepsorgaan. In deze zin zal ook het horen door de officier van justitie in de WAHV dienen te verlopen.

262 TK 1990-1991, 22061, nr. 3, pag. 47.

263 Zic daarwoor uitgcbreider: G.J.M. van den Biggclaar, Toetsing van de Wet administratiefrechtelijke handhaving van verkeersvoorschriften aan het wetsvoorstel Algemene wet hestuursrceht, NTB 1990/5, pag. 139-145.

264 Vgl. MvA WAHV, TK 1987-1988, 20329, nr. 6, pag. 5. 
In tegenstelling tot art. 7:16 lid 2 Awb (dat in het gewijzigde art. 7 WAHV niet van toepassing wordt verklaard ${ }^{265}$ ) wordt in de WAHV slechts de indiener van het beroepschrift in de gelegenheid gesteld te worden gehoord en niet andere belanghebbenden.

De Awb bevat algemene regels voor het administratief beroep zoals het horen van de belanghebbende (art 7:16 - 7:23), de gevolgen voor gehele of gedeeltelijke vernietiging van het besluit (art. 7:25), de motivering van de uitspraak (art. 7:26 lid 1 en 2), de bekendmaking van de uitspraak (art. 7:26 lid 4), de vermelding van de rechtsmiddelen (art. 7:29 lid 5). Zodoende kunnen veel van de regels van de WAHV vervallen. Verder zijn de beroepsgronden bij de officier van justitie (art. 7 lid 2 (oud) WAHV) geschrapt, zodat de belanghebbende vrij is in het aanvoeren van argumenten, op grond waarvan de oplegging van de sanctie onterecht zou zijn. Voor de beroepsgronden op de kantonrechter blijft art. 9 gelden, waarin verwezen wordt naar art. 6 lid 2 WAHV. 266

Enkele verschillen blijven bestaan: onverminderd art. 6:5 Awb (bij de bekendmaking van Aanpassingswet I wordt hier ten onrechte verwezen naar art. 6:6 Awb) moet het beroepschrift volgens de WAHV nog bevatten: de geboortedatum, geboorteplaats en het geboortejaar van de insteller van het beroep, alsmede zijn bank-of girorekeningnummer.

Een ander verschil tussen de WAHV en de Awb dat resteert betreft de verplichting van de officier van justitie om, onverminderd het bepaalde in art. 7:24 lid 1, 3 en 4 Awb, zo spoedig mogelijk op het beroep te beslissen. Volgens deze bepaling van de Awb dient een beroepsorgaan in beginsel binnen zestien weken na ontvangst van het beroepschrift een beslissing te nemen. De WAHV bindt de officier van justitie bij het nemen van zijn beslissing dus niet aan een vaste termijn.

Tijdens de behandeling van de WAHV in de Tweede Kamer is er door het kamerlid Korthals (VVD) op gewezen dat een burger recht heeft op antwoord binnen een redelijke termijn. Degene, tegen wie de beschikking is genomen, moet altijd binnen een vastgestelde termijn actie ondernemen, terwijl voor de officier van justitie en de kantonrechter vaak geldt dat zij zo spoedig mogelijk een beslissing moeten nemen. Het kamerlid vraagt zich af of het niet redelijk is ook voor hen een vaste termijn in de wet vast te leggen. ${ }^{267}$ De minister van Justitie antwoordt hierop dat de positie van de betrokkene die voor één zaak beroep instelt en de positie van de officier van justitie en de kantonrechter, die een aantal beroepen krijgen, zo wezenlijk van elkaar verschillen, dat hij het voldoende vindt dat deze instanties de verplichting krijgen om zo spoedig mogelijk te reageren. Zij moeten niet aan een termijn gebonden worden. Daarnaast ziet hij van de verkeershandhaving vreselijk weinig terecht komen, indien de betrokkene, als de officier van justitie de termijn niet zou halen, "eruit springt". Bovendien is van te voren moeilijk na te gaan hoeveel beroepen er

265 Aanpassingswet III, Stb. 1993, 690.

266 Aanpassingswet III.

267 Handelingen II, 14 februari 1989, TK 48, 48-4869/4870. 
zullen worden ingesteld, welk deel van het parket voor dit soort zaken kan worden ingesteld en of een termijn van 30 dan wel 60 dagen redelijk is. Hij voorziet dat, als een termijn van een aantal dagen wordt gesteld, de neiging groot zal zijn om pas tegen het eind van die termijn te reageren. De onzekerheid van de burger is volgens de bewindsman inherent aan het feit dat hij in beroep is gegaan. Het kamerlid Korthals is het hier niet mee eens. De onzekerheid is inherent aan het feit dat er een administratieve beschikking aan hem is gezonden, terwijl hij vindt dat er niets fout is gegaan. De minister is van mening dat er van uitgegaan moet worden dat er wél iets fout is gegaan. ${ }^{26 s}$

Hoe men er ook over denkt, duidelijk is dat de WAHV op dit punt afwijkt van de Awb.

Ik ben van mening dat ook deze afwijking had moeten verdwijnen. ${ }^{20}$ De WAHV wil een korte efficiënte procedure scheppen voor de afdoening van verkeersovertredingen. Het stellen van een termijn voor de beslissing in beroep beantwoordt aan deze doelstelling. Een gedeelte van het parket kan mijns inziens vrijgemaakt worden voor de behandeling van deze zaken, namelijk het gedeelte dat zich tot nu toe met de strafrechtelijke handhaving van deze verkeersvoorschriften bezighoudt, i.c. de verkeersschouten. Wanneer er helemaal geen termijn wordt gesteld is volgens mij de neiging groot, "niets menselijks is ook het openbaar ministerie vreemd" te laten liggen. Bovendien biedt art. 7:24 Awb het beroepsorgaan de mogelijkheid de termijn te verlengen.

Volgens het Eindrapport blijken, weliswaar bij wijze van uitzondering, beslissingstermijnen tot 5 maanden voor te komen.

Ook art. 9 betreffende het beroep op de kantonrechter is gewijzigd. Allereerst is vervallen het vereiste dat het instellen van het beroep moest gebeuren "binnen dertig dagen na de dag van verzending schriftelijk", zodat ook hier nu de uniforme termijn van zes weken (art. 6:7 Awb) geldt.

Aan dit eerste lid wordt toegevoegd:"Op het beroep is hoofdstuk 6 van de Algemene wet bestuursrecht van toepassing". Volgens de toelichting is dit gebeurd omdat blijkens art. 1.4 (nu 1:4) van de Awb de kantonrechter geen administratieve rechter is in de zin van die wet. ${ }^{271}$ Zoals ik hierboven al vermeldde, is in de tweede tranche art. 1:4 Awb aangevuld in die zin dat de kantonrechter, optredende in de WAHV, als een administratieve rechter wordt beschouwd.

Op een belangrijk punt bestond discrepantie tussen de WAHV en de Awb, namelijk op het punt van de regeling van de niet-ontvankelijkheid van de belanghebbende

268 Handelingen II, 15 februari 1989, TK 49, 49-4952/4953.

269 Zo ook L.J.J. Rogier in zijn commentaar bij art. 7 WAHV, a.w., pag. 66 (tweede druk).

$270 \mathrm{Vgl}$. de minister van Justitie tijdens de openbare behandeling van de WAHV in de Tweede Kamer,

15 februari 1989, TK 49, 49-4953.

271 TK 1990-1991, 22061, nr. 3 pag. 47. 
indien hij niet voldeed aan het vereiste van de zekerheidstelling. Bij de Aanpassingswet I werd dit verschil uitdrukkelijk gehandhaafd. Aan art. 11 WAHV werd toegevoegd: "in afwijking van de Algemene wet bestuursrecht". Het zou vooral deze verplichting tot zekerheidstelling zijn die een afremmende werking op het instellen van beroep heeft. Het schrappen van deze verplichting zou de regeling volgens de wetgever ernstig schaden. ${ }^{27}$ Het vereiste is echter sterk genuanceerd door de hiervoor besproken jurisprudentie van de Hoge Raad. In de Aanpassingswet III ${ }^{273}$ is art. 11 lid 1 WAHV aan de jurisprudentie aangepast, zij het niet volledig. De Hoge Raad ging uit van een hersteltermijn van 30 dagen, art. 11 WAHV van 14 dagen. Bij Aanpassingswet I wordt art. 14 WAHV betreffende het beroep in cassatie aan de Awb aangepast in die zin dat art. 6:24 van de Awb van toepassing wordt verklaard en dat in het tweede lid de termijn voor het instellen van cassatie wordt vervangen door "binnen zes weken". Verder worden in de artt. 23, 24 en 25 WAHV de termijnen geharmoniseerd met die in het systeem van de Awb, dat uitgaat van een vermelding in weken in plaats van dagen. De betreffende termijnen zijn nu gesteld op twee, vier, resp. vier weken.

Bij Aanpassingswet III wordt in art. 26 lid 3 WAHV het woord "bezwaarschrift" vervangen door "verzetschrift", evenals in art. 27 lid 6. Verder worden termijnbepalingen uitgedrukt in weken in plaats van dagen. Art. 33 lid 1 spreekt voortaan over "beroep instellen bij de kantonrechter" in plaats van "bij met reden omkleed bezwaarschrift opkomen". Uitdrukkelijk wordt bepaald dat art. 7:1 Awb (verplicht bezwaar voorafgaand aan administratief beroep op de rechter) niet van toepassing is. In de leden 4, 5 en 6 wordt "beroepschrift" vervangen door "bezwaarschrift" en de termijnbepaling aangepast.

\section{Andere voorstellen tot wijziging van de WAHV}

Nu de WAHV een aantal jaren functioneert, blijkt deze niet altijd goed te functioneren. Daarom is er op het ministerie van justitie gewerkt aan enkele wijzigingen van de wet door een zogenaamde leemtewet. De concrete voorstellen zijn gepubliceerd in een wetsvoorstel Wet Verbetering Wet Mulder. ${ }^{274}$

Verder zijn er wijzigingsvoorstellen gedaan vanuit 'het veld', met name door Crébolder, kantonrechter te Utrecht, een WAHV-rechter van het eerste uur. ${ }^{275}$

De voorstellen van Crébolder betreffen hoofdstuk 5, beroep op de kantonrechter. Allereerst stelt hij voor de beroepsgronden van art. 9 te laten vervallen. Verder denkt hij aan een aanzienlijke wijziging van art. 11. De griffier zou de betrokkene per brief

272 MvT Aanpassingswet I, TK 1990-1991, 22061, nr. 3, pag. 47.

273 Stb. 1993,690 .

274 Ingediend op 18 april 1994, TK 1993-1994, 23689.

275 L.E.G.W. Crébolder, De wet Mulder, Trema, afl. 1, januari 1992, pag. 15-20 en tijdens het symposium De Wet Mulder in Bedrijf, 1 september 1992, Erasmus Universiteit Rotterdam. 
op de hoogte moeten stellen van de verplichting tot zekerheidstelling. Deze zekerheidstelling zou uitsluitend voldaan moeten worden middels overmaking van het bedrag per giro- of bankrekening. De termijn voor zekerheidstelling moet worden verlengd van 14 naar 30 dagen, te rekenen vanaf de dag van verzending van de brief. Het gevolg van het achterwege blijven van de zekerheidstelling kan zijn de niet-ontvankelijkheid.

Ten aanzien van de beroepsprocedure bij de kantonrechter schept Crébolder de mogelijkheid de zaak zonder voorafgaande zitting, dus op grond van de stukken af te doen. De beslissing wordt in het openbaar uitgesproken.

Ook ten aanzien van art. 26 met betrekking tot het verzet vindt hij dat het mogelijk moet zijn dat behandeling van het verzet plaatsvindt op basis van de stukken. Het betalen van griffierecht moet beter worden geregeld: binnen 30 dagen per giroof bankrekening. De griffier moet betrokkene wijzen op gevolg van niet-betaling: eventuele niet-ontvankelijkheid. Bij (gedeeltelijke) gegrondbevinding moet het griffiegeld worden terugbetaald.

\section{Administratiefrechtelijke of strafrechtelijke handhaving?}

\subsection{Inleiding}

Tijdens de voorbereiding en de evaluatie van de WAHV komt herhaaldelijk de vraag naar voren of de werking van de wet niet kan worden uitgebreid naar andere overtredingen. ${ }^{26}$ Het strafrechtelijk apparaat loopt vast en is niet meer in staat de grote hoeveelheid zaken af te doen. Er wordt gezocht naar andere methoden van afdoening, waarbij de administratiefrechtelijke in de picture komt, omdat hiermee sneller en efficiënter kan worden gewerkt. Ook het administratief recht kent de mogelijkheid om sancties vanwege de overheid op te leggen. De wijze waarop dat gebeurt is anders. De procedure tot vaststelling en oplegging van een administratieve sanctie onderscheidt zich op een aantal punten van die van een strafsanctie. De procedure voor administratieve sancties verloopt doorgaans sneller. Het opleggen van de sanctie is een accessoire bevoegdheid van het bestuursorgaan. Dit orgaan heeft inzicht in het belang dat door de overtreding is geschaad. De sanctie wordt eenzijdig, zonder tegenspraak, vastgesteld. Wanneer de burger het met deze sanctie niet eens is moet hij zelf actie ondernemen. In het administratieve recht geldt het vrije bewijsstelsel. De burger zelf moet doorgaans 'tegenbewijs' leveren. Beroep heeft in het algemeen geen schorsende werking. De rechter oefent repressief toezicht uit op de straf en strafmaat die door het bestuursorgaan is vastgesteld. In het strafrecht geldt daarentegen dat de procedure langer en omslachtiger en dus duurder is. De straf wordt vastgesteld en opgelegd door een onafhankelijke instantie, de rechter, die in beginsel geen 
verantwoordelijkheid draagt voor het gevoerde beleid. De ernst van het feit, de omstandigheden waaronder het is begaan en de persoon van de dader zijn factoren die de straf bepalen. Er is dus preventief toezicht van de rechter. In het strafrecht geldt het negatief-wettelijk bewijsstelsel. Uitgegaan wordt van de onschuld van de verdachte. Het instellen van een rechtsmiddel schorst de tenuitvoerlegging van de sanctie (art. 557 lid 2 Sv).

Ik vind het van belang erop te wijzen dat deze verschillen tussen beide procedures relatief zijn ${ }^{2 n}$ en dat de vraag welke overeenkomsten er zijn meer nadruk dient te krijgen. ${ }^{278}$

Evenals dit in het strafproces het geval is ligt ook in het bestuursrecht het initiatief vaak bij de overheid, bijvoorbeeld in de vorm van toezicht, waarbij aan toezichthouders bepaalde bevoegdheden worden verleend om hun taak uit te voeren. ${ }^{20}$ Met name op het gebied van het milieurecht is dit te zien. Evenals dit ten aanzien van ieder bestuursorgaan het geval is wordt het handelen van het OM aan beginselen van behoorlijk bestuur getoetst. Zoals ik in Hoofdstuk 10 zal betogen, zijn deze beginselen dezelfde als de algemene beginselen van behoorlijk bestuur in het bestuursrecht. ${ }^{200}$ De strafrechter krijgt niet meer alle zaken waarin sancties worden opgelegd onder ogen, hij ziet alleen de zwaardere delicten. Strafbare feiten worden in toenemende mate door het bestuur (het $\mathrm{OM}$ ) in de vorm van een transactie afgedaan. Het $O M$ voert een vervolgingsbeleid (transactie- en vervolgingsrichtlijnen), waarbij de strafrechter ook meer is gaan optreden als onafhankelijk controleur van het beleid van het $O M{ }^{281}$ De verschillen tussen de gehanteerde bewijsleren tussen het strafrecht en bestuursrecht vervagen. Ook de strafrechter tendeert naar een vrijere bewijsleer. ${ }^{228}$ Het strafproces gaat uit van het vermoeden van onschuld. Uit jurisprudentie van de WAHV valt op te maken dat ook de kantonrechter hiervan uitgaat. De bestuursrechter in de Awb krijgt een actieve rol, hij kan zich niet lijdelijk opstellen.

De snelheid waarmee de administratieve procedure gepaard zou gaan valt overigens tegen. Dit vindt wellicht een verklaring in de overbelasting van het apparaat en niet

277 Vgl. L. Rogier en A. Hartmann, Verschillen en overeenkomsten tussen strafrecht en bestuursrecht, DD 1993, pag. 1042-1058.

278 In de theorie van Rogier en Hartmann ga ik uit van een hetcronome visie op het strafrecht, in tegenstelling tot de autonome zienswijze, waarbij de nadruk wordt gelegd op de verschillen. $\mathbf{L}$. Rogier en A. Hartmann, a.w., pag. 1042-1043.

279 Zie Hoofdstuk Handhaving Awb, derde tranche, afdeling 5.1 Toezicht. Zie voor commentaar bij het Voorontwerp: S.Pront-van Bommel, Hoofdstuk 6 Handhaving \$ 2 Toezicht, uit: W. Konijncnbelt, De derde tranche, Alphen aan den Rijn 1992, pag. 111-124.

$280 \mathrm{Vgl}$. P. Wiewel, De beslissing tot vervolgen is bestuur, DD 1991, pag. 7-15.

281 Vgl. A.F.M. Brenninkmeijer en Y.D.M. Zoomers, De rechterlijke toetsing van sancties in het bestuursrecht. NTB 1988/2, pag. 52.

$282 \mathrm{Vgl}$. A. Minkenhof, De Nederlandse strafvordering, bewerkt door J. Reijntjes, Arnhem zesde druk 1993, pag. 269. 
in de procedure zelf. ${ }^{2 \pi}$ Overigens ligt de kracht van de procedure in art. 6:16 Awb: in beginsel schorst het bezwaar of beroep niet de werking van het besluit.

Ook door de Europese jurisprudentie is een strakke scheiding tussen administratieve en strafrechtelijke afdoening vervaagd. De afdoeningsprocedure moet voldoen aan de eisen die art. 6 EVRM stelt, wanneer het gaat om een 'criminal charge', dat wil zeggen wanneer met de straf leedtoevoeging vanwege de overheid wordt beoogd.

Als we kijken naar het materiële strafbegrip, en dit dan definiëren als een bijzonder leed, vanwege de staat als handhaver van de openbare rechtsorde door het met rechtsbedeling bevoegde gezag uit te spreken tegen de overtreder van een rechtsvoorschrift, dan wordt het aangeven van een onderscheid moeilijker, zeker indien het effect van de sanctie voor de burger gelijk is, zoals bijvoorbeeld het geval is bij betaling van een geldsom als de strafrechtelijke geldboete of administratieve boete. Het is dan vooral op dit punt dat men zich kan afvragen of er en wat het verschil in aard is tussen die twee. Doordat in de WAHV een strafsanctie (geldboete) eigenlijk vrij eenvoudig is omgezet in een administratieve sanctie (administratieve boete) lijkt het erop dat er weinig verschil bestaat tussen het karakter van deze twee soorten sancties. Is er dat verschil wel?

Deze vraag is van belang voor de theorievorming over de grens tussen het strafrecht en bestuursrecht. ${ }^{2+4}$ Welke gedragingen komen voor een strafrechtelijke dan wel administratiefrechtelijke handhaving in aanmerking?

\subsection{Inhoudelijk criterium}

De vraag of er een principieel verschil in karakter bestaat tussen de administratieve sanctie en de strafrechtelijke sanctie houdt juristen van beide rechtsgebieden reeds lang bezig. Hieronder zal ik verschillende mogelijke criteria bespreken.

In zijn preadvies voor de VAR van 1957 stelde Belinfante dat de administratieve sanctie, in tegenstelling tot de strafsanctie, dient 'om te verrichten hetgeen in strijd met de norm is nagelaten, om te herstellen wat in strijd met de norm is geschied en om te verhinderen dat verder in strijd met de norm zal worden gehandeld'. De administratieve sanctie is naar zijn mening meer gericht op het bewerkstelligen van een bepaalde toestand dan op het opleggen van leed. De administratieve sanctie richt zich meer up de toestand, de strafrechtelijke sanctie meer op de persoon. ${ }^{235}$

283 Vergelijk W. Duk, Handhaving van bestuursrecht, NTB 1988/4, pag. 108.

284 Zie ook: C.J. Kleijs-Wijnnobel, Bestuurs-en strafsancties; een LAT-relatie, uit: C.P.J. Goorden e.a., Kronick van het bestuursrecht, Zwolle 1993.

285 A.D. Belinfante, Strafrechtelijke en administratiefrechtelijke sancties. Geschrift VAR nr. XXXVI, 1957, pag. 41-42. 
Mede-preadviseur Mulder nuanceerde deze tegenstelling en vond dat de strafrechtsbeoefenaren te veel de nadruk legden op de persoon van de dader en de wetenschappers in het administratieve recht teveel oog hadden voor de onrechtmatige toestand. ${ }^{256}$ Pompe betoogde in 1959 dat het onderscheidende kenmerk van de straf gelegen is in de vergelding van de normovertreding, omdat en voor zover zij aan de schuld van de overtreder is te wijten. Het onderscheid tussen strafsancties en andere sancties baseert hij dus op de vergelding van schuld, die alleen bij strafsancties een rol zou spelen. ${ }^{237}$

Ook Oostenbrink vond de benadering van de administratieve sancties van Belinfante te eenzijdig. In zijn nog steeds toonaangevende proefschrift ${ }^{289}$ plaatst hij, na een onderzoek naar de administratieve sancties, de administratieve sanctie tussen twee uitersten. Aan de ene kant zet hij de groep van personele administratieve sancties. Deze sancties worden opgelegd uitsluitend ter vergelding van schuld van de overtreder. Zij richten zich tot de persoon van de overtreder. De administratie benadert hier de functie van de rechter die straffen oplegt. Het bestuurlijk aspect speelt een ondergeschikte rol. Aan de andere kant plaatst hij de categorie van situatieve administratieve sancties. Deze beogen het tot stand brengen van een wijziging in de situatie. Hierbij gaat het om gevallen van intrekking van aan burgers toekomende rechten. Deze sanctie heeft niet als doel schuld te vergelden, al kan de schuld een rol spelen onder de motieven die leiden tot oplegging van de sanctie. Een aanzienlijke groep van de door Oostenbrink onderzochte administratieve sancties waren 'gemengd'. De stelling (van Belinfante) dat de strafsanctie zich tegen de persoon richt en de administratieve sanctie op de situatie is volgens Oostenbrink dan ook niet te handhaven.

Duk, op zoek naar een algemene sanctietheorie, maakt een onderscheid tussen reparatoire en retributieve of repressieve sancties. Met de eerstgenoemde wordt uitsluitend beoogd het bewerkstelligen of herstellen van de toestand die zou zijn ingetreden dan wel zou blijven bestaan indien de overtreding niet zou zijn begaan of het benaderen van die toestand door compensatie. $\mathrm{Zij}$ dienen ertoe onlust te verplaatsen. Alle andere sancties noemt hij repressief of retributief. Hieronder vallen ook de administratieve sancties die vergelding beogen. Voor deze laatste sancties ziet Duk eigenlijk geen plaats in het stelsel van administratief recht. ${ }^{2 * 3}$ De toepassing van het strafrecht leidt bij uitstek tot oplegging van retributieve sancties. Fundamentele strafrechtelijke regels moeten dan volgens Duk ook vatbaar zijn voor analoge toepassing in gevallen waarin een bestuursorgaan beslist over de oplegging van een

286 A. Mulder, De verhouding van administratieve sancties en straffen. Geschrift VAR nr. XXXVI, 1957, pag. 71.

287 W.P.J. Pompe, Handboek van het Nederlandse strafrecht, 1959, pag. 7.

288 J.J. Oostenbrink, Administratieve sancties. Proefschrift Utrecht, 1967.

289 W. Duk, Tanden van het recht. Zwolle 1973; Maatstaven voor de beoordeling van sancties, AA 1981, pag. 231-238; Handhaving van bestuursrecht, NTB 1988/4, pag. 105-110. 
retributieve sanctie. ${ }^{\infty}$ Dit standpunt komt overeen met de (latere) jurisprudentie van het EHRM.

De Commissie Vermogensstraffen stelt dat men er van moet afzien de leed toevoeging, de 'traditionele' rechtvaardiging van de strafrechtelijke straf, als wezenlijk kenmerk van de straf te bestempelen. Dit om recht te doen aan de maatschappelijke ontwikkeling. Volgens deze commissie moet de strafrechtelijke sanctie aangemerkt worden als een 'te-recht-wijzing'. Deze te-recht-wijzing vindt plaats op grondslag van de constatering dat bepaald gedrag wederrechtelijk was en dat een normaal mens in een normale situatie dit gedrag had behoren te vermijden. Hiermee wordt impliciet het gedrag afgekeurd. ${ }^{201}$

Jonkers vindt deze typering van de straf door de Commissie Vermogensstraffen eenzijdig en onvolledig. Doordat zij de leedtoevoeging als kenmerk van de straf afwijst, miskent de commissie volgens Jonkers de realiteit van de strafsanctie. Hét kenmerk van de strafsanctie, in tegenstelling tot sanctie van andere delen van het recht (waaronder het administratieve recht) is dat de strafsanctie gericht is op een pijnlijke terechtwijzing, zij is gericht op leedtoevoeging. Andere sancties zijn er doorgaans op gericht een bepaalde toestand te corrigeren. Dit kan wellicht een afkeuring impliceren, maar daarop is zij niet primair gericht. ${ }^{202}$

Uit bovenstaande vloeit voort dat het zeer moeilijk is een duidelijk onderscheid aan te geven tussen de grondslag van de administratieve en de strafrechtelijke sanctie. Duk signaleert dat niet veel verder is gekomen in de theorievorming over sancties en dat het zeer moeilijk is om tot een algemene sanctietheorie te komen. Het traditionele onderscheid lijkt echter niet meer onverkort te handhaven. We kunnen niet meer volhouden dat strafsancties slechts leedtoevoeging beogen en administratieve sancties slechtsgericht zijn op reparatie of herstel van een toestand. ${ }^{203}$ Dit blijkt des te duidelijker wanneer één en dezelfde handeling zowel in het strafrecht als het bestuursrecht als sanctie wordt gehanteerd, bijvoorbeeld de betaling van een geldbedrag of (momenteel actueel) de intrekking van het rijbewijs. Uit de Europese jurisprudentie is inmiddels af te leiden dat louter door overbrenging van een sanctie van het strafrecht naar het administratieve recht het leedtoevoegende karakter niet verdwijnt en dus straf blijft. Tussen het strafrecht en het administratief recht ligt een mistig gebied van sancties, waarvan onduidelijk is wat ze precies beogen. Het is meer een kwestie van meer of minder: herstel van de toestand of afkeuring van bepaald gedrag.

290 W. Duk, Maatstaven voor de beoordeling van sancties, AA 1981, pag. 235.

291 Commissic Vermogensstraffen, Interimrapport 1969, pag. 16.

292 W. Jonkers, Het penitentiair recht, Hoofdstuk II, pag. 3.

293 Vgl. bijvoorbeeld W. Duk, Handhaving van het bestuurstecht, Capita Selecta, NTB 1988/4; LJJ. Rogier, Strafisancties, administratieve sancties cn het una via beginsel, Arnhem 1992, hoofdstuk 3; C.J. Kleijs-Wijnnobel, a.w., pag. 39-40. 
Dit rechtvaardigt naar mijn idee de stelling dat des te kleiner het onderscheid tussen het doel van sancties is, des te gemakkelijker de overdracht van een sanctie uit het ene naar het andere rechtsgebied verloopt.

Als we bekijken welke overwegingen geleid hebben tot de WAHV zien we dat de toedeling van de strafsanctie bestaande uit een geldboete naar het administratieve recht in de vorm van een administratieve boete (hoewel dat woord wordt vermeden in de wet) niet bepaald is door een wijziging in de aard van de norm of de aard van de sanctie. Toedeling werd hier veeleer instrumenteel, pragmatisch bepaald. Het administratieve recht is gekozen vanwege doelnatigheidoverwegingen, de te verwachten effectiviteit. Het argument dat het hier om feiten zou gaan waarbij de overtreder geen morele blaam zou treffen, vind ik dan ook een schijnargument en bovendien een miskenning voor het administratief recht (hierop kom ik nog terug). De betekenis van de grondslag of karakter van de sanctie blijft onderbelicht. De overgang is wellicht enigzins bevreemdend, nu er in het administratief recht in het verleden voor is gepleit bij het toedelen aan het bestuur van de bevoegdheid zelfstandig boetes op te leggen, terughoudendheid te betrachten. Toekenning van de bevoegdheid tot het opleggen van administratieve boetes behoorde uitzondering te blijven, niettegenstaande de mogelijkheid van beroep op de rechter'. ${ }^{24}$ Momenteel is er echter een andere tendens waar te nemen. De populariteit van de administratieve boete groeit duidelijk. Volgens Michiels is de oorzaak hiervan gelegen in het doelmatigheids-denken, dat meer en meer de overhand krijgt. ${ }^{25}$ Koeman bijvoorbeeld pleit voor een vervanging van de dwangsom, in de daarvoor geëigende gevallen, door een administratieve boete, daar deze minder werklast met zich meebrengt voor de rechter. ${ }^{266}$ Dit doelmatigheidsidee uit zich in het streven naar invoering van administratieve boete en naar de vervanging van strafrechtelijke door bestuursrechtelijke handhaving. Michiels stelt hierbij terecht kritische vragen: is het wel zo doelmatig om het bestuur straffen te laten uitdelen? en: Hoe zit het met andere waarden, zoals behoorlijke rechtsbescherming en waarborging van de grondrechten? Kortom: is het op grote schaal invoeren van de bevoegdheid voor het bestuur om boeten op te leggen wel zo gewenst?

De vraag waaraan ik vervolgens aandacht wil schenken is, of er, ondanks de constatering dat er tussen de aard der sancties van de twee rechtsgebieden geen duidelijk onderscheid is te maken, een criterium valt te geven voor de toedeling van bepaalde gedragingen aan het ene of andere rechtsgebied.

294 Rapport Algemene Bepalingen van Administratief Recht. Alphen aan de Rijn, 1984.

295 F.C.M.A. Michiels, De boete in opmars? Oratie VU, Zwolle 1994, pag. 4-5.

296 N.S.J. Koeman, Dwangsom Hoofdstuk $6 \$ 4$, uit: W. Konijnenbelt (red.) De derde tranche, Alphen aan den Rijn 1992, pag. 131-134, m.n. 133.

297 F.C.M.A. Michiels, a.w., pag. 5-6. 
Pas daarna zal ik aansluiten bij de binnen het bestuursrecht bestaande wens naar uithreiding van de administratieve hoete.

\subsection{Criterium voor toedeling van gedragingen aan strafrecht of bestuursrecht}

Bij de lijst met verkeersovertredingen die voortaan administratieve gedragingen heten, is aangesloten bij de strafbare feiten die tot nu toe door middel van politietransactie afgedaan kunnen worden.

De minister legt het criterium voor de vraag welke feiten op een administratiefrechtelijke wijze kunnen worden afgedaan bij het al dan niet moreel verwerpelijk zijn van de gedraging. Voor feiten die geen moreel verwijt inhouden is het strafproces te omslachtig. Hierboven ( $\$ 11.2$ ) is reeds betoogd dat dit een miskenning van het administratief recht inhoudt en daarom niet te handhaven is. Voor een aantal delicten die naar het administratief recht overgebracht zijn kan inderdaad gezegd worden dat van overtreding weinig of geen moreel verwijt gemaakt kan worden, bijvoorbeeld bij overtredingen die de technische inrichting van een voertuig betreffen. Een niet onaanzienlijke groep van overgebrachte overtredingen zijn een soort voor-delict van het ernstige delict van art. $36 \mathrm{WVW}$, dood respectievelijk lichamelijk letsel door schuld. Dat dit delict een morele lading heeft zal niemand ontkennen. Een overtreding die uiteindelijk zou kunnen leiden tot dood of lichamelijk letsel door schuld, kan een morele lading naar mijn mening niet geheel ontzegd worden, omdat zij in dezelfde mate de verkeersveiligheid kan aantasten. Het rijden door een kinderrijke woonwijk, waarbij de maximum snelheid met 25 kilometer per uur overschreden word, het met de auto een andere auto inhalen op een weg waar dit verboden is, terwijl er een tegenligger nadert, het als bestuurder geen voorrang verlenen aan het verkeer dat van rechts komt zijn hiervan voorbeelden.

Voor een groot aantal delicten zal er overeenstemming bestaan over de morele verwerpelijkheid ervan. Echter niet bij alle delicten zal dit het geval zijn. De morele verwerpelijkheid zal ook samenhangen met de tijd waarin en de plaats waarop ze gepleegd worden, waarbij we bijvoorbeeld kunnen denken aan milieu-overtredingen. Nu gebleken is dat de minister de feiten, waarvan de handhaving op administratieve wijze zal geschieden, in de toekomst wil uitbreiden, waarbij hij dan bijvoorbeeld denkt aan milieu-overtredingen (overtredingen die thans volop in de belangstelling staan en die door een groot deel van de bevolking zeker als moreel verwijtbaar zullen worden bestempeld) biedt dit morele criterium naar mijn mening te weinig houvast. Bovendien vind ik het zeer gevaarlijk om een moreel inzicht door middel van het strafrecht op te leggen aan burgers, omdat op die manier door de staat een te grote 
inbreuk kan worden gemaakt op de individuele vrijheid van mensen, wok al vormen de andersdenkenden een minderheid. ${ }^{208}$

In de literatuur is de vraag naar criteria voor strafbaarstelling regelmatig aan de orde geweest. ${ }^{2}$ Getracht is steeds criteria te formuleren aan de hand waarvan toedeling van normen aan civiel, administratief of strafrecht zou moeten plaatsvinden. Genoemd zijn onder meer een moreel criterium ${ }^{300}$ en een frequentiecriterium." Het AIDP-congres in 1989 te Wenen gaf een sterke impuls tot afsplitsing van gedragingen uit het strafrecht naar het bestuursstrafrecht, maar gaf mijns inziens daarvoor geen duidelijk onderscheidend criterium aan. Gegeven werden grenzen aan de toepassing van het bestuursstrafrecht. Het kwam erop neer dat de grondbeginselen van het strafrecht in het bestuursstrafrecht zouden moeten gelden. ${ }^{302}$

In de discussie in dit verband met betrekking tot de WAHV ${ }^{303}$ ging men naar mijn gevoel uit van een verkeerd uitgangspunt: welke gedragingen kunnen van het strafrecht naar het administratief recht? Men haalde uit de gedragingen van de WAHV criteria en ging die vervolgens toepassen op andere gedragingen. Men ging puur pragmatisch, instrumentalistisch te werk, zonder tot een onafhankelijke, oorspronkelijke verantwoording te komen. Als criteria werden dan genoemd: gedragingen die veel voorkomen, gedragingen die gemakkelijk op te sporen zijn, die met een vast tarief gesanctioneerd kunnen worden, de omstandigheden waaronder de gedraging is begaan zijn van weinig belang, er is geen sprake van schade of letsel, gedragingen met een geringe normatieve lading enz. Ook de werkgroep die zich op het ministerie

298 Deze kwestic komt uitgebreid aan de orde in de dissertatie van Th. A. de Roos, Strafbaarstelling van ecunomische delicten, Arnhem 1987, Hoofdstuk II: Strafrecht, moraal en de opvatting van de mecrderheid.

299 Zie onder andere: G.J.M. Corstens, Civielrechtclijke, administraticfrcchtelijke of strafrechtelijke rechtshandhaving. Preadvies NJV 1984, I; Th.A. de Roos, Strafbaarstelling van economische delicten, dissertatic RUU, Arnhem 1987, m.n. hoofdstuk III; M.S. Groenhüjsen, Criterium van strafbaarstelling, DD 1993, pag. 1-6. Zie voor een overzicht van genoemde criteria: P.M. van Russen Groen, Eindrapport Juridische evaluatie Wet Mulder, hoofdstuk 10 (vreemd genoeg noemt deze De Roos niet).

300 VgI. de parlementaire behandeling van de WAHV.

301 D. Schaffmeister, Politiële en justitiële delicten, Handelingen NJV 1984, deel I, Zwolle 1984, en van dezelfde auteur Afzonderlijk straf-en strafprocesrecht voor de veel voorkomende criminaliteit, JV 1990, nr. 4, pag. 8-28.

302 Zie het Verslag van het XIVe Internationaal Strafrechtscongres van het AIDP te Wencn, 1 tot 7 oktober 1989, sectie 1: De juridische en praktische problemen hij het aanbrengen van een onderscheid tussen strafrecht en bestuursstrafrecht.

303 Zie bijwoorbeeld: H. de Doelder, Van strafrecht naar administratief recht, in: De Wet Mulder in perspectief, a.w., pag. 85-94; uit de7cllde bundel: A. Kosto, De Wet Mulder in perspecticf, pag. 141-145; uit dezelfde bundel: A. Kors, Administratiefrechtelijke handhaving: toekomstperspectief, pag. $77-84$. 
van justitie bezighoudt met de uitbreiding van de WAHV naar andere gedragingen, gaat op dezelfde manier te werk. ${ }^{\text {. }}{ }^{-4}$

In zijn dissertatie 'Strafbaarstelling van economische delicten' formuleerde De Roos zes beginselen die als een normatief schema konden fungeren voor strafbaarstellingsbeleid (strafbaarstelling, afzien van strafbaarstelling of decriminalisering) in het algemeen. Hij paste dit schema exemplarisch toe op economische delicten. Dit schema van De Roos zou ik als uitgangspunt willen nemen.

De Roos onderscheidt de volgende beginselen:

- beginsel van aannemelijkheid en motivering van schade; Voor strafbaarstelling komen gedragingen in aanmerking die schade veroorzaken aan derden (dus aan de maatschappij). De schadevaststelling moet resultaat zijn van objectief onderzoek. De Roos onderscheidt verschillende vormen van schade: fysieke en psychische schade, materiële en immateriële schade, collectieve en individuele schade, directe en indirecte schade en geconcentreerde en diffuse schade (pag. 43-44). Het schadebegrip op zich is algemeen en vaag. De overheid moet als het ware de schade stellen en bewijzen. De Roos erkent dat dit beginsel 'weliswaar inhoudelijk weinig houvast biedt, maar als uitgangspunt voor een rationele discussie over de grenzen van het strafrecht toch een dam kan opwerpen tegen moralistisch absolutisme en intolerantie' (pag. 53). Het schade-oordeel bevat weliswaar morele aspecten, maar het mag niet zo zijn dat vooroordelen, puur emotionele afkeer en napraterij de overhand krijgen.

In deze zin bedoelde ik mijn opmerkingen hierboven over een moreel criterium. Als kritiek op dit schadecriterium is aan te voeren dat bij de strafbaarstelling soms (de vorm van) de schade niet is te voorzien of de omvang niet exact vast te stellen. Er zou dan eerst sociaal-wetenschappelijk onderzoek dienen plaats te vinden om te kijken of er en hoe groot het nadeel is dat door de strafbaar te stellen handeling is verricht. Naar mijn idee is dat echter niet persé nodig. Het gaat meer om het kwalitatieve dan om het kwantitatieve schadebegrip. ${ }^{3.5}$

- tolerantiebeginsel; Dit beginsel houdt in dat ook al staat vast dat een bepaalde gedraging schadelijk is, de wetgever zich van strafbaarstelling dient te onthouden omdat dat een te ver gaande inbreuk zou betekenen op de individuele vrijheid. Hierbij kunnen we bijvoorbeeld denken aan gedragingen op het gebied van de zedelijkheidswetgeving of op het gebied van een verbod van schadelijk geachte genotmiddelen.

- subsidiariteitsbeginsel; Dit beginsel houdt in dat het strafbaarstelling pas in aanmerking komt indien de handhaving van een bepaalde norm niet door andere middelen (juridische of buiten-juridische) kan worden gegarandeerd. Strafrecht

304 Zic Eindrapport juridische evaluatie, pag. 157-158.

305 Vgl. M.S. Groenhuijsen, Criterium voor strafbaarstelling, DD 1993, pag. 3-4. 
is ultimum remedium. De wetgever moet, alvorens tot strafbaarstelling over te gaan, kijken of er adequate alternatieven zijn. Toegespitst op dit onderzoek betekent dit dat het strafrecht in aanmerking komt indien het bestuursrecht, gezien bepaalde kenmerken van de administratieve procedure of gezien het ontbreken van bepaalde dwangmiddelen of eigenschappen van de sancties (bijvoorbeeld vrijheidsontneming) te kort zal schieten voor de handhaving van een norm. Sommige normovertredingen vereisen speciale straffen, maatregelen of dwangmiddelen. - proportionaliteitsbeginsel; Er moet verhouding zijn tussen de schadelijkheid van het gedrag en de reactie van de staat daarop. De inschakeling van het strafrecht moet proportioneel zijn aan het eventueel strafbaar te stellen gedrag. De wetgever dient zich bij een beslissing tot strafbaarstelling af te vragen of de strafbaarstelling en de zwaarte van de te bedreigen sanctie in verhouding staat met de ernst van de betreffende gedraging. De meest elementaire vraag hierbij is of men de effectiviteit van de strafbedreiging zo zwaar mag laten wegen dat de evenredigheid in het gedrang komt (pag. 70). Het is moeilijk een absolute maatstaf te geven voor de vraag hoever het strafrecht kan gaan en daardoor is de werkbaarheid van dit criterium slechts beperkt. In ons strafstelsel komt de werking van dit beginsel bijvoorbeeld tot uitdrukking in de toedeling door de wetgever van strafbare gedragingen aan de categorie van misdrijven of overtredingen of de indeling van een gedraging in een categorie van vrijheidsbenemende dan wel vermogenssancties.

- legaliteitsbeginsel; Kort gezegd houdt dit beginsel in:

- geen straf voor een bepaalde gedraging zonder dat deze gedraging in een wettelijke bepaling strafbaar is gesteld;

- de strafbepaling moet duidelijk zijn (Bestimmtheitgebot). Als een bepaalde norm niet duidelijk kan worden geformuleerd, dient een strafrechtelijke sanctionering achterwege te blijven.

- beginsel van praktische hanteerbaarheid en effectiviteit. Dit komt erop neer dat bekeken dient te worden of opneming in het strafrecht zal leiden tot een zinvolle toepassing, of dat bij voorbaat reeds gezegd kan worden dat vanwege de hanteerbaarheid van de delictsomschrijving, de capaciteit van het strafrechtelijk handhavingssysteem en de effectiviteit van de strafbaarstelling (generaal-preventieve werking) gekozen moet worden voor een ander handhavingssysteem.

De wetgever dient, wanneer hij strafbaarstelling overweegt, deze aspecten te laten meewegen.

Naar mijn mening houdt dit ook voor de tegenovergestelde figuur, het decriminaliseren van gedragingen, in dat de wetgever zich aan de hand van deze criteria dient af te vragen of strafbaarstelling achterwege kan blijven. Het louter verwijzen naar redenen van effectiviteit biedt naar mijn mening onvoldoende legitimatie. Overigens ben ik van mening dat, de geformuleerde criteria toepassende op verkeersvoorschriften, waarbij geen letsel of schade aan derden is opgetreden (waarbij ik me realiseer dat dit niet altijd direct en eenvoudig is vast te stellen), gesteld mag worden dat strafrechtelijke handhaving achterwege zou kunnen blijven. 
Deze door De Roos ontworpen criteria zouden als basis kunnen dienen voor de verdere discussie omtrent een uitbreiding van de administratiefrechtelijke handhaving van (voorheen strafrechtelijke) overtredingen. In de inleiding signaleerde ik dat in de ordeningswetgeving veel strafbaarstellingen zijn opgenomen. Deze strafbaarstellingen zijn over het algemeen anders dan de klassieke strafbaarstellingen en laten zich meer vergelijken met administratiefrechtelijke regelingen. De Roos constateert dat de strafbaarstelling in het ordeningsrecht vaak een ondergeschikt aspect is in een omvangrijke en gecompliceerde niet-strafrechtelijke materie, met als gevolg dat de motivering voor strafbaarstelling vooral op dit gebied vaak ontoereikend is. ${ }^{305} \mathrm{Het}$ lijkt mij dat met behulp van de door De Roos genoemde beginselen, met name het schadebeginsel, het subsidiariteitsbeginsel en het proportionaliteitsbeginsel een afweging te maken moet zijn voor overbrenging van meerdere overtredingen vanuit het strafrecht naar het administratief recht. Ik stel me zo voor dat gekomen zou kunnen worden tot een algemene Wet administratiefrechtelijke afdoening van bepaalde overtredingen, gemodelleerd naar de WAHV.

Hierbij moet worden bedacht dat de administratiefrechtelijke afdoening van verkeersvoorschriften vrij 'gemakkelijk' verloopt doordat het overgrote deel van de sancties wordt opgelegd via de kentekenregistratie. Een eventuele administratiefrechtelijke afhandeling van andere overtredingen heeft een dergelijk hulpmiddel waarschijnlijk niet.

\subsection{De administratieve boete}

Zoals eerder beschreven in $\S 8.4$ ten aanzien van de fiscale boete, sluit de discussie over de overgang van strafrechtelijke naar bestuursrechtelijke handhaving aan bij de binnen het bestuursrecht bestaande discussie omtrent de wettelijke invoering en uitbreiding van de bestuursrechtelijke boete. Deze discussie is voor ons onderwerp natuurlijk niet zonder belang, omdat, na de overgang van strafrecht naar bestuursrecht, de handhaving volgens die regels zal hebben te verlopen.

De discussie en jurisprudentie omtrent die bestuurlijke boete is nog niet volledig uitgekristalliseerd.

De volgende punten zijn hierbij van belang: ${ }^{307}$

1. Als gevolg van het Öztürk-arrest ${ }^{308}$ zullen bestuurlijke boeten met een bestraffend karakter moeten voldoen aan art. 6 EVRM.

306 Th.A. de Roos, a.w., pag. 57.

307 Zie witgebreider: M.W.C. Feteris, Fiscale administratieve sanctics en het recht op een cerlijk proces. Dissertatic UvA, Deventer 1993, pag. 253-260 en 351-362; F.M.C.A. Michiels, De boete in opmars? Oratie VU, Zwolle 1994, pag. 20-29.

308 EHRM 21 februari 1984, NJ 1988, 973 m.nt. EAA. 
2. Welke overtredingen mogen door het bestuur worden beboet? In het Öztürk-arrest werd gesproken over 'minor offences' (dus niet: lage boeten), waaraan in het Lutzarrest ${ }^{300}$ de toevoeging werd gegeven 'which are not so discreditable that the offenders deserve the stigma of a criminal penalty'. Deze schandelijke overtredingen dienen dus in het strafrecht te blijven;

3. De bestuurlijke boeten met een bestraffend karakter zullen behoren te voldoen aan de vereisten van art. 6 lid 2 EVRM: de presumptio innocentiae, nemo tenetur, bepaalde rechten ter verdediging. Art. 14 lid 5 IVBP vereist daamaast rechtspraak in twee feitelijke instanties voor sancties tegen zwaardere overtredingen. Het gaat hierbij om de grens tussen lichte en zware overtredingen.

4. Er zal een regeling moeten komen om dubbele bestraffing te vermijden. ${ }^{310}$ Art. $68 \mathrm{Sr}$ is in dit verband niet toereikend omdat het slechts geldt voor strafsancties onderling. ${ }^{311}$

Ik acht het van belang, evenals Michiels ${ }^{32}$, te wijzen op een mogelijk nadeel van het eenzijdig benadrukken van het doelmatigheidsstreven van bij de invoering van bestuurlijke boeten. De kans bestaat dat het slechts een verschuiving van werklast met zich meebrengt. Michiels stelt dat een nieuwe sanctie misschien niet nodig is wanneer er meer controle zou bestaan op naleving van voorschriften. Een stelling, waarmee ik absoluut kan instemmen. Gedrag van burgers wordt onder meer beïnvloed door een effectieve snelle reactie in de vorm van een sanctie, maar zeker ook door een aanmerkelijke kans op ontdekking van een overtreding. Wanneer er meer gecontroleerd zou worden, vergroot dit het risico voor de burger op betrapping, waardoor normconform gedrag wordt gestimuleerd (vgl. de aangekondigde snelheidscontrole op de snelweg A2 tussen Amsterdam en Utrecht: er vinden veel minder snelheidsovertredingen plaats). Hierdoor wordt sanctie-oplegging overbodig hetgeen ook tot werklastbesparing leidt.

De sanctie-oplegging dient geen doel op zichzelf te zijn, maar in dienst te staan van het uiteindelijke doel: gedrag volgens de regels.

Concreter: ik ben benieuwd of invoering van de WAHV heeft geleid tot minder verkeersovertredingen.

309 EHRM 25 augustus 1987, NJ 1988, 938 m.nt. EAA.

$310 \mathrm{Het}$ ne bis in idem beginsel staat in art. 4 Zevende Protocol EVRM en in art. 14 lid 7 IVBP. Het protocol is niet door Nederland geratificecrd $\mathrm{en}$ bij art. 14 IVBP is een voorhehoud gemaakt, met als redenering dat het beginsel beperkt is tot art. $68 \mathrm{Sr}$.

311 Zie hierover: LJJ. Rogier, Strafsancties, administratieve sanctics en het una via-beginsel. Dissertatic EUR, Arnhem 1992, pag. 167.

312 F.C.M.A. Michicls, a.w., pag. 48. 


\section{Slotopmerkingen}

\subsection{Karakter van de WAHV}

De wet beoogt een administratieve procedure te scheppen. De vraag is of men hierin is geslaagd. Voor mijn gevoel blijft de strafrechtelijke procesgang zichtbaar, al wordt dit door middel van de aanpassingswetgeving minder.

Voor de meeste burgers zal de regeling van de WAHV (vooralsnog) ervaren worden als strafrecht. Het blijft dezelfde politieambtenaar die de bon schrijft. Dat heet dan nu geen bekeuring meer maar een beschikking. Volgens het Eindrapport blijft overigens ook de gemiddelde politieambtenaar de WAHV zien als strafrecht. ${ }^{313}$

Het blijft een typisch strafrechtelijke instantie, het OM, waar men terecht komt als men het niet eens is met de opgelegde sanctie. De rol van het $\mathrm{OM}$ in de procedure is wel beperkter geworden.

In het vervolg van de procedure komt de betrokkene bij de kantonrechter en de Hoge Raad, toch (nog) geen typisch administratiefrechtelijke instanties. Bij de Hoge Raad vindt behandeling nota bene plaats door de strafkamer!

Voor de opname van de WAHV is aangesloten bij de wetteksten strafrecht en niet bij het administratief recht.

Met betrekking tot de procedure is aangesloten bij het administratief recht, de instanties zijn hetzelfde gebleven. Het verhaal vindt plaats via een procedure die vrijwel letterlijk uit het WvSv is gehaald.

Men mag bij dit alles niet uit het oog verliezen dat het overschakelen van de ene naar de andere procedure natuurlijk ook een kwestie van gewenning is. Naar mate men vertrouwder zal zijn met de afhandeling volgens de WAHV, zal het gevoel met het strafrecht te maken te hebben misschien wat minder worden. Ikzelf heb een dergelijke gewenningsperiode ook ervaren. In wezen is de positie van het OM niet 'vreemd' omdat het dezelfde rol vervult als andere bestuursorganen, namelijk die van beroepsinstantie.

Ook vanuit administratiefrechtelijke hoek werd erop gewezen dat de (oorspronkelijke) wet niet geheel voldeed aan de eisen die vanuit het bestuursrecht kunnen worden gesteld ${ }^{1 / 4}$ Door het opleggen van een sanctie komt er in het administratieve recht objectief recht tot stand, waartegen de burger zich kan verzetten. De sanctiebevoegdheid zoals de WAHV deze introduceert is van andere aard, het is toch een afkeuring van gedrag. Het is in het administratief recht niet gebruikelijk het beroepsorgaan (in casu het $\mathrm{OM}$ ) een matigingsbevoegdheid te geven, zoals in de WAHV wordt ingevoerd. Het zwaartepunt van de bevoegdheidsuitoefening zou daarmee te nadruk-

313 Eindrapport deel II, pag. 172.

31.4 M.J. Sluijs, Administraticve sancties in een strafrechtelijke context, NJB 1988, pag. 522-528. 
kelijk bij het beroepsorgaan komen te liggen. Ik ben van mening dat art. 7:11 Awb een dergelijke regeling wel toelaat.

Het stellen van zekerheid als voorwaarde voor ontvankelijkheid bij de kantonrechter is een vreemde eend in de administratieve bijt. Hieraan zal ik hierna nog apart aandacht schenken.

De wet heeft kenmerken van zowel het strafrecht als het administratief recht en als zodanig te rekenen tot het rechtsgebied van het bestuursstrafrecht. De ontwikkeling van de spelregels van het bestuursstrafrecht is nog in volle gang. ${ }^{315}$ Art. 6 EVRM speelt hierbij een belangrijke rol.

\subsection{Zekerheidstelling}

Om een lichtvaardig beroep op de kantonrechter tegen te gaan, voerde de wetgever de zekerheidstelling in. Indien de betrokkene niet aan de voorwaarde van zekerheidstelling voldeed, zou niet-ontvankelijkheid van het beroep bij de kantonrechter het gevolg zijn, art. 11 lid 1 WAHV.

In de praktijk is de zekerheidstelling aanleiding geweest voor veel problemen en onduidelijkheden. Een relatief groot aantal cassatieberoepen betrof de zekerheidstelling. Zo was de vraag waar (griffie of CJIB) moest worden betaald, de wijze waarop moest worden betaald (bij griffie kantongerecht, door middel van cheques, overmaking per bank- of girorekening, door middel van voldoening van het sanctiebedrag aan het CJIB), wat er moest gebeuren indien te laat of in het geheel niet was betaald (extra termijn na mededeling van de griffie) en hoe het zat met de terugbetaling die in de ogen van in het gelijk gestelden veel te lang op zich liet wachten.

Nu zijn voor al deze problemen oplossingen te bedenken, zoals onder meer blijkt uit een aantal aanbevelingen zoals die in het Eindrapport worden gedaan (pag. 212213). Hiervoor kies ik vooralsnog niet.

Ondanks het gegeven dat de in de WAHV opgenomen zekerheidstelling door de Hoge Raad niet in strijd is geoordeeld met art. 6 EVRM, zou ik willen voorstellen het vereiste van de zekerheidstelling in zijn geheel te laten vervallen. Hiervoor zijn een aantal argumenten aan te voeren:

1. het aantal beroepen op de kantonrechter blijkt zeer klein te zijn. Hierbij zaten relatief veel betrokkenen die ondanks bezwaren tegen de zekerheidstelling toch betaalden.

2. er bestaan al twee drempels tegen lichtvaardig beroep bij de kantonrechter: de betrokkene moet zelf in beroep komen bij de officier van justitie en zelf beroep instellen bij de kantonrechter. De drempel van zekerheidstelling is niet meer nodig. 
3. ik vind het principieel onjuist om nog in deze fase een drempel op te werpen: degene die meent echt een inhoudelijk verweer te hebben, moet dat ongehinderd kunnen doen.

4. relatief veel betrokkenen bleken principiële bezwaren te hebben tegen de zekerheidstelling: het werd toch meer gezien als het voldoen van de sanctie voor een gedraging waarmee men soms niets te maken had.

5. de zekerheidstelling past niet in het systeem van de administratiefrechtelijke procedure.

6. de Hoge Raad heeft nu als oordeel gegeven dat de zekerheidstelling niet in strijd is met art. 6 EVRM voor wat betreft het recht op toegang tot de rechter. De vraag is of dit oordeel in de toekomst stand kan houden. Wellicht zou de hoogte van het sanctiebedrag (en dus het bedrag van de zekerheidstelling), momenteel maximaal $f 500,-$, een rol kunnen gaan spelen. ${ }^{36}$

Daarnaast kan men zich afvragen of de zekerheidstelling niet in strijd komt met een ander aspect van art. 6 EVRM, namelijk met het vermoeden van onschuld. Ziet men de zekerheidstelling feitelijk als een begin van executie van de sanctie (en veel hetrokkenen voelen dit als zodanig), dan kan volgens sommige auteurs van strijdigheid sprake zijn. ${ }^{37}$ De Hoge Raad is deze mening niet toegedaan (HR 26 oktober 1993, NJB-katern 1994, pag. 97, nr. 33).

\subsubsection{Positic betrokkene}

'Ter afsluiting van deze paragraaf lijkt het mij zinvol nu eens op een rijtje te zetten wat er nu bij de administratieve afdoening precies verandert in de positie van de betrokkene ten opzichte van de strafrechtelijke wijze. Hierbij moet een onderscheid worden gemaakt tussen degenen die in het strafrechtelijk systeem niet voldeden aan de transactie, niet verschenen ter zitting of althans daar geen inhoudelijk verweer voerden en vervolgens de opgelegde boete niet voldeden en degenen die niet aan de transactie voldeden om ter zitting een inhoudelijk verweer te voeren. ${ }^{318}$ Voor de eerste groep geldt dat de boete (meestal) eerder executoir wordt (zie hiervour). De zittingsfase wordt overgeslagen, de rechter komt er niet aan te pas. Een grote verandering van de feitelijke situatie brengt dat niet met zich mee, want een zeer groot gedeelte van deze groep stelde in het systeem van strafrechtelijke handha-

316 Vgl. de conclusie van A-G Meijers bij HR 11 februari 1992, NJ 1992, 692, m.nt. C.

317 Zie bijvoorbeeld: D. Allewijn, De bestuursrechtelijke toetsing in de Wet Mulder, in: H. de Doelder e.a. (red.), De wet Mulder in perspectief, Amhem, 1990, pag. 76; J.D. den Hartog, Artikel 6 EVRM: grenzen aan het streven de straf eerder op de daad te doen volgen, Antwerpen-Apeldoorn, 1992, pag. 268-297.

318 Hierbij wordt er dus vanuit gegaan dat er voor de groep verdachten die terstond de politietransactie voldeed en voor de groep betrokkenen die nu de administratieve boete tijdig voldoet weinig verandert. 
ving toch geen prijs op inhoudelijke behandeling van de zaak door de rechter en liet verstek gaan.

Voor de tweede groep betekent het wel een ingrijpende wijziging in de feitelijke situatie. Ten eerste moet men zelf initiatief nemen indien men het met de beschikking niet eens is, terwijl in het strafrechtelijk systeem het initiatief bij het OM lag. Ten tweede moet men, indien men het met de beslissing van de officier van justitie niet eens is en de zaak wil voorleggen aan de rechter, zekerheid stellen voor het te betalen bedrag, terwijl dit bij de strafrechtelijke afdoening niet hoeft. Ten derde wordt ter zitting van de administratieve rechter de beslissing van de officier van justitie als uitgangspunt genomen, echter op een andere wijze dan dit met de tenlastelegging in het strafrecht het geval is. De officier behoeft het plegen van het feit niet te bewijzen, het wordt als 'waar' aangenomen, totdat de betrokkene het tegenbewijs levert. Een omkering van de bewijslast derhalve. Dit behoeft echter relativering. In het administratieve recht moet de rechter zelfstandig nagaan of de motivering van een beschikking op een juiste feitelijke grondslag berust en dat die motivering de beschikking moet kunnen dragen.

De meeste betrokkenen vinden dat hun rechtspositie erop achteruit is gegaan, zoals uit het Eindrapport is bekend geworden. De meeste moeite blijkt men te hebben met het stellen van zekerheid, en in een nog 'erger' geval het voldoen van de sanctie plus verhogingen plus incassokosten, ter zake van een gedraging waar men niets mee van doen heeft gehad of waarvan men oprecht en op goede gronden dacht dat het geen gevolgen zou hebben.

\subsection{Slotopmerking}

De praktijk van de WAHV heeft veel twijfels die vooraf bestonden weggenomen. $\mathrm{Nu}$ de hele procedure (inclusief het dwangtraject) is doorlopen en enkele wijzigingen zijn doorgevoerd, blijkt de wet over het algemeen bevredigend te functioneren. De vraag over de verenigbaarheid van de WAHV met het EVRM is in ieder geval door de Hoge Raad beantwoord in die zin dat van strijd met art. 6 lid 1 en lid 2 geen sprake is. Straatsburgse jurisprudentie is nog niet verschenen.

Het feit dat de WAHV tot bevredigende resultaat leidt, betekent een stimulans voor de wetgever voor uitbreiding van de administratieve handhaving. Zo wordt er op het ministerie van justitie gewerkt aan nieuwe wetsvoorstellen. Voorbeelden hiervan zijn voorstellen betreffende administratieve boeten met betrekking tot de visserij ${ }^{319}$

319 Zie NJB 1993, pag. 1222 ; Zie hierover uitgebreider: A. Mulder, De bestuurlijke boete als middel tot bestrijding van economische delicten, SEW 1994, pag. 219-235. In het naschrift van dit arlikel wordt melding gemaakt van een door de staatssecretaris van Economische Zaken aan de SER voorgelegde adviesaanvraag omtrent nieuwe mededingingswet waarin een lans wordt gebroken voor de bestuurlijke handhaving van (nationale) kartclwetgeving. 
en in de Meststoffenwet. ${ }^{330}$ In de vierde tranche van de Awb zullen voorstellen ter zake van de administratieve boete worden opgenomen.

320 NRC 13 december 1993. 


\section{Dienstverlening}

\section{Begripsbepaling en verantwoording}

Onder dienstverlening wordt thans verstaan het verrichten van (nuttige) werkzaamheden ten behoeve van de samenleving door een veroordeelde van een strafbaar feit, aan wie anders een korte vrijheidsstraf zou zijn opgelegd. De dienstverlener is de veroordeelde die deze werkzaamheden verricht. ${ }^{321}$

Oorspronkelijk kon dienstverlening een rol spelen in verschillende stadia van het strafproces, zoals in het voorbereidend onderzoek, op het onderzoek ter terechtzitting en bij de tenuitvoerlegging van de straf.

Dienstverlening kon worden opgelegd volgens twee modellen: het officiersmodel en het rechtersmodel. In het officiersmodel komt de strafzaak niet op de terechtzitting; over dienstverlening beslist de officier van justitie, de zaak wordt buitengerechtelijk door het OM afgedaan. In het rechtersmodel is het, de naam zegt het al, de rechter die dienstverlening oplegt. Hij kan dit doen tijdens de zitting, maar ook tijdens het voorbereidend onderzoek in de vorm van schorsing van de voorlopige hechtenis. Inmiddels is een wet betreffende de invoering van de dienstverlening (Wet Aanvulling van het Wetboek van Strafrecht met de straf van onbetaalde arbeid) ingevoerd. ${ }^{322}$ Door deze wet is dienstverlening een straf geworden (artt. 9, 22b en 22c Sr) die uitsluitend nog volgens het rechtersmodel kan worden toegepast. De straf van het verrichten van onbetaalde arbeid ten algemenen nutte kan worden opgelegd als alternatief voor een onvoorwaardelijke vrijheidsstraf van maximaal zes maanden of voor een vrijheidsstraf waarvan het onvoorwaardelijk ten uitvoer te leggen gedeelte niet meer dan zes maanden bedraagt.

Hoewel met het officiersmodel is geëxperimenteerd, is deze modaliteit niet in de wet opgenomen. Het lijkt mij daarom van weinig nut thans nog de feitelijke gang van zaken van de betreffende officiersmodaliteiten uitgebreid te bespreken.

321 Overgenomen van $\mathbf{M}$. Bol en J. Overwater, Dienstverlening, vervanging van de vrijheidsstraf in het strafrecht voor volwassenen, deel 1. WODC, Den Haag 1983, met dien verstande dat de definitie toen nog uitging van de mogelijkheid dat ook een verdachte van een strafbaar feit ter voorkoming van een veryolging of veroordeling dergelijke werkzaamheden kon verrichten.

322 Wet van 25 oktober 1989, Stb. 482, inwerkingtreding 1 december 1989. 
Ondanks de omstandigheid dat de dienstverlening als afdoeningsmodaliteit van het OM niet meer voorkomt (althans in het volwassenenstrafrecht) lijkt het mij toch van belang enige aandacht aan de dienstverlening te wijden, die vooral zal uitgaan naar de argumenten voor de keuze tussen het rechters- en tegen het officiersmodel. ${ }^{32}$ Wellicht kunnen deze argumenten een rol spelen (of juist niet) in de discussie met betrekking tot andere afdoeningsmodaliteiten. Te denken valt hierbij aan de transactie of het voorwaardelijk sepot.

Om de discussie met betrekking tot de keuze tussen het rechtersmodel en het officiersmodel goed te begrijpen is het nodig enig inzicht te hebben in de ontwikkeling die het instituut van de dienstverlening heeft doorgemaakt. Daarom volgen nu eerst enige "historische" notities.

\section{Historie}

De nog korte historie van de dienstverlening vangt aan in 1971, wanneer de Arnhemse politierechter in de IJzervlechterszaak drie verdachten veroordeelt tot een gedeeltelijk voorwaardelijke vrijheidsstraf met als bijzondere voorwaarde dat zij in een proeftijd gedurende een periode van drie maanden werkzaamheden zouden verrichten in sociale instellingen, die zich reeds bereid hadden verklaard zich hiervoor beschikbaar te houden. Het OM gaat in hoger beroep en het Hof vemietigt vervolgens het vonnis. Het is van oordeel dat de voorwaarde ontoelaatbaar is omdat zij het karakter heeft van een straf. De rechter kan niet middels een voorwaardelijke veroordeling een straf opleggen die niet tot het straffenarsenaal van het $\mathrm{WvS}_{\mathrm{r}}$ behoort. Verder vermeldt het Hof dat de voorwaarde 'op zichzelf' niet strijdig is met (het toenmalige) art. $14 \mathrm{c} \mathrm{Sr}$.

De Hoge Raad vernietigt het arrest van het Hof wegens innerlijke tegenstrijdigheid en komt aan een oordeel over de toelaatbaarheid van de gestelde voorwaarde niet toe (HR 31 oktober 1972, NJ 1973, 44 m.nt. ThWvV). De zaak wordt verwezen naar het Hof 's-Hertogenbosch.

Dit Hof oordeelt dat de voorwaarde niet in strijd is met het WvSr omdat het hier een voorwaarde betreft die betrekking had op het gedrag van de veroordeelde en omdat geen leedtoevoeging werd beoogd. Wel acht het Hof de werkvoorwaarde in strijd met het Verdrag van Genève betreffende dwangarbeid, omdat in dit geval

323 Voor andere aspecten, zoals de gevallen waarin dienstverlening kan worden toegepast, de inhoud en de duur, de organisatic, de controle op de uitwering, etc., wordt verwezen naar onder andere M. Bol en J. Overwater, Dienstverlening. Vervanging van de vrijheidstraf in het strafrecht voor volwassenen. Deel 1: totstandkoming en uitwoering, WODC 1983; Decl 2: Dienstverleners en projectverschaffers, WODC 1983; Deel 3: De plaats van de dienstverlening in de Nederlandse strafrechtpleging, WODC 1983; Dienstverlening. Eindrapport van het onderzoek naar de vervanging van de vrijheidsstraf in het strafrecht voor volwassenen, WODC 1984. 
niet gesproken kan worden van vrijwillige arbeid (Hof Den Bosch 16 januari 1974, NJ 1974, 229 m.nt. ThWvV).

In de cassatieprocedure die hierop volgt stelt de Hoge Raad dat het toelaatbaar is dat het Hof een andere straf oplegt dan de politierechter had gedaan. Wederom komt ons hoogste rechtscollege niet toe aan de hoofdvraag of de werkvoorwaarde toelaatbaar is (HR 22 oktober 1974, NJ 1975, 39 m.nt. ThWvV).

Desondanks geeft deze jurisprudentie aanleiding tot een aantal interessante juridische beschouwingen betreffende de werkvoorwaarde, bijvoorbeeld over de vrijwilligheid van de werkverrichting en strijd met internationale verdragen ${ }^{324}$, over het (straf)karakter van de werkvoorwaarde ${ }^{325}$, over de verantwoordelijkheid bij de uitvoering van het werk ${ }^{326}$ en over de vraag of deze voorwaarde past in ons Nederlands strafstelsel. ${ }^{3 n}$ In een pre-advies aan de NJV over de voorwaardelijke veroordeling wijden Mulder en Schootstra ook speciale aandacht aan de werkvoorwaarde. Zij komen tot de slotsom dat een bijzondere voorwaarde die een verrichting op sociaal-charitatief terrein inhoudt, naar het geldende recht ontoelaatbaar is. Zij spreken zich uit voor een wetswijziging welke zou moeten inhouden dat de werkvoorwaarde als een bijzondere voorwaarde bij een voorwaardelijke veroordeling kan worden opgelegd. ${ }^{328}$ De vraag in welke fase van het strafproces de werkvoorwaarde een rol kan spelen maakt eveneens deel uit van de discussie (zie hiervoor $\$ 5.3$ ).

Ook het parlement laat zich niet onbetuigd. ${ }^{3 \mathfrak{x}}$ De motivering voor de dienstverlening hinkt op twee gedachten, hetgeen reeds bij de discussie over de uitbreiding van de transactie geconstateerd kon worden. Aanvankelijk overheersen ideeën over humanisering van het strafrecht door terugdringen van de vrijheidsstraf, om later plaats te maken voor meer financiële argumenten. Bij een tekort aan financiële middelen en een tekort aan gevangenisplaatsen kan de dienstverlening een 'goeclkoop' alternatief zijn.

324 Zie onder andere: W.H.A. Jonkers, (iedwongen tewerkstelling als sanctic? Proces 1972, pag. 151-152; Anton van Kalmthout en Hendrik Quint, Met het systcimperspectief blijven we altijd zitten. AA XXII, pag. 262-262.

325 Zie onder andere: W.H.A. Jonkers, a.w., pag. 152; Nicole Wennekers, Hendrik Quint en Anton van Kalmthout, Wie niet zitten wil, mag ook niet werken. AA XXII, no. 3, pag. 127-128.

326 Zie onder andere: W.H.A. Jonkers, a.w., pag. 154.

327 Zie onder andere: Wennekers, Quint en Van Kalmthout, a.w., pag. 116; C.P.Chr.M. Oomen, 'Werken' in plaats van zitten: een gewenste nieuwe ontwikkeling in de strafrechtspraak? NJB 1972, pag. 257-267.

328 G.E. Mulder en H. Schootstra, De voorwaardclijke veroordeling, Preadvies Nederlandse Juristenvereniging, 1974.

329 Zie voor een overcicht van de parlementaire debatten: H. Singer-Dekker, Diensivirlening (Monografieên Strafrecht deel 4). Arnhem 1984, pag. 42-49. 


\section{Openbaar ministerie of rechter?}

De vraag welke instantie de beschikking zou krijgen over het opleggen van de dienstverlening vormt een punt van discussie.

In een reactie op hetgeen A-G Hustinx bij de behandeling in hoger beroep van het vonnis van de Amhemse politierechter in zijn requisitoir naar voren bracht, namelijk dienstverlening in de fase waarin het $\mathrm{OM}$ beslist over al dan niet vervolgen, zien Wennekers, Quint en Van Kalmthout als nadeel dat deze wijze van dienstverlening "zich onttrekt aan de controle van een gejuridiseerde procesgang". ${ }^{30}$

Asscher pleit voor onderbrenging van de dienstverlening bij een zogenaamd sepotteam, bestaande uit reclassering, districtspsychiater, raadsman en OM. Hij ziet de alternatieve sancties niet als strafrechtelijke sancties, maar meer als correctieve maatregelen, waarvan de oplegging niet bij de rechter kan liggen ${ }^{331}$ Van der Kruijs en Montijn zijn van mening dat de dienstverlening wel degelijk een strafrechtelijke reactie is, gezien het vrijheidsbenemende karakter ervan. ${ }^{32}$ Singer-Dekker vindt dat er aan het $\mathrm{OM}$ ruimte zal moeten worden gelaten voor nieuwe vormen van strafbaar gedrag, binnen het kader van een voorwaardelijk sepot, toe te laten. Volgens haar blijft er dan toch een groep over die niet op deze manier te helpen is en die voor de rechter komt. Ook dan moet de alternatieve straf nog tot de mogelijkheden behoren. ${ }^{33}$

\section{Verdere ontwikkeling}

Naar aanleiding van de behandeling van de Justitiebegroting van $1974^{334}$ wordt de Commissie Alternatieve Strafrechtelijke Sancties ingesteld ${ }^{335}$, aanvankelijk Commissie Enschede, later, na vervanging van haar voorzitter, Commissie Van Andel genaamd. De taakopdracht van deze commissie is van advies te dienen omtrent de vraag of het wenselijk is meer verscheidenheid te brengen in het strafstelsel van het Wetboek van Strafrecht en zonodig voorstellen te doen tot aanvulling van het algemene strafrecht met andere strafrechtelijke sancties.

In 1979 (!) verschijnt het Interimrapport van deze commissie betreffende de dienstverlening. De commissie streeft niet naar definitieve standpuntbepalingen omdat nog te weinig gegevens over de dienstverlening bekend waren. De commissie is van mening dat de dienstverlening gericht moet zijn op de terugdringing van de vrijheids-

330 Nicole Wennekers, Hendrik Quint en Anton van Kalmthout, a.w., pag. 123.

331 B.J. Asscher, Alternatieve straften of anders. Proces 1976, pag. 159.

332 P.W. van der Kruijs, Alternatieven in de strafvervolging, strafoplegging en strafexecutic. L.R. Montijn, Straffen, anders .... Proces 1976, no. 10.

333 H. Singer-Dekker, Alternatieve sanctics. DD 1977, pag. 219-224.

334 Handelingen II 1973-1974, pag. 698-800.

335 Stcrt. 17 septcmber 1974 , no. 180. 
straf, dat de werkverrichting slechts mag plaatsvinden met instemming van de veroordeelde, dat het te verrichten werk maatschappelijk zinvol moet zijn en dat het zoveel mogelijk in de vrije tijd van de veroordeelde moet plaatsvinden.

Over de vraag volgens welk model de dienstverlening zou moeten plaatsvinden komt de commissie niet tot overeenstemming. Twee commissieleden, te weten Hulsman en G.E. Mulder, staan tegenover elkaar, hetgeen ongetwijfeld te maken heeft met hun ideeën over de functie van het strafrecht.

Hulsman is voorstander van het zogenaamde vrijwillige model. Dit model van dienstverlening zou worden ingeleid door een overeenkomst die de verdachte nog tijdens het voorbereidend onderzoek sluit met de reclassering, waarin een goed uitgewerkt voorstel ligt. Het resultaat van deze overeenkomst moet aan de behandelend officier van justitie worden voorgelegd en deze beslist dan over de aanvaarding van de overeenkomst. Dit zou kunnen gebeuren volgens van te voren opgestelde regels, waarbij de officier van justitie, wanneer hieraan voldaan wordt, verplicht is het dienstverleningsaanbod te aanvaarden, of zonder opgestelde regels, waarbij de officier vrij is het aanbod wel of niet te aanvaarden. Stemt de officier met de inhoud van het voorstel in, dan ziet hij onvoorwaardelijk af van vervolging. Het niet (volledig) nakomen van de dienstverleningsverplichting leidt niet tot het alsnog voortzetten van de strafvervolging. In dit model neemt het OM dus een centrale positie in.

Hierin zien we de visie van Hulsman op het strafrecht terug. Er moet zo min mogelijk met het strafrecht ingegrepen worden. Dienstverlening mag niet worden tot een nieuwe straf, want dat zou betekenen dat het strafrecht weer meer mogelijkheden om in te grijpen zou hebben. Hulsman is van mening dat burgers hun conflicten zoveel mogelijk zelf moeten oplossen.

Mulder staat het zogenaamde verplichte model voor. Het staat de verdachte vrij een dienstverleningsvoorstel aan te bieden. De strafrechtsfunctionaris (wie dat is hangt af van de fase waarin de verdachte dit doet) is betrokken bij het vaststellen van de omvang van de taak. Wordt het aanbod aanvaard dan is de verdachte verplicht zijn taak te volbrengen, waarbij hij door of namens de met de strafrechtstoepassing belaste functionarissen wordt gecontroleerd. Bij niet of niet volledige voltooiing van de dienstverlening volgt in principe alsnog een sanctie. Er zijn dus negatieve gevolgen verbonden aan niet-nakoming. Dit model kan betrekking hebben op het voorbereidend onderzoek en het onderzoek ter terechtzitting. Een andere variant betreft de fase van de tenuitvoerlegging. Oplegging door de officier van justitie kan gebeuren in het kader van een voorwaardelijk sepot of een kennisgeving van niet verdere vervolging. Bij oplegging door de rechter kunnen we denken aan dienstverlening als eindsanctie, maar we kunnen het ook plaatsen in het kader van uitstel van vonniswijzing. De dienstverlening in de fase van de tenuitvoerlegging kan men zich als volgt voorstellen: in bepaalde regels wordt neergelegd wanneer de veroordeelde er recht op heeft dat de hem opgelegde straf niet ten uitvoer zal worden gelegd indien hij een overeenkomst tot dienstverlening sluit en daaraan voldoet.

In dit verplichte model speelt de rechter een grotere rol. 
De commissie adviseert de regering experimenten te doen plaatsvinden met het verplichte en het vrijwillige model.

Op 1 mei 1980 stelt de minister van Justitie de Voorbereidingsgroep Experimenten Dienstverlening (VED) in, onder voorzitterschap van $H$. van Buuren. Deze groep moet advies uitbrengen over de arrondissementen waar de experimenten met betrekking tot de dienstverlening moeten plaatsvinden, de voorzieningen die getroffen moeten worden om dienstverlening mogelijk te maken en de wijze waarop het toezicht op dienstverlening in concrete gevallen zal kunnen geschieden. Daarnaast krijgt de VED de opdracht de experimenten te begeleiden en te evalueren. ${ }^{336}$

Nadat de VED met voorstellen daartoe is gekomen, bericht de minister van Justitie middels een circulaire aan de hoofdofficieren van justitie en de reclasseringsinstellingen $^{337}$ (zittende magistratuur en balie ontbreken) dat op 1 februari 1981 een aanvang gemaakt zal worden met de experimenten met de dienstverlening als vervanging van de korte vrijheidsstraf. Alkmaar, Almelo, Assen, Breda, Groningen, Haarlem, 's-Hertogenbosch en Zutphen zijn de proefarrondissementen. Dienstverlening is mogelijk in het kader van het onvoorwaardelijk sepot, het uitstel van de vervolgingsbeslissing, waarbij de officier van justitie seponeert nadat de dienstverlening met succes is verricht, het voorwaardelijk sepot en het uitstel van vonniswijzing, waarbij de verdachte ter zitting met een voorstel komt. Dalarnaast kan de dienstverlening ook als cen bijzondere voorwaarde bij een voorwaardelijke veroordeling worden toegepast, hoewel de VED dit minder gewenst acht, omdat dan de kans groot is dat de dienstverlening als dwangarbeid wordt geïnterpreteerd ( $\mathrm{Bij}$ de experimenten wordt deze modaliteit wel gehanteerd).

Tijdens de experimenteerfase wordt nog een andere modaliteit toegevoegd, te weten de dienstverlening in het kader van gratie.

De VED geeft de voorkeur aan de toepassing van de dienstverlening in een zo vroeg mogelijk stadium van het strafproces, om zo het tijdsverloop tussen het begaan van het delict en de dienstverlening zo beperkt mogelijk te houden. De nadruk ligt derhalve op het officiersmodel.

Het model waarbinnen de dienstverlening moet plaatsvinden komt in de Tweede Kamer onder meer aan de orde bij de behandeling van het wetsontwerp Verandering in de Grondwet van bepalingen aangaande Justitie (16.162). Daarbij kiest de minister van Justitie eveneens voor het officiersmodel. De argumentatie daarvoor is niet sterk. Dienstverlening is volgens de minister geen straf omdat ze immers niet door de strafrechter wordt opgelegd. Ze berust op een overeenkomst tussen dader en OM. De berechting van strafbare feiten is niet aan de orde. In de toelichting bij het betref-

336 Stcrt. 6 mei 1980 , no. 86.

337 D.d. 10 november 1980, als bijlage I gevocgd bij Dienstverlening, van experiment naar wet. Eindadvies VED, Den Haag 1984. 
fende wetsontwerp schrijven de betrokken bewindslieden dat de berechting van strafbare feiten, dat wil zeggen het rechtens kennisnemen en afdoen van zodanige feiten, uitsluitend is opgedragen aan de gerechten van de rechterlijke macht ${ }^{388}$ en dat art. 6 EVRM ertoe leidt dat deze feiten door een onpartijdige en onafhankelijke rechterlijke instantie berecht moeten worden. ${ }^{339}$ Naar aanleiding hiervan vragen enkele kamerleden zich af of de transactie en de dienstverlening dan eigenlijk wel tot de competentie van het $\mathrm{OM}$ behoren, aangezien deze toch op daden van berechting lijken. Hierop komt de minister met het zeer formalistische antwoord dat de uitoefening van deze bevoegdheden juist ertoe leidt dat geen berechting plaatsvindt en dus niet gezien wordt als rechtspreken. ${ }^{3+0} \mathrm{De}$ cirkel is daarmee rond: berechting van strafbare feiten is aan de rechter opgedragen, noem berechting geen berechting en afdoening door het $\mathrm{OM}$ is toegestaan.

Voor de aanvang van het experiment heeft het WODC onderzocht welke opvattingen er over dienstverlening leefden. ${ }^{34}$ Omdat verwacht werd dat de dienstverlening vooral opgelegd zou worden door het OM, werd besloten het onderzoek te houden onder leden van het $\mathrm{OM}$, reclassering en strafrechtelijke advocatuur. De zittende magistratuur werd niet naar de mening gevraagd. Achteraf gezien is dit te betreuren, omdat op deze manier niet alle bij het proces betrokken instanties hun mening hebben kunnen geven, waardoor de uitkomst niet geheel objectief is. ${ }^{342}$ Onder andere vanwege de responspercentages dient enige voorzichtigheid betracht te worden bij de interpretatie van de gegevens. In dit onderzoek kwam onder meer de vraag aan de orde op welke manier de dienstverlening toegepast moest worden. Hierbij werd uitgegaan van de modaliteiten zoals de VED die had voorgesteld.

De modaliteit 'uitstel van vonniswijzing' werd het vaakst genoemd. Opvallend is de voorkeur van het OM voor die modaliteiten, waarbij men na afloop van de dienstverlening nog 'vrij' is een beslissing te nemen. Het $\mathrm{OM}$ is meer dan de reclassering en de advocatuur voor een afhandeling van de dienstverlening door het $\mathrm{OM}$. Slechts $15 \%$ van de respondenten gaf een toelichting, waardoor het moeilijk is hierover concrete uitspraken te doen. Heel algemeen kan worden gesteld dat het OM wat meer nadruk legde op het feit dat het wenselijk is om, in geval van een mislukte dienstverlening, alsnog strafrechtelijk adequaat te kunnen ingrijpen. De reclassering legde meer nadruk op de zekerheid voor de verdachte. De advocatuur lette het meest op de plaats van de dienstverlening in het strafproces. ${ }^{343}$ Wat hiermee precies bedoeld wordt blijkt helaas niet uit het rapport.

338 MvT 16.162 , no. 1 , pag. 6.

339 idem, pag. 48.

340 Kamerstuk 16.162, no. 8, pag. 8.

341 Jaap de Hullu, Opvattingen over dienstverlening. WODC, Den Haag 1981.

342 Vgl. Jaap de Hullu, a.w., pag. 1.

343 Jaap de Hullu, a.w., pag. 6. 
In het algemeen kunnen we stellen dat de keuze voor het officiers- of het rechtersmodel samenhangt met de vraag of de dienstverlening gezien moet worden als een straf of als een alternatief voor straf. Degene die haar als alternatief ziet voor straf zal de betrokkene zo snel mogelijk uit het strafproces willen weghalen; wie de dienstverlening als straf ziet, waarmee een diepe inbreuk gemaakt kan worden op de persoonlijke levenssfeer kiest eerder voor dienstverlening in het rechtersmodel, vanwege de rechtswaarborgen.

\section{Evaluatie van de experimenten}

Het grootste gedeelte van het onderzoeksmateriaal werd verzameld over de periode februari 1981 tot en met mei 1982. Gegevens over de organisatie werden in de loop van 1983 verzameld. In 1983 bracht het WODC drie deelrapporten uit. ${ }^{2+4}$ In 1984 volgde het eindrapport. ${ }^{345}$

Wellicht ten overvloede zij hier vermeld dat de bespreking van de resultaten van de experimenten zich ook hier zal beperken tot de gehanteerde modaliteiten van de dienstverlening. Voor de evaluatie van andere resultaten, bijvoorbeeld betreffende de organisatie, procedures, projektwerving, begeleiding etc., wordt verwezen naar de betreffende deelrapporten.

Zoals uit de vorige paragraaf is gebleken lag de voorkeur van de VED en van de minister van Justitie bij de aanvang van de experimenteerperiode bij het officiersmodel.

De onderzoekers hebben de verdeling over het rechters- en het officiersmodel over twee periodes apart bekeken en stelden vast dat er een verschuiving heeft plaatsgevonden in de richting van het rechtersmodel. In het begin was de verdeling over de twee instanties vrijwel gelijk. In de tweede periode verliep ongeveer driekwart van de dienstverlening volgens het rechtersmodel en een kwart via het $O M$. Over de gehele periode blijkt ruim tweederde van het aantal dienstverleningen tot stand te zijn gekomen via de rechter en eenderde via de officier van justitie.

Als modaliteiten die op OM-niveau konden worden toegepast, noemde de VED aanvankelijk de volgende mogelijkheden:

1. onvoorwaardelijk sepot, ongeacht de afloop van de dienstverlening;

2. uitstel van de beslissing tot verdere vervolging;

$344 \mathrm{M}$. Bol en J. Overwater, Dienstverlening, vervanging van de vrijheidsstraf in het strafrecht voor volwassenen. Deel 1: Totstandkoming en uitvoering. WODC 1983; Deel 2: Dienstverleners en projectverschaffers. WODC 1983; Deel 3: De plaats van de dienstverlening in de Nederlandse strafrechtspleging. WODC 1983.

345 M.W. Bol en J.J. Overwater, Dienstverlening, Eindrapport van het onderzoek naar de vervanging van de viijheidsstraf in het strafrecht voor volwassenen. WODC 1984. 
3. voorwaardelijk sepot, met een (goed) verloop van de dienstverlening als voorwaarde.

In de praktijk blijken ook andere modaliteiten te zijn toegepast:

4. voorwaardelijk sepot, ongeacht de afloop van de dienstverlening;

5. voorwaardelijk sepot na een goed verloop van de dienstverlening (bijvoorbeeld met de voorwaarde dat de betrokkene binnen een bepaalde proeftijd geen nieuwe delicten pleegt);

6. de officier van justitie zal ter zitting geen onvoonwaardelijke gevangenisstraf eisen, mits de dienstverlening goed verloopt;

7. de officier van justitie zal positief adviseren bij een gratieverzoek, mits de dienstverlening goed verloopt;

8. de officier van justitie zal geen onvoorwaardelijke geldboete eisen, als de dienstverlening goed verloopt.

Het meest wordt het onvoorwaardelijk sepot na een goede afloop van de dienstverlening toegepast. Daarna komt de categorie 'onbekend', waarbij de onderzoekers er van uitgaan dat dit meestal een uitstel van de vervolgingsbeslissing inhoudt. Het onvoorwaardelijk sepot, ook als de dienstverlening mislukt (het model van Hulsman) komt ongeveer even vaak voor als het voorwaardelijk sepot na een geslaagde dienstverlening.

Voor toepassing van het rechtersmodel koos de VED voor de volgende mogelijkheden:

1. uitste] van vonniswijzing;

2. dienstverlening als bijzondere voorwaarde bij een voorwaardelijke veroordeling.

Later werd de gratievariant aan deze modaliteiten toegevoegd.

Binnen het rechtersmodel werd uitstel van vonniswijzing het meest toegepast. In ongeveer eenvijfde van deze zaken stond in het procesverbaal van de zitting omschreven welke straf zou volgen als de dienstverlening niet volgens afspraak werd uitgevoerd.

In de zomer van 1983 werd aan de verschillende instanties die bij de dienstverlening zijn betrokken, gevraagd naar hun mening over de dienstverlening, gebaseerd op enkele jaren ervaring. Daarbij kwam onder andere de vraag aan de orde welke modaliteit men geschikt acht. Het resultaat was dat meer dan de helft van de respondenten de modaliteiten onvoorwaardelijk sepot mits de dienstverlening slaagh, uitstel vonniswijzing met strafomschrijving bijzondere voorwaarde bij voorwaardelijke veroordeling, positief gratie-advies na geslaagde dienstverlening en de modaliteiten in 
combinatie met schorsing van de voorlopige hechtenis bijzonder geschikt vinden. De zittende magistratuur en het $\mathrm{OM}$ vinden het positief gratie-advies minder geschikt dan de reclassering en de advocatuur. Zij achten daarentegen de bijzondere voorwaarde bij de voorwaardelijke veroordeling geschikter. De zittende magistratuur vindt de modaliteit voorwaardelijk sepot, mits de dienstverlening slaagt minder geschikt dan de andere functiegroepen. Driekwart van de advocatuur vindt de modaliteiten gecombineerd met een schorsing van de voorlopige hechtenis geschikt, terwijl slechts $15 \%$ van het OM dit vindt. Met betrekking tot de meningen over de geschiktheid van de modaliteiten blijken tussen de verschillende arrondissementen nogal wat verschillen te bestaan. ${ }^{346}$

Dit onderzoek betreft helaas slechts een inventarisatie van de bestaande voorkeuren voor bepaalde modaliteiten. Hieruit blijkt niet wat de motivering van de verschillende functiegroepen geweest is om een bepaalde modaliteit meer of minder geschikt te achten.

Een reële vergelijking op dit punt met het onderzoek naar de opvattingen over dienstverlening voor de aanvang van de experimenten (zie vorige paragraaf) is naar mijn mening niet goed te maken omdat de zittende magistratuur bij dit laatste onderzoek niet betrokken was en omdat het aantal modaliteiten in de loop van het experiment uitgebreid is. Héél globaal kunnen we stellen dat de voorkeur van het OM voor een OM-modaliteit gedaald is, terwijl deze voorkeur bij de advocatuur en de reclassering juist is toegenomen.

De verschuiving van de voorkeur van het officiers- naar het rechtersmodel kan verband houden met het oordeel van de betrokkenen over het karakter van de dienstverlening. Uit het WODC-onderzoek blijkt dat ruim $70 \%$ van de zittende magistratuur, tweederde van de reclassering en ruim $50 \%$ van de leden van het OM de dienstverlening als straf zien. Ruim $62 \%$ van de dienstverleners heeft de dienstverlening als een straf ervaren. ${ }^{347}$

Ook de VED is nu deze mening toegedaan. Gewezen wordt hierbij op het vergeldende karakter en op de materiële genoegdoening aan de samenleving die ermee wordt nagestreefd. ${ }^{48}$

$\mathrm{Na}$ het uitvoeren van de experimenten betreffende de dienstverlening kunnen we als samenvattende conclusie over de afweging tussen de modaliteiten stellen dat:

1. het aantal modaliteiten zich tijdens de experimenten heeft uitgebreid;

346 Zic deelrapport 3, pag. 79.

347 Eindrapport, pag. 83-84.

348 Dienstverlening, van experiment naar wet. Eindadvies VED, Den Hatg 1984, pag. 17. 
2. er zich een verschuiving heeft voorgedaan van het officiers- naar het rechtersmodel.

In haar eindadvies komt de VED met betrekking tot de gehanteerde modaliteiten tot de conclusie dat een vereenvoudiging wenselijk is. $\mathrm{Zij} \mathrm{kiest} \mathrm{voor} \mathrm{de} \mathrm{volgende}$ modaliteiten: $:^{399}$

1. Dienstverlening bij wege van transactie. De VED blijft voorstander van een strafrechtelijke reactie op een zo vroeg mogelijk tijdstip na het plegen van het strafbaar feit, zodat een officiersmodaliteit gehandhaafd moet worden. De VED ziet de dienstverlening niet als een vrijheidsbenemende, maar als een vrijheidsbeperkende straf, reden waarom zij niet van mening is dat dienstverlening uitsluitend door de rechter kan worden opgelegd. Nu zij dienstverlening kwalificeert als een hoofdstraf is het onjuist haar als bijzondere voorwaarde bij een voorwaardelijk sepot toe te laten. Zodoende blijft slechts de mogelijkheid van dienstverlening in het kader van transactie over. Naar het oordeel van de VED dient het OM hierbij in zekere mate gecontroleerd te worden. Een rechterlijke controle wordt echter vanwege de tijd die ermee gemoeid zal zijn afgewezen. Door de verdachte er op te wijzen dat hem een raadsman kan worden toegevoegd, waarmee hij overleg kan plegen over het transactie-aanbod van het $\mathrm{OM}$ en de dienstverlening wordt een controle-element ingebouwd.

2. Dienstverlening bij eindvonnis. Deze modaliteit wordt mogelijk wanneer de dienstverlening als hoofdstraf is ingevoerd. Zij vervangt de modaliteiten dienstverlening bij uitstel van vonniswijzing en dienstverlening als bijzondere voorwaarde bij een voorwaardelijke veroordeling, die tijdens de experimenteerperiode werden gebruikt.

In het vonnis dient de rechter expliciet de duur van de vrijheidsstraf, welke door de dienstverlening wordt vervangen, te vermelden.

De VED acht het wenselijk, dat art. 14a Sr zodanig wordt gewijzigd dat het mogelijk wordt bij deze modaliteit de dienstverlening te combineren met een gedeeltelijk voorwaardelijke vrijheidsstraf, en zonodig met een bijzondere voorwaarde. Deze wijziging zal niet zover mogen gaan dat de dienstverlening zelf voorwaardelijk kan worden opgelegd.

Een combinatie van een onvoorwaardelijke vrijheidsstraf met een dienstverlening wordt afgewezen.

In het geval de dienstverlening niet naar behoren wordt vervuld, kan zij omgezet worden in een andere straf.

3. Dienstverlening bij aanhouding van de gratieheslissing. De procedure zoals die in de experimenteerperiode werd gehanteerd ${ }^{350}$ blijft gehandhaafd.

$349 \mathrm{Zie}$ Jaap de Hullu, Opvattingen over dienstverlening. WODC 1981, pag. 19.

350 Zic cen circulaire van de staatssecretaris van Justitic d.d. 15 april 1982, als bijlage 2 opgenomen in het eindadvies van de VED (Den Haag 1984). 
In de voorgaande paragraaf lag de nadruk voornamelijk op een inventarisatie van de gehanteerde modaliteiten binnen de beide modellen. Voordat de wet over de dienstverlening besproken wordt, acht ik het zinvol het officiers- en het rechtersmodel inhoudelijk te waarderen om zo een verantwoorde afweging te kunnen maken.

\subsection{Het officiersmodel}

Kenmerkend voor dit model is dat de beslissing tot dienstverlening genomen wordt door een lid van het $\mathrm{OM}$, zonder dat deze beslissing rechterlijk getoetst wordt. Voordelen hiervan zijn:

1. de dienstverlening kan plaatsvinden betrekkelijk kort na het tijdstip waarop het strafbaar feit gepleegd is. Hierdoor is het verband tussen het delict en de strafrechtelijke reactie daarop voor de verdachte duidelijker;

2. de procedure verloopt sneller; ambtsedige processen-verbaal lijken niet nodig, een dagvaarding kan worden vermeden, bewijskwesties en -verweren komen niet aan de orde enz. Kortom: strafzaken kunnen efficiënter en goedkoper worden afgedaan. Ook voor de verdachte heeft dit voordelen: hij blijft anoniemer, hij hoeft niet in het openbaar terecht te staan en hij krijgt geen aantekening op zijn strafblad.

3. Door afdoening van strafzaken in de vervolgingsfase is een grotere flexibiliteit van de gestelde voorwaarden mogelijk. ${ }^{351}$

De bezwaren van dit model zijn talrijk. ${ }^{32}$ Zij zijn voor een groot deel te plaatsen onder de noemer:

1. De dienstverlening is een sanctie. De dienstverleningsprocedure is met onvoldoende rechtswaarborgen omkleed: er wordt een sanctie opgelegd door een niet onafhankelijke en niet onpartijdige rechterlijke instantie, hetgeen in strijd is met art. 6 EVRM; het bewijs van het gepleegde feit en van de schuld van de verdachte staan niet vast; de verdachte heeft geen andere mogelijkheid om bezwaar aan te tekenen tegen het dienstverleningsvoorstel dan de zaak op de zitting te laten komen. De verdachte bevindt zich in een dwangpositie, want hij weet niet welke straf de officier van justitie gatat eisen en de rechter zal opleggen als hij het op een strafzitting liat aankomen. In het geval de verdachte niet over een raadsman

351 A. van Oortmerssen, De dienstverlening in het officiersmodel. Trema 1986, pag. 67.

$352 \mathrm{Vgl}$. A.M. van Kalmthout, Het weltelijk kader voor de dienstverlening. JV 6/1984, pag. 72 e.x; A. van Oortmerssen, a.w., pag. 65-69. 
beschikt, is het voor hem helemaal moeilijk een afweging te maken; het inquisitoire karakter van het strafproces wordt er door versterkt.

Als andere bezwaren kunnen worden genoemd:

2. Het gevaar is aanwezig dat de dienstverlening volgens het officiersmodel een aanzuigende werking zal krijgen. Dat wil zeggen dat in gevallen die eerder door middel van een (voorwaardelijk) sepot of transactie met lichtere voorwaarden werden afgedaan, nu ook een dienstverlening zal plaatsvinden. ${ }^{333}$

3. Dienstverlening vervangt een korte vrijheidsstraf. Deze vrijheidsstraf wordt opgelegd door de rechter. Hetgeen gebeurt ter vervanging van deze vrijheidsstraf moet dan ook door de rechter beslist worden. ${ }^{34}$

4. Door de dienstverlening volgens het officiersmodel kan sociale discriminatie in de rechtsgang worden vergroot. Volgens Huisman is het heel goed invoelbaar dat een officier van justitie een verdachte uit een wat beter milieu of met een redelijke opleiding beter in staat acht de dienstverlening tot een goed einde te brengen dan degenen die dat niet of nauwelijks hebben. ${ }^{355}$

\subsection{Het rechtersmodel $^{3 s_{i}}$}

In dit model wordt de beslissing tot dienstverlening genomen door een rechter. Voordelen hiervan zijn:

1. De dienstverlening wordt pas opgelegd na een strafprocedure, waarbij de rechtswaarborgen van de verdachte beschermd worden. Zo wordt er recht gesproken door een onafhankelijke en onpartijdige rechter, waarbij het bewijs van het feit en de schuld van de verdachte vastgesteld moeten worden. Getuigen en deskundigen worden gehoord en ook de verdachte, die zich kan laten bijstaan door een raadsman. De verdachte heeft het recht van hoger beroep, wanneer hij het met de opgelegde sanctie niet eens is;

2. De verdachte weet beter waar hij aan toe is in het geval de dienstverlening (gedeeltelijk) mislukt. Indien de dienstverlening naar behoren wordt vervuld, weet de verdachte dat hij niet opnieuw ter zake van hetzelfde feit vervolgd zal worden;

3. De dienstverlening komt tot stand in het openbaar. Hierdoor ontstaat er minder snel dan bij het OM het geval is een idee van 'handje klap'. Het risico van een aanzuigende werking is minder. Het kan althans beter gecontroleerd worden.

$353 \mathrm{Vgl.} \mathrm{A.M.} \mathrm{van} \mathrm{Kalmthout,} \mathrm{a.w.,} \mathrm{pag.} 73$.

$354 \mathrm{Vgl}$. R.A. Huisman, De tockomstige dienstverlening. Proces 1983, pag. 150.

355 R.A. Huisman, a.w., pag. 150. Vgl. ook A. van Oortmerssen, a.w., pag. 68.

356 Zic A.M. van Kalmthout, a.w., pag. 76-83. 
Als bezwaren tegen het rechtersmodel kunnen worden genoemd:

1. Een onherroepelijke veroordeling leidt tot een strafblad voor de verdachte;

2. De verdachte moet in het openbaar terecht staan. Hij kan niet anoniem blijven;

3. De periode tussen het tijdstip waarop de verdachte het strafbaar feit heeft begaan en het moment waarop de zitting plaatsvindt is doorgaans redelijk lang. Het gevolg hiervan is dat het verband tussen het feit en de dienstverlening minder wordt;

4. Een procedure voor de strafrechter is omslachtig en kostbaar.

\section{Wet Aanvulling van het Wetboek van Strafrecht met de straf van onbetaalde arbeid}

$\mathrm{Na}$ een inventarisatie van meningen en adviezen van betrokken instanties naar aanleiding van het advies van de VED komt de minister van Justitie op 2 september 1987 met een wetsvoorstel betreffende een wettelijke regeling van de dienstverlening. ${ }^{37}$ Voorgesteld wordt het verrichten van onbetaalde arbeid ten algemene nutte (kortweg: dienstverlening) op te nemen als hoofdstraf in het Wetboek van Strafrecht. Het voorstel bepaalt dat de rechter de dienstverlening kan opleggen in plaats van een onvoorwaardelijke vrijheidsstraf van niet meer dan zes maanden (art. 22b). Tevens wordt de mogelijkheid geopend de dienstverlening op te leggen in het kader van de tenuitvoerlegging van een voorwaardelijke vrijheidsstraf, indien deze straf niet meer dan zes maanden bedraagt. Met dit voorstel wordt beoogd de korte onvoorwaardelijke vrijheidsstraf terug te dringen, omdat daaraan verschillende bezwaren zitten. Daarnaast speelt ook een ander aspect een rol: " Daarenboven neemt daar waar de dienstverlening de tenuitvoerlegging van de korte vrijheidsstraf vervangt. de druk op de capaciteit van het gevangeniswezen af' ${ }^{3 s 8}$ Mooi meegenomen?

Het wetsvoorstel voorziet in één modaliteit van dienstverlening, namelijk de dienstverlening op te leggen bij eindvonnis (art. 22b). Met deze modaliteit is niet geëxperimenteerd omdat toepassing ervan een wetswijziging vergde, die nu wordt voorgesteld. In de MvT wordt de keuze voor het rechtersmodel als volgt beargumenteerd: "De kwalificatie van de dienstverlening als hoofdstraf betekent, gelet op het systeem van het Wetboek van Strafrecht waarin straffen worden opgelegd door de rechter, dat de dienstverlening uitsluitend door de rechter kan worden opgelegd. Deze kwalificatie heeft dan tot gevolg dat andere modaliteiten die tijdens de experimenten zijn beproefd niet meer gehanteerd zullen worden". Het officiersmodel verdwijnt hiermee van het dienstverleningstoneel, want de kwalificatie van de dienstverlening als hoofdstraf impliceert, volgens de MvT, dat het principieel onjuist zou zijn dat het $\mathrm{OM}$ deze straf als voorwaarde bij sepot of bij wege van transactie zou opleggen. Straffen

357 Wetsvoortsel Aanvulling van het Wetboek van Strafrecht met de straf van onbetaalde arbeid. TK 1986-1987, no. 20074.

358 MvT, TK 1986-1987, 20074, no. 3, pag. 4. 
worden opgelegd door de rechter en niet door het OM dat slechts een schikkingsaanbod kan doen. In tegenstelling tot de VED is de minister van mening dat de modaliteit van dienstverlening bij wege van transactie ongeschikt is, omdat de dienstverlening een straf is die de vrijheid van de verdachte aanzienlijk beperkt en als zodanig dermate zwaar is dat zij, evenals de vrijheidsstraf, slechts na een met waarborgen omgeven procedure mag worden opgelegd..$^{3.9} \mathrm{Na}$ kamervragen hieromtrent komt de minister er in de MvA nog eens op terug: De voorwaarde om gedurende enkele maanden dienstverlening te verrichten is van een heel andere orde dan de voorwaarde die de officier van justitie in het kader van transactie kan stellen, namelijk de betaling van een som geld of afstand van bepaalde voorwerpen. Dienstverlening is volgens hem een straf die de vergelijking met een vrijheidsstraf kan doorstaan. $\mathrm{Hij}$ acht het dan in het belang van de verdachte dat deze straf kan worden opgelegd als aan min of meer vergelijkbare waarborgen is voldaan als bij de vrijheidsstraf. De minister vermeldt verder dat de keuze voor het rechtersmodel gebaseerd is op de ervaringen die tijdens de experimenteerperiode met de dienstverlening zijn opgedaan. ${ }^{3 \times 0}$ In december 1989 is de Wet Aanvulling van het Wetboek van Strafrecht met de straf van onbetaalde arbeid ingevoerd."

\section{Kanttekeningen}

Sinds het begin van de experimenten met de dienstverlening (1980) is de belangstelling voor het officiersmodel terug gelopen. Aanvankelijk zagen VED en de minister van Justitie een belangrijke rol voor het $\mathrm{OM}$ weggelegd bij de dienstverleningsbeslissing. Reeds gedurende de experimenten bleek dat toepassing van de dienstverlening binnen het officiersmodel minder werd ten voordele van het rechtersmodel. In de uiteindelijke wet heeft dit geresulteerd tot een regeling van de dienstverlening uitsluitend via het rechtersmodel. De motivering hiervoor van de minister komt er in het kort op neer dat dienstverlening gekwalificeerd kan worden als een straf en dat een straf pas opgelegd kan worden na een met rechtswaarborgen voor de verdachte omklede procedure. Dienstverlening via het $\mathrm{OM}$ voldoet hieraan niet.

Ik kan instemmen met het gekozen dienstverleningsmodel. Het opleggen van de dienstverleningssanctie moet ook naar mijn mening met de nodige waarborgen omringd worden. Het officiersmodel biedt deze waarborgen niet. Door nu de beslissing tot dienstverlening in handen van het $\mathrm{OM}$ te leggen, zou de macht van dit orgaan ten opzichte van de burger in ontoelaatbare mate uitgebreid worden. Toch wil ik hierbij een paar kanttekeningen plaatsen.

Deze wet past niet in de ontwikkeling van het $\mathrm{OM}$ tot een zelfstandig beleidvoerend orgaan, een ontwikkeling die reeds geruime tijd gaande is. Dit impliceerde een sterke

360 TK 1987-1988, 20074, no. 6, pag. 8.

361 Wet van 25 oktober 1989, Stb. 482, inwerkingtreding 1 december 1989. 
uitbreiding van de bevoegdheden van het $\mathrm{OM}$, zoals bijvoorbeeld bij het nemen van de vervolgingsbeslissing. Dit heeft zich onder andere gemanifesteerd door een ruimere hantering van het opportuniteitsbeginsel en een uitbreiding van de transactiebevoegdheid in 1983. Afgezien van de vraag of deze ontwikkeling van het $\mathrm{OM}$ we] zo gelukkig moet worden genoemd moge duidelijk zijn deze wet van deze ontwikkeling afwijkt. Het OM kan de dienstverlening niet meer hanteren in het kader van zijn vervolgingsbeleid.

De dienstverlening moet volgens de minister via de rechter lopen omdat zij als een straf gekwalificeerd kan worden. Met dezelfde stelligheid betoogde een voormalig minister van Justitie voor de aanvang van de experimenten dat de dienstverlening geen straf was, omdat juist een formele strafprocedure daarmee voorkomen kon worden. Hierbij gaf ik toen als commentaar dat deze redenering zeer formeel was. Zolang men op een reactie op een strafbaar feit niet het etiket 'straf' plakt, behoeft deze reactie niet met waarborgen ongeven te zijn. Het is te waarderen dat de minister heeft ingezien dat de verrichtingen in het kader van een dienstverlening we] degelijk als een 'straf' kunnen worden beschouwd. Hierbij heeft hij ongetwijfeld rekening gehouden met het oordeel hierover van de betrokkenen bij de dienstverlening, zoals dat uit het WODC-onderzoek naar voren kwam. Ik zou deze redenering willen vergelijken met andere methoden van buitengerechtelijke afdoening door het $\mathrm{OM}$, zoals de transactie en met name het voorwaardelijk sepot. De betaling van een schikking is geen vrijheidsbenemende straf, waarvan de oplegging door de Grondwet (art. 113) aan de rechter is opgedragen. Het is echter, materieel gezien, wel degelijk als een straf te beschouwen. Degenen die het bedrag moeten betalen zullen het als een straf ondergaan. Naarmate het te betalen transactiebedrag (in de praktijk wordt reeds vaak de term 'boete' gebruikt!) hoger is, en sinds 1983 kunnen de bedragen aardig oplopen, zal ook deze verdachte meer behoefte aan een met waarborgen omkleed proces hebben. De voorwaarden zoals die bij het voorwaardelijk sepot opgelegd worden mogen naar mijn mening niet het karakter hebben van een straf. De officier behoeft bij het opleggen van de voorwaarden geen verantwoording af te leggen. De voorwaarden die opgelegd kunnen worden zijn niet wettelijk vastgelegd. Zeer goed denkbaar is, en in de praktijk gebeurt dit ook, dat voorwaarden opgelegd worden die de bewegingsvrijheid van de verdachte beperken, zo niet benemen. We kunnen hierbij bijvoorbeeld denken aan een straatverbod, maar ook aan opname in een ontwenningskliniek of een psychiatrische behandeling. De huidige (niet-) wettelijke regeling van het voorwaardelijk sepot laat naar mijn mening zelfs de mogelijkheid bestaan dat de officier een voorwaarde oplegt die te vergelijken is met een verrichting in het kader van een dienstverlening. Dus dan kan de dienstverlening via het officiersmodel door de achterdeur terugkeren.

Hiermee heb ik duidelijk willen maken dat het op zich te waarderen is dat de dienstverleningssanctie omgeven wordt door rechtswaarborgen, maar dat dit evenzeer zou moeten gelden voor andere buitengerechtelijke afdoeningsmethoden. 


\section{Voeging ad informandum}

\section{Inleiding en begripsbepaling ${ }^{362}$}

In de praktijk van het strafproces worden een verdachte, die een serie nog niet berechte delicten heeft begaan, doorgaans niet al deze strafbare feiten ten laste gelegd. De officier van justitie volstaat met een keuze daaruit, met het verzoek aan de rechter met de ad informandum gevoegde feiten rekening te houden bij de strafbepaling. De niet tenlastegelegde feiten worden dan bij de bepaling van de strafmaat mede in aanmerking genomen, als bijzondere redenen die de straf (voor de wel tenlastegelegde delicten) bepalen (art. 359 lid 5 Sv).

De bedoelde feiten, welke in het proces-verbaal of in het vervolg-proces-verbaal zijn vermeld, komen dus niet voor in de tenlastelegging, maar komen ter kennis (ter informatie, ad informandum) van de rechter, die er bij de strafoplegging rekening mee kan houden.

Het is van belang deze voeging ad informandum te onderscheiden van de voeging ter berechting, waarbij meerdere tenlastegelegde feiten tijdens hetzelfde onderzoek ter terechtzitting worden behandeld (art. $259 \mathrm{~Sv}$ ). Ad informandum gevoegde zaken worden niet in de tenlastelegging opgenomen, doch slechts ter informatie bij het dossier gevoegd. Soms worden de ad informandum te voegen zaken reeds op de dagvaarding zeer in het kort vermeld.

Deze praktijk van de voeging ad informandum heeft geen wettelijke basis.

Tot 1979 werd er in de jurisprudentie vanuit gegaan dat de ad informandum gevoegde feiten slechts dienden als bijzondere redenen die de straf mede bepaalden. In het Jaarverslag van het OM over 1975 bijvoorbeeld concluderen de procureurs-generaal

$362 \mathrm{Na}$ het verschijnen van de dissertatie van A.A. Franken over de voeging ad informandum in strafadken heb ik besloten de omvang van dit hooldstuk, in vergelijking met de oorspronkelijke versie, te beperken om doublures te voorkomen. Franken benadert de voeging ad informandum vanuit twee gezichtspunten: (1) als bijzondere omstandigheden die de straf mede bepalen, hoofdstuk 2 ; (2) als cen alternatieve afdoeningsmodaliteit voor het $\mathrm{OM}$, hoofdstuk 3. Met name het laatste is voor dit onderzoek van belang. A.A. Franken, De voeging ad informandum in strafzaken, dissertatie KUB, Arnhem 1993. 
dat de voeging ad informandum niet te beschouwen is als een sepot, maar als een vorm van een dagvaardingstechniek, waarbij de zaak niet afzonderlijk wordt vervolgd maar gekoppeld aan een andere zaak ter kennisneming aan de rechter wordt voorgelegd en op deze wijze in de straftoemeting wordt betrokken ${ }^{303}$ Dit hield de mogelijkheid open dat de verdachte ten aanzien van de ad informandum gevoegde feiten opnieuw zou kunnen worden vervolgd.

In 1979 veranderde de opvatting van de Hoge Raad. Ad informandum gevoegde feiten die door de verdachte waren bekend konden niet meer afzonderlijk worden vervolgd. Hierdoor werd de voeging ad informandum een aparte, vereenvoudigde wijze van afdoen.

Op grond van het opportuniteitsbeginsel kan de officier van justitie beslissen een bepaald strafbaar feit niet (verder) te vervolgen. Niet-vervolgen (seponeren) leidt ertoe dat de zaak niet ter fine van be- en veroordeling aan de rechter zal worden voorgelegd. Strikt genomen is een voeging ad informandum echter niet gelijk te stellen met een sepot. De zaak wordt wel door de rechter, zij het op andere wijze, afgedaan. $\mathrm{Er}$ is echter evenmin sprake van een 'echte' vervolging omdat de feiten niet in de tenlastelegging zijn opgenomen en dus niet op normale wijze bij de rechter aanhangig worden gemaakt.

Ik denk dat we de voeging ad informandum een eigen status moeten toekennen. Ik ben van mening dat de voeging ad informandum een zelfstandige afdoeningsmodaliteit is, die qua vorm tussen het sepot en een vervolging in ligt. ${ }^{364}$ Deze wijze van afdoen is naar mijn mening niet te baseren op het opportuniteitsbeginsel omdat dat heginsel het $\mathrm{OM}$ de mogelijkheid biedt niet of onder voorwaarden niet tot vervolging over te gaan. Bij de voeging ad informandum wordt echter wel vervolgd, volgens een procedure die niet op de wet is gebaseerd.

Het onderwerp van deze studie is: 'De buitengerechtelijke afdoening van strafbare feiten door het OM'. Strikt genomen is de voeging ad informandum geen buitengerechtelijke afdoeningsmethode. De zaken die op deze manier afgedaan worden komen wel op de strafzitting. Er zijn echter nair mijn mening goede redenen dit onderwerp hier op te nemen.

De ad informandum gevoegde zaken worden niet in de tenlastelegging opgenomen en krijgen daarom ook geen volledige behandeling door de rechter, zoals de tenlastegelegde feiten dat wel krijgen. De rechter onderzoekt op grondslag van de tenlastelegging (artt. 348 en $350 \mathrm{~Sv}$ ) of de strafbare feiten uiteindelijk tot een veroordeling kunnen leiden. De ad informandum gevoegde zaken zijn niet in de tenlastelegging

363 TK 1976-1977, 14.000, hoofdstuk VI, no. 3, pag. 47.

364 Vgl. P.J.P. Tak, Voorstellen rond de voeging ad informandum, DD 1978, pag. 80; S.A.M. Stolwijk, Veeging ad informandum, DD 1984, pag. 520; A.A. Franken, Voeging ad informandum in strafzaken, Arnhem 1993. 
opgenomen en worden derhalve niet aan een dergelijk onderzoek door de rechter onderworpen. Kunnen we hier niet spreken van een buitengerechtelijke, van een volledig "binnengerechtelijke" afdoening is ook geen sprake. Het OM gebruikt de voeging ad informandum als alternatieve afdoeningsmodaliteit.

\section{Rechtsgrond van de voeging ad informandum}

Zoals hierboven reeds gememoreerd heeft de voeging ad informandum geen wettelijke basis.

Wanneer het instrument van de voeging ad informandum zijn intrede in ons strafproces heeft gedaan is niet precies aan te geven. Bij de behandeling van het huidige Wetboek van Strafvordering, ingevoerd in 1926, komt het niet aan de orde. Literatuurverwijzingen van voor 1930 ontbreken. Het oudste artikel dateert bij mijn weten van 1930." Het dossier ad informandum werd echter voor een deel anders gehanteerd dan nu het geval is. Eén of meer andere strafzaken, die dus wel volledig donr de rechter behandeld waren en tot een veroordeling hadden geleid, werden bij de stukken van de te behandelen strafzaak gevoegd. Volgens de schrijver gebeurde dit om recidivebepalingen te omzeilen, omdat die in het in het betreffende geval niet van toepassing waren. Bijvoorbeeld: iemand staat terecht voor zware mishandeling en is voordien reeds veroordeeld wegens een serie diefstallen. Deze feiten recidiveren niet met elkaar (art. $421 \mathrm{Sr}$ ). Om nu de vroegere veroordeling te kunnen laten meewegen bij de strafoplegging met betrekking tot de mishandeling worden de eerdere feiten bij de stukken gevoegd. De auteur signaleerde daarnaast ook dat er dossiers bijgevoegd werden die het nooit tot een openbare zitting hadden gebracht. Hiermee werd naar zijn mening een grondbeginsel van strafvordering met voeten getreden. Of de strafbare feiten zijn te bewijzen en de officier van justitie brengt ze op zitting en ze worden berecht, of ze zijn niet te bewijzen en mogen dan ook niet meewegen bij bepaling van de straf bij de berechting van een ander feit.

Frielink verklaart het feit dat de voeging ad informandum sinds de dertiger jaren gehanteerd wordt uit een toename van bepalingen die het economisch leven moesten hanteren. ${ }^{366}$ Het aantal strafbaarstellingen nam aanmerkelijk toe. Daardoor is de voeging ad informandum in de praktijk ontstaan als een methode waarbij meerdere feiten sneller konden worden afgedaan. Een beeld dat ons bekend voorkomt.

Een wettelijke bepaling waarin deze afdoeningswijze wordt geregeld, ontbreekt. Kan het opportuniteitsbeginsel als rechtsgrond dienen? Op grond van het opportuniteitsbeginsel kan de officier van justitie van vervolging afzien. Licht hij uit een reeks van strafbare feiten enkele van deze zaken ter vervolging en voegt de rest ad informan-

365 M. Schorlesheim, Dossiers ad informandum. NJB 1930, pag. 216-221.

366 Paul Frielink, Voorwaarden ter voeging ad informandum. AA 1984, pag. 246. 
dum, dan zou gezegd kunnen worden dat hij voor deze overgebleven feiten gebruikt maakt van het opportuniteitsbeginsel, zonder dat dit gelijk gesteld kan worden met een sepot. De rechtsgrond van de voeging ad informandum wordt op deze manier gevonden in het opportuniteitsbeginsel. Hiervoor ( $\$ 1)$ merkte ik al op dat het opportuniteitsbeginsel de mogelijkheid biedt om al dan niet voorwaardelijk van vervolging af te zien, maar niet gezien mag worden als rechtsgrond van de voeging ad informandum, omdat hierbij feitelijk wel wordt vervolgd.

De conclusie moet zijn dat de praktijk van de voeging ad informandum geen legitieme rechtsgrond heeft. Indien de praktijk behoefte heeft aan een dergelijke afdoeningsmodaliteit zal daarvoor een wettelijke basis moeten worden geschapen.

Processueel spelen de ad informandum gevoegde zaken een rol bij de strafmaatbepaling, als de bijzondere reden van art. 359 lid 2 Sv. Volgens Pompe (in zijn noot onder HR 6 juni 1961, NJ 1962, 17) verbiedt de wet dit niet. ${ }^{367}$

De voeging ad informandum wordt gehanteerd als een belangrijk processueel instrument voor de strafrechtspleging. ${ }^{3.5}$ Deze afdoening maakt lange en onoverzichtelijke tenlasteleggingen overbodig en voorkomt langdurige zittingen. ${ }^{30}$ De hantering van het instrument van de voeging ad informandum wordt dus vooral ingegeven door proceseconomische overwegingen.

$\mathrm{Na}$ een onderzoek bij verschillende rechtbanken constateert Franken dat de praktijk van de voeging ad informandum een verdeeld beeld laat zien. ${ }^{\text {in }}$ Indien, overeenkomstig de voorstellen van de Cie. Moons, een vereenvoudigde procedure voor bekennende verdachten in de wet zou worden opgenomen, vervalt volgens hem iedere bestaansgrond voor de voeging ad informandum.

\section{Rechtsgevolg van de voeging ad informandum}

De meeste (gedateerde) literatuur over de voeging ad informandum bracht als voornaamste bezwaar tegen deze afdoeningswijze naar voren dat het geen rechtsgevolg heeft, in die zin dat een verdachte niet meer vervolgd zal worden ter zake van strafbare feiten die eerder ad info zijn gevoegd bij een andere strafzaak. ${ }^{3 n}$

Fen wettelijke regeling, zoals bijvoorbeeld art. $255 \mathrm{~Sv}$ die geeft voor het rechtsgevolg van een kennisgeving van niet verdere vervolging, ontbrak. Een dergelijke regeling

367 Zie vitgebreider P.J.P. Tak, a.w., pag. 81.

368 Leyten sprak zelfs van gemakzucht. J. Leyten, De bloemlezing in de dagvaarding, NJB 1956, pag. 489.

369 Vgl. P.J.P. Tak, a.w., pag. 79; S.A.M. Stolwijk, a.w., pag. 519; Paul Frielink, a.w., pag. 245.

370 A.A. Franken, Vocging ad informandum in strafaken, disscrtatic KUB, Arnhem 1993, pag. 101-110.

371 Vgl. P.J.P. Tak, a.w., pag. 85-87; Egbert Myjer. De verdachte in het geding - ter informatic. DD 1974, pag. 244-245; J.C.M. Leyten, De strafmaat in verband mct nict telastcgelcgde feiten, NJB 1964 , pag. 42. 
onthrak eveneens bij het informeel sepot, doch dalar zijn de heginselen van hehoorlijke procesorde te hulp gekomen. Het verschil tussen het sepot en de voeging ad informandum ligt hierin dat bij deze laatste vorm van afdoening de rechter met deze gevoegde feiten reeds rekening gehouden heeft bij de strafoplegging voor andere feiten.

Konden deze strafbare feiten alsnog (of: wederom?) vervolgd en bestraft worden? De Hoge Raad heeft vroeger bepaald dat het OM ontvankelijk is de vervolging van een strafbaar feit, dat eerder heeft meegewogen bij de berechting van een ander feit (HR 20 december 1960, NJ 1961, 211 m.nt. Röling; HR 6 juni 1961, NJ 1962. 17 m.nt. WP).

Dus enerzijds werden niet tenlastegelegde feiten bij de strafmaatbepaling meegerekend en daarmee doorgaans als afgedaan beschouwd, maar anderzijds bestond er voor de verdachte daaromtrent geen enkele wettelijke zekerheid. Het risico was dus aanwezig dat een verdachte in feite voor dezelfde gebeurtenis tweemaal gestraft werd.

In hun noot bij de hiervoor genoemde arresten uitten de annotatoren kritiek op het ontbreken van een wettelijk rechtsgevolg. Het vervolgen van een strafbaar feit dat reeds eerder ad informandum was gevoegd, was volgens Pompe in strijd met het beginsel dat aan art. $68 \mathrm{Sr}$ ten grondslag ligt. Al kan men bij vervolging van het feit niet aannemen dat verdachte opnieuw wordt vervolgd, hij is wel reeds mede voor dit feit gestraft.

Myjer zag als enige manier, waarop een verdachte tegen een dergelijke vervolging zou kunnen optreden, het instellen van een kort geding tegen de Staat der Nederlanden wegens optreden in strijd met beginselen van behoorlijk bestuur. ${ }^{372} \mathrm{Hij}$ was verder van mening dat het de Hoge Raad niet vrijstaat de werking van art. $68 \mathrm{Sr}$ uit te breiden tot de zaken die ad info zijn gevoegd en door de verdachte zijn bekend althans niet weersproken en die bij de strafmaatbepaling hebben meegewerkt. Een wetswijziging zou noodzakelijk zijn.

Het standpunt dat het het OM zou vrijstuan ad informandum gevoegde zaken die bij de strafoplegging meegewogen zijn bij de veroordeling van het tenlastegelegde feit alsnog te vervolgen, is inmiddels achterhaald.

Sinds 1978 (Menten I HR 29 mei 1978, NJ 1978, 358) is het mogelijk dat vervolgingsbeslissingen van het $\mathrm{OM}$ door de rechter worden getoetst aan algemene beginselen van behoorlijk bestuur, in strafrechtjargon algemene beginselen van behoorlijke procesorde genoemd. Een verdachte aan wie een uitdrukkelijke sepotmededeling is gedaan mag erop vertrouwen dat hij ter zake van dat feit niet alsnog zal worden vervolgd. Het $\mathrm{OM}$ is aan zijn toezeggingen gebonden, tenzij zwaarwichtiger belangen 
zich hiertegen verzetten. Wordt het strafbaar feit in strijd hiermee toch vervolgd dan leidt dat tot de niet-ontvankelijkheid van het $\mathrm{OM}$ in de vervolging. ${ }^{37}$

In deze lijn ligt het arrest van HR 13 februari 1979, NJ 1979, 243 m.nt. ThWvV. Een verdachte van heling geeft ter terechtzitting in hoger beroep op dat hij zich aan meerdere strafbare feiten heeft schuldig gemaakt. Het Hof neemt bij de strafoplegging deze feiten mede in aanmerking. Bij de Hoge Raad wordt hiertegen door de verdachte bezwaar gemaakt onder andere omdat hij ter zake van deze feiten opnieuw kan worden vervolgd. Het Hof kan niet uitsluiten dat de verdachte ter zake van de ad informandum gevoegde zaken niet opnieuw zal worden vervolgd en veroordeeld. De Hoge Raad is van oordeel dat, vanwege het feit dat ter zitting van de kant van het OM (de procureur-generaal ter zitting) tegen deze afdoening door middel van een voeging ad info geen bezwaar wordt gemaakt, het OM hiermee instemt. Het Hof mag er onder deze omstandigheden van uitgaan dat ter zake van deze feiten geen vervolging meer tegen de verdachte zal worden ingesteld.

Hiermee wordt een geval van voeging ad informandum ondergebracht in de categorie van situaties, waarin algemene beginselen van strafprocesrecht een vervolging verhinderen. In zijn noot onder dit arrest merkt Van Veen op dat het de rechtszekerheid ten goede komt dat de rechter duidelijk aangeeft met welke feiten hij rekening heeft gehouden en uitdrukkelijk constateert dat het $\mathrm{OM}$ met deze afdoening heeft ingestemd. In een noot bij het arrest van HR 13 maart 1979, NJ 1979, 269 stelde dezelfde annotator dat het daarom goed is in het proces-verbaal van de zitting deze zaken te noemen en in de motivering van de straf in het vonnis het aantal zaken op te nemen dat op deze wijze bij dit vonnis is afgedaan.

Indien een verdachte ter terechtzitting een ad informandum gevoegd feit ontkent, kan hij, ondanks de toezegging van de officier van justitie een ter informatie gevoegde zaak niet afzonderlijk te vervolgen, toch vervolgd worden (HR 15 juni 1982, NJ 1983, 216). De toezegging van het $O M$ niet meer te vervolgen is voorwaardelijk, namelijk onder de voorwaarde dat het feit meegenomen wordt bij de strafmaat. Indien de verdachte het feit ontkent, draagt het niet bij aan de straftoemeting. Anders oordeelde echter de Rb. Dordrecht, 28 juli 1988, NJ 1989, 94 m.nt. ThWvV. De dagvaarding ter zake van eerdere ad info gevoegde zaken-die overigens door de verdachte zowel bij de politie als ter zitting werden ontkend-acht de rechtbank in strijd met beginselen van een goede procesorde. Evenals de annotator zie ik voor deze uitspraak geen steun in de jurisprudentie van de Hoge Raad.

Een andere vraag is of de officier van justitie een ad info gevoegd feit mag vervolgen, indien het tenlastegelegd feit niet met een veroordeling is geëindigd.

Indien de zaak geëindigd is naar aanleiding van één der voorvragen van art. 348 Sv zal het oorspronkelijk gevoegd feit ook in een nieuwe vervolging mogen worden betrokken. Problemen rijzen indien de hoofdzaak geëindigd is met een vrijspraak 
of een ontslag van rechtsvervolging. Gesteld kan worden dat het ad info gevoegd feit geen rol heeft gespeeld bij de straftoemeting en dat de verdachte ten aanzien van dit feit gedagvaard mag worden. De voeging ad informandum is geschiedt onder de voorwaarde dat ten aanzien van het tenlastegelegde feit bestraffing volgt. ${ }^{374}$ Aan de andere kant kan worden verdedigd dat de officier van justitie door, op grond van proceseconomische overwegingen feiten ter informatie te voegen, daarmee het risico aanvaardt dat deze bij een niet-veroordeling niet zullen meewegen. De ad info gevoegde feiten hebben weliswaar niet de status van een tenlastegelegd feit, dat aan een volledig onderzoek wordt onderworpen, maar het gaat mij te ver om te zeggen dat ze in het geheel niet onderzocht worden. Op grond hiervan ben ik geneigd te stellen dat, indien ten aanzien van de tenlastegelegde feiten geen veroordeling volgt, ook ten aanzien van de ad info gevoegde feiten de zaak als afgedaan moet worden beschouwd. Een andere opvatting zou er bijvoorbeeld toe kunnen leiden dat het $O M$ steeds opnieuw deze feiten ad info zou voegen, het steeds opnieuw kan "proberen", hetgeen mij niet fair lijkt. Overeenkomstig deze gedachtengang was een uitspraak van het Hof Amsterdam van 17 juni 1991, NJ 1991, 583: Het OM kan een ad info gevoegde zaak, nadat in de hoofdzaak vrijspraak is gevolgd, niet meer separaat vervolgen. Een dergelijke vervolging zou in strijd komen met het vertrouwensbeginsel.

In praktijk speelt dit probleem blijkbaar niet vaak. Het OM stelt in een dergelijk geval geen nieuwe vervolging in. ${ }^{35}$ Wellicht is dit een indicatie voor de gedachte dat er feiten ad info gevoegd worden die er toevallig nog staan, maar die anders waarschijnlijk geseponeerd zouden zijn.

In $\S 1$ en 2 pleitte ik al voor een wettelijke regeling van de voeging ad informandum. Voor de rechtszekerheid van de verdachte zou een wettelijke regeling, waarin de hier beschreven ontwikkeling met betrekking tot de rechtsgevolgen bevestigd wordt, meer op zijn plaats zijn. Ook de voorwaarden welke zijn verbonden aan een voeging ad info zouden in daarin een regeling moeten krijgen. ${ }^{376}$

\section{Voorwaarden aan de voeging ad informandum}

Het strafproces wordt herhaaldelijk (mede)beïnvloed door redenen van efficiëntie. Het rechtvaardigheidsaspect treedt daarbij wat op de achtergrond. De hantering

$374 \mathrm{Vgl}$. A.A. Franken, De voeging ad informandum in strafraken, diss. KUB, Arnhem 1(x)3. pag. 87-111.

375 Vademecum Strafzaken, pag. [23] 86-89.

376 In het kader van overwegingen over ten eventuele hercodificatie van het Wethock van Strafvordering pleiten Corstens en Doorenbos ook voor ecn codificatic van de voeging ad informandum. G.J.M. Corstens en D.R. Dourenbos, Hercodificatic van strafprocesrecht? NJB 1991, pag. 1613-1618, met name pag. 1616. 
van de voeging ad informandum, omdat dit de doelmatigheid en efficiëntie van het strafproces ten goede komt, mag in mijn ogen niet ten koste gaan van de rechtvaardigheid van de strafrechtspleging. De strafprocessuele regels dienen er onder andere toe de individuele verdachte te beschermen tegen te 'enthousiast' optreden van justitie. Zo dient de dagvaarding er onder meer toe de verdachte op de hoogte te brengen van hetgeen tegen hem wordt ingebracht, teneinde zich te kunnen voorbereiden op zijn verdediging. Veelal is hij echter niet op de hoogte van de aard en de omvang der gevoegde zaken.

Om te voorkomen dat de voeging ad informandum een ongerechtvaardigde inbreuk maakt op de rechtspositie van de verdachte, is het naar mijn mening noodzakelijk dat de toepassing ervan aan bepaalde voorwaarden gebonden wordt.

1. Het $O M$ mag slechts strafbare feiten ad informandum voegen die bewijsbaar zijn en waarbij de strafbaarheid van de verdachte aannemelijk is. Het is derhalve onaanvaardbaar dat de officier van justitie feiten, die wegens gebrek aan bewijs niet afzonderlijk vervolgbaar zijn, ad informandum voegt. Deze feiten moeten geseponeerd worden (technisch sepot).

Indien de rechter de ad informandum zaken laat meewegen bij de straftoemeting, moet het voor hem aannemelijk zijn dat de verdachte de ad informandum gevoegde zaken heeft begaan en dat dit hem verweten kan worden. Een ad informandum gevoegde zaak, waarin een verweer wordt gevoerd dat bij gegrondbevinding zou leiden tot vrijspraak, mag bij de strafoplegging niet in aanmerking worden genomen (HR 12 november 1985, NJ 1986, 421).

De rechtspraak stelt de eis dat de verdachte deze feiten heeft erkend of dat ze door hem niet worden weersproken (HR 6 juni 1961, NJ 1962, 17 m.nt. WP). ${ }^{3 m}$ In een uitspraak van 29 november 1983, NJ 1984, 277 heeft de Hoge Raad dit vereiste in die zin uitgelegd dat de erkenning of het niet-weerspreken op de terechtzitting dient plaats te vinden. Zodoende mag de rechter met ad info gevoegde zaken geen rekening houden indien de verdachte bij verstek wordt veroordeeld. Volgens Tak kan dit vereiste tot onbillijkheden leiden, bijvoorbeeld in het geval de verdachte bepaalde feiten bij de politie of rechter-commissaris heeft bekend en deze ter zitting ontkent. ${ }^{378}$ Het vereiste, dat de ad info gevoegde zaken ter zitting erkend althans niet weersproken dienen te worden, vervalt, indien bij het uitbrengen van de dagvaarding, althans tijdig voor de aanvang van de zitting aan de verdachte is meegedeeld dat dit niet tenlaste gelegd feit door het OM ter terechtzitting ter sprake zal worden gebracht met het doel dat dit feit bij de strafoplegging in aanmerking wordt genomen (HR 25 september 1984, NJ 1985, 317; 26 januari 1988, NJ 1988, 817; HR 1 juni 1993, NJB-katern 1993, pag. $388-389$, nr. 166 ).

377 Vgl. J.C.M. Leyten, De strafmaat in verband met niet tenlastegelegde feiten, NJB 1964, pag. 36-43; HR 13 fcbruari 1979, NJ 1979, 243 m.nt. ThWvV; HR 13 maart 1979, NJ 1979, 269 m.nt. ThWvV. 37 P.J.P. Tak, a.w., pag. 84. 
Een middel om tegen een ad informandum voeging van feiten, waarvan de bewijsbaarheid twijfelachtig is, dus waarbij aan de hier gestelde voorwaarde niet is voldaan, op te komen, is het bezwaarschrift tegen de dagvaarding, art. $262 \mathrm{~Sv}$. (Zie bijvoorbeeld Rb. Alkmaar, 16 december 1986, NJ 1987, 397). Dit is slechts mogelijk indien de verdachte op de hoogte is van de voeging, bijvoorbeeld door een korte aanduiding van deze feiten op de dagvaarding. Deze vermelding is echter geen regel.

2. Het is naar mijn mening een onjuist gebruik van de voeging ad informandum wanneer een minder ernstig feit tenlaste wordt gelegd en een ernstiger feit ad info zou worden gevoegd. Een argument voor een dergelijke handelswijze zou bijvoorbeeld kunnen zijn dat het laatste feit te ingewikkeld of te omvangrijk is. Een dergelijke constructie zou tot gevolg kunnen hebben dat het tenlastegelegde feit niet van bepalende invloed is op de straftoemeting. Vervolging van dit feit ligt dan niet voor de hand. ${ }^{3 x}$

Voor de straftoemeting door de rechter mogen de ad info gevoegde feiten slechts een ondersteunende en geen bepalende rol spelen. De ad info gevoegde feiten spelen mee als 'bijzondere redenen', art. 359 lid 5 Sv, die de straf (mede) bepalen. ${ }^{1.5}$ Indien het feit dat ad info is gevoegd ernstiger is dan het tenlastegelegd feit is het risico aanwezig dat het eerstgenoemde niet slechts een ondersteunende functie zal hebben. Dit moet worden vermeden.

3. Een andere voorwaarde is dat de rechter ten aanzien van de berechting van het ad info gevoegd feit bevoegd en het OM ontvankelijk in de vervolging van dat feit dient te zijn. Uitzonderingen hierop zijn mogelijk. De relatieve bevoegdheid van de rechter kan afwijken in het geval de verdachte verschillende feiten in verschillende arrondissementen begaan heeft. Tegen zo'n afwijking bestaat naar ik meen weinig bezwaar.

Ook de absolute competentie kan een afwijking van de regel vertonen. Toegestaan lijkt mij dat overtredingen ad info gevoegd kunnen worden bij de berechting van misdrijven voor de arrondissementsrechtbank.

Het omgekeerde, een ad info gevoegd misdrijf voegen bij de behandeling van een overtreding door de kantonrechter, moet afgewezen worden, mede in verband met het hierboven onder (2) vermelde.

Het beroep op de niet-ontvankelijkheid van het $\mathrm{OM}$ kan op verschillende gronden berusten. Bij ad info gevoegde zaken moet op dezelfde gronden bekeken worden of het OM ontvankelijk is. Delicten, waarvan de verjaringstermijn (art. 70 e.v. $\mathrm{Sr}$ ) is verstreken, kunnen niet via de voeging ad informandum alsnog worden berecht. Hetzelfde geldt voor strafzaken waarin het OM een te lange termijn heeft laten verlopen tussen de aanvang van de vervolging en de uiteindelijke

379 Vgl. P.J.P. Tak, a.w., pag. 82; Paul Frielink, a.w., pag. 248.

380 Zie bijvoorbeeld HR 13 februari 1979, NJ 1979, 243 m.nt. ThWvV; HR 13 maart 1979, NJ 1979, 269 m.nt. ThWvV; HR 27 maart 1979, NJ 1979, 431. 
berechting (HR 23 september 1980, NJ 1981, 116 m.nt. GEM). Nu de Hoge Raad heeft bepaald dat het laten verlopen van de redelijke termijn niet slechts tot gevolg heeft dat het OM niet-ontvankelijk is in de vervolging, maar dat daarnaast strafvermindering tot de mogelijkheden behoort (HR 7 april 1987, NJ 1987, 587 m.nt. ThWvV), zou hierover genuanceerder worden gedacht. Je zou ook als volgt kunnen redeneren: als een zaak ad informandum wordt gevoegd is hij kennelijk niet belangrijk genoeg voor een plaats op de dagvaarding. Bij overschrijding van de redelijke termijn rijst de vraag of de regel wel opgaat dat de samenleving wel belang heeft bij vervolging en berechting. Zo niet: niet-ontvankelijkheid. Strafzaken, die in een eerdere vervolging geleid hebben tot een vrijspraak of een ontslag van rechtsvervolging kunnen niet opnieuw vervolgd worden (art. 68 $\mathrm{Sr}$ ) en derhalve ook niet ad informandum worden gevoegd.

De voeging ad informandum in het geval de officier van justitie een uitdrukkelijke toezegging heeft gedaan het strafbaar feit niet te vervolgen, leidt tot niet-ontvankelijkheid wegens strijd met de algemene beginselen van behoorlijke procesorde, met name het vertrouwensbeginsel (Rb. Alkmaar, 16 december 1986, NJ 1987, 397). Een dergelijk beroep op het vertrouwensbeginsel gaat niet op indien de verdachte het feit later ter zitting heeft ontkend en het feit vervolgens niet bij de strafmaat is meegenomen (HR 15 juni 1982, NJ 1983, 216).

4. Er moet een verband bestaan tussen het tenlastegelegde feit en de ad info gevoegde zaken, bijvoorbeeld met betrekking tot de aard der delicten en het tijdsverloop waarbinnen deze zijn begaan. De rechter gebruikt de ad info gevoegde zaken immers bij de straftoemeting, als bijzondere reden die de strafmaat van het tenlastegelegde feit bepaalt. Dan moet er mijns inziens wel enig verband bestaan tussen de delicten.

5. Strafbare feiten waarbij de verdachte in verzekering of in voorlopige hechtenis is gesteld of waarbij een gerechtelijk vooronderzoek heeft plaatsgevonden, behoren naar mijn mening niet ad info gevoegd te worden. Wanneer tegen de verdachte deze dwangmiddelen zijn ingesteld heeft hij recht op een volledige behandeling van zijn zaak, waarbij dan ook de toepassing van deze dwangmiddelen getoetst kan worden. Bovendien zou het ad info voegen van een dergelijk delict de situatie in het leven roepen dat het feit zwaar genoeg is om een genoemd dwangmiddel in te stellen, maar niet zwaar genoeg om gewoon te vervolgen. Dit lijkt me niet te verdedigen.

In het geval een verdachte veroordeeld wordt tot een vrijheidsstraf wordt de tijd die hij in voorarrest heeft doorgebracht afgetrokken (art. $27 \mathrm{Sr}$ ). Ten aanzien van ad info gevoegde zaken kan deze aftrek niet plaatsvinden, omdat de veroordeling niet geschiedt naar aanleiding van deze feiten. 


\section{De positie van het slachtoffer van het ad informandum gevoegde feit}

Een slachtoffer van een delict heeft de mogelijkheid zijn vordering tot schadevergoeding tijdens de strafprocedure te stellen. Hij kan zich ter zake van deze vordering in een strafzaak voegen (art. $332 \mathrm{~Sv}$ ). De wijze waarop een dergelijke vordering in een strafzaak behandeld wordt, kunnen we vinden in de artt. 332-337 Sv.

Het slachtoffer kan zich voegen "in het geding over de strafzaak" (art. 332 lid $1 \mathrm{~Sv}$ ). Dit betekent dat strafzaken die het stadium van een onderzoek ter terechtzitting niet bereiken, zich niet lenen voor voeging door de beledigde partij. Het slachtoffer kan zich evenmin voegen in een strafzaak die weliswaar een rol speelt tijdens de terechtzitting, maar dat niet in de dagvaarding is ten laste gelegd en zodoende ook niet onderworpen wordt aan de vragen van artt. 348 en 350 Sv. Een ad informandum gevoegde zaak is een dergelijke strafzaak. ${ }^{381}$ Een dergelijke uitleg vinden we reeds bij Blok en Besier: de beledigde partij zal aan haarvordering geen andere of anders omschreven feiten ten grondslag mogen leggen, dan in de tenlastelegging worden aangetroffen. ${ }^{3 * 2}$ Stolwijk voegt hieraan toe dat de berechting meestal zo oppervlakkig is dat een juiste vaststelling niet mogelijk is, waardoor de derde benadeeld zou kunnen worden. ${ }^{383}$

Deze situatie is onwenselijk, vooral in een tijd dat de positie van het slachtoffer in het strafproces (terecht) meer aandacht krijgt.

Door de vergadering van procureurs-generaal is op 24 januari 1983 de werkgroep Justitieel beleid en slachtoffer -naar haar voorzitter de werkgroep Vaillant genoemdingesteld met als taakopdracht te bezien op welke wijze aan de belangen van het slachtoffer van een misdrijf, binnen het kader van de justitiële verwerking van de strafzaak tegen de verdachte, meer recht kan worden gedaan.

Voor wat betreft de voeging ad informandum sluit de werkgroep zich aan bij de in het arrondissement Zutphen (waar de voorzitter van de werkgroep hoofdofficier van justitie is) bestaande praktijk. Dit komt er op neer dat het OM van de ad informandum gevoegde zaken melding maakt op een bijlage gevoegd bij de dagvaarding, waarin wordt verwezen naar het proces-verbaal. De rechtbank toont zich bereid de vordering toe te wijzen omdat de betreffende zaak zodoende geheel in het rechtsgeding is betrokken. De werkgroep meent in navolging hiervan dat een vordering van het slachtoffer in een bij de politie erkende ad informandum gevoegde zaak kan worden toegewezen, indien aan een aantal voorwaarden is voldaan:

1. Aan de verdachte is bij of op de dagvaarding meegedeeld welke zaken ad info zijn gevoegd;

381 Vgl. Melai c.s., aant. 9 bij artt. 332-337.

382 Blok-Besier II, a.w., pag. 113.

383 S.A.M. Stolwijk, a.w., pag. 525. 
Vervolgens bestaat er volgens de werkgroep, indien aan deze voorwaarden voldaan is, nog een andere mogelijkheid om het slachtoffer in een ad informandum gevoegde zaak schadeloos te stellen, namelijk door oplegging van schadevergoeding in de vorm van een bijzondere voorwaarde bij een (gedeeltelijk) voorwaardelijke straf (art. 14c lid 1 sub $1 \mathrm{Sr}$ ). . $^{\mathrm{kis}}$

Op dit voorstel van de werkgroep, dat ook al gepubliceerd was in een tussenrapport in 1984, is vrij forse kritiek geuit. ${ }^{366}$ Auteurs zijn unaniem van mening dat de voorgestelde regeling in strijd is met de wettelijke bepalingen van artt. 332-337. Immers het vereiste verband tussen het tenlastegelegde feit en de schade ontbreekt. ${ }^{387}$ Een ander zwaarwegend argument tegen de door de werkgroep Vaillant voorgestelde regeling is dat deze in strijd is met het accessoire karakter van de civiele vordering in strafzaken. De civiele rechtsstrijd is ondergeschikt aan het strafgeding en de vordering wordt door de strafrechter beoordeeld omdat deze toch al bemoeienis heeft met de zaak. Het is de wetgever er niet om te doen geweest een vereenvoudigde civiele procedure te ontwerpen. ${ }^{388}$ De voorstellen van de werkgroep betekenen in feite een ontkoppeling van de civiele procedure van het strafproces. En daardoor zouden slachtoffers van delicten gemakkelijker hun schade kunnen verhalen dan degenen die afhankelijk zijn van een civiele uitspraak.

We hebben reeds gezien dat een voeging ad informandum slechts toelaatbaar is indien het delict zodanig is dat een afzonderlijke tenlastelegging en een afzonderlijke berechting niet van belang zijn. Ad informandum gevoegde zaken spelen derhalve, vanwege hun geringe ernst, geen strafmaatbepalende, doch slechts een ondersteunende rol. Het gegeven dat een bepaald delict schade heeft toegebracht aan een derde verhoogt naar mijn mening de ernst daarvan. Door toekenning van een civiele vordering wordt de op te leggen sanctie wezenlijk veranderd. ${ }^{3 w}$

In diverse publicaties wordt vermeld dat een regeling zoals de werkgroep deze ziet, in strijd is met verschillende ressortelijke richtlijnen, die bepalen dat een mogelijke

384 Eindrapport werkgroep Vaillant, pag. 24.

385 Eindrapport werkgroep Vaillant, pag. 25.

386 Zie onder andere: M.S. Groenhuijsen en A.M. van Kalmthout, Commentaar op rapport Vaillant, DD 1984, pag. 836-851; overgenomen door Mclai c.s., aant. 9 bij artt. 332-337; P. Frielink, De positic van het slachtoffer in ad informandum gevoegde stralyaken, NJB 15 juni 1985, pag. 777 e.v.

$387 \mathrm{Vgl}$. P. Frielink, a.w., pag. 777; Mclai c.s., aant. 9 bij artt. 332-\$37.

388 Mclai c.s., a.w., aant. 13 bij artt. 332-337; M.S. Groenhuijsen en A.M. van Kalmthout, a.w., pag. 848.

389 Vgl. Melai c.s., aant. 9; M.S. Groenhuijsen en A.M. van Kalmthout, a.w., pag. 848. 
vordering van de gelaedeerde een vrij dwingende contra-indicatie oplevert voor het OM om een zaak ad info te voegen. ${ }^{30}$

De regeling voldoet naar mijn mening bovendien niet, omdat, als bij voeging ad informandum de schade al vast te stellen is, het vaststellen van het causaal verband veelal problematischer is. Een nader onderzoek zal dan toch noodzakelijk zijn.

Dit alles leidt tot de conclusie dat een slachtoffer van een delict dat informandum wordt afgedaan benadeeld wordt ten opzichte van degene die zich voegt in een normale procedure.

Frielink geeft een manier aan waarop aan het slachtoffer van een ad info gevoegd feit tegemoet kan worden gekomen, namelijk door een voorwaardelijke voeging ad informandum. De officier van justitie stelt voor bepaalde feiten ad info te voegen, mits de schade, die door deze feiten is veroorzaakt, door de verdachte vergoed worden. ${ }^{31}$ Ik denk dat deze methode niet erg praktisch zal zijn. Het gaat van de veronderstelling uit dat het voegen ad informandum van bepaalde strafbare feiten een bewuste keuze van de officier van justitie is.

Het zou mijns inziens aan te bevelen zijn dat het feit dat een derde zich wil voegen in de strafzaak, voor de officier van justitie reden is deze zaak niet ad informandum te voegen, maar apart te vervolgen. ${ }^{\$ 2}$ Een voorwaarde hierbij is dat de gelaedeerde op de hoogte is van de voegingsmogelijkheid en van de stand van zaken van de strafzaak. Een gelaedeerde kan, nadat het vonnis waarin het ad informandum gevoegde feit meegewogen heeft bij de strafoplegging in kracht van gewijsde is gegaan, niet meer zijn beklag doen over het niet-vervolgen ex art. $12 \mathrm{~Sv}$. Het alsnog vervolgen van een dergelijk feit zou in strijd komen met beginselen van behoorlijke procesorde (HR 20 mei 1986, NJ 1987, 192). De officier moet dus óf seponeren, waarna de gelaedeerde een art. $12 \mathrm{~Sv}$-procedure kan starten, of vervolgen, waarbij hij zich in de strafzaak kan voegen. Door een strafzaak ad informandum te voegen valt het slachtoffer, wat zijn schadevergoeding betreft, tussen wal en schip.

Hiertegen zou kunnen worden ingebracht dat proceseconomische belangen zich tegen een dergelijke methode verzetten. Wanneer het OM echt van plan is een slachtoffervriendelijk beleid te voeren kan dat inderdaad ten koste gaan van een andere doelstelling. Kwestie van prioriteiten.

390 Vgl. Melai c.s., aant. 9; Groenhuijsen en Van Kalmthout, a.w., pag. 847.

391 P. Frielink, De positie van het slachtoffer in ad informandum gevoegde zaken, NJB 1985, pag. 778.

392 Vgl. S.A.M. Stolwijk, a.w., pag. 525. 



\section{OM: onderdeel van de rechterlijke macht of bestuursorgaan?}

\section{Inleiding}

Het $\mathrm{OM}$ neemt in ons staatsbestel een wat merkwaardige, maar ook gecompliceerde positie in. Het kenmerkt zich door een zekere tweeslachtigheid, waardoor het zich moeilijk in een systeem van machtenscheiding lijkt te laten inpassen. Enerzijds wordt het vaak gezien als een onderdeel van de rechterlijke macht (de staande magistratuur tegenover de zittende), anderzijds wordt het beschouwd als een orgaan dat belast is met de uitvoering van overheidsbeleid. In de staats- en administratiefrechtelijke literatuur wordt deze uitvoerende functie, ter onderscheiding van de wetgevende en de rechtsprekende, de bestuursfunctie genoemd. ${ }^{3 \%}$

Het was Montesquieu die in zijn boek 'De l'Esprit des Lois' (1748) betoogde dat de drie staatsfuncties (Trias Politica), te weten de wetgevende, de uitvoerende en de rechterlijke macht, verdeeld moesten worden over verschillende staatsorganen, die van elkaar onafhankelijk waren teneinde een te grote concentratie van macht bij één van hen te voorkomen, waarbij hij een evenwicht tussen de verschillende machten aanbrengt, met name tussen de wetgevende (een vertegenwoordigend lichaam over verschillende kamers verdeeld) en de uitvoerende (de Koning). ${ }^{\text {s4 }}$ De totstandkoming van de wetten zou bijvoorbeeld gebonden kunnen worden aan goedkeuring door de uitvoerende macht, terwijl het wetgevend orgaan toezicht had op bepaalde uitvoeringsdaden. De enige die echt onafhankelijk blijft is de rechterlijke macht, hiermee mogen de anderen zich niet bemoeien. Op deze manier zou de vrijheid van de burger ten opzichte van de overheid zo optimaal mogelijk worden verzekerd. De vervolging van strafbare feiten valt onder de uitvoerende macht:

393 Zie bijvoorbeeld A.M. Donner, Nederlands bestuursrecht, algemeen deel, Alphen aan den Rijn, 1987, Hoofdstuk I; A.D. Belinfante, Kort begrip van het administratief recht, Alphen aan den Rijn, 1981, pag. 11; Rapport Algemene Bepalingen van Administratief Recht, Alphen aan den Rijn 1984, pag. 1-2.

394 In tegenstelling tot wat vaak betoogd wordt was het idee van de machtenscheiding niet afkomstig van Montesquicu. Dit idce bestond recds. Montesquicu vocgt daar enkele clementen aan toc, onder andere de onderlinge afhankelijkheid van de verschillende machten. Vgl. W. Konijnenbelt, openingsrede VAR-congres 25 april 1986, VAR 1986 XCV, pag. 8; P.M. Langbrock, Machtenscheiding en Decentralisatie, Enschede 1988, pag. 20-39. 
"Nous avons aujourd'hui une loi admirable, c'est celle qui veut que le prince établi pour faire exécuter les loix, prépose un officier dans chaque tribunal, pout poursuivre en son nom tous les crimes: de sorte que la fonction des délateurs est inconnue parmi nous" en: "La partie publique veille pour les citoyens; elle agit et ils sont transquilles".

Overigens is van dit oorspronkelijke model in ons huidig staatsbestel niet veel over. ${ }^{36}$ Zo worden bepaalde functies door meerdere organen uitgeoefend. Wetgeving bijvoorbeeld is een gezamenlijke taak van regering en parlement. De uitvoerende macht van de regering wordt gecontroleerd door het parlement. Ook worden bepaalde functies door een ander orgaan uitgeoefend dan door Montesquieu oorspronkelijk was bedoeld. De wetgevende macht neemt beslissingen die qua inhoud eigenlijk tot de uitvoering behoren. De uitvoerende macht voert wetten uit door zelf nieuwe regels te stellen, bijvoorbeeld in de vorm van AMvB's. Geschillenoplossing is niet enkel voorhehouden aan de rechter, maar ook bestuursorganen treden als zodanig op, bijvoorbeeld bij het administratief beroep. ${ }^{3 n 7}$ De rechter zit, min of meer gedwongen, in toenemende mate op de stoel van wetgever en bestuurder, in die zin dat wetten worden getoetst aan het Statuut, de Grondwet of internationale verdragen. ${ }^{\text {sp }}$ De rechter mag zich volgens art. 11 Wet $A B$ niet inlaten met de innerlijke beoordeling van een wetsbepaling (De regter moet volgens de wet rechtspreken; hij mag in geen geval de innerlijke waarde of billijkheid der wet beoordelen). De onafhankelijkheid van de rechterlijke macht ten opzichte van de andere staatsmachten, in die zin dat de anderen geen invloed kunnen uitoefenen op de onafhankelijke rechter, staat nog overeind en ligt in de huidige Grondwet verankerd (art. 117).

De meningen over de staatsrechtelijke positie van het OM, concreter: of het $O M$ onderdeel is van de rechterlijke macht of deel uitmaakt van de executieve, het algemeen bestuur, zijn sinds jaar en dag verdeeld. ${ }^{* *}$ Grofweg kan worden gesteld dat het OM vindt dat het onderdeel is van de rechterlijke macht, anderen, vooral bestuursrechtjuristen, zijn van mening dat het $\mathrm{OM}$ een bestuursorgaan is.

395 Hoofdstuk VIII.

$3 \%$ Zic hierover: A.F.M. Brenninkmcijer, De plaats van de rechter in onze constitutionele rechtsorde, vit: De rechter als dictator? Dynamiek in de trias. Verschuivingen in de verhouding regelgeving, bestuur en rechtspraak. Lochem 1987.

397 In de Benthem-zaak is door het Europese Hof beslist, dat de hoogstē administratieve beroepsinstantie, de Kroon, nict voldoet aan art. 6 EVRM, dat onder andere het recht op toegang tot een onafhankelijke en onpartijdige rechterlijke instantie garandeert. Benthem-arrest, EHRM 23 oktober 1985, AB 1986, 1 m.nt. Hirsch Ballin.

398 Vgl. F.A.M. Stroink, De plaats van de rechter in het staatsbestel, oratie RL, Zwolle 1990.

399 Naast zijn taken op strafrechtelijk gebied heeft het OM een aantal functies op het civielrechtelijk vlak, zoals bijworbecld neergelegd in titel 5 Boek I Rven in een aintal afzonderlijke wetten, bijvoorbeeld in art. 1: 29 lid $4 \mathrm{BW}$, art. 1 F, artt. 10, 12, $29 \mathrm{en} 70 \mathrm{Wct}$ op de Lijkbezorging. In het kader van dit onderzock beperk ik mij tot de strafrechtelijke functic en laat de bevoegdheden die het $\mathrm{OM}$ op andere rechtsgebieden heeft buiten beschouwing. 
Beantwoording van deze vraag is onder meer van belang voor het bepalen van de mate van zelfstandigheid en onafhankelijkheid van het $\mathrm{OM}$ ten opzichte van regering en volksvertegenwoordiging. Deze zelfstandige en onafhankelijke positie zou meer nadruk krijgen naarmate het OM meer als een rechterlijk orgaan kan worden gezien. Hierop heeft de discussie zich dan ook grotendeels geconcentreerd.

De gestelde vraag lijkt mij echter nog om een andere reden interessant. Indien de beantwoording ervan namelijk zou luiden dat het OM een onderdeel is van de executieve, uitvoerder van overheidsbeleid, een bestuursorgaan, komt onmiddellijk de vraag op of het $\mathrm{OM}$ bij het nemen van zijn beslissingen, die dan gekwalificeerd zouden kunnen worden als bestuursbesluiten, gebonden behoort te zijn aan regels en beginselen die gelden voor bestuursbesluiten in het algemeen, zoals bepalingen met betrekking tot de totstandkoming van een dergelijk besluit, regels van administratief beroep en algemene beginselen van behoorlijk bestuur.

De wetsbepalingen die met dit vraagstuk samenhangen zijn:

art. 113 lid $1 \mathrm{GW}$ : Aan de rechterlijke macht is voorts opgedragen de berechting van strafbare feiten;

art. 116 lid $2 \mathrm{GW}$ : De wet regelt de inrichting, samenstelling en bevoegdheid van de rechterlijke macht;

art. 117 lid $1 \mathrm{GW}$ : De leden van de rechterlijke macht met rechtspraak belast en de procureur-generaal bij de Hoge Raad worden bij koninklijk besluit voor het leven benoemd.

art. 3 lid 1 RO: Het openbaar ministerie wordt uitgeoefend door de procureurgeneraal bij de Hoge Raad, door de procureurs-generaal bij de gerechtshoven en, voor zover het de lagere gerechten betreft, door de officieren van justitie.

art. 4 RO:

Het openbaar ministerie is bijzonderlijk belast met de handhaving der wetten, met de vervolging van strafbare feiten en het doen uitvoeren van alle strafvonnissen. Hetzelfde moet worden gehoord voor zover de wet zulks voorschrijft.

art. 5 RO:

De ambtenaren bij het openbaar ministerie zijn verplicht de bevelen na te komen, welke hun in hun ambtsbetrekking door de bevoegde macht, vanwege de Koning, zullen worden gegeven.

De vragen die hier onderzocht worden zijn: is het OM een bestuursorgaan of een onderdeel van de rechterlijke macht, of is het geen van beide of juist allebei? en: Stel het OM kan gezien worden als een bestuursorgain, zijn de beslissingen die door of namens het OM genomen worden dan bestuursbesluiten of wellicht beschikkingen, begrippen uit het administratief recht? Of zijn het misschien besluiten sui generis? In dit hoofdstuk zal getracht worden op de eerste vraag (rechterlijke macht of be- 
stuursorgaan?) een antwoord te geven. In het volgende hoofdstuk komt de andere kwestie (kwalificatie van OM-besluiten) aan bod.

We zullen de vraag vanuit drie gezichtspunten bekjjken. Allereerst wordt onderzocht wat de Grondwet verstaat onder rechterlijke macht. Ik noem dit het constitutioneel aspect $(\S 2)$. Hierbij is van belang dat de huidige Grondwet na de grondwetsherziening van 1983 aan de term 'rechterlijke macht' een andere, meer beperkte uitleg geeft dan de vorige Grondwet deed.

Vervolgens worden de inhoudelijke argumenten besproken op grond waarvan het OM bestempeld wordt als een rechterlijk dan wel bestuursorgaan ( $\$ 3$ ).

Tenslotte komen administratiefrechtelijke aspecten aan de orde (\$4).

\section{Constitutioneel aspect}

In 1983 is de Grondwet ingrijpend herzien. Bij deze herziening onderging ook het hoofdstuk over de rechtspraak een belangrijke wijziging. In 1987 vonden er nog enkele wijzigingen van de Grondwet plaats, bijvoorbeeld op het gebied van het binnentreden van woningen. Wanneer in het navolgende gesproken wordt van de herziene, huidige of de nieuwe Grondwet, wordt daarmee bedoeld de Grondwet van na de herziening van 1983.

De vorige Grondwet (van vóór 1983 dus) gebruikte de term 'rechterlijke macht' in twee betekenissen:

- de functie van het rechtspreken (art. 169 oud eerste zin); hieronder wordt verstaan het oplossen van een conflict door toepassing van een bepaalde wettelijke regeling, met behulp van een aantal rechtsvindingstechnieken, op het onderliggende geschil.

- het orgaan dat met rechtspraak is belast (bijvoorbeeld in artt. 167 oud, 180 lid 2 oud); dit is een veel ruimer begrip.

Omdat de tweeledige betekenis in de oude Grondwet tot onduidelijkheden leidde, is deze in de Grondwet van 1983 niet overgenomen. De term dient volgens de MvT uitsluitend te worden opgevat volgens laatstgenoemde betekenis, als aanduiding van het orgaan-complex..$^{+\infty} \mathrm{Bij}$ het geven van inhoud aan dit begrip heeft men de traditionele grondwettelijke betekenis, in die zin dat tot de 'gewone' rechterlijke macht behoren de kantongerechten, de arrondissementsrechtbanken, de gerechtshoven en de Hoge Raad, alsmede de bijzondere rechters die tot deze gerechten die onder deze gerechten vallen, verlaten. Gekozen is voor "alle rechterlijke instanties, die binnen onze rechtsorde een duurzame rechterlijke taak vervullen". Hieronder vallen 
niet alleen de genoemde gerechten, maar het kan ook betrekking hebben op administratieve rechters of militaire rechters. ${ }^{\text {tol }}$

In art. 116 lid 1 is te lezen dat het de wetgever is die bepaalt welke gerechten tot die rechterlijke macht behoren. Het staat de wetgever vrij allerlei colleges als onderdeel van de 'rechterlijke macht' te maken, met als enige eis dat aan art. 117 Grondwet moet zijn voldaan. Wil een orgaan dus bestempeld worden als onderdeel van de rechterlijke macht, dan zal dat dus bij formele wet dienen te gebeuren. Allereerst zijn dat dan de organen die in art. 1 Wet RO als gerechten behorende bij de rechterlijke macht worden aangewezen: de kantongerechten, de arrondissementsrechtbanken, de gerechtshoven en de Hoge Raad. Voorts de in andere wetten aangewezen bijzondere kamers bij deze gerechten bijvoorbeeld de kinderrechter, economische kamers, belastingkamer bij de gerechtshoven, ondernemingskamer, pachtkamer en de penitentiaire kamer. Ook de militaire rechter kan op grond van dit lid in de rechterlijke macht geïntegreerd worden. Deze mogelijkheid is ten slotte ook gecreëerd voor de administratieve rechter. De (grond)wetgever verwachtte dat de wetgever ook de administratieve gerechten als gerechten behorende tot de rechterlijke macht zal verklaren. ${ }^{402}$

Het $\mathrm{OM}$ wordt in geen enkele formele wet als onderdeel van de rechterlijke macht aangewezen, zodat het, naar het mij voorkomt, dus niet als zodanig gekwalificeerd mag worden.

Uit art. 117 lid 1 is af te leiden dat het $O M$ de rechtspositionele onafhankelijkheid mist die de rechterlijke macht heeft. De basis voor de onathankelijkheid van de rechterlijke macht ligt in art. 117 lid 1, benoeming voor het leven, en lid 4, regeling van de bezoldiging bij wet. Deze onafhankelijkheid is tevens gerealiseerd voor de procureur-generaal bij de Hoge Raad, vanwege het feit dat deze is belast met de vervolging van de leden der Staten-Generaal, de ministers en de staatssecretarissen wegens ambtsmisdrijven in die betrekkingen gepleegd. Ik ben van mening dat deze onathankelijkheid beperkt is tot deze met name genoemde taak. Deze onafhankelijkheid van de procureur-generaal bij de Hoge Raad bestaat bovendien slechts met betrekking tot zijn rechtspositie. Functioneel is hij niet onafhankelijk. ${ }^{403}$ Ook uit deze afzonderlijke vermelding van de procureur-generaal (lid van het $O M$ ) in zijn bijzondere functie kunnen we a-contrario afleiden dat alle andere leden van het OM geen deel uitmaken van de rechterlijke macht, anders had voor de procureurgeneraal geen uitzondering behoeven te worden gemaakt.

De Grondwet is in haar terminologie echter niet helemaal consequent. Naast de term 'rechterlijke macht' wordt het begrip 'rechterlijke macht met rechtspraak belast'

401 MvT, TK 1979-1980, 16162, nr. 3, pag. 4-5.

402 MvT, TK 1979-1980, 16162, nr. 3, pag. 16.

403 Vgl. C.A.J.M. Kortmann, De Grondwetsherzieningen 1983 en 1987, Deventer 1987, pag. 329. 
gebruikt. ${ }^{404}$ Dit is te zien in art. art. 116 lid 4 en art. art. 117 lid 1 . Hieruit valt af te leiden dat er ook een rechterlijke macht bestaat die niet met rechtspraak is belast. Volgens de MvA aan de Tweede Kamer moet daaronder, naast de griffie, inderdaad de leden van het $\mathrm{OM}$ onder worden verstaan. ${ }^{405} \mathrm{Op}$ deze manier behoudt de term 'rechterlijke macht' (bedoeld als orgaan) een verwarrende betekenis (evenals in de oude Grondwet het geval was, art. 180 lid 2), namelijk 'de gerechten'. Ik stel voor dan te spreken van rechterlijke macht in ruime zin, waarvan het $O M$ deel uitmaakt, en van rechterlijke macht in enge zin wanneer wordt bedoeld 'rechterlijke macht met rechtspraak belast'.

Nog duidelijker lijkt het mij twee verschillende termen te gebruiken en te spreken over 'rechterlijke macht' wanneer we bedoelen 'in enge zin' en voor de rechterlijke macht in ruime zin een andere term te reserveren, bijvoorbeeld 'gerechtelijke instanties' of 'rechterlijke organisatie'.

De conclusie uit het voorgaande is dat de huidige Grondwet slechts die gerechtelijke instanties tot de rechterlijke macht (in enge zin) rekent die door de wetgever worden aangewezen. Een formele wet waarin het $\mathrm{OM}$ als zodanig wordt aangemerkt ontbreekt, zodat het formeel niet tot de rechterlijke macht (in enge zin) behoort. Ik ben het dan ook niet eens met de mijns inziens innerlijk tegenstrijdige stelling van Elzinga dat het OM behoort tot de rechterlijke macht, maar dat de Grondwet en de Wet RO het OM geen materieel sterke positie als onderdeel van de rechterlijke macht realiseren. ${ }^{\text {aco }}$

\section{Inhoudelijke aspecten}

Nu uit de Grondwet valt af te leiden dat het OM niet behoort tot de rechterlijke macht, zou het wellicht niet meer ter zake doen welke inhoudelijke argumenten er in het verdere en meer recente verleden zijn aangevoerd om het OM wel of niet tot de rechterlijke macht te rekenen. Naast formele kunnen inhoudelijke argumenten niet worden gemist.

404 Kortmann spreckt in dit verband van een 'ongelukkige terminologic'. C.A.J.M. Kortmann, De grondwetsherzieningen 1983 en 1987, Deventer 1987, pag. 326.

405 MvA, EK 1980-1981, 16162, nr. 100b, pag. 5.

406 D.J. Elzinga, Een volle ministeriële verantwoordelijkheid voor het Openbaar Ministerie - maar geen ongebreidelde sturing van het OM, NJB 1994, pag. 534. 


\subsection{Verschillende standpunten}

Voor beantwoording van de vraag of het OM gerekend moet worden tot de rechterlijke macht of gezien moet worden als een bestuursorgaan zullen nu verschillende opvattingen van wetgever, wetenschappers en het OM zelf uit het (recente) verleden de revue passeren. Hierbij moeten we wel bedenken dat de standpunten uit het wat verdere verleden niet los gezien kunnen worden van de toenmalige, wat andere, functies van het OM. ${ }^{\text {4n }}$

Gestreefd is niet naar een volledig overzicht van alle gepubliceerde standpunten. Getracht is de belangrijkste opinies weer te geven, waarbij met name de motivering van belang is. De standpunten zijn geplaatst in chronologische volgorde.

\subsubsection{Wet op de Zamenstelling der Regterlijke Magt en het Beleid der Justitie, 1827}

De Franse overheersing (1810-1813) betekende onder andere de introductie van de Franse rechterlijke organisatie. De Fransen kenden een openbaar ministerie dat één en ondeelbaar was om te kunnen functioneren als een instrument voor de centrale uitvoerende macht. Vóór die tijd was de strafrechtspleging in ons land vooral een taak van de bestuurlijke overheid geweest ${ }^{\text {ta }}$ en werden de officieren van justitie als vertegenwoordigers van die overheid gezien. ${ }^{409} \mathrm{Na} 1813$ bleef de Franse situatie bestaan en werd het openbaar ministerie als één organisatie in 1827 wettelijk ingevoerd. Dit gebeurde door de Franse invloed.

In de Wet op de Zamenstelling der Regterlijke Magt en het Beleid der Justitie van 1827 werd, ondanks niet geringe oppositie, in art. 5 bepaald:

"De Ambtenaren bij het openbaar ministerie zijn verpligt, de bevelen na te komen, welke hun in hunnen ambtsbetrekking door de daartoe bevoegde magt, vanwege den Koning, zullen worden gegeven".

Minister van Justitie Van Maanen lichtte de positie van het openbaar ministerie in de Tweede Kamer als volgt toe:

"Het openbaar ministerie beslist niets; het zongt alleen voor de belangen van de Regering en de behoorlijke toepassing van en opvolging der wetten, door de juiste ontwikkeling

407 Hiervoor zij verwezen naar het preadvics van P. Mostert, Vereisen de functies van het Openbaar Ministerie nieuwe wettelijke voorzieningen? Preadvies NJV 1968, HNJV 1968, decl 1.

$408 \mathrm{Zie}$ voor de ontwikkeling van het OM voor 1811: P. Mostert, Vercisen de functics van het Openhaar Ministerie nicuwe wettelijke voorzicningen? Preadvies NJV, HNJV 1968, deel 1, pag. 264-265. $409 \mathrm{Vgl}$. A.H. Martens van Sevenhoven, De justitiüle colleges in de stcden en op het plattcland van Holland 1795-1811, diss. Utrecht 1912. 
der beginselen welke daarmee in verband staan, en door in dien zin zijne requisitoiren en conclusiën te nemen, welke nogtans den regter, die geheel onafhankelijk blijft, tot niets verbinden" en: "Het openbaar ministerie is dus niet eene eigenlijk gezegde regterlijke autoriteit, maar de tolk, de zaakwaamemer der Hooge Regering; het is eene van het eigenlijk gezegde regterambt geheel afgescheiden magistratuur...." en: "De officieren van het openbaar ministerie zijn niet officieren van de wet, of van de natie, maar van de Koning".410

Duidelijk dus.

De gedachte dat het $\mathrm{OM}$ niet onder de bevelen van de regering moest worden gesteld bleef echter bestaan. Dit bleek bijvoorbeeld uit verschillende grondwetsvoorstellen die bepleitten dat de aanstelling voor het leven behalve voor rechters ook voor ambtenaren van het OM zou moeten gelden." De grondwet van 1848 beperkte deze aanstelling voor het leven tot de procureur-generaal bij de Hoge Raad. De toelichting motiveerde dit door te stellen dat de invloed van de regering op het openbaar ministerie een nuttige werking had gehad. In 1848 stelde Thorbecke de vraag of strafvervolging een zwaard mag worden in de hand van een politisch of administratief bestuur, naar de inzichten van dat bestuur gezwaaid of in de schede gehouden. Hij was van mening dat de aanvang van vervolging slechts door rechtvaardigheid geleid mag worden. In 1860 verklaart hij niet tegen een van de regering afhankelijk openbaar ministerie te zijn, maar tegen onbepaalde onderwerping, een afhankelijkheid zonder maat of voorwaarde. ${ }^{42}$ Op zich lijkt mij dit niet zo bijzonder. Hetzelfde zou gezegd kunnen worden met betrekking tot het leger of de politie (geen "Befehl ist Befehl").

\subsubsection{Opleiding van rechters en officieren van justitie, 1953}

In 1953 komt de positie van het OM als onderdeel van de rechterlijke macht ter sprake bij bespreking van een nota waarin onder andere voorstellen worden gedaan met betrekking tot de opleiding van rechters en officieren van justitie. Minister van Justitie Donker pleit voor een gezamenlijke opleiding, hetgeen stuit op bezwaren bij een kamerlid, dat vindt dat de opleiding gescheiden moet plaatsvinden omdat de leden van de zittende magistratuur onafhankelijk zijn, terwijl de leden van de staande magistratuur ondergeschikt zijn aan de minister. De minister antwoordt hierop dat zowel de Grondwet als de Wet op de rechterlijke organisatie staande en zittende magistratuur tot de rechterlijke macht rekent. Weliswaar is er tussen beide een

410 Tweede Kamer 10 april 1827.

411 Zie hierover uitgebreider: G. Duisterwinkel, Preadvies NJV 1968, HNJV 1968, deel 1, m.n. pag. 198-200.

412 Handelingen Staten-Generaal 1860-1861, pag. 164. 
belangrijk verschil, namelijk de onafhankelijkheid van de zittende magistratuur, maar daarmee wordt de staande magistratuur niet buiten de rechterlijke macht gesteld. ${ }^{413}$

In de zestiger jaren van deze eeuw wordt het onderwerp weer actueel. Dit hangt samen met een veranderende functie van het strafrecht en, daarbinnen, van het $\mathrm{OM}$.

\subsubsection{Jaarvergadering Nederlandse Juristenvereniging, 1968, en de reacties daarop}

De jaarvergadering van de Nederlandse Juristenvereniging in 1968 werd aan de positie van het OM gewijd. De exacte vraagstelling was: "Vereisen de functies van het Openbaar Ministerie nieuwe wettelijke voorzieningen?" Preadviseurs waren Mostert en Duisterwinkel. ${ }^{414}$ Beiden zijn duidelijk: het $O M$ is een onderdeel van de uitvoerende macht. Duisterwinkel zegt expliciet:

"In feite lijkt de positie van de officieren van justitie i.c. geen andere dan die van de ambtenaren van de arbeidsinspectie (een rijksdienst); dezen zijn belast met de handhaving van de arbeidswet en de medewerking aan de uitvoering daarvan, waiarbij zij werkzaam zijn onder de bevelen van de minister van sociale zaken en volksgezondheid"..15

\section{Mostert stelt:}

"Het Openbaar Ministerie is het aangewezen orgaan om bestuurlijke instanties, zowel de centrale als de locale, bij de rechter te vertegenwoordigen. De rechter heeft immers een zo sterke positie bij de handhaving van het strafrecht, dat de Regering zich niet kan permitteren dat haar zienswijze over het algemeen belang, dat met vrijwel ieder strafbaar feit gemoeid is, niet ter kennis van die rechter zou worden gebracht. De Regering moet in staat zijn een beslissing van de rechter uit te lokken. Wanneer het Openbaar Ministerie ook tegenover de Regering vrij zou zijn zaken al dan niet aan te brengen, dan zou het conflict tussen het algemene en het particuliere belang buiten de rechtszalal terecht komen tussen de Regering en het Openbaar Ministerie en tevens onoplosbaar worden". 416 "Het OM is gelieerd aan het bestuur, geaccrediteerd bij de rechter".

Hij vervolgt:

"Uit vorenstaande magniet worden geconcludeerd dat het Openbaar Ministeric beschouwd zou moeten worden als een instrument zonder meer" ${ }^{\prime 17}$ en "Door te aanvaarden, dat het Openbaar Ministerie dient te beschikken over een hoge mate van zelfstandigheid

413 Handelingen II 1953-1954, pag. 2158.

414 G. Duisterwinkel, P. Mostert, Handelingen der Nederlandse Juristenvereniging 1968 deel I.

415 G. Duisterwinkcl, a.w., pag. 202.

416 P. Mostert, a.w., pag. 310.

417 pag. 311. 
bij de uitoefening van zijn taken, geeft men het de noodzakelijke slagvaardigheid en bouwt men tevens in het ambtelijk apparaat ten aanzien van de strafrechtspleging een vliegwielwerking in, waardoor continuitteit van rechtsopvattingen en crimineel beleid ontstaat op enige afstand van de politieke invloeden".18

Dit laatste zou gezegd kunnen worden voor alle ambtelijke activiteit.

In zijn bespreking van bovengenoemde preadviezen stelt Remmelink de -zijns inziensstoutmoedige vraag of het eigenlijk wel juist is met een beroep op de afhankelijkheid (met inbegrip van van het niet-voor-het-leven-benoemd-zijn) van het OM te stellen dat het behoort tot de uitvoerende macht, tot het bestuur, zoals gebruikelijk is. ${ }^{\text {st }}$ Hij vraagt zich af of, gezien de huidige verhoudingen, vastgehouden moet worden aan de beschouwingen van minister Van Maanen uit 1827, die gebaseerd waren op Franse gedachten. Remmelink verdedigt de opvatting dat het OM primair gezien moet worden als een stuk rechterlijke macht naast de eigenlijke rechter. Hij verwijst daarbij naar het Belgische stelsel. Voorts is een dergelijke opvatting naar zijn oordeel meer in overeenstemming met de wet, die het OM ook onder de rechterlijke macht doet ressorteren. ${ }^{400}$ Verder wijst hij op de vele "gelijkstellingen" met de rechter zoals de salariëring bij wet, eisen van bekwaamheid, beletselen van bloed- en aanverwantschap, titulatuur en kostuum. Van meer belang zijn volgens Remmelink de eed, plaats op het podium en de omstandigheid, dat de eerbied, die de advocaat moet zweren, ook het OM omvat. Het rechterlijk moment domineert in zijn hoofdtaak, zijn optreden ter terechtzitting. "Hier spreekt hij -zij het niet beslissend; hij vordertrecht". ${ }^{421}$ Bij de afhankelijkheid van het OM zet Remmelink vraagtekens. Evenmin als de rechter kan de officier van justitie oordelen voordat het onderzoek ter terechtzitting is afgesloten. Hij moet, evenals de rechter, oordelen naar aanleiding van het onderzoek ter terechtzitting. Het $\mathrm{OM}$ is niet aan een door de minister voorgeschreven requisitoir gebonden. Remmelink geeft toe dat het $O M$ de rol van partij speelt tijdens een strafgeding, maar dit mag er niet toe leiden dat het partijdig is. Het behoort objectief te blijven. Het rechterlijk moment komt naar zijn mening ook naar voren daar waar de wetgever het OM met bepaalde bevoegdheden heeft bekleed, waarbij hij vooral denkt aan de vervolgingsbeslissing, de keuze inzake het onderwerp van de rechtsstrijd en de tenlastelegging.

418 pag. 312.

419 J. Remmelink, Het openbaar ministerie ter discussie. VR 1968, pag. 169-174 en 193-197, m.n. pag. 171.

420 Hij verwijst hicrhij naar art. 180 van de (oude) Grondwet en naar bepalingen uit de wet RO. Art. 180 correspondecrt met art. 117 van de huidige grondwet.

421 pag. 172. 


\subsubsection{Jaarverslag OM 1974}

Uit het Jaarverslag OM 1974 blijkt dat het OM zichzelf als een zelfstandig orgaan ziet:

"Het openbaar ministerie voor welks activiteiten of achterwege blijven daarvan de minister van justitie tegenover het parlement wel politiek verantwoordelijk is, heeft een eigen in de wet (...) omschreven autonome taak. Het heeft rechtstreeks in de wet omschreven plichten en bevoegdheden. Het is in eerste instantie, belast als het is met de handhaving van de strafwet bij de rechter, geaccrediteerd bij de rechter en ontmoet daar toetsing van zijn handelen en niet-handelen". ${ }^{42}$

De controle op het handelen en niet handelen van het OM wordt bij de rechter en niet bij de minister van Justitie gelegd. Voorts wordt dan ook gesteld dat het OM een eigen gezicht heeft en zelfstandig beleid kan bepalen, mits de minister daarvoor verantwoordelijkheid kan dragen tegenover het parlement. De praktijk zou zijn dat de minister het gevoerde beleid marginaal toetst. ${ }^{42}$

\subsubsection{Dissertatie en oratie Corstens}

Corstens betongt dat het $\mathrm{OM}$, ten aanzien van de vervolgingstaak, uiteindelijk onder het gezag van de regering staat. De minister van Justitie is immers op grond van art. $5 \mathrm{RO}$ bevoegd bevelen aan het $\mathrm{OM}$ te geven. Hieruit blijkt dat het $\mathrm{OM}$ deel uitmaakt van het staatsbestuur. Het kan zijn beleid niet volledig zelfstandig bepalen, daar de regering belang kan hebben bij het vervolgingsbeleid. Bovendien moet de minister verantwoording afleggen over de wijze waarop hij gebruik heeft gemaakt van zijn bevoegdheid die voortvloeit uit art. $5 \mathrm{RO}^{.24}$

In zijn oratie, die de verhouding tussen de rechter en het OM als onderwerp heeft, voert Corstens aan dat, nu het $\mathrm{OM}$ het orgaan is dat een selectie moet maken uit het totale aanbod van strafbare feiten en gezien het feit dat het $\mathrm{OM}$ in toenemende mate het opportuniteitsbeginsel is gaan toepassen, er voor het $\mathrm{OM}$ een werkterrein is ontstaan dat losstaat van dat van de rechter. ${ }^{425}$ De band met het werk van de rechter is minder overheersend geworden. Het werk van het $\mathrm{OM}$ voltrekt zich voor een belangrijk gedeelte buiten de rechter om. Het OM volstaat niet meer zozeer met het nemen van individuele beslissingen, maar voert een intern en extern geharmoniseerd beleid. Met betrekking tot het bestuursstrafrecht is het OM de strafrechtelijk

422 TK 1975-1976, 13600, no. 3, pag. 15.

423 idem, pag. $27-28$.

424 G.J.M. Corstens, Waarborgen rondom het vervolgingsbeleid, dissertatie UvA, Zwolle 1974.

425 GJ.M. Corstens, De verhouding rechter - openbaar ministerie; cen LAT-relatie in het strafrecht, oratie KUN, Arnhem 1983. 
uitvoerder van de wet naast het bestuur. Het is dan niet meer de individuele officier die de zaak aan de rechter voordraagt, maar een vertegenwoordiger van de organisatie, het OM, die na eventueel overleg met andere bestuursorganen de zaken voorlegt aan de rechter. Als gevolg van externe harmonisatie, het $\mathrm{OM}$ als deelnemer van binnenlands bestuur, staat het $\mathrm{OM}$ niet zozeer naast de rechter als vervolger van de verdachte, maar stelt het zich op als uitvoerder van overheidsbeleid tegenover de verdachte. De rol van rechtsvorderaar maakt plaats voor de rol van bevorderaar van overheidsbeleid.

\subsubsection{Het politieke debat naar aanleiding van concrete gebeurtenissen}

\subsubsection{Bloemenhove}

In een aantal politieke debatten naar aanleiding van concrete zaken kwam de verhouding tussen $\mathrm{OM}$, minister en Tweede Kamer aan de orde. ${ }^{46}$

De kwestie Bloemenhove was, zover mij bekend, de eerste zaak waarin de minister van Justitie door de Tweede Kamer ter verantwoording werd geroepen over optreden van het $\mathrm{OM}$ in een concreet geval. ${ }^{427}$

De feiten (voor zover hier van belang): Bloemenhove was een kliniek in Heemstede waar abortus provocatus werd verricht, ook bij zwangerschappen die langer dan twaalf weken hadden geduurd. Na medische complicaties bij een vrouw met Duitse nationaliteit werd door het betreffende echtpaar aangifte gedaan bij de politie. Door de hoofdoflicier van justitie werd, met machtiging van de toenmalige minister van Justitie Van Agt (KVP), besloten tot inbeslagneming door verzegeling van de inventaris van de operatie- en een der behandelkamers.

Voorafgaand aan dit justitieel optreden was door de Tweede Kamer en de minister overeengekomen, dat, wanneer betreffende maatregelen werden overwogen, hiervoor de weg van art. 111 Sv bewandeld zou worden, hetgeen inhoudt dat de zaak door de officier van justitie bij de rechter-commissaris zou worden aangebracht. Alleen bij dringende noodzakelijkheid, hieronder moet worden verstaan dat bij uitstel van de beslissing de in beslag te nemen goederen buiten bereik van justitie worden gebracht, zou art. 97 Sv worden toegepast, op grond waarvan de officier van justitie zelf huiszoeking tot inbeslagneming kan doen. Het toenmalige kamerlid Roethof (PvdA) vroeg zich bij zijn interpellatie af waarom in deze zaak van die afspraak was afgeweken. Hij was van mening dat de minister daarover vooraf in overleg had moeten treden met de betrokken vaste kamercommissies (hierom was door enkele leden verzocht), zodat nadere informatie verschaft had kunnen worden. Hij drong er bij de minister op aan de genomen beslissing in heroverweging te nemen en hier-

426 Zie hierover ook: H.Tb.J.F. van Maarseveen, Ministeriële verantwoordelijkheid en Openbaar

Ministerie na 1976, NJB 1977, pag. 209-215.

427 Handelingen II 1975-1976, 19 mei 1976, pag. 4226-4238. 
over in normaal overleg met de kamer te treden. Hij diende een motie in waarin de minister verzocht werd de vraag of tot beslagneming dan wel tot sluiting moest worden overgegaan eerst ter beoordeling aan de onafhankelijke rechter voor te leggen. In zijn antwoord stelde de minister onder andere dat hij om de volgende redenen niet was ingegaan op het voornoemd verzoek tot overleg:

"De hoofdofficier in Haarlem gaf te kennen het zijn plicht te achten, op deze wijze gebruik te maken van wettelijke bevoegdheden in het kader van het Wetboek van Strafvordering. Ik had geen reden om hem in dat voornemen belemmeringen in de weg te leggen. Ik vind ook niet dat de Kamer, of commissies van de Kamer, zich behoren te begeven in toetsing vooraf van de vraag, of ambtenaren van het openbaar ministerie in een concrete zaak al of niet gebruik behoren te maken van wettelijke bevoegdheden waarover zij ontegenzeglijk beschikken. Ik vind dat die toetsing vooraf, in een concrete zaak, of het openbaar ministerie al of niet en zo ja, op welke wijze, gebruik zal maken van wettelijke bevoegdheden, naar mijn mening noch door het parlement, noch door zijn commissies aan zich moet worden getrokken. In het algemeen vind ik dat én de Minister én het parlement terughoudend behoren te zijn bij het toetsen van het justitiële optreden in concrete zaken, in individuele gevallen. Ik betwist uiteraard niet in het minst dat het parlement de volle bevoegdheid heeft en geen terughoudendheid behoeft te betrachten bij het bespreken en bekritiseren, desnoods bijsturen van het algemene vervolgingsbeleid of delen daarvan, maar niet toegespitst op individuele strafzaken".

De motie Roethof werd met een ruime meerderheid aanvaard, doch de minister weigerde de uitvoering ervan. Uiteindelijk werd hij door actievoerders hiertoe gedwongen. In een afsluitend debat betoogde de minister over het recht van de kamer het vervolgingsbeleid van het $O M$ te beoordelen:

"Evenwel is het daarbij een goede praktijk, om niet te zeggen staatsrechtelijke gewoonte, dat de Kamer zich niet dan in zeer bijzondere gevallen begeeft in individuele zaken. De Kamer pleegt zich met het vervolgingsbeleid bezig te houden in meer algemene zin door het beleid te beoordelen zoals het wordt toegepast op groepen van gevallen, zonder te duiken in individuele gevallen". ${ }^{\mathrm{n} 28}$

Hier nuanceerde hij zijn eerdere uitspraak enigszins. Hij maakte een uitzondering mogelijk voor bijzondere gevallen en zwakte af van "behwicn" naar "plegen".

Wanneer deze redenering van de minister vergeleken wordt met de concrete gang van zaken in de Bloemenhove-kwestie blijkt naar mijn mening toch van enige inconsequentie. De minister botoogt namelijk dat minister en parlement afstand moeten bewaren tot het handelen van het $\mathrm{OM}$ in individuele strafzaken, maar tegelijkertijd was de minister ten zeerste betrokken bij de toepassing van een dwangmiddel doordat voor de inbeslagneming zijn machtiging was vereist. Ecn dergelijke machtiging wordt 
door het Wetboek van Strafvordering niet vereist. De hoofdofficier heeft wellicht zo gehandeld omdat het een zaak betrof die politiek gevoelig lag. Het wel of niet verlenen van de machtiging door de minister was een politieke keuze. Afstandelijkheid van het parlement zou dan inhouden dat het zich niet zou kunnen mengen in deze door de bewindsman gemaakte keuze, namelijk de wijze waarop hij deze machtiging gehanteerd heeft.

Bij dergelijke politiek importante individuele strafzaken kan en mag het parlement naar mijn overtuiging echter niet op afstand worden gehouden, omdat de belangen die ermee zijn gemoeid het individuele geval te boven gaan.

\subsubsection{Lockheed}

Naar aanleiding van onthullingen in de Amerikaanse senaat met betrekking tot de Lockheed Aircraft Corporation, waarbij gesuggereerd werd dat de Prins der Nederlanden Bernhard, echtgenoot van de toenrnalige koningin Juliana, betalingen zou hebben ontvangen, werd door de Nederlandse regering een commissie ingesteld die onderzoek moest doen naar de betrokkenheid van de prins bij deze steekpenningen-affaire. Naar aanleiding van de uitkomst van dit onderzoek verklaarde de regering dat de prins het belang van de staat had geschaad en zich terug moest trekken uit een aantal functies. ${ }^{d y}$ In deze regeringsverklaring werd tevens de vraag aan de orde gesteld of het openen van een opsporings-dan wel gerechtelijk vooronderzoek noodzakelijk was. De regering wilde hiervan afzien op de volgende gronden:

1. Het instellen van een strafrechtelijk onderzoek heeft alleen zin en is slechts gerechtvaardigd bij het bestaan van een reële mogelijkheid dat een latere berechting tot een verourdeling zou kunnen leiden. Die mogelijkheid ontbreekt voor zover het recht tot strafvordering, indien er sprake van een delict zou zijn geweest, is verjaard;

2. De uitoefening van het recht tot strafvordering, voor zover nog geen verjaring is ingetreden, zou een zeer geruime tijd vergen en het is onzeker of uit een strafrechtelijk onderzoek tenslotte een voor berechting vatbare zaak zou resulteren;

3. De regering is van oordeel dat, juist met het oog op de gelijkheid van rechtsbedeling, dat Prins Bernhard door het bekend maken van het rapport en door de conclusies die de regering aan het rapport verbindt, al ingrijpende gevolgen van zijn gedrag zal ondervinden;

4. Het instellen van een strafrechtelijk onderzoek en een eventuele strafrechtelijke vervolging zouden ernstige gevolgen hebben voor de positie van het staatshoofd. 
Tijdens het kamerdebat naar aanleiding van deze kwestie $e^{430}$ werd door vrijwel alle politieke partijen dit standpunt van de regering gedeeld. Herhaaldelijk kwam nog het argument naar voren dat het algemeen belang hier niet met een strafrechtelijk onderzoek gediend is, dat het opportuniteitsbeginsel de mogelijkheid biedt het aspect van het algemeen belang in de overwegingen te betrekken, dat met een vervolging hogere belangen zouden worden geschaad of dat met het seponeren het algemeen belang lijkt te worden gediend. ${ }^{431}$ Het kamerlid Van der Lek (PSP) maakt bezwaar tegen het afzien van een strafrechtelijk onderzoek. ${ }^{432}$ Deze partij heeft de indruk dat vooral het laatste argument de doorslag heeft gegeven en heeft er moeite mee dat er om die reden van vervolging wordt afgezien. Door de PSP wordt dan ook een motie ingediend die de regering verzocht een gerechtelijk vooronderzoek in te stellen om zo tot opheldering te komen van een aantal duister gebleven zaken en om meer feiten over wat zich afspeelt bij wapenaankopen aan het licht te brengen. Deze motie werd met grote meerderheid verworpen; alleen de leden van de PSP stemden voor.

Opmerkelijk in deze zaak was dat regering en parlement zich uitdrukkelijk bemoeiden met de vraag of er in deze individuele zaak een gerechtelijk vooronderzoek en verdere strafvervolging moesten plaatsvinden. Noch door de bewindslieden, noch door de kamerleden werd deze bevoegdheid betwist. Uit de hierboven weergegeven bewoordingen blijkt dat kamerleden er geen moeite mee hadden de beslissing, die volgens de wet aan het $\mathrm{OM}$ toekomt ${ }^{43}$ zelf te nemen. Ook de motie werd door de toenmalige minister-president Den Uyl en de minister van Justitie Van Agt niet bestreden met het argument dat de Kamer niet gerechtigd zou zijn een dergelijk verzoek te doen. Bij de vraag of er wel of niet een gerechtelijk vooronderzoek zou moeten worden ingesteld in dit individueel geval, is het $\mathrm{OM}$ niet betrokken geweest. De beslissing hierover is uitsluitend op politiek niveau genomen. ${ }^{434}$

\subsubsection{Menten}

In de zaak Menten riep de Tweede Kamer de minister van Justitie ter verantwoording omdat het OM niet of niet goed zou zijn opgetreden. De feiten: De miljonair Menten

430 Handelingen II 1975-1976, 26 en 30 augustus 1976, pag. 5115-5117 en 5135-5163.

431 Zie bijvoorbceld Wiegel (VVD), pag. 51.35; Van Thijn (PvdA), pag. 5137, Abma (SGP), pag. 5146, Terlouw (D66), pag. 5148.

432 pag. $5151-5152$.

433 artt. 167 en 242 Sv: Indien naar aanleiding van het ingestelde opsporingsonderzock resp. voorbereidend onderzoek het $O M$ van mening is dat vervolging, resp. verdere vervolging moet plaatshebben, gaat het daartoe zo snel mogelijk over. Van vervolging resp. verdere vervolging kan worden afgcrien op gronden aan het algemeen belang ontleend.

434 Van Maarseveen wijst hierbij op de volgende tegenspraak: op 30 augustus in het debat over Prins Bernhard stemt de minister ermee in dat de kamer zich bemoeit met het individucle geval, terwijl hij dat een dag later in het Bloemenhove-debat de kamer juist verweet. H.Th.J.F. van Maarseveen, a.w., pag. 212. 
bood een aantal kunstvoorwerpen ter veiling aan, waaronder zich stukken zouden bevinden die in de Tweede Wereldoorlog geroofd zouden zijn. Na protesten van derden werd de veiling afgelast. Journalistiek speurwerk leidde vervolgens in de richting van een verdenking jegens Menten van oorlogsmisdaden. Het $\mathrm{OM}$ stelde een onderzoek in. Toen het $\mathrm{OM}$ uiteindelijk besloot de verdachte te arresteren, was deze gevlucht. Hieraan wijdde de Tweede Kamer een debat. Evenals de Tweede Kamer was de minister van Justitie van mening dat er ernstige fouten waren gemaakt door het OM. Voor sommige kamerleden was dit aanleiding nog eens te benadrukken dat de minister, hoewel hij zich niet met ieder individueel geval hoeft bezig te houden, in politiek gevoelige zaken, gezien zijn politieke verantwoordelijkheid, dit wel behoort te doen. Dat hij dit in dit geval niet gedaan heeft, is een tekortkoming ${ }^{435}$. Het kamerlid Van der Spek (PSP) vond dat door deze gang van zaken de positie van de betreffende minister onhoudbaar was geworden ${ }^{436}$. In zijn antwoord stelde de bewindsman dat hij zijn politieke verantwoordelijkheid aldus had verstaan dat hij het OM had voorzien van de algemene richtlijn die het behoefde om in een eventueel moeilijke situatie op te kunnen treden en te kunnen beslissen. Echter, toen het op besluiten aankwam heeft het $O M$ overleg gepleegd met hoofdambtenaren van het departement van justitie. Vervolgens komt hij met de ondoorzichtige redenering dat voor het optreden van deze ambtenaren, die volgens de minister in een geheel andere verhouding tot hem staan dan ambtenaren van het $O M$, de minister slechts kan instaan voor zover hij hun gedrag goedkeurt ${ }^{437}$. Volgens enkele kamerleden had de minister in dit geval niet kunnen volstaan met het geven van een algemene richtlijn, maar had hij zich in de verschillende fasen van het onderzoek op de hoogte moeten houden. Verder werd, mijns inziens zeer terecht, gesteld dat de minister verantwoordelijk is voor het $\mathrm{OM}$ en voor ambtenaren van zijn departement, ook wanneer hij hun gedrag niet voor goed houdt. De Kamer kan het $O M$ en de departementsambtenaren niet ter verantwoording roepen. Daarvoor is er de minister die daarom de Kamer dient in te lichten over de details van het beleid van het $O M$. De minister van Justitie zegde onder andere toe dat over het verloop van het strafrechtelijk onderzoek een nota van verantwoording zou worden geschreven die, vanwege de volledigheid ervan, aan de vaste kamercommissie voor Justitie in vertrouwelijkheid verstrekt zou worden. In deze vaste commissie is de zaak verder behandeld. Ook over dit individuele geval is aan de Kamer dus volledige verantwoording afgelegd.

Naar aanleiding van de behandeling van deze actuele gebeurtenissen in het parlement trok Van Maarseveen onder andere de volgende conclusies: de minister van Justitie heeft meer directe bemoeienis gekregen met het algemeen beleid van het OM en

435 Zie bijwoorbeeld Kosto, Handelingen Tweede Kamer 1976-1977, 18 november 1976, pag. 1359;

Kappeyne van de Coppello, pag. 1361; Terlouw, pag. 1364;

436 Van der Spek, pag. 1366;

437 Handelingen Tweede Kamer 1976-1977, 18 november, pag. 1376. 
in politiek relevante zaken ook met het dagelijks beleid; de controle van het parlement ten aanzien van het beleid van het OM beperkt zich niet meer tot het algemene beleid. Indien een individuele strafzaak van politiek belang is, gaat het parlement er zich mee bemoeien; het OM-beleid past niet meer alleen in een strafrechtelijk maar ook in een politiek kader, de staatsrechtelijke en ook de politieke aspecten zijn niet meer weg te denken. Het in het jaarverslag van 1974 ingenomen standpunt van de procureurs-generaal is zijns inziens dan ook achterhaald. ${ }^{438}$

Ook uit het parlementair debat naar aanleiding van het opheffen van het interregionaal rechterche team (IRT) ${ }^{439}$ blijkt dat de Tweede Kamer zich wel degelijk voor het beleid en de beleidsuitvoering van het $O M$ interesseert en dat de minister van Justitie daarover verantwoording aan het parlement schuldig is. ${ }^{\star 10}$

\subsubsection{Voorbereiding grondwetswijziging}

Bij de bespreking van het begrip 'rechterlijke macht' (zie hiervoor $\$ 2$ ) werd in het Voorlopig Verslag door de fractie van D'66 de vraag gesteld of het juist is de leden van de staande magistratuur zuiver als deel van een bepaalde tak van ambtelijke hiërarchie te beschouwen. Men vroeg zich af of dit voldoende recht deed aan de vergaande zelfstandige bevoegdheden van het $\mathrm{OM}$, met name de seponerings- en transactiebevoegdheid. Men vroeg de bewindsman aan te geven waarom dit niet tot de uitvoering van een 'rechterlijke taak' behoorde, hetgeen impliceerde dat het OM niet tot de 'rechterlijke macht' moest worden gerekend. $\mathrm{Zij}$ stelden zich de vraag of de mate van onafhankelijkheid, die de leden van het $O M$ bij de uitoefening van hun taak bezitten, niet grondwettelijk moest worden vastgelegd. Hierbij werd verwezen naar de conclusie van A-G Remmelink voor het arrest van HR 22 mei 1979, NJ 1979, 301..$^{+11}$ In de MvA aan de Tweede Kamer stelden de verantwoordelijke bewindslieden dat, wil de minister van Justitie zijn verantwoordelijkheid voor het functioneren van het OM kunnen dragen, dat slechts kan indien hij over dit apparaat zeggenschap heeft. Deze zeggenschap heeft de minister op grond van art. 5 RO. De uitoefening door het $\mathrm{OM}$ van de taken, die het krachtens de wet heeft, moet worden ingepast in het algemeen beleid, waarvoor de minister van Justitic verantwoording moet kunnen dragen. De seponerings- en transactiebevoegdheid van het OM kunnen niet worden vereenzelvigd met de uitoefening van een rechterlijke taak. Deze bevoegdhe-

438 H.Th.J.F. van Maarsseveen, Ministeriële verantwoordelijkheid en openbaar ministerie na 1976, NJB 1977 , pag. 209 e.v.

439 Deze zaak speelde in april 1994.

440 Zie hierover: DJ. Elringa, Een volle ministeriële verantwoordelijkheid voor het Openbaar Ministeric -maar geen ongebreidelde sturing van het OM, NJB 1994, pag. 529-537.

441 Voorlopig Verslag, TK 1980-1981, 16162, nr. 6, pag. 6. 
den leiden er juist toe dat er geen berechting plaatsvindt. ${ }^{42}$ De fractie van D'66 was met dit antwoord, in tegenstelling tot bijvoorbeeld de CPN-fractie ${ }^{\text {t3 }}$, niet helemaal tevreden. Men was van mening dat de verwarring over de positie van het $\mathrm{OM}$ hiermee alleen maar groter was geworden. Het probleem bij het afleggen van verantwoording door de minister van Justitie over het OM lag nu juist in de onduidelijke en -in elk geval schijnbare- onafhankelijke positie van het OM. ${ }^{\text {w4 }}$ In het Voorlopig Verslag van de Eerste Kamer werd door de fractie van de PvdA de vraag gesteld of uit art. 6.5 lid 1 (art. 180 lid $2 \mathrm{GW}$, gudb) mag worden afgeleid dat er naast de zittende rechterlijke macht ook een staande rechterlijke macht is, en, indien deze vraag bevestigend wordt beantwoord, of hiermee de leden van het $O M$ worden bedoeld. ${ }^{\text {us }}$ In de MvA aan de Eerste Kamer geeft de regering aan dat de Wet RO de leden van het OM beschouwt als te behoren tot de rechterlijke macht, zij het dan niet met rechtspraak belast. ${ }^{46}$ Zoals reeds betoogd in $\$ 2$ moet er naar mijn mening een formele wet bestaan op grond waarvan het $\mathrm{OM}$ tot de rechterlijke macht in enge zin wordt aangewezen. Deze aanwijzing geschiedt niet door de Wet RO.

\subsubsection{Dissertatie Stroink}

Op deze plaats kan niet onvermeld blijven de dissertatie van Stroink welke het leerstuk der deconcentratie als onderwerp heeft. ${ }^{47}$ Hoewel velen het $O M$ als een op zichzelf staande rechtsvorm beschouwen, valt het $O M$ naar de mening van Stroink onder de term 'gedeconcentreerd ambt'. ${ }^{48}$ Onder deconcentratie verstaat hij: de attributie/delegatie van publiekrechtelijke bevoegdheden aan ambten, waarvan de vertegenwoordigers departementsambtenaren zijn. ${ }^{* 9}$ In principe is er volgens hem geen verschil tussen het $\mathrm{OM}$, dat op grond van attributieve bepalingen bevoegdheden uituefent, en de overige gedeconcentreerde ambten die eveneens op grond van attributie of delegatie bevoegdheden uitoefenen. Tegenargumenten, inhoudende dat het $O M$ tot de rechterlijke macht behoort en dat leden van het OM dezelfde eed afleggen als rechters, overtuigen hem niet. Deze omstandigheden zijn naar zijn oordeel niet relevant.

442 MvA, TK 1980-1981, 16162, nr. 8, pag. 8.

443 Handelingen II, zitting 1980-1981, 18 februari 1981, pag. 3267.

444 Eindverslag. TK zitting 1980-1981, 16162, nr. 10, pag. 2.

445 EK 1980-1981, 16162, nr. 100a, pag. 3.

446 MvA EK 1980-1981, 16162, nr. 100b, pag. 4-5.

447 F.A.M. Stroink, Deconcentratie, dissertatie RUU, 's-Gravenhage 1978.

448 F.A.M. Stroink, a.w., pag. 157-158.

449 F.A.M. Stroink, a.w., pag. 62. 
"Waar het op aankomt, is (a) dat het OM op eigen naam bevoegdheden uitoefent, en (b) dat de leden van het $O M$ ambtenaren van het ministerie van justitie zijn en dus tevens in een hiërarchische relatie tot de minister staan".

Met betrekking tot de concrete ministeriële aanwijzingsbevoegdheid maakt Stroink een uitzondering voor het OM. Acht hij ten opzichte van andere gedeconcentreerde ambten een dergelijke bevoegdheid ongewenst, juist voor het OM acht hij deze wel aanwezig, gezien de grote beslissingsvrijheid die leden van het OM op grond van het opportuniteitsbeginsel bezitten. ${ }^{451}$

\subsubsection{Commissie Mendlik; Nederlandse Vereniging voor Rechtspraak, 1980}

Door de Nederlandse Vereniging voor rechtspraak werd in 1980 de Commissie relatie $\mathrm{OM} /$ zittende magistratuur in het leven geroepen, naar haar voorzitter de Cie. Mendlik genoemd. ${ }^{452}$ Onder de taakopdracht viel de vraag naar de constitutionele positie van het OM binnen het geheel van de rechterlijke macht, in het bijzonder de vraag of het OM deel uitmaakt c.q. dient te maken van de rechterlijke macht in eigenlijke zin. De commissie bestond uit leden van de staande en zittende magistratuur. In haar rapport maakt de commissie een onderscheid naar de taken van het OM. Met betrekking tot de handhaving der wetten is zij van mening dat het OM wezenlijk deel uitmaakt van de rechterlijke macht en deelt in de onafhankelijkheid en zelfstandigheid van de rechterlijke macht ten opzichte van de bestuurlijke overheid. Met betrekking tot de opsporing en vervolging van strafbare feiten is het OM volgens de commissie duidelijk meer een orgaan van de overheid. Bepaalde ontwikkelingen (die hiervoor reeds aangegeven zijn) hebben ertoe geleid dat het OM toegroeit naar een bestuurlijke aanpak van zijn vervolgingstaak. Een dergelijke manier van taakuitoefening is vreemd aan de rechterlijke macht, waar immers onafhankelijkheid en zelfstandigheid ten opzichte van de bestuurlijke overheid bestaat. ${ }^{253}$ De commissie signaleert overigens wel dat de wet geen duidelijk onderscheid maakt tussen de zittende en staande magistratuur. In de conclusies van het rapport komt het gemaakte onderscheid niet erg duidelijk naar voren. De commissie stelt dat het openbaar ministerie deel uitmaakt van de rechterlijke macht, zoals bedoeld in de GW en Wet RO. Samen met de griffiers vormen de officieren van justitie het deel van de rechterlijke macht dat niet met rechtspraak belast is. De onafhankelijkheid, die de zittende magistratuur heeft, bezit het OM echter niet. In twee van zijn taken is het OM ondergeschikt aan de minister van Justitie. Deze ondergeschiktheid betekent nog niet dat het OM noodzakelijkerwijs in een afhankelijke positie verkeert. De wettelijke taakomschrijving,

450 F.A.M. Stroink, a.w., pag. 158-159.

451 F_A.M. Stroink, a.w., pag. 159.

452 Zie over het rapport van de Cic. Mendlik: Trema 1981, ant. 5, pag. 113-130.

453 Trema 1981, pag. 116-117. 
de gebondenheid aan de afgelegde eed, de sterke verwevenheid met de onafhankelijke rechter en de staatsrechtelijke positie scheppen ruimte voor eigen beleidsvorming. ${ }^{\text {ss }}$ Het argument van gebondenheid aan de afgelegde eed vind ik niet sterk. Ook officieren in het leger, politiefunctionarissen, ja zelfs ministers leggen een dergelijke eed af.

\subsubsection{Dissertatie Lubberdink, 1982}

In de dissertatie van Lubberdink, betreffende de betekenis van de ministeriële verantwoordelijkheid voor de organisatie van het openbaar bestuur ${ }^{455}$, komt de verhouding tussen het $O M$ en de minister van Justitie aan de orde. Lubberdink is van mening dat op geen enkele wijze staande kan worden gehouden dat het $O M$ juridisch gezien een zekere zelfstandigheid bezit ten opzichte van de minister van Justitie, althans een andere positie inneemt, dan welke hooggekwalificeerde departementsafdeling sok. Dat de minister aan het OM een grote vrijheid laat bij het inrichten en uitvoeren van zijn taak is volgens hem een kwestie van beleid van de minister. Het $O M$ is hiërarchisch ondergeschikt aan de minister van Justitie die op zijn beurt volledig verantwoordelijk is voor het doen en laten van het $\mathrm{OM}{ }^{4{ }^{40}}$

\subsubsection{Dissertatie Van de Bunt, 1985}

In zijn meer sociologische benadering van de officier van justitie als vervolger van stratbare feiten onderscheidt Van de Bunt drie aspecten: de officier als magistraat, als ambtenaar en als werker. ${ }^{457}$ Deze aspecten zijn waarneembaar in de buitengerechtelijke afdoening. De officier oordeelt zelfstandig over de bewijsvraag in de vervolgingsfase en over de opportuniteit om te vervolgen, waarbij hij zowel het algemeen belang als omstandigheden betreffende de persoon van de verdachte meeweegt (rechterlijk aspect); hij voorkomt ondoelmatig en disfunctioneel strafrechtelijk optreden, waarbij onderlinge (rechts)gelijkheid in het nemen van beslissingen relevant is (ambtelijk aspect); Daarnaast maakt hij, gedwongen door een hoge werklast, een efficiënte afhandeling mogelijk (werkersaspect). ${ }^{459}$ Geschetste ontwikkelingen binnen het $\mathrm{OM}$ tot beleidvoerend orgaan leggen de nadruk op het ambtelijke aspect bij de afdoening van een groot aantal strafbare feiten (hierbij moeten we denken aan

454 Trema 1981, pag. 125.

455 H.G. Lubberdink, De betekenis van de ministeriële verantwoordelijkheid voor de organisatic van het openbaar bestuur. Devenier 1982, met name pag. 62-70.

456 Lubberdink, a.w., pag. 70.

457 H.G. van de Bunt, Officieren van justitie; verslag van een participerend observatieonderzock, dissertatie RUU, Zwolle 1985.

458 Van de Bunt, a.w., pag. 49-59 en 109. 
overtredingen en kleine commune misdrijven). Beslissingen van de officier zijn derhalve niet alleen individuele beslissingen meer, maar zij worden genomen aan de hand van gemaakte richtlijnen en gegeven instructies. Het magistratelijk aspect, het individueel afdoen en bescherming van de rechtspositie van de verdachte, wordt ondergeschikt. De zaken worden doorgaans afgedaan op hasis van het dossier, waarbij het belang van de persoonlijke omstandigheden van het geval afneemt. Met andere woorden: bij de afdoening van deze zaken krijgt de officier van justitie de rol van beleidsuitvoerend overheidsorgaan. Het werkersapect (efficiënte afdoening) heeft hieraan ook meer betekenis gegeven. ${ }^{45}$ Van de Bunt constateert tenslotte dat het OM ten opzichte van de minister van Justitie relatief zelfstandig is gebleven.

"Ondanks de formele onderschikking van het $O M$ hebben de bevelsbevoegde bewindsmannen het $\mathrm{OM}$ altijd met 'fluwelen' handschoenen benaderd. Deze traditie, die binnen het OM wordt gekoesterd, is ondanks de ontwikkelingen van de laatste decennia, waarin de ambtelijke organisatie $O M$ zich als beleidsvoerend orgaan profileert, in ere gehouden. Dit is alleen maar te begrijpen als men beseft dat het OM geen buitendienst van de centrale executieve is, maar een intergrerend onderdeel van de onafhankelijke rechterlijke macht".

Dit laatste is naar mijn idee niet helemaal juist. De omstandigheid dat de minister van Justitie terughoudend is in het gebruik maken van zijn bevelsbevoegdheid heeft andere oorzaken. Deze zullen in het vervolg van dit hoofdstuk aan de orde komen.

\subsubsection{Oratie De Doelder, 1988}

In zijn oratie 'Het OM in positie' stelt De Doelder het onderwerp opnieuw aan de orde. ${ }^{4 \infty}$ Zich onder andere baserend op Remmelink, wiens opvatting volgens De Doelder in de literatuur de boventoon is gaan voeren, ${ }^{+61}$ verkondigt hij de mening dat het OM zich bij zijn functioneren moet laten leiden door zijn rechterlijke attitude. Dit houdt in dat het bij de uitoefening van zijn taak (in art. 4 RO omschreven als 'wetshandhaving', maar in navolging van 't Hart op te vatten als 'rechtshandhaving') steeds "de in het geding zijnde instrumentele belangen moet afwegen tegen de rechtsbeschermende belangen". $462 \mathrm{Bij}$ het nemen van beslissingen in de opsporingsfase zou dit volgens de Doelder concreet betekenen dat het $O M$ niet alleen moet letten op op het belang om resultaten te boeken (wat hier onder verstaan moet worden

459 Van de Bunt, a.w., pag. 109-113.

$460 \mathrm{H}$. de Doelder, Het OM in positic, oratie EUR, Arnhem 19s\$.

$461 \mathrm{H}$. de Doelder, a.w., pag. 10. Enigrins vreemd is het dat De Doclder niet verwijst naar een dissertatic uit administratiefrechtelijke hoek over dit onderwerp, waarin het OM bestempeld wordt als cen overheidsorgaan. Bedoeld zijn de reeds aangehaalde proefschrift van Stroink en van Lubberdink, die overigens op zijn beurt nalaat niet naar het mijns inziens niet onbelangrijke artikel van Remmelink in Verkeersrecht te verwijzen.

462 De Doelder, a.w., pag. 13. 
wordt niet nader aangegeven), maar ook het belang van de verdachten en andere betrokkenen in het proces in het oug moet houden. In de vervolgingsfase dient hetzelfde te gebeuren.

"Op dit beschermende aspect, dat naast het instrumentele aspect, het begrip recht kenmerkt dat gehandhaafd moet worden, steunt de meer beschermende en rechterlijke taak van het Openbaar Ministerie". ${ }^{403}$

Deze rechtshandhavende taak kan het OM volgens De Doelder alleen waarmaken als het een zekere zelfstandige positie ten opzichte van het bestuur kan innemen. Deze stelling is naar mijn mening te algemeen. Het instrumentele en rechtsbeschermende aspect zijn geen te scheiden grootheden, maar zij dienen beide het algemeen belang. Hieronder kom ik hier op terug. Daarnaast lijkt het mij toe dat de afweging van instrumentele belangen tegen rechtsbeschermende belangen niet slechts een rechterlijk aspect is, doch ook een bestuurlijk.

\subsubsection{Rede minister van Justitie Korthals Altes, 1988}

Op 15 oktober 1988 houdt minister van Justitie Korthals Altes een inleidende rede voor de sectie OM van de Nederlandse Vereniging van Rechtspraak. ${ }^{46}$ Sprekend over de ministeriële verantwoordelijkheid maakt hij een onderscheid tussen de formele en de materiële verantwoordelijkheid. Onder de formele verantwoordelijkheid verstaat hij de verantwoordelijkheid van de uitvoerende macht aan de volksvertegenwoordiging. De materiële, inhoudelijke, verantwoordelijkheid levert meer problemen op. De minister is verantwoordelijk voor wat hij zelf zegt en doet en, al wordt dit al moeilijker, voor hetgeen ambtenaren namens de minister doen of nalaten. ${ }^{\text {ts }}$ Nog problematischer wordt het in gevallen waarbij krachtens attributie of mandaat delen van overheidstaken overgedragen of opgedragen zijn aan organen die geen deel uitmaken van departementen van algemeen bestuur, maar die de minister wel kan beïnvloeden. In navolging van de bestuursrechtwetenschap ${ }^{\text {tco }}$ spreekt de minister over departementale buitendiensten of van zelfstandige bestuursorganen, waarbij de term 'zelfstandig' enigzins misleidend is: bedoeld zijn eigen bevoegdheden ter uitvoering van een tak die opgelegd is. Volgens de minister is dit op het OMvan

463 De Doelder, a.w., pag. 13.

464 De tekst van deze inleiding 'De verhouding tussen minister van justitie en het openbaar ministerie' is afgedrukt in Trema 1988, pag. 367-373.

465 Vgl. R.J. Hoekstra, Ministeriēle verantwoordelijkhcid, uit: Gegeven de Grondwet, Deventer 1988, pag. 100.

$466 \mathrm{Hij}$ baseert zich met name op de dissertatic van Lubberdink. 
toepassing ${ }^{407}$ De wet geeft het een aantal bevoegdheden die het zelfstandig uitoefent, terwij] de minister door art. 5 RO mogelijkheden heeft tot beïnvloeding.

De minister is volledig verantwoordelijk wat de formele verantwoordelijkheid betreft. Aangaande de materiële verantwoordelijkheid gaat die zover als de uitoefening van bevoegdheden waarover hijzelf beschikt. Hiertoe behoren niet de opsporing en vervolging, wel zijn beïnvloeding daartoe ex. art. $5 \mathrm{RO}$. Het argument dat het OM deel uitmaakt van de rechterlijke macht vindt bij de minister geen instemming: het kan slechts à contrario uit art. 117 lid $1 \mathrm{GW}$ worden afgeleid en er zijn geen verdere rechtsgevolgen aan verbonden. ${ }^{\text {th }}$

In zijn commentaar op deze rede ${ }^{4 / 5}$ voert De Doelder aan dat de minister en bestuursgeleerden te weinig oog hebben voor de magistratelijke taak van het $\mathrm{OM}$. Hij maakt een onderscheid tussen opsporings- en vervolgingsbeleid in het algemeen en in concrete gevallen. In deze laatste, hij denkt hier bijvoorbeeld aan toepassing van een dwangmiddel of aan een requisitoir, kan de officier niet de belangen van de politiek behartigen, maar moet hij de belangen van de verdachte laten meewegen. Bij dit rechterlijk onderdeel van het werk van het OM kan de minister zich niet als hiërarchisch meerdere opstellen: "strafzaken behoren niet te worden geregisseerd door welk politiek orgaan dan ook ${ }^{110}$ De rol van het parlement moet zijns inziens dan ook terughoudend zijn. De Doelder erkent dat een groot gedeelte van de officier van justitie als overwegend bestuurlijk kan worden aangemerkt. Ten aanzien van dit werk is de minister dan hiërarchisch de meerdere. In de afdoening van de individuele strafzaak overheerst echter de rechterlijke component van de officier van justitie, waarmee de minister en de Tweede Kamer zich volgens De Doelder niet dwingend mogen bemoeien.

\subsubsection{Jaarverslag OM 1988}

Het Jaarverslag OM 1988 draagt als titel: Het Openbaar Ministerie in zijn bestuurlijke omgeving. Het behandelt de contacten die het OM met het bestuur heeft bij het vaststellen en uitvoeren van het beleid ten aanzien van verschillende vormen van criminaliteit. Ingezien wordt dat bestuurlijk en justitieel beleid elkaar aanvullen in de aanpak van de bestrijding ervan, hoewel de benadering niet gelijk is. Deze gezamenlijke aanpak uit zich bijvoorbeeld in interne en externe overlegstructuren, werkafspraken en uitvoeringsvoorschriften en het heeft grote gevolgen voor de interne organisatie. Kortom: het OM zal aandacht moeten hebben voor de bestuurlijke aspecten van strafzaken. Men moet zich echter realiseren dat de 'magistratelijke

467 Trema 1988, pag. 370.

468 Trema 1988, pag. 371-372.

469 H. de Doelder, De ministeriële verantwoordelijkheid voor het OM, Trema 1988, pag. 374-377. 470 Trema 1988, pag. 375. 
basishouding van het openbaar ministerie', waarbij het gaat om de puur juridische kanten aan een strafzaak (bewijs, onverbindenheid van een strafbepaling) het $O M$ kan dwingen een ander standpunt in te nemen dan het door de overheid ingenomen standpunt. ${ }^{411}$

\subsubsection{Voorjaarsvergadering NVvR 1991 en verdere discussie}

De Voorjaarsvergadering van de Nederlandse Vereniging voor Rechtspraak (NVvR), gehouden in 1991 te Maastricht, liet zien dat het onderwerp nog niet aan actualiteit had ingeboet. Men discussieerde namelijk over de vraag: de officier van justitie, magistraat of bestuursambtenaar? De volgende standpunten werden naar voren gebracht. ${ }^{4 / 2}$

Ficq neemt een soort tussenpositie in. De constatering dat op grond van art. 5 RO het OM hiërarchisch onderschikt is aan de minister van Justitie, waardoor het OM een buitendienst is van het ministerie van justitie, is hem te simpel. Aan de andere kant doorbreekt de attributie van publiekrechtelijke bevoegdheden aan het $\mathrm{OM}$ de normale hiërarchische verhoudingen niet. Zuiver bestuursrechtelijk beschouwd kan het $\mathrm{OM}$ worden gekwalificeerd tot een gedeconcentreerd bestuursorgaan. Het is echter de eigen aard en zelfs het wezen van het OM dat het tot beide dimensies behoort, aldus Ficq. Hij acht het voor het functioneren van het $O M$ van bepalende hetekenis dat het formeel een onderdeel vormt van de rechterlijke macht. Zie ik het goed, dan baseert hij dit op art. 117 lid $1 \mathrm{GW} .^{433}$

Remmelink neemt als uitgangspunt van zijn bijdrage het bestrijden van het standpunt van Lubberdink, zoals hij dat in zijn dissertatie poneerde (zie § 3.1.10). ${ }^{.71}$ Remmelink verdedigt zijn (reeds eerder door mij beschreven) standpunt dat het $\mathrm{OM}$ deel uitmaakt van de rechterlijke macht. Als argumenten die deze stelling ondersteunen noemt hij: (a) uit art. 117 lid $1 \mathrm{GW}$ kan worden afgeleid dat er ook leden van de rechterlijke macht zijn die niet met rechtspraak zijn belast; (b) uit art. 29 RO valt op te maken dat rechters en leden OM dezelfde eed afleggen; (c) art. 5 RO geeft de minister weliswaar bevelsbevoegdheid, maar niet de mogelijkheid opdracht te geven een bepaald requisitoir te houden. Een opdracht een strafvervolging in te stellen zal de minister wel kunnen geven, maar het moet dan om een hijzonder geval gaan.

471 Jaarverslag Openbaar Ministerie 1988, Het Openbaar Ministerie in zijn bestuurlijke omgeving, pag. 21.

472 De bijdragen van de vergadering zijn gepubliceerd in Trema XIV, afl. 6, juni 1991.

473 C.R.L.R.M. Ficq, De officier van justitie, magistraat (of bestuursambtenaar?), Trema XIV, all. 6, juni 1991, pag. 158-166.

474 J. Remmclink, De officier van justitie, magistraat of bestuursambtenaar? Trema XIV, afl. 6, juni 1091, pag. 167-179. 
Remmelink geeft toe dat de historie van art. $5 \mathrm{RO}$ zijn stelling zwakker maakt; (d) wanneer het $\mathrm{OM}$ als bestuursorgaan wordt beschouwd, impliceert dit dat het parlement inspraak heeft. Dit acht hij ongewenst, omdat daardoor bijvoorbeeld de vervolgingsvraag in de sfeer van partijpolitiek terecht zou kunnen komen; (e) de stelling van Lubberdink is onhoudbaar, omdat een deel van het OM, namelijk de P-G bij de Hoge Raad, uitdrukkelijk wel tot de rechterlijke macht behoort; (f) door het parlement zelf is nooit beweerd dat het OM een departementale buitendienst zou zijn.

Remmelink acht de onafhankelijkheid van het $\mathrm{OM}$ het grootst bij het functioneren van de officier ter terechtzitting en zittingen die daarmee direct verband houden, zoals die waarbij bewaring en voorlopig hechtenis aan de orde zijn. In deze fase zijn de mogelijkheden om aanwijzingen te geven voor de minister naar zijn oordeel buitengewoon klein. Deze mogelijkheid wordt groter ten aanzien van de vervolgingsbeslissing. De beslissing tot het aanbieden van een transactie of de hoogte daarvan is daaraan echter onttrokken en kan uitsluitend intern (via de P-G bij het Hof) beïnvloed worden. Het feit dat de officier van justitie meer bestuurlijk is gaan functioneren, betekent nog niet dat hij geen magistraat meer is.

In zijn bijdrage aan de vergadering plaatst Schalken de vraag: 'officier van justitie: magistraat of bestuursambtenaar?' in het kader van art. $5 \mathrm{RO} .{ }^{475}$ De tegenstelling magistraat-bestuursambtenaar (zoals de titel van de vergadering suggereert) is een schijntegenstelling. De officier van justitie is, afhankelijk van de context van zijn optreden, zowel magistraat als bestuursambtenaar. Het gaat volgens hem niet om de tegenstelling tussen bestuurlijke en magistratelijke taken die elkaar immers steeds vaker overlappen, maar om de vraag in welke mate van onafhankelijkheid het $O M$ ten opzichte van het lokale en centrale bestuur zijn magistratelijke functie inhoud kan geven. ${ }^{476} \mathrm{Bij}$ de beoordeling van individuele zaken heeft het $\mathrm{OM}$ naar de mening van Schalken een zelfstandige verantwoordelijkheid, ook al heeft de minister op grond van art. $5 \mathrm{RO}$ de bevoegdheid zich daarmee te bemoeien. Juist in de beoordeling van individuele zaken ligt de meerwaarde van het OM. Deze taak volgt uit wettelijke attributie, op basis waarvan het vervolgingsmonopolic is geformuleerd. De bevoegdheden van het $\mathrm{OM}$ worden in eerste instantie uitgeoefend ten behoeve van de rechtspraak. Daarom dient het OM over een zekere mate van onafhankelijkheid te beschikken, om te voorkomen dat politieke argumenten gaan overheersen. Schalken redeneert:

"als het openbaar ministerie niet een marge van onafhankelijkheid zou bezitten, zou art. 5 RO geen bestaansrecht hebben. Juist omdat het openbaar ministerie geen ambtelijke

475 T.M. Schalken, Het taboe van art. 5 RO, Trema XIV, afl. 6, juni 1991, pag. 179-193.

476 T.M. Schalken, a.w., pag. 180. 
buitendienst van de minister is, heeft de wetgever hem een duidelijke aanwijzingsbevoegdheid gegeven". $4 \pi$

Deze aanwijzingsbevoegdheid mag naar het oordeel van Schalken niet naar willekeurig politiek inzicht worden ingevuld. Als de minister het OM wil betrekken bij de algemene criminaliteitsbestrijding, dient het $\mathrm{OM}$ dat te respecteren, maar slechts zover daaruit voor het $\mathrm{OM}$ consequenties voortvloeien met betrekking tot de strafrechtstoepassing. Schalken heeft er geen bezwaar tegen dat het OM meer opschuift in de richting van het bestuur, mits het OM zijn magistratelijke taken kan blijven uitvoeren. Dit geldt volgens hem met name in die gevallen die zelfstandig door het OM worden afgedaan. Het gaat er om in hoeverre het OM bij zijn bestuurlijk werk inhoud kan geven aan zijn magistratelijke taak. Verderop legt hij dit uit: het OM moet geen automatisch verlengstuk worden van de lokale of centrale overheid. Het moet blijven beschikken over de mogelijkheid om zelfstandig vervolging in te stellen (evt. tegen de overheid). Van deze marge van onafhankelijkheid blijft minder over, naar mate de centrale sturing groter wordt. ${ }^{48}$

De vraag waar het volgens Schalken om gaat is: in welke mate behoort de minister zich de op hem uitgeoefende politieke druk aan te trekken en hoe vertaalt hij die in zijn verhouding tot het $\mathrm{OM}$ ? $^{\mathrm{N}}$ Schalken ziet de volgende mogelijkheden: (a) anticipatie van het $O M$ op de ministeriële verantwoordelijkheid (bijvoorbeeld in euthanasie-zaken; (b) vervolgingsbeleid van het $\mathrm{OM}$ is, daar het $\mathrm{OM}$ over een monopolie beschikt, aan democratische controle onderworpen. Met betrekking tot het algemeen beleid zal het OM zich moeten onderwerpen. In individuele gevallen moet de minister volgens Schalken wel erg goede redenen hebben om in te grijpen, maar ook dan zal het OM zich uiteindelijk bij het oordeel van de minister hebben neer te leggen.

Hoe geeft het $O M$ inhoud aan zijn magistratelijke functie? En in hoeverre is de officier magistraat? In ieder geval is hij geen rechter, ook niet in de zin van het EVRM ${ }^{+\infty}$ Het OM draagt er mede zelf toe bij dat de officier van justitie niet meer vanzelfsprekend als een magistraat wordt gezien, die bij zijn beslissingen oog heeft voor de rechten van de verdachte of diens verdediging, maar eerder als procespartij of tegenpartij.

De wisselwerking tussen departement en OM is gecompliceerd. Volgens Schalken wordt dit mede veroorzaakt door de wijze waarop het centrale forum tussen departement en OM, de vergadering van de procureurs-generaal, functioneert. Schalken schrijft:

477 T.M. Schalken, a.w., pag. 182.

478 T.M. Schalken, a.w., pag. 183.

479 T.M. Schalken, a.w., pag. 183-184.

480 pag. 185. 
"De PG-vergadering als vaste ontmoetingsplaats blinkt nou ook niet bepaald uit door helderheid in structuur, strafvorderlijke competentie, staatsrechtelijke positie en duidelijkheid in de omgangscultuur". ${ }^{281}$

Onduidelijk is in hoeverre de procureurs-generaal voor de belangen van hun eigen OM opkomen. Schalken verwijt de procureurs-generaal dat zij zich laten onderdompelen in een ambtelijke massagecultuur, waarin onduidelijkheid en aardigheid de boventoon voeren en waar geen plaats is voor kritiek. Verschil van inzicht wordt in ambtelijke wolligheid opgelost. Binnen het OM wordt de P-G-vergadering gezien als een doorgeefluik van departementaal beleid, waarbij onvoldoende rekening wordt gehouden met wat er in de eerste lijn bij het OM gebeurt. Er is een te grote afstand tussen beleid en uitvoering. ${ }^{42}$ Volgens Schalken moet de P-G-vergadering weer een echte en zelfstandige vertegenwoordiging van het $O M$ worden met eigen verantwoordelijkheden. Alleen op deze manier behoudt het $\mathrm{OM}$ zijn marge van onafhankelijkheid. Een andere oorzaak van de onduidelijke verhouding tussen departement en OM is gelegen in de hantering van art. $5 \mathrm{RO}$. Momenteel wordt art. $5 \mathrm{RO}$ in de opinie van Schalken foutief toegepast: het wordt gehanteerd als een preventieve in plaats van een repressieve bevoegdheid. Zodoende hoeft het niet uitdrukkelijk te worden toegepast, maar functioneert het wel als een subtiele, onzichtbare vorm van beïnvloeding (in feite op het niveau van telefoontjes). Schalken pleit ervoor art. 5 RO volgens het staatsrecht toe te passen: toepassen in die sprekende gevallen waarin de politieke verantwoordelijkheid van de minister predominant is. ${ }^{483}$ Hierdoor zou de bemoeienis van de minister met het OM weer onder parlementaire controle komen.

Volgens Schalken is het verstandiger dat de minister van Justitie het OM op een zekere afstand houdt, waardoor het OM zich meer op de kwaliteit van de strafrechtspleging kan concentreren.

Hirsch Ballin tenslotte plaatst de vraag "magistraat of bestuursambtenaar?" in het kader van de staatsrechtelijke positie van het $O M{ }^{\text {tw }}$ Deze vraag veronderstelt een tegenstelling, die volgens Hirsch Ballin niet bestaat. Het gaat om complementaire zaken. In de discussie omtrent de positie van het OM wordt de omstandigheid dat het $\mathrm{OM}$ als een departementale buitendienst zou kunnen worden beschouwd blijkbaar als een beklagenswaardige positie gezien. Daarmee zou de magistratelijke taak, en daarmee zelfs de onafhankelijke positie van de officier van justitie worden uitgehold. Hirsch Ballin ziet dit anders. Bovendien mogen emotionele elementen niet de overhand krijgen.

481 T.M. Schalken, a.w., pag. 186.

482 T.M. Schalken, a.w., pag. 186.

483 T.M. Schalken, a.w., pag. 190.

484 E.M.H. Hirsch Ballin, De officier van justitie, magistraat of bestuursambtenaar? Trema XIV, afl. 6, juni 1991, pag. 195-200. 
Teruggrijpend op Belinfante gaat Hirsch Ballin uit van het volgende: in een democratisch bestel heeft ieder orgaan voor de uitoefening van de bevoegdheden ofwel de medewerking van een ander orgaan nodig, ofwel is aan de controle ervan onderworpen. Hieruit is af te leiden: (a) geen bevoegdheid zonder grondslag in wet of Grondwet; (b) niemand kan een bevoegdheid uitoefenen zonder verantwoording schuldig te zijn of zonder dat op die uitoefening controle bestaat.

De bevoegdheden van de leden van het OM zijn opgenomen in de wet, voornamelijk in het WvSv en de Politiewet. Deze bevoegdheden worden toegekend aan bepaalde organen, niet aan het $\mathrm{OM}$ als collectief. In de controle- en verantwoordingsstructuur ten aanzien van de uitoefening van deze bevoegdheden is de rechter maar ten dele betrokken, namelijk slechts in concrete zaken die aan hem worden voorgelegd. Bij de hantering van een strikt legaliteitsbeginsel zou dit systeem sluitend zijn. Vanwege het opportuniteitsbeginsel, waardoor niet alle feiten voor de rechter worden gebracht, moet controle op een andere manier worden verwezenlijkt. Ook de controle door middel van art. $12 \mathrm{~Sv}$ is niet sluitend. Verantwoording en controle, fundamentele beginselen van onze rechtsstaat, moeten op een andere manier worden verwezenlijkt, aldus Hirsch Ballin. ${ }^{\text {Ns }}$ Ten aanzien van het bestuurlijk aspect van de taken van het $\mathrm{OM}$ merkt Hirsch Ballin op dat het OM een schakelfunctie inneemt wat betreft de afstemming van het vervolgingsbeleid op activiteiten van het bestuur en de politie. De maatschappelijke effectiviteit van de rechtshandhaving is in toenemende mate afhankelijk van de mate waarin het OM zijn coördinerende taak goed weet uit te voeren. Deze taak krijgt mede gestalte door overleg met andere bestuursorganen. Deze bestuurlijke tilak van het $\mathrm{OM}$ groeit in omvang. Hierbij zijn het ministerie van justitic en het $O M$ op elkiar aangewezen. Zijn staan beide voor hetzelfde belang: een effectieve rechtshandhuving. Ter uitvoering van deze taak zal het OM echter meer als eenheid moeten optreden en zal de traditionele rol- en persoonsgerichte cultuur dienen te worden doorbroken, teneinde de beschikbare verwerkingscapaciteit van het handhavingsapparaat optimaal te kunnen benutten. Dit stelt eisen aan de organisatie van de parketten.

De algemene verantwoordelijkheid voor het rechtshandhavingsbeleid ligt bij de minister van Justitie, die zich ook voor het generieke strafvervolgingsbeleid dient te verantwoorden. In verband met het toenemende belang van de bestuurlijke taak van het $O M$ zal de verantwoordingsrelatie van het $O M$ ten opzichte van de minister van Justitie op dit terrein intensiever worden. Dit blijkt volgens Hirsch Ballin ook uit de tuenemende politieke belangstelling voor het rechtshandhavingsbeleid. ${ }^{136}$ De relevante verantwoordingsstructuur loopt volgens hem langs de hiërarchische lijn, die krachtens art. 5 RO uiteindelijk uitkomt bij de minister van Justitie, die ter zake van het gevoerde beleid politieke verantwoording schuldig is aan het parlement. De bevoegdheden die door de wet aan de ambtsdragers zijn verleend kunnen

485 E.M.H. Hirsch Ballin, a.w., pag. 196-197.

486 E.M.H. Hirsch Ballin, a.w., pag. 199. 
niet worden uitgeoefend zonder dat verantwoording schuldig is of zonder dat op die uitoefening controle bestaat. Deze controle is slechts voor een beperkt gedeelte van de taken opgedragen aan de rechter. Voor het overige is door de wet in een aparte hiërarchische structuur voorzien. Los daarvan bepaalt de individuele officier van justitie welke houding hij inneemt ten opzichte van de rechter. ${ }^{\text {th }}$

Hirsch Ballin concludeert: het is staatsrechtelijk gezien onzinnig om met betrekking tot het $O M$ en de organen daarvan in welk opzicht dan ook te spreken over het OM dat zijn onafhankelijkheid dreigt te verliezen, het is evenzeer onzinnig om het OM gelijk te stellen met ambtenaren die uitsluitend krachtens mandaat van hun minister beslissingen nemen. De leden van het OM zijn ambtsdragers met eigen publiekrechtelijke bevoegdheden, die conform de wet en het ongeschreven recht, waaronder de regels van het recht en de beginselen van behoorlijk bestuur moeten worden uitgeoefend en waarvoor uiteraard als eis van de rechtsstaat gold, geldt en zal blijven gelden: niemand kan een bevoegdheid uitoefenen zonder verantwoording schuldig te zijn of zonder dat op die uitoefening controle bestaat.

Hierna verschijnen er nog meer publicaties over dit onderwerp en blijft de discussie actueel. ${ }^{4 \% 9}$

Van belang acht ik hier expliciet in te gaan op de zg. Paasbrief van de procurersgeneraal, verstuurd aan de minister van Justitie, als reactie op een in de Tweede Kamer gevoerd debat over de toedeling van verantwoordelijkheden aan de minister enerzijds en het $\mathrm{OM}$ anderzijds met het oog op de parlementaire controle op het beleid van de minister. ${ }^{9 \%}$ In de MvT bij de Justitiebegroting 1992 had de minister van Justitie geschreven dat de minister in individuele zaken aanwijzingen kan geven aan een lid van het $\mathrm{OM}$ en dat een officier van justitie ook omtrent een requisitoir de minister vooraf moest raadplegen indien het een strafzaak betreft die van betekenis is voor het algemene beleid. In hun brief rekenen de procurerus-generaal af met het onderscheid tussen algemeen beleid en individuele beoordeling van strafzaken als criterium voor toedeling van verantwoordelijkheden aan respectievelijk minister en OM. Deze tegenstelling is verouderd, omdat het OM zich ook met beleid bezighoudt. Om dezelfde reden bevat de vraag of de officier van justitie een magistraat dan wel een bestuursfunctionaris is, een oneigenlijke tegenstelling. In mijn ogen behoort het juridisch beleid, in tegenstelling tot het politiek beleid, tot het terrein

$4 \$ 7$ E.M.H. Hirsch Ballin, a.w., pag. 199-21 10 .

488 E.M.H. Hirsch Ballin, a.w., pag. 200.

489 Zie onder andere de bijdragen in de bundel Magistraat met beleid: de officier van justitie en zijn omgeving, red. T.M. Schalken e.a., Arnhem 1992, van S.A.M. Stolwijk, De minister van Justitie, het Openbaar Ministeric en artikel 5 RO, pag. 33-40; J.R.H. Kuyper, Rechtshandhaving en het Openbaar Ministerie, pag. 53-63; B.J. Asscher, De officier van justitie door het oog van ecn rechter, of: de derivatieve uitvoering van originaire bevocgdheden, pag. 145-153.

490 Deze brief is niet gepubliceerd (voor zover ik weel), maar wordt besproken door T.M. Schalken, Een nieuwe cultuur binnen het openbaar ministerie? NJB 25 juni 1992, afl. 26, pag. 813-818. 
van het $\mathrm{OM}$. Hieronder wordt verstaan de praktische uitwerking van het politieke beleid in de rechterlijke context waaraan het $\mathrm{OM}$ in de uitoefening van zijn bevoegdheden is gebonden. De procureurs-generaal signaleren dat een groot aantal zaken niet-rechterlijk wordt afgedaan, bijvoorbeeld door transactie en sepot. Hiervoor geldt de eis dat deze zaken voor de rechter acceptabel moeten blijven, met andere woorden: de beslissing tot niet vervolgen mag niet zijn gebaseerd op argumenten die ten opzichte van de rechter niet te verdedigen zijn (wie controleert dat? gvdb). Het $\mathrm{OM}$ neemt, ter uitvoering van het onder de verantwoordelijkheid van de minister tot stand gekomen beleid, in concrete gevallen zelf beslissingen. De brief komt op voor de magistratelijke functie van de officier van justitie: het aan de rechter voorleggen van zaken die aan elementaire normen van deugdelijkheid moeten voldoen, hetgeen met zich meebrengt dat men de integriteit van de strafrechtspleging dient te bewaken, of, zoals Schalken het uitdrukt: men vraagt aandacht voor de behoorlijkheid van de rechtspleging als kern van de publiekrechtelijke ethiek die de verhouding tussen overheid en burger beheerst..$^{401}$ Dit moet ertoe leiden dat de rol van de officier van justitie niet wordt teruggebracht tot die van technisch uitvoerder van beleid, maar dat er ruimte blijft voor een zelfstandige magistratelijke afweging in het concrete geval.

$\mathrm{Na}$ overleg met de procureurs-generaal schijnt de minister enigzins op zijn standpunt te zijn terug gekomen, in die zin dat de minister alleen bij zeer zwaar wegende redenen de officier van justitie opdrachten zal geven en zich in principe alleen achteraf met individuele zaken zal bemoeien. Zoals de kop boven een NRC-artikel het uitdrukt: Debat over relatie OM en minister nog niet beëindigd. ${ }^{\$ 92}$

Samengevat: het $O M$ is van mening dat officieren van justitie, als magistraten, een hoge mate van vrijheid moeten hebben bij het bepalen van hun beleid. Ze vallen formeel weliswaar onder het ministerie van justitie, maar mogen niet als departementale buitendienst worden beschouwd.

\subsection{Jurisprudentie Europese instanties}

\subsubsection{Beslissingen van Hof en Commissie}

\section{Art. 5 lid 3 EVRM schrijft voor dat}

"everyone arrested or detained in accordance with the provisions of paragraph 1c of this Article shall be brought promptly before a judge or other officer authorised by law to exercise judicial power and shall be entitled to trial within a reasonable time or to release pending trial. Release may be conditioned by guarantees to appear for trial. ${ }^{\text {wio3 }}$

491 pag. 818.

492 NRC Handelsblad d.d. 28 november 1992 , pag. 6.

493 Het corresponderende artikel uit het IVBP-verdrag is art. 9 lid 3. 
Dit artikel stelt dus onder andere tot eis dat iedere aangehoudene of gedetineerde verdachte onmiddellijk moet worden geleid voor een rechter of voor een andere autoriteit die door de wet bevoegd verklaard is om rechterlijke macht uit te oefenen. De vraag is of de officier van justitie, de bevoegde autoriteit inzake de verlenging van de inverzekeringstelling (art. 58 lid $2 \mathrm{~Sv}$ ), voldoet aan de vereisten die aan deze autoriteit worden gesteld. Alvorens deze vraag te beantwoorden, volgt eerst een behandeling van Europese jurisprudentie met betrekking tot dit onderwerp.

In het arrest Schiesser vs Zwitserland ${ }^{\text {st }}$ geeft het Europese Hof voor de Rechten van de Mens een beslissing over de vraag of de Zwitserse Bezirksanwalt (een instantie die zowel met de instructie als met de vervolging is belast, in hiërarchie onder de Staatsanwalt staat en wordt gekozen door het volk) in casu beschouwd moest worden als een in art. 5 lid 3 omschreven autoriteit. Wil hiervan sprake zijn dan moet voldaan zijn aan drie vereisten:

1. De waarborg van onafhankelijkheid: de autoriteit moet onafhankelijk zijn van de uitvoerende macht en van partijen. Dit betekent niet dat de autoriteit niet ondergeschikt zou mogen zijn aan andere rechters of autoriteiten, mits deze in gelijke mate onafhankelijk zijn;

2. De processuele waarborg: de autoriteit moet de verdachte zelf horen;

3. De materiële waarborg: de autoriteit is verplicht zowel de feiten die vóor als de feiten die tegen hechtenis pleiten te onderzoeken, zodat hij de rechtmatigheid van de detentie kan beoordelen en op grond daarvan de verdachte in vrijheid kan stellen.

Vervolgens concludeerde het Hof dat aan deze vereisten was voldaan. De Bezirksanwalt was slechts opgetreden als onderzoeksinstantie en niet als vervolgende instantie, daar hij niet de dagvaarding had opgesteld en niet was opgetreden namens het $\mathrm{OM}$ tegenover een rechter. Hij had geen aanwijzingen of advies ontvangen van de justitiële autoriteiten. Klager was, nadat hij zichzelf had aangegeven, persoonlijk door de Bezirksanwalt verhoord, waarbij deze hem had verteld waarvan hij verdacht werd en hem had gewezen op de mogelijkheid van beroep tegen het bevel tot hechtenis. Het bevel was gebaseerd op twee gronden die het Zürichse WvSv noemt.

In de zaak Skoogström vs Zweden ${ }^{\text {sos }}$ paste de Europese Commissie de door het Hof in de Schiesser-case ontwikkelde criteria toe op de positie van de openbare aanklager in Zweden. Toetsing aan de criteria 1 en 2 leidde tot de conclusie dat de Zweedse officier van justitie niet voldeed aan de voorwaarden die aan "een autoriteit die door de wet bevoegd verklaard is om rechterlijke macht uit te oefenen" gesteld

4944 december 1979, Publ. ECHR Series A, vol. 34; NJ 1980, 547 m.nt. Alkema.

495 ECRM 15 juli 1983, nr. 8582/79; EHRM 2 oktober 1984, Publ. ECHR Series A, vol. 83. 
worden. Hoewel de Commissie erkent dat de aanklager deel uitmaakt van de executieve, betekent dit nog niet dat hij niet onafhankelijk zou zijn. De Zweedse openbare aanklager heeft een persoonlijke onafhankelijkheid hetgeen inhoudt dat hij nooit bij de beslissing in een bepaalde zaak instructies van het ministerie van justitie kan ontvangen. Niet voldaan werd aan de voorwaarde dat de officier onafhankelijk moet zijn van de partijen. Hij is éen der partijen. $\mathrm{Zijn}$ taak kan onder andere zijn het leiden van het opsporingsonderzoek, het nemen van de vervolgingsbeslissing, het opstellen van de tenlastelegging en het ter zitting optreden als vervolgende instantie. In het algemeen worden deze taken door een en dezelfde officier uitgevoerd, zodat er geen sprake is van een scheiding tussen onderzoeks- en vervolgingsinstantie. Daarbij komt dat organisatie van de vervolgingsfunctie hiërarchisch georganiseerd is, waardoor een hogere in de hiërarchie algemene aanwijzingen mag geven aan een lagere. Tevens werd niet voldaan aan de tweede door het Hof in de Schiesser-zaak gestelde voorwaarde. De aanklager had de verdachte niet zelf gehoord, maar dit overgelaten aan een politie-ambtenaar, die de aanklager de resultaten van het verhoor telefonisch doorgegeven had. Art. 5 lid 3 vereist dat het verhoor door de aanklager persoonlijk plaatsvindt, delegatie van deze hoorplicht is derhalve niet toegestaan. Gezien deze bevindingen vindt de Commissie het niet meer noodzakelijk de materiële waarborg uitdrukkelijk te beoordelen.

In de zaak De Jong, Baljet en Van den Brink/ Van der Sluis, Zuiderveld en Klappe/ Duinhof en Duijf ${ }^{\text {twit }}$ werd onder andere de vraag aan de orde gesteld of de Nederlandse auditeur-generaal beschouwd kan worden als een autoriteit, bedoeld in art. 5 lid 3 EVRM. Wederom wordt door het Hof getoetst aan de in de zaak Schiesser gestelde voorwaarden. Het Hof deed dit met betrekking tot de auditeur-generaal vóor de verwijzing, de auditeur-generaal na de verwijzing en de officier-commissaris. De eerste bezat volgens het Hof geen bevoegdheid de verdachte in vrijheid te stellen (hij kon slechts de verwijzingsofficier daartoe adviseren) en was daarnaast niet onafhankelijk van partijen, omdat hij in een latere fase procespartij kon worden. Dit laatste gold ook voor de auditeur-generaal na verwijzing, reden om hem, ondanks het feit dat hij nu wel de bevoegdheid tot invrijheidstelling had, niet als genoemde autoriteit te beschouwen. De officier-commissaris voldeed volgens het Hof ook niet aan de gestelde voorwaarden, omdat hij niet de bevoegdheid bezat over de rechtmatigheid van de detentie te oordelen en de verdachte in vrijheid te stellen.

In de Brogan-case ${ }^{407}$ stond de vraag centraal wat verstaan moest worden onder 'onmiddellijke voorgeleiding van een verdachte aan een autoriteit die door de wet bevoegd verklaard is om rechterlijke macht uit te oefenen', art. 5 lid 3 EVRM. Het

496 EHRM 22 mei 1984, Publ. ECHR Scries A, vol. 77, 78 en 79, NJ 1986, 507 m.nt. EAA. 497 EHRM 29 november 1988, Publ. ECHR Serics A, vol. 145-B. 
Hof oordeelde, kort gezegd, dat een termijn van vier dagen en zes uren te lang was om als onmiddellijk in de zin van art. 5 lid 3 EVRM te kunnen beschouwen. Toevalligerwijs komt deze termijn overeen met onze maximale termiln voor inverzekeringstelling (inclusief de verlenging) en de daaraan voorafgaande fase voor het ophouden van verhoor. Hiervan kan dus gezegd te worden dat deze, met toepassing van de uitspraak van het $H$ of in de Brogan-case, te lang is. Bij beoordeling van de vraag of de regeling van de inverzekeringstelling in het Nederlandse WvSv daardoor in strijd is met art. 5 lid 3 EVRM, moet dus bekeken worden of de officier van justitie beschouwd kan worden als een 'other officer authorised by law'. Bij een positieve beantwoording hiervan wordt immers toch aan de eis van art. 5 EVRM voldaan, doordat de officier van justitie op grond van art. 58 lid $2 \mathrm{~Sv}$ de inverzekeringstelling verlengt.

3.2.2 Toepassing van de in de Europese jurisprudentie ontwikkelde criteria op de Nederlandse officier van justitie bij de inverzekeringstelling ${ }^{498}$

Toepassing van de in het arrest Schiesser ontwikkelde criteria op de Nederlandse officier van justitie moet naar mijn mening tot de slotsom leiden dat de officier van justitie bij de inverzekeringstelling niet als een "andere autoriteit die door de wet bevoegd is verklatard om rechterlijke macht uit te oefenen" kan worden aangemerkt. ${ }^{50}$ Met name het eerste en het tweede criterium leveren problemen op. Volgens het eerste moet een dergelijke autoriteit onafhankelijk zijn van de uitvoerende macht en van partijen. Deze onafhankelijkheid van de executieve lijkt mij niet aanwezig, daar officieren van justitie, op grond van art. 5 RO verplicht zijn bevelen vanwege de Koning, hetgeen inhoudt van de minister van Justitie, na te komen. Evenmin bestaat er een onafhankelijkheid van partijen, omdat dezelfde officier van justitie die de verdachte inverzekeringstelt, of de inverzekeringstelling verlengt, later met de vervolging belast kan zijn. Aan de tweede voorwaarde, de verdachte moet door de officier van justitie zelf worden gehoord, wordt in het Nederlandse systeem doorgaans niet voldaan. Het verhoor, voorafgaande de inverzekeringstelling, geschiedt in de regel door een hulp-officier van justitie. In de zaak Skoogström stelde de Europese Commissie dat deze hoorplicht niet gedelegeerd mocht worden. Ook bij de verlenging van de inverzekeringstelling stelt het WvSv niet uitdrukkelijk de eis dat

498 Zic daarover ook: Renske de Bruijn, De Officier van Justitie als rechterlijk ambtenaar? AA 1989, pag. 973-979.

499 Vgl. E. Myjer, rubriek Strafrecht en Mensenrechten, NJCM-bulletin 1989, pag. 194-195; A.E. Harteveld, Inverzekeringstelling en artikel 5 lid 3 EVRM, NJB 1989, pag. 109-111; Commissie Herijking Wetboek van Strafvordering (Commissic Moons), De inverzekeringstellingsprocedure in het licht van art. 5 EVRM, pag. 31; H.L. Wattel, Inverzekeringstelling en rechterlijke toetsing, DD 1989 , pag. 846; Anders: J.A.W. Lensing, Uitspraak Europees Hof in Britse zaak noopt tot bezinning op Nederlandse praktijk inverzekeringstelling, Trema, januari 1989, pag. 14. 
officier van justitie de verdachte moet horen alvorens een bevel tot verlenging te geven. Voorgeleiding vindt pas plaats indien de officier van justitie een vordering tot bewaring nodig acht (art. $60 \mathrm{~Sv}$ ). Dit zal in de regel tegen het einde van de termijn van inverzekeringstelling zijn.

De conclusie moet zijn dat de Nederlandse officier van justitie die beslist over de inverzekeringstelling, geen autoriteit is door de wet met rechterlijke macht belast, zoals art. 5 lid 3 EVRM voorschrijft, waardoor de termijn van vrijheidsbeneming voor verhoor en inverzekeringstelling na de uitspraak van het Europese Hof in de zaak Brogan te lang is om te voldoen aan de in dit artikel gestelde eis dat de verdachte onmiddellijk voor een rechter geleid moet worden. Wetswijziging is derhalve noodzakelijk. Een voorstel is daartoe ingediend. ${ }^{500}$ Door de vergadering van P-G's (22 maart 1989) is, in afwachting van de wet, een gedragslijn voor het $O M$ vastgesteld met betrekking tot de termijn van inverzekeringstelling. Deze mag niet langer dan 3 dagen en 15 uren duren (wordt bijgewerkt na vaststelling van de wet). De vordering tot bewaring moet op een dusdanig tijdstip worden ingediend dat de voorgeleiding voor de rechter-commissaris binnen 3 keer 24 uur na de aanvang van de inverzekeringstelling kan plaatsvinden.

\subsection{Commentaar}

\subsubsection{Algemene opmerkingen}

Alvorens in deze kwestie met een eigen standpunt te komen, wil ik enkele algemene kanttekeningen maken bij de hierboven weergegeven standpunten.

Te constateren is dat de opinies over de vraag of het OM onderdeel is van de rechterlijke macht of gezien moet worden als een bestuursorgaan, verdeeld zijn.

Tegelijkertijd kan ik me niet aan de indruk onttrekken dat er verschillende interpretaties aan het begrip 'rechterlijk' gegeven worden. Uit de toelichting van minister Van Maanen bij de Wet op de Zamenstelling der Regterlijke Magt en het Beleid der Justitie kan afgeleid worden dat hij de beslissingsbevoegdheid als hét kenmerk van de rechter ziet. Eenzelfde zienswijze zien we terug bij Mostert. Remmelink verwijst voor de inhoud van het begrip rechterlijk naar een aantal kenmerken: salariëring bij wet, eisen van bekwaamheid, beletselen van bloed- en aanverwantschap, titulatuur, kostuum, eedaflegging, plaats op het podium, de eed van de advocaat ten opzichte van het OM. De Commissie Mendlik ziet het rechterlijk aspect vooral in de onafhankelijkheid en zelfstandigheid ten opzichte van de bestuurlijke overheid. Volgens Van de Bunt komt het rechterlijk aspect tot uiting bij het individueel afdoen van zaken en de bescherming van de rechtspositie van de verdachte voorop. Hetzelfde zien we ook bij Remmelink. De Doelder ziet de rechterlijke attitude in de afweging die 
gemaakt moet worden tussen de in het geding zijnde instrumentele belangen en de rechtsbeschermende belangen. Dit rechtsbeschermende aspect maakt de talak van het OM tot een rechterlijke. In het Schiesser-arrest heeft het Europese Hof drie vereisten gesteld, waaraan voldaan moet zijn wil er sprake zijn van een rechterlijke instantie in de zin van art. 5 EVRM: (dubbele) onafhankelijkheid, een processuele en een materiële waarborg.

Deze interpretatieverschillen maken de discussie troebel. Een zinnige en interessante discussie is niet goed mogelijk zonder een overeenstemmend begrippenkader.

Verder wordt er niet altijd even duidelijk aangegeven welke taak van het OM men op het oog heeft en, daarmee samenhangende, de fase van het strafproces waarin de officier een bepaalde beslissing neemt. In art. $4 \mathrm{RO}$ is aan het OM opgedragen de handhaving der wetten, de vervolging van alle strafbare feiten en het doen uitvoeren van alle strafvonnissen. Op grond van art. $148 \mathrm{~Sv}$ kan hieraan toegevoegd worden de opsporing van strafbare feiten. Remmelink maakt in zijn eerst genoemde bijdrage in Verkeersrecht 1968 geen expliciet onderscheid naar taak en fase. Uit zijn bijdrage kunnen we impliciet afleiden dat hij zich voornamelijk richt op het optreden van de officier van justitie ter zitting, ${ }^{\text {sor }}$ waar hij recht vordert. Hier overheerst dan volgens hem het rechterlijk moment. In zijn voordracht voor de NVvR te Maastricht maakt hij dit onderscheid expliciet. De Commissie Mendlik geeft in haar rapport aan dat er een nuancering gemaakt moet worden naar de taken van het OM (In de conclusie van het rapport blijft dit naar mijn mening wat onderbelicht). Met betrekking tot opsporing en vervolging is het $O M$ volgens deze commissie uit de $\mathrm{NVvR}$ meer een orgaan van de overheid. De bespreking van de positie van het $O M$ in het proefschrift van Lubberdink betreft voornamelijk de vervolgingsbevoegdheid. Ook in de oratie van Corstens is dit het geval. Van de Bunt beperkt zich in zijn proefschrift uitdrukkelijk tot de vervolgingstaak van het OM. De oratie van De Doelder daarentegen brengt deze beperking niet aan. De in de Europese jurisprudentie naar aanleiding van art. 5 lid 3 EVRM opgeworpen vraag of de officier van justitie gezien kon worden als een 'andere rechterlijke autoriteit' betrof de fase van inverzekeringstelling.

Verder valt op te merken dat het functioneren van het $O M$ door bestuursrechtelijke respectievelijk strafrechtelijke auteurs anders wordt belicht. Eerstgenoemden (bijvoorbeeld Lubberdink, Stroink, Hirsch Ballin) bekijken het OM en het individueel handelen van de officieren van justitie meer vanuit een staatkundig standpunt. $\mathrm{Zij}$ bezien het $\mathrm{OM}$ in verhouding tot de staat en tot andere staatsorganen. Strafrechtelijke auteurs (bijvoorbeeld Remmelink, De Doelder) leggen de nadruk op het meer feitelijke en misschien ook het persoonlijke functioneren van de officieren van justitie.

S01 Remmelink noemt het optreden ter terechtzitting de hoofdtaak van het OM. J. Remmelink, a.w., pag. 172 . 
In de hierboven weergegeven literatuur en jurisprudentie zijn meerdere inhoudelijke kenmerken genoemd als een rechterlijk of een bestuurlijk aspect. In het nu volgende worden hierbij kanttekeningen gezet. Achtereenvolgens komen aan de orde:

- zelfstandigheid

- onafhankelijkheid;

- objectiviteit;

- heslissingsbevoegdheid, inhoud van de beslissing.

\subsubsection{Zelfstandigheid}

Door verschillende auteurs (De Doelder, Van de Bunt, Remmelink) wordt de zelfstandigheid die leden van het OM bezitten bij het nemen van hun beslissingen in individuele gevallen gezien als de grondslag voor de rechterlijke positie van de leden van het OM. Het begrip 'zelfstandigheid' (ter onderscheiding van 'onafhankelijkheid, volgende paragraaf) vat ik hier op als bevoegd om in een individueel geval een beslissing te nemen zonder dat daarvoor de goedkeuring of toestemming van een ander orgaan is vereist. Er is dan geen hiërarchie in die zin dat er een verantwoordingsplicht bestaat en onderwerping aan concrete aanwijzingen.

In feite heeft de officier van justitie bij het nemen van een groot aantal beslissingen een bepaalde vrije becordelingsruimte, een beleidsruimte, waarbinnen hij zijn beslissing kan nemen en waarbij hij alle relevante belangen tegen elkaar kan afwegen en een beslissing kan nemen zonder dat hij daarvoor de goedkeuring van een ander orgatan nodig heeft. Binnen de marges beslist hij inderdaad als een zelfstandig orgaan en men zou dit als een magistratelijk aspect kunnen zien. Hierbij passen enkele opmerkingen.

De beoordelingsruimte die de officier van justitie heeft is niet in alle gevallen gelijk. Hierbij kunnen we een onderscheid maken naar de soort beslissing (bijvoorbeeld de vervolgingsbeslissing of de beslissing tot het vorderen van bewaring), het soort strafbaar feit (bijvoorbeeld overtreding van art. $26 \mathrm{WVW}$, een milieudelict of doodslag) en de fase waarin het strafproces zich bevindt. In het ene geval heeft de officier een grote zelfstandigheid, in het andere geval krijgt hij de beslissing als het ware gedicteerd. Inzake de vervolgingsbeslissing inzake een strafbaar feit, waarvoor een vervolgingsrichtlijn bestaat, is deze zelfstandigheid, hoewel er van de richtlijn mag worden afgeweken, kleiner en is de beslissing cenvoudiger te toetsen, zeker indien de richtlijn gepubliceerd is. Denkbaar is ook dat de officier denkt een bepaalde beslissingsbevoegdheid te bezitten omdat hij die 'normaliter' heeft, maar dat in een concreet geval de minister van Justitie of een hoger geplaatste in de hiërarchie van het $O M$ het nodig vindt in te grijpen. De 'zelfstandigheid' van de officier van justitie bij het nemen van beslissingen is dus relatief. 
De minister van Justitie, hoewel geen deel uitmakend van het OM (hij wordt niet genoemd in art. $3 \mathrm{RO}$ ), is op grond van art. $5 \mathrm{RO}^{\mathrm{soz}}$ bevoegd bevelen aan het $\mathrm{OM}$ te geven. Vast staat derhalve dat het $O M$ hiërarchisch ressorteert onder de minister van Justitie. Hieraan doet niet af dat het OM geattribueerde bevoegdheden heeft. Voorbeelden van attributie van bevoegdheden zijn onder andere de artt. 167 en $242 \mathrm{~Sv}^{503}$ Door deze attributie van bevoegdheden worden de normale hiërarchische verhoudingen niet doorknuist. ${ }^{504}$ Art. 5 RO geeft de minister van Justitie de mogelijkheid invloed uit te oefenen op of aanwijzingen te geven met betrekking tot het opsporings- en vervolgingsbeleid van het $O M$. De minister is op zijn beurt verantwoording schuldig aan de volksvertegenwoordiging over de wijze waarop hij van deze bevoegdheid gebruik heeft gemaakt. Zou dit niet zo zijn, dan zou het $\mathrm{OM}$ als een 'staat in de staat' functioneren, zonder invloed of controle van een democratisch gekozen orgaan. Het feit dat de minister van zijn bevoegdheid tamelijk weinig gebruik maakt en het $\mathrm{OM}$ zo redelijk zelfstandig laat functioneren, doet aan de bestaande ondergeschiktheidsverhouding naar mijn mening niet af. Een andere vraag is hoever de bevelscq. aanwijzingsbevoegdheid van de minister gaat. ${ }^{50.5}$ In het algemeen kan worden gesteld dat door de attributie van bevoegdheden de centrale rol van de strafvordering bij het OM ligt en dat de minister (en in het verlengde daarvan het parlement) op enige afstand staat.

Dat er in het verleden door de minister niet vaak gebruik gemaakt is van de bevelsbevoegdheid, en dat dit ook nu niet vaak gebeurt, kan verschillende andere oorzaken hebben. ${ }^{506}$ In een tijd dat het opportuniteitsbeginsel niet of slechts in beperkte mate wordt gehanteerd en dus in principe ieder bewijsbaar strafbaar feit wordt vervolgd, is er bijvoorbeeld weinig reden vervolging te bevelen. ${ }^{587}$ Het algemene beleid van het $O M$ wordt door de vergadering van de P-G's onder voorzitterschap van de secretaris-generaal (of, zonodig, van de minister van Justitie) centraal vastgesteld en naar de basis geparachuteerd. We mogen er dus vanuit gaan dat dit beleid dan reeds de instemming, althans formeel, van de verantwoordelijke bewindsman heeft. Indien de individuele leden van het $\mathrm{OM}$ hun taak verrichten conform het vastgestelde beleid,

502 Art. 5 RO luidt: De ambtenaren bij het openbaar ministerie zijn verplicht de bevelen na te komen, welke hun in hun ambisbetrekking door dc daartoc bevoegde macht, vanwege de koning, zullen worden gegeven.

503 Artl. 167 resp. 242 Sv luiden: (1) Indien naar aanleiding van hel ingesielde opsporingsonderzoek, resp. voorbereidende onderzoek het openbaar ministeric van oordeel is dat vervolging resp. verdere vervolging moet plaat shebben, gaat het daartoe zo spoedig mogelijk over. (2) Van vervolging resp. verdere vervolging kan worden afgezien op gronden (ook) aan het algemeen belang ontleend.

504 Rapport ABAR 1984, vijfde druk, pag. 15-18.

S05 Zie over deze problematiek onder andere: Melai c.s., aant. 5-7 bij artt. 7-11 Sv; H. de Doelder, Het OM in positie, oratie EUR, Amhem 1988.

506 Vgl. H.Th.J.F. van Maarseveen, Ministeriële verantwoordelijkheid en Openbaar Ministerie na 1976, NJB 1977, pag. 209-215.

507 Vgl. A.C. '1 Hart, Instrumentalisme en strafrechtelijk beleid, in: Rechtsstaat en sturing, M.A.P. Bovens, W. Dirksen en W.J. Witteveen (red.), Zwolle 1987, pag. 39-45. 
in de meeste gevallen zal dit het geval zijn, is er voor de minister vanzelfsprekend weinig aanleiding om in te grijpen. Verder moet in aanmerking worden genomen dat de verantwoordelijke minister zich niet tot in detail met elk beleidsterrein kan bezighouden. Het zal onder meer van de politieke gevoeligheid van het onderwerp afhangen in welke mate de minister een actieve beleidsvormende rol toekomt. ${ }^{\text {so }}$ Ook de mate waarin de minister zich bemoeit met een individuele strafzaak, is afhankelijk van deze factoren. De minister moet echter wel de politieke verantwoordelijkheid kunnen dragen.

De minister kan door het parlement ter verantwoording worden geroepen met betrekking tot de wijze waarop hij van zijn bevoegdheid ex. art. 5 RO gebruik heeft gemaakt. Hierdoor heeft het parlement de mogelijkheid controle op het OM uit te oefenen. Dat dit zich niet zo veelvuldig voordoet kan wellicht voortvloeien uit het geringe politieke belang (of interesse?) dat met een bepaalde zaak gemoeid is. Verschillende keren is gebleken dat in politiek gevoelige zaken het parlement de vraag hoe de minister van Justitie van zijn bevoegdheid gebruik maikt we] interessant genoeg vindt, bijvoorbeeld in de zaken betreffende Menten, Bloemenhove, Lockheed en, meer recent, de affaires Hans Kok en Oude Pekela ${ }^{500}$ en, nog recenter, de IRTaffaire. Uit de twee eerstgenoemde zaken bleek trouwens dat de minister zich, zonodig, wel tot in detail met het OM-beleid inlaat.

Criminaliteitsbestrijding is niet slechts een taak voor het OM maar is onderdeel van het totale overheidsbeleid. De laatste decennia mag deze criminaliteitsbestrijding zich 'verheugen' op toegenomen politieke (en wetenschappelijke) belangstelling. Hêt voorbeeld hiervan zijn de verschillende beleidsplannen die zijn gepubliceerd. Hierin wordt het beleid van het OM een integrerend onderdeel van de criminaliteitsbestrijding naast andere vormen van overheidsbeleid. Omdat het parlement daarover de uiteindelijke zeggenschap heeft, is het OM-beleid niet slechts een zaak van het $\mathrm{OM}$ zelf, maar ook van de volksvertegenwoordiging.

Zelfstandigheid, zij het met de hierboven aangegeven beperkingen, bij het nemen van een concrete beslissing is niet alleen een kenmerk van het OM. Allerlei bestuursorganen hebben een beoordelingsruimte waarbinnen de beslissing genomen kan worden waarbij het orgaan een redelijke mate van zelfstandigheid heeft. ${ }^{510}$ Deze zelfstandigheid is relatief. Men moet onder meer rekening houden met het gevoerde beleid, met beslissingen die eerder werden genomen, met gewekte verwachtingen, met de belangen van degene ten opzichte van wie de beslissing genomen wordt en van derden en het belang van de overheid. Denk bijvoorbeeld maar aan de beslissing

$508 \mathrm{Vgl.} \mathrm{MvT} \mathrm{Justitiebegroting} 1975$.

509 Deze zaken zijn vervolgens aanleiding tol discussies over de vraag over de verhouding tussen minister en $O M$ in parlement en literatuur. Zie de openbare briefwisseling tussen Corstens en de minister van Justitic in het NJB, 1988 pag. 226 e.v. en pag. 324 en H. van Maarsscvecn NJB 1988 pag. 301.

$510 \mathrm{Het}$ administratieve recht spreekt in dit verband van vrije en gebonden beschikkingen. Vgl. H.D. van Wijk/W. Konijnenbelt, Hoofdstukken van administraticf rccht. Culemborg 1988, pag. 240-259. 
om een hinderwetvergunning te verlenen of om politiedwang toe te passen. Beschouwt men de zelfstandigheid van de officier van justitie als een magistratelijk aspect, dan moet dit tevens aan andere bestuursorganen toegedicht worden. Ik zou eerder geneigd zijn deze zelfstandigheid als een bestuurlijk aspect te beschouwen.

Conclusie: het OM ontbeert volledige functionele zelfstandigheid.

De stelling van Lubberdink dat het $\mathrm{OM}$ in wezen niets anders is dan een andere departementsafdeling, gaat mij echter te ver. In tegenstelling tot een dergelijke afdeling is het OM een bestuursorgaan dat zijn taken, zoals hierboven reeds vermeld, rechtstreeks door de wet (attributie) opgedragen krijgt. Het OM is eerder te vergelijken met andere 'buitendiensten' die hun taak door de wet opgedragen krijgen, ${ }^{\text {s11 }}$ zoals de belastingdienst (Algemene wet inzake rijksbelastingen) en de arbeidsinspectie (Arbeidswet en Veiligheidswet) en de universiteiten. Hoewel hiërarchisch ondergeschikt aan de minister van Justitie, Financiën respectievelijk Sociale Zaken en Werkgelegenheid, respectievelijk Onderwijs en Wetenschappen nemen de ambtenaren van deze diensten in de regel hun beslissingen met een grote mate van zelfstandigheid.

In het bestuursrecht wordt onderscheid gemaakt tussen gedecentraliseerde en gedeconcentreerde organen. ${ }^{512}$ Kenmerkend voor dit onderscheid is de vraag of er een ondergeschiktheidsverhouding bestaat tussen minister en ambtenaar. Is er geen hiërarchische verhouding dan spreken we van een gedecentraliseerde bevoegdheidsuitoefening. Voorbeeldenvan gedecentraliseerde organenzijn:gemeenten, provincies, Sociaal Economische Raad, Nederlandse orde van Advocaten en universiteiten. Bestaat er wel ondergeschiktheid, dan wordt gesproken van een gedeconcentreerd ambt. Stroink verstaat onder deconcentratie: de attributie/delegatie van publiekrechtelijke bevoegdheden aan ambten, vertegenwoordigd door departementsambtenaren. ${ }^{513}$ Ik ben het met Stroink eens dat het OM valt onder de omschrijving deconcentratie..$^{\text {sid }}$ De Wet RO kent in art. 4 bevoegdheden toe aan 'het ambt OM' (niet aan de officieren van justitie) en de leden van het $O M$ staan op grond van art. $5 \mathrm{RO}$ in een ondergeschiktheidsrelatie tot de minister (hoe die ook wordt uitgevuld).

Stroink wijst op het verschil tussen het $\mathrm{OM}$ en andere gedeconcentreerde ambten. ${ }^{51 s}$ Meestal bevat de bevoegdheidsuitoefening van gedeconcentreerde ambten een meer gebonden karakter, waardoor aan de concrete ministeriële aanwijzingsbevoegdheid in de praktijk weinig behoefte bestaat. Ook de bevoegdheidsuitoefening van het $\mathrm{OM}$ is gebonden, in die zin dat het WvSv voorschriften geeft omtrent opsporing en vervolging. Deze gebondenheid wordt echter kleiner wanneer het de te nemen

511 Vgl. F.A.M. Stroink, Deconcentratie, 's-Gravenhage 1978, pag. 158.

512 F.A.M. Stroink, Deconcentratie, 's-Gravenhage, 1978, pag. 21-22.

513 F.A.M. Stroink, a.w., Hoofdstuk 1.

514 Vgl. F.A.M. Stroink, a.w., pag. 157-159.

515 F.A.M. Stroink, a.w., pag. 159-161. 
vervolgingsbeslissing betreft. Op grond van het opportuniteitsbeginsel immers is het OM vrijer te bepalen of er wel of niet vervolgd zal worden. Omdat de toepassing van het opportuniteitsbeginsel belangrijke politieke beslissingen met zich kan meebrengen heeft de minister volgens Stroink niet alleen een algemene maar ook een concrete aanwijzingsbevoegdheid op grond van art. 5 RO. ${ }^{5 ! \cdot}$ Hierbij sluit ik mij aan.

\subsubsection{Onafhankelijkheid}

In het Schiesser-arrest wordt, wil er sprake zijn van een gerechtelijke autoriteit in de zin van art. 5 lid 3 EVRM, onder andere de eis gesteld van onafhankelijkheid: onafhankelijkheid van de uitvoerende macht en onafhankelijkheid van partijen. Deze onafhankelijkheid betekent niet dat de autoriteit niet ondergeschikt zou mogen zijn aan andere rechters of autoriteiten, maar dan moeten deze in gelijke mate onafhankelijk zijn. Evenals de eis van de objectiviteit (zie volgende paragraaf) is deze voorwaarde naar mijn mening te abstraheren van de inverzekeringstellingsfase, omdat ook in art. 6 lid 1 EVRM de eis wordt gesteld van een onafhankelijke en onpartijdige rechterlijke instantie.

Deze onafhankelijkheid houdt in, dat er geen binding is met het democratisch gekozen bestuur en daardoor met volksvertegenwoordiging of, daardoor, met politieke partijen. Het begrip 'onafhankelijkheid' heeft naar mijn idee betrekking op de rechtspositie, terwijl 'zelfstandigheid' moet worden gezien in het kader van het nemen van een concrete beslissing.

De Grondwet stelt niet nadrukkelijk dat de rechterlijke macht onafhankelijk is. Waarborgen voor deze onafhankelijkheid liggen echter wel in de constitutie verankerd: art. $117 \mathrm{GW}$ : de leden van de rechterlijke macht worden voor het leven benoemd (lid 1); op eigen verzoek en bij het bereiken van een bij de wet te bepalen leeftijd worden zij ontslagen (lid 2) en de wet regelt overigens hun rechtspositie (lid 4). Dit kenmerk van rechterlijke macht, de onafhankelijkheid ten opzichte van de regering en parlement, ontbeert mijns inziens het Nederlands OM. ${ }^{517}$ Leden van het OM zijn ambtenaar in de zin van de Ambtenarenwet 1929.

Vanuit het oogpunt van een democratische rechtsstaat bekeken denk ik dat het $\mathrm{OM}$ ook niet onafhankelijk behoort te zijn. Het $O M$ heeft het vervolgingsmonopolie. Wij kennen in Nederland geen private vervolging, maar slechts vervolging van overheidswege. Bij het plegen van een strafbaar feit wordt door de dader inbreuk gemaakt op bepaalde rechten van medeburgers. Onder meer om eigenrichting te voorkomen ocfent de overheid namens die burger het vervolgingsrecht uit. De burger heeft zijn vervolgingsrecht overgedragen aan cle overheid, die op haar beurt bij de uitoefening van dat recht aan regels is gebonden.

516 F.A.M. Stroink, a.w., pag. 161-162.

517 Vgl. MvA, EK 1980-1881, 16162, nr. 100b, pag. 4. 
Bij de uitoefening van haar werkzaamheden dient de overheid het belang van de burgers, het algemeen belang, zo optimaal mogelijk te dienen (het beginsel van de dienende overheid).$^{518}$ Namens de overheid wordt dit recht uitgeoefend door het OM, dat daardoor macht over de burgers heeft. Vereist is dat dit optreden van de overheid aan wettelijke regels is gebonden (het rechtszekerheidsbeginsel). De burger moet die overheid, i.c. het $\mathrm{OM}$ bij de uitoefening van die taak kunnen controleren (het democratiebeginsel), zodat machtsmisbruik wordt voorkomen. Met andere woorden: de overheid, het $O M$, is verantwoording schuldig over het namens en ten opzichte van de burgers uit te oefenen vervolgingsrecht. Het orgaan dat deze controle namens de burgers uitvoert is het parlement, dat de minister van Justitie ter verantwoording kan roepen. De minister kan echter geen verantwoordelijkheid voor het gedrag van het $\mathrm{OM}$ dragen indien hij geen bepaalde bevoegdheden ten opzichte van dat orgaan heeft. Het OM kan dus helemaal niet onafhankelijk zijn van de regering, omdat er dan ook geen verantwoording zou kunnen worden afgelegd, hetgeen in strijd zou komen met een der grondregels uit ons democratisch bestel: Geen bestuurder kan een bevoegdheid uitoefenen zonder verantwoording schuldig te zijn of zonder dat op die uitoefening controle bestaat. ${ }^{\text {siv }}$

\section{Conclusie: het OM ontbeert rechtspositionele onafhankelijkheid.}

De eis van onafhankelijk houdt volgens de Europese jurisprudentie, naast onafhankelijkheid van de uitvoerende macht, tevens in dat de gerechtelijke autoriteit onafhankelijk dient te zijn van een rechter of autoriteit die zelf afhankelijk is. In mijn terminologie (zelfstandigheid bij feitelijk functioneren en onafhankelijkheid in rechtspositie) heeft deze toch eerder betrekking op het aspect van de zelfstandigheid.

Is de Nederlandse rechter onafhankelijk van de uitvoerende en wetgevende macht, hij heeft daarnaast ook een zelfstandige positie ten opzichte van andere rechters. Hiermee bedoel ik niet dat er binnen de rechterlijke macht geen controle zou zijn. Op grond van art. 116 lid $4 \mathrm{GW}$ jo. art. 11 e.v RO wordt toezicht uitgeoefend door de Hoge Raad en de presidenten van de arrondissementsrechtbanken. ${ }^{520}$ Dit toezicht houdt echter niet in dat binnen de rechterlijke macht de ene rechter de andere een bevel kan geven een bepaalde beslissing te nemen in een strafzaak, bijvoorbeeld met betrekking tot de straftoemeting. Het $\mathrm{OM}$ daarentegen kenmerkt zich door een sterke interne hiërarchie. Vanuit de top van het orgaan kunnen bevelen naar onderen worden doorgegeven. Hoe deze hiërarchische lijn loopt wordt geregeld in de Wet

518 In zijn bijdrage 'De rechtsstaat' tracht Scheltema het begrip rechtsstaat te structureren. Hij onderscheid daartoe vier elementen: het rechtszckerheids-, het gelijkheids-, het democratiebeginsel cn het beginsel van de diendende overhcid. M. Scheltema, De rechtsstaat, in: De rechisstaat herdacht. J.W.M. Engels e.a. (red.), Zwolle 1989, pag. 11-25.

519 A.D. Belinfante, J.L. de Reede, Beginselen van Nederlands staatsrecht, Alphen aan den Rijn 1987, pag. 22-25.

520 Vgl. H.E. Ras, De onafhankelijkheid van de rechterlijke macht, NJB 1989, pag. 1272-1274. 
RO en in het zogenaamde Reglement I. Uit de artt. $52^{521}$ en $53^{522}$ kan worden afgeleid dat de procureur-generaal bij de Hoge Raad als leider van het OM wordt gezien. Deze rol wordt echter gespeeld door de procureurs-generaal bij de gerechtshoven, die op grond van art. 54 Regelement I, ieder in de gehele uitgestrektheid van zijn ressort, belast zijn met de uitoefening en het beleid der criminele justitie, en met een gelijke zorg als in art. 52 is bepaald, bij het gerechtshof en bij de daaronder resorterende arrondissementsrechtbanken en kantongerechten, terwijl art. 140 lid $1 \mathrm{~Sv}$ de procureur-generaal bij het gerechtshof (volgens art. $141 \mathrm{~Sv}$ zelf geen opsporingsambtenaar) belast met het toezicht op de 'richtige opsporing'. Daartoe kan hij bevelen geven aan de hoofdofficier van justitie (art. 140 lid $2 \mathrm{~Sv}$ ). De periodieke vergadering van de procureurs-generaal onder leiding van de secretaris-generaal (ter vervanging van de minister van Justitie die zonodig zelf de vergadering voorzit) vormt de top van de hiërarchie van het $O M$, van waaruit het beleid naar beneden wordt doorgegeven. Deze organisatiestructuur werkt door op alle taken van het $\mathrm{OM}$ en kan bijvoorbeeld inhouden het voorschrijven van een bepaald requisitoir. De hiërarchie draagt ertoe bij dat de regering haar taak met betrekking tot het bevorderen van een goede justitie over het gehele land op verantwoorde wijze kan vervullen. ${ }^{53}$ Dit betekent overigens niet dat leden van het OM niets anders doen dan bevelen van hogerhand uitvoeren, maar dat zij bereid moeten zijn het vastgestelde beleid, na overleg, zo goed mogelijk uit te voeren.

Tenslotte moet de vraag beantwoord worden of de Nederlandse officier van justitie onafhankelijk is van partijen in het strafgeding. In ons systeem van strafvordering is dit naar mijn overtuiging niet het geval. Integendeel, hij is steeds één van de partijen: hij leidt het opsporingsonderzoek (art. $148 \mathrm{~Sv}$ ), hij vordert de bewaring van de verdachte bij de rechter-commissaris (art. $63 \mathrm{~Sv}$ ), hij neemt de vervolgingsbeslissing (artt. 167 en $242 \mathrm{~Sv}$ ), hij maakt de zaak aanhangig ter terechtzitting door het uitbrengen van een dagvaarding aan de verdachte ( 258 lid $1 \mathrm{~Sv}$ ), hij bepaalt de omvang van het rechtsgeding door het opstellen van de tenlastelegging (art. $261 \mathrm{~Sv}$ ) en hij vordert een straf of maatregel tegen de verdachte (art. $311 \mathrm{~Sv}$ ). Vaak worden deze bevoegdheden in een bepaalde strafzaak door een en dezelfde officier van justitie uitgeoefend.

521 Art. 52: De procureur-generaal bij den Hoge Raad waakt in het bijzonder voor de handhaving en uitvoering der wetten en reglementen bij den Hoge Raad, bij al de Geregtshoven, Regtbanken en Kanton-gerechten in het Koninkrijk.

522 Art. 53: De procureurs-generaal bij de gerechtshoven en de hoofdofficieren van justitie zijn verplicht de bevelen na te komen, die hun, naar aanleiding van art. 5 der Wet op de rechterlijke organisatie, tot vitvoering van het vorig artikel door den procureur-generaal bij den Hoge Raad in hunnen ambtsbetrekking zullen gegeven worden.

$523 \mathrm{Vgl}$. G. Duisterwinkel, Enige facetten van de taak van het openhaar ministerie naar Nederlands recht, Deventer 1965 , pag. 5-6. 
De conclusie moet zijn dat de Nederlandse officier van justitie niet voldoet aan de vereisten die door het Europese Hof zijn gesteld aan een 'rechterlijke autoriteit'.

\subsubsection{Objectiviteit}

Formeel behoort het OM het algemeen belang te behartigen. Uit het onderzoek van Van de Bunt blijkt dat veel officieren van justitie zelf als opvatting over hun taak hebben dat zij een afweging tussen de verschillende relevante belangen maken, waaronder het belang van de verdachte. ${ }^{524}$ Door een aantal schrijvers (Remmelink, Van de Bunt en De Doelder) wordt de objectiviteit die de officier van justitie betracht bij het nemen van zijn beslissingen als een magistratelijk aspect beschouwd. Ook het Europese Hof blijkt deze mening toegedaan, zoals blijkt uit het in het Schiesserarrest gestelde criterium van de materiële waarborg: de verplichting zowel de feiten die voor als die tegen hechtenis pleiten te onderzoeken. We kunnen dit vereiste abstraheren van de fase van de inverzekeringstelling en laten gelden voor de hele procesgang, omdat dit vereiste terug te vinden is in art. 6 EVRM, dat berechting door een onpartijdige rechterlijke instantie garandeert. Het vereiste van objectiviteit houdt in dat een rechterlijke autoriteit zowel de feiten die voor als die tegen de verdachte pleiten moet onderzoeken.

Aangenomen wordt dat de officier van justitie, naast aandacht voor het algemeen belang oog moet hebben voor de rechtspositie en het belang van de verdachte. Hier worden dus het algemeen belang en het belang van de verdachte tegenover elkaar gezet. Ten onrechte, naar mijn mening. ${ }^{525}$

Wanneer bescherming van de rechtspositie van de verdachte inhoudt dat bepaalde voorschriften nageleefd moeten worden, bijvoorbeeld bij de toepassing van een dwangmiddel of bij het vergaren van bewijs, kan hiervan niet gezegd worden dat dit slechts strekt ter bescherming van de verdachte. Een correcte naleving van regels is ook in het algemeen belang, namelijk in het belang van een goede en rechtvaardige strafrechtspleging. In deze optiek is bescherming van de rechtspositie niet een tegengesteld belang van het algemeen belang, maar maakt het van het laatste onderdeel uit. Indien de officier van justitie de rechtspositie van de verdachte laat meewegen dient hij hiermee het algemeen belang en dat van de verdachte.

Door de belangen van de verdachte te laten meewegen doet het $O M$ overigens nalar mijn mening niets anders dan andere bestuursorganen behoren te doen: het dienen van het algemeen belang met een zo optimaal mogelijke bescherming van individuele belangen. In administratiefrechterlijk jargon: een redelijke belangenafweging. ${ }^{\text {sa }}$ Het belang van de burger mag bij het nemen van een beslissing van een bestuursorgaan niet onnodig in het gedrang komen (verbod van willekeur). De genoemde

524 Van de Bunt, a.w., pag. 123-124.

525 Vgl. A.Q.C. Tak, Overheidsbestuur en Privaalrecht, 1978, hoofdstuk 3.

526 Zie bijvoorbeeld: H.D. van Wijk/W. Konijnenbelt, Hoofdstukken van administratief recht, Culemborg 1988, pag. 125-130. 
objectiviteit is dus geen typisch kenmerk van een rechterlijk orgaan, maar behoort ook drijfveer te zijn bij besluiten van overheidsorganen. In het bestuursrecht is het uiteindelijk de rechter die toetst of er een redelijke belangenafweging heeft plaatsgevonden.

Overigens heeft Van de Bunt er op gewezen dat onder invloed van de toegenomen werkdruk deze afweging van belangen in veel gevallen tot het hoognodige wordt beperkt. De aandacht wordt beperkt tot enkele kerngegevens uit het dossier (aard en omvang delict, strafblad, sekse en leeftijd verdachte). ${ }^{52}$ Op deze plaats moet ook vermeld worden dat met name bij de buitengerechtelijke afdoening van strafbare feiten deze belangenafweging zich binnenskamers afspeelt, zodat deze niet gecontroleerd kan worden. ${ }^{528}$

Conclusie: het in het oog houden van het belang van betrokkene, als onderdeel van het algemeen belang, is niet een typisch kenmerk van het OM maar van ieder bestuurorgaan.

\subsubsection{Inhoud van de beslissing}

Een rechterlijk aspect in het functioneren van de officier van justitie wordt door een aantal auteurs gelegd bij de inhoud van een aantal van zijn beslissingen. Hierbij wordt gedoeld op de besluiten die qua inhoud eigenlijk besluiten zijn die de rechter zou moeten nemen of eerder ook nam. Als voorbeelden worden genoemd de vervolgingsbeslissing en het aanbieden van een transactie.

Tegen beide voorbeelden heb ik bezwaren. Door het instituut van de rechtsingang af te schaffen en de vervolgingsbeslissing geheel in handen van het $O M$ te leggen wordt juist bevestigd dat het $\mathrm{OM}$ en de rechter ieder een eigen functie hebben in het strafproces. De officier neemt de beslissing tot vervolgen, de rechter be- en veroordeelt (of juist niet). Van de transactie wordt inderdaad vaak gezegd dat het OM hier in feite op de stoel van de rechter gaat zitten en een straf, namelijk de geldboete, oplegt. Ik denk dat deze zienswijze feitelijk klopt, in praktijk zal het ook zo worden ervaren. Formeel echter doet de officier van justitie slechts een aanbod tot transactie, waarbij de verdachte niet verplicht is hierop in te gaan.

Ik zie het rechterlijk aspect wel terug in een beslissing van de officier waardoor er een rechtstreekse strafrechtelijke reactie wordt gegeven op het gepleegde delict. Deze besluiten beogen in feite de verdachte reeds te straffen voor wat hij gedaan heeft. Een voorbeeld hiervan was de alternatieve sanctie volgens het officiersmodel

527 H.G. van de Bunt, Officieren van Justitic, pag. 55.

528 Zie daarover bijvoorbeeld C. Brants, Slavenburg: een geslaagde transactic? R en K, no. 13 (1987) 
in het minderjarigenstrafrecht, ${ }^{58}$ waarbij de strafreactie komt van de officier van justitie. Een ander voorbeeld is de berisping ten parkette van een minderjarige verdachte door de officier van justitie (niet te verwisselen met de berisping van de minderjarige door de rechter, art. $77 \mathrm{~g}$ jo $77 \mathrm{p} \mathrm{Sr}$ !). Hierbij moet de minderjarige verschijnen op het kantoor van de officier van justitie, waarbij deze de jongere vermanend toespreekt. Deze vermanende toespraak heeft de bedoeling van een straf, te vergelijken met de berisping door de rechter, die door de wet als een straf is gekwalificeerd. Ten aanzien van de berisping door de officier is niet voorgeschreven op welke wijze dit mag of dient te geschieden. Mij is overigens gebleken dat dit nogal kan verschillen. Verwerpelijk vind ik het geval dat de officier van justitie in het kader van een dergelijke berisping de jongere een "boete" oplegt en hem waarschuwt het de volgende keer niet bij deze "boete" te laten maar de zaak dan aan de rechter voor te leggen. De transactie wordt hier in feite dwingend opgelegd en de verdachte wordt geen keuze gelaten. In feite is er van een "fair trial" (art. 6 EVRM) zo geen sprake en komen ook andere waarborgen in het gedrang. Enige controle hierop bestaat niet.

Ook hier dringt zich de vergelijking op met het bestuursrecht. Bij niet-naleving van verplichtingen die voortkomen uit administratiefrechtelijke normen kan de overheid machtsmiddelen aanwenden in de vorm van administratiefrechtelijke sancties. Voorbeelden hiervan zijn de bestuursdwang, het intrekken of wijzigen van een begunstigende beschikking, het opleggen van een administratieve boete en het opleggen van een dwangsom. Indien een burger de regels overtreedt, kan het bestuursorgaan reageren met het opleggen van een administratieve sanctie. Alhoewel leedtoevoeging bij een administratiefrechtelijke sanctie niet voorop behoeft te staan, ${ }^{500}$ valt naar mijn mening niet te ontkennen dat dit element zeker aanwezig is en door degene aan wie de sanctie wordt opgelegd als zodanig zal worden ervaren. Dit doet zich met name voor in het geval de prestatie die de burger moet leveren hetzelfde is als bij de strafrechtelijke sanctie, dus bij een administratiefrechtelijke boete. Hierbij moet wel worden bedacht dat de waarborgen van art. 6 EVRM wel degelijk dienen te worden gerespecteerd.

Indien het reageren op een overtreding van regels op een manier die inhoudelijk overeenkomt met een sanctie als een rechterlijk aspect wordt beschouwd, moet dit naar mijn mening betekenen dat ook bestuursorganen bij het opleggen van administratiefrechtelijke sancties rechterlijke trekken vertonen.

529 Deze modaliteit is in de huidige wettelijke regeling van de dienstverlening niet opgenomen, juist vanwege het feit dat deze afdoening het karakter van een straf droeg, zodat deze dan ook door de rechter behoorde te worden opgelegd. In het minderjarigenstrafrecht bestaat deze modaliteit nog.

530 Zie over het karakter van cen administraticfrechtelijke sanctic Hoofdstuk 4 en de daar aangehaalde literatuur, met name JJ. Oostenbrink en W. Duk. 


\subsubsection{Recente ontwikkelingen}

Dat het OM in feite een bestuursorgaan is en door de wetgever ook als zodanig gezien wordt, kan worden geïllustreerd aan de hand van ontwikkelingen die zich de laatste jaren hebben voorgedaan, waarbij het OM ook in een procedure nadrukkelijk de rol van bestuursorgaan opgelegd heeft gekregen. Ik doel hierbij op de uitbreiding van de transactieregeling (onderdeel van de Wet Vermogenssancties) en op de administratiefrechtelijke handhaving van bepaalde verkeersovertredingen. Op grond van de sinds 1983 bestaande transactieregeling is het mogelijk overtredingen en misdrijven waarop niet meer dan zes jaar gevangenisstraf staat, door middel van een transactie af te doen. Voor een groot aantal strafbare feiten zijn door de vergadering van de procureurs-generaal vervolgings- en transactierichtlijnen opgesteld, aan de hand waarvan de officier van justitie individuele zaken afdoet. Naar mate deze richtlijnen waren gepubliceerd en naar mate volgens deze richtlijnen werd gehandeld werd de vrijheid van de officier van justitie bij het nemen van een dergelijke beslissing beperkter, omdat de betrokkene, indien de officier afwijkt van de richtlijn, zich trachtte te beroepen op het rechtszekerheids- en het gelijkheidsbeginsel. De richtlijn bepaalde het overheidsoptreden in de betreffende zaken. Deze ontwikkeling is door de Hoge Raad vastgelegd door de te bepalen dat een strafrechtelijke richtlijn moet worden beschouwd als 'recht' in de zin van art. $99 \mathrm{RO}$ (HR 19 juni 1990, NJ 1991, 119, m.nt. ThWvV en MS. Zie hierover Hoofdstuk $10 \S 2.3 .9$ ).

Door de wetgever wordt de transactie als een "publiekrechtelijke rechtshandeling sui generis" beschouwd, die als rechtsgevolg heeft dat het recht tot strafvordering vervalt, en als een rechtshandeling "met een typisch bestuurlijk karakter".: De transactie is een aanbod van het $O M$, als vertegenwoordiger van de overheid, van vervolging af te zien indien aan de te stellen voorwaarde wordt voldaan. Op de vraag om welk soort publiekrechtelijke rechtshandeling het hier gaat, wordt later ingegaan.

Bij de administratiefrechtelijke handhaving van verkeersovertredingen krijgt de officier van justitie de rol van administratief-beroepsinstantie. Hierbij is de officier de tegenpartij van de verweerder (formeel: klager) die in beroep gaat van een door een lager bestuursorgian, namelijk de politie, uitgevaardigde beschikking. De zelfstandige positie van het OM wordt hiermee aangetast. Door de wetgever wordt het OM als bestuursorgian gekwalificeerd.

Ook in de toelichting bij art. 1:6 Awb worden opsporingsambtenaren, openbaar ministerie en minister van Justitie uitdrukkelijk als bestuursorgaan gekwalificeerd ${ }^{52}$ (zie $\S 4)$.

531 MvA, EK 1982-1983, 15012, nr. 31a, pag. 9.

532 MvT Awb, 21221, pag. 42. 
Beslissingen van het OM kunnen in meer of mindere mate rechterlijke kenmerken dragen. Dit betekent naar mijn mening niet dat het OM daarmee tot de rechterlijke macht kan worden gerekend. Het typische kenmerk van de rechterlijke macht in enge zin is de onafhankelijkheid. Dit ontbeert het OM. Het OM is wel een gerechtelijke instantie, in die zin dat het voornamelijk functioneert bij en voor het gerecht. Het $\mathrm{OM}$ heeft als andere bestuursorganen een publieke taak: het dienen van het algemeen belang, waarbij beleidsvoorbereiding en beleidsuitvoering kernbegrippen zijn.

Ik ben geneigd op grond van inhoudelijke kenmerken het OM te beschouwen als een bestuursorgaan, dat bij de uitoefening van zijn taken magistratelijke trekken vertoont die echter van geval tot geval anders kunnen zijn. Hierbij denk ik voornamelijk aan de mate van zelfstandigheid bij een beslissing in een concreet geval en het strafkarakter van een concrete beslissing. Het gaat mij echter te ver het $O M$ vanwege dit rechterlijk aspect als onderdeel van de rechterlijk macht te beschouwen. Blijkbaar is ook de recente wetgever deze mening toegedaan, gezien de regeling van de administratieve handhaving van verkeersovertredingen en de toelichting bij de Awb.

De mening van Remmelink zoals gepubliceerd in 1968 en die volgens De Doelder in 1988 nog steeds de heersende zou zijn, lijkt mij gedateerd. Sindsdien heeft het gebruik van het opportuniteitsbeginsel door het $\mathrm{OM}$ een grote vlucht genomen. De hoofdtaak van het OM ligt niet meer zozeer in het optreden ter terechtzitting, maar is verschoven naar het vooronderzoek bij het nemen van de vervolgingsbeslissing. ${ }^{533}$ Vervolging of niet vervolging is voor een aanzienlijk deel van de strafzaken een beleidskwestie geworden. ${ }^{534}$

\section{Administratiefrechtelijke bepalingen}

Voor de vraag of het OM wel of niet beschouwd kan worden als een bestuursorgaan kunnen we ook een antwoord trachten te vinden via bepalingen van administratief rechtelijke aard die beogen rechtsbescherming te bieden tegen de overheid.

De Wet $\mathrm{BAB}^{\mathrm{sis}}$ was de eerste 'overkoepelende' ${ }^{356}$ wet die algemeen aanvullende rechtsbescherming tegen de overheid beoogde te geven. Vooralsnog beperkte deze

$533 \mathrm{Ik}$ bedoel hiermee niet te zeggen dat hierin ook het grootste gedeclte van de werktijd van de leden van het OM gaat zitten, maar dat in deze fase de meest importante beslissing genomen wordt.

534 Vgl. W.J. van Eijkern, Aanzet tot een evaluatie van onze strafvordering, Uit: P. Nicolaï e.a. (red.) Recht op scherp (Duk-bundel), pag. 131.

535 Stb. 27 juni 1963, inwerkingtreding 1 januari 1964.

$536 \mathrm{Er}$ bestonden reeds wetten die regcls voor rechtsbescherming bevatten ten aanzien van een specifick terrein, bijvoorbceld de Beroepswet 1902, de Ambtenarenwet 1929, wet op de Bedrijfsorganisatic. 
wet zich tot beschikkingen van de centrale overheid. In deze wet moest dus worden bepaald welke organen vielen onder de term 'administratief orgaan van de centrale overheid'. In het volgende betoog wordt deze wet als uitgangspunt genomen, gevolgd door de Wet AROB en de Awb.

\subsection{Wet Beroep tegen Administratieve Beschikkingen}

De Wet BAB verstond in art. 1 lid 1 onder 'administratief orgaan': iedere persoon en ieder college, met enig openbaar gezag binnen Nederland bekleed, uitgezonderd:
a. de wetgevende macht;
b. de Kamers der Staten-Generaal;
c. de Algemene rekenkamer;
d. de stembureaus, hoofdstembureaus en centrale stembureaus;
e. de rechterlijke macht;
f. overige personen of colleges, geheel of ten dele met rechtspraak belast en te dien aanzien van het openbaar bestuur onafhankelijk voor zoveel het deze recht- spraak betreft;
g. de Octrooiraad;
h. organen, op wier handelingen de rechterlijke macht toeziet en wel voor zover het deze handelingen betreft.

De wet koos voor een algemeen begrip administratief orgaan (echter, de werking van de wet beperkte zich wel tot organen van de centrale overheid) en maakte daar voor de werking van de wet $\mathrm{BAB}$ uitzonderingen op.

Laten we het OM tegen het licht van dit artikel houden. Het woord 'administratief' was functioneel bedoeld: een orgaan van de centrale overheid is administratief (volgens de Wet $\mathrm{BAB}$ ) wanneer het een beschikking neemt krachtens een in enig staatsof administratiefrechtelijk voorschrift vervatte bevoegdheid. ${ }^{57}$ Aangezien de bevoegdheden van het $\mathrm{OM}$ gebaseerd zijn op wetten kan worden aangenomen dat het OM onder deze omschrijving valt.

De uitzonderingen a $\mathrm{t} / \mathrm{m} \mathrm{d}$ zijn voor deze studie niet interessant (en bovendien lijken ze mij duidelijk). Uitzondering e. roept de ons bekende vraag op wat verstaan moet worden onder 'rechterlijke macht'. Volgens Steenbeek wordt hiermee bedoeld de onafhankelijke, voor het leven benoemde, rechtsprekende autoriteit. Zijn conclusie is dat het $O M$ niet valt onder uitzondering e. en derhalve wel als administratief orgaan kan worden beschouwd. ${ }^{58}$ Ook uitzondering $f$. is niet van toepassing op

537 J.G. Steenbeek, Het beroep tegen administratieve beschikkingen, 's-Gravenhage 1965, pag. 56. 538 J.G. Steenbeek, a.w., pag. 57-58. 
het OM. Hiermee werd gedoeld op ambtenaren en colleges die beslissingen nemen in administratief beroep.

Ten aanzien van uitzondering h. valt een uitspraak te noteren: uit een $K B$ van 15 augustus 1970, AB 1971, 170 blijkt dat het OM beschouwd wordt als een orgaan op wier handelingen de rechterlijke macht toeziet (en derhalve valt onder de uitzondering sub. h). In casu had de officier van justitie aan klager (niet de verdachte) Jaten weten in de betreffende zaak geen strafvervolging in te stellen. Klager had middels een art. $12 \mathrm{~Sv}$ - procedure (beklag over niet-vervolgen) de zaak aan de rechter kunnen voorleggen. Dit orgaan, OM, valt wat deze procedure betreft onder de uitzondering sub. h. en is dan niet een administratief orgaan omdat het onder rechterlijk toezicht staat.

\subsection{Wet Administratieve Rechtspraak Overheidsbeschikkingen}

De Wet Administratieve Rechtspraak Overheidsbeschikkingen (AROB), inwerkinggetreden in 1976, stelt algemeen aanvullend rechtmatigheidsberoep open tegen, in principe, alle administratieve beschikkingen van alle (dus ook lagere) overheden op Afdeling rechtspraak van de Raad van State.

De Wet AROB verstaat in art. 1 lid 1 onder een administratief orgaan: iedere persoon en ieder college, met openbaar gezag binnen Nederland bekleed, uitgezonderd:
a. de wetgevende macht;
b. de Kamers der Staten-Generaal;
c. de Algemene Rekenkamer;
d. de rechterlijke macht; spraak betreft; $\checkmark$ van de Grondwet; het deze handelingen betreft;
i. de Nationale Ombudsman;
j. de Onderwijsraat;

e. overige personen of colleges, geheel of ten dele met rechtspraak belast en te dien aanzien van het openbaar bestuur onafhankelijk voor zoveel het deze recht-

f. de Octrooiraad en de Raad voor het Kwekersrecht;

g. organen van openbare lichamen van beroep of bedrijf, als bedoeld in Hoofdstuk

h. organen, op wier handelingen de rechterlijke macht toeziet en wel voor zover

Deze tekst van art. 1 AROB komt overeen met het corresponderende artikel 1 uit de voorganger van de Wet $A R O B$, de Wet $B A B$, met dien verstande dat onderdeel d. Wet $B A B$ is vervallen en in de Wet $A R O B$ onderdelen g., (en later) i. en j. zijn toegevoegd. Onderdeel $h$. in de Wet AROB correspondeert met onderdeel h. Wet BAB. In de MvT kreeg dit artikel verder geen bijzondere aandacht. 
Het grote verschil tussen de Wet $B A B$ en de Wet $A R O B$ is, dat de Wet BAB zich beperkte tot beschikkingen van organen van de centrale overheid, terwijl de wet AROB tevens beroep openstelt tegen beschikkingen van lagere overheden. Dit verschil doet voor ons onderwerp niet ter zake, omdat wij hier de positie onderzoeken van het $\mathrm{OM}$, een orgaan van de centrale overheid.

We kunnen er van uit gaan dat het OM een persoon of college is "met enig openbaar gezag binnen Nederland bekleed". "Enig openbaar gezag" houdt in dat er direct (attributie) of indirect (na delegatie) verwezen moet kunnen worden naar een wettelijke grondslag voor bevoegdheidsuitoefening. ${ }^{\text {ssy }}$ Ten aanzien van het $O M$ is dit het geval.

Vervolgens dient bekeken te worden of het $\mathrm{OM}$ onder één der uitzonderingen geplaatst moet worden. Hierbij zijn met name de excepties genoemd onder d. en h. van belang. Zoals boven vermeld heeft de MvT zich hierover niet expliciet uitgelaten, er wordt verwezen naar de Wet BAB. Uit een uitspraak van de afdeling Rechtspraak RvSt, 24 februari 1983, tB/S VIII, pag. 280, nr. 75 volgt dat met het begrip "rechterlijke macht" de 'gewone' rechterlijke macht wordt bedoeld, de rechterlijke macht als bedoeld in de Grondwet. Zoals we in $\$ 2$ reeds zagen, behoort het $\mathrm{OM}$ niet tot de "rechterlijke macht" zoals bedoeld in de Grondwet. Ten aanzien van de uitzondering sub. h. kunnen we als volgt redeneren: het $O M$ valt onder de uitzondering sub. h., niet omdat het zelf "rechterlijke macht" zou zijn (integendeel), maar omdat de rechterlijke macht op zijn handelen toeziet. Dit laatste is nu juist bij de buitengerechtelijke afdoening niet het geval.

\subsection{Algemene wet bestuursrecht}

In deze wet wordt het algemeen deel van het bestuursrecht zoveel mogelijk gecodificeerd. De wet geeft algemene bepalingen voor het verkeer tussen burgers en bestuursorganen (bijvoorbeeld de behandeling van verzoekschriften), algemene bepalingen over besluiten, waaronder de codificatie van een aantal algemene beginselen van behoorlijk bestuur, en bijzondere bepalingen over bijvoorbeeld beschikkingen. Tevens bevat de wet bepalingen over de handhaving en over administratief procesrecht.

In art. 1:1 Awb wordt een definitie gegeven van het begrip 'bestuursorgaan':

1. Onder bestuursorgaan wordt verstaan:

a. een orgaan van een rechtspersoon die krachtens publiek recht is ingesteld, of

b. een ander persoon of college, met enig openbaar gezag bekleed. 
2. De volgende organen, personen en colleges worden niet als bestuursorgaan aangemerkt:
a. de wetgevende macht;
b. de kamers en de verenigde vergadering der Staten-Generaal;
c. onafhankelijke, bij de wet ingestelde organen die met rechtspraak zijn belast;
d. de Raad van State en zijn afdelingen;
e. de Algemene Rekenkamer;
f. de Nationale Ombudsman en de substituut-ombudsmannen;
g. de voorzitters, leden, griffiers en secretarissen van de in de onderdelen b tot en met $f$ bedoelde organen, de procureur-generaal en de advocaten-gene- raal bij de Hoge Raad, alsmede de commissies uit het midden van de in de onderdelen $b$ tot en met $f$ bedoelde organen;

3. Een ingevolge het tweede lid uitgezonderd orgaan, persoon of college wordt wel als bestuursorgaan aangemerkt voor zover het orgaan, persoon of college besluiten neemt of handelingen verricht ten aanzien van een niet voor het leven benoemde ambtenaar als bedoeld in artikel 1 van de Ambtenarenwet als zodanig, zijn nagelaten betrekkingen of zijn rechtverkrijgenden.

In vergelijking met art. 1 lid 1 van de Wet $A R O B$ valt het op dat de Awb een ruimere omschrijving geeft van het begrip 'bestuursorgaan' doordat een aantal in de Wet AROB opgenomen uitzonderingen in dit wetsvoorstel ontbreekt, onder andere de voor dit onderwerp van belang zijnde uitzondering genoemd onder art. 1 lid 1 onder h. AROB. In de MvT wordt gesteld dat uit de ruimere optiek van de Awb voortvloeit dat er geen reden is de uitzonderingen van art. 1 lid 1 onder f. g. en h. AROB over te nemen. De specifieke reden voor deze uitzonderingen in de Wet AROB (het bestaan van een eigen rechtsgang tegen besluiten van deze organen) geldt voor de Awb niet. Art. 1:1 heeft de bedoeling organen die weliswaar met openbaar gezag zijn bekleed maar die niet tot de uitvoerende macht behoren, uit te sluiten..$^{50}$ In art. 1:6 Awb wordt, evenals dat in art. 5 AROB het geval was, de werking van de wet echter beperkt door bepaalde handelingen van hestuursorganen niet onder de wet te laten vallen. Hierop zal later nader worden ingegatan.

Om te bekijken of het OM c.q. een officier van justitie een bestuursorgaan is in de zin van art. 1:1 Awb moet onderzocht worden of het een college c.q. persoon is 'met enig openbaar gezag bekleed'. Volgens de MvT gaat het hierbij "om een orgaan met een publiekrechtelijke bevoegdheid tot het bepalen van de rechtspositie (de rechten en/of verplichtingen) van andere rechtssubjecten. Organen met deze publiekrechtelijke bevoegdheid zijn in de eerste plaats de organen die hun grondslag en regeling vinden in het publiekrecht, die dus zijn ingesteld bij of krachtens wettelijk 
voorschrift"..$^{\text {sin }}$ Hoewel het $\mathrm{OM}$ in de reeks voorbeelden die de MvT vervolgens noemt, niet opgenomen is, mag toch duidelijk zijn dat dit onder deze omschrijving valt. Het orgaan vindt zijn grondslag immers in art. 3-6b van de Wet op de rechterlijk organisatie en een groot gedeelte van de bevoegdheden is geregeld in het Wetboek van Strafvordering.

Een aantal bestuursorganen wordt vervolgens in het tweede lid van art. 1:1 Awb uitgezonderd. Nagegaan dient te worden of we het OM onder deze excepties moeten scharen. In dit kader zijn de uitzonderingen die genoemd worden onder $\mathrm{c}$ en $\mathrm{g}$ van

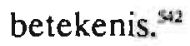

Onder $\mathrm{c}$ worden de onafhankelijke, bij wet ingestelde organen die met rechtspraak zijn belast, genoemd. Zoals hiervoor reeds is uiteengezet, valt het OM niet te beschouwen als een onderdeel van de rechterlijke macht in enge zin. Het OM valt dus niet onder de in art. 1:1 lid 2 onder $c$ genoemde uitzondering.

Onder $g$ worden (onder andere) de procureur-generaal en de advocaten-generaal bij de Hoge Raad uitgezonderd. Dit heeft te maken met de in de Wet RO opgenomen tuchtrechtelijke regeling ten aanzien van rechterlijk ambtenaren. De Hoge Raad, een onafhankelijk rechterlijk orgaan, zoals bedoeld in art. 1:1 lid 2 onder $c$, beslist over het ontslag of de schorsing van rechters. Volgens art. 13a RO is de procureurgeneraal of, indien zijn ontslag of schorsing in het geding is de oudste advocaatgeneraal, bevoegd te beslissen of een klacht aan de Hoge Raad wordt voorgelegd. Een dergelijke regeling is ook van toepassing indien er een klacht is tegen een lid van de rechterlijke macht, art.14 a-e RO. ${ }^{\text {s.3 }}$ Volgens de MvT noodzaakt dit de uitzondering ten aanzien van genoemde functionarissen. ${ }^{\text {st }} \mathrm{Nu}$ in art. 1:1 lid 2 onder $\mathrm{g}$ Awb een uitdrukkelijke uitzondering gemaakt wordt voor bepaalde leden van het $\mathrm{OM}$, kunnen we stellen dat als hoofdregel geldt dat het OM valt onder 'bestuursorgaan'. Ware dat anders, dan was deze uitdrukkelijke exceptie niet nodig geweest. Conclusie: het $\mathrm{OM}$, met uitzondering van de procureur-generaal en de advocatengeneraal bij de Hoge Raad, wordt ingevolge art. 1:1 Awb beschouwd als een bestuursorgaan.

In de toelichting bij art. 1:6 wordt dit nogmaals bevestigd. ${ }^{\text {sis }}$

541 MvT Awb, 21221, pag. 27.

542 Hierbij ga ik er vanuit dat op voorhand vaststaat dat het openbaar ministerie niet valt onder de uitzonderingen onder $a, b, d, e$ en $f$.

543 Hier wordt bedoeld een lid van de zittende magistratuur.

544 MvT Awb, 21221, pag. 31.

545 MvT Awb, 21221, pag. 42. 


\section{Algehele conclusie}

In dit hoofdstuk is getracht een antwoord te geven op de vraag of het OM onderdeel is van de rechterlijke macht of dat het als een bestuursorgaan dient te worden beschouwd. Hiervoor zijn een drietal aspecten onderzocht, namelijk constitutionele, inhoudelijke en administratiefrechtelijke.

Zowel constitutionele, inhoudelijke als administratiefrechtelijke aspecten leiden tot de slotsom dat het OM geen onderdeel is van de rechterlijke macht, maar gezien moet worden als een bestuursorgaan.

Uit art. $116 \mathrm{GW}$ volgt dat een orgaan, om gerekend te kunnen worden tot de rechterlijke macht in enge zin, daartoe door een formele wet moet zijn aangewezen. Met betrekking tot het $\mathrm{OM}$ is dit niet het geval.

Het kenmerk van de rechterlijke macht is met name de rechtspositionele onafhankelijkheid van de andere machten, in het bijzonder de uitvoerende. Het OM staat in een hiërarchische relatie tot de minister van Justitie, zodat er niet van zelfstandigheidheid ten opzichte van de uitvoerende macht kan worden gesproken.

De beslissingen van het OM bevatten veelal zowel rechterlijke als bestuurlijke componenten. Dit is trouwens ook het geval bij besluiten van bestuursorganen. Het gaat te ver deze organen daarom tot de rechterlijke macht te rekenen.

De Awb rekent het OM uitdrukkelijk tot de bestuursorganen.

Nu we tot de slotsom zijn gekomen dat het OM een bestuursorgaan is, komt de vraag aan de orde of elke beslissing die door het OM genomen wordt als een bestuursbesluit moet worden gezien. Volgt op deze vraag namelijk een positief antwoord, dan zou de stelling kunnen worden verdedigd dat die besluiten van het OM dan ook dienen te voldoen aan de regels zoals die gelden voor bestuursbesluiten in het algemeen. 


\section{Karakter van de OM-beslissing}

\section{Inleiding}

Het OM neemt vele beslissingen, bijvoorbeeld de beslissing tot vervolgen, beroep tegen een schorsing van de bewaring, de executie van een straf, enzovoort. We hebben reeds geconstateerd dat de beslissingen van het $\mathrm{OM}$ in meer of mindere mate bestuurlijke en rechterlijke kenmerken kunnen bevatten. Tevens stelden we vast dat het $\mathrm{OM}$ in de eerste plaats beschouwd moet worden als een bestuursorgaan. We zouden nu als volgt kunnen redeneren: beslissingen van het $\mathrm{OM}$ (een bestuursorgaan) kunnen worden gezien als een bestuursbesluit en/of een beschikking ${ }^{\text {ss }}$ in het bestuursrecht. Het gevolg van deze denkwijze zou zijn dat deze beslissingen zouden moeten voldoen aan de vereisten die voor bestuursbesluiten in het algemeen zijn gesteld.

Om te onderzoeken of deze redenering opgaat, zal een beslissing van het OM onder de omschrijving van bestuursbesluit, zoals opgenomen in art. 1:3 lid $1 \mathrm{Awb}$ behoren te vallen.

\section{Besluit en beschikking}

Als uitgangspunt voor deze toetsing wordt de Awb genomen. Het bereik van de Awb gaat verder dan de Wet AROB die, de naam zegt het reeds, beperkt was tot beschikkingen en uitsluitend rechtsbescherming beoogde. De Awb heeft in art. 1:3 lid 1 als uitgangspunt het 'besluit' genomen: een schriftelijke beslissing van een bestuursorgaan, inhoudende een publiekrechtelijke rechtshandeling. ${ }^{567}$ De beschikking wordt, evenals in de Wet AROB het geval was, in het tweede lid van art. 1:3 Awb gedefinieerd als een speciaal soort besluit: een besluit dat niet van algemene strekking is, met inbegrip van de afwijzing van de aanvraag daarvan.

546 De Awb neemt het bestuursbesluit als uitgangspunt (art. 1:3 lid 1). In de Wet AROB was dat de beschikking, die in de Awb als een type besluit wordt gezien (art. 1:3 lid 2).

547 De MvT geeft hiervoor als reden dat het hierdoor mogelijk is dat de wetgever verscheidene algemene regels vaststelt die voor alle besluiten gelden. Deze algemene regels zijn opgenomen in hoofdstuk 3. MvT Awb, TK 1988-1989, 21221, pag. 36. 
Voor de uitleg van het begrip 'bestuursorgaan' wordt verwezen naar het vorige hoofdstuk. De andere drie elementen van het begrip 'besluit' (schriftelijk, publiekrechtelijk, rechtshandeling) zijn, zij het in iets andere bewoordingen, geïnspireerd door de omschrijving van het begrip 'beschikking' in de Wet AROB (art. 2 lid 1 en voor wat het publiekrechtelijke van de handeling betreft (niet zijnde een rechtshandeling naar burgerlijk recht) lid 2). Het 'speciale'van de beschikking, het niet zijn van algemene strekking, komt uit het tweede lid van art. 2 AROB. Voor wat betreft de inhoud van de verschillende begrippen kan dan ook mede worden uitgegaan van die, welke zij in de Wet AROB hadden. ${ }^{\text {sts }}$

Als eerste kenmerk van een besluit stelt art. 1:3 Awb de schriftelijkheid. Het begrip 'schriftelijk' wordt door de Arob-rechter zo uitgelegd dat het genomen besluit uit een schriftelijk stuk kenbaar moet zijn. ${ }^{\text {(1) }}$ Tevens is bepaald dat het een eis van behoorlijkheid is, dat een daarvoor geschikte beschikking op schrift wordt gesteld. ${ }^{50}$ Ware dit niet zo, dan zou het bestuursorgaan de beschikking aan toetsing kunnen onttrekken door deze niet op schrift te zetten. Volgens de MvT kan schriftelijke verslaglegging slechts achterwege blijven als het besluit gericht is op onmiddellijke uitvoering door degene aan wie het mondeling of door een teken wordt bekend gemaakt. Wordt door een bestuursorgaan echter volstaan met een mondelinge mededeling in het geval een schriftelijk besluit mocht worden verwacht, dan staat dit ontbreken van een schriftelijke besluit gelijk aan de weigering een besluit te nemen voor wat betreft de voorschriften betreffende bezwaar en beroep, art. 6.1.3 (nu 6:2) Awb. ${ }^{\text {sin }}$ Het vereiste van het op schrift gesteld zijn is voornamelijk opgenomen om bewijsredenen ${ }^{52}$ De rechter kan zich moeilijk een oordeel vormen over een tegen een beschikking ingesteld beroep, indien die beschikking niet op schrift is vastgelegd. Bovendien komt het de rechtszekerheid van de burger ten goede.

Ik ben van mening dat het eigenlijk niet correct is het op schrift gesteld zijn als een impliciet kenmerk van een bestuursbesluit te beschouwen. Het is zeer wel denkbaar dat de aard van het besluit zich daartegen verzet. Het Rapport ABAR (1973) noemt in dit verband als voorbeeld een bevel van een verkeersagent en zegt vervolgens dat het aan te bevelen is dat een beschikking in schriftelijke vorm wordt gegoten en schriftelijk wordt meegedeeld. ${ }^{350}$ In de volgende druk van dit rapport $(1984)^{54}$

548 Telkens wanneer in de volgende alinea in dit verband wordt gesproken over een 'beschikking' dient men in het achterhoofd te houden dat dit ook een 'besluit' is in de zin van art. 1:3 Awb. Dit blijkt uit de MvT waarin voor de uitleg van de onderdelen van 'besluit' in de zin van de Awb steeds wordt teruggegrepen naar het beschikkingsbegrip uit de Wet AROB, MvT Awb, pag. 36-37.

549 AR RvS 20 december 1976, AB 1979, 70.

$550 \mathrm{Vz}$ AR RvS 14 augustus 1978, tB/S V, pag. 341, nr. 97.

551 MvT Awb, pag. 37.

552 Volgens Michiels is dit af te leiden uit de parlementaire geschiedenis van de Wet BAB. F.C.M.A. Michiels, De Arob-beschikking, 's-Gravenhage 1987, pag. 67-68.

553 Rapport ABAR vierde druk 1973, Alphen aan den Rijn 1980, pag. 78. 
wordt gesteld dat het element van de schriftelijkheid om praktische redenen aan de omschrijving is toegevoegd. ${ }^{\text {sss }}$ In de wetenschappelijke discussie klonk door dat dit vereiste niet aan een beschikking behoorde te worden gesteld. Ook Ten Berge en Stroink stellen in hun commentaar bij de artikelen 2 en 3 van de Wet AROB dat het vereiste van schriftelijkheid niet inherent is aan het beschikkingsbegrip, maar dat het is ingegeven om bewijsproblemen te voorkomen. ${ }^{\text {.56 }}$

In het algemeen voldoen de beslissingen van het $\mathrm{OM}$ aan deze eis van schriftelijkheid. De meeste worden op schrift gesteld en schriftelijk aan de betrokkene meegedeeld. Een belangrijke groep beslissingen voldoet echter hieraan niet. Het betreft hier de zogenaamde informele sepots, dat wil zeggen strafzaken die geseponeerd worden zonder dat daaraan een gerechtelijk vooronderzoek of voorlopige hechtenis is voorafgegaan. Hiervan krijgt de (ex)verdachte doorgaans geen bericht. Wel moet van het sepot, voor de interne verslaggeving, worden vastgelegd op welke grond een zaak geseponeerd is. Het is naar mijn mening echter onjuist deze groep beslissingen alleen vanwege het feit dat ze niet op schrift zijn gesteld niet als een bestuursbesluit te beschouwen, daar de schriftelijkheid niet als een impliciet kenmerk van een bestuursbesluit beschouwd kan worden. Veeleer komt de vraag op of de eis van schriftelijkheid, vanwege de rechtszekerheid, ook niet aan deze categorie beslissingen moet worden gesteld. Hierop wordt later ingegaan.

Het besluit moet een publiekrechtelijk karakter hebben. De MvT Awb drukt het zo uit, dat rechtshandelingen naar burgerlijke recht er niet onder vallen. ${ }^{37}$ Hiermee wordt bedoeld dat het besluit niet uitsluitend privaatrechtelijk van aard mag zijn. ${ }^{358}$ Dit verhindert niet dat de beschikking privaatrechtelijke gevolgen kan hebben, bijvoorbeeld (voor ons onderwerp van belang) het ontstaan van een betalingsplicht bij een transactie of een verbeurdverklaring (art. $74 \mathrm{Sr}$ ). Hoewel dus een beslissing van het

554 De Wet AROB, die in art. 2 lid 1 de beschikking definiecrt als 'het schriftelijk besluit van een administratief orgaan, gericht op enig rechtsgevolg' is dan inmiddels ingevoerd.

555 Rapport ABAR 1984, vijfde druk, Alphen aan den Rijn 1984, pag. 58. Dezelfde bewoordingen worden aangetroffen bij het artikelgewijs commentaar van Steenbeek bij de Wet BAB, waarin dere cis onk was opgenomen. J.G. Steenbeek, Het beroep tegen administratieve beschikkingen, 's-Gravcnhage 1\%5, pag. 85.

556 J.B.J.M. ten Berge en F.A.M. Stroink, Commentaar op artikelen 2 en 3 in: Administratieve rechtspraak overheidsbeschikkingen. Losbladig. Samson, pag. 3-4; Vgl. verder: J.G. Steenbeek, Wet administratieve rechtspraak overheidsbeschikkingen, 's-Gravenhage 1979, pag. 41-42; J.G. Stcenbeek en F.A.M. Stroink, Wet administ ratieve rechtspraak overheidsbeschikkingen, 's-Gravenhage 1988, pag. 81-82; J.B.J.M. ten Berge en F.A.M. Stroink, AROB in vogelvlucht, 1982, pag. 54-55; A.Q.C. Tak, Bevoegdheidsafbakening van de AROB-rechter; kunstig of gekunsteld? Oratic RL, Deventer 1984, pag. 13.

557 MvT Awb, TK 1988-1989, 21221, pag. 37.

558 Zie uitgebreider over de rechtshande ling naar burgerlijk recht: F.C.M.A. Michick, a.w., hoofdstuk 4. 
OM van invloed kan zijn op privaatrechtelijke verhoudingen staat het publiekrechtelijk karakter up de voorgrond.

Tenslotte moet de beslissing gericht zijn op enig rechtsgevolg. Dit houdt in dat het hier om een rechtshandeling gaat, in tegenstelling tot een rechtsfeit, waarbij een rechtsgevolg intreedt onafhankelijk hiervan of het rechtsgevolg beoogd is. ${ }^{5 \$ 9}$ Een rechtshandeling brengt een wijziging teweeg in de rechtsverhouding van het bestuursorgaan tot een of meer anderen. Beslissingen die louter een interne wijziging binnen het bestuursorgaan beogen, vallen er niet onder. ${ }^{560}$

De besluiten van het $O M$ voldoen aan deze vereisten.

Voor de invulling van het begrip 'beschikking' in de Awb is aansluiting gezocht bij het beschikkingsbegrip van de Wet AROB en de jurisprudentie van de Afdeling rechtspraak. ${ }^{\text {s.t }}$ Dit leidt ertoe dat 'beschikking' in de Awb wordt gedefinieerd als een besluit dat niet van algemene strekking is. ${ }^{502}$ Van besluiten van algemene strekking kennen we verschillende soorten bijvoorbeeld alle (formele en materiële) wetten en verordeningen, beleidsregels, plannen en circulaires. Bij een besluit van algemene strekking is de beslissing niet gericht tot een meer individueel bepaalde, concreet aangeduide (rechts)persoon of orgaan. Ter onderscheiding van normen en plannen enerzijds en beschikkingen anderzijds worden (werden) door de AROB-rechter drie criteria gehanteerd: ${ }^{563}$ het persoons, het zaaks- en het samenhangs- criterium. Het eerste criterium komt erop neer dat een besluit als een beschikking wordt beschouwd indien dit besluit ten doel heeft zich direct te richten tot natuurlijke personen, rechtspersonen of organen. Bij het tweede criterium gaat het om besluiten waarbij de aard, de hoedanigheid van een nauwkeurig omschreven zaak bepalend is voor het nemen van het besluit. Als voorbeeld kennen we het onbewoonbaar verklaren van een woning. Het derde criterium ziet op (groepen) individualiserende rechtsbesluiten die kunnen worden gezien als onderdeel van een plan.

Toegepast op dit studie-object: de opsporings- en vervolgingsrichtlijnen van de procureurs-generaal kunnen worden gezien als besluiten van algemene strekking. Een (vervolgings)beslissing van het $\mathrm{OM}$ in een bepaalde strafzaak heeft een dergelijke algemene strekking niet.

Aparte aandacht schenkt de MvT aan de afwijzing van een aanvraag. De vraag is of een dergelijke afwijzing onder het beschikkingshegrip valt. Niet ieder niet-reageren van een bestuursorgaan levert een beschikking in de zin van de Awb op. Dit is slechts

559 Vgl. R.M. van Male, Onvoltooid recht, Oratie EUR, Zwolle 1993, pag. 12-13.

560 MvT Awb, TK 1988-1989, 21221, pag. 38.

$561 \mathrm{MVT}$ Awb, TK 1988-1989, 21221, pag. 38.

562 MvT Awb, TK 1988-1989, 21221, pag. 39.

563 Zie hierover uitgebreider: J.B.J.M. ten Berge en F.A.M. Stroink, a.w., pag. 68-73. 
het geval als het een afwijzing van een verzoek van een belanghebbende betreft, aldus de $\mathrm{MvT}^{344}$

\section{Uitzonderingen}

In art. $5 \mathrm{AROB}$ werd een aantal categorieën beschikkingen van de werking van de wet uitgeschakeld. Hier is van belang de uitzondering genoemd in art. 5 sub g. AROB: beschikkingen op grond van het Wetboek van Strafrecht of van het Wetboek van Strafvordering of van andere bepalingen van strafrechtelijke aard, voor zover betrekking hebbende op een verdachte of een gevonnist persoon. Deze bepaling komt overeen met het corresponderende artikel uit de Wet BAB. Tijdens de parlementaire behandeling van de Wet AROB werd aan deze uitzondering geen speciale aandacht meer besteed en werd aangesloten bij de Wet BAB. In de MvT van de Wet BAB sas worden aan deze uitzondering (f) enkele overwegingen gewijd:

"Dat deze beschikkingen, waaronder ook vallen beschikkingen krachtens regelingen ter uitvoering van de beide genoemde wetboeken, buiten de werkingssfeer van het onderhavig wetsontwerp vallen is vanzelfsprekend. Men denke bijvoorbeeld aan (.....) en voor wat betreft de andere bepalingen van strafrechtelijke aard aan de transactieheschikkingen op grond van art. 229 over de heffing van in- en uit- en doorvoer en van de accijnzen, alsmede (....). Het betreft hier een gebied, zo nauw verbonden aan dat der strafrechtspraak, dat een beroepsmogelijkheid, als thans wordt voorgesteld, voor deze beschikkingen niet als de meest geeigende voorziening kan worden beschouwd".

Ook de Awb sluit in art. 1:6 bepaalde categorieën bestuursbesluiten uit van de werking van de wet. ${ }^{566} \mathrm{Zo}$ is volgens onderdeel a. van art. 1:6 de Awb niet van toepassing op de opsporing en vervolging van strafbare feiten, alsmede de tenuitvoerlegging van strafrechtelijke beslissingen. Volgens de MvT wordt hiermee, gelet op de eigenstandige positie van het (materiële en formele) strafrecht en op het feit dat de strafrechtelijke regeling uitputtend is bedoeld, een ongewenste vermenging van rechtssferen voorkomen. ${ }^{567}$ De strafrechtelijke regelgeving is uitputtend bedoeld. Als deze uitzonderingen niet in de wet zouden worden opgenomen dan zouden de besluiten en handelingen van opsporingsambtenaren, OM en minister van Justitie die typisch in de sfeer van vervolging en executie liggen onder de Awb vallen. ${ }^{3 \times 8}$ De beslissingen van het $\mathrm{OM}$ inzake opsporing, vervolging en executie zijn dus geen bestuursbesluiten in de zin van de Awb.

S64 MvT Awb, TK 1988-1989, 21221, pag. 39.

565 MvT Wet BAB, TK 1958-1959, 5363, pag. 13-14.

566 Vergelijkbaar zijn de artt. 8:4 en 8:5 Awb waarin bepaalde besluiten worden uitgezonderd van het beroep op de rechtbank, zoals de besluiten op grond van de WAHV.

567 MvT Awb, TK 1988-1989, 21221, pag. 42.

568 MvT Awb, TK 1988-1989, 21221, pag. 42. 
Afgezien van het feit dat ik met deze uitzondering niet volledig kan instemmen (zie hierna en de hoofdstukken 10 en 11), was naar mijn mening correcter geweest in art. 1:6 Awb te spreken over de 'beslissingen omtrent opsporing en vervolging, alsmede de tenuitvoerlegging van strafrechtelijke beslissingen'. Onder de huidige tekst zouden, letterlijk genomen, beslissingen inhoudende niet-vervolgen, zoals een sepot of transactie, niet onder de uitzondering vallen en wel moeten voldoen aan de Awb. Zij zouden ook niet gezien kunnen worden als een afwijzend besluit, omdat daarvoor (meestal) een verzoek van betrokkene ontbreekt.

\section{Toepassing op de OM-beslissing tot buitengerechtelijke afdoening}

Hiermee is nog niet gezegd dat bedoelde besluiten van het OM geen bestuursbesluiten zijn. Omdat de Awb beslissingen inzake opsporing, vervolging en executie zo nadrukkelijk uitsluit, betekent dit dat het in feite wel bestuursbesluiten zijn, anders behoeven ze niet 'kunstmatig' uitges loten te worden. Een vergelijkbare uitzondering wordt gemaakt in art. 8:4 Awb. Een voorbeeld van een andere wetgevingstechniek toont art. 2 lid 2 AROB: 'Geen beschikking in de zin van deze wet is:' en dan volgen een besluit van algemene strekking en een rechtshandeling naar burgerlijk recht.

Ik zou ervoor willen pleiten de beslissingen van het $\mathrm{OM}$ die leiden tot buitengerechtelijke afdoening van strafbare feiten niet bij voorbaat in het algemeen uit te sluiten van de werking van de Awb. Hiervoor zijn drie argumenten aan te voeren:

(1) De uitsluiting past niet in het unificatiestreven inzake alle bestuursbesluiten. Daarmee bedoel ik dat misschien wat al te lichtvaardig tot uitsluiting is besloten, alhoewel ik besef dat ook de Wet BAB (art. 5 sub g.) en de Wet AROB (art. 5 sub g.) een dergelijke uitsluiting kenden. In tegenstelling tot de Awb kenden deze wetten echter niet uitdrukkelijk dit unificatiestreven.

(2) De redenering van de MvT, die er op neer komt dat zich een vermenging van rechtssferen zou voordoen, gaat maar gedeeltelijk op. In de eerste plaats is mij de inhoud van de term 'rechtssferen', warvan een vermenging ongewenst zou zijn, niet geheel duidelijk. Deze vermenging zou ontstaan omdat het strafrecht een eigenstandige positie heeft en doordat de strafrechtelijke regelgeving uitputtend is bedoeld. Aan de eigenstandige positie van het strafrecht valt naar mijn idee sterk te twijfelen. We hebben reeds gezien dat er bijvoorbeeld op het terrein van de sancties een vermenging tussen straf-en administratief recht gaande is. En is het niet veel meer een uitdaging te zoeken naar overeenkomsten dan bij voorbaat een scheiding aan te brengen? Ik heb het gevoel dat de MvT bedoelt te zeggen: door besluiten van het $\mathrm{OM}$ te onderwerpen aan de Awb ontstaat er een vermenging in de sfeer van de rechterlijke competentie. De vraag is of de redenering dan wel opgaat.

Ter zake van besluiten van het OM tijdens de strafzitting of beslissingen die rechtstreeks aan de strafrechter ter toetsing worden voorgelegd, zou zich inderdaad deze vermenging voordoen. Deze besluiten zijn dan terecht van de werking van de Awb 
uitgesloten. Met betrekking tot de buitengerechtelijke afdoening van strafbare feiten manifesteert dit probleem zich naar mijn idee niet direct. Het typische van deze besluiten is dat een verdere strafrechtelijke behandeling door deze afdoeningswijzen wordt voorkomen. De strafrechter wordt doorgaans niet gevraagd een oordeel te geven over de wijze van totstandkomen en over de inhoud van de beslissing. Het in de MvT van de Awb vermelde argument van een vermenging van rechtssferen doet zich ten aanzien van deze beslissingen doorgaans niet voor. De beslissing tot buitengerechtelijke afdoening is een beslissing van een bestuursorgaan naar een burger toe. In deze fase en in deze verhouding komt er geen rechter aan te pas, zodat er naar mijn idee ook niet gesproken kan worden van een vermenging van rechtssferen. Kortom: besluiten van het $\mathrm{OM}$ tot buitengerechtelijke afdoening zouden kunnen worden gezien als bestuursbesluiten, ten aanzien waarvan de vraag moet zijn of ze terecht worden uitgesloten werking van art. 1:6 Awb. Ten aanzien van deze groep besluiten mag de vraag worden gesteld in hoeverre administratiefrechtelijke vereisten van toepassing zijn, zonder het eigen strafrechtelijk karakter volledig aan te tasten. ${ }^{\mathrm{s} t}$

(3) Verdraagt deze uitsluiting zich met het grondrecht van toegang tot de rechter, neergelegd in de Grondwet en internationaalrechtelijke bepalingen? Zelfs al kan men stellen dat de buitengerechtelijke afdoening (met name voorwaardelijk sepot en transactie), waartegen geen enkele rechter kan worden geadieerd, vrijwillig geschiedt (is niet altijd het geval en ook niet te controleren), impliceert dit dan automatisch dat er geen schending van de artikelen 6 EVRM en 14 IVBP? Met andere woorden: kan men vrijwillig afstand doen van het grondrecht van toegang tot de rechter? Hierbij is van belang te vermelden dat er, in tegenstelling tot het privaatrecht, een ongelijkheid van partijen bestaat. Juist deze ongelijkheid kan een beperking betekenen van het afstand doen van het recht van beroep op de rechter en de omstandigheden waaronder dit gebeurt. ${ }^{570}$ Een andere complicatie voor het strafrecht is, dat de verdachte niet zelfstandig beroep op de rechter kan doen. De officier van justitie bepaalt of de zaak aan de rechter wordt voorgelegd en doorgaans zal de verdachte geen moeite doen zijn zaak voor de rechter te krijgen. Je kunt je juist afvragen of hij dat ten aanzien van een opgelegde voorwaaarde ter voorkoming van strafvervolging wel zou moeten hebben.

In art. $17 \mathrm{GW}$ is neergelegd dat niemand tegen zijn wil van de rechter die de wet hem toekent kan worden afgehouden. Dit impliceert dat iemand afstand van dit recht kan doen indien hij de wil daartoe heeft geuit, dus: op basis van vrijwilligheid. De vraag waar het mijns inziens om draait is: wanneer is er sprake van vrijwilligheid? Art. 6 EVRM bevat de bepaling dat een ieder recht heeft op toegang tot een hij wet ingestelde rechter. Dit artikel vermeldt dus niets expliciet over het afstand doen

$569 \mathrm{Vgl}$. de noot A.C. 't Hart onder het arrest Tuindersfraude, HR 22 oktober 1991, NJ 1992, 282 onder 5 .

570 Zie S. Pront-van Bommel, Afsland van beroep op de administratieve rechter, NTB 1993/5, pag. 182-189. 
van het betreffende recht. Ook het Europese Hof heeft zich er nog niet expliciet over uitgelaten. Een aanknopingspunt vinden we in het arrest Pfeifer en Plankl, EHRM 25 februari 1992, Publ. ECHR Series A, vol. 227. In deze zaak was onder meer aan de orde het afstand doen door een verdachte van zijn recht een rechter (i.c. twee rechters) te wraken. Hoewel het hier gaat om het recht op de onpartijdigheid van de rechter, zijn de argumenten die het Hof heeft gehanteerd bruikbaar. Het Hof overwoog namelijk dat afstand van een door het EVRM gegarandeerd recht, voor zover überhaupt toelaatbaar, op ondubbelzinnige wijze vast dient te komen staan. Bovendien moet de afstand van recht, in het geval van procedurele rechten, vergezeld gaan van minimum waarborgen die in overeenstemming zijn met het belang ervan. Hieruit kunnen we afleiden dat het vrijwillig afstand doen, voorzover überhaupt toelaatbaar, moet voldoen aan vereisten. Vaststaat dat (a) dit afstand doen op uitdrukkelijke wijze dient te geschieden; (b) er moet aan bepaalde waarborgen zijn voldaan. Aan de eerste voorwaarde lijkt me bij vs en transactie niet voldaan, sterker nog, zij hebben geen recht het oordeel van de rechter in te roepen. De onder (b) genoemde voorwaarde komt uiteindelijk neer op de vraag die we hierboven reeds stelden: wanneer is er sprake van vrijwilligheid? In een groot aantal gevallen waarin een voorwaarde ter voorkoming van strafvervolging wordt opgelegd mogen we aannemen dat de verdachte deze voorwaarde vrijwillig, graag zelfs, ondergaat. Dit is echter niet altijd het geval en het gaat mij daarom te ver de categorie besluiten tot buitengerechtelijke afdoening door het $\mathrm{OM}$ uit te sluiten, hetgeen de implicatie is van art. 1:6 Awb.

De conclusie uit het voorgaande is dat de besluiten van het $\mathrm{OM}$ die leiden tot buitengerechtelijke afdoening door mij in beginsel worden gezien als bestuursbesluiten, waarop administratiefrechtelijke bepalingen van de Awb van toepassing zouden kunnen zijn.

In de volgende hoofdstukken zal worden onderzocht welke regels er gelden voor bestuurshesluiten in het algemeen. Vervolgens wordt bekeken in hoeverre de bestaande regelingen ter zake van buitengerechtelijke afdoening reeds volgens die normen verlopen om daarna te beoordelen of, wanneer dit niet het geval is, regelingen uit het administratieve recht uitkomst kunnen bieden ter verbetering van deze procedures. 
Hoofdstuk 9

\section{Bestuursrechtelijke normen}

\section{Inleiding}

In het eerste deel van dit boek is een overzicht gegeven van de verschillende methoden die door het OM gehanteerd kunnen worden ter afdoening van een strafzaak buiten het 'normale' strafgeding, dat wil zeggen buiten een terechtzitting om, dus zonder dat er een rechter over de zaak geoordeeld heeft. In een aantal gevallen wordt bij een zodanige afdoening door het $\mathrm{OM}$ een sanctie opgelegd, bijvoorbeeld in de vorm van betaling van een geldbedrag of de vervulling van een andere voorwaarde, ter voorkoming van strafvervolging. We hebben daarbij kunnen zien dat er verschuivingen waarneembaar zijn binnen de verschillende wijzen van afdoening, maar ook dat, onder druk der omstandigheden, steeds gezocht is naar nieuwe methoden.

De twee hoofdstukken die aan dit hoofdstuk zijn voorafgegaan, zijn te beschouwen als een soort opmaat naar de in de volgende hoofdstukken te componeren theorie. Allereerst constateerde ik dat het OM, op grond van constitutionele, inhoudelijke en administratiefrechtelijke argumenten beschouwd dient te worden als een onderdeel van de uitvoerende macht, een bestuursorgaan, om vervolgens te kunnen vaststellen dat de besluiten die dan door dat bestuursorgaan, het $\mathrm{OM}$ en de politie, genomen worden in beginsel als bestuursbesluiten te kwalificeren zijn.

Het bestuursrecht sluit bepaalde groepen beschikkingen, waaronder beschikkingen op grond van strafrechtelijke bepalingen, nadrukkelijk uit van de werking van administratiefrechtelijke bepalingen (zie Wet AROB, art. 5 onder g en de Awb art. 1:6 en $8: 4$ en $8: 5$ ).

Het verlaten van het strafproces voor grote groepen van de meer lichtere delicten en het zelfstandig afdoen van deze zaken door het $\mathrm{OM}$ tendeert echter zeer duidelijk naar het bestuursrecht. Zo bedient het $\mathrm{OM}$ zich hierbij van bestuursrechtelijke praktijken, zoals richtlijnen en overlegstructuren. Ook de recent ingevoerde wettelijke regeling inzake de administratiefrechtelijke afdoening van een grote groep verkeersovertredingen is illustratief. De wetgever bezigt zelfs de term 'administratiefrechtelijk'.

Dit brengt mij tot de centrale vraag: in hoeverre lenen de voorschriften van de Awb, welke gelden voor een bestuursorgaan bij het nemen van een discretionaire beslissing 
zich voor de afdoening buiten het strafgeding door het $\mathrm{OM}^{\text {s1 }}$ en in hoeverre c.q. v(x)r welke afdoeningsvormen zou derhalve de uitzondering van art. 1:6 Awb kunnen worden geschrapt?

Ten aanzien van de administratiefrechtelijke handhaving van verkeersvoorschriften ligt toetsing van de procedure aan bestuursrechtelijke regels voor de hand. De transmissie van een aantal verkeersovertredingen van het strafrecht naar het administratief recht impliceert immers dat de handhaving in beginse $1^{5 n}$ dan ook moet voldoen aan bestuursrechtelijke normen. ${ }^{53}$

Om tot toetsing te kunnen overgaan, zal eerst duidelijk moeten zijn welke regels er in het bestuursrecht gelden ten aanzien van een beslissing van een bestuursorgaan. Deze zullen hieronder worden beschreven. Hierbij zal ik aansluiten bij de Awb ${ }^{\text {sid }}$ en de beschrijvingen zoals die in de bestuursrechtelijke literatuur worden gegeven..$^{\text {s/ }}$ Waar mogelijk worden deze geïllustreerd met meer of minder recente uitspraken,

571 Dit is het spiegelfeeld van de in het bestuursrecht, met name in het fiscale recht, veelvuldig gestelde vraag: in hoeverre zijn strafrechtelijke regels van toepassing op administratieve sancties? Zie voor een overzicht van jurisprudentie betreffende deze vraag: P.M. Frielink, Inleiding fiscaal strafrecht, Zwolle 1991, pag. 69-74. Verder onder meer: R.F.W. van Brederode, De rechten van de mens in het belastingrecht, WFR 1987/5779 18 juni 1987, pag. 749-760; NJCM-Werkgroep "Belastingrecht en mensenrechten", Strafvervolging in fiscale zaken. Waar liggen de grenzen? NJCM-bulletin 14-3 (1989), pag. 378-394; G.J.M. Corstens en P.M. Frielink, De Hoge Raad en de fiscale boete: twee maal in de pas, een maal uit de pas, WFR 1989, pag. 216-224.

572 Indien specifieke kenmerken van een bepaald terrein dit noodzakelijk maken laat de Awb uitzonderingen toe. Deze noodzakelijkheid zal dan wel moeten worden aangegeven, MVT Awb, TK 1988-1989, 21221, pag. 6.

573 Zie daarover uitgebreider mijn bijdrage in het NTB mei 1990, pag. 139 e.v. Toetsing van de wet Administraticfrechtelijke handhaving verkeersvoorschriften aan het wetsvoorstel Algemene wet bestuursrecht (m.n. over de procedure) en: Hugo Pennartz, Lex Mulder: van strafrecht naar bestuursrecht. Rechtshulp 1990, no. 6/7, pag. 11-14 (m.n. over de toetsingsgronden).

574 De eerste tranche van de Awb werd als wet5voorstel 21221 bij de Tweede Kamer (1988-1989) ingediend en als Wet van 4 juni 1992 afgekondigd in het Staatsblad 1992, 315. De wet is inwerking getreden op 1 januari 1994. Dit hing samen met het voornemen de inwerkingtreding te laten samenvallen met de inwerkingtreding van de tweede tranche van de Awb. Deze tweede tranche (Tweede Kamer 1991-1992, wetsvoorstel 22495) bevat het bestuursprocesrecht en de invoering van de nicuws bestuursrechter. Ook deze wet is inwerking getreden op 1 januari 1994. Van de derde tranche is eind 1991 een Voorontwerp verschenen (Voorontwerp Algemene wet bestuursrecht, Derde tranche, SDU Den Haag 1991) en op 29 april 1994 een wetsvoorstel ingediend (Aanvulling van de Algemene wet bestuursrecht, derde tranche) Dit wetsvoorstel bevat de volgende onderwerpen: mandaat en delegatie, toexicht op bestuursorganen, subsidies, beleidsregels en handhaving. Voor regels betreffende de motivering wordt een aparte afdeling aán hoofdstuk 3 (was 4) toegevoegd. De regels betreffende de bekendmaking van besluiten worden aangevuld.

575 Met name: J. in 't Veld/N.S.J. Koeman, Beginselen van behoorlijk bestuur, Zwolle 1985; H.D. van Wijk/Willem Konijnenbelt, Hoofdstukken van administratief recht, Culemborg 1988; P. Nicolai, Beginselen van behoorlijk bestuur, Deventer 1990; J.B.J.M. ten Berge en A.Q.C. Tak, Nederlands administratief proeesrecht, deel 1, Zwolle 1983. 
waarin het bestuursbesluiten betrof waarbij, evenals dit bij de afdoening door het OM het geval kan zijn, een sanctie door het bestuursorgaan werd opgelegd. Hierbij valt te denken aan het opleggen van disciplinaire straffen aan ambtenaren (jurisprudentie Centrale Raad van Beroep), het opleggen van een fiscale boete door de belastingrechter of de toepassing sancties in het milieurecht (bijvoorbeeld de dwangsom) zoals dat getoetst kan worden door de Afdeling Geschillen van Bestuur van de Raad van State. Tevens zal gekeken worden naar de vereisten, zoals de Nationale Ombudsman deze stelt aan het optreden van overheidsorganen tegenover burgers in het algemeen. ${ }^{576}$

In het navolgende zal ik eerst enkele algemene opmerkingen maken over bestuursrechtelijke normen, om daarna over te gaan tot een specifieke bespreking van de voorschriften neergelegd in de Awb, waarbij als uitgangspunt wordt genomen de Awb zoals die op 1 januari 1994 inwerking is getreden (eerste en tweede tranche) en het wetsvoorstel derde tranche..$^{\text {sn }}$

Aan het einde van het hoofdstuk zal aandacht worden geschonken aan de nieuwe gerechtelijke procedure, te weten het beroep bij de administratieve kamer van de rechtbank, waar ingevolge de Awb (tweede tranche) besluiten van het bestuursorgaan ter toetsing kunnen worden voorgelegd.

\section{Bestuursrechtelijke normen}

\subsection{Inleiding}

Tot voor kort was het moeilijk algemene regels uit het geschreven bestuursrecht en hestuursprocesrecht te destilleren. De wetgeving op dit gebied was tamelijk onoverzichtelijk en onsamenhangend. Er bestond niet zoiets als hét bestuursrecht of hét bestuursprocesrecht (zoals dat voor het burgerlijk en strafrecht grotendeels wel geldt), maar de regeling van het bestuursrecht was meer een lappendeken van allerlei verschillende wetten. Dit kan gezien worden tegen de achtergrond van de onstuimige groei die het bestuursrecht de laatste jaren ondergaan heeft. Op allerlei deelgebieden van dit rechtsgebied werden wetten vastgesteld, uitvoeringsregelingen gecreëerd en rechterlijke instanties in het leven geroepen, bijvoorbeeld op het gebied van de sociale verzekeringen, ruimtelijke ordening of het milieu, zonder dat er voldoende onderlinge afstemming plaatsvond. ${ }^{\text {57 }}$

576 Hierbij moet in het oog worden gehouden dat de Nationale Ombudsman niet mag worden beschouwd als ecn administratieve rechicr.

577 TK 1993-1994, 23700.

578 Zie hierover uitgebreider: A.Q.C. Tak, De Algemene wet bestuursrecht (het nieuwe bestuursprocesrecht), tweede druk, Zwolle 1993, pag. 1-14; MVT Awb, TK 1988-1989, 21221, pag. 3. 
De Algemene wet bestuursrecht (Awb) beougt een algemene regeling voor het gehele bestuursrecht te treffen. Eén van de doelstellingen van de Awb is dan ook de eenheid binnen de bestuursrechtelijke wetgeving te bevorderen. ${ }^{\text {sm }}$

Bij mijn onderzoek naar de mogelijkheid bestuursrechtelijke regels toe te passen op de methodes ter afdoening van strafbare feiten buiten het strafgeding om, zal ik me dan ook zoveel mogelijk baseren op de bestuursrechtelijke normen zoals deze in de Awb zijn neergelegd.

\subsection{Geschreven en ongeschreven normen}

Een deel van het bestuursrecht is neergelegd in geschreven normen. Tot \pm 1940 bestonden er alleen geschreven normen. Voorschriften met betrekking tot bestuursbesluiten, bijvoorbeeld aangaande de aanvraag, de behandeling van de aanvraag en de verlening van een beschikking of de termijn voor bezwaar of beroep tegen een (afwijzende) beschikking, zijn in verschillende wettelijke regelingen neergelegd. Bestuursorganen zijn naar huidige opvatting bij hun activiteiten echter niet alleen gebonden aan geschreven rechtsregels, maar dienden daarnaast te handelen naar regels van ongeschreven recht: de algemene beginselen van behoorlijk bestuur (abbb). Deze beginselen hebben zich in de jurisprudentie ontwikkeld als een afzonderlijke rechterlijke toetsingsgrond. ${ }^{500}$ Een aantal van deze beginselen zijn als categorie in de loop der tijd in de afzonderlijke administratiefrechtelijke wetten als toetsingsgrond opgenomen, zoals daar bijvoorbeeld zijn art. 8 Wet AROB, art. 2 TwK, art. 5 ARBO, art. 58 Ambt.wet 1929 en art. 27 lid 2 AWR. Art. 26 Wet NO heeft als algemene toetsingsgrond de vraag of het administratief orgaan zich in de door de Nationale Ombudsman onderzochte aangelegenheid al dan niet behoorlijk heeft gedragen. Volgens art. 8 AROB kan beroep worden ingesteld indien: (a) de beschikking met een algemeen verbindend voorschrift strijdt; (b) het administratieve orgaan bij het geven van de beschikking van zijn bevoegdheid kennelijk tot een ander doel gebruik heeft gemaakt dan tot de doeleinden, waartoe die bevoegdheid is gegeven; (c) het administratieve orgaan bij de afweging van de betrokken belangen niet in redelijkheid tot de beschikking heeft kunnen komen; (d) het administratieve orgaan anderszins heeft beschikt in strijd met enig in het algemeen rechtsbewustzijn levend beginsel van behoorlijk bestuur.

570 Dit betekent niet dat afwijking van deze algemene regels in gcen enkel geval mogelijk zal zijn. De vraag welke afwijkingen van de algemene wet in bestaande bijzonderc wetten moeten worden gehandhaafd, wordt bij de aanpassingswetgeving, waarin de geldende wetgeving aan de nieuwe wet wordt aangepast, bcantwoord.

580 Zie voor een (zeer) vitgebreide beschrijving van de historische ontwikkeling van deze beginselcn: P. Nicolaï, Beginselen van behoorlijk hestuur, Deventer 1990, pag. 11-205. 
De uitwerking van de genoemde beginselen vond plaats in de rechtspraak, door de verschillende administratieve rechters.

Ten aanzien van de uitwerking van de meeste beginselen van behoorlijk bestuur, zoals het zorgvuldigheidsbeginsel, het verbod van détournement de pouvoir, het motiveringsbeginsel, beginsel van fair play (gedeeltelijk), het evenredigheidsbeginsel en het verbod van willekeur zijn thans in de Awb een aantal bepalingen opgenomen. Het voordeel hiervan is dat deze beginselen nu rechtstreeks als positieve gedragsnorm voor het bestuursorgaan zijn geformuleerd. Er heeft echter (nog) geen codificatie plaatsgevonden van alle algemene beginselen. ${ }^{\text {s.1 }}$ Zo ontbreekt vooralsnog het beginsel dat gerechtvaardigde verwachtingen dienen te worden geëerbiedigd. ${ }^{92} \mathrm{Het}$ wel opnemen van uitwerkingsbepalingen betekent niet dat de ontwikkeling van de bedoelde algemene beginselen daarmee ten einde is: het mag geen belemmering zijn voor nieuwe ontwikkelingen in de rechtspraak. ${ }^{\text {skt }}$

Wanneer in het navolgende de algemene beginselen van behoorlijk bestuur behandeld gaan worden, baseer ik me op zowel de geschreven als de ongeschreven uitwerking ervan.

Hoewel de algemene beginselen van behoorlijk bestuur in eerste instantie een rol speelden als toetsingsgrond door de rechter, ligt hun belangrijkste functie nu daarin dat zij richtsnoer zijn voor overheidshandelen. Het zijn normen waarnaar het bestuursorgaan zich bij de uitvoering van haar taak ten opzichte van de burger heeft te gedragen.

Bij de behandeling van de bestuursrechtelijke voorschriften volg ik, zoals gezegd, zoveel mogelijk de Awb. Algemene beginselen welke elders of nog niet zijn opgenomen, komen daarna afzonderlijk aan de orde.

In meerdere wetten en in de literatuur worden verschillende indelingen en benamingen van de algemene beginselen van behoorlijk bestuur gehanteerd. ${ }^{\text {ses }}$ Deze indelin-

581 Dit houdt verband met het karakter van deze wetgeving, zg. aanbouwwetgeving: niet alle delen van de wet komen tegelijkertijd tot stand. MvT Awb, TK 1988-1989, 21221, pag. 9; Vgl. M. Scheltema, De Algemene wet bestuursrecht, NJB 1994, pag. 2-8, m.n. pag. 3.

$582 \mathrm{De}$ MvT vermeldt dat dit beginsel zal worden opgenomen met latere bepalingen over intrekking en wijziging van besluiten, MVT Awb, TK 1988-1989, 21221, pag. 61; Vgl. M. Scheltema, De Algemene wet bestuursrecht, NJB 1994, pag. 6. Zie hicrover ook de noot van F.H. van der Burg onder de zaak Alutech, Hof van Justitie van de Europese gemeenschappen, 20 september 1990, AB 1993, 143.

583 Vgl. M. Scheltema, De Algemene wet bestuursrecht, NJB 1994, pag. 6.

584 Vgl. H.D. van Wijk/Willem Konijnenbelt, a.w., pag. 75; P. Nicolaï, a.w., pag. 255; J.B.J.M. ten Berge en A.Q.C. Tak, Nederlands administratief procesrecht, deel 1, Zwolle 1983, pag. 293; MVT Awb, TK 1988-1989, 21221, pag. 65.

585 Zie bijvoorbecld: art. 5 ARBO, art. 8 AROB of art. 58 Ambt. wct (1929). Zic voor indelingen in de literatuur bijvoorbeeld: W. Duk, Maatstaven voor beoordeling van sancties, AA 1981, pag. 231-238; J.B.J.M. ten Berge en A.Q.C. Tak, Nederlands administratief procesrecht 1983, pag. 2.3.341; 
gen beogen bij te dragen aan de gedachtenvorming over de beginselen. Vandaar dat soms van een verregaande rubricering en gedetailleerde benoeming sprake is (Nicolaii). Het doel van dit boek is anders. Onderzocht gaat worden of en in hoeverre de beginselen van behoorlijk bestuur in het algemeen ook richtsnoer zouden moeten zijn voor het $O M$, als bestuursorgaan bij de afdoening van strafbare feiten buiten het strafgeding. Een vergaande indeling en benoeming zou dit doel, denk ik, niet ten goede komen. Daarom heb ik gekozen voor de benamingen van de beginselen zoals die in de wet en jurisprudentie doorgaans worden onderscheiden.

\section{Algemene wet bestuursrecht}

\subsection{Algemeen}

De kern van het wetsvoorstel Awb wordt gevormd door de regeling van het besluit (die in het bestuursrecht een centrale rol speelt) en die van het bezwaar en beroep, in samenhang met algemene bepalingen betreffende de administratieve rechtsbescherming. Regels omtrent de beschikking worden gegeven in hoofdstuk 3, waarin algemene bepalingen over besluiten staan beschreven, en in hoofdstuk 4, dat bepalingen over afzonderlijke soorten besluiten bevat (naar mijn mening was de titel 'Bepalingen over bijzondere besluiten' dan ook beter geweest dan 'Bijzondere bepalingen over besluiten'). ${ }^{586}$ In hoofdstuk 6 wordt een aantal algemene regels gegeven met betrekking tot de rechtsbescherming. Hoofdstuk 7 geeft afzonderlijke regels over het administratief bezwaar en afzonderlijke regels over het administratief beroep (hier is de titel wél juist). Hoofdstuk 8 bevat een algemene regeling van het bestuursprocesrecht. Hierbij moet worden bedacht dat een groot gedeelte van het nieuwe procesrecht reeds in de eerste tranche werd geregeld, namelijk in de bepalingen betreffende bezwaar en beroep (hoofdstukken 6 en 7 ).

In het navolgende zal, voor zover de hoofdstukken voor bespreking in aanmerking komen, dezelfde volgorde worden aangehouden.

Voor de duidelijkheid wordt erop gewezen dat normen uit de Awb, die voor ons onderwerp niet van belang zijn, niet besproken worden. Zo worden voorschriften die zich niet richten tot een bestuursorgaan maar bijvoorbeeld tot de burger of tot derden, in dit kader niet aan de orde gesteld.

ABAR-rapport 1984, Se druk, pagr. 116-204; J. in 't Veld en N.S.J. Kocman, Beginsclen van behoorlijk bestuur, Zwolle 1985; H.D. van Wijk en Willem Konijnenbelt, Hoofdstukken van administraticf recht, Culemborg 1988, pag. 85 e.v.; P. Nicolai, Beginselen van behoorlijk bestuur, Deventer 1990 , hoofdstuk 11.

586 Regeling van andere afzonderlijke besluiten zoals beleidsregels is te vinden in de derde tranche. 
Tevens zullen bepalingen over bijzondere besluiten, niet zijnde een beschikking, buiten beschouwing blijven, omdat er bij een vervolgingsbeslissing, zoals we eerder constateerden, wel sprake is van een beschikking. Wel zullen de bepalingen omtrent beleidsregels aan de orde komen.

De Awb kent de volgende indeling:

1. Inleidende bepalingen

1A. Bepalingen over bestuursorganen (wetsvoorstel derde tranche)

2. Verkeer tussen burgers en bestuursorganen

3. Algemene bepalingen over besluiten

3.1 Inleidende bepalingen

3.2 Zorgvuldigheid en belangenafweging

3.3 Advisering

3.4 Openbare voorbereidingsprocedure

3.5 Uitgebreide openbare voorbereidingsprocedures

3.6 Bekendmaking en mededeling

4. Bijzondere bepalingen over besluiten (gedeeltelijk wetsvoorstelderde tranche)

4.1 Beschikkingen

4.1.1 De aanvraag

4.1.2 De voorbereiding

4.1.3 Beslistermijn

4.1.4 Motivering (gaat in wetsvoorstel derde tranche naar hoofdstuk 3)

5. Handhaving (wetsvoorstel derde tranche)

6. Algemene bepalingen over bezwaar en beroep

7. Bijzondere bepalingen over bezwaar en administratief beroep

8. Bijzondere bepalingen over beroep bij de rechtbank

9. Overgangs- en slotbepalingen

\subsection{Inleidende bepalingen}

In het eerste hoofdstuk van de Awb wordt een dantal begrippen vastgesteld. Dit hoofdstuk bevat dus geen expliciete normen voor het gedrag van bestuursorganen bij het nemen van bestuursbesluiten.

Vermelding van één bepaling lijkt me hier echter wel van belang, omdat daaruit wellicht een norm af te leiden is. Ik heb hier het oog op een zinsnede uit art. 1:3: "In deze wet wordt verstaan onder besluit: een schriftelijke beslissing van een bestuursorga:n, inhoudende een bestuursrechtelijke rechtshandeling". Volgens de toelichting bij dit artikel zal in het algemeen schriftelijke vastlegging slechts achterwege blijven als het besluit gericht is op onmiddellijke uitvoering door degene aan wie 
het mondeling of door een teken wordt bekend gemaakt. ${ }^{577}$ In het vorige hoofdstuk hebben we gezien dat schriftelijke vastlegging van een besluit nog om een andere reden wenselijk is, namelijk wegens bewijstechnische gronden. Het is te betreuren dat de toelichting bij de Awb dit argument niet noemt.

\subsection{Verkeer tussen burgers en bestuursorganen}

De artikelen 2:1 en 2:2 behandelen de regeling van rechtsbijstand en vertegenwoordiging. Erkend wordt dat rechtsbijstand niet slechts noodzakelijk is in procedures voor een rechter, maar in iedere fase van het bestuurlijk proces, zo ook de beroepsfase. Art. 2:1 geeft de belanghebbende het recht zich in het verkeer met een bestuursorgaan te laten bijstaan. Hiernaast bestaat de mogelijkheid dat de belanghebbende zich laat vertegenwoordigen. Art. 2:2 geeft het bestuursorgaan de bevoegdheid tot weigering van vertegenwoordiging of bijstand door een bepaalde persoon tegen wie ernstige bezwaren bestaan. Deze bevoegdheid ontbreekt ten aanzien van advocaten (lid 3).

Art. 2:3 is gewijd aan de situatie dat een geschrift door de belanghebbende gezonden is naar een onbevoegd bestuursorgaan. Dit orgaan is verplicht dit geschrift onverwijld naar het bevoegde orgaan door te sturen en hiervan melding te maken aan de afzender. Van belang is hier alvast te vermelden dat voor het doorzenden van bezwaaren beroepschriften een bijzondere regel is opgenomen in art. 6:15 Awb.

Art. 2:4 legt het bestuursorgaan de verplichting op zich objectief op te stellen. Letterlijk: het bestuursorgaan vervult zijn taak zonder vooringenomenheid. Het gaat er hierbij om dat het bestuursorgaan de hem toevertrouwde belangen niet oneigenlijk behartigt door zich bijvoorbeeld door persoonlijke belangen of voorkeuren te laten beïnvloeden. ${ }^{588}$ In het tweede lid van art. 2:4 wordt deze regel nader uitgewerkt voor de situatie dat personen die tot het betreffende bestuursorgaan behoren of die voor dat orgaan werkzaam zijn een persoonlijk belang bij het te nemen besluit hebben. In dit geval dient ervoor te worden gewaakt dat deze personen de besluitvorming beïnvloeden. Voorkomen moet worden dat er een vermenging van belangen optreedt.

Begrijp ik het goed, dan kan in deze bepaling een onderdeel van het beginsel van fair play worden gezien. ${ }^{\star}$ Dit beginsel immers verbiedt het overheidsorgaan op een zodanige wijze te handelen dat daardoor de burger de mogelijkheid voor zijn recht op te komen wordt ontnomen of bemoeilijkt. Dit handelen van het orgaan kan formeel niet in strijd zijn met de wet, maar toch leiden tot een unfaire benadering

587 MvT Awb, TK 1988-1989, 21221, pag. 37.

588 MvT Awb, TK 1988-1989, 21221, pag. 53.

589 De MvT noemt dit beginsel als zodanig niet. 
van de burger. Verder volgt uit dit beginsel dat het bestuursorgaan elke schijn van partijdigheid dient te vermijden. Dit beginsel is overigens nooit tot ontwikkeling gekomen. In de jurisprudentie komt toetsing aan dit beginsel slechts sporadisch voor. In de door mij bekeken jurisprudentie met betrekking tot het opleggen van een administratieve sanctie ben ik toetsing aan dit beginsel niet tegengekomen. ${ }^{. * 0}$

Art. 2:5 bevat een geheimhoudingsbepaling. Degenen die betrokken zijn bij de uitvoering van een bestuurstaak zijn verplicht gegevens waarvan zij het vertrouwelijk karakter kennen of redelijkerwijs moeten vermoeden geheim te houden.

\subsection{Algemene bepalingen over besluiten}

Hoofdstuk 3 heeft betrekking op voorschriften die in beginsel op alle bestuursbesluitenvan bestuursorganen van toepassing zijn. ${ }^{.91}$ Voor de verschillende soorten besluiten (bijvoorbeeld de beschikking of de beleidsregel) zijn meer toegesneden bepalingen opgenomen in hoofdstuk 4.

Hoofdstuk 3 bevat onder andere de codificatie van een groot aantal algemene beginselen van behoorlijk bestuur. In art. 3:2 komt één aspect aan bod van het zorgvuldigheidsbeginsel, namelijk de vergaring door het bestuursorgaan van de nodige kennis omtrent de feiten en de af te wegen belangen in de voorbereidingsfase.

Een ander aspect van dit beginsel, eveneens betrekking hebbend op de voorbereiding van een besluit is neergelegd in art. 3:4 lid 1: zorgvuldige afweging van alle betrokken belangen.

In art. 3:3 is het verbod van détournement de pouvoir neergelegd: het bestuursorgaan mag de bevoegdheid tot het nemen van een besluit niet voor een ander doel gebruiken dan waarvoor die bevoegdheid is verleend.

Het zogenaamde evenredigheidsbeginsel is gecodificeerd in het tweede lid van art. 3:4: de voor een of meer belanghebbenden nadelige gevolgen van een besluit mogen niet onevenredig zijn in verhouding tot de met het besluit te dienen doelen. Tevens strekt dit tweede lid ertoe het verbod van willekeur te codificeren. ${ }^{922}$ In afdeling 3.6 komt de motiveringsplicht aan de orde. Deze materie kreeg in de eerste tranche aanvankelijk een plaats in hoofdstuk 4. In het Voorlopig Verslag werd de vraag

590 In HR 8 april 1987, BNB 1987/191 m.nt. H.J. Hofstra, werd een regeling met betrekking tot een belastingaanslag vernietigd op grond van het zorgvuldigheidsbeginsel, hoewel naar mijn mening het fair play-beginsel aan de orde leek te zijn. $\mathrm{Na}$ indiening van een bezwaarschrift tegen een belastingaanslag kwam tussen betrokkene en inspectie een compromis tot stand met betrekking tot de aft rckbaarheid van bepaalde kosten. Betrokkene werd hierbij echter op een zodanige manier onder druk gezet dat hij niet vrij was in zijn beslissing zich met het compromis accoord te verklaren.

$591 \mathrm{Vgl}$. een uitspraak van de AR RvS waaruit blijkt dat beleidsregels moeten voldoen aan de algemene normen voor besluiten: AR RVS 24 september 1992, AB 1993, 61 m.nt. RMvM, waarin een beleidsregel in strijd werd geacht met het formele zorgvuldigheidsbeginsel (art. 3:2 Awb).

592 MvT Awb, TK 1988-1989, 21221, pag. 61 
opgeworpen of de regeling van de motivering niet slechts voor beschikkingen zou gelden, maar voor alle besluiten. ${ }^{53}$ In de MvA werd toegezegd dat deze materie in de derde tranche nader zou worden bezien. ${ }^{\text {s. }}$ Het wetsvoorstel Awb derde tranche geeft de regeling van de motivering een plaats in hoofdstuk 3, afdeling 3.7. Inhoudelijk komen de bepalingen grotendeels overeen met de regeling zoals die in eerste tranche in hoofdstuk 4 was neergelegd, met dien verstande dat nu niet meer gesproken wordt van motivering van de beschikking maar van het besluit.

In het navolgende krijgen deze beginselen ruimer aandacht, gevolgd door de nog niet gecodificeerde beginselen, die natuurlijk ook als algemene bepalingen over besluiten moeten worden gezien.

\subsubsection{Zorgvuldigheidsbeginsel}

Dit beginsel houdt in dat een besluit op een zorgvuldige wijze moet zijn voorbereid en genomen. Zoals hierboven reeds vermeld is dit beginsel neergelegd in art. 3:2 en art. 3:4 lid 1. De zorgvuldige voorbereiding van de beschikking wordt uitgewerkt in de afdelingen 3.4 en 3.5 . $^{\text {.rs }}$

Alle relevante feiten en omstandigheden dienen te worden onderzocht en meegewogen. Indien het bestuursorgaan zelf niet beschikt over de noodzakelijke kennis heeft het de verplichting om advies te vragen, zodat op die manier een verantwoorde beslissing kan worden genomen. Het bestuursorgaan houdt dan wel een eigen bevoegdheid tot de vaststelling van feiten en omstandigheden en is zelf voor de beslissing verantwoordelijk. ${ }^{\text {sæi }}$ Het bestuursorgaan behoeft zich niet door het advies te laten leiden, het mag ervan afwijken. In dat geval heeft het echter wel de verplichting dit goed te motiveren.

Het zorgvuldigheidsvereiste bevat de volgende elementen:

1. onderzoek van alle feiten en omstandigheden:

a. advisering;

b. hoor en wederhoor ${ }^{97}$;

593 VV Awb, TK 1988-1989, 21221, nr. 4, vraag 143.

594 MvA Awb, TK 1990-1991, 21221, nr. 5, pag. 80.

595 Vgl. een uitspraak van de Nationale Ombudsman van 7 december 1992, AB 1993, 84 m.nt. PJS.

596 Een functiewaarderingsbesluit werd door de CRvB geacht te zijn genomen in strijd met de zorgvuldighcid, omdat aan de behandeling door de benwarencommissie en aan de totstandkoming van het advies aan B\&W gebreken kleefden, CRvB 9 januari 1090, TAR 1990, 54.

597 Een besluit werd geoordecld in strijd met de zorgvuldigheid te zijn genomen nadat de betrokkene (ontslagen ambtenaar) niet tijdig in kennis werd gesteld van de schriftelijk en mondeling tegen hem ingebrachte feiten en omstandigheden, verklaringen van getuigen niel ondertekend waren en niet aan de betrokkene ter beschikking waren gesteld (CRvB 15 december 1988, TAR 1989 nr. 46). Het zorgvuldigheidsheginsel vereist volgens de Nationale Ombudsman tevens dat het beginsel 
2. voortvarendheid van het onderzoek ${ }^{598}$;

3. afwegen van alle betrokken belangen.

\subsubsection{Verbod van détournement de pouvoir}

Dit beginsel houdt in dat een bestuursorgaan een bevoegdheid niet voor een ander doel mag gebruiken dan waarvoor die bevoegdheid is verleend. ${ }^{\text {s9o }}$ Deze beroepsgrond was reeds in verschillende wetten opgenomen. Ook de Awb heeft er plaats voor vrijgemaakt in art. 3:3. In de bestuursrechtelijke jurisprudentie speelt dit beginsel echter geen grote rol. Op zich is dit niet onbegrijpelijk. Het begrip speelt vooral een rol bij de interpretatie van wettelijke bepalingen. De volgende redenering kan dan worden gebruikt: de bevoegdheidsuitoefening is in strijd met het doel van de wettelijke regeling dus de bevoegdheidsuitoefening is in strijd met de wet (een afzonderlijke toetsingsgrond). Bovendien is het moeilijk détournement de pouvoir aan te tonen. Hiervoor moet men de motieven weten van het bestuursorgaan. Deze zullen, wanneer er sprake is van détournement de pouvoir, niet snel naar voren worden gebracht. Bij toetsing aan buitenwettelijke bevoegdheden kan het begrip wel degelijk een rol spelen. Sommigen zien het verbod van détournement de pouvoir als een toepassing van het specialiteitsbeginsel hetgeen inhoudt dat iedere administratieve wet slechts op haar eigen speciale, door die wet afgebakende terrein mag worden toegepast en niet mag dienen tot het bereiken van daarbuiten gelegen doeleinden. ${ }^{\infty}$ In de rechtspraak inzake de oplegging van administratieve sancties kwam ik een beroep op dit beginsel niet tegen.

van hoor en wederhoor wordt toegepast (NO 28 juni 1989, AB 1989, 459; NO 29 september 1989, AB 1989, 559).

598 Uit jurisprudentie van de Nationale Ombudsman blijkt dat onder het zorgvuldigheidsvereiste ook wordt verstaan dat het overheidsorgaan verzoeken van burgers met voortvarendheid moet behandelen. Een interne organisatic bijvoorbeeld vormt geen rechtvaardiging (NO 28 februari 1989, AB: 1989, 222; NO 24 april 1989, AB 1989, 274; NO 4 oktober 1989, AB 1989, 560; NO 16 november 1989, AB 1990, 138). Soms is een langere behandelingstermijn nodig. De betrokkene moet dan wel tussentijds op de hoogte worden gehouden (NO 28 februari 1990, AB 1990, 333).

599 Nicolai ziet hierin niet een afzonderlijk beginsel, maar plaatst dit verbod onder het beginsel van een draagkrachtige motivering. Hanteert het orgaan haar bevoegdheid immers voor een niet bedold doel, dan berust dat op een onjuiste interpretatie van de betreffende wettelijke bepaling. J. Nicolaï, a.w., pag. 354-355.

600 Vgl. F.H. van der Burg, G.J.M. Cartigny en M. Overkleeft-Verburg, Rechtsbescherming tegen de overheid, 1985, pag. 109; F.A.M. Stroink en B.W.N. de Waard, Het specialiteitsbeginsel, uit: Burger en overheid (Steenbeekbundel), 1984. 
Dit evenredigheidsbeginsel heeft betrekking op de verhouding tussen het doel dat het bestuursorgaan met een bepaald besluit wil bereiken en de middelen en maatregelen die het daartoe hanteert. Doel en middelen moeten met elkaar in verhouding staan. ${ }^{\text {601 }}$

'Tot voor kort speelde dit beginsel voornamelijk een rol bij het opleggen van administratieve sancties. Het evenredigheidsbeginsel hield in dat er evenredigheid moest bestaan tussen de op te leggen sanctie en de ernst van de normovertreding. Algemene hantering van het evenredigheidsbeginsel bij strafoplegging in het bestuursrecht is van betrekkelijk recente datum. Alleen de Ambtenarenwet 1929 kent dit beginsel van oudsher als toetsingsgrond in art. $58 \mathrm{lid} 3 .^{602}$ In andere zaken betreffende strafoplegging in het bestuursrecht werd wel impliciet, doch tot voor kort niet expliciet aan dit beginsel getoetst. Toetsing vond plaats aan de zogenaamde 'c-grond': de onredelijke belangenafweging ${ }^{63}$ as, strijd met de zorgvuldigheid of aan het motiveringsbeginsel. ${ }^{605}$

In een kwestie met betrekking tot de intrekking van een ontheffing van een sluitingsuur toetste de AR RvS expliciet en stelt vast dat dit beginsel in zijn toepasselijkheid op het opleggen van administratieve sancties behoort tot de in het algemeen rechtsbewustzijn levende beginselen van behoorlijk bestuur. ${ }^{606}$ Ook de CRvB toetst aan het evenredigheidsbeginsel. Hierbij moet worden bedacht dat de sociale zekerheidswetgeving geen toetsingsgronden noemt. In twee meer recente gepubliceerde uitspraken van de CRvB wordt expliciet aan het evenredigheidsbeginsel getoetst. ${ }^{607} \mathrm{Het}$ ging hierbij om sanctietoepassing in het kader van art. 27 lid $1 \mathrm{WW}$.

601 Zie: E.M.H. Hirsch Ballin en A.J.C. de Moor-van Vugt, Doel en middel in het bestuursrecht, AA 1986, pag. 783-790, m.n. 788-789.

602 Zie bijvoorbeeld CRvB 21 februari 1989, TAR 1989, 91; 11 juli 1989, TAR 1989, 188; Nog in CRvB 2 januari 1990, TAR 1990, 52 besliste de Raad dat bij de tenuitvoerlegging van een voorwaardelijke straf geen plaats is voor een onevenredigheidstoetsing.

603 Zie bijvoorbeeld AR RvS 1 juli 1985, AB 1986, 91 , geannoteerd in hiervoor aangehaald artikel van Hirsch Ballin en De Moor-van Vugt; CRvB 12 mei 1987, RSV 1988, 28; andere voorbeelden worden genoemd door Van Wijk/Konijnenbelt, a.w., pag. 124.

604 Nicolai erkent dit evenredigheidsbeginsel dan ook niet als een apart beginsel, maar rekent het tot het beginsel van redelijke en billijke belangenafweging. J. Nicolai, a.w., pag. 325-326.

$605 \mathrm{Vgl}$. A.J.C. de Moor-Van Vugt, Algemene beginselen van behoorlijk bestuur en buitenlandse equivalenten, Zwolle 1987, pag. 34.

606 AR RvS 15 maart 1989, Gem.st. 1989, 6878, pag. 223-225.

$607 \mathrm{Zie}$ over de toetsing van sancties van de WW aan het evenredigheidsbeginsel: A.F.M. Brenninkmeijer en Y.D.M. Zoomers, De rechterlijke toetsing van sancties in het bestuursrecht, NTB 1988/2, pag. 49-56, m.n. pag. 53-54.

608 CRvB 31 juli 1990, AB 1991, 3; CRvB 14 augustus 1990, AB 1991, 4. Voor beide uitspraken geldt dat ze zijn afgedrukt in Administratiefrechtelijke beslissingen/NJ 1990. Ik neem aan dat het hier om een vergissing gaat en 1991 is bedoeld. De publicatie vond plaats in de cerste aflevering van $A B$ van 1991. 
uitspraak toetste de Raad zowel de redelijkheid als de evenredigheid van de getroffen sanctie:

"De Raad heeft in de omstandigheden van dit geval dan ook geen aanleiding kunnen vinden om te oordelen dat gedaagde niet in redelijkheid tot de door hem getroffen sanctie heeft kunnen geraken noch ook dat het treffen van die sanctie strijd oplevert met enig ander hrginsel van behoorlijk bestuur waaronder meergenoemd evenredigheidsbeginsel".

In de tweede zaak werd iemand ontslagen en geplaatst in de hoogste sanctie-categorie, waarbij de sanctie van een blijvend gehele weigering van uitkering was opgelegd. De Raad achtte het besluit betrokkene in te delen in de zwaarste boete-categorie niet in strijd met de redelijkheid (getoetst als verbod van willekeur), maar was wel de mening toegedaan dat er i.c. geen evenredigheid bestond tussen de opgelegde sanctie en de ernst van het handelen van betrokkene.

Een uitspraak van de AG RvS van 22 april 1993, AB 1993, 387, is interessant, omdat daar de evenredigheidstoetsing een rol speelde bij cumulatie van een strafsanctie en een administratieve sanctie. Kort de feiten: betrokkene heeft gehandeld in strijd met art. 30 lid $2 \mathrm{ABW}$ door inkomsten van zijn echtgenote niet te vermelden. Hij wordt daarvoor door de strafrechter veroordeeld tot drie maanden voorwaardelijke hechtenis. Tevens wordt een administratieve sanctie opgelegd in de vorm van strafkorting. Betrokkene beroept zich op art. 14 lid 7 IVBP (schending ne-bis-in-idem beginsel) $e n$ is verder van mening dat bij het bepalen van de hoogte van de administratieve sanctie geen rekening is gehouden met de cumulatie van de straffen. De AG redeneert als volgt: (1) Nederland heeft art. 14 lid 7 IVBP slechts aanvaard voor zover daaruit geen verdere verplichtingen voortvloeien dan zijn neergelegd in art. $68 \mathrm{Sr}$.; (2) De strafrechter heeft rekening gehouden met de administratieve sanctie, zodat niet omgekeerd weer bij het bepalen van de administratieve sanctie rekening moet worden gehouden met de strafsanctie; (3) Gezien de ernst van de gebleken feiten, de duur van de periode waarin deze zich hebben voorgedaan, de mate van verwijtbaarheid en de omstandigheden van appellant, kan de opgelegde sanctie qua hoogte en duur niet als onevenredig worden aangemerkt.

Van meer recente datum is de hantering van het evenredigheidsbeginsel als beginsel van behoorlijke belangenafweging. ${ }^{\circ}$ Er moet evenredigheid bestaan tussen het door het bestuur te dienen belang en het belang dat daardoor wordt aangetast. In de Awb is het evenredigheidsheginsel in deze zin gecodificeerd in art. 3:4 lid 2. Het evenredigheidsbeginsel is in dat artikel neergelegd samen met het zorgvuldigheidsbeginsel en het verbod van willekeur, beginselen die, evenals het evenredigheidsbeginsel, te maken hebben met belangenafweging en die in de jurisprudentie eerder in de

609 Overigens bediende Wiarda zich in 1952 reeds van de term 'beginsel der evenwichtigheid'. GJ. Wiarda, Algemenc beginsclen van behoorlijk bestuur, preadvies VAR XXIV, Haarlem 1952, pag. 84-89. 
plaats van het evenredigheidsbeginsel werden gehanteerd (zie hierboven). Toespitsing van art. 3:4 lid 2 op het evenredigheidsbeginsel heeft te maken met de omstandigheid dat de zogenaamde c-grond, zoals die in verschillende administratieve wetten voorkomt, zich niet leent voor opneming in de Awb. Bovendien krijgt het evenredigheidsbeginsel hierdoor een ruimer toepassingsbereik dan de disciplinaire strafoplegging. Hiermee is aangesloten op jurisprudentie van het Hof van Justitie van de Europese Gemeenschappen. ${ }^{\text {610611 }}$

In het wetsvoorstel Awb (derde tranche) speelt het evenredigheidsbeginsel een rol bij het opleggen van een dwangsom. In art. 5.3.1 lid 4 laatste volzin is namelijk te lezen dat het vastgestelde bedrag (van de dwangsom) in redelijke verhouding dient te staan tot de zwaarte van het geschonden belang en de beoogde werking van de dwangsomoplegging. In de MvT wordt dit overigens niet nader toegelicht.

In de jurisprudentie is dit evenredigheidsbeginsel al enige keren expliciet toegepast, vooral op het gebied van de rechtshandhaving. De Moor-van Vugt maakt hierbij een onderscheid tussen het evenredigheidsbeginsel als beginsel van behoorlijke bestuurlijke straftoemeting en als beginsel van behoorlijke belangenafweging als het gaat om handhaving van het objectieve recht, zoals bij bestuursdwang. ${ }^{612}$ Uit het overzicht dat zij geeft blijkt dat de verschillende administratieve rechters het evenredigheidsbeginsel vooral hanteerden als beginsel van sanctierecht.

Voor de volledigheid wordt hier vermeld dat het evenredigheidsbeginsel verder een rol kan spelen op het grensgebied met het gelijkheidsbeginsel, met name waar het gaat om de gelijke verdeling van publieke lasten. Dit impliceert dat de nadelige gevolgen van overheidsmaatregelen in het algemeen belang in principe voor alle betrokken particulieren gelijk zijn. Dit beginsel van lastengelijkheid heeft vorm gekregen in het instituut van financiële bestuurscompensatie ter zake van rechtmatig overheidshandelen. Daar dit onderwerp in ons onderzoek niet van toepassing is, wordt hiervoor naar andere literatuur verwezen. ${ }^{613}$

\subsubsection{Verbod van willekeur}

Dit verbod van willekeur, ook wel genoemd kennelijke onredelijkheid, wordt in verschillende wetten als volgt omschreven: "dat het administratieve orgaan bij afwe-

610 MvT Awb, TK 1988-1989, 21221, pag. 69.70.

611 Zie yoor een overzicht van de jurisprudentie van het Hof van Justitie: A.J.C. de Moor-van Vugt, Symbiose van evenredigheidstoersen? NTB 1993/1, pag. $26-37$.

612 A.J.C. de Moor-van Vugt, Symbiose van evenredigheidstoetsen? NTB 1993/1, pag. 26-37.

613 Zie bijvoorbeeld: S. Prechal en T. Heukels, A.tgemene beginselen in het Nederlandse recht en het Europees recht: rechtsvergelijking en interactic, SEW 1986, pag. 305-307 en de daar aangehaalde literatuur en jurisprudentie. 
ging van de betrokken belangen niet in redelijkheid tot de beschikking heeft kunnen komen", zie bijvoorbeeld art. 8 lid 1 onder c AROB, art. 5 onder c Wet ARBO, art. 58 lid 1 onder c Ambtenarenwet 1929. Ook wordt wel gesproken van de zogenaande 'c-grond'. ${ }^{\text {st }}$ Volgens Donner wordt aldus in een negatieve formulering naar de norm verwezen dat aan iedere beslissing een afwegen van alle in aanmerking komende belangen ten grondslag moet liggen, dat die belangen overeenkomstig hun ernst en gewicht behoren mee te wegen en dat geen belangen, die niet in aanmerking behoren te komen, gewicht mogen hebben. ${ }^{\text {.15 }}$ Overigens relativeert Donner de scherpe scheiding tussen détournement de pouvoir, het willekeursverbod en schending van algemene beginselen van behoorlijk bestuur. Volgens hem zijn het drie "invalshoeken" voor de toetsing van ambtelijk fatsoen. ${ }^{616}$ Tak en Bakker zien dit verbod van willekeur als het centrale, aan alle overheidsoptreden (dus inclusief wetgeving en rechtspraak) gemeenschappelijke, toetsingsbeginsel."17

Art. 3:4 Awb strekt ertoe het verbod van willekeur te codificeren. Van willekeur is sprake bij afwezigheid van afweging van alle in aanmerking komende belangen, indien die belangen niet naar ernst en gewicht zijn meegewogen of belangen zijn meegewogen die niet in aanmerking hadden behoren te komen.

Vaak heeft een bestuursorgaan bij het nemen van een bepaalde beslissing een discretionaire bevoegdheid. Er is ruimte tot het voeren van een beleid. In beginsel is het binnen de grenzen van dat beleid vrij in het nemen van beslissingen. Deze beslissingen moeten echter binnen het redelijke blijven. Twee vragen zijn hier van belang, $\mathrm{nl}$. hoe kan de rechter een aangevochten besluit beoordelen zonder op de stoel van het bestuursorgaan te gaan zitten? en: wanneer is een beslissing (on)redelijk? Om met de eerste vraag te beginnen, de rechter mag het besluit slechts van een afstand beoordelen, hij moet terughoudendheid betrachten. $\mathrm{Hij}$ mag niet zelf de verschillende belangen tegen elkaar afwegen. In principe moet hij de beleidsvrijheid van een bestuursorgaan respecteren. Deze afstandelijke toetsing wordt aangeduid met de term 'marginale toetsing. ${ }^{\text {sis }}$ De tweede vraag is moeilijk te beantwoorden, omdat een concrete maatstaf ontbreekt. In het algemeen kan worden gesteld dat

614 Niet in alle wetten komt de willekeurstoetsing onder de c-grond voor, zie bijvoorbeeld art. 27 lid 2 onder b AWR.

615 A.M. Donner, Nederlands bestuursrecht, Algemeen deel, 1974, pag. 97.

616 Idem vorige noot.

617 A.O.C. Tak en R.E. Bakker, De centrale rol van het willekeursverbod bij de toetsing van overheidshandelen, uit: A.W. Heringa en N. Verheij (red.), Publiekrechtelijke bewegingen, Deventer 1990, pag. 205-218.

618 In de sociale-verzekeringsrechtspraak wordt door de wet een bijzondere vorm van redelijkheidstoetsing aangereikt, namelijk een die ligt tussen de volle belcidstoetsing (zoals in het administratief berocp) en de marginale toetsing. Zic onder andere: H.D. van Wijk/W. Konijnenbelt, a.w.,pag. 130-131; De redelijkheidstoetsing speelt vooral een rol bij oplegging van administratieve sancties: A.F.M. Brenninkmeijer en Y.D.M. Zoomers, De rechterlijk toetsing van sancties in het bestuursrecht, NTB 1988, pag. 49-56. 
van kennelijke onredelijkheid sprake is als van de bestuurshandeling gezegd moet worden dat zij op afweging van belangen niet kán berusten. Op deze manier behoudt het bestuursorgaan haar beleidsruimte. ${ }^{619}$ Van het bestuursorgaan mag worden verlangd dat het alle betrokken belangen op een objectieve manier tegen elkaar afweegt.

In de literatuur vindt men de opvatting dat van het willekeursverbod het materiële zorgvuldigheidsbeginsel kan worden onderscheiden. ${ }^{6 \curvearrowright}$ Dit beginsel zou erop toezien dat de overheid bij het nemen van bepaalde maatregelen de verschillende belangen zoveel mogelijk in de gaten houdt. Wanneer bepaalde maatregelen noodzakelijk zijn, is het vaak onvermijdelijk dat dit ten koste gaat van andere belangen. Op grond van het zorgvuldigheidsbeginsel dient de schade zo beperkt mogelijk te worden gehouden, eventueel door het aanbieden van een schadevergoeding. Erkend wordt dat toetsing van dit beginsel aan de materiële kant tegen de willekeurstoetsing aan ligt, waarbij getoetst wordt of het bestuursorgaan bij afweging van de in aanmerking komende belangen in redelijkheid tot het bestreden besluit had kunnen komen. Ten Berge en Tak verwerpen dit onderscheid, omdat met de materiële zorgvuldigheid strikt genomen niets anders bedoeld kan zijn dan het verbod van willekeur. ${ }^{\alpha 1}$

Toetsing aan de materiële zorgvuldigheid komt dan ook niet vaak voor. Meestal wordt gekozen voor de willekeurstoetsing, hetgeen blijkt uit een formulering als: "in redelijkheid (niet) tot het bestreden besluit had kunnen komen".

\subsubsection{Motiveringsbeginsel}

In de eerste tranche van de Awb werden de motiveringsbepalingen geregeld in hoofdstuk 4. Omdat de Tweede Kamer ${ }^{623}$ deze regels ook wil laten gelden voor andere besluiten dan de heschikking, verhuist de regeling (in het Wetsvoorstel Awb derde tranche) van hooldstuk 4 naar hoofdstuk 3 , afdeling $3.7 .^{624}$ In het navolgende wordt de artikelaanduiding van dit wetsvoorstel aangehouden.

In aldeling $, 3,7$ is een tot nu toe ongeschreven beginsel van behoorlijk bestuur gecodifceerd: het motiveringsbeginsel. Dit beginsel bevat twee componenten. Het stelt de

619 Zie: B. de Goede/ H. van den Brink, Beeld van het Nederlands Bestuursrecht, 's-Gravenhage. 1986 , pag. 186.

$620 \mathrm{Vgl}$. H.D. van Wijk/W. Konijnenbelt, Hoofdstukken van administratief recht, a.w., pag. 119 c.v. 62.1 J.B.I.M. ten Berge en A.Q.C. Tak, Nederlands administratief procesrecht, deel 1, Zwolle 1983, pag. 311.

622. Voorbeelden zijn CRvB 12 december 1989, TAR 1990, 29; CRvB 21 december 1989, TAR 1990, 37.

623 VV Awb, TK 1988-1989, 21221, nr. 4 en MvA Awb, TK 1990-1991, 21221, nr. 5, pag. 80.

624 Omdat de regeling van de motiveringsverplichting inhoudelijk nict is gewijzigd en slechts op enkele punten is aangevuld kan verwezen blijven worden naar de MvT Awb, TK 1988-1989, 21221 
eis dat de beslissing gedragen moet kunnen worden door de daaraan ten grondslag liggende motivering en de eis dat de motivering naar buiten toe moet blijken. ${ }^{25}$ Het eerste vereiste is neergelegd in art. 3.6.1. Dit vereiste heeft twee aspecten, namelijk dat de feiten juist moeten zijn vastgesteld en dat deze vaststelling moet leiden tot de genomen beslissing. Het kenbaar maken van de motivering is voorgeschreven in art. 3.6.2. Dit kenbaarheidsvereiste houdt in dat het bestuursorgaan inzicht moet geven in de gevolgde gedachtengang en dat de vermelding zodanig moet zijn dat het voor de betrokkene redelijkerwijs begrijpelijk is.

Soms is het voor een bestuursorgaan, in verband met vereiste spoed, niet mogelijk de motivering bij het geven van de beschikking te vermelden. Daarin voorziet art. 3.6.2 lid 3. De motivering volgt dan zo snel mogelijk. Lid 4 is in de derde tranche ingevoegd. Dit lid dient ertoe het uitgangspunt dat, indien de motivering niet meteen kon worden gegeven maar later wordt verstrekt, ook vast te leggen voor besluiten die niet tot één belanghebbende zijn gericht.

Art. 3.6.3 beschrijft het geval dat het bestuursorgaan de motivering niet hoeft te vermelden omdat de belanghebbende daarbij geen belang heeft. Mocht deze er toch om vragen dan wordt de motivering zo snel mogelijk verstrekt.

De artikelen 3.6.4 en 3.6.5 hebben betrekking op het geval het besluit steunt op een uitgebracht advies. Indien dit advies de motivering bevat en het ter kennis van de belanghebbenden is gebracht, kan voor de motivering van de beschikking hiermee worden volstaan. Indien het besluit afwijkt van het uitgebrachte advies moet deze afwijking in de motivering met redenen worden omkleed.

In het administratieve recht bestaat geen algemene motiveringsplicht in die zin dat een bestuursorgaan is bij elk besluit verplicht kenbaar te maken welke overwegingen aan dat besluit ten grondslag hebben gelegen. Een duidelijke motivering is echter bijvoorbeeld wel van groot belang wanneer de betrokken burger tegen een besluit bezwaar of beroep wil instellen. Een motiveringsverplichting bestaat bijvoorbeeld bij een afwijzende beslissing (een beslissing dat niet overeenkomstig de aanvraag is) of bij beslissingen die voor derden belastend kunnen zijn. Naar mijn mening is een motivering vooral vereist bij een besluit waarbij een administratieve sanctie wordt opgelegd, omdat de betrokkene er belang bij heeft te weten op welke gronden de sanctionering berust, zodat hij zich daartegen in bezwaar of beroep kan verweren. In de Awb is als het uitgangspunt van het motiveringsbeginsel opgenomen dat de vermelding ervan achterwege kan blijven indien redelijkerwijs kan worden aangenomen dat daaraan geen behoefte bestaat (art. 3.6.3 lid 1).

Het vereiste van een draagkrachtige motivering is een veelvoorkomende vernietigingsgrond. Redenen waarom een motivering niet draagkrachtig is, kunnen zijn: de feiten waarop de motivering rust zijn niet juist of niet volledig, de motivering is niet begrij- 
pelijk, de motivering is in strijd met de wet, de motivering is strijdig met het beleid, de motivering berust op onaanvaardbaar beleid.

Dat de feiten, waarop de motivering rust, juist en volledig moeten zijn, spreekt wel voor zich. Daarnaast moet de motivering begrijpelijk zijn, in die zin dat deze logisch en consistent is, voor één uitleg vatbaar. De redenering moet te volgen zijn, niet te vaag en mag geen tegenstrijdigheden bevatten. Een motivering is in strijd met de wet indien deze berust op een onjuiste interpretatie van een wettelijk voorschrift of indien aan het besluit een motivering is gegeven die volgens de wet niet van toepassing mag zijn. Evenzo moeten beleidsregels, waarop de motivering is gebaseerd, op een juiste wijze worden geïnterpreteerd. Er is bovendien strijd met het motiveringsbeginsel indien beleidsregels min of meer automatisch worden toegepast zonder dat er in het concrete geval bekeken wordt of er eventueel reden is van de beleidslijn af te wijken. Het beleid, op grond waarvan een besluit is genomen, mag niet in strijd zijn met de wet.

Strijd met het motiveringsbeginsel is een regelmatige vernietigingsgrond voor besluiten waarin een administratieve sanctie een rol speelt, met name in jurisprudentie in ambtenarenzaken. ${ }^{26} 627$

\subsubsection{Overige bepalingen van hoofdstuk 3}

Afdeling 3.3 buschrijft de procedure waarbij een persoon of college inzake het door een bestuursorgaan te nemen besluit dit orgaan van advies dient.

In afdeling 3.4 wordt een openbare voorbereidingsprocedure behandeld. Deze is gecreëerd teneinde belanghebbenden in bepaalde gevallen vroegtijdig in de gelegenheid te stellen hun mening over een voorgenomen besluit naar voren te brengen: de hoorplicht. Volgens art. 3:10 Awb moet deze procedure worden gevolgd indien

626 Zie hierover: A. Beuker-Tilstra, Jurisprudentie Centrale Raad van Beroep in ambtenarenzaken 1988-1989, Bestuurswetenschappen 1990, nr. 3, pag. 219-220.

627 CRvB 17 november 1988, TAR 1989, 8 (gronden niet door feiten gedekt); CRvB 23 maart 1989, TAR 1989, 116 (gronden ontoereikend); CRvB 18 mei 1989, TAR 1989, 144 (onvoldoende onderbouwing door feiten); CRvB 19 oktober 1989 TAR 1990, 242 (onvoldoende onderbouwing door feiten); CRvB 11 januari 1990, TAR 1990, 55 (feiten verwijzen naar andere ontslaggrond); CRvB 7 november 1989, TAR 1990, 8 (advies onvoldoende gemoliveerd); CRvB 8 december 1988, TAR 1989, 29 (in motivering wordt verwezen naar beleidsregels, zonder dat deze voldoende inzichtelijk worden gemaakt); CRvB 22 december 1988, TAR 1989, 51 (beroep op beleidsregels, zonder nadere berading over de feiten en omstandigheden van het conerete geval); CRvB 9 maart 1989, TAR 1989, 99 (idem). Ook de Nationale Ombudsman oordeelde overeenkomstig, NO 8 november 1989, AB 1990, 64 en 13 november 1989, AB 1990, 565. Inzake de oplegging van een dwangsom toetste de Afdeling Geschillen van Bestuur aan het motiveringsbeginsel: AG RvS 20 februari 1989, M en R 1990, 10 (weigering oplegging dwangsom) en AG RvS 15 september 1989, AB 1990, 239 m.nt. G.T.J.M. Jurgens (verhoging dwangsom). 
dat bij wettelijk voorschrift is bepaald of indien het bestuursorgaan dat doelmatig oordeelt. (Aangezien dit bij de buitengerechtelijke afdoening door het $O M$ niet het geval zal zijn, is deze afdeling niet van toepassing. Verdere behandeling ervan zal hier dan ook niet plaatsvinden.)

Afdeling 3.6 geeft aan hoe het door het bestuursorgaan genomen besluit aan belanghebbenden bekend moet worden gemaakt. Dit geschiedt volgens art. 3:41 door toezending of uitreiking. Richt het besluit zich tot een grotere groep belanghebbenden dan vindt publicatie plaats in dag-, nieuws-, of huis-aan-huis-bladen of op een andere geschikte wijze.

Degene die bij de voorbereiding van het besluit betrokken zijn geweest worden tevens van het besluit op de hoogte gesteld, art. 3:43.

Indien tegen het besluit bezwaar gemaakt of beroep ingesteld kan worden wordt daarvan bij de bekendmaking melding gemaakt. Vermeld wordt door wie, binnen welke termijn en bij welke instantie dit bezwaar of beroep kan worden ingesteld. Volgens de MvT houdt dit niet in dat moet worden vermeld dat degene tot wie zich het besluit richt in beroep kan komen. Volstaan kan worden met een categorale aanduiding. ${ }^{\text {ses }}$

3.4.7 Andere -niet-gecodificeerde- beginselen van behoorlijk bestuur

\subsubsection{Rechtszekerheidsbeginsel}

Een ander in de jurisprudentie ontwikkeld beginsel is het rechtszekerheidsheginsel. Dit beginsel houdt in dat een bestuursbesluit zekerheid moet verschaffen aan de betrokkene(n). Ten Berge en Tak onderscheiden 3 aspecten $^{620}$ :

(1) Allereerst dient de rechtspositie van de betrokkene duidelijk te zijn. Dit betekent dat een besluit op een zorgvuldige wijze en voldoende concreet moet zijn geformuleerd zodat het niet voor meerdere uitleg vatbaar is. Het besluit moet voor de betrokkene duidelijk zijn, zonder dat nadere uitleg voor hem nodig is. Kortom: de betrokkene dient zonder nadere toelichting te weten waar hij aan toe is, hij mag niet in onzekerheid verkeren over de rechtsgevolgen van een besluit. ${ }^{630}$

628 MvT Awb, TK 1988-1989, 21221, pag. 83.

629 J.B.J.M. ten Berge en A.Q.C. Tak, a.w., pag. 324-325.

630 Strijd met dit beginsel werd aanwezig geacht toen bij beschikking een dwangsom werd opgelegd (art. 28a Hinderwet), zonder dat uit de beschikking duidelijk bleek welke voorschriften werden overtreden. Gelet op het karakter van de bestreden beschikking, namelijk een sanctiemaatregel, was dit onaanvaardbaar (Vz AG RvS 2 september 1988, AB- TwK 1988, 507, m.nt. F.O.). Bij de aanschrijving tot politiedwang moet het voor de betrokkene duidelijk zijn wat hij verkeerd doet 
(2) Het intrekken van een begunstigde beschikking kan onder omstandigheden in strijd komen met het rechtszekerheidsbeginsel.

(3) Nadat betrokkenen de tegen een beschikking openstaande rechtsmiddelen hebben laten verlopen, kan niet tegen de beschikking opnieuw worden opgekomen.

\subsubsection{Vertrouwensbeginsel}

Verwant met het rechtszekerheidsbeginsel is het beginsel der gewekte verwachtingen/ vertrouwensbeginsel. In de literatuur wordt ook het standpunt ingenomen dat het ongewenst is onderscheid te maken tussen rechtszekerheidsbeginsel en het vertrouwensbeginsel. Het gaat er bij beide om dat verwachtingen in een concreet geval moeten worden gehonoreerd. ${ }^{631}$ Toch meen ik dat een onderscheid gerechtvaardigd is. Bij het rechtszekerheidsbeginsel hangt het vertrouwen rechtstreeks samen met het genomen besluit terwijl bij het beginsel der gewekte verwachtingen/vertrouwensbeginsel het vertrouwen is gewekt nog voordat het besluit zal worden genomen. Met andere woorden: in het laatste geval is de afstand tussen vertrouwen en concreet besluit groter. ${ }^{\text {a32 }}$

Ook over de termen 'beginsel der gewekte verwachtingen' en 'vertrouwensbeginsel' wil ik nog een opmerking maken. In de literatuur worden, bijvoorbeeld door Konijnenbelt, hier twee beginselen onderscheiden. ${ }^{(3)}$ Het beginsel der gewekte verwachtingen heeft volgens hem betrekking op de toestand dat door het bestuur in het algemeen verwachtingen zijn gewekt, terwijl voor het vertrouwensbeginsel plaats is wanneer door het bestuursorgaan concreet verwachtingen zijn gewekt. Het maken van dit onderscheid kan verhelderend werken (zie volgend hoofdstuk). Daar in de jurisprudentie dit onderscheid niet als zodanig wordt gemaakt, zal ik in het onderstaande uitgaan van één beginsel.

Dit beginsel heeft als uitgangspunt dat het door de overheid bij de burger gewekte gerechtvaardigd vertrouwen zoveel mogelijk gehonoreerd moet worden. Het gaat hier dus om gedrag van het bestuursorgaan waaraan de burger terecht meent bepaalde verwachtingen te mogen ontlenen. Enkele vragen moeten nader worden bekeken, namelijk: hoe kunnen verwachtingen worden gewekt?; door wie worden ze gewekt?; zijn de verwachtingen gerechtvaardigd? en: hoe zit het met contra legem gewekt vertrouwen?

of wat hij moet doen om politiedwang te voorkomen, AR RvS 30 januari 1979, tB/S III, pag. 571 , nr. 109.

631 Vgl. bijwourbeeld het ABAR-rapport, vijfde druk, 1984, pag. 190-191.

632 Vgl. J.B.J.M. ten Berge en A.Q.C. Tak, a.w., pag. 325.

633 W. Konijnenbelt, preadvies VAR 1975, Rechtsverwerking door het bestuur: het vertrouwensbeginsel in het administratieve recht, VAR-geschriften 1975 LXXIV, pag. 60-62. 
Verwachtingen kunnen op tal van manieren door het bestuur worden gewekt. Naast, vanzelisprekend, een uitdrukkelijke toezegging, kunnen we denken aan: precedenten en pseudo-wetgeving; algemene toezeggingen en inlichtingen; eerder gegeven regelmatige beschikkingen; onregelmatige beschikkingen; overeenkomsten; individuele toezeggingen en inlichtingen; gedogen van een onwettige toestand; feitelijk overheidshandelen. ${ }^{64}$ Het gaat voor ons onderwerp te ver alle methoden uitvoerig te behandelen. Van belang lijken vooral eerdere beschikkingen, pseudo-wetgeving en individuele toezeggingen. Door in een behoorlijk aantal vergelijkbare gevallen op een bepaalde manier te beschikken wordt ten aanzien van toekomstige gevallen de verwachting gewekt dat op dezelfde manier besloten zal worden ${ }^{63}$, behoudens bevoegdheid van het bestuur om om te gaan. Eén enkele beslissing rechtvaardigt geen vertrouwen. ${ }^{36}$

Door de publicatie van richtlijnen, waarin vermeld wordt hoe door een bestuursorgaan beschikt zal worden in een aantal voorkomende gevallen, wekt de overheid verwachtingen. Burgers mogen erop vertrouwen dat het bestuursorgaan bij de uitvoering van het beleid de richtlijnen in acht zal nemen, tenzij zwaarwegende belangen zich hiertegen verzetten. ${ }^{67}$ Jurisprudentie, waarin een beroep wordt gedaan op het vertrouwensbeginsel onder verwijzing naar beleidslijnen c.q. richtlijnen is talrijk. Dit doet zich bijvoorbeeld veelvuldig voor in belastingzaken. ${ }^{638}$

Jurisprudentie van de AR RvS gaat ervan uit dat bestuursorganen hun discretionaire bevoegdheden niet-willekeurig, maar beleidsmatig, met beleid, conform beleidsregels moeten uitoefenen. ${ }^{\text {as }}$

Tot voor kort heerste er onduidelijkheid omtrent de status van beleidsregels (de in het bestuursrecht gangbare term). In 1990 gaf de Hoge Raad hierover zekerheid. In het arrest van 28 maart 1990, NJ 1991, 118 m.nt. MS inzake de Leidraad admini-

634 Opsomming uit het reeds genoemde preadvies VAR 1975 van Konijnenbeit, pag. 63.

635 Ook het nog te behandelen gelijkheidsbeginsel vereist dat een reeds gevolgde lijn ook wordt tocgepast op nieuwe gevallen.

636 HR 28 maart 1984, BNB 1984/253 m.nt. J.P. Scheltens: door een enkele vergissing is er geen sprake van een rechtens te beschermen vertrouwen.

637 Zie hierover uitgebreider J.H. van Kreveld, Belcidsregels in het recht, Deventer 1983, m.n. deel IV Gebondenheid aan beleidsregels; J. Nicolai, Beginselen van behoorlijk bestuur, Deventer 1990, pag. 367.

638 CRvB 7 november 1989, TAR 1990, 7; NO 8 november 1989, AB 1990, 64 (geen bijzondere omstandigheden aangegeven die nopen tot afwijking van het beleid); NO 13 november 1989, AB 1989, 565; NO 25 november 1989, AB 1989, 147; Hof 's-Gravenhage (belastingkamer) 25 januari 1983, BNB 1984/120; Hof 's-Gravenhage (belastingkamer) 25 januari 1983, BNB 1984/121; HR 27 augustus 1985, BNB 1986/269; HR 4 december 1985, BNB 1986/159 m.nt. van Brunschot; HR 14 oktober 1987, BNB 1988/115 m.nt. H.J. Hofstra; Hof 's-Gravenhage 23 december 1988, BNB 19\%)/28.

639 Zie bijvoorbeeld AR RvS 25 januari 1985, AB 1986, 62. Zie voor verdere jurisprudentie J.H. van Kreveld, Beleidsregels in bet recht (dissertatie 1983), hoofdstuk 12. 
stratieve boeten 1984, kwam de Hoge Raad terug op eerdere rechtspraak (met name HR 19 juni 1985, NJ 1986, 104) door de genoemde Leidraad als 'recht' in de zin van art. 99 RO te begrijpen. De HR overweegt (4.5):

"Gelet op de steeds gewichtiger rol die beleidsregels zijn gaan spelen bij het bepalen van de verhouding tussen overheid en burger, en gezien de daarmee samenhangende behoefte aan eenvormige interpretatie van en zekerheid omtrent de inhoud en strekking van die regels, is het wenselijk dat de -onder meer op het bewaken van de rechtseenheid gerichtetaak van de cassatierechter zich mede tot de uitlegging van zodanige regels uitstrekt".

\section{(4.6):}

"Een en ander geeft grond om -in aansluiting op de uitspraak van de burgerlijke kamer van de HR van 11 okt. 1985, NJ 1986, 322-onder 'recht' in meergemelde zin mede te begrijpen door een bestuursorgaan binnen zijn bestuursbevoegdheid vastgestelde en behoorlijk bekendgemaakte regels omtrent de uitoefening van zijn beleid, die weliswaar niet kunnen gelden als algemeen verbindende voorschriften omdat zij niet krachtens enige wetgevende bevoegdheid zijn gegeven, maar die het bestuursorgaan wel op grond van enig algemeen beginsel van behoorlijk bestuur binden en die zich naar hun inhoud en strekking ertoe lenen jegens de bij de desbetreffende regeling betrokkenen als rechtsregel te worden toegepast. Daaraan doet niet af dat de aard van de gebondenheid aan een zodanige regel kan meebrengen dat het bestuursorgaan daarvan onder bepaalde omstandigheden kan afwijken".

Van belang is hier verder overweging 4.8 :

"Opmerking verdient dat, gelet op de aard van de cloor een bestuursorgaan vastgestelde beleidsregels, en met name ook op de grondslag waarop zij dat orgaan binden, de rechter niet tot ambtshalve toepassing ervan is gehouden, hetgeen meebrengt dat de cassatierechter slechts gehouden is over schending van beleidsregels te oordelen indien en voor zover over zodanige schending in cassatie is geklaagd".

De Hoge Raad zet de kenmerken van beleidsregels nog eens op een rij. Het gaat om regels die:

1. door het bestuursorgaan binnen zijn bestuursbevoegdheid zijn vastgesteld;

2. behoorlijk bekend zijn gemaakt;

3. de uitoefening van zijn beleid betrelfen;

4. het bestuursorgaan binden op grond van enig abbb;

5. zich naar inhoud en strekking ertoe lenen jegens de bij de desbetreffende regeling betrokkenen als rechtsregel te worden toegepast.

Bekijken we deze kenmerken van de heleidsregel nug eens nader. dan kan daarover het volgende worden opgemerkt. In tegenstelling tot algemeen verbindende voorschriften berust een beleidsregel niet op ein wettelijke bepaling. Het is een regel die het 
bestuursorgaan voor de uitoefening van zijn eigen bevoegdheid, of die van een ondergeschikte vaststelt. Van der Meulen c.s. onderscheiden hierbij drie vormen, te weten:

1. beleidsregels in enge zin. Dit zijn regels die het bevoegd gezag voor de uitoefening van zijn eigen bestuursbevoegdheid vaststelt;

2. aanwijzingen. Hiermee wordt gedoeld op regels die door een bestuursorgaan worden gegeven voor beleid dat krachtens mandaat of delegatie door een ander bestuursorgaan wordt gevoerd;

3. instructies welke worden gegeven aan hiërarchisch ondergeschikten. ${ }^{60}$

Als een behoorlijke bekendmaking kan volgens de Hoge Raad (zie overweging 4.7) gelden de plaatsing in de Staatscourant of in een ander vanwege de overheid algemeen verkrijgbaar gesteld publikatieblad, dan wel een andere door of met goedvinden dan wel medeweten van de overheid gedane bekendmaking op zodanige wijze dat verzekerd is dat de regels voor de betrokkenen kenbaar en toegankelijk zijn. Dit rweede vereiste wordt in de literatuur niet gezien als een vereiste om van een beleidsregel te kunnen spreken. Ook het hanteren van een bepaalde, constante beleidslijn kan als een beleidsregel worden aangemerkt. Ook hieraan is het bestuursorgaan gebonden krachtens de abbb, zij het dat daarover in cassatie niet kan worden geklaagd..$^{\omega 1}$ Volgens Scheltema in zijn noot onder het arrest gaat het dan echter niet om beleidsregels, omdat zij niet zijn vastgesteld. Er moet dan eerst een besluit tot vastlegging zijn. Beleidsregels binden het bestuursorgaan op grond van enig abbb. Hierbij moet met name worden gedacht aan het gelijkheidsbeginsel, het vertrouwensbeginsel en het verbod van willekeur. De binding van beleidsregels is beperkt tot concrete individuele gevallen, zij hebben geen algemene werking. De binding is eenzijdig in die zin dat zij het bestuursorgaan binden (tenzij gebruik gemaakt wordt van de afwijkingsbevoegdheid), maar niet rechtstreeks de burgers. Het moet gaan om abstract gestelde regels die zich ertoe lenen herhaalde malen te worden toegepast.

De gebondenheid aan beleidsregels berust dus op de werking van algemene beginselen van behoorlijk bestuur. Na invoering van het wetsvoorstel Awb (derde tranche), waarin een titel 4.4. over beleidsregels is opgenomen, zal dit veranderd zijn en zal de gebondenheid voortaan berusten op de wet, namelijk op art. 4.4.5..$^{\text {st }}$ Aan art. 1:3 voegt de derde tranche een vierde lid toe, luidende: Onder beleidsregel wordt verstaan: een besluit, niet zijnde een algemeen verbindend voorschrift, dat een algemene regel geeft voor het gebruik van een bevoegdheid van een bestuursorgaan en is vastgesteld door het daartoe krachtens artikel 4.4 .1 bevoegde orgaan. Een

640 Bernd van der Meulen e.a., Bestuursbevoegdheid als bron van recht, NTB 1991/5, pag. 135.

$641 \mathrm{Vgl}$. Bernd van der Meulen e.a., Bestuursbevoegdheid als bron van recht, NTB 1991/5, pag. 133-141.

$642 \mathrm{Bij}$ de bespreking van dit ontwerp met betrekking tot beleidsregels zal ik me voornamelijk richten op die bepalingen en onderwerpen die voor dit onderzoek van belang zijn, dus die op enigerlei wijze van toepassing zijn op de strafrechtelijke beleidsregels. 
heleidsregel is volgens dit wetsvoorstel dus een besluit in de zin van de Awb hetgeen impliceert dat alle algemene bepalingen omtrent besluiten zoals opgenomen in hoofdstuk 3 Awb (zorgvuldigheid en belangenafweging, advisering, inwerkingtreding, bekendmaking en motivering) op het vaststellen van een beleidsregel van toepassing zijn. Een concrete heschikking op basis van een beleidsregel moet wederom voldoen aan de vereisten van hoofdstuk $3 .^{0.43}$

Het wetsvoorstel handhaaft in art. 1:3 lid 4 het onderscheid, zoals dat in de jurisprudentie ook werd gehanteerd (HR 28-3-1990, AB 1990, 306), tussen een algemeen verbindend voorschrift en een beleidsregel. ${ }^{6+4}$ De bevoegdheid tot het maken van beleidsregels ligt opgesloten in de bevoegdheid tot het nemen van beschikkingen. Daardoor kan een beleidsregel niet in dezelfde mate bindend zijn dan een algemeen verbindend voorschrift, omdat in bijzondere gevallen van een beleidsregel kan worden afgeweken. Een practisch gevolg van dit onderscheid is volgens de MvT dat de rechter, hoewel een beleidsregel recht is in de zin van art. $99 \mathrm{RO}$, niet ambtshalve aan een beleidsregel behoeft te toetsen. De MvT verwijst hierbij naar het hiervoor aangehaalde arrest.

De MvT maakt een uitdrukkelijk onderscheid tussen een beleidsregel en een vaste bestuurspraktijk. Deze laatste ont- of bestaat door (respectievelijk uit) een slechts mondeling naar buiten gebrachte gedragslijn. Een eventuele gebondenheid aan een dergelijke gedragslijn is dan niet gebaseerd op de wet (art. 4.4.5 Awb), maar kan worden aangenomen op grond van algemene beginselen van behoorlijk bestuur, met name het gelijkheids- en het vertrouwensbeginsel. ${ }^{(46}$

Hoofdstuk 4 titel 4 geeft enkele bijzondere bepalingen over beleidsregels. Art. 4.4.1 geeft aan met welk doel beleidsregels kunnen worden vastgesteld. Het artikel luidt: een bestuursorgaan kan beleidsregels vaststellen over de wijze waarop belangen worden afgewogen, feiten worden vastgesteld of wettelijke voorschriften worden uitgelegd bij het gebruik van een hem toekomende of onder zijn verantwoordelijkheid uitgeoefende bevoegdheid. Naarmate het wettelijk voorschrift dat een bestuursorgaan een grotere discretionaire ruimte geeft bij de uitoefening van zijn bevoegdheid is er meer ruimte voor het maken van beleidsregels. ${ }^{\text {s7 }}$ Dit artikel impliceert ook dat, indien een hoger bestuursorgaan dat verantwoordelijk is voor de uitoefening van bevoegdheden door een lager orgaan en daarvoor instructies geeft aan dat lager

643 Op de kwalilicatic van de beleidsregel als een besluit in de zin van de Awb wordt kritiek geleverd, onder andere door: P. Nicolai in zijn bijdrage Beleidsregels, uit: De derde tranche, Willem Konijnenbelt (red.), Alphen aan den Rijn 1992, pag. 82-102, m.n. pag. 84-85; Sectie bestuursrecht Rijksuniversiteit Limburg, Beleidsregels: gebruiksaanwijzing van bestuursbevoegdheid, Regelmaat 1993 , pag. 54-60. Zijgaan ervan uit dat de beleidsregel geen zelfstandige besluit-status kan hebben, maar slechts een voorbereidingshandeling daartoe is. Rechtsvaststelling vindt niet plaats door de beleidsregel, maar door het besluit.

644 MvT Awb derde tranche, 23700, pag. 84-86.

645 MvT Awb derde tranche, 23700, pag. 86.

$646 \mathrm{MvT}$ Awb derde tranche, 23700, pag. 88.

647 MvT Awb derde tranche, 23700, pag. 94. 
orgaan en deze instructies bekend maakt, dat lagere bestuursorgaan zich aan deze instructies heeft te houden. ${ }^{648}$

Indien een vaste gedragslijn in een beleidsregel is neergelegd wordt de motiveringsplicht van het bestuursorgaan bij het nemen van een concreet besluit overeenkomstig die beleidslijn verlicht. Ingevolge art. $4.4 .3 \mathrm{kan}$ dan worden volstaan met een verwijzing naar die beleidsregel. De toevoeging in de vorm van een korte overweging dat er geen redenen zijn van de beleidslijn af te wijken, is voldoende. ${ }^{60}$

Art. 4.4.4 beoogt de rechtszekerheid van de betrokkenen te vergroten. Het schrijft voor dat bij de bekendmaking van een beleidslijn zo mogelijk het wettelijk voorschrift, waaruit de bevoegdheid waarop de beleidslijn betrekking heeft voortvloeit, wordt vermeld.

Tot nu toe vloeide de gebondenheid aan beleidsregels voort uit de algemene beginselen van behoorlijk bestuur, met name het vertrouwensbeginsel. Voortaan zal zij voortvloeien uit art. 4.4.5, de voornamste bepaling over de beleidsregel in het kader van de bespreking van het vertrouwensbeginsel. Hierin is neergelegd dat het bestuursorgaan handelt overeenkomstig de beleidsregels, tenzij dat voor een of meer belanghebbende gevolgen zou hebben die wegens bijzondere omstandigheden onevenredig zijn in verhouding tot de met de beleidsregel te dienen doelen. Enerzijds bindt de beleidsregel, anderzijds bindt zij niet volledig. Indien de beleidsregel niet is totstandgekomen overeenkomstig de algemene regels die voor bestuursbesluiten gelden kan het bestuursorgaan zich niet op de beleidsregel beroepen. Met andere woorden: de beleidsregel is onverbindend. In beginsel kan een belanghebbende zich ook niet op een onverbindende beleidsregel beroepen. Hier kunnen echter het vertrouwens(de onverbindende beleidsregel heeft verwachtingen doen ontstaan) en het gelijkheidsbeginsel (op grond van de onverbindende beleidsregel is een vaste praktijk ontstaan) corrigerend werken, in die zin dat toch overeenkomstig de beleidsregel gehandeld wordt ten opzichte van en belanghebbende voor wie dit gunstig is. ${ }^{630}$

Met deze bepalingen van titel 4.4 is de rol van het vertrouwensbeginsel bij beleidsregels niet geheel uitgespeeld. Met name zal dit beginsel van belang blijven met betrekking tot het bij de invoering of wijziging van beleidsregels in acht te nemen overgangsrecht. Eerder is al gewezen op het belang van het vertrouwensbeginsel bij beleidsregelgeving die niet valt onder de werkingssfeer van titel 4.4. (bijvoorbeeld de vaste bestuurspraktijk).

Art. 4.4.5 laatste volzin geeft het bestuursorgaan de mogelijkheid van de beleidsregel af te wijken. In de volgende gevallen moet worden onderzocht of er redenen zijn voor afwijking: (1) indien er sprake is van bijzondere omstandigheden, en (2) de nadelige of voordelige gevolgen van het handelen overeenkomstig de beleidsregel onevenredig zouden zijn in verhouding tot de met de beleidsregel te dienen doelen. Ook indien aan een justitiabele een toezegging is gedaan die in strijd is met een

648 MvT Awb derde tranche, 23700, pag. 95.

649 MvT Awb derde tranche, 23700, pag. 99.

650 MvT Awb derde tranche, 23700 , pag. 102. 
bepaalde beleidsregel, kan op grond van het vertrouwensbeginsel de toezegging moeten worden nagekomen.

Van belang is of degene aan wie de burger het vertrouwen ontleende, daartoe bevoegd was. Het gaat er om of degene die het vertrouwen bij de burger wekte, op dat punt beslissingsbevoegdheid heeft. Een bestuursorgaan waaraan een bepaalde bevoegdheid is gedelegeerd of geattribueerd heeft voor de uitoefening van die bevoegdheid een eigen verantwoordelijkheid en is door het wekken van verwachtingen daaraan gebonden. Anders is het wanneer degene die de verwachting wekt op dat punt niet een eigen zelfstandige beslissingsbevoegdheid heeft. We kunnen hierbij bijvoorbeeld denken aan de situatie dat een lid van een beslissingsbevoegd college het vertrouwen wekt of dat dit gebeurt door een ambtenaar. Wat betreft de uitoefening van een collegiale bevoegdheid waardoor bij de burger bepaalde verwachtingen worden verwekt is de jurisprudentie niet eenduidig. Met betrekking tot het vertrouwenwekkende handelen van een ambtenaar is van belang of aan de betreffende ambtenaar mandaat was verleend. Is dat het geval dan kan handelen worden toegerekend aan het bevoegde orgaan. Is terzake geen mandaat verleend, dan ligt het moeilijker. Mag van de burger worden verwacht dat hij inzicht heeft in de vraag of een ambtenaar bevoegd handelt? Moet de burger het risico dragen van een onbevoegd handelend en toezeggende ambtenaar? Met Nicolaï ben ik van mening in beginsel onbevoegd gewekte verwachtingen aan het ambt moeten worden toegerekend. ${ }^{\omega 2}$ De jurisprudentic tendeert in die richting.'st

Niet met elke verwachting van de burger behoeft rekening te worden gehouden. IIct moct gaan om terechte verwachtingen, verwachtingen dus die op goede gronden berusten. ${ }^{\text {as }}$

Tenslotte moet de vraag nog beantwoord worden of het vertrouwen op een toezegging die in strijd met de wet is gedaan, moet worden gehonoreerd. We spreken van toepassing van het vertrouwensbeginsel 'contra legem'. .ss Deze 'contra legem' toepassing veronderstelt een afweging tussen de zwaarte van de schending van het vertrouwensbeginsel en het belang van de betreffende wettelijke bepaling. Jurisprudentie op

651 Vgl. Nicolaii, a.w., pag. 363.

652 J. Nicolaī, a.w., pag. 363-364. Zie hierover ook: F.W ıer Spill en A.Q.C. Tak, Onwetmatig bestuur, preadvies VAR 1981, eerste hoofdstuk.

653 Zie voor voorbeelden W. Konijnenbelt, Hoofdstukken van administratief recht, pag. 106-107.

654 Een voorbeeld daarvan is een uitspraak van de CRvB 6 april 1989, TAR 1989, 120, waarin het ging om een intrekking van een beschikking tot benoeming in vaste dienst. I.c. berustte het vertrouwen niet op goede gronden, maar op een foutieve mededeling die tijdig gecorrigeerd is. In een arrest van 12 oktober 1988, BNB 1989/333 bepaalde de Hoge Raad dat niet kan worden aanvaard dat reeds op grond van tijdsverloop aan het bij belanghebbende gewekte vertrouwen rechtens bescherming wordt verleend.

655 Deze 'contra legem' toepassing kan zich ook voordoen bij andere beginselen, maar in de praktijk zal het meestal gaan om het vertrouwens- of het gelijkheidsbeginsel. 
dit punt is niet eenduidig. De belastingkamer van de Hoge Raad heeft toepassing contra legem aanvaard (HR 12 april 1978, NJ 1979, 533 m.nt. MS), evenals de Centrale Raad van Beroep. Het is echter afgewezen door CBB en AR RvSt. ${ }^{3 s}$ Soms wordt vereist dat de burger handelingen heeft verricht waardoor hij, indien het vertrouwen wordt beschaamd, schade lijdt. Konijnenbelt duidt dit aan met het dispositievereiste. ${ }^{.57}$

\section{Samengevat:}

- verwachtingen kunnen op verschillende manieren worden gewekt;

- degene die de verwachting wekte is beslissingsbevoegd;

- het moet gaan om terechte verwachtingen

\subsubsection{Gelijkheidsbeginsel}

Het gelijkheidsbeginsel houdt in dat gelijke gevallen gelijk behandeld worden en ongelijke gevallen ongelijk naar de mate waarin zij verschillen.

Een aspect van dit gelijkheidsbeginsel vormt het discriminatieverbod, het verbod om onderscheid te maken op grond van groepskenmerken. Dit discriminatieverbod is neergelegd in art. $1 \mathrm{GW}$ : 'Allen die zich in Nederland bevinden, worden in gelijke gevallen gelijk behandeld. Discriminatie wegens godsdienst, levensovertuiging, politieke gezindheid, ras, geslacht of op welke grond ook, is niet toegestaan'.

Het bestuursrecht kende het gelijkheidsbeginsel als ongeschreven beginsel van behoorlijk bestuur al langer. Voor individuele beschikkingen impliceert dit beginsel dat zij dienen te worden genomen overeenkomstig de met betrekking tot deze beschikkingen tot dan toe aangehouden beleidslijn. Bestaande criteria voor toepassing voor het beleid moeten op een juiste wijze worden gehanteerd. ${ }^{. s s}$ Evenals bij toepassing van het vertrouwensbeginsel spelen met ook betrekking tot het gelijkheidsbeginsel vastgestelde beleidsregels, pseudo-wetgeving een rol..$^{(50}$ Het gelijkheidsbeginsel en het vertrouwensbeginsel gaan dan als het ware hand in hand. ${ }^{\infty}$

656 Zie voor een overzicht van deze jurisprudentie Van Wijk / Konijnenbelt, Hoofdstukken van administratief recht, pag, 132-146.

657 W. Konijnenbelt, preadvies VAR 1975, De rechtsverwerking in het administratieve recht, pag. 63; Hoofdstukken van administratief recht, pag. 104. Dit vereiste wordt door Nicolai in zijn proefschrift in twijfel getrokken. J. Nicolaï, a.w., pag. 366.

658 Zie daarover D.W.P. Ruiter, Het ongrijpbare gelijkheidsbeginsel, Preadvies VAR 1985, pag. 45-46.

$659 \mathrm{Zie}$ over het gelijkheidsbeginsel in verband met een leidraad in belastingzaken J.P. Scheltens in zijn noot onder HR 23 november 1988, BNB 1989/29.

660 Zie J. Nicolai, a.w., pag. 358-359; De rol van het gelijkheidsbeginsel bij de toepassing van beleidsregels is volgens Van Kreveld in zijn dissertatie beperkt. Gebondenheid aan deze regels ontstaat niet zozeer door het gelijkheidsbeginsel, maar door het door hem genoemde consistentiebeginsel. J.H. van Kreveld, a.w., pag. 221-222. 
Uit jurisprudentie blijkt dat een beroep op het gelijkheidsbeginsel niet vaak wordt gehonoreerd. Redenen daarvoor kunnen zijn:

- Twee gevallen zijn niet gelijk. Gevallen kunnen op het eerste gezicht gelijkenis vertonen, maar bij nader inzien toch een andere beslissing nopen. ${ }^{\star 11}$ Omgekeerd kan het zich voordoen dat gevallen op het eerste gezicht een verschil vertonen, maar dat dit verschil niet zodanig is dat het tot een verschil in behandeling moet leiden. ${ }^{62}$

- Het geval waarnaar met een beroep op het gelijkheidsbeginsel wordt verwezen, berust op een incidentele en/of foutieve beslissing. ${ }^{63}$ Het zou niet redelijk zijn dat een bestuursorgaan, na eenmaal een vergissing te hebben gemaakt, voortaan genoodzaakt was dit voort te zetten.

- Verandering van beleid. Nieuwe gevallen kunnen niet meer worden gelijkgesteld met gevallen van voor de beleidswijziging. Verandering van jurisprudentie vereist niet dat een onaantastbaar geworden beschikking door de werking van het gelijkheidsbeginsel opengebroken zou moeten worden. ${ }^{6 * 1}$

- De gevallen waarnaar met een beroep op het gelijkheidsbeginsel wordt verwezen, zijn niet beslist door of onder verantwoordelijkheid van het orgaan dat het bestreden besluit nam.

- Een andere grond wordt gehanteerd (bijvoorbeeld het verbod van willekeur of ondeugdelijke motivering).

\subsection{Bijzondere bepalingen over besluiten}

In hoofdstuk $4 \mathrm{Awb}$ vindt nu nog slechts de beschikking een afzonderlijke regeling. Het wetsvoorstel derde tranche voegt daar aan toe: subsidies en beleidsregels. Achtereenvolgens worden de aanvraag, de voorbereiding en de beslistermijn van de beschikking behandeld.

661 Een voorbeld hiervan vinden we in een uitspraak van de CRvB 11 juli 1989, TAR 1989, 188, waarin cen ambtenaar, ontslagen wegens plichtsverzuim, wijst op ander vergelijkbaar handelen dat als ernstig plichtsverzuim kon worden aangemerkt, maar waarbij veel geringere straffen zijn opgelegd. Volgens de Raad zijn de gevallen onvoldoende vergelijkbaar.

602 Dit deed zich voor in een uitspraak van de CRvB van 21 februari 1989, TAR 1989, 91, waarin een ambtenaar strafontslag was aangezegd in verband met het aannemen van gelden. Door de raadsman van de ambtenaar werd gesteld dat door de werking van het gelijkheidsbeginsel de zwaarste straf (i.c. onvoorwaardelijk ontslag) voorbchouden had moeten blijven aan degenen die zich op nog ernstiger wijze dan de betreffende ambtenaar gedragen hadden. De Raad deelde deze opvatting nict.

663 Bijvoorbeeld CRvB 1 februari 1990, TAR 1990, 78.

664 Bijvoorbeeld NO 10 maart 1989, AB 1989, 241. 
De aanvraag van de beschikking lijkt misschien voor ons onderwerp op het eerste gezicht niet interessant, daar in beginsel niemand het $O M$ om een sanctie zal verzoeken. Deze bepalingen kunnen echter van belang zijn in het geval iemand het OM verzoekt een vervolgingsbeslissing te nemen of, indien hij een dagvaarding ontvangen heeft, het OM vraagt de zaak bijvoorbeeld door middel van een transactie af te doen. Voor de administratiefrechtelijke afdoening van verkeersvoorschriften zijn deze bepalingen zeer belangrijk, daar het bezwaarschrift een vorm van aanvraag is, waarop echter ingevolge art. 7:14 de afdelingen 3.4 en 3.5, de artikelen 3:41 tot en met 3:45, afdeling 3.6 en hoofdstuk 4, met uitzondering van art. 4:19 niet van toepassing zijn.

Tenzij de betreffende wet anders bepaalt, wordt een aanvraag schriftelijk ingediend, art. 4:1. Deze aanvraag moet aan een aantal formele vereisten voldoen. Deze zijn beschreven in art. 4:2. Volgens art. 4:3 kan de aanvrager weigeren bepaalde gevoelige of persoonlijke gegevens te verschaffen. Art. 4:4 biedt een bestuursorgaan de mogelijkheid om een formulier vast te stellen voor indiening van een aanvraag. De situatie kan zich voordoen dat de aanvrager niet aan alle vereisten heeft voldaan. Alvorens het bestuursorgaan de beslissing neemt de aanvraag niet te behandelen, moet het de aanvrager in de gelegenheid stellen binnen een termijn zijn aanvraag aan te vullen, art. 4:5. Eenzelfde regeling geeft het tweede lid van dit artikel voor het geval de aanvraag of de daarvoor noodzakelijke gegevens in een buitenlandse taal zijn gesteld. De aanvraag moet dan worden aangevuld met een vertaling. Het besluit van het bestuursorgaan om de aanvraag niet in behandeling te nemen wordt de aanvrager bekendgemaakt binnen vier weken nadat de aanvraag is aangevuld of nadat de daarvoor bedoelde termijn is verstreken, lid 3 .

$\mathrm{Na}$ een geheel of gedeeltelijk afwijzende beschikking kan de aanvrager een nieuwe aanvraag indienen. Hij moet dan nieuw gebleken feiten of gewijzigde omstandigheden vermelden. Laat de aanvrager dit achterwege, dan kan het bestuursorgaan de aanvraag afwijzen zonder dat het daarvoor een nieuwe termijn behoeft te stellen ter aanvulling van gegevens (art. 4:6).

De Awb bevat een uitgebreide procedure voor de voorbereiding van een aangevraagd besluit. Dit is de neerslag van het zorgvuldigheidsvereiste, dat onder andere een zorgvuldige voorbereiding van een bestuursbesluit vereist. De Awb geeft in art. 4:7 en 4:8 aan hoe de voorbereiding van een aangevraagde beslissing er uit ziet:

1. Voordat een bestuursorgaan een aanvraag tot het geven van een beschikking geheel of gedeeltelijk afwijst, stelt het de aanvrager in de gelegenheid zijn zienswijze naar voren te brengen indien:

a. de afwijzing zou steunen op gegevens over feiten en belangen die de aanvrager betreffen, en 
b. die gegevens afwijken van gegevens die de aanvrager ter zake zelf heeft verstrekt.

2. Het eerste lid geldt niet indien sprake is van een afwijzing van de aanvraag die slechts van geringe betekenis voor de aanvrager kan zijn.

1. Voordat een bestuursorgaan een beschikking geeft waartegen een belanghebbende die de beschikking niet heeft aangevraagd naar verwachting bedenkingen zal hebben, stelt het die belanghebbende in de gelegenheid zijn zienswijze naar voren te brengen indien:

a. de beschikking zou steunen op gegevens over feiten en belangen die de belanghebbende betreffen, en

b. die gegevens niet door de belanghebbende zelf ter zake zijn verstrekt.

2. Het eerste lid geldt niet indien de belanghebbende niet heeft voldaan aan de wettelijke verplichting gegevens te verstrekken.

In de artikelen 4:9 en 4:10 wordt vervolgens aangegeven hoe de belanghebbende in de gelegenheid moet worden gesteld zijn zienswijze kenbaar te maken. Vervolgens geeft art. 4:11 een drietal uitzonderingen op de hoorplicht van artt. 4:7 en 4:8, nl. indien er sprake is van spoed, indien de belanghebbende reeds in een eerder stadium in de gelegenheid is gesteld te worden gehoord en indien de beschikking effect zou missen als de belanghebbende daarvan vooraf op de hoogte is.

Van groot belang voor dit onderwerp is echter art. 4:12:

Ilet bestuursorgaan kan toepassing van de artikelen 4:7 en 4:8 voorts achterwege laten bij een beschikking die strekt tot het vaststellen van een financiële verplichting of aanspraak indien:

a. tegen die beschikking bezwaar kan worden gemaakt of administratief beroep kan worden ingesteld en de hoofdstukken 6 en 7 van toepassing zijn, en

b. de nadelige gevolgen na bezwaar en beroep volledig ongedaan kunnen worden gemaakt.

(In het wetsvoorstel derde tranche wordt hier een tweede lid aan toegevoegd, waarin weer een uitzondering wordt gemaakt ter zake van de aanvraag van een subsidie).

In het voorontwerp van de eerste tranche ontbrak de uitzondering van het eerste lid. Deze bepaling is alsnog opgenomen om tegemoet te komen aan bezwaren die bestonden tegen de werkzaamheden die de hoorregeling bij financiële beschikkingen met zich mee zou brengen. Met name werd hier gedacht aan beschikkingen op het terrein van belastingen, sociale verzekeringen en subsidieregelingen. ${ }^{\infty}$ s 
Afdeling 4.1.3 geeft een regeling van de termijn waarbinnen beslist moet zijn op de aanvraag van een beschikking. Hoewel uniformiteit op dit gebied door een vaste termijn voor de beslissing op te nemen de voorkeur zou verdienen, is dit in verband met het grote aantal soorten beschikkingsaanvragen niet mogelijk. Bovendien verschillen de beschikkingen in moeilijkheidsgraad of spoedeisendheid, zodat een redelijke termijn voor de ene een onredelijk lange termijn voor de andere beschikking zou zijn. Daarom heeft de Awb in art. 4:13 de mogelijkheid opengelaten dat bij iedere soort beschikking in de wettelijke regeling een afzonderlijke beslissingstermijn wordt opgenomen. ${ }^{6 \infty}$ Indien zulk een termijn in de wettelijke regeling ontbreekt moet in beginsel deze termijn redelijk zijn. Ter bevordering van de rechtszekerheid wordt in het tweede lid voorgeschreven dat, indien de beslissing niet binnen acht weken kan worden gegeven, het bestuursorgaan binnen die acht weken moet laten weten wanneer de beslissing wel zal worden genomen. De burger weet dan in ieder geval na acht weken waar hij aan toe is. ${ }^{.67}$ De termijn wordt ingevolge art. 4:15 opgeschort met ingang van de dag waarop het bestuursorgaan de aanvrager verzoekt tot aanvulling, tot de dag waarop de aanvrager hieraan voldoet of de daarvoor gestelde termijn is verlopen.

\subsection{Handhaving}

Het wetsvoorstel Awb (derde tranche) bevat een hoofdstuk over handhaving. Hierin wordt behandeld het toezicht op de naleving van het in administratieve wetten bepaalde (afdeling 5.1). Verder worden er in afdeling 5.2. en 5.3 handhavingsinstrumenten beschreven, te weten bestuursdwang en dwangsom. Vooralsnog ontbreekt een regeling van het voor dit onderzoek relevante handhavingsinstrument van de administratieve boete. De regeling daarvan is voorzien in de vierde tranche. In tegenstelling tot het voorontwerp wordt er in de toelichting bij het wetsvoorstel ruim aandacht besteed aan algemene handhavingsaspecten en de verhouding tussen bestuursrechtelijke en strafrechtelijke sancties. ${ }^{68}$

\subsection{Algemene bepalingen over bezwaar en beroep}

Wat onder de begrippen 'bezwaar' en 'beroep' verstaan moet worden kan men lezen in art. 1:5 Awb. Onder het maken van bezwaar wordt verstaan het gebruik maken van de ingevolge een wettelijk voorschrift bestaande bevoegdheid, voorziening tegen

666 MvT Awb, TK 1988-1989, 21221, pag. 104.

667 MVT Awb, TK 1988-1989, 21221, pag. 105.

668 MvT Awb derde tranche, TK 1993-1994, 23700, pag. 106-109. 
een besluit te vragen bij het bestuursorgaan dat het besluit heeft genomen. Met het instellen van administratief beroep wordt bedoeld het gebruik maken van de ingevolge een wettelijk voorschrift bestaande bevoegdheid voorziening tegen een besluit te vragen bij een ander bestuursorgaan dan hetwelk het besluit heeft genomen. Wanneer de term 'het instellen van beroep' wordt gebezigd wordt gedoeld op het instellen van administratief beroep dan wel beroep op een administratieve rechter.

In hoofdstuk 6 van de Awb is een aantal onderwerpen geregeld die zowel gelden voor het maken van bezwaar, het instellen van administratief beroep als voor beroep op de administratieve rechter. Ingevolge art. 6:24 is afdeling 6.2, met uitzondering van art. 6:12 van overeenkomstige toepassing op het hoger beroep of beroep in cassatie dat tegen enkele uitspraken van een aantal administratieve rechters openstaat. $^{\alpha \otimes}$

In artikel 6:1 wordt het toepassingshereik van hooftstukken 6 en 7 vastgesteld, namelijk indien in de betreffende wettelijke regeling is voorzien in de mogelijkheid tot het maken van bezwaar of het instellen van beroep tegen een besluit en indien deze mogelijkheid is gegeven tegen andere handelingen van bestuursorganen. In art. 6:2 wordt dit bereik uitgebreid: met een besluit wordt gelijkgesteld een schriftelijke weigering een besluit te nemen of het niet tijdig beslissen op de aanvraag van een besluit, terwijl art. $6: 3$ een beperking bevat: een beslissing inzake de voorbereiding van een besluit is in beginsel niet vatbaar voor bezwaar of beroep.

In art. 6:4 wordt aangegeven op welke manier het bezwalar of beroep aanhangig wordt gemaakt, namelijk door indiening van het bezwaar- respectievelijk beroepschrift bij beslissingsgerechtigde orgaan.

Art. 6:5 bevat een aantal formele vereisten waaraan het bezwaar- of beroepschrift moet voldoen: het moet ondertekend zijn en minimaal bevatten de naam en het adres van de indiener, de dagtekening, een omschrijving van het bestreden besluit en de gronden van het bezwaar of beroep. Bij het beroepschrift (dit vereiste geldt dus niet bij het maken van bezwaar) wordt zo mogelijk een afschrift van het bestreden besluit overgelegd. Indien het bezwaar- of beroepschrift in een vreemde taal is gesteld moet de indiener, wanneer dit voor de behandeling noodzakelijk te zorgen voor een vertaling.

Indien aan deze, of aan enig ander bij de wet gesteld vereiste ${ }^{670}$ voorwaarden niet wordt voldaan kan het bezwaar- of beroepschrift niet-ontvankelijk worden verklaard, mits de indiener de kans heeft gehad het verzuim te herstellen, art. 6:6.

Een belangrijke bepaling ter harmonisatie van wetgeving en ter vergroting van de rechtszekerheid is te vinden in art. 6:7, waarin de termijn voor het indienen van een bezwaar- of beroepschrift wordt gesteld op zes weken, te rekenen vanaf de dag

669 Zie voor de motivering van deze harmonisatie: MvT Awb, TK 1988-1989, 21221, pag. 113-114. 670 Bijvoorbeeld het vereiste van zekerheidstelling bij het beroep op de rechter in de WAHV. 
na die waarop het bestuursbesluit bekend is gemaakt (art. 6:8). Deze zes wekentermijn moet, zo mogelijk, overal gelden. Alleen wanneer er dringende redenen bestaan hiervan af te wijken, kan de wetgever dit in de bijzondere regeling doen. ${ }^{61}$ De tweede tranche van de Awb heeft aan art. 6:8 twee leden toegevoegd, namelijk voor de gevallen het een bezwaarschrift tegen een besluit betreft waartegen alleen een of meer belanghebbenden administratief beroep kunnen instellen, of het een bezwaarschrift tegen een besluit betreft dat aan goedkeuring is onderworpen.

Het bezwaar- of beroepschrift kan op verschillende manieren worden ingediend, bijvoorbeeld per post of door afgifte aan de balie. In beginsel geldt hiervoor dat voor het verstrijken van de termijn het bezwaar- of beroepschrift ontvangen moet zijn. Met betrekking tot de verzending per post kan dit tot onduidelijkheden leiden. Daarom is op deze wijze van indiening, mits de verzending binnen Nederland plaatsvindt, de verzendtheorie van kracht: voor het verstrijken van de termijn moet het bezwaar- of beroepschrift verzonden zijn, art. 6:9.

Het kan voorkomen dat een bezwaar- of beroepschrift wordt ingesteld nog voordat de termijn begint te lopen. In beginsel leidt dit niet tot een niet-ontvankelijkheidsverklaring. De behandeling van het bezwaar of beroep kan dan worden aangehouden tot het begin van de termijn, art. $6: 10$.

Art. 6:11 regelt de tegenovergestelde figuur, namelijk het geval dat het bezwaarof beroepschrift na afloop van de termijn is ingediend. Het artikel geeft aan wanneer dit verschoonbaar is en dus geen niet-ontvankelijkheidsverklaring zal volgen. Wel geldt als eis dat de betrokkene kan aantonen dat hij het hezwaar- of beroepschrift zo snel als redelijkerwijs mogelijk was heeft ingediend. ${ }^{672}$

De hier bedoelde termijn geldt niet indien het bezwaar- of beroepschrift wordt ingesteld tegen het niet tijdig beslissen van het bestuursorgaan op een aanvraag. Het zou onredelijk, maar ook onpraktisch zijn de aanvrager hier aan een termijn te binden. Art. 6:12 lid 3 zegt dat het indienen van een rechtsmiddel in een dergelijk geval niet onredelijk laat mag geschieden.

Bij de tweede tranche van de Awb is ingevoegd art. 6:13. Dit artikel houdt in dat geen beroep kan worden ingesteld tegen een besluit dat werd genomen op bezwaar of in administratief beroep, wanneer aan de belanghebbende redelijkerwijs kan worden verweten, dat hij geen bezwaar heeft gemaakt of administratief heroep heeft ingesteld tegen het oorspronkelijke besluit.

Ter bevordering van de rechtszekerheid schrijft art. 6:14 voor dat de indiener van het bezwaar of beroep daarvan een schriftelijke ontvangstbevestiging krijgt. Indien beroep is ingesteld wordt het orgaan dat de beslissing nam zo snel mogelijk van het beroep op de hoogte gesteld door het orgaan waar het beroep is ingesteld. Het kan voorkomen dat de betrokkene zijn rechtsmiddel instelt bij de verkeerde instantie. Hierin voorziet art. 6:15. Het legt het orgaan dat het bezwaar- of beroep-

671 MvT Awb, TK 1988-1989, 21221, pag. 124.

672 Het artikel onderging een redactionele wijziging in de tweede tranche Awb. 
schrift per abuis ontvangt de verplichting op dit zo spoedig mogelijk door te sturen naar de bevoegde instantie, waarbij dit tegelijkertijd wordt meegedeeld aan de afzender. Dit geldt tevens voor het geval er in plaats van een bezwaarschrift een beroepschrift is ingediend en omgekeerd.

Een hoofdregel van het administratief procesrecht is dat het maken van bezwaar of het instellen van beroep geen schorsende werking heeft. Deze regel is vastgelegd in art. 6:16. Het wachten op de uitkomst van een beroepsprocedure kan voor de belanghebbende natuurlijk schade opleveren, die niet zo eenvoudig ongedaan kan worden gemaakt. Het artikel laat de mogelijkheid open dat van deze hoofdregel in een afzonderlijk wettelijk voorschrift wordt afgeweken.

Op grond van art. 2:1 kan een belanghebbende zich in een procedure tegen een bestuursorgaan laten vertegenwoordigen. Art. 6:17 bepaalt dat, indien iemand zich in bezwaar of beroep laat vertegenwoordigen, de stukken met betrekking tot de zaak in ieder geval aan de gemachtigde worden verstuurd. De stukken worden dus primair aan de gemachtigde gezonden.

De artikelen 6:18 en 6:19 behandelen de mogelijkheid dat, hangende een procedure, het betreffende besluit gewijzigd of ingetrokken wordt. Het bestuursorgaan moet de vrijheid houden het besluit in te trekken of te wijzigen, maar dit mag niet leiden tot verlies van rechtsbescherming voor de burger ten gevolge hiervan. Van de intrekking of wijziging moet aan het orgaan, waar het bezwaar of beroep aanhangig is, mededeling worden gedaan. Lid 3 en lid 4 van art. 6:18 en art. 6:19 waken tegen een onjuist gebruik van de intrekkings- of wijzigingsbevoegdheid, waardoor het beroepsrecht zou worden gefrustreerd of de rechtsbescherming in de knel zou komen. Art. 6:20 geeft een aantal regels voor het geval het bezwaar of beroep is gericht tegen het niet tijdig beslissen op een aanvraag van een besluit. Het instellen van bezwaar of beroep in zo'n geval ontslaat het hestuursorgaan niet van de verplichting alsnog op de aanvraag te beslissen.

Ter bevordering van de rechtszekerheid bepaalt art. 6:21 dat intrekking van het bezwaar of beroep in principe schriftelijk moet geschieden. Ook tijdens de zitting kan tot intrekking worden overgegaan, hetgeen dan mondeling kan gebeuren.

Is het orgaan dat op het bezwaar of beroep beslist verplicht tot vernietiging over te gilan indien blijkt dat enig vormvoorschrift is geschonden? Uit art. 6:22 volgt dat vernictiging niet altijd het gevolg behoeft te zijn. Het berocpsorgaan heeft de bevoegdheid de beslissing in stand te laten indien blijkt dat de belanghebhende daardoor niet is benadeeld.

Zoals reeds in art. 3:45 voor alle besluiten is voorgeschreven, wordt in art. 6:23 nog eens gesteld dat bij bekendmaking van beslissingen op bezwaar en beroep moet worden vermeld welk(e) rechtsmiddel(en) nog openstaa(t)(n). 
Alle hier genoemde bepalingen zijn van overeenkomstige toepassing op het doen van verzet, ${ }^{\text {S/3 }}$ het hoger beroep en het beroep in cassatie tegen de uitspraak van een administratieve rechter, met uitzondering van art. 6:12, art. 6:24 lid 1. In afwijking van hetgeen in art. 6:4 is voorgeschreven geschiedt het instellen van cassatie door het indienen van een beroepschrift bij de rechter tegen wiens uitspraak het beroep is gericht, art. 6:24 lid 2 .

\subsection{Bijzondere bepalingen over bezwaar en administratief beroep}

\subsubsection{Bijzondere bepalingen over bezwaar}

Bijzondere bepalingen betreffende de bezwaarschriftprocedure zijn te vinden in afdeling 7.1 Awb. Er is een algemene verplichting opgenomen tot het volgen van een bezwaarschriftprocedure. Deze verplichting is neergelegd in art. 7:1. In een viertal gevallen staat deze procedure niet open. In deze in het tweede lid met name genoemde situaties (het besluit is op bezwaar of beroep genomen, het besluit is aan goedkeuring onderworpen, het besluit houdt de goedkeuring van een ander besluit in of de weigering van die goedkeuring) heeft er al op een andere manier in een verplichte voorprocedure plaatsgevonden. Tegen de beslissing op het bezwaar staat beroep open volgens de regels die gelden voor het instellen van beroep tegen het besluit waartegen het bezwaar werd gemaakt. ${ }^{\text {is }}$

Een zeer belangrijke fase van de bezwaarschriftprocedure is neergelegd in art. 7:2: voordat op het bezwaarschrift wordt beslist moet het bestuursorgaan de belanghebbenden horen, de zogenaamde hoorplicht. Zowel de indiener als andere belanghebbenden worden in de gelegenheid gesteld hun standpunt toe te lichten. Dit horen is echter niet alleen een waarborg voor de belanghebbende, maar het biedt tevens het bestuursorgaan de gelegenheid zich ervan te vergewissen dat zij alle relevante informatie bezit die nodig is voor een zorgvuldige heroverweging en besluitvorming. ${ }^{65}$ In art. 7:3 is een aantal uitzonderingen op de hoofdregel van het verplicht horen geformuleerd. Het betreft hier gevallen waarin het horen voor een zorgvuldige heroverweging en besluitvorming niet nodig is. Van het horen kan worden afgezien (a) indien het bezwaar kennelijk niet-ontvankelijk is, (b) het bezwaar kennelijk ongegrond is, (c) de belanghebbende heeft verklaard geen behoefte te hebhen te worden gehoord of (d) aan het bezwaar volledig wordt toegekomen en andere belanghebbenden daardoor niet in hun belangen kunnen worden geschaad. De onder (b) beschreven uitzondering lijkt me van groot belang en kan de meeste problemen opleveren. Deze hepaling geeft het bestuursorgaan de mogelijkheid om een bezwaarschrift op inhoudelijke gronden vereenvoudigd af te doen (maar zonder verzetsmogelijkheid van artt.

173 Ingevocgd in de tweede tranche Awb, art. 8:55 lid 1.

674 Zic hicrover A.Q.C. Tak, Kleine lapsus in de Awb, NTB 1993, pag. 190.

675 MvT Awb, TK 1988-1989, 21221, pag. 144. 
8:54-8:55). Maar wanneer is nu een bezwaar kennelijk ongegrond en wie bepaalt dat? Van een kennelijk ongegrond bezwaar is volgens de MvT sprake wanneer uit het bezwaarschrift zelf aanstonds blijkt dat de bezwaren van de indiener van het bezwaarschrift ongegrond zijn en er redelijkerwijs geen twijfel daarover mogelijk is. ${ }^{776}$ Dit is echter een open formule. Als voorbeelden worden genoemd: gehele of gedeeltelijke tegemoetkoming aan het bezwaar is evident in strijd met een wettelijk voorschrift; het bezwaar richt zich tegen de afwijzing van een herhaalde aanvraag zonder dat uit het bezwaurschrift blijkt van nieuwe feiten of veranderingen; de beslissing waartegen het hezwaar zich richt komt overeen met vast -door de rechter aanvaard- beleid. In de MvT wordt erkend dat het bestuursorgaan art. 7:3 met grote zorgvuldigheid en behoedzaamheid moet toepassen. Er mag niet lichtvaardig met de uitzondering worden omgesprongen. Een zekere waarborg zou het zijn als de vaststelling dat het bezwaar kennelijk ongegrond is niet (uitsluitend) wordt genomen door het orgaan dat de primaire beslissing nam. Ook rechterlijke kontrole kan een garantie bieden. Wanneer de rechter van oordeel is dat de belanghebbende ten onrechte niet op zijn bezwaar is gehoord kan hij de beslissing op het bezwaar vernietigen. Verder moet het bestuursorgaan aangeven op welke gronden van het horen is afgezien (motiveringsverplichting), art. 7:12.

Het horen zelf kan plaatsvinden in een tamelijk informele procedure. Minimum voorschriften waaraan deze procedure moet voldoen vinden we in de artt. 7:4 tot en met 7:8. Zo kunnen belanghebbenden tot tien dagen voor het horen nadere stukken indienen en hebben zij in beginsel inzage in stukken die op de zaak betrekking hebben (art. 7:4). In art. 7:5 lid 1 wordt bepaald aan welke eisen degenen die de belanghebbende horen, moeten voldoen. Een algemene regel over de openbaarheid van de hoorzitting wordt niet gegeven. Voor zover in het afzonderlijk wettelijk voorschrift een regeling ontbreekt, moet het bestuursorgaan daarover een beslissing nemen (art. 7:5 lid 2). Wanneer er meer dan één belanghebbende is, worden dezen volgens art. 7:6 in beginsel in elkaars aanwezigheid gehoord. Art. 7:7 schrijft voor dat van het horen een verslag wordt gemaakt. In welke vorm en hoe uitgebreid dit dient te gebeuren vermeldt dit artikel niet. Art. 7:8 bepaalt dat op verzoek van de belanghebbende (en ook op zijn kosten) door hem meegebrachte getuigen en deskundigen worden gehoord.

Art. 7:9 ziet op de mogelijkheid dat naar aanleiding van de hoorzitting nader onderzoek noodzakelijk is. Feiten en omstandigheden die uit dit onderzoek naar voren komen en die voor de beslissing van belang kunnen zijn, moeten aan de belanghebbende worden meegedeeld.

In art. 7:10 is een algemene regeling neergelegd met betrekking tot de termijnen waarbinnen op het bezwaarschrift moet zijn beslist. In beginsel bedraagt deze termijn zes weken. Indien ten behoeve van het bezwaarschrift een adviescommissie is ingesteld, geldt een termijn van tien weken. Overschrijding van de termijn betekent niet 
dat niet meer op het bezwaarschrift kan worden beslist. Het gevolg is dat beroep kan worden ingesteld bij de instantie die bevoegd is over de beslissing op het bezwaar te oordelen. Wanneer de procedure op het bezwaarschrift nog niet kan beginnen door een verzuim van de indiener wordt de termijn opgeschort, aldus het tweede lid. Lid 3 geeft het bestuursorgaan de mogelijkheid de beslissing voor maximaal vier weken te verdagen, indien het niet mogelijk is binnen de gestelde termijn tot een beslissing te komen. Hiervan moet de indiener schriftelijk bericht ontvangen. Op grond van lid 4 is verder uitstel mogelijk voor zover indiener en (eventueel) andere belanghebbenden daarmee instemmen en de laatsten hierdoor niet in hun belangen kunnen worden geschaad.

De artikelen 7:11 en 7:12 hebben betrekking op de beslissing die op het bezwaar wordt genomen. Indien het bezwaar ontvankelijk is moet het bestuursorgaan, op grondslag van het bezwaar, overgaan tot een heroverweging van het besluit. Dit houdt in dat de toetsing niet beperkt mag blijven tot de rechtmatigheid, maar dat deze ook gericht moet zijn op kwesties van beleid. ${ }^{n}$ Art. 7:11 verzet zich er niet tegen dat het bestuursorgaan de heroverweging mag gebruiken om een verslechtering van de positie van de indiener te bewerkstelligen die ook zonder de bezwaarschriftprocedure mogelijk zou zijn geweest. ${ }^{67}$ Het tweede lid van art. 7:11 geeft aan wat er moet gebeuren indien de uitkomst na heroverweging is dat het bestreden besluit niet in stand kan blijven. Het bestuursorgaan herroept dan het bestreden besluit en neemt, voor zover dat nodig is, een nieuw.

De beslissing op het bezwaar dient deugdelijk gemotiveerd te zijn en de bekendmaking ervan dient van deze motivering vergezeld te gaan. Dit is de strekking van art. 7:12 lid 1. Lid 2 heeft betrekking op de bekendmaking. Dit gebeurt door toezending of uitreiking aan degene tot wie de beslissing is gericht. Andere belanghebbenden die aan de bezwaarschriftprocedure hebben deelgenomen of bij de voorbereiding van het besluit betrokken waren, moeten op de hoogte worden gesteld, aldus lid 3. Bij deze bekendmaking is art. 7:10 (termijnen) van toepassing en wordt voorzien in de mededeling van openstaande rechtsmiddelen.

Art. 7:13 behandelt de procedure die gevolgd wordt indien er ten behoeve van de beslissing op het bezwaar een adviescommissie is ingesteld.

De beslissing op een bezwaarschrift is in terminologie van de Awb een beschikking (en wel én op aanvraag) en een besluit. Zonder nadere bepaling zouden de hoofdstukken 3 en 4 daarop in zijn geheel van toepassing zijn. Afdeling 3.4 (voorbereiding

MvT Awb, TK 1988-1989, 21221, pag. 152.

678 Dit betekent niet dat het bestuursorgaan het besluit niet kan wijzigen ten nadele van de belanghebbende. Deze bevoegdheid bestaat dan reeds op andere gronden dan die welke de belanghebbende aanvoert.

Dit betekent ook niet dat als gevolg van de bezwaarschriftprocedure het primaire besluit nimmer kan worden gewijzigd ten nadele van degene tot wie het besluit primair was gericht. Een dergelijke wijziging zal zich met name voordoen wanneer de indiener van het bezwaarschrift cen derdebelanghebbende is. 
van een besluit) komt hiervoor echter niet in aanmerking. In art. 7:14 wordt deze afdeling dan ook uitgesloten. Ten aanzien van de bekendmaking van de beslissing geeft art. 7:12 bijzondere bepalingen, zodat ook de artikelen 3:41 tot en met 3:45 overbodig zijn. Afdeling 3.6 (motivering).wordt in het Voorontwerp derde tranche uitgesloten. Hoofdstuk 4 behandelt dezelfde materie als waarvoor in de hoofdstukken 6 en 7 regels voor de bezwaarschriftprocedure zijn opgenomen. Om misverstanden te voorkomen is hoofdstuk 4 in zijn geheel uitgesloten.

Voor de behandeling van het bezwaarschrift is geen recht verschuldigd, art. 7:15. Dit zou niet stroken met de aard van de bezwaarschriftprocedure, die ook in het belang is van het bestuursorgaan, dat daardoor immers in staat is een beter onderbouwd besluit te nemen. ${ }^{6 x}$ Wel wordt griffierecht geheven voor de indiener van een bezwaarschrift die tevens verzoekt om een voorlopige voorziening, art. 8:82 Awb.

\subsubsection{Bijzondere bepalingen over administratief beroep}

Zoals in afdeling 7.1 bijzondere bepalingen betreffende het bezwaar zijn opgenomen, bevat afdeling 7.2 deze voor het administratief beroep. Op meerdere punten lijkt het administratief beroep op het bezwaar. Het grote onderscheid is dat in geval van administratief beroep de zaak opnieuw bekeken wordt door een ander -hoger- bestuursorgaan dan het orgaan dat de primaire beslissing nam, terwijl bij bezwaar besloten wordt door het bestuursorgaan dat de beslissing nam.

Omdat er veel overeenkomsten zijn tussen het bezwaar en administratief beroep, zijn ook veel procedureregels hetzelfde. Een aantal bepalingen uit afdeling 7.1. komt dan ook terug in afdeling 7.2. Bespreking van deze bepalingen zal hier niet meer plaatsvinden. Slechts die bepalingen worden vermeld die afwijken van de bezwaarschriftprocedure.

Evenals art. 7:2 bevat art. 7:16 het voorschrift dat belanghebbenden moeten worden gehoord. Bij het administratief beroep moeten daarvan op de hoogte worden gesteld de indiener van het beroepschrift, het bestuursorgaan dat het besluit heeft genomen, de belanghebbenden die bij de voorbereiding van het besluit betrokken zijn geweest of die bij de behandeling van het bezwaarschrift hun zienswijze naar voren brachten. Ook bij administratief beroep kan van deze hoorplicht worden afgezien. De gronden dalirvoor stemmen overeen met die genoemd in art. 7:3 a, b en c. Grond d komt hier echter niet terug, omdat in de beroepsprocedure ook het bestuursorgaan dat de beslissing nam verwerende partij is.

Uitgangspunt van art. 7:19 is dat het horen geschiedt door het beroepsorgaan. Dit kan worden opgedragen aan een adviescommissie. Indien van deze commissie een of meer leden niet onder verantwoordelijkheid van het bestuursorgaan werkzaam 
zijn, kan dit slechts indien deze commissie bij of krachtens de wet is ingesteld. In beginsel vindt het horen in het openbaar plaats.

De termijn voor behandeling van het beroepschrift is in beginsel op zestien weken gesteld, art. 7:23. In het geval echter het beroepsorgaan behoort tot hetzelfde lichaam als het in eerste instantie beslissende orgaan, geldt dezelfde termijn dan die voor de behandeling van een bezwaarschrift is gesteld: zes weken. Evenals dat bij het bezwaar mogelijk was, bevat het artikel mogelijkheden tot verdaging van de beslissing. Een volledige heroverweging van het besluit, zoals die in art. 7:11 is voorgeschreven in een bezwaarschriftprocedure, is voor het beroep niet opgenomen. Hoewel er geen sprake is van beperkte toetsingsgronden, dus vol beroep, kan het beroepsorgaan van oordeel zijn dat het door het primair beslissende orgaan gevoerde beleid gerespecteerd moet worden. Wel is vastgelegd dat het beroepsorgaan niet kan volstaan met gehele of gedeeltelijke vernietiging van het primaire besluit, maar dat het, voor zover dit nodig is, een nieuw besluit neemt, art. 7:24.

\section{Beroep bij de rechtbank}

Tot op heden waren er verschillende soorten administratieve rechters aan wie het bestuursrechtelijk optreden ter toetsing kon worden voorgelegd. Ook hier zorgt de Awb voor unificatie. Belangrijkste wijziging is dat er administratieve kamers bij de rechtbanken zijn ingesteld. Bij de tweede tranche Awb is voor de herziening van de rechterlijke organisatie bij de rechtbanken in verband met het behandelen en beslissen van bestuursrechtelijke zaken administratieve rechtspraak in twee instanties ingevoerd. Daartoe is in de Awb een hoofdstuk 8 opgenomen betreffende het beroep bij de rechtbank. In de toekomst zal dit hoofdstuk van toepassing zijn op de procedures bij alle administratieve rechters. Dit betekent dat ook het beroep op de rechter volgens de WAHV in de toekomst volgens de procedure van de Awb zal galan verlopen. ${ }^{60}$ Dat heeft in de eerste plaats als consequentie dat het beroep zal moeten plaatsvinden bij de rechtbank en niet meer bij de kantonrechter.

Omdat het hoofdstuk dus op termijn ook zal gaan gelden voor de administratiefrechtelijke handhaving van verkeersvoorschriften zal ik hier aandacht schenken aan het beroep bij de rechtbank. Ik zal me evenwel beperken tot die onderwerpen, waar mogelijk ingrijpende verschillen te constateren zijn. In tegenstelling tot de Awb kent de WAHV bijvoorbeeld geen rechtspraak in twee instanties. Van de beslissing van de rechtbank kan beroep in cassatie worden ingesteld bij de Hoge Raad.

680 Hoofdstuk 6, algemene bepalingen over bezwaar en beroep, dus inclusief het beroep bij de rechtbank, geldt wel terstond. 
Art. 8:1 vormt de kernbepaling van het nieuwe bestuursprocesrecht. ${ }^{681}$ In deze bepaling is de absolute bevoegdheid in bestuursrechtelijke gedingen gelegd bij de rechtbank. Object van het geding is het besluit. ${ }^{622}$ Het ging de regering te ver beroep open te stellen tegen algemeen verbindende voorschriften en beleidsregels (art. 8:2), zoals het Oorspronkelijk Regeringsontwerp met betrekking tot beleidsregels had voorgesteld. ${ }^{\infty i j}$ Bij de behandeling in de Tweede Kamer werd echter bij amendement een nieuw artikel (IVA) ingevoegd in de Overgangs- en slotbepalingen, ${ }^{64}$ waardoor vijf jaren na inwerkingtreding van deze wet art. 8:2 zal vervallen, waardoor de uitzondering van algemeen verbindende voorschriften en beleidsregels zal vervallen. Dan zal dus ook beroep open staan tegen algemeen verbindende voorschriften en beleidsregels. ${ }^{\text {tos }}$

Volgens art. 8:10 worden de zaken in beginsel in behandeling genomen door een enkelvoudige kamer. Achtergrond hiervan is het uitgangspunt van behandeling in twee instanties, waardoor de behandeling door de tweede instantie toch bij een meervoudige kamer komt. De WAHV kent echter slechts behandeling in één instantie, waarvoor dit argument dus niet zou opgaan.

Aanvankelijk werd het griffierecht in art. 8:41 bepaald op f50,-. In de MvT kan men lezen dat de regering een Jaag griffierecht wilde omdat het niet zo mag zijn dat bepaalde groepen rechtzoekenden in feite door een hoog griffierecht de toegang tot de rechter wordt ontnomen. Hierbij speelt natuurlijk mee dat de een van de doelstellingen van de Awb rechtsbescherming van de burger was. Een bedrag van f50,- werd billijk geacht. ${ }^{\alpha 5}$ Des te meer bevreemding wekt het dat het principe van rechtsbescherming moest wijken voor de "nood van de schatkist". ${ }^{687}$ In de Tweede Nota van Wijziging ${ }^{608}$ werd het art. 8:41 compleet gewijzigd. Er is nu een gedifferentieerd griffierecht voorgesteld, voor natuurlijke personen variërend van $f 50$,- tot $f 200$,in eerste aanleg en van $f 150$,- tot $f 300$,- in hoger beroep. Voor rechtspersonen bedraagt het griffierecht $f 400$,- in eerste aanleg en $f 600$,- in appel. Het kabinetsbeleid zou er nu meer op gericht zijn een relatie te leggen tussen de prijs en de kosten van diensten. Als men dit bedrijfseconomisch principe voor overheidshandelen wil invoeren (hetgeen ikzelf zeker niet zou willen propageren en volgens mij ook niet mogelijk is daar het winstbegrip geen rol mag spelen) moet men echter ook serieus aandacht schenken aan de keerzijde ervan: het zo laag mogelijk houden van de kostprijs. Nog ernstiger weegt het volgende bezwaar: de burger wordt door de over-

681 Vgl, A.O.C.Tak, De Algemene wet bestuursrecht, het nieuwe bestuursprocesrecht, tweede druk, Zwolle 1993, pag. 109.

682 Zie hierover uitgebreider: A.Q.C. Tak, a.w., pag. 104-115.

683 MvT Awb tweede tranche, TK 1991-1992, 22495, nr. 3, pag. 92-93.

684 Amendement Jurgens-Biesheuvel, Tweede Kamer 1992-1993, 22495, nr. 19.

685 Zic voor kritick hicrop: A.Q.C. Tak, a.w., pag. 105-106, 107, 110, 112.

686 MvT Awb tweede tranche, TK 1991-1992, 22945, nr.3, pag. 125-126.

687 A.Q.C. Tak, a.w., pag. 120.

688 TK 1992-1993, 22945, nr. 12. 
heid gebruikt voor de controle van de eigen besluiten. Daarom geldt in het bestuursprocesrechtrecht het beginsel van de kosteloosheid (wat nu dus is verkracht). Anders dan onder de Wet AROB is er nu zelfs geen mogelijkheid om te vragen om vermindering of vrijstelling. In wezen wordt hiermee de rechtsbescherming tegen de overheid om zeep gebracht.

De gerechtelijke procedure bij de administratieve kamer van de rechtbank kent een tamelijk uitgebreid vooronderzoek dat te verdelen is tussen een schriftelijke voorbereiding (art. 8:42 tot 8:45) en het voorbereidend onderzoek (art. 8:46 tot 8:51). Zo dient het betreffende bestuursorgaan binnen vier weken na de dag van verzending van het beroepschrift de op het geding betrekking hebbende stukken en een verweerschrift in te dienen. Wanneer deze verplichtingen niet worden nagekomen geeft art. 8:31 de rechtbank de bevoegdheid de gevolgtrekkingen te maken die haar juist lijken. Hierbij valt onder meer te denken aan gegrondverklaring van het beroep.

De Awb kent een vereenvoudigde behandeling voor het geval aanstonds duidelijk is: de onbevoegdheid van de rechter, de niet-ontvankelijkheid van het beroep, de ongegrondheid van het beroep of de gegrondheid van het beroep (artt. 8:54 en 8:55). Verder bestaat de mogelijkheid van een versnelde procedure van spoedeisende zaken, art. 8:52.

Afdeling 8.2.5 regelt het onderzoek ter zitting.

In afdeling 8.2.6 staan de bepalingen omtrent de uitspraak. De omvang van het geschil wordt bepaald door de omvang van het ingestelde beroep. De rechtbank doet dan ook uitspraak (onder meer) op de grondslag van het beroepschrift (art. 8:69 lid 1). Hieruit vloeit voort dat onderdelen van het besluit waartegen niet wordt opgekomen buiten beschouwing blijven ${ }^{60}$ Verder heeft dit als consequentie dat de insteller van het beroep niet in een slechtere positie komt. Een zogenaamde reformatio in peius wordt hiermee uitgesloten. ${ }^{\oplus 1}$ Volgens Tak wordt hiermee het karakter van het bestuursproces als toetsing van een besluit, waarbij meerdere algemene en bijzondere belangen betrokken zijn, ontkend ${ }^{692}$ Het tweede en derde lid van art. 8:69 bepalen dat de rechter de rechisgronden ambtshalve moet aanvullen en de feiten ambtshalve kan aanvullen.

De volgende uitspraken zijn mogelijk (art. 8:70):
a. onbevoegdverklaring van de rechter;
b. niet-ontvankelijkheid van het beroep;
c. ongegrondverklaring van het beroep;
d. gegrondverklaring van het beroep.

Dit is dan ook nog op onbehoorlijke wijze gebeurd. Zo is er geen gelegenheid geboden tot advies aan de Raad van State, er is geen inspraak gewecst voor maatschappelijke groeperingen en door niet te reageren op een petitie van alle universiteiten is de wetenschap volstrekt genegeerd. MvT Awb tweede tranche, TK 1991-1992, 22495, nr. 3, pag. 141. MvT Awb tweede tranche, TK 1991-1992, 22495, nr. 3, pag. 142. 
Deze laatste uitspraak is aangewezen indien de rechtbank het bestreden besluit op een of meer van de aangevoerde gronden, dan wel ambtshalve, onrechtmatig acht. De toetsingsgronden staan, in tegenstelling tot tot nu toe geldende administratieve wetten, niet in de wet vermeld. In art. 8:77 lid 2 wordt dit enigszins gecorrigeerd. Bij gegrondverklaring van het beroep dient namelijk in de uitspraak te worden vermeld welke geschreven of ongeschreven rechtsregel of welk algemeen rechtsbeginse] is geschonden. Met deze nuime omschrijving wordt volgens de MvT beoogd de rechtszekerheid alsmede de verdere rechtsontwikkeling te bevorderen. ${ }^{.03}$

$\mathrm{Na}$ gegrondverklaring van het beroep volgt gehele of gedeeltelijke vernietiging van het besluit, art. 8:72 lid 1. Meestal is object van het geding de beslissing op het bezwaarschrift. Na gegrondbevinding van het beroep en na vernietiging van de beslissing op het bezwaarschrift is dus nog niet op het bezwaar beslist. Hiervoor zijn verschillende oplossingen denkbaar: volstaan met vernietiging, terugverwijzing naar het bestuursorgaan dat de beslissing nam (art. 8:72 lid 4 eerste volzin) of herbeslissingsbevoegdheid voor de rechter (art. 8:72 lid 4 laatste volzin). Volgens Tak wordt verwacht dat de rechter deze bevoegdheid slechts dan gebruikt als slechts én beslissing mogelijk is. ${ }^{6+1}$ De beslissing van de rechter zal ex nunc gaan gelden, terwijl bij de beoordeling van het beroep is uitgegaan van feiten en omstandigheden van het besluit ex tunc. 


\section{Vergelijking van de methoden tot buitengerechtelijke afdoening door het openbaar ministerie met bestuursrechtelijke normen}

\section{Inleiding}

In het vorige hoofdstuk werden de normen besproken die gelden voor bestuursorginen bij het nemen van besluiten. Dit is gedaan met het oog op onze centrale vraag in hoeverre de normen die gelden voor een bestuursorgaan bij het nemen van een besluit ook zouden moeten gelden voor het OM bij het nemen van een besluit tot afdoening van een strafzaak buiten het strafgeding om. En, verder redenerend: zou dan ook de uitzondering die art. 1:6 Awb maakt ten aanzien van de vervolgingbeslissing voor wat betreft de beslissingen tot buitengerechtelijke afdoening van strafbare feiten kunnen worden geschrapt? Deze specifieke beslissing werd in hoofdstuk 8 gekwalificeerd als een bestuursbesluit.

De bedoeling van dit hoofdstuk is te komen tot toetsing van de vraag of de besluiten tot buitengerechtelijke afdoening verlopen volgens de beschreven bestuursrechtelijke normen en op welk punt deze normen van elkaar afwijken. Het kan natuurlijk best zo zijn dat de regelingen van de verschillende methoden ter afdoening buiten het strafgeding om reeds verlopen overeenkomstig (een aantal van) deze bestuursrechtelijke normen. Nagegaan zal worden in hoeverre dit het geval is en op welke onderdelen de afdoeningsmethoden afwijken van de bestuursnormen.

Bij constatering van een dergelijke afwijking zal moeten worden bekeken of deze gehandhaafd moet of kan blijven of dat de afdoeningsmethode bijstelling c.q. wijziging behoeft. Indien deze laatste vraag positief beantwoord wordt, komt aan de orde of deze bijstelling c.q. wijziging al dan niet moet geschieden in de vorm van aanpassing aan de algemene bestuursrechtelijke norm.

Wordt tot bijstelling c.q. wijziging van de norm besloten, dan zal dat in de vorm van een aanbeveling worden aangegeven.

De buitengerechtelijke afdoeningsmethoden zoals die door het OM gehanteerd worden, worden niet alleen beheerst door wettelijke voorschriften uit het Wetboek van Strafvordering en de Wet op de Rechterlijke Organisatie. Hiervoor gelden ook verdragsbepalingen van het EVRM en het IVBP, te weten art. 6 resp. art. 14. Deze bepalingen garanderen onder meer een eerlijke en openbare behandeling van een strafzaak, binnen een redelijke termijn, door een onafhankelijke en onpartijdige 
rechterlijke instantie; de verdachte wordt voor onschuldig gehouden totdat zijn schuld volgens de wet bewezen is. ${ }^{\text {os }}$

Evenals dit bij bestuursbesluiten het geval is, zijn ook op de strafvordering, en met name daar waar het strafproces overeenkomst vertoont met het bestuursrecht (dit doet zich, zoals ik hierna betoog, voor bij de buitengerechtelijke afdoening) ongeschreven regels van toepassing die betrekking hebben op de behoorlijkheid van de procedure. In de strafrechtspraak worden deze op verschillende wijzen aangeduid, onder andere als beginselen van een goede procesorde, beginselen van een behoorlijke procesvoering, beginselen van een behoorlijk vervolgingsbeleid, beginselen van een behoorlijke strafrechtsbedeling, beginselen van een deugdelijke procesvoering en ook als algemene beginselen van behoorlijk bestuur. ${ }^{\theta \diamond}$

Deze behoorlijkheidsvereisten functioneren op twee wijzen. In de eerste plaats richten zij zich tot de instanties zelf. Het zijn normen waarnaar de handelende justitiële organen zich moeten gedragen. Daarnaast fungeren zij als een toetsingsnorm voor de rechter, die daarmee achteraf controleert of het optreden van de betreffende instantie(s) behoorlijk is geweest. Cleiren duidt deze aspecten aan als het gedragsrespectievelijk het geldingsaspect. ${ }^{\text {miz }}$ Door middel van toetsing door de rechter worden weer indirect aanwijzingen gegeven aan de betreffende instantie hoe zich in een voorkomende vergelijkbare situatie op te stellen of te handelen. De twee functies kunnen elkaar als het ware aanvullen. Hierbij zij opgemerkt dat de mogelijkheden voor de strafrechter om het betreffende gedrag te sanctioneren beperkter zijn dan in het bestuursrecht. Dit hangt samen met het feit dat in het bestuursrecht het optreden van het bestuursorgaan rechtstreeks voorwerp is in een geding, terwijl in het strafgeding primair het tenlastegelegde feit voorwerp is van onderzoek. Met andere woorden: het gedragsaspect wordt niet steeds gedekt door het geldingsaspect.

695 In de rechtspraak worden de verdragsbepalingen soms genoemd naast de algemene beginselen van behoorlijke strafrechtspleging, maar soms ook gerien als onderdecl daarvan. Zie voor voorbeetden: C.P.M. Cleiren, Beginselen van een goede procesorde. Arnhem 1989, pag. 320-321.

696 Zie voor een uitgebreide analyse van ongeschreven beginselen in het strafrecht: C.P.M. Cleiren, Beginselen van een goede procesorde. Arnhem 1989. Voor dit onderwerp is verder met name Hoofdstuk 3, $\$ 3$ van belang. Cleiren kiest uiteindelijk voor de benaming beginselen van behoorlijke strafrechtspleging en maakt daarbij enkele specificaties, waaronder die van beginselen van behoorlijke vervolging en beginselen van behoorlijk vervolgingsbeleid, Hoofdstuk V $\S 4$ en 5 . Zie voor andere literatuur: J.A. Borman, Openbaar Ministerie en beginselen van behoorlijk bestuur, Trema 1981, pag. 103-112; T. Hoogenboom, De macht van het Openbaar Ministerie en de grenzen van het bestuursrecht uit: $H$. van de Bunt e.a. (red.), De macht van het OM, Nijmegen 1983, pag. 100-117; J. Steenbrink, Het Openbaar Ministerie en de beginselen van een behoorlijke procesorde, AA 1984, pag. 593-601; G.J.M. Corstens, Beginselen van behoorlijk procesrecht, Trema 1985, pag. 173-191.

697 C.P.M. Cleiren, a.w., pag. 260. Zie over sanctionering door de strafrechter pag. 295-306. 
De behoorlijkheidsvereisten gelden voor de gehele procedure en voor alle deelnemende instanties. ${ }^{\oplus 8}$ De strafrechtelijke literatuur met betrekking tot deze beginselen concentreert zich echter op de toetsing door de rechter van het vervolgingsbeleid van het OM. Dit hangt ongetwijfeld samen met de positieve toepassing van het opportuniteitsbeginsel, op grond waarvan het $\mathrm{OM}$ een discretionaire bevoegdheid heeft tot het nemen van een vervolgingsbeslissing. De ruimte die het OM wordt gegeven, biedt het een grote vrijheid van handelen.

Cleiren, daarbij onder meer verwijzend naar 't Hart en De Doelder, betoogt dat, hoewel er overeenkomsten zijn aan te wijzen tussen de (door haar genoemde) beginselen van behoorlijke strafrechtspleging en ongeschreven normen op andere rechtsgebieden waaronder het bestuursrecht, deze beginselen niet geïdentificeerd mogen worden met de normen geldend voor andere rechtsgebieden. Als reden hiervoor geeft zij een zodanig eigen karakter van de publieke taak van de justitiële organen in het kader van de strafvordering. ${ }^{(x)}$ In het algemeen moge deze stelling juist zijn (erkend moet worden dat de positie van de officier van justitie ter zitting, de rechtercommissaris, de raadkamer en de rechter ter zitting een specifieke strafrechtelijke rol vervullen, die zich moeilijk laat vergelijken met die van het bestuursorgaan bij het nemen van een bestuursbesluit), de positie van het $\mathrm{OM}$ bij de buitengerechtelijke afdoening van strafbare feiten door de beschreven afdoeningsmethoden, waarbij eventueel de betrokken burger een sanctie krijgt opgelegd, kan een dergelijke vergelijking met een bestuursbesluit naar mijn mening wél doorstaan. Ook de vervolgingsbeslissing op zichzelf is een besluit dat zich naar mijn mening uitstekend met de administratiefrechtelijke beschikking laat vergelijken, zowel materieel als qua vorm. Het zijn namelijk, zoals reeds betoogd in hoofdstuk 8, beslissingen afkomstig van een publiekrechtelijk orgaan, gericht op enig rechtsgevolg. Evenals dit bij bestuursbesluiten het geval is worden zij pas achteraf, nadat de burger kenbaar heeft gemaakt het niet met de beslissing eens te zijn (evenals dat in het bestuursrecht het geval is), aan de rechter voorgelegd en pas dan is er sprake van een conflict. ${ }^{700}$ Cleiren acht met name het verschil in taak van de rechter op dit punt doorslaggevend voor haar opvatting dat beginselen van behoorlijke strafrechtspleging moeten worden onder-

698 Cleiren beschrijft in haar bock de beginsclen zoals die in de rechtspraak naar voren komen met betrekking tot de volgende instantics: opspuringsambtenaren, Opunbaar Ministeric/officicr van justitie, griffier, rechtcr-commissaris, radkamer, rechter in fuitelijke instantie, Hogc Raad en raadsman/verdachte. C.P.M. Cleiren, a.w.

699 C.P.M. Clciren, a.w., pag. 272-273. Zic ook: C.P.M. Cleiren, Identiteit van behoorlijke strafrechtspleging en beginselen van behoorlijk bestuur? DD 1990, pag. 497-514.

700) Het enige 'rechtsmiddel' dat de burger heeft tegen een zajns inziens ontcrechte transacticbeslissing of een besluit waarbij een voorwaarde wordt opgelegd waarvan vervulling zal betekenen dat nict (verder) zal worden vervolgd, is de voorwaarde niet te accepteren en de zaak voor de rechter te laten komen. Verderop in dit onderzoek zal worden betoogd dat hiervoor een ander rechtsmiddel zal dienen te worden gecreëerd. 
scheiden van algemene beginselen van behoorlijk bestuur. ${ }^{\text {r1 }} \mathrm{Zij}$ betoogt dat de taak van de strafrechter erop is toegesneden om het tenlastegelegde handelen van de verdachte te beoordelen, terwijl in het administratieve geding het optreden van het overheidsorgaan inzet vormt van het geding. Afgezien van het feit dat ik niet de relatie van de rechter met de algemene beginselen als onderwerp van onderzoek heb gekozen, maar de positie van het $\mathrm{OM}$ in samenhang daarmee, denk ik dat het door haar gegeven onderscheid te scherp is en dat de beschrijving van de taak van de strafrechter in deze niet volledig is. De strafrechter beoordeelt, voor zover hij hiervoor de mogelijkheid heeft, wel degelijk ook het optreden van het vervolgend overheidsorgaan, het OM. Bekeken wordt in ieder geval of het OM ontvankelijk is in zijn vervolging. Redenen van niet-ontvankelijkheid kunnen wel degelijk gelegen zijn in het optreden van de justitiële organen. Zoals verder in dit hoofdstuk herhaaldelijk zal blijken, erken ik dat er verschil bestaat in rechterlijk optreden, met name daar waar een transactiebesluit geen voorwerp van onderzoek ter zitting is, maar ben ik tegelijkertijd van mening dat bepaalde verschillen, juist omdat het hier 'een vorm van bestuur' betreft, zouden dienen te verdwijnen.

Zoals hierboven gememoreerd handelt dit onderzoek over de positie van het OM bij het nemen van een besluit tot buitengerechtelijke afdoening van een strafzaak. Het gaat dus in eerste instantie niet over de rol van de strafrechter. Ik acht met name de zelfstandigheid ten opzichte van de rechter, waarmee de individuele officier van justitie zijn beslissing neemt, doorslaggevend voor de opvatting dat het hier 'een vorm van bestuur' betreft. De partijpositie van het OM laat zich vergelijken met die van een voor het algemeen belang verantwoordelijk overheidsorgaan, zoals bijvoorbeeld bij een onteigenings- of belastingrechtelijke procedure. Kortom: het OM is altijd (partijdig) bestuur. Daarom moet overwogen worden of bij de buitengerechtelijke afdoening het bestuursrecht (Awb) rechtstreeks voor volledige toepassing in aanmerking komt. Art. 3:1 lid 2 heeft betrekking op de directe toepassing van de Awb op vervolgingsbeslissingen van het $O M$.

Indien de betrokken burger niet te kennen geeft het met de beslissing van de officier van justitie niet eens te zijn krijgt zijn zelfstandig genomen beslissing direct rechtsgevolgen. Deze beslissing voldoet aan de definitie van "besluit" in de zin van art. 1:3 Awb.

Omdat het $O M$ in die vervolgingsfunctie (waaronder ik dan versta zijn bevoegdheid wel of niet of voorwaardelijk niet te vervolgen), dus in de periode voordat er sprake is van een rechtsgeding, naar mijn mening niet fundamenteel afwijkt van het functioneren van een ander bestuursorgatan, heeft het mijn voorkeur ook in dit verband te spreken van algemene beginselen van hehoorlijk bestuur, met als specificatie beginselen van behoorlijke vervolging. Hierbij ben ik mij ervan bewust dat deze beginselen deel uitmaken van een grotere groep, namelijk beginselen die gelden voor het strafproces als geheel. Cleiren reserveert de term beginselen van behoorlijke

701 Zie het reeds aangehaalde artikel uit DD 1990, pag. 499. 
vervolging voor handelingen en beslissingen in het kader van de vervolging waarbij het betreffende orgaan geen discretionaire bevoegdheid heeft en voor gevallen waarin de rechter-commissaris een discretionaire bevoegdheid heeft waarvan de uitoefening niet samenhangt met het beleid van het OM, bijvoorbeeld volgend uit art. 6.3 lid $3 \mathrm{~Sv}$ en $187 \mathrm{~Sv}^{\text {T2 }}$ Ik ben van echter mening dat deze term bewaard moet worden voor besluiten die rechtstreeks samenhangen met de vervolgingsbeslissing van het $\mathrm{OM}$ (waartoe de door Cleiren genoemde beslissingen niet behoren), waaronder zowel de formele als de materiële beginselen (deze laatstgenoemde duidt Cleiren aan als beginselen van behoorlijk vervolgingsbeleid) vallen.

Samenvattend: voor toetsing van de besluiten tot buitengerechtelijke afdoening aan bestuursrechtelijke normen komen zowel de geschreven (nationale en internationale) als ongeschreven regels in aanmerking. De laatste zullen worden aangeduid als algemene beginselen van behoorlijk bestuur.

Enkele beperkingen dienen hier nog te worden gemaakt. Niet alle afdoeningsmethoden zijn namelijk voor toetsing geschikt.

Zo zal de afdoening door middel van dienstverlening volgens het officiersmodel buiten beschouwing blijven, omdat deze modus sinds de invoering van de alternatieve sanctie als werkstraf in art. $9 \mathrm{Sr}$ niet meer buiten het strafgeding om als sanctie kan worden opgelegd.

Toetsing van de voeging ad informandum stuit op problemen, omdat deze methode niet geheel buiten het strafgeding om gaat. Tijdens het strafgeding gelden de door het WvSv gestelde normen. Dit sluit toetsing aan bestuursrechtelijke normen uit, omdat er anders een conflict van rechtssferen zou ontstaan (vgl. art. 3:1 lid 2 Awb).

Enkele opmerkingen dienen nog te worden gemaakt over de methode van onderzoek. Ik ga een vergelijking maken tussen de beschreven bestuursrechtelijke normen en de normen van de genoemde afdoeningsmethoden om te bezien in hoeverre de methoden van buitengerechtelijke afdoening reeds verlopen volgens dezelfde normen dan die voor een bestuursbesluit.

In het eerste deel van dit boek zijn de wettelijke normen voor de buitengerechtelijke afdoeningsmethoden afzonderlijk beschreven. Een uitgebreide en overzichtelijke beschrijving van de jurisprudentie met betrekking tot de ongeschreven beginselen zoals die gelden voor de verschillende modaliteiten van een vervolgingsbeslissing, waaruit normen gedestilleerd worden, wordt gevonden in de boeiende dissertatie van Cleiren, Beginselen van een goede procesorde. ${ }^{m a}$ Het lijkt mij niet erg zinvol op deze plaats een 'blote' herhaling te geven van de door haar gemaakte analyse. Ik wil de lezer daar dan ook graag naar verwijzen. In het onderzoek van Cleiren

702 C.P.M. Cleiren, a.w., pag. 278.

703 C.P.M. Cleiren, Beginselen van een gocde procesorde. Een analyse van rechtspraak in strafzaken. Arnhem 1989. Met name hoofdstuk III $\$ 3$, hoofdstuk V en hoofdstuk VI zijn van belang. 
is de rechtspraak verwerkt tot augustus 1987 . Hier zal, waar nodig, worden volstaan met een aanvulling daarop.

Een punt van overweging is geweest wat als uitgangspunt voor bespreking zal worden genomen. Hierbij zijn verschillende opties mogelijk. Ik heb een keuze gemaakt uit twee mogelijkheden. Ik zou de afzonderlijke afdoeningsmethoden als vertrekpunt kunnen nemen en bij ieder van deze aangeven wat de verschillen met normen ten aanzien van een bestuursbesluit zijn. Het nadeel hiervan is dat herhalingen onvermijdelijk zijn, omdat bepaalde afwijkingen gelden voor meerdere afdoeningsmethoden. Een ander nadeel is dat de jurisprudentie dan verbrokkeld aan de orde komt, namelijk bij die afdoeningsmethode waarop een bepaalde uitspraak betrekking heeft, terwijl de uitspraak evengoed van belang is of kan zijn voor een andere modaliteit. Een andere optie is uit te gaan van de verschillende normen en ten aanzien van elk van die normen te bekijken of ze bij de afdoening buiten het strafgeding om gerespecteerd worden. Zonodig kan dan toch nog een differentiatie gemaakt worden tussen de verschillende modaliteiten.

Een en ander tegen elkaar afwegend kies ik voor de laatste optie, omdat deze het meest verhelderend maar ook het prettigst leesbaar is. Hierbij zal de volgorde van de te vergelijken bestuursrechtelijke normen worden aangehouden zoals ik die in het vorige hoofdstuk heb gehanteerd, dat wil zeggen de volgorde van de Awb.

Omdat de WAHV voor de handhaving van verkeersovertredingen reeds een afzonderlijke administratiefrechtelijke procedure heeft geschapen, zal deze wet in zijn geheel in een aparte paragraaf aan administratiefrechtelijke normen van de Awb worden getoetst.

\section{Vergelijking}

\subsection{Inleidende bepalingen}

\subsubsection{Schriftelijkheid}

Zoals in hoofdstuk 8 werd opgemerkt is het op schrift gesteld zijn een kenmerk van een bestuursbesluit. Het besluit moet zo nodig blijken uit een schriftelijk stuk, wil er sprake zijn van een besluit. Het op schrift gesteld zijn heeft voornamelijk een bewijsfunctie. Er is dus geen sprake van een uitdrukkelijke norm. De meeste besluiten tot buitengerechtelijke afdoening door het $\mathrm{OM}$ worden schriftelijk aan de verdachte bekendgemaakt. Dit is ook daar van belang in verband met het rechtsgevolg dat aan een dergelijk besluit is verbonden. Voor één besluit geldt dit echter niet, namelijk voor het informeel onvoorwaardelijk sepot. Als soort besluit wijkt dit besluit naar mijn mening niet af van een formeel sepot of van een voorwaardelijk sepot, die wel op schrift worden gesteld. Gezien het rechtsgevolg en gezien de bewijsfunctie van een dergelijke schriftelijke mededeling, zou ik er voor willen pleiten dat de verdachte 
die op de hoogte is van een tegen hem bestaande verdenking, van een besluit tot informeel onvoorwaardelijk sepot een schriftelijke mededeling ontvangt. Zie over de bekendmaking $\$ 2.3 .6$.

\section{Verkeer tussen burgers en bestuursorganen}

\subsubsection{Rechtsbijstand}

De wettelijke bepalingen met betrekking tot het besluit tot buitengerechtelijke afdoening bevatten geen specifieke bepalingen met betrekking tot bijstand in rechte of vertegenwoordiging. Dat wil niet zeggen dat men zich niet kan laten bijstaan. Indien de verdachte in voorlopige hechtenis heeft gezeten of nadat een gerechtelijk vooronderzoek is ingesteld, heeft hij meestal wel een raadsman.

Indien gekomen zal worden tot een algemene regeling met betrekking tot buitengerechtelijke afdoening of tot afdoening onder voorwaarden, zal deze regeling een soortgelijke bepaling als de Awb (art. 2:1) dienen te bevatten.

\subsubsection{Fair play (zonder vooringenomenheid en onpartijdigheid)}

Het fair-play beginsel ligt, zo blijkt uit de MvT, impliciet ten grondslag aan het strafprocesrecht. Aan de vervolgende en onderzoekende instanties zijn middelen in handen gegeven om hun taak zo optimaal mogelijk te verrichten, terwijl de verdachte zoveel mogelijk in de gelegenheid wordt gesteld alles wat ter ontlasting van zijn schuld kan dienen aan te dragen, een en ander voor zover het onderzoek daardoor niet wordt belemmerd. De conclusie zou dan ook kunnen zijn dat het strafproces, ondanks het per definitie voor de verdachte belastende karakter, zo eerlijk mogelijk is ingericht.

Een onderdeel van het fair-play beginsel, dat mij in dit kader van belang lijkt, is neergelegd in art. 2:4 Awb: Het bestuursorgaan vervult zijn taak zonder vooringenomenheid (lid 1); Het bestuursorgaan waakt ertegen dat tot het bestuursorgaan behorende of daarvoor werkzame personen die een persoonlijk belang bij een besluit hebben, de besluitvorming beïnvloeden (lid 2). Met name het hier genoemde eerste lid verdient de aandacht. Weliswaar wordt het OM geacht zowel belastende als ontlastende bevindingen te laten meewegen bij zijn vervolgingsbeslissing, maar een zekere vooringenomenheid ten aanzien van het bewijs van het feit en de schuld van de verdachte als gevolg waarvan een veroordeling op zijn plaats is, lijkt mij inherent aan de rol van het $O M$ in het strafproces. Het $O M$ heeft er doorgaans niets aan zaken waarvan het zeker weet dat geen veroordeling zal volgen voor de rechter te brengen. In dit opzicht zou deze bestuursrechtelijke bepaling voor het strafproces weinig zin hebben. Zonder enige betekenis is de bepaling toch ook weer niet. Het zou politie- en OM-functionarissen ertoe kunnen aanzetten voorzichtig te zijn in 
de toepassing van bepaalde dwangmiddelen, hoewel aan de formele vereisten daartoe is voldaan. Zo is mij een geval bekend van een man (first offender) die verdacht werd van het plegen van een overval op een benzinestation. Op basis van het signalement werd hij gearresteerd, verhoord en in verzekering gesteld, hoewel hij een geldig alibi had (hij was tijdens het tijdstip op zijn werk). Pas na enkele dagen was de politie bereid dit alibi na te gaan en werd de verdachte op vrije voeten gesteld.

Conclusie: een zekere vooringenomenheid ten aanzien van het bewijs, de schuld en de mogelijke veroordeling van de verdachte is inherent aan de positie van het OM als vervolgende instantie in het strafproces. Wel moet vanaf de aanvang van het onderzoek serieus worden omgegaan met voor de verdachte ontlastend materiaal. Uitdrukkelijke opname van een dergelijke bepaling lijkt mij aan de huidige gang van zaken weinig toevoegen.

Ook het tweede lid van art. 2:4 verdient aandacht. Hierbij doen zich twee denkbare situaties voor: (1) de voor het bestuur werkzame personen hebben, bijvoorbeeld als slachtoffer of als bekende van een slachtoffer, belang bij een zo zwaar mogelijke strafrechtelijke reactie; (2) de voor het bestuur werkzame personen hebben, bijvoorbeeld als familielid of bekende van een verdachte, belang bij een zo licht mogelijke strafrechtelijke reactie. Hierbij is moeten we bedenken dat het bij de buitengerechtelijke afdoening vaak gaat om relatief lichtere vergrijpen die doorgaans op een lager niveau binnen het $\mathrm{OM}$ worden afgedaan. Uitschakeling van persoonlijke belangen zou kunnen plaatsvinden door alle beslissingen te laten controleren. Dit lijkt mij tamelijk overdreven. I $k$ denk dat standaardisering en automatisering bijdragen aan uitschakeling van persoonlijke belangen. Een andere oplossing zou zijn (zoals in fiscale zaken) de plicht om in een dergelijk geval de zaak aan een collega over te laten.

Verder lijkt mij het fair-playbeginsel van belang voor de rechtspositie van de verdachte bij de totstandkoming van de transactie. Toepassing van dit beginsel betekent dat de officier van justitie dient te voorkomen dat de verdachte onder ongeoorloofde druk komt te staan om aan de transactievoorwaarde te voldoen, terwijl hij het in feite niet met het transactie-aanbod (bijvoorbeeld met het aanbod op zich of met de hoogte van het transactiebedrag) eens is. Naar mijn mening is het op grond van dit beginsel niet toegestaan dat de officier van justitie ter zitting een hogere boete eist en hiervan op het transactieformulier mededeling doet aan de verdachte.

\subsection{Algemene bepalingen over hesluiten}

\subsubsection{Zorguldigheidsbeginsel}

Het zorgvuldigheidsvereiste, zowel in de betekenis dat er een zorgvuldig onderzoek naar de feiten moet plaatsvinden als in de zin dat de betrokken belangen zorgvuldig dienen te worden afgewogen (artt. 3:2 resp. 3:4 lid $1 \mathrm{Awb}$ ), komen we in de wettelijke 
bepalingen omtrent de buitengerechtelijke afdoeningsmethoden niet uitdrukkelijk tegen. Dit wil echter niet zeggen dat ten aanzien daarvan het zorgvuldigheidsvereiste niet zou gelden. Integendeel, aan het hele strafproces, zo valt op te maken uit de MvT, ligt het impliciet ten grondslag. ${ }^{704}$

"Een goed ingericht strafproces moet zooveel mogelijk bevorderen de toepassing van de strafwet op den werkelijk schuldige en tevens de veroordeeling, kan het zijn, de vervolging van de niet-schuldigen naar vermogen verhinderen. Aan politie en justitie moeten dus de middelen worden in handen gegeven, die zij behoeven om misdrijven en schuldigen op te sporen, om zich met bekwamen spoed van de beschikbare bewijzen te verzekeren, om alle maatregelen te treffen, noodig om den vermoedelijk schuldige zoo spoedig mogelijk voor den rechter te kunnen brengen. De met opsporing en vervolging belaste autoriteiten moeten snel en krachtig kunnen optreden, kunnen doen wat de omstandigheden vereischen, niet belemmerd worden door enge, te zeer bindende voorschriften. Aan hun oordeel en inzicht moet veel worden overgelaten. Worden de regelen van het strafproces aldus gesteld, dan kan inderdaad eene krachtige repressie verkregen worden, doch dan kunnen tevens de rechten en vrijheden van het individu, niet alleen van de verdachten doch ook van anderen, die met het vermoedelijk gepleegd feit op eenigerlei wijze in betrekking staan of daarvan verdacht worden, zeer in het gedrang komen en meer dan noodig worden prijsgegeven. Met het doel den vermoedelijk schuldige te vatten en gevangen te houden kunnen maatregelen worden getroffen, welke de belangen van niet-schuldigen, van derden, zeer ernstig kunnen schaden. Bij elke regeling van het strafproces vertoont zich een zoodanig conflict en moet dus naar eene verzoening tusschen tegenstrijdige belangen worden gestreefd"

en

"men kan beproeven het noodzakelijke compromis op zoodanige wijze te vinden, dat aan de vervolging alle rechten worden gegeven, die zij voor hare taak behoeft, aan de verdachten en aan de verdediging alle bevoegdheden, welke met het doel van het strafproces niet onvoorwaardelijk in strijd komen"

en

"Bij het Ontwerp zijn nu ook reeds tijdens het vooronderzoek aan den verdachte belingrijke' rechten toegekend, is er voor gewaakt, dat hij voor zijne belangen bij den rechter kan opkomen en die helangen kan doen verdedigen, zich als procespartij kan laten gelden"iais

en

"Uit al het vorenstaande blijkt voldoende, dat de rechten der justitie, ook en vooral tegenover den verdachte, belangrijk zijn versterkt. Toch zou men zich eene onjuiste voorstelling van het Ontwerp kunnen vormen, wanneer er daartegenover niet op werd gewezen, dat bij de

704 MvT Vaststelling van een Wetboek van Strafvordering, TK 1912-1913, no. 286.

705 MvT pag. 55 en 56. 
meeste van de hier genoemde voorschriften bepalingen zijn gevoegd, waardoor wordt getracht verkeerde toepassing te voorkomen en de belangen van den verdachte naar vermogen te waarborgen". 706

Steeds is dus gestreefd naar een verzoening tussen de belangen van strafvervolging en de belangen van het individu. Het zorgnuldigheidsbeginsel in de zin van een zorgvuldige belangenafweging ligt dus impliciet in de wet verankerd. De vraag is of genoemde bepalingen uit de Awb hieraan iets zouden toevoegen. Ik betwijfel dat. In mijn ogen zal toevoeging voor de materiële afweging die de officier van justitie maakt, van weinig invloed zijn.

Dat er een zorgvuldig onderzoek naar de feiten dient plaats te vinden (de andere component van het zorgvuldigheidsbeginsel), is een vanzelfsprekendheid in het strafproces. Vindt dit namelijk niet correct of onvolledig plaats, dan loopt het OM het risico dat de zaak stukloopt bij de rechter omdat het OM niet-ontvankelijk wordt verklaard in zijn vervolging of de verdachte wordt vrijgesproken wegens gebrek aan bewijs.

\subsubsection{Verbod van détournement de pouvoir}

Dit beginsel houdt in dat een bevoegdheid van een bestuursorgaan niet gebruikt mag worden voor een ander doel dan het doel waarvoor de bevoegdheid door de wetgever is verleend (art. 3:3 Awb).

In de strafrechtelijke jurisprudentie met betrekking tot de vervolgingsbeslissing van het OM komen we toetsing aan dit beginsel niet tegen. In andere strafvorder]ijke kwesties komt toetsing aan dit beginsel wel voor, bijvoorbeeld wanneer de officier van justitie alleen in appel is gekomen om te voorkomen dat de appelrechter slechts met eenparigheid van stemmen een hogere straf kan opleggen dan in eerste instantie is opgelegd (HR 22 juni 1982, NJ 1983, 73; HR 23 oktober 1984, NJ 1986, 8 m.nt. N. Keijzer) of in het geval het opsporingsonderzoek na aanvang van het gerechtelijk vooronderzoek wordt voortgezet, alleen om de rechten van de verdediging te schaden (HR 2 juni 1987, NJ 1988, 180). Dit wil niet zeggen dat het beginsel bij een vervolgingsbeslissing geen rol zou kunnen spelen. Hierbij denk ik bijvoorbeeld aan de mogelijkheid dat de officier van justitie, van mening dat de kans bestaat dat hij in een bepaalde strafzaak het bewijs niet zal rondkrijgen waardoor ter zitting geen veroordeling zal volgen, een transactie aanbiedt in plaats van de zaak te seponeren. Toetsing aan dit beginsel door de rechter zal in een dergelijk geval niet plaatsvinden omdat hetzij de verdachte de transactie (onterecht) voldoet en daarmee de zaak is afgedaan, hetzij de verdachte de transactie weigert en de officier van justitie de zaak alsnog seponeert, hetzij de verdachte de transactie weigert en de officier van 
justitie hem ter zitting dagvaart, waarbij niet transactiebesluit van de officier van justitie voorwerp is van onderzoek maar het al dan niet strafwaardig gedrag van de verdachte (met een vrijspraak als gevolg). Het beginsel heeft hier niet de functie van toetsingsgrond voor de rechter, maar fungeent hier als gedragsnorm voor de officier van justitie.

\subsubsection{Evenredigheidsbeginsel}

Het beginsel, dat in het bestuursrecht van oudsher een belangrijke rol speelt op het gebied van de sanctionering, houdt in dat er evenredigheid dient te bestaan tussen het doel dat het orgaan wil bereiken en de middelen en maatregelen die het daartoe hanteert. Toegespitst op de sanctionering: er dient evenredigheid te bestaan tussen de emst van de normovertreding en de zwaarte van de sanctionering. ${ }^{\text {nomos }}$ In het strafrecht bestaat dit beginsel als zodanig niet, hetgeen op het eerste gezicht niet tot verbazing behoeft te leiden. Van oorsprong was het in het strafrecht de rechter ter zitting die de sanctie bepaalde. Het Wetboek van Strafrecht bood daarbij een straffenarsenaal in de vorm van specifieke maximum straffen op de verschillende delicten. Het werd aan de rechter overgelaten een verantwoorde sanctie op te leggen die paste bij de ernst van het delict en de persoon van de dader. In de praktijk komt de rechter in zijn strafoplegging zelden toe aan de maximum op te leggen straf, ook niet met betrekking tot overtredingen. Deze maximum straf wordt slechts toegepast in de ernstigste gevallen. Bij de vaststelling van de straf laat de rechter zich leiden door factoren als vergelding, generale en speciale preventie. Bij de sanctionering van overtredingen, waarbij veelal een boete wordt opgelegd, zijn het voornamelijk de twee laatstgenoemde factoren die de zwaarte van de straf bepalen. Door de afweging van genoemde factoren tracht de rechter te komen tot een sanctie die in verhouding staat tot de betreffende overtreding, waardoor er sprake is van evenredigheid (hierbij worden ook andere factoren meegewogen zoals de persoon van de verdachte, maatschappelijke omstandigheden e.d.).

Deze situatie bestaat niet meer. In een zeer groot aantal van de normovertredingen is het niet meer de rechter die sanctioneert. De zaak komt niet meer op de rechtszitting, maar wordt voordien reeds afgedaan, al dan niet door oplegging van een sanctie door het OM. Bij dit laatste kunnen we met name denken aan de afdoening door middel van een transactie of, in mindere mate, aan een voorwaardelijk sepot. In het navolgende wordt vooral gedoeld op de transactie.

Bij deze afdoeningsmethode heeft het $O M$ geen 'wetboek' als leidraad voor de sanctie-oplegging. De wet geeft in art. 74 lid $2 \mathrm{Sr}$ aan welke voorwaarden kunnen worden gesteld. Ten aanzien van de belangrijkste voorwaarde, de betaling van een geldsom,

707 In dcze zin ook: H. van Wijk/W. Konijnenbelt, Hoofdstukken van administraticf recht, Culemborg 1988, pag. 122.

708 Dit beginsel is erkend door de AR RvS 15 maart 1989, Gem.st. 1989, 6879; AB 1991, 3/4. 
is bepaald dat deze ten minste vijf gulden bedraagt en ten hoogste het maximum van de geldboete die voor het feit kan worden opgelegd. Daartussen is de officier van justitie in beginsel vrij. Weliswaar bestaan er ten aanzien van de transactie talloze richtlijnen waarin "tarieven" zijn opgenomen, maar deze richtlijnen zijn door het OM zelf opgesteld en er is, zij het in beperkte mate, afwijking toegestaan. Bovendien bestaan lang niet voor alle normovertredingen transactielijsten. Toch ben ik van mening dat, overeenkomstig het bestuursrecht, ook in de sanctie die het OM oplegt er sprake dient te zijn van een evenredigheid tussen straf en overtreding. Het OM zal zelf een afweging moeten maken om tot een sanctie te komen die evenredig is aan de overtreding.

De vraag is: wanneer bestaat er evenredigheid tussen normovertreding en sanctie? Is dat objectief vast te stellen of zijn daar algemene regels voor te geven? In het bestuursrecht kan de sanctie zoals die door het bestuursorgaan is opgelegd door de administratieve rechter aan het evenredigheidsbeginsel worden getoetst. Het is dan in feite de rechter die vaststelt dat er bij een bepaalde sanctionering geen sprake is van evenredigheid (zie bijvoorbeeld de ambtenarenrechter). Deze mogelijkheid bestaat in het strafrecht niet. Is de verdachte het niet eens met de hoogte van het transactiebedrag dan rest hem niets anders dan voldoening te weigeren. Op de zitting die dan (meestal) volgt, wordt niet in eerste instantie de hoogte van het transactiebedrag getoetst, maar volgt een onderzoek naar de normovertreding van de betrokken verdachte. Trouwens, door het transactieaanbod niet te aanvaarden riskeert de verdachte een hogere boete. Dit wordt hem door het $\mathrm{OM}$ in het vooruitzicht gesteld door mededeling op het transactieformulier.

$\mathrm{Nu}$ is het $\mathrm{OM}$ niet helemaal vrij in de vaststelling van de hoogte van het transactiebedrag. Bij de totstandkoming respectievelijk uitbreiding van de transactieregeling is steeds gezegd dat de individuele officier van justitie zich bij vaststelling van de hoogte van het transactiebedrag moet laten leiden door de hoogte van de geldboete zoals de rechter die doorgaans ter zitting oplegt ${ }^{700}$ (en die geacht wordt in verhouding te staan tot de gepleegde overtreding). In de praktijk blijkt hier echter niet altijd de hand aan te worden gehouden. Een andere beweging is zichtbaar. Door verhoging van de wettelijke strafmaxima door het parlement of door verhoging van de transactiebedragen in richtlijnen wordt getracht het straftoemetingsbeleid van de rechter te beïnvloeden in die zin dat deze hogere sancties gaat opleggen. ${ }^{710} \mathrm{Nu}$ kan een richtlijn wel van invloed zijn op het straftoemetingsbeleid van de rechter, maar uiteindelijk heeft de rechter het laatste woord en heeft het OM zich daarnaar te richten. Op

709 Zie hierover Hoofdstuk 3.

710 Zie hierover ook: Th.W. van Veen, lets over de geldbocte, redactionele kanttekeningen, RM Themis 1991, pag. 313-314. 
deze manier wordt een consistente straftoemeting het meest optimaal gewaarborgd. Evenals Van Veen zou ik me dan ook tegen deze ontwikkeling willen keren. ${ }^{\text {pi }}$

Conclusie: in tegenstelling tot het bestuursrecht speelt het evenredigheidsbeginsel geen expliciete rol bij de sanctionering door het bestuursorgaan OM. In mijn ogen zou dit beginsel wel een rol dienen te spelen bij de sanctionering door het OM. In de huidige regeling kan dat, evenals een aantal andere beginselen, slechts als gedragsnorm voor het $\mathrm{OM}$, niet als toetsingsnorm door de rechter, ${ }^{12}$ daar het transactiebesluit als zodanig geen voorwerp van onderzoek is voor de rechter (in de huidige transactieregeling). Bij een eventueel te creëren beroepsmogelijkheid tegen de transactie (zie hierna) zou dit evenredigheidsbeginsel als een grond voor beroep kunnen worden geïntroduceerd.

Welke rol speelt dit evenredigheidsbeginsel in de WAHV? Als beroepsgrond was in eerste instantie (voor de aanpassingswet) opgenomen het gegeven dat de omstandigheden de sanctie niet billijken of voor de officier van justitie aanleiding hadden moeten zijn een lagere sanctie op te leggen. Dit is niet helemaal hetzelfde als het evenredigheidsbeginsel. Daar is eigenlijk ook geen plaats voor, omdat men werkt met standaardbedragen bij de verschillende overtredingen. Deze beroepsgrond geeft de officier van justitie en de rechter de mogelijkheid de sanctie te matigen, maar volgens de MvT moet daar zeer terughoudend gebruik van worden gemaakt "in uitzonderlijke omstandigheden". ${ }^{713}$

\subsubsection{Verbod van willekeur}

In het strafrecht is het de officier van justitie die de beslissing neemt of er in een bepaalde strafzaak vervolgd zal worden of niet. Hij weegt de daarbij spelende be]angen tegen elkaar af. Deze belangenafweging ligt primair bij het OM (vervolgingsmonopolie) en niet bij de rechter, HR 8 november 1988, NJ 1989, 368. Slechts wanneer deze beslissing van de officier van justitie in strijd is met een der beginselen van behoorlijk bestuur kan dit leiden tot de niet-ontvankelijkheid van het OM. De uit-

711 Van Veen noemt in zijn in de vorige noot aangchaalde artikel nog een ander argument tegen: bij de terugdringing van het aantal overtredingen wordt uitsluitend gesproken over de geldboete, terwijl, in zijn ogen, daarvoor de korte vrijheidsstraf een uitstekend middel zou kunnen zijn. Deze sanctic kan echter niet worden opgelegd buiten de rechter om hetgeen de beleidsmakers niet zo goed uitkomt. Bovendien herbergt de geldboete volgens Van Veen het gevaar in zich dat het feit, dat de geldboete geld in de staatskas brengt, zou kunnen gaan meespelen. Th.W. van Veen, a.w., pag. 314.

712 Dit is bijvoorbeeld het geval in de ambtenarenrechtspraak. In art. 58 lid 3 Ambt.wet is bepaald dat er beroep tegen een disciplinaire straf kan worden ingesteld ter zake dat er tussen de opgelegde straf en de gepleegde overtreding onevenredigheid bestaat.

713 MvT WAHV, pag. 17. 
komst van de belangenafweging dient echter wel redelijk te zijn, met andere woorden: er mag geen sprake zijn van willekeur. Door middel van dit beginsel kan de inhoud van een vervolgingsbeslissing van de officier van justitie worden getoetst. Toetsing van dit beginsel door de rechter is echter tamelijk problematisch. Wanneer is een beslissing onredelijk? Wanneer de officier van justitie besluit vervolging in te stellen kan dat in de ogen van de verdachte eerder het geval zijn dan in de ogen van het slachtoffer. Met andere woorden: het stempel onredelijk of onbillijk wordt sterk subjectief ingekleurd. De rechter dient zich bij zijn oordeel over de onredelijkheid van de vervolgingsbeslissing terughoudend op te stellen. De officier van justitie heeft op grond van het opportuniteitsbeginsel bij het nemen van de vervolgingsbeginsel een discretionaire bevoegdheid. Voorkomen moet worden dat de rechter de belangenafweging van de officier van justitie overdoet en op die manier op de stoel van de vervolgende instantie zou plaatsnemen. Hij kan de vervolgingsbeslissing slechts marginaal toetsen, HR 21 januari 1986, NJ 1987, 663; HR 22 maart 1988, NJ 1988, 861 ; Overtreding van het beginsel is pas aanwezig indien de vervolgingsbeslissing apert onredelijk is.

Tuetsing aan dit beginsel door de Hoge Raad in strafzaken komt, in tegenstelling tot het bestuursrecht, slechts sporadisch voor. De hierboven genoemde arresten zijn hiervan voorbeelden. Wel zien we vaker de formule "dat het Openbaar Ministerie in redelijkheid (niet) tot vervolging heeft kunnen overgaan", hetgeen misschien doet vermoeden dat het hier om het willekeursheginsel gaat. In deze zaken werd dan meestal een beroep gedaan op een ander beginsel, bijvoorbeeld het vertrouwensof gelijkheidsbeginsel.

Een arrest, waarin de raadsman van verdachte en het hof het verweer toespitsten op het verbod van willekeur was dat van HR 21 juni 1988, NJ 1988, 1021 m.nt. 'tH. Kort de feiten: door een aantal personen van de Centrumpartij, onder wie de verdachte, zijn een aantal pamfletten verspreid. Een aantal van deze personen werd geverbaliseerd en later vervolgd. Niet geverbaliseerd werd de politieke voorman van deze partij. Hij kon echter als eerstverantwoordelijke worden beschouwd voor de inhoud ervan. Het OM zag het feit om hem niet te vervolgen gegrond op het algemeen belang, men wilde van hem geen "martelaar" maken met het oog op de komende verkiezingen. Het hof verklaarde het $\mathrm{OM}$ niet-ontvankelijk wegens schending van het verbod van willekeur, met als argumentatie dat het gaat om het niet-vervolgen van de hoofdschuldige, van wie de specifieke mate van betrokkenheid door het hof wordt omschreven, zonder dat er voor dit niet-vervolgen aan het algemeen belang ontleende gronden waren. Omdat het hof niets heeft vastgesteld omtrent de gronden wiarop de officier van justitie niettemin is overgegaan tot vervolging van de verdachte is het oordeel van het hof niet naar de eis der wet met redenen omkleed, aldus de Hoge Raad. Aan een beoordeling van het verbod van willekeur komt de HR niet toe. De constructie van het hof stuit bij annotator't Hart op grote bezwaren. Het niet vervolgen van sommige verdachten en het wel vervolgen van anderen leidt op zichzelf nog niet tot niet-ontvankelijkheid van het OM. Daar moet meer bijkomen, i.c. de omstandigheid dat de hoofdschuldige buiten schot blijft. Het bezwaar is dat 
het hof alleen ingaat op het juridisch niet onderbouwde sepot en niet op de vervolgingsbeslissing van de verdachte in de zaak zelf. Volgens 't Hart is er pas sprake van willekeur bij het ontbreken van gronden, niet bij ondeugdelijke gronden, met andere woorden: van willekeur is pas sprake indien afweging van belangen geacht moet worden niet te hebben plaatsgehad. Deze uitleg van ' $t$ Hart is beperkter dan de uitleg van het verbod van willekeur in het bestuursrecht. Daar is van willekeur ook sprake als de gronden z 6 ondeugdelijk moeten worden geacht dat belangenafweging geacht moet worden niet te hebben plaatsgevonden (HR 25 februari 1949, NJ 1949, 558 Doetinchemse woonnimtverordening). Daarnaast is de annotator van mening dat een toetsing van het gelijkheidsbeginsel meer voor de hand had gelegen. Bij de bespreking van het vertrouwensbeginsel en het gelijkheidsbeginsel in latere paragrafen wordt vermeld dat bij afwijking van vervolgingsrichtlijnen of vervolgingsbeleid, naast een beroep op strijd met deze beginselen een beroep zou kunnen worden gedaan op het verbod van willekeur. Daarom wil ik er ook op deze plaats enige aandacht aan schenken. Een afwijking van bestaande vervolgingsrichtlijnen behoeft niet beoordeeld te worden als 'willekeurig'. Evenals ik dat beschreven heb bij het vertrouwens- en het gelijkheidsbeginsel, kan, indien lokale of de verdachte betreffende omstandigheden daartoe aanleiding geven, een dergelijke afwijkinggerechtvaardigd zijn. Een persoonlijke opvatting van de individuele officier van justitie mag geen aanleiding zijn tot afwijking. Een afwijking van de richtlijn behoort vergezeld te gaan van een deugdelijke motivering, waaruit hlijkt welke belangen zijn meegewogen en waarom een bepaald belang voorrang heeft gekregen.

Meer dan de andere beginselen functioneert het willekeursverbod niet zozeer als een positieve gedragsnorm voor de officier van justitie, maar voornamelijk als een toetsingsnorm voor de rechter. De norm 'de betrokken belangen dienen tegen elkaar te worden afgewogen, zodanig dat de beslissing redelijk is', zegt op zichzelf niet zoveel. Natuurlijk zal een officier van justitie de betrokken belangen afwegen, maar wat in een bepaald geval als een onredelijke beslissing zal worden bestempeld valt moeilijk vooraf te bepalen. Het is aan de rechter om uit te maken (waarbij hij dan ook nog een zekere terughoudendheid dient te betrachten) of in het concrete geval de beslissing niet apert onredelijk is geweest.

Vergelijking met het bestuursrecht: evenals in het bestuursrecht komt toetsing aan het verbod van willekeur aan de orde indien de wetgever het bestuursorgaan viijheid heeft gegeven bij het nemen van een besluit. Het bestuursorgaan beschikt over beleidsvrijheid. Bij het nemen van een besluit dienen alle relevante belangen te worden meegewogen. De rechter moet terughoudendheid betrachten bij toetsing van de vervolgingsbeslissing aan het verbod van willekeur. 


\subsubsection{Motivering van de beslissing}

Art. 3.6.1 Awb bepaalt dat een besluit dient te berusten op een deugdelijke motivering.

Eén van de aspecten van dit motiveringsbeginsel in het bestuursrecht is dat de motivering naar buiten toe moet blijken (art. 3.6.2 Awb). Achtergrond hiervan is dat de beslissing voor de betrokkene begrijpelijker wordt nu hij de motieven erachter kent. Bovendien kan hij hierop zijn bezwaar- c.q. beroepschrift baseren.

In het strafproces bestaat, evenals in het bestuursrecht, geen algemene motiveringsplicht in die zin dat de vervolgende of berechtende instanties gehouden zijn bij al hun beslissingen de motivering te vermelden. In het bestuursrecht kan vermelding van de motivering achterwege blijven indien redelijkerwijs kan worden aangenomen dat daaraan geen behoefte bestaat (art. 3.6.3 lid 1). Indien echter de belanghebbende verzoekt om motivering, wordt deze zo spoedig mogelijk verstrekt (art. 3.6.3 lid 2). Dit wil natuurlijk niet zeggen dat er in het strafproces helemaal geen verplichting tot motivering zou bestaan. Deze is echter in verschillende afzonderlijke bepalingen opgenomen. Een voorbeeld van een motiveringsverplichting voor de officier van justitie, tevens van belang voor dit onderzoek, lezen we in art. $247 \mathrm{~Sv}$. In een aantal gevallen moet in de kennisgeving van niet verdere vervolging worden aangegeven op welke grond wordt geseponeerd. Dit is voorgeschreven indien van verdere vervolging wordt afgezien wegens: a. onbevoegdheid van de rechtbank; b. vereniging met een strafzaak welke voor een andere rechtbank in onderzoek is; c. niet-ontvankelijkheid van de officier van justitie; d. niet-strafbaarheid van het feit of de verdachte; e. onvoldoende aanwijzing van schuld. De vermelding van de sepotgrond kan van belang zijn indien later (zie art. $255 \mathrm{~Sv}$ ) alsnog tot vervolging wordt besloten.

De vraag die kan worden gesteld is of deze motiveringsplicht ook zou moeten gelden voor een informeel sepot. Verder is hier van belang of met de genoemde seponeringsgronden kan worden volstaan, of dat deze motiveringsverplichting aan uitbreiding toe is, in die zin dat ook andere seponeringsgronden vermeld moeten worden. Daarnaast rijst de meer principiële vraag: is het $\mathrm{OM}$ verplicht iedere vervolgingsbeslissing te motiveren, zowel de beslissing om wel als die om niet te vervolgen? Hoe staat het met de motivering bij afwijking van het vervolgingsbeleid?

De vraag of een motiveringsverplichting opgenomen zou moeten worden voor een informeel sepot (waarbij de betrokkene op de hoogte is van een tegen hem bestaande verdenking) verdient volgens mij een positieve beantwoording. Ik ben van mening dat een dergelijk sepot dezelfde bunadering verdient als een formeel sepot. Ook die verdachte heeft recht op rechtszekerheid.

Bij de bespreking van het vereiste dat een besluit op schrift moet zijn gesteld stelde $i k$ voor ook een besluit tot een informeel sepot (ten aanzien van een verdachte die op de hoogte is van een tegen hem bestaande verdenking) op schrift te stellen. Dit kan dan voorzien worden van een korte motivering in die zin, dat de seponeringsgrond wordt vermeld. 
Aanbeveling: De mededeling van een besluit tot een informeel sepot wordt voorzien van een motivering.

In hoofdstuk 2 betreffende het onvoorwaardelijk sepot is te lezen dat er tal van seponeringsgronden bestaan die onder te verdelen zijn in gronden die leiden tot een technisch sepot en gronden die leiden tot een beleidssepot. De gronden zoals die in art. 247 Sv staan vermeld zijn alle aanleiding voor een technisch sepot: ook al zou de officier van justitie willen vervolgen, dan zou dit naar alle waarschijnlijkheid toch niet tot een veroordeling door de rechter leiden. De rechtszekerheid van de verdachte zou ermee gediend zijn indien de officier van justitie ook gehouden zou zijn de grond(en) van een beleidssepot te vermelden. Bovendien zou dit meer inzicht geven in het vervolgingsbeleid van het OM.

Hetzelfde lijkt mij aangewezen voor een transactiebesluit ten aanzien waarvan geen richtlijn bestaat.

Aanbeveling: De motiveringsverplichting zoals die in art. $247 \mathrm{~Sv}$ is opgenomen ten aanzien van een formeel sepot en die ingevolge de vorige aanbeveling tevens zou dienen te gelden voor een informeel sepot, moet worden uitgebreid in die zin dat ook gronden die leiden tot een beleidssepot worden vermeld.

De vraag die ik vervolgens opwierp was of ook de beslissing tot wel vervolgen voorzien zou moeten zijn van een motivering. Men zou kunnen redeneren: Als het minst zware middel (sepot) gemotiveerd moet worden, althans de sepotgrond vermeld, dan geldt dat zeker voor het zwaarste (vervolging). Ik zou willen betogen dat in beginsel een dergelijke motivering overbodig is, daar deze uit het tenlastegelegde (met daarin een impliciete verwijzing naar de betreffende wetsovertreding) en het requisitoir zal blijken. Daaruit blijkt echter niet waarom de officier van justitie, terwijl hij een keuze kan maken uit tal van afdoeningsmogelijkheden, in dit specifieke geval besloten heeft tot vervolging. In een tijd waarin het grootste deel van alle strafzaken buiten het gerecht om wordt afgedaan, zou het niet misstaan dat de officier van justitie zijn keuze juist voor de vervolgingsbeslissing van een nadere motivering voorziet.

Een andere benadering vraagt het indien de beslissing om te vervolgen genomen is in afwijking van het gevoerde beleid of in strijd met daarvoor geldende richtlijnen, waardoor meer materiële beginselen (vertrouwensbeginsel, gelijkheidsbeginsel en het verbod van willekeur) in het geding zijn. Voor een meer uitgebreide bespreking van deze beginselen in het kader van richtlijnen verwijs ik naar $\$ 2.3 .9$. Met betrekking tot de motivering van een beslissing die genomen is in overeenstemming met daarvoor geldende richt]ijnen geldt in het bestuursrecht dat een dergelijke.beslissing niet vergezeld behoeft te gaan van een motivering. In het wetsvoorstel Awb (derde tranche) is dit neergelegd in art. 4.4.3: ter motivering van een besluit kan slechts worden volstaan met verwijzing naar een vaste gedragslijn voor zover deze is neergelegd in een beleidsregel. Achtergrond hiervan is dat de motiveringsverplichting reeds 
geldt bij de publicatie van de richtlijn. ${ }^{14}$ Vergelijken we dit met de strafrechtelijke richtlijn, dan is hiervan het gevolg dat een beslissing genomen overeenkomstig een voor dat feit bestaande richtlijn, waarvan de bekendmaking vergezeld ging van een deugdelijke motivering, niet nog eens gemotiveerd behoefd te worden. Deze motiveringsverlichting blijft echter wel noodzakelijk indien de verdachte vooraf het $\mathrm{OM}$ heeft verzocht zijn zaak in afwijking van de betreffende richtlijn af te doen.

Aanbeveling: Indien de officier van justitie, in afwijking van het verzoek van de verdachte om zijn strafzaak niet overeenkomstig de betreffende richtlijn af te doen, beslist overeenkomstig de richtlijn, wordt deze beslissing voorzien van een motivering.

\subsubsection{Bekendmaking}

Richt een bestuursbesluit zich tot een of meer bepaalde individuen dan dient dit aan deze(n) te worden bekendgemaakt door middel van toezending of uitreiking (art. 3:41 Awb).

Ten aanzien van de meeste besluiten van buitengerechtelijke afdoening is bepaald dat zij schriftelijk aan de verdachte worden bekend gemaakt. Bij een voorwaardelijk sepot en de transactie zal de verdachte op de hoogte moeten zijn van de voorwarde waaraan hij moet voldoen om vervolging te voorkomen. De transactie wordt bekendgemaakt middels een voorgedrukte acceptgirokaart, waarop onder andere staat vermeld de begane overtreding, het te betalen bedrag en de datum waarvoor dit moet zijn overgemaakt. Deze acceptgirokaart wordt per post toegezonden.

Van een kennisgeving van niet verdere vervolging doet de officier van justitie de verdachte kennisgeven, art. 244 en 245 lid 1 Sv. Onduidelijk was voorheen of de wet ten aanzien van deze mededelingen betekening vereist. Uit art. 585 lid 1 en 2 zou kunnen worden afgeleid dat volstaan kan worden met toezending van een gewone of aangetekende brief bij post. Lid 3 van datzelfde artikel bepaalt dat dagvalardingen en aanzeggingen die aan het $\mathrm{OM}$ zijn opgedragen steeds betekend worden. Om aan deze onduidelijkheid een einde te maken heeft de Termijnenwet een voorstel gedaan in de vorm van een nieuw art. 245a Sv: Kennisgevingen van verdere vervolging en van niet verdere vervolging worden aan de verdachte betekend.

Hetzelfde resultaat had bereikt kunnen worden door in de wet op te nemen dat ook een kennisgeving van (niet) verdere vervolging aan de verdachte moet worden betekend. Een aanvulling van lid 3 van art. 585 Sv na 'dagvaardingen' met de woorden 'kennisgeving van (niet) verdere vervolging' zou hiervoor voldoende zijn geweest. 'Ten alanzien van het informeel sepot is niet voorgeschreven dat dit aan de verdachte moet worden bekendgemaakt, laat staan hoe dat in zijn werk zou moeten gaan. Ten aanzien van een strafbaar feit, waarbij de betrokkene niet op de hoogte is van de 
tegen hem bestaande verdenking kan als volgt worden geredeneerd: het $O M$ is een overheidsorgaan dat openheid dient te betrachten bij zijn activiteiten. Als gevolg hiervan moet een burger ten opzichte van wie een verdenking heeft bestaan, hiervan altijd op de hoogte worden gebracht. Dit laatste zou bijvoorbeeld kunnen geschieden door middel van een individuele berichtgeving, maar ook kan worden gedacht aan het openbaar maken van een bepaalde registratie. Ik ben hiervan voorstander, omdat het, indien het OM alsnog zou vervolgen, zal leiden tot niet-ontvankelijkheid. De bekendmakingsplicht zou in ieder geval aanwezig dienen te zijn indien de verdachte wel weet heeft van een verdenking jegens hem, bijvoorbeeld doordat er tegen hem proces-verbaal is opgemaakt, hij door de politie is verhoord of in verzekering is gesteld. Door het achterwege laten van een sepotmededeling blijft hij in onzekerheid verkeren omtrent een eventuele vervolging.

Aanbeveling: Aan deze onzekerheid behoort mijns inziens een einde te worden gemaakt door het $\mathrm{OM}$ te verplichten binnen een bepaalde termijn een vervolgingsbeslissing te nemen en deze aan de verdachte schriftelijk bekend te maken. Aan deze mededeling zou dan, evenals bij een kennisgeving van niet verdere vervolging, het rechtsgevolg verbonden dienen te zijn dat daarmee de zaak is beëindigd, behoudens nieuwe bezwaren. Op deze manier wordt voorkomen dat een officier van justitie, oordelend dat een strafzaak niet ernstig genoeg is om te vervolgen, bij een latere vervolging van een ander feit op deze beslissing zou terugkomen. Op deze manier kan tevens rechtsongelijkheid worden voorkomen, die ontstaat doordat sommige verdachten (eventueel via een raadsman), nadat zij de officier van justitie vroegen van vervolging af te zien, een uitdrukkelijke sepotmededeling verkregen, waarna de zaak in beginsel beëindigd is (zie hierna: vertrouwensbeginsel).

Of een sepotmededeling ook de reden van het afzien van vervolging moet bevatten vormt onderdeel van de paragraaf betreffende het motiveringsbeginsel.

\subsubsection{Rechtszekerheid}

In de bestuursrechtelijke jurisprudentie heeft zich het principe ontwikkeld dat na het nemen van een besluit door een administratief orgaan de rechtspositie van de burger duidelijk moet zijn. Zonder nadere toelichting dient hij te weten waar hij aan toe is. Men noemt dit de materiële rechtszekerheid. Dit beginsel is niet als zodanig als toetsingsgrond in de Awb opgenomen.

Hierv6́r zagen we dat de rechtspositie van een verdachte, wiens strafzaak buitengerechtelijk door het OM wordt afgedaan, niet altijd even duidelijk is.

Zeer onduidelijk en onzeker is de rechtspositie van de verdachte wiens zaak door middel van een voorwaardelijk sepot is afgedaan. Hieraan wil ik apart aandacht schenken.

Ten eerste bestaat er ten aanzien van de concrete toepassing van het voorwaardelijk sepot onduidelijkheid. Welke voorwaarden mogen er worden opgelegd? De wet 
vermeldt hieromtrent niets. Dit betekent echter niet dat dan elke willekeurige voorwaarde mag worden opgelegd. Een grens ligt in het verbod van détournement de pouvoir. De verdachte kan in een dwangpositie komen te verkeren. Als hij de gestelde voorwaarde, hoe onredelijk ook, niet accepteert, riskeert hij te worden gedagvaard en veroordeeld. $\mathrm{Nu}$ is een zekere dwang ten aanzien van een te vervullen voorwaarde natuurlijk niet uit te sluiten en ook zeker niet altijd misplaatst, maar nu is er op dit punt helemaal niets geregeld. Daarnaast behoeft over de opgelegde voorwaarde door het $\mathrm{OM}$ ook geen concreet verslag te worden gedaan. Controle op het $\mathrm{OM}$ is moeilijk. Externe verantwoording van het $\mathrm{OM}$ over de wijze waarop het voorwaardelijk sepot hanteert is niet voorgeschreven.

Een andere onzekere factor ten aanzien van het voorwaardelijk sepot wordt gevormd door het feit dat de wet niet de garantie geeft dat na nakoming van de voorwaarden niet alsnog vervolgd zal worden. Het toekennen van een dergelijk rechtsgevolg aan het voorwaardelijk sepot is naar mijn oordeel toch zeer wenselijk. Het vertrouwensbeginsel zou hier eventueel voor een deel uitkomst kunnen bieden. Een waterdichte oplossing biedt dit echter niet, omdat, zoals we nog zullen zien, voor honorering van het gewekte vertrouwen aan bepaalde vereisten moet zijn voldaan.

Aanbeveling: om aan allerlei onzekerheden een einde te maken gaat mijn voorkeur dan ook uit naar een wettelijke regeling van het voorwaardelijk sepot, waarin de genoemde zaken een regeling zullen vinden. Zoals reeds betoogd in hoofdstuk 2 ontbeert het voorwaardelijk sepot tot nu toe een wettelijke status, waaraan naar mijn mening wel behoefte bestaat. Voor het ontwerp van een dergelijke wettelijke regeling zou aansluiting gezocht kunnen worden bij de transactie, art. 74 e.v. Sr. De wet zou in de eerste plaats bepalingen dienen te bevatten omtrent de te stellen voorwaarden. Zoals art. $74 \mathrm{Sr}$ een opsomming geeft van een aantal meer materiële voorwaarden waardoor strafvervolging wordt voorkomen, zou ten aanzien van het voorwaardelijk sepot een aantal voorwaarden betreffende de persoon van de verdachte kunnen worden opgenomen. Hierbij valt te denken aan een limitatieve of een meer open opsomming. Hoewel de eerstgenoemde mogelijkheid de meeste rechtszekerheid zou bieden krijgt de laatstgenoemde mijn voorkeur, omdat het daardoor toch mogelijk blijft enige creativiteit te betrachten bij het stellen van een voorwarde waardoor deze aangepast of toegespitst wordt op de persoon of de persoonlijke omstandigheden van de verdachte. Eén beperking ten aanzien van de te stellen voorwaarden moet nog worden gemaakt: een voorwaarde die de persoonlijke vrijheid van de verdachte beperkt door bijvoorbeeld opname in een (gesloten) inrichting of kliniek, kan niet in het kader van een voorwaardelijk sepot worden opgelegd. Voor een dergelijke inbreuk op het grondrecht van persoonlijke viijheid moet volgens art. $15 \mathrm{GW}$ rechterlijke toetsing openstaan.

Verder zou de wettelijke regeling van het voorwaardelijk sepot een bepaling dienen te bevatten over het rechtsgevolg dat aan het voldoen aan de voorwaarde( $n)$ is verbonden. Dit rechtsgevolg zou er naar mijn idee uit moeten bestaan dat door vervulling van de voorwaarde de zaak is geëindigd. Welke formulering is hiervoor het meest 
geschikt? Art. $74 \mathrm{Sr}$ gebruikt: door voldoening aan de voorwaarde vervalt het recht tot strafvordering. Art. $246 \mathrm{~Sv}$ zegt: door een kennisgeving van niet verdere vervolging eindigt de zaak. Het verschil tussen beide formuleringen is, dat die met betrekking tot de transactie de meest definitieve is. Ten aanzien van de kennisgeving van niet verdere vervolging blijft het namelijk mogelijk dat de zaak heropend wordt, namelijk indien nieuwe bezwaren bekend worden (art. $255 \mathrm{~Sv}$ ). Bij acceptatie van deze formulering zou dat kunnen betekenen dat, ondanks de vervulling van een voorwaarde, alsnog tot vervolging zou kunnen worden overgegaan. Omdat er, zoals ik eerder betoogde in hoofdstuk 2, geen wezenlijk onderscheid meer bestaat tussen de transactie en het voorwaardelijk sepot, valt er volgens mij het meest voor te zeggen het rechtsgevolg van de transactie ook te laten gelden voor het voorwaardelijk sepot.

Op dezelfde plaats bleek dat ik er voorstander van was de regeling van het voorwaardelijk sepot te incorporeren bij die van de transactie. De voorwaarden betreffende de persoon van de verdachte zouden daar toegevoegd kunnen worden. Dit zou tegelijkertijd impliceren dat er een einde kwam aan het "illegale" informeel voorwaardelijk sepot, zoals dat in de praktijk is ontstaan.

\subsubsection{Vertrouwensbeginsel}

Dit beginsel speelt vooral een rol bij het informeel en het voorwaardelijk sepot, omdat bij deze afdoeningsmethoden het rechtsgevolg van een sepotmededeling niet wettelijk vastligt. Dit laatste is wel het geval ten aanzien van een formeel sepot en een transactie. Indien zich na een formeel sepot geen nieuwe bezwaren voordoen is de zaak door de kennisgeving van niet verdere vervolging beëindigd, art. 246 lid $1 \mathrm{~Sv}$. Door voldoening van de bij het transactie-aanbod door de officier van justitie gestelde voorwaarde(n) vervalt het recht tot strafvordering, art. 74 lid 1 laatste volzin.

Voor een goed begrip is het raadzaam twee vormen van het vertrouwensbeginsel te onderscheiden: de concreet individuele en de abstract algemene vorm. De eerste vorm doet zich voor indien er in een concreet geval door actief gedrag van de vervolgende instantie bij een verdachte vertrouwen worden gewekt. Meestal gaat het hierbij om het vertrouwen dat niet (verder) zal worden vervolgd. Bij de tweede vorm ontstaan er door abstract handelen, dat zich niet richt tot één individu maar meer in het algemeen is bedoeld, verwachtingen bij (een groep) burgers. Zoals ik in het vorig hoofdstuk aangaf, wordt er in de literatuur ten aanzien van de eerste vorm ook wel gesproken van het gewekte vertrouwen, ten aanzien van de tweede over gewekte verwachtingen.

Bij de eerste vorm rijst de vraag onder welke omstandigheden een vertrouwen, gebaseerd op een handeling dat een strafzaak zal worden geseponeerd, dient te worden gerespecteerd. In de, naar mijn weten, eerste uitspraak waarin deze kwestie als gevolg van een toezegging vanwege het $\mathrm{OM}$ een rol speelde, verbond de Hoge Raad, in 
tegenstelling tot A-G Remmelink, geen gevolgen aan een sepotmededeling. Aan de verdachte was meegedeeld dat de zaak voorwaardelijk zou worden geseponeerd. De zaak werd toch vervolgd, Macintosh-arrest, HR 18 oktober 1977, NJ 1978, 128 m.nt. GEM. De Hoge Raad veranderde van opvatting in het Menten-arrest (HR 29 mei 1978, NJ 1978, 358 m.nt. ThWvV), waarin hij overwoog dat bij de vraag of het $\mathrm{OM}$ na een door de minister van Justitie gedane sepotmededeling alsnog tot vervolging mag overgaan 'rekening moet worden gehouden met de beginselen van een goede procesorde, welke onder meer medebrengen dat de voor het justitiële beleid verantwoordelijke organen niet handelen naar willekeur, doch -tenzij zwaarwichtiger belangen zich daartegen verzetten- in gebondenheid jegens de verdachte aan toezeggingen welke bij de laatstgenoemde gerechtvaardigde verwachtingen hebben opgewekt'. Uit deze uitspraak en uit latere jurisprudentie blijkt dat voor honorering van het ontstane vertrouwen aan een aantal voorwaarden dient te zijn voldaan:
A. het vertrouwen moet gerechtvaardigd zijn;
B. de toezegging moet afkomstig zijn van voor het justitiële beleid verantwoordelijke organen;
C. zwaarwichtiger belangen mogen zich er niet tegen verzetten.

ad $\mathrm{A}$. Het moet gaan om een duidelijke mededeling dat niet zal worden vervolgd. Berichten, dat wellicht niet zal worden vervolgd of dat nog niet duidelijk is of zal worden vervolgd, leveren geen gerechtvaardigd vertrouwen op.

In een arrest van HR 26 juni 1984, NJ 1985, 41 is de Hoge Raad van mening dat het oordeel van het Hof dat de officier van justitie niet-ontvankelijk diende te worden verklaard wegens schending van de regels van een behoorlijke procesvoering en behoorlijk bestuur voldoende is gemotiveerd met het feitelijk oordeel dat de raadsman van de verdachte de door de officier van justitie gedane mededeling mocht begrijpen ills een sepot dat betrekking had op het gehele strafrechtelijk gebeuren.

ad B. Hierbij doet zich de vraag voor wie of welk orgaan is te beschouwen als een voor het justitiële beleid verantwoordelijk orgaan. Als zodanig worden personen aangemerkt die verantwoordelijk zijn voor het $O M$ en personen die vallen onder de verantwoordelijkheid van het $O M$. Onder de eerste groep valt de Minister van justitie, die immers de politieke verantwoordelijkheid draagt voor het OM (zie het genoemde Menten-arrest), en de leden van het OM. Daartoe behoort bijvoorbeeld niet een griffie-ambtenaar die per abuis aan een kantoorgenoot van de raadsman van een verdachte meedeelt dat de officier van justitie niet zal appelleren (HR 28 juni 1983, NJ 1984, 77) of de staatssecretaris of minister van Volksgezondheid en Milieuhygiëne, die aan een verdachte meedeelde dat ter zake van bepaalde feiten geen strafvervolging zou worden ingesteld (HR 17 december 1985, NJ 1986, 591, m.nt. ThWvV). Het door A-G Remmelink genoemde argument dat het OM een van de bestuurlijke overheid onafhankelijke justitiële instantie is, is naar mijn mening niet juist of doet niet ter zake. Het gaat er om dat het vertrouwen afkomstig was 
van een orgaan dat geen bevoegdheid draagt voor het vervolgingsbeleid. De vraag kan worden gesteld of deze uitspraak rechtvaardig is. Behoeft het OM nooit de verantwoordelijkheid te nemen voor mededelingen of toezeggingen die buiten zijn bevoegdheid vallen? Wellicht zou er wat te zeggen zijn voor een staatsrechtelijk beginsel dat (exclusieve) bevoegdheidstoekenning aan een bepaald ambt impliceert dat dit ambt, voor zover dit binnen het redelijke valt, moet waken tegen de schijn van bevoegdheid terzake van andere ambten.

Voor welke personen is het OM verantwoordelijk? Onder deze verantwoordelijkheid vallen politieambtenaren, werkzaam in het kader van de handhaving van de rechtsorde. ${ }^{715}$ Mag een verdachte er op vertrouwen dat hij ter zake van een strafbaar feit niet meer zal worden vervolgd nadat een politieambtenaar hem een zodanige mededeling heeft gedaan? Hier manifesteert zich in volle omvang het gebrek aan duidelijkheid omtrent het politiesepot.

Deze kwestie was expliciet aan de orde in het Brigadiers-arrest, HR 13 september 1988, NJ 1989, 403. Een brigadier van de gemeentepolitie deelde, op verzoek van de verdachte en zonder toestemming van de officier van justitie, aan verdachte mee dat de officier van justitie van oordeel was dat de zaak niet hard te maken zou zijn. Verdachte was bekend dat de brigadier een niet met vervolging belaste instantie was. Verdachte deed een beroep op de niet-ontvankelijkheid van de officier van justitie, omdat hij aan deze sepotmededeling het vertrouwen mocht ontlenen dat hij niet meer zou worden vervolgd. De Hoge Raad verwierp dit verweer omdat deze mededeling noch was gedaan door de officier van justitie, noch in diens opdracht, terwijl zij evenmin anderszins kan worden beschouwd als een aan het OM toe te rekenen toezegging. ${ }^{710}$ In een zes dagen later gewezen arrest (HR 19 september 1988, NJ 1989, 379 Parkeerwachter) kwam de Hoge Raad tot een ander oordeel. ${ }^{717}$ Een parkeerwachter had bij constatering van een parkeerovertreding verdachte te kennen gegeven niet over te gaan tot het opmaken van een proces-verbaal, doch dit bij herhaling van de overtreding wél te doen. Verdachte deed, toen hij toch gedagvaard werd ter zake van de betreffende overtreding, een beroep op de niet-ontvankelijkheid van de officier van justitie. De Hoge Raad overwoog dat -mede gelet op de aard van de gepleegde verkeersovertreding (eenvoudig) en de omstandigheden waaronder de bedoelde mededeling werd gedaan- bij de verdachte het gerechtvaardigde vertrouwen is gewekt dat hij van verdere vervolging verschoond zou blijven. In dit arrest heeft de Hoge Raad voor de eerste keer het rechtsgevolg van niet-ontvankelijkheid van de officier van justitie verbonden aan het politiesepot.

715 Politieambtaren die werkzaam zijn in het kader van de handhaving van de openbare orde vallen onder de verantwoordelijkheid van de burgemeester.

716 Ook mededelingen van een raadsman aan zijn cliënt over een afspraak met het OM omtrent niet verdere vervolging, zijn niet aan het OM toe te rekenen, HR 6 juni 1989, NJ 1990, 117.

717 Zie daarover T.M. Schalken, HR en politiesepot: de carrière van een parkeerwachter, NJB 1989, pag. 917-918. 
Uit deze twee uitspraken valt af te leiden dat de vraag of een door een politieambtenaar gedane mededeling dat niet zal worden vervolgd leidt tot de niet-ontvankelijkheid van de officier van justitie omdat de verdachte mocht vertrouwen op de gedane mededeling, afhankelijk is van een aantal omstandigheden:

1. Valt het seponeren onder de eigen bevoegdheid van de betreffende ambtenaar? In het Brigadier-arrest (bewijssepot) lag het beoordelen van het bewijs bij de officier van justitie en niet bij de betreffende brigadier. Hier kon dus in feite geen sprake zijn van een politiesepot, maar van een sepot door het OM. Ik zou dit cen oneigenlijk politiesepot willen noemen. Het was de ambtenaar die daarvan mededeling deed aan de verdachte, zonder dat de officier van justitie daarvan op de hoogte was of daarvoor toestemming had gegeven. In dit arrest was de beslissing om al dan niet te vervolgen een OM-bevoegdheid. In het Parkeerwachterarrest (beleidssepot) daarentegen behoorde het al dan niet opmaken van een proces-verbaal tot de bevoegdheid van de ambtenaar zelf. Ik zou dit een eigenlijk politiesepot willen noemen.

2. Is de verdachte van deze bevoegdheidsverdeling op de hoogte? Met andere woorden: kan hij overzien of de politie-ambtenaar handelt vanuit zijn eigen bevoegdheid of vanuit die van de officier van justitie?

3. De aard van de overtreding (zwaar of licht) en de omstandigheden waaronder de mededeling is gedaan.

Conclusie: Niet aan ieder politiesepot is het OM gebonden, gebondenheid kan onder omstandigheden worden aangenomen.

Deze gang van zaken bevredigt mij niet helemaal. In de eerste plaats vind ik het criterium 'aard van de overtreding' niet goed bruikbaar. In het Parkeerwachter-arrest ging het om een relatief lichte overtreding, maar heeft een verdachte van een relatief zwaarder vergrijp minder reden op een sepotmededeling te vertrouwen? Je zou ook kunnen betogen dat een opsporingsambtenaar ter zake van een zwaardere overtreding meer terughoudend moet zijn bij het doen van dergelijke uitspraken. Doet hij dan toch een sepotmededeling, dan dient het daardoor ontstane vertrouwen te worden gehonoreerd. In de tweede plaats leidt het criterium of de verdachte op de hoogte is van de sepotbevoegdheid van de opsporingsambtenaar tot onduidelijkheden. Ook al is iemand hiervan op de hoogte, dan kan toch nog een gerechtvaardigd vertrouwen worden gewekt, bijvoorbeeld ondat betrokkene denkt dat hij zich heeft vergist. De gevallen waarin en de omstandigheden waaronder sepotmededelingen door opsporingsambtenaren worden gedaan kunnen zeer verschillend zijn. Opsporingsambtenaren dienen terughoudend te zijn met het doen van dergelijke mededelingen, zeker wanneer dit hun bevoegdheid te buiten gaat.

Uitgangspunt blijft echter dat slechts het vertrouwen op een sepotmededeling kan worden gehonoreerd, indien deze wordt gedaan door een opsporingsambtenaar die daartoe bevoegd was. Slechts bij hoge uitzondering kan het vertrouwen op een sepot- 
mededeling, gedaan door een opsporingsambtenaar die daarmee zijn bevoegdheid overschrijdt, worden gehonoreerd.

ad.C. Het vertrouwensbeginsel werkt niet absoluut maar is relatief. Er kunnen omstandigheden zijn die zich tegen het tegemoetkomen aan bij de verdachte bestaande verwachtingen verzetten. Niet elke omstandigheid leidt echter tot een dergelijke relativering, deze moet dan wel 'zwaarwichtig' zijn. Dit betekent dat er een afweging gemaakt moet worden tussen het belang van de verdachte bij het niet-vervolgen en het belang dat wordt gediend bij wél vervolgen. Met andere woorden: bij ernstige feiten mag een verdachte minder gauw verwachten dat hij niet zal worden vervolgd. In het Menten-arrest bleek de ernst van het feit, ondanks gewekte verwachtingen, reden om toch tot vervolging over te gaan. Geabstraheerd van de betreffende strafzaak (oorlogsmisdaden) lijkt mij hantering van dit criterium erg riskant, het kan op zijn beurt weer leiden tot willekeur: wanneer is een bepaald strafbaar feit ernstig genoeg? En gaat het daarbij alleen om het feit zelf of ook om de omstandigheden waaronder het begaan is? En moet niet juist met betrekking tot een verdenking ter zake van een ernstig feit terecht bestaande vertrouwen gehonoreerd worden? Immers, bij ernstiger feiten zal een verdachte minder snel verwachten dat hij niet zal worden vervolgd. Hiermee zou in de hand gewerkt worden dat vanwege het OM (en de politie) meer voorzichtigheid zou moeten worden betracht bij het geven van verwachtingen bij de meer ernstige zaken. Het is zo'n 'open' criterium, later kan altijd het vertrouwensbeginsel onderuit gehaald worden met: het is een ernstig strafbaar feit. Men zou ook als volgt kunnen redeneren: dat had het $\mathrm{OM}$, juist bij een ernstig strafbaar feit, eerder moeten bedenken. Bij het genoemde Menten-arrest kunnen we de vraag te stellen of het bij een andere verdachte in een andere strafzaak ook zo zou zijn gegaan. Met andere woorden: werkt men op deze manier een zeker opportunisme niet in de hand? Het lijkt mij duidelijk dat in de Menten-zaak door een vervolgingsbeletsel uit te sluiten tegemoet kon worden gekomen aan onrustgevoelens in de samenleving.

Vergelijken we dit nu met het bestuursrecht, dan is naar mijn mening de conclusie gerechtvaardigd dat de werking van het vertrouwensbeginsel (in concrete vorm) bij de vervolgingsbeslissing van het $\mathrm{OM}$ zich laat vergelijken met hetzeltde beginsel in het bestuursrecht. Ten aanzien van de onder C. genoemde voorwaarde kunnen we verwachten dat in het strafrecht eerder dan in het bestuursrecht wordt aangenomen dat het algemeen belang zich tegen honorering van het vertrouwensbeginsel zal verzetten daar in het strafrecht in het algemeen sprake is van zwaarder wegende algemene belangen. Waarschijnlijk hangt dit samen met het karakter van het strafrecht: het gaat om de vervolging van strafbare feiten. Niet alleen het belang van de verdachte speelt daarbij een rol, maar ook het belang dat de samenleving heeft bij de vervolging van een strafbaar feit. Dit laatste vormt een verschil met het bestuursrecht. Dit onderscheid is echter niet echt wezenlijk maar slechts gradueel: ook in het bestuursrecht vindt afweging plaats tussen individueel en algemeen belang. 
Ik blijf van mening dat het OM met de onder C. gestelde voorwaarde terughoudend zal moeten omgaan.

Verwachtingen kunnen ook op een andere manier ontstaan, namelijk door een meer abstract optreden van het $\mathrm{OM}$, dat zich niet speciaal richt tot één individu, maar meer in het algemeen bedoeld is. Hierbij kunnen we bijvoorbeeld denken aan de publicatie van richtlijnen, eerder gedane uitspraken en algemene inlichtingen en algemeen beleid. ${ }^{7 x}$ De gepubliceerde richtlijnen nemen een steeds belangrijker plaats in.

Omdat de problematiek van de status van strafrechtelijke richtlijnen niet alleen een rol speelt bij toepassing van het vertrouwensbeginsel, maar evenzo bij het gelijkheidsbeginsel en het verbod van willekeur en gezien de importantie van de problematiek, lijkt het mij noodzakelijk hieraan een aparte subparagraaf te wijden.

\subsubsection{De status van richtlijnen}

Allereerst lijkt het mij van belang duidelijkheid te verschaffen over de gebruikte terminologie. In het strafrechtelijk kader blijf ik het woord 'richtlijn' gebruiken, ook al heeft dit woord in het bestuursrecht een andere betekenis. ${ }^{719}$ Het woord 'richtlijn' is een in het strafrecht ingeburgerde term. Ik gebruik dus het woord 'richtlijn' waar in het bestuursrecht 'beleidsregel' wordt gehanteerd.

Het strafrecht kent verschillende soorten richtlijnen. Een grote groep wordt gevormd door de veelvuldig voorkomend(e) opsporings-en vervolgingsrichtlijnen waarbij ten aanzien van de opsporing en vervolging van een aantal specifiek genoemde delicten (bijvoorbeeld drugsdelicten, vuurwapendelicten, rijden onder invloed) prioriteiten worden gesteld. Dergelijke richtlijnen bestaan er ook ten aanzien van de strafvordering. ${ }^{720}$ In deze richtlijnen, opgesteld door de top van het $\mathrm{OM}$, de vergadering van

718 Hierbij dient te worden opgemerkt dat in een dergelijk geval in de praktijk op verschillende beginselen een heroep wordt gedaan. Zo worden genoemd het vertrouwensbcginsel, het gelijkheidsbeginsel en verbod van willekeur.

719 Het kenmerkende onderscheid, in bestuursrechtelijke terminologie, tussen beleidsregels en richtlijnen ligt in de mate van zelfbinding van het bevoegde bestuursorgaan. In tegenstelling tot beleidsregels binden richllijnen niet het orgaan dat de richtlijn uitvaardigt. Zie H.E. Bröring, Richtlijnen, disscrtatie RUG, Deventer 1993, pag. 21-22.

720 Dit type richtlijn moet worden onderscheiden van een tweede soort richtlijn, namelijk die welke een nadere uitvocring geeft aan een bevoegdheid van het $O M$, anders dan de vervolging van een specifick delict. In cen dergelijke richtlijn wordt nadere invulling gegeven aan cen beoordelingsruimte van het $O M$ bij de uitvoering van een bepaalde bevoegdheid, anders dan de vervolging van bepaalde delicten. Deze bevoegdheid kan dus wel betrekking hebben op vervolging, maar niet op de vervolging van cen bepaald met name genoemd delict. Te denken valt hier bijvoorbeeld aan een nadere richllijn voor het beleid inzake de inbeslagneming, richtlijnen voor de toepassing van de Krankzinnigenwet, 
de procureurs-generaal, wordt ten aanzien van de betreffende strafbare feiten de strafwaardigheid "genuanceerd". Feitelijk gaat het hier om beleidsregels die afwijken van de wettekst, hetgeen in het algemeen neerkomt op een versoepeling van de wettelijke regeling in die zin dat met betrekking tot een delict, dat door de wet strafbaar is gesteld, bepaald wordt dat het onder omstandigheden niet opgespoord en/of vervolgd zal worden of dat volstaan kan worden met een transactie ter hoogte van een vastgesteld bedrag, een bedrag dat lager ligt dan de maximale straf voor dat feit.

Wat is nu de functie van de bestuursrechtelijke beleidsregel respectievelijk de strafrechtelijke richtlijn?

In het bestuursrecht is de beleidsregel in feite een soort formalisering van een vaste gedragslijn. Het bestuursrecht biedt op tal van terreinen een "vrije" bevoegdheid, bijvoorbeeld de bevoegdheid om vergunningen af te geven of om bepaalde subsidies te verstrekken. Vereist wordt dat deze bevoegdheid gehanteerd wordt op een regelmatige, beleidsmatige wijze, met andere woorden: er dient beleid te zijn. Dit beleid krijgt dan vorm door vaste regels. Deze regels gaan na herhaalde toepassing werken als een soort "bewijs" van het bestaan van bepaald beleid, waar de burger een zeker vertrouwen aan mag ontlenen. In tegenstelling tot de wet zit in iedere beleidsregel echter een inherente afwijkingsbevoegdheid en zo nodig een afwijkingsplicht. Tot het arrest van HR 28 maart 1990, NJ 1991, 118 m.nt. MS, was controle op toepassing van beleidsregels slechts mogelijk met behulp van de algemene beginselen van behoorlijk bestuur, met name het vertrouwensbeginsel. Beginselen beperken zich echter tot een individueel geval en geven nooit aanspraak op algemene toepassing van de beleidsregel. ${ }^{721} \mathrm{Na}$ dit arrest, waarin de beleidsregel de status kreeg van "recht" in de zin van art. $99 \mathrm{RO}$, kan de concrete toepassing direct aan de beleidsregel worden getoetst en is ook rechtstreekse controle door de Hoge Raad op het beleid mogelijk geworden, waardoor wellicht meer rechtseenheid kan worden bereikt. Dit wordt geformaliseerd in het wetsvoorstel Awb (derde tranche) in art. 4.4.5. Gebondenheid aan een beleidsregel zal dan rechtstreeks uit dit artikel voortvloeien.

De strafrechtelijke richtlijn beoogt in feite ook de hantering van een vaste gedragslijn. De strafwetgever heeft een aantal gedragingen strafbaar gesteld. Bij constatering van een overtreding van een strafbepaling is het $O M$ bevoegd strafvervolging in te stellen tegen de overtreder ervan. Vanwege een aantal redenen, die besproken zijn in eerdere hoofdstukken, kiest het $\mathrm{OM}$ er echter voor niet tot vervolging over te gaan. Dezelfde wetgever heeft hiertoe de mogelijkheid geboden door middel van het opportuniteitsbeginsel, artt. 167 en $242 \mathrm{~Sv}$. Om nu toch tot een zekere uniformiteit

richtlijnen inzake de gelijktijdige vordering bewaring en verlenging bewaring of het (toenmaligc) beleid inzake vervolging na dienstverlening.

721 Zie ook: Bernd van der Meulen e.a., Bestuursbevocgdheid als bron van recht? NTB 91/5, pag. 134. 
in de hantering van dit beginsel te komen, worden er door de top van het $\mathrm{OM}$, de procureurs-generaal bij de hoven (formeel) onder leiding van de minister van Justitie, richtlijnen uitgevaardigd en (veelal) gepubliceerd. Hebben deze richtlijnen in de eerste plaats de functie van een soort "instructie" aan ondergeschikten (interne coördinerende functie), door publicatie alsmede een frequente toepassing ervan krijgen zij een meer externe functie, met name een bewijsfunctie, en daardoor ook een bindende kracht naar de burgers toe. ${ }^{722}$ Voor de duidelijkheid: de richtlijnen werken eenzijdig, dat wil zeggen zij binden het $O M$, maar scheppen geen verplichtingen voor de burgers. De wet(gever) geeft het OM immers de mogelijkheid middels het opportuniteitsbeginsel van vervolging af te zien. Richtlijnen zou men dan kunnen zien als een categorale toepassing van dit beginsel.

Wat is nu de status van de hier bedoelde strafrechtelijke richtlijnen? Vóór het hieronder te bespreken arrest kon worden betoogd dat de bindende kracht van de strafrechtelijke richtlijn niet in de richtlijn zelf lag. Het was immers geen "echte" beleidsregel. Bindende kracht werd echter wel geschapen door herhaalde toepassing ervan, waarbij de algemene beginselen van behoorlijk bestuur (vertrouwensbeginsel, gelijkheidsbeginsel, verbod van willekeur) een rol gingen spelen. Het OM was immers gebonden aan richtlijnen die het zelf had opgesteld, gepubliceerd én had toegepast. Men kon daar dan niet naar willekeur van afwijken.

In navolging van onder andere het in het vorige hoofdstuk aangehaalde arrest van HR 28 maart 1990, NJ 1991, 118 m.nt. MS inzake de Leidraad administratieve boeten 1984, heeft de strafkamer van de Hoge Raad bepaald dat ook een strafrechtelijke richtlijn moet worden beschouwd als 'recht' in de zin van art. 99 RO, HR 19 juni 1990, NJ 1991, 119 m.nt. ThWvV en MS inzake de Richtlijn Openbaar Ministerie Belastingdienst van 16 januari 1985 (Stcr. 1985, 15). Een beschikking van het Hof Arnhem, waarin het OM niet-ontvankelijk werd verklaard, werd aan de Hoge Raad voorgelegd

"aangezien in de praktijk van justitiële en fiscale instanties behoefte bestaat aan meer duidelijkheid wat betreft de visie van de rechter in dergelijke zaken en nu heroverwegingen en/of herformulering van de genoemde richtlijnen thans in bespreking is",

aldus de algemene toelichting bij het cassatieberoep. In het cassatieberoep was gesteld dat met de richtlijn was beoogd uniformiteit in het land te bereiken met betrekking tot de opsporing, vervolging en strafvordering van belastingdelicten inzake art. 68 lid 2 AWR. Tevens was de bedoeling hiermede verspilling van onderzoekscapaciteit

722 Ik ben van mening dat, zolang richtlijnen zelf geen strafbaarheid creëren, er geen sprake is van tegen-wettelijkheid. Wel speelt hier op de achtergrond een meer constitutioneel probleem mee: hoever mag het uitvoerend orgaan hiermee gaan? Ik denk dat deze bevoegdheid begrensd wordt door de democratische controle van het parlement middels de ministeriële verantwoordelijkheid. Wanneer het parlement het niet eens is met de inhoud van de door het OM opgestelde richllijnen kan het daarover de minister van justitie aanspreken. 
te voorkomen. Voorop heeft gestaan een gedragslijn uit te zetten voor OM en de fiscus, waarbij ruimte werd gelaten in concrete gevallen van de uitgezette beleidslijn af te wijken. Het is niet de bedoeling geweest de vervolgingsbevoegdheid van het OM in te perken. De verdachte kan dan ook niet aan de richtlijn het vertrouwen ontlenen dat hij niet zou worden vervolgd. De Hoge Raad is een andere mening toegedaan en overweegt dat op de gronden neergelegd in de r.o. 4.5-4.7 van het arrest van HR 28 maart 1990 (NJ 1991, 118) de richtlijn OM Belastingdienst moet worden beschouwd als 'recht' in de zin van art. $99 \mathrm{RO}$.

"Deze richtlijn bevat immers door de procureurs-generaal bij de hoven vastgestelde en behoorlijk bekend gemaakte regels omtrent de uitoefening van het beleid van het $O M$, die weliswaar niet kunnen gelden als algemeen verbindende voorschriften omdat zij niet krachtens enige wetgevende bevoegdheid zijn gegeven, maar die het $O M$ wel op grond van beginselen van behoorlijke procesorde binden, en die zich naar hun inhoud en strekking ertoe lenen jegens betrokkenen als rechtsregels te worden toegepast".

Dit arrest heeft als gevolg dat, in geval van afwijking van een richtlijn door het $O M$, de rechter rechtstreeks aan de richtlijn mag toetsen en daarvoor niet meer, indirect, een der algemene beginselen van behoorlijk bestuur behoeft te hanteren. Daarnaast is de afwijking van een richtlijn rechtstreeks toetsbaar geworden in cassatie, hetgeen tot een grotere rechtseenheid zal leiden. ${ }^{729}$

De richtlijn laat het afwijken van de regel toe. Ook het hof was dit in casu van oordeel. Echter, een dergelijke afwijking dient, met het oog op de bewijsfunctie, vergezeld te gaan van een deugdelijke motivering door het $\mathrm{OM}$ waarom in dit speciale geval toch tot vervolging wordt overgegaan. De rechterlijke toetsing blijft naar mijn mening een marginale. De rechter onderzoekt of de officier van justitie, binnen de mogelijkheden die de richtlijn biedt, in redelijkheid tot zijn vervolgingsbeslissing heeft kunnen komen. Zo blijft de opportuniteit van de vervolging toch een zaak van het OM. In zijn noot onder het genoemde arrest van HR 19 juni 1990, NJ 1991, 119 pleit Van Veen ervoor, in tegenstelling tot zijn mede-annotator Scheltema, de mogelijkheid open te houden om van een richtlijn af te wijken. Reden voor deze afwijking ziet hij in generaal-preventieve omstandigheden in een bepaald arrondissement. Scheltema ziet niet in waarom het gelijkheidsbeginsel en het rechtszekerheidsbeginsel voor het optreden van het $\mathrm{OM}$ minder betekenis zou hebben dan voor dat van andere bestuursorganen. Hierbij wil ik enkele opmerkingen plaatsen. Met Van Veen ben ikvan mening dat, gezien de specifieke doelen van het strafrecht, generale en speciale preventie, afwijking van de richtlijn mogelijk moet zijn. De grond voor deze afwijkingsmogelijkheid hoeft zich naar mijn idee niet te beperken tot verschillen tussen de arrondissementen. Ook meer lokale omstandigheden kunnen aanleiding zijn binnen eén arrondissement van de vervolgingsrichtlijn af te wijken. Met name zien we dit gebeuren inzake soft-drugsdelicten, die op lokaal niveau overlast veroorzaken (zie

723 Vgl. G.J.M. Corstens, Richtlijnen: recht in de zin van art. 99 RO, DD 1991, pag. 4. 
bijvoorbeeld HR 5 maart 1991, NJ 1991, 694 m.nt. C). Hieraan zou ik willen toevoegen dat de speelruimte van het $\mathrm{OM}$ voor afwijkende beslissingen niet groot is en dat afwijking uitzondering behoort te blijven. Strafrechtelijke richtlijnen hebben niet louter een interne coördinerende functie, zoals de Hoge Raad vaststelde, maar werken, gelijk de bestuursrechtelijke beleidsregels, naar de burgers toe, die daaraan vertrouwen mogen ontlenen.

Opvallend is dat overweging 4.8 van het arrest van de belastingkamer, waarin staat vermeld dat de rechter niet gehouden is tot ambtshalve toepassing van de beleidsregel, in het arrest inzake de strafrechtelijke richtlijn niet wordt overgenomen. Dit leidt tot onduidelijkheden. Mogen we hieruit, a-contrario, afleiden dat de strafrechter wél tot een dergelijke ambtshalve toetsing is gehouden? Zo ja, waardoor wordt dan dit verschil in benadering gerechtvaardigd? Is dit onderscheid bewust gemaakt? Volgens de MvT bij het Voorontwerp Awb (derde tranche) was deze overweging (overweging 4.8 uit HR 28-3-1990, AB 1990,306) gebaseerd op het onderscheid tussen een algemeen verbindend voorschrift en een beleidsregel. ${ }^{\text {7u }}$ De bevoegdheid tot het maken van beleidsregels ligt opgesloten in de bevoegdheid tot het nemen van beschikkingen. Daardoor kan een beleidsregel niet in dezelfde mate bindend zijn dan een algemeen verbindend voorschrift, omdat in bijzondere gevallen van een beleidsregel kan worden afgeweken. Een praktisch gevolg van dit onderscheid is volgens de MvT dat de rechter, hoewel een beleidsregel recht is in de zin van art. $99 \mathrm{RO}$, niet ambtshalve aan een beleidsregel behoeft te toetsen.

Een rechtvaardiging voor het verschil op dit punt tussen het bestuursrecht en het strafrecht zie ik niet. Bovendien ben ik het met de hierboven weergegeven toelichting niet eens. Ik ben van mening dat, indien de afwijking van de beleidsregel c.q. richtlijn niet nader is gemotiveerd, ambtshalve toetsing door de rechter op zijn plaats is. Ik zie niet in waarom de administratieve rechter, indien op de hoogte van de betreffende beleidsregel, niet verplicht zou zijn tot een ambtshalve toepassing. Als mogelijke reden voor een verschil in benadering beschouw ik de praktische uitvoerbaarheid ervan. Door de grote hoeveelheid bestuursrechtelijke beleidsregels is de rechter eenvoudig niet in staat deze allemaal te kennen en zonodig ambtshalve toe te passen. Het strafrechtelijk terrein is wat dit betreft wellicht wat beter te overzien. ${ }^{\text {TS }}$

Van belang is te vermelden dat een hierboven besproken afwijking van een richtlijn zich niet alleen kan voordoen ten nadele, maar ook ten voordele van burgers. En dat zo'n 'positieve' afwijking categoraal gebeurd, dus ook weer als beleid bestempeld kan worden, maakt de zaak extra gecompliceerd. Een dergelijke casus deed zich voor in het zogenaamde Tuindersfraude-arrest, HR 22 oktober 1991, NJ 1992, 282, m.nt. 'tH. In het kort de casus: inzake tuindersfraude bestond een Richtlijn Openbaar

724 MvT Voorontwerp Awb derde tranche, pag. 114-116.

725 Zie ook: G.J.M. Corstens, Richtlijnen: recht in de zin van art. 99 RO, DD 1991, pag. 4. 
Ministerie Belastingdienst van 16 januari 1985 (Stcrt. 1985, 15). Deze richtlijn kwam er op neer dat bij fraudes van $f 50.000$, - of meer strafrechtelijk zou worden vervolgd, terwijl fraudes beneden dat bedrag administratief zouden worden afgedaan. Verdachte had gefraudeerd voor een bedrag van ongeveer $f 140.000$,- en werd vervolgd. Ter zitting in eerste aanleg verklaarde de officier van justitie een ander vervolgingscriterium te hanteren dan in de Richtlijn was neergelegd: bij een fraude hoger dan $f 200.000$, volgt strafrechtelijke vervolging, bij fraude tussen $f 100.000$,- en $f 200.000$,- volgt een schikking en bij een fraude lager dan $f 100.000$,- wordt de zaak administratief afgedaan. Deze, interne, afspraken waren gemaakt vanwege capaciteitsproblemen en omdat het in de richtlijn opgenomen criterium van te weinig geheven belastingpremie niet goed te hanteren viel. Hoewel dus verdachte in de categorie 'schikking' viel werd hij, in tegenstelling tot ongeveer vierhonderd mede-fraudeurs, wel vervolgd. Eén van de vragen die hier speelden was, aan welke beleidsregels nu moest worden getoetst, aan de Richtlijn of aan de afwijkende afspraken. ${ }^{\text {ro }}$ Zowel de rechtbank, het hof, A-G Leijten als de Hoge Raad zijn van mening dat de Richtlijn buiten beschouwing mocht worden gelaten en dat de vervolging in strijd was met de beleidsafspraken, hetgeen tot gevolg heeft niet-ontvankelijkheid van de officier van justitie. Een oordeel waar annotator 't Hart zich bij aansluit. Binnen de globale groep van gevallen die de richtlijn bestrijkt is er een meer specifieke groep waartoe de onderhavige zaak behoort. Die specifieke groep is dan de meest nabije en het meest voor de hand liggende referentiepunt voor toetsing.

Samenvattend, sinds het hier besproken arrest van HR 19 juni 1990, NJ 1991, 119 m.nt. ThWvV en MS, is de strafrechtelijke richtlijn te beschouwen als 'recht' in de zin van art. $99 \mathrm{RO}$. Hiermede heeft de strafrechtelijke richtlijn dezelfde status verkregen als de bestuursrechtelijke (zie HR 28 maart 1990, NJ 1991, 118 m.nt. MS). De positie van het $\mathrm{OM}$ bij het nemen van een vervolgingsbeslissing aan de hand van een richtlijn is niet principieel anders dan de positie van een ander overheidsorgaan bij het nemen van een bestuursbesluit.

Weliswaar wordt in het arrest van de strafkamer niet verwezen naar overweging 4.8 van het arrest van de belastingkamer, waarin staat dat de rechter niet gehouden is tot ambtshalve toepassing van de beleidsregel, doch dit kan terug te voeren zijn op louter praktische oorzaken.

Zowel in het bestuursrecht als in het strafrecht bij het nemen van een vervolgingsbeslissing is afwijking van een beleidsregel c.q. richtlijn mogelijk en zo nodig verplicht. Dit dient dan wel gemotiveerd te gebeuren (HR 5 maart 1991, NJ 1991, 694, m.nt. C). Van belang acht ik hier de argumentatie van annotator Corstens:

"Het is volkomen acceptabel dat een orgaan als het Openbaar Ministerie dat over veel macht beschikt, moet uitleggen waarom het anders handelt dan mag worden verwacht".

726 De andere vraag, aan welk beginsel kon worden getoetst, komt in de volgende paragraaf aan de orde. 
Wellicht is er in het strafrecht meer reden voor afwijking, gezien de speciale doelstellingen van het strafrecht, speciale en generale preventie, alsmede vanwege omstandigheden die gelegen zijn in de persoon van de verdachte, een omstandigheid waarmee het bestuursrecht, naar het mij voorkomt, minder rekening behoeft te houden.

\subsubsection{Gelijkheidsbeginsel}

Het gelijkheidsprincipe heeft onder meer wettelijke grondslag gekregen in art. 1 GW: allen die zich in Nederland bevinden, worden in gelijke gevallen gelijk behandeld. Discriminatie wegens godsdienst, levensovertuiging, politieke gezindheid, ras, geslacht of op welke grond dan ook, is niet toegestaan.

Gelijke gevallen dienen gelijk behandeld te worden. Dit is grofweg de inhoud van het gelijkheidsbeginsel. Deze stelling lijkt eenvoudiger dan hij in werkelijkheid is. Dit moge blijken uit het gegeven dat dit beginsel in het strafrecht slechts een zeer geringe rol speelt. Hoewel de Hoge Raad in beginsel de mogelijkheid erkent dat schending van het gelijkheidsbeginsel kan leiden tot de niet-ontvankelijkheid van het $\mathrm{OM}^{27}$, heeft hij bij mijn weten een beroep daarop tot voor kort (zie hierna) nooit gehonoreerd. Een aantal oorzaken is hiervoor aan te wijzen.

Vaak wordt door de verdachte een dergelijk beroep gedaan door te verwijzen naar een vergelijkbare kwestie waarin van vervolging werd afgezien. Dit gegeven is echter voor honorering van het beginsel niet voldoende. ${ }^{728}$ In de eerste plaats spelen vooral in meer ernstige strafzaken zoveel factoren een rol bij de vervolgingsbeslissing, dat het moeilijk spreken is van een "vergelijkbaar" geval. De zaak is dan zo gecompliceerd dat eenvoudigweg niet alle factoren te vergelijken zijn (zie de conclusie van Remmelink voor HR 20 oktober 1987, NJ 1988, 473: "Ik voeg hieraan toe, dat (bagatelzaken daargelaten) een toetsing als door de geëerde steller van het middel bedoeld, niet mogelijk zal zijn. De menselijke en feitelijke omstandigheden verschillen nu eenmaal"). Ik vraag me af of het voor een succesvol beroep op het gelijkheidsbeginsel noodzakelijk is dat alle omstandigheden tot in detail identiek zijn met de omstandigheden in zaken waarmee vergeleken wordt. Het gaat mijns inziens om gelijkheid op een aantal, doorslaggevende punten: "relevante gelijkheid" of "relevante verschillen", hetgeen ook in de literatuur en jurisprudentie wordt erkend.

Zelfs binnen de omvang van één zaak kunnen er voor het $O M$ redenen zijn de ene verdachte wel en de andere niet te vervolgen. Het niet vervolgen van een medeverdachte is volgens de Hoge Raad op zich niet in strijd met het gelijkheidsbeginsel (beschikking HR 27 mei 1986, NJ 1987, 29; arrest HR 26 april 1988, NJ 1989, 37).

727 HR 24 juni 1980, NJ 1981, 659 m.nt. JAB.

728. Cleiren merkt hierbij op dat het niet gaat om de inhoudelijke beoordeling van wetten en beleidsregels (dat is de taak van de wetgever en belcidsmakers), maar om de toepassing ervan in het concrete geval. Het gaat er dus om dat binnen het bereik van één bepaalde wettelijke bepaling of geformaliseerde beleidsregel gelijke gevallen gelijk behandeld worden. C.P.M. Cleiren, a.w., pag. 117 . 
De verdachte zal stellen dat het om een "niet relevant verschillend" feit gaat. De officier zal dit bestrijden. Het is voor de rechter problematisch een strafzaak met een andere, die niet is vervolgd, te vergelijken, omdat hij deze niet kende en derhalve niet kan beoordelen waarom in die kwestie niet tot vervolging werd overgegaan. ${ }^{\text {To }}$ Ik denk dat van de rechter mag worden verwacht, dat hij, bij een beroep daarop, in staat moet zijn tot een (beperkte) dossiervergelijking.

Indien de vervolging van soortgelijke delicten is neergelegd in richtlijnen en beleid speelt dit laatste probleem echter minder ${ }^{30}$, hoewel van richtlijnen en beleid (gemotiveerd) kan worden afgeweken, waardoor verschillende beslissingen mogelijk zijn, bijvoorbeeld tussen verschillende arrondissementen. Wanneer van het beleid wordt afgeweken lijkt het mij aan het $\mathrm{OM}$ de noodzaak daartoe aan te tonen. ${ }^{73}$ In hoeverre een dergelijke afwijking in strijd komt met het willekeursverbod, komt in een andere paragraaf aan de orde. Schending van het gelijkheidsbeginsel kan volgens mij worden aangenomen indien onverplicht is afgeweken van het beleid en het $O M$ volgens de rechter in redelijkheid niet tot deze afwijking had kunnen komen. Het is dan aan de verdachte aan te tonen dat het om eenzelfde soort zaak gaat en dat er van een bepaalde beleidslijn is afgeweken. Het OM zal dan de noodzaak van deze afwijking hebben te verdedigen. Opgemerkt moet hier nog worden dat een beroep op toepassing van het beleid, gebaseerd op richtlijnen en/of een genomen vervolgingsbeslissing in een andere (vergelijkbare) strafzaak, wordt gedaan zowel op grond van het vertrouwensbeginsel, het gelijkheidsbeginsel alsook op het verbod van willekeur, de zg. materiële beginselen, zie bijvoorbeeld het hierboven genoemde arrest van 5 maart 1991. Is de verdachte zelf onbekend met het bestaande beleid dan kan er geen sprake zijn van een gewekt vertrouwen.

Het bij mijn weten eerste arrest waarin de Hoge Raad schending van het gelijkheidsbeginsel honoreerde was het in de vorige paragraaf besproken Tuindersfraude-arrest (HR 22 oktober 1991, NJ 1992, 282 m.nt. 'tH). Voor de feiten verwijs ik naar de vorige paragraaf.

De rechtbank was van mening dat hier het vertrouwensbeginsel was geschonden. Hiervan kon echter geen sprake zijn omdat verdachte op het moment van zijn vervolging niet op de hoogte was van de interne afspraak en daar dus ook geen gerechtvaardigd vertrouwen aan kon ontlenen. Het hof achtte het gelijkheidsbeginsel geschonden, alsmede het verbod van willekeur. Het feit dat de Hoge Raad de toetsing aan het gelijkheidsbeginsel door het hof in cassatie overeind laat, acht ik, met 't Hart, een groot winstpunt. De tot dan gehanteerde argumenten tegen het gebruik van het gelijkheidsbeginsel als toetsingsgrond, "strafzaken zijn nooit precies gelijk" en "de strafrechter kan alleen oordelen over het voorliggende geval en is niet tot in detail

$729 \mathrm{Er}$ kunnen zich in die zaak bijvoorbeeld bewijsproblemen hebben voorgedaan, HR 10 februari 1987, NJ 1987, 950; HR 20 oktober 1987, NJ 1988, 473;

$730 \mathrm{Zie}$ het in de vorige paragraaf besproken arrest van HR 5 maart 1991, NJ 1991, 694 m.nt. C.

71 In bet bestuursrecht geldt dat, indien de afwijking van het beleid door de burger wordt gewenst, hij de grond daartoe moet aangeven. 
op de hoogte van andere zaken" krijgen daardoor minder gewicht. A-G Leijten acht het beter hier te spreken van het aan het gelijkheidsbeginsel zeer verwante consistentiebeginsel.

Ook bij de transactie als afdoeningsmethode speelt het gelijkheidsbeginsel een rol. Steeds weer blijkt dat door individuele officieren van justitie van de transactierichtijj. nen wordt afgeweken of dat, bij het ontbreken van richtlijnen, verschillende transactiebedragen worden gehanteerd. Ook hierbij geldt dat in principe afwijking van de richtlijnen mogelijk moet zijn of dat er een (beperkte) mogelijkheid dient te bestaan tot het vocren van een eigen beleid indien hiervoor indicaties bestaan op grond van de verdachte betreffende of regionale of lokale omstandigheden. Er moet dus wel degelijk grond voor zijn. Deze zal door de officier aangetoond en de afwijking gemotiveerd dienen te worden, bijvoorbeeld op het transactieformulier. Ik ben me ervan bewust dat controle hierop moeilijk is, omdat de beoordeling van het transactieaanbod doorgaans niet tot de competentie van de rechter behoort. Deze norm zal, zolang het transactiebesluit niet aan rechterlijke controle is onderworpen, niet zozeer als een toetsings- dan wel als een gedragsnorm dienen te fungeren.

Uit een onderzoek van het WODC, gepubliceerd op 20 september $1993^{72}$, naar de prestaties van de verschillende parketten bleek overigens dat er grote verschillen bestaan in de manier waarop zaken worden afgedaan. Op bepaalde parketten werd eerder of meer vervolgd, geschikt of gewaarschuwd dan in andere parketten. Als mogelijke oorzaak werd onder andere gezien een onevenredige personeelsverdeling. Kleinere arrondissementen hadden relatief meer personeel.

Het gelijkheidsbeginsel kwam ook aan de orde in een beschikking van het Hof Amsterdam naar aanleiding van een klacht tegen niet-vervolging, art. $12 \mathrm{~Sv}$ (Hof Amsterdam 10 februari 1993, NJ 1993, 355). De officier van justitie had een feit niet vervolgd overeenkomstig het landelijk vervolgingsbeleid op dat punt. In hun advies naar aanleiding van de klacht over dit niet-vervolgen wijken de hoofdofficier van justitie en de procureur-generaal af van dit bestaande beleid en achten derhalve vervolging wel geboden. Het Hof overweegt onder meer dat door in dit individuele geval van het landelijk beleid af te wijken ongelijkheid van behandeling ontstaat in dit opzicht gelijke gevallen en weigert derhalve het door klagers gewenste bevel tot vervolgen.

Vergelijken we de werking van het gelijkheidsbeginsel met betrekking tot de vervolgingsbeslissing met de werking van het gelijkheidsbeginsel in het bestuursrecht, dan valt te constateren dat de abstracte omschrijving en de concrete toepassing van het gelijkheidsbeginsel op beide gebieden overeenkomst vertonen. In principe is toetsing aan dit beginsel op beide gebieden mogelijk, zij het dat toepassing ervan in zeer weinig gevallen wordt gehonoreerd. Misschien is er met betrekking tot de vervolgings-

732 Hierover werd gepubliceerd in NJB 1993, pag. 1258. 
beslissing minder ruimte om het gelijkheidsbeginsel te honoreren, vanwege omstandigheden die gelegen zijn in de persoon van de betrokkene, omstandigheden die, naar het mij voorkomt, in het bestuursrecht minder relevant zouden kunnen zijn dan in het strafrecht.

\subsection{Bïzondere bepalingen over besluiten (beschikking)}

\subsubsection{Aanvraag en voorbereiding}

Op het eerste gezicht lijken de bepalingen betreffende de aanvraag van een beschikking voor dit hoofdstuk niet relevant. Immers, in de door mij beschreven procedures vraagt de verdachte doorgaans niet om een beschikking. In het vorige hoofdstuk echter zagen we dat een beslissing op bezwaar een beschikking is en wel één op aanvraag.

\subsubsection{Hoorplicht}

In het bestuursrecht is in de voorbereidingsprocedure van een beschikking (afd. 4.1.2) onder andere een voorwaardelijke horen van belanghebbende voorgeschreven (art. 4:7 Awb) als onderdeel van een zorgvuldige voorbereiding. Deze dient ertoe de belanghebbende in de gelegenheid te stellen zijn mening aan het bestuursorgaan kenbaar te maken.

In het strafproces kan een onderscheid worden gemaakt tussen het "horen" en "verhoren" van de verdachte. ${ }^{73}$ De eerste term heeft betrekking op het bieden van een mogelijkheid tot verweer aan de verdachte, zoals bij de toepassing van bepaalde dwangmiddelen. De term "verhoor" wordt gebruikt in de functie van ondervraging van de verdachte over zijn betrokkenheid bij het strafbaar feit. Het gaat hierbij om een vaststelling van de feiten. ${ }^{7 \mathrm{H}}$

In het strafproces, in het bijzonder het vooronderzoek, wordt de verdachte niet zozeer gehoord, maar verhoord. Hij wordt ondervraagd naar zijn betrokkenheid bij een strafbaar feit. Hij kan daarbij zijn mening over het geheel kenbaar maken, maar dat is niet het hoofddoel van het verhoor. Dit hangt samen met zijn per definitic ongelijke positic ten opzichte van de vervolgende instantie in het vooronderzoek. De verdachte is voorwerp van onderzoek.

733 Zie hierover uitgebreider: J.A.W. Lensing, Het verhoor van de verdachte in strafzaken, Arnhem 1988, pag. 34-39.

734 Hoewel het kan voorkomen dat deze twee betekenissen niet strikt gescheiden worden gehanteerd, en ook door wet en jurisprudentie niet altijd consequent worden gebezigd, is er volgens Lensing geen reden dit onderscheid als achterhaald te beschouwen. J.A.W. Lensing, a.w., pag. 37-38. 
Een formele hoorplicht zoals die in het bestuursrecht geldt en waarbij wordt uitgegaan van een gelijkwaardigheid van partijen, is hierbij in het algemeen niet goed mogelijk Een dergelijke hoorplicht is mijns inziens echter niet ondenkbaar indien het $\mathrm{OM}$ tijdens het vooronderzoek tot de beslissing komt de zaak zelf af te doen door middel van een voorwaardelijk sepot. Het horen zou dan betrekking moeten hebben op de te stellen voorwaarde. Op deze manier wordt de verdachte reeds in een vroeg stadium geconfronteerd met de hem op te leggen voorwaarde en kan hij eventueel daartegen zijn bezwaren kenbaar maken. Zo worden mislukkingen achteraf voorkomen. Mij lijkt overigens dat voorwaarden die "in overleg" zijn vastgesteld grotere kans van slagen hebben dan eenzijdig opgelegde. Uit het oogpunt van proceseconomie verdient het aanbeveling dat de verdachte vooraf in de gelegenheid wordt gesteld zijn zienswijze naar voren te brengen.

\subsubsection{Beslistermijn}

In het bestuursrecht wordt voorgeschreven dat, tenzij een wettelijke termijn bestaat, de beslissing op een aanvraag van een beschikking binnen een redelijke termijn genomen dient te worden (art. 4:13 lid $1 \mathrm{Awb}$ ). In het tweede lid van dit artikel wordt bepaald dat de in het eerste lid bedoelde termijn is verstreken wanneer niet binnen acht weken een beschikking is gegeven of een kennisgeving tot uitstel (zie volgend artikel) is gedaan. Is het, bij het ontbreken van een wettelijke termijn, voor het bestuursorgaan niet mogelijk de beschikking binnen acht weken te geven, dan moet het bestuursorgaan binnen acht weken laten weten wanneer de beslissing wel te verwachten is (art. 4:14 Awb). Dit ter bevordering van de rechtszekerheid. Allereerst moeten we ons hier de vraag stellen of een beslissing tot een sepot, een voorwaardelijk sepot of een transactie vergeleken mag worden met een beslissing van een bestuursorgaan die op aanvraag wordt genomen. Overigens gelden ook voor niet op aanvraag te nemen bestuursbesluiten (bijvoorbeeld premieheffingen en aanslagen niet op aangifte) wettelijke termijnen.

In een aantal gevallen wordt van de zijde van de verdachte contact opgenomen met het $O M$ met het verzoek een strafzaak niet te vervolgen maar buitengerechtelijk af te doen. Hier zou inderdaad gesproken kunnen worden van een aanvraag, waarvoor evenwel geen formele procedure bestaat. In de meeste gevallen gebeurt dit echter niet. Vaak kan dit ook niet omdat de betrokkene er niet van op de hoogte is dat hij van een strafbaar feit wordt verdacht.

Al wordt dus de vervolgingsbeslissing meestentijds niet op atanvraag genomen, de motivering achter het stellen van een termijn in het bestuursrecht, namelijk de bevordering van de rechtszekerheid, laat zich zeker wel vergelijken. Het gaat er dan om dat de belanghebbende respectievelijk de verdachte niet te lang in onzekerheid mag blijven over zijn rechtspositie nadat zijn zilak, aanvraag van een beschikking respectievelijk een strafzaak, in behandeling is genomen. Voor de strafprocedure zou hier 
een nuancering nodig zijn, in die zin dat het betreft een strafzaak waarvan de verdachte weet dat hij in behandeling is genomen bij de justitiële instanties.

Dat deze rechtszekerheidsgedachte het strafprocesrecht niet vreemd is, blijkt natuurlijk al uit de wettelijke regeling van de te nemen vervolgingsbeslissing nadat er een gerechtelijk vooronderzoek heeft plaatsgevonden of voorlopige hechtenis is toegepast (artt. 244 en $245 \mathrm{~Sv}$ ). Ook op die plaats in de wet zijn termijnen opgenomen omdat de verdachte niet te lang in onzekerheid mag worden gelaten omtrent zijn rechtspositie. Zie voor een uitgebreide omschrijving Hoofdstuk 2.

Bijde hierna te maken opmerkingen bij de vervolgingsbeslissing van de officier van justitie, gaat het, wat betreft het sepot, niet slechts om het beleidssepot. Ook indien er sprake is van seponeren op technische gronden zijn de termijnbepalingen van toepassing.

Onderzocht zal nog moeten worden of deze regeling overeenkomt met de bestuursrechtelijke regeling omtrent de beslistermijn.

Verder zal de vraag nog beantwoord dienen te worden of ook buiten het geval van een gerechtelijk vooronderzoek of toepassing van voorlopige hechtenis het opnemen van een termijn gewenst en/of mogelijk is.

Bij bestudering van de artt. 244 en 245 e.v. Sv was reeds de conclusie getrokken dat weliswaar volgens de MvT de rechtszekerheid bevorderd diende te worden door het opnemen van termijnen, maar dat bij de uitvoering hiervan toch veel ruimte is gelaten. Het bleek dat slechts in één geval de mededeling van de vervolgingsbeslissing aan een strikte termijn gebonden is, namelijk indien de vervolgingsbeslissing wordt genomen na beëindiging van het gerechtelijk vooronderzoek. De officier van justitie dient in dat geval volgens art. 244 lid 1 Sv uiterlijk binnen twee maanden (na invoering van de Termijnenwet) nadat de beschikking tot sluiting van het gerechtelijk vooronderzoek voor de verdachte onherroepelijk geworden is, deze in kennis te stellen van zijn vervolgingsbeslissing. Overeenkomstig de genoemde bepaling van de Awb (art. 4:13 lid 2) zou ik hier een termijn van acht weken prefereren, vanwege de unificatiegedachte.

Aanbeveling: art. 244 lid 1 Sv komt te luiden: Indien een gerechtelijk vooronderzoek heeft plaatsgehad, doet de officier van justitie, buiten het geval van het voorgaande artikel, uiterlijk binnen acht weken nadat de beschikking tot sluiting daarvan voor de verdachte onherroepelijk is geworden, hetzij deze kennis geven dat hij hem ter zake van het feit waarop dat onderzoek betrekking had, niet verder zal vervolgen, of dat in verband met dat onderzoek tot verdere vervolging van enig bepaald omschreven feit zal worden overgegaan, hetzij hem dagvaarden ter terechtzitting.

Ten aanzien van de kennisgeving van niet verdere vervolging, nadat de officier van justitie reeds tijdens het gerechtelijk vooronderzoek tot de beslissing is gekomen dat verdere vervolging niet noodzakelijk is, geeft de wet geen duidelijke termijn. 
De officier van justitie moet de verdachte 'onverwijld' van zijn beslissing op de hoogte brengen. Het is van het grootste belang dat de verdachte zo spoedig mogelijk een dergelijke kennisgeving ontvangt in verband met het belangrijke rechtsgevolg dat de wet eraan verbindt. Door een dergelijke kennisgeving namelijk eindigt de zaak (tenzij van nieuwe bezwaren sprake is): art. 246 lid 1 jo art. 255 lid 1 Sv. De term 'onverwijld' geeft echter geen vaste termijn aan. Waarschijnlijk is dat in dit geval ook niet strikt noodzakelijk omdat de officier van justitie beëindiging van het gerechtelijk vooronderzoek niet zal afwachten om zijn mededeling aan de verdachte te doen. Toch zou ik hier, als een soort vangnet, een vaste termijn willen opnemen en deze, evenals dat in art. 244 lid 1 het geval dient te zijn, willen stellen op in ieder geval binnen acht weken nadat de beschikking tot sluiting van het gerechtelijk vooronderzoek voor de verdachte onherroepelijk is geworden.

Aanbeveling: Art. 243 Sv komt als volgt te luiden: In geval van de mededeling genoemd in art. 237, eerste lid, doet de officier van justitie den verdachte onverwijld, doch uiterlijk binnen acht weken nadat de beschikking tot sluiting van het gerechtelijk vooronderzoek voor den verdachte onherroepelijk is geworden, kennis geven dat hij hem ter zake van het feit waarop het gerechtelijk vooronderzoek betrekking had, niet verder zal vervolgen.

In het geval van een vervolgingsbeslissing na toepassing van voorlopige hechtenis (zonder dat sprake is van een gerechtelijk vooronderzoek) wordt er door de wet evenmin een duidelijke termijn gesteld waarbinnen mededeling van de vervolgingsbeslissing aan de verdachte moet worden gedaan. De wet bepaalt in art. 245 lid $1 \mathrm{~Sv}$ namelijk dat de officier van justitie deze mededeling doet 'zodra de zaak tot klaarheid is gebracht'. In dit geval biedt het tweede lid van dit artikel de verdachte de gelegenheid de rechter te verzoeken de officier van justitie een termijn te stellen waarbinnen hij zijn vervolgingsbeslissing moet nemen. Het opnemen van een strikte termijn lijkt me in dit geval wat problematisch, omdat het moment waarop de zaak tot klaarheid is gebracht, moeilijk exact is te bepalen. Wel mogelijk is het naar mijn opvatting, wederom als een soort vangnet, te bepalen dat binnen acht weken vanaf het moment dat de zaak tot klaarheid is gebracht de verdachte van de vervolgingsbeslissing in kennis wordt gesteld.

Aanbeveling: art. 245 lid 1 komt te luiden: Indien een gerechtelijk vooronderzoek niet heeft plaatsgehad, doch voorlopige hechtenis is toegepast, doet de officier van justitie, zodra de zaak tot klaarheid is gebracht, doch uiterlijk binnen acht weken nadat de zaak tot klaarheid is gebracht, hetzij de verdachte kennis geven dat hij hem ter zake van het feit, waarvoor de voorlopige hechtenis is toegepast, niet verder zal vervolgen, of dat tot verdere vervolging van enig bepaald omschreven feit zal worden overgegaan, hetzij hem dagvaarden ter terechtzitting. 
Hoe zit het met de vervolgingsbeslissing in een strafzaak waarin geen gerechtelijk vooronderzoek heeft plaatsgevonden noch voorlopige hechtenis is toegepast, terwijl de betrokkene wel op de hoogte is van een bestaande verdenking tegen hem? Betekent dit dat de officier van justitie aan geen termijn gebonden is bij het nemen van een dergelijke beslissing? Deze conclusie mogen we niet trekken. Van de eerder genoemde verdragsrechtelijke bepalingen is hier met name van belang het voorschrift dat de berechting dient plaats te vinden binnen een redelijke termijn (undue delay). ${ }^{\text {Ts }}$ Achtergrond van deze bepalingen is dat de verdachte niet langer dan nodig in onzekerheid mag blijven over de tegen hem ingestelde strafvervolging. Volgens de jurisprudentie begint de termijn te lopen zodra vanwege de staat een handeling is verricht jegens de betrokkene waaruit deze de verwachting heeft ontleend -en redelijkerwijs mocht ontlenen- dat het $\mathrm{OM}$ een vervolging tegen hem zou instellen (o.a. HR 3 maart 1987, NJ 1988, 298 m.nt. C). Voor berekening van de termijn is niet (slechts) van belang de periode tussen de aanvang van de vervolging en de berechting in eerste instantie, maar de periode van vervolging tot de einduitspraak, eventueel verlengd met het tijdsverloop tussen het aanwenden van een rechtsmiddel tegen de laatste einduitspraak en de beslissing hierop. In het algemeen wordt een periode van twee jaar voor afwikkeling van een strafzaak als redelijk aangemerkt (o.a. HR 19 februari 1985, NJ 1985, 581 m.nt. ThWvV). Wordt deze termijn overschreden, dan kan dit leiden tot de niet-ontvankelijkverklaring van het $\mathrm{OM}$ of tot een verlaging van de straf. $^{36}$

De bepaling omtrent de redelijke termijn geeft een norm aan voor het geval de officier van justitie besluit de betreffende verdachte te vervolgen. De vraag komt op wat de rechtspositie van de betrokkene is indien de officier van justitie de beslissing neemt om niet te vervolgen. Doorgaans hoort de verdachte ( $z 0$ al op de hoogte van een verdenking) niets van deze sepotbeslissing. Mag een verdachte die ervan op de hoogte is dat het OM hem verdenkt van een strafbaar feit, ervan uitgaan dat, indien hij daarvan niets meer hoort, hem niet zal vervolgen? Met andere woorden: wordt door geen mededeling te doen bij de betrokkene het vertrouwen gewekt dat hij niet zal worden vervolgd? In de jurisprudentie wordt dit niet aangenomen (arrest Menten II, HR 22 mei 1979, NJ 1979, 301 m.nt. GEM: een dergelijke verwachting is alleen gerechtvaardigd indien dit tevens stoelt op een handeling: een uitdrukkelijke en onvoorwaardelijke toezegging dat niet zal worden vervolgd). Dan is vervolgens de vraag van belang of de officier van justitie bij een sepotbeslissing aan een termijn gehouden zou moeten zijn en of voor hem de verplichting bestaat hiervan aan de betrokkene mededeling te doen. De eerste vraag is tevens van belang voor een ander dan een sepotbesluit, namelijk voor de beslissing tot het aanbieden van een transactie, waarbij geen voorlopige hechtenis is toegepast of een gerechtelijk vooronderzoek

735 Bij de bespreking van de afzonderlijke afdoeningsmethoden is uitvocrig aandacht bestecd aan dit voorschrift. Hicr wordt volstaan met een korte samenvatting.

736 Zie onder andere: W.E. Haak, De sanctie op ovcrschrijding van de redelijke termijn, in: Naar eer en gewcten, Arnhem 1987, pag. 151 e.v. 
is ingesteld (we zouden dit een informele transactie kunnen noemen). Art. $74 \mathrm{Sr}$ bepaalt dat de officier van justitie de voorwaarden kan stellen voor de aanvang van de terechtzitting. Hij is bij het nemen van zijn beslissing echter niet aan een termijn gebonden.

Voor de duidelijkheid: ik ga nog steeds uit van verdachten die op de hoogte zijn van een tegen hen bestaande verdenking, terwijl geen gerechtelijk vooronderzoek is ingesteld of voorlopige hechtenis is toegepast.

Helemaal zonder een termijn is de wet op dit punt niet. In art. $70 \mathrm{Sr}$ worden verjaringstermijnen genoemd. De termijn voor de verjaring van een overtreding bijvoorbeeld bedraagt twee jaren. $\mathrm{Na}$ overschrijding hiervan vervalt het recht tot strafvordering. We zouden nu als volgt kunnen redeneren: door binnen deze in de wet genoemde periodes niet vervolgd te worden ontvangt de verdachte "van rechtswege" een sepotmededeling. Een uitdrukkelijke mededeling is dientengevolge overbodig. Deze vlieger gaat echter niet op omdat het beginpunt van de termijn ligt op het moment dat het strafbaar feit wordt gepleegd en dit niet hoeft samen te vallen met de aanvang van de vervolging of het moment dat de verdachte ervan op de hoogte raakt dat er tegen hem een verdenking bestaat. Bovendien worden voor de verjaring van misdrijven langere termijnen gesteld, variërend van zes tot achttien jaren (art. 70 onder $2 \mathrm{t} / \mathrm{m} 5 \mathrm{Sr}$ ). Deze termijnen zouden mijns inziens te lang zijn voor een sepotmededeling "van rechtswege".

Een ander houvast zou art. 6 EVRM kunnen bieden, dat onder andere uitgaat van een berechting binnen een redelijke termijn, door de jurisprudentie globaal gesteld op twee jaren nadat een vervolging is aangevangen. Daar het bij een informeel sepot en een informele transactie juist handelt om een strafzaak waarin géén vervolging is ingesteld, kunnen we met deze verdragshepaling hier niet uit de voeten. Het idee echter erachter is naar mijn mening wel te gebruiken. We zouden nu kunnen redeneren: door binnen twee jaren nadat de verdachte door toedoen van de justitiële autoriteiten ervan op de hoogte is gekomen dat er een verdenking tegen hem bestaut. niet te zijn gedagvaard of geen transactievoorstel te hebben ontvangen, mag de verdachte ervan uitgaan dat zijn zaak is geseponeerd.

Ik kan instemmen met een termijn van twee jaren. Een dergelijke redenering vind ik echter voor het $\mathrm{OM}$ iets te vrijblijvend. Ik zou er toch voor willen pleiten dat aan de verdachte een sepotmededeling wordt gedaan, ter verhoging van zijn rechtszekerheid. Het te laat doen van een transactievoorstel zal dienen te leiden tot de nietontvankelijkheid van de officier van justitie. De termijn van twee jaren acht ik redelijk vanwege een aantal redenen: deze sluit aan bij de in de jurisprudentie gestelde (globale) termijn waarbinnen de berechting dient te hebben plaatsgevonden, bijzondere omstandigheden daargelaten; het OM moet de tijd gegeven worden voldoende onderzoeksictiviteiten te kunnen verrichten. De termijn van acht weken waarbinnen in het bestuursrecht de beslissing dient te worden genomen (deze termijn is slechts aanvullend bedoeld; voorop staat art. 4:13 lid 1) lijkt mij voor het strafrecht niet haalbaar. Natuurlijk gaat het in het strafrecht vaak om redelijk eenvoudige strafzaken, waarover wel binnen een korte termijn een beslissing kan worden genomen. Met 
het oog op de meer ernstige zaken wijs ik die af. De invoering van een gedifferentieerde termijnstelling op dit punt acht ik voor beide partijen, verdachte en $O M$, te verwarrend.

Een overweging moet nog worden gewijd aan de vraag op welk tijdstip de termijn zal gaan lopen. Hiervoor zijn verschillende alternatieven voor handen. In navolging van de art. $6 \mathrm{EVRM}$-jurisprudentie kan als beginpunt worden overwogen het moment waarop de verdachte op de hoogte komt van een tegen hem bestaande verdenking. Een proces-verbaal kan echter eerst nog een periode bij de politie liggen, alvorens dit (eventueel) naar het OM wordt doorgestuurd. Het OM heeft de termijn dan niet 'in eigen beheer'. Een andere mogelijkheid is dan als vertrekpunt te nemen het moment waarop het proces-verbaal het $\mathrm{OM}$ bereikt. Deze laatste oplossing heeft als nadeel dat het voor de verdachte geen volledige zekerheid biedt. Bovendien kunnen er al onderzoeksactiviteiten door de politie worden verricht. Ik kies voor de tweede mogelijkheid.

De wijze waarop de beslissing aan de betrokkene bekend dient te worden gemaakt wordt behandeld in paragraaf 9.2.1.

Aanbeveling: ook in het geval van een informeel sepot dient de officier van justitie aan een termijn te zijn gebonden, waarbinnen hij een beslissing moet nemen én aan de verdachte meedelen. Hiervoor geldt de termijn van twee jaren die de jurisprudentie stelt (als nadere invulling van 'redelijke termijn' van art. 6 EVRM) in het geval dat een verdachte wél wordt vervolgd.

Aan deze termijn van twee jaren is de officier van justitie eveneens gebonden bij een voorstel ter afdoening onder voorwaarden (voorheen: transactie en voorwaardelijk sepot). Overschrijdt hij deze termijn, dan heeft dat de niet-ontvankelijkheid van de officier van justitie tot gevolg.

\subsection{Algemene bepalingen over bezwaar en beroep}

\subsubsection{Bezwaarschriftprocedure}

In het voorgaande hebben we kunnen constateren dat, hoewel een bepaald beginsel ten grondslag zou liggen aan een transactiebesluit van het $\mathrm{OM}$, toetsing van die beginselen door de rechter niet geheel zonder problemen is. Natuurlijk kan een verdachte niet aan het transactieaanbod voldoen, de zaak ter zitting laten komen en ter zitting aanvoeren dat het transactiehesluit van het $O M$ moet leiden tot nietontvankelijkheid van het $\mathrm{OM}$. Aan deze gang van zaken zijn voor de verdachte de nadelen verbonden dat hij toch in het openbaar terecht moet stian en bovendien een hogere boete riskeert.

Voor de vervolgingsbeslissing 'sec' bestaat wel een dergelijke toetsingsmogelijkheid in de vorm van de bezwaarschriftprocedure. De vraag die kan worden gesteld is of er in het strafproces behoefte bestaat aan een mogelijkheid voor de verdachte 
om ook een transactiebesluit aan de rechter voor te leggen en welke vorm die mogelijkheid dan zou moeten krijgen.

Het bestuursrecht kent, althans in de Awb, een algemene bezwaarschriftprocedure in die zin dat degene aan wie het recht is toegekend tegen een besluit in beroep te komen eerst moet overgaan tot het maken van bezwaar tegen dat besluit. Deze procedure geldt niet met betrekking tot die besluiten waarbij er al op een of andere manier een voorprocedure heeft plaatsgevonden. Een belangrijk onderdeel van deze bezwaarschriftprocedure is de (relatieve) verplichting van het bestuursorgaan de betrokkene te horen. De functie van de bezwaarschriftprocedure ligt onder meer in een heroverweging van het besluit door het orgaan dat dit besluit nam. ${ }^{m 7}$

Ook het strafproces kent een bezwaarschriftprocedure ${ }^{78}$, neergelegd in art. 250 e.v. Sv. ${ }^{79}$ De term 'bezwaar' leidt hier tot verwarring, omdat het hier niet gaat om een procedure bij het orgaan dat de beslissing (dagvaarding of kennisgeving van verdere vervolging) nam, het $O M$, maar om een bezwaar dat ingediend wordt bij en beoordeeld wordt door de rechtbank. In bestuursrechtelijke terminologie zou hier sprake zijn van administratieve rechtspraak. Het gaat hier namelijk om het beroep bij een rechter. In het bestuursproces gaat daaraan steeds een voorprocedure (meestal bezwaar) vooraf, art. 7:1 Awb.

In deze strafrechtelijke bezwaarschriftprocedure kan de verdachte bezwaar maken tegen een kennisgeving van verdere vervolging of een dagvaarding, indien hij van mening is dat het $\mathrm{OM}$ lichtvaardig tot vervolging is overgegaan.

Een verdachte kan dus bezwaar maken tegen een besluit waarbij tot vervolging is overgegaan. Ten aanzien van een besluit waarbij van vervolging wordt afgezien heeft hij deze mogelijkheid niet. ${ }^{70} \mathrm{Zijn}$ aan de beslissing om niet (verder) te vervolgen voor de verdachte geen voorwaarden gesteld, dan zal hij doorgaans weinig behoefte hebben tegen dit besluit bezwaar te maken. Ook bij een voorwaardelijk sepot zal dit niet snel het geval zijn, omdat er, wil de voorwaarde effect hebben en door de verdachte serieus worden genomen, vooraf overleg nodig is. Blijkt dan reeds dat de verdachte 'geen zin heeft' waardoor de kans groot is dat de zaak zal mislukken, dan zal de officier van justitie waarschijnlijk afzien van een voorwaardelijk sepot en overgaan tot dagvaarden. Wel bestaat de mogelijkheid dat het uiteindelijke voorwaardelijk sepot een andere voorwaarde of vorm van voorwaarde bevat dan de verdachte in eerdere instantie verwacht had. Het zou voor de verdachte mogelijk moeten zijn bezwaren kenbaar maken.

737 Zie de MvT Awb, TK 1988-1989, 21221, pag. 114-115.

738 Zie hierover: W.E.C.A. Valkenburg, Het bezwaarschrift tegen de dagvaarding, dissertatie KUB, Arnhem 1993.

739 Deze is recent gewijzigd bij wet van 10 oktober $1988, S 474$. Onder andere is vervallen de bepaling dat indiening van een bezwaarschrift de dagvaarding in haar geheel doet vervallen.

740 Tegen een besluit tot niet (verdere) vervolging kan overigens de rechtstreeks belanghebbende beklag doen bij het gerechtshof, art. 12 e.v. Sv. 
Ten aanzien van de transactie geldt een ander verhaal. Eén van de grootste bezwaren van de huidige transactieregeling is het gebrek aan voldoende rechtsbescherming voor de verdachte. De vrijwilligheid van de verdachte om al dan niet aan het transactievoorstel te voldoen, is in het geding. Op de eerste plaats kan de verdachte niet altijd overzien of het feit waarvan hij wordt verdacht in aanmerking had kunnen of moeten komen voor een sepot. Hierbij is het van belang te herinneren aan de nieuwe praktijk van de transactie (zie hoofdstuk $3, \S 5$ ). Bij de geautomatiseerde afhandeling van de transactie (het Compas), waarbij het overgrote deel van de transigabele delicten op gestandaardiseerde wijze door de administratie van het parket wordt afgedaan, wordt de zaak niet meer inhoudelijk beoordeeld. Dit heeft als gevolg dat omstandigheden, die eerder leidden tot een technisch sepot, niet meer in overweging kunnen worden genomen. Daarnaast is er te weinig ruimte voor de verdachte die bezwaar heeft tegen het schikkingsvoorstel om er niet op in te gaan, omdat hij daarmee het risico loopt na een rechtszitting zwaarder te worden gestraft. Daarnaast kan het in het openbaar terechtstaan 'sec' de verdachte schade berokkenen, reden voor hem aan het transactievoorstel te voldoen ook al is er van erkenning van de beschuldiging geen sprake.

Wanneer we hier spreken over 'verdachte' moeten we ons goed realiseren dat het hier niet alleen gaat om een individuele natuurlijke persoon die een transactie van enkele tientjes krijgt aangeboden, maar dat het ook een rechtspersoon kan betreffen waarbij het transactiebedrag kan oplopen tot duizenden guldens. Vanzelfsprekend zijn er in dit laatste geval meerdere belangen gemoeid bij de afdoening door middel van een transactie. Zo zal het bijvoorbeeld voor een rechtspersoon van belang zijn de openbaarheid van een rechtszitting te vermijden. En als dit belang, in geld uitgedrukt, groter is dan de hoogte van het transactiebedrag is de 'keuze' waarschijnlijk niet moeilijk te maken. Meestal worden deze zaken niet bekend. De zaak van de Haagse advocaat Wladimiroff werd in de pers (vnl. het NRC-Handelsblad) gevolgd. Deze bekende fraude-advocaat en hoogleraar economisch strafrecht te Utrecht werd verdacht van bedrieglijke bankbreuk en heling. Hij betaalde een schikking van $f 65.000$, f5.000 minder dan het bedrag dat hij onrechtmatig zou hebben verkregen, hoewel hij de beschuldigingen steeds ontkende. Daarmee wilde de advocaat, zo bleek uit perspublicaties, zichzelf, zijn familie, zijn beroepsgroep en universiteit de publicitaire schade van een openbaar strafproces besparen. ${ }^{711}$

(Een vraag die buiten dit onderzoek staat maar die ik wel van belang acht en daarom op deze plaats toch even aan de orde breng, is of strafzaken die met dergelijke hoge transactiehedragen worden afgedaan, vanwege hun importantie, eigenlijk wel buiten het proces om mogen worden afgedaan. Met andere woorden: verdienen verdachten in dergelijke strafzaken buiten de openbaarheid te blijven?)

741 Theo de Roos en Judith Serrarens, De zaak-Wladimiroff, uit: Criminecl Jaarboek 1993 (red. L. van Almelo), pag. 178-184. 
Geredeneerd zou nu kunnen worden: door niet aan de gestelde voorwaarde te voldoen en de zaak voor de rechter te laten komen (daarmee openbaarheid en een hogere boete riskerend, dus geen reële keuze), maakt de verdachte impliciet bezwaar tegen het transactiebesluit en gaat hiertegen in beroep. Dit gaat volgens mij echter niet op, omdat in de daarop volgende terechtzitting niet in eerste instantie het door de officier van justitie genomen transactiebesluit voorwerp is van onderzoek, maar de verdachte en het hem tenlastegelegde feit inzet zijn van het geding.

Een reële beroepsmogelijkheid biedt de wet de verdachte niet. En zolang de verdachte die niet heeft, is het voor de rechter nagenoeg onmogelijk gedane en aanvaarde transactievoorstellen te toetsen. Hiermee zijn we beland bij de in de 'transactiehistorie' voortdurend spelende vraag: wel of geen inmenging van de rechter? ? $^{72}$ Recentelijke pleitte Corstens, vanwege de grote vlucht die de verschillende vormen van vereenvoudigde afdoening (waartoe enkele vormen van buitengerechtelijke afdoening behoren) hebben genomen, ook weer voor rechterlijke controle. ${ }^{7 * 3}$

Sinds het bestaan van een wettelijke regeling omtrent de transactie is er veelvuldig voor gepleit een mogelijkheid tot rechterlijke controle te creëren, vanwege de te grote machtspositie van de officier van justitie..$^{7+4}{ }^{745}$ Ook Osinga is van mening dat de huidige transactieregeling ten onrechte een rechterlijke inmenging ontbeert. $\mathrm{Hij}$ zoekt de oplossing in het strafrechtelijk kort geding. ${ }^{746} \mathrm{Ik}$ vind dat wel een erg zwaar middel om voor alle transactiebesluiten in te voeren.

Naar mijn mening is een dergelijke 'kunstgreep' niet nodig. In de inleiding ben ik uitgegaan van de hypothese dat een besluit tot buitengerechtelijke afdoening in wezen een bestuursbesluit is, een besluit echter dat door art. 1:6 Awb van de werking van deze wet wordt uitgezonderd. Door deze uitzondering te schrappen, wordt het besluit tot huitengerechtelijke afdoening vatbaar voor bezwaar c.q. beroep bij een administratieve rechter. Ten aanzien van een besluit tot buitengerechtelijke afdoening dat geen verdere gevolgen heeft voor de verdachte (er zijn geen voorwaarden aan verbonden) zal een bezwaar- c.q. beroepsprocedure doorgaans niet van belang zijn. Voor een besluit tot buitengerechtelijke afdoening waaraan wel voorwaarden zijn verbonden (transactie en voorwaardelijk sepot, in hoofdstuk 12 te benoemen als afdoening onder voorwaarden) kan deze bestuursrechtelijke procedure uitkomst bieden.

742 Dẹze vraag vormde één van de dric onderwerpen van onderzock, ter ondersteuning van de centrale vraag: wat is de plaats van de rechter in de Nederlandse staat tussen $1813 \mathrm{en} 1920$, in de rechissociologische dissertatie van Pieterman. Roel Pieterman, De plaats van de rechter in Nederland 1813-1920, Arnhem 1990.

743 G.J.M. Corstens, Consensualiteit, DD 1994, pag. 4-8.

744 Zie hoofdstuk 3, \$ 3.1. Zie verder ook de genoemde dissertatie van Pieterman.

$745 \mathrm{Zie}$ voor meer recente voorstellen o.a. D.H. de Jong. De afdoening van strafzaken buiten proces, preadvies 1985; A.L.J. Janssens, De botte bijl gewet? uit: Grensoverschrijdend strafrecht. 1990.

746 P. Osinga, Transactie in strafzaken, dissertatic KUB, Arnhem 1992, pag. 243-244. 
Door voor wat betreft de buitengerechtelijke afdoening te kiezen voor het bestuursrecht wordt naar mijn mening een leemte opgevuld. Immers, er is geen sprake meer van strafvordering, want de bedoeling is juist om strafvordering te voorkomen. En als er geen sprake is van strafvordering, wat is het dan wel? Antwoord: bestuursrecht. De motivering van de MvT bij art. 1:6 Awb voor de uitsluiting van vervolgingsbeslissingen (er zou een vermenging van rechtssferen ontstaan) gaat naar mijn mening niet op: er is immers geen sprake van strafvordering, waardoor er zich geen vermenging van straf(proces)recht en bestuurs(proces)recht kan voordoen.

Een soortgelijke figuur als de voorgestelde regeling kent het bestuursrecht al, namelijk in de vorm van de administratieve boete, bijvoorbeeld in het milieurecht, het sociaal verzekeringsrecht en het fiscale recht. In het bestuursrecht wordt hiervan in toenemende mate gebruik gemaakt. ${ }^{77}$ Deze administratieve boete heeft (helaas ${ }^{748}$ ) nog geen plaats gekregen in het hoofdstuk Handhaving van het wetsvoorstel Awb (derde tranche) en zal waarschijnlijk een regeling krijgen in de vierde tranche (rond 1996). Oorzaak hiervan is wellicht dat de theorievorming rond deze administratieve boete nog niet geheel is uitgekristalliseerd. De administratieve boete brengt een aantal specifieke problemen met zich mee. Met name de verenigbaarheid met de mensenrechtenverdragen EVRM en IVBP leveren stof voor discussie. ${ }^{79}$ Een uitgewerkt wetsvoorstel over de werking van de administratieve boete in het fiscale recht is reeds ingediend. ${ }^{\text {so }}$

Ik zou ervoor willen pleiten dat bij de theorievorming en wetgeving ter zake van de administratieve boete de door mij voorgestelde regeling van de buitengerechtelijke afdoening wordt betrokken.

Zonder daar nu al te diep op in te gaan (de administratieve boete levert genoeg stof op voor een afzonderlijk proefschrift) zou ik enkele randvoorwaarden voor de regeling van de afdoening van strafzaken in het bestuursrecht willen noemen:

(1) De regeling moet voldoen aan de vereisten van de mensenrechtenverdragen. Met name art. 6 lid 2 EVRM kan problemen geven. Misschien is voor verenigbaarheid met deze bepaling noodzakelijk dat de grens tussen delicten die wel of niet voor een dergelijke afdoening in aanmerking komen anders komt te

$747 \mathrm{Vgl}$. A. Michiels, De boete in opmars? oratie VU, Zwolle 1994.

748 Vgl. N.S.J. Koeman, Hoofdstuk 6 Handhaving $\$ 1$ Handhaving in de Awb, uit: Willem Konijnenbelt (red.), De derde tranche, Alphen aan den Rijn 1992, pag. 203-110

749 Zie daarover uitgebreid: M.C.W. Futcris, Fiscale administratieve sancties cn het recht op cen eerlijk proces, dissertatie UvA, Deventer 1993.

750 Wijziging van de Algemene wet inzake rijksbelast ingen en van de Invorderingswet 1990 in verband met de herziening van het stelsel van administraticve boeten en van het fiscale strafrecht, TK 19931994, 23470. Zie voor een bespreking van dit wetsvoorstel: M.W.C. Feteris, Het derde wetsvoorstel tot aanpassing van de fiscale administratieve he,tes, WFR 1994, pag. 43-59. 
liggen, waardoor ernstige vormen van misdrijven buiten deze regeling zouden blijven.

Overigens is nog te bezien of de verschillen tussen behandeling door de strafrechter en de bestuursrechter zo groot zijn. Mijn indruk is dat deze verschillen kleiner worden (zie Hoofdstuk 4, § 12.1). ${ }^{\text {si }}$ Uitspraken in het kader van de WAVH ondersteunen deze opvatting.

(2) Er dient een mogelijkheid te zijn voor rechtspraak in twee feitelijke instanties (in tegenstelling tot de WAHV). In de Awb is noggeen regeling voor het hoger beroep opgenomen. Normaliter staat er beroep open bij de sinds 1 januari 1994 gevormde Afdeling Bestuursrechtspraak van de Raad van State. Er wordt nog gediscussieerd over de vraag welke instantie als hoger beroepsinstantie in de Awb zal moeten optreden. ${ }^{752}$ Wordt dat de Afdeling Bestuursrechtspraak van de Raad van State of wordt hoger beroep mogelijk gemaakt bij de gewone rechter, in casu het Hof? Ik zou willen opteren voor het laatst genoemde alternatief. De vraag is of een Afdeling Bestuursrechtspraak van de Raad van State als een onafhankelijk college in de zin van art. 6 lid 1 kan worden beschouwd. ${ }^{x_{3}}$ Bovendien zie ik niet in waarom de argumenten om de rechtspraak in eerste instantie te leggen bij administratieve kamers van de rechtbanken (tweede tranche Awb, ingevoerd per 1 januari 1994) niet zouden opgaan voor het hoger beroep.

(3) Na het opleggen van een administratieve boete dient strafvervolging voor hetzelfde feit te worden uitgesloten en, omgekeerd, zodra een strafrechtelijke vervolging geleid heeft tot een terechtzitting is administratiefrechtelijke afdoening niet meer mogelijk.

Kiezend voor de bestuursrechtelijke procedure bestaan er twee alternatieven: (1) de openbare voorbereidingsprocedure (afdeling 3.4) eventueel gevolgd door beroep bij de rechter; (2) de bezwaarschriftprocedure (hoofdstuk 6 en 7) eventueel gevolgd door beroep bij de rechter. Een dergelijke afdoening kent ons systeem reeds door invoering van de WAHV. Omdat het mij niet nodig lijkt bij elk besluit tot afdoening onder voorwaarden een voorbereidingsprocedure te volgen, opteer ik voor het tweede alternatief, waarbij de verdachte die een transactie-aanbod heeft ontvangen een met redenen omkleed bezwaar indient bij de instantie die, formeel, het transactiebesluit nam: het OM. Hierbij komen naast de rechtmatigheids- tevens de doelmatigheidsaspecten aan bod kunnen komen. Concreter: is er terecht een transactie-aanbod gedaan of had de officier van justitie dienen te seponeren?; is de betreffende voorwaarde terecht gesteld?; is het transactiebedrag niet te hoog? De bezwaarschriftprocedure

751 Vgl. L. Rogier en A. Hartmann, Verschillen en overeenkomsten tussen strafrecht en bestuursrueht, DD 1093, pag. 1042-1058, m.n. pag. 1055-1056.

752 Vgl. A.F.M. Brenninkmeijer, Spannend bestuursprocesrecht, NJB 1994, pag. 12-18. $753 \mathrm{Zie}$ daarvoor uitgebreider het in de vorige noot genoemde artikel van Brenninkmeijer. 
zoals die in het ontwerp Awb is opgenomen, kan hier, met de daarvoor geldende termijnen, als voorbeeld een rol spelen.

De vraag is of de bezwaarschriftprocedure iets kan toevoegen aan het oorspronkelijk besluit. Ik meen van wel. Door deze bezwaarschriftprocedure wordt de officier van justitie gedwongen op het bezwaarschrift een gemotiveerde beslissing te nemen. Voor het merendeel van de zaken zal dit erop neerkomen dat de officier van justitie ze voor het eerst zelf onder ogen krijgt. Voor het eerst ook zal er met betrekking tot deze zaken een inhoudelijk oordeel worden gegeven. ${ }^{74}$ Er kan dan naar mijn mening niet meer worden volstaan met een simpele verwijzirig naar richtlijnen of het geven van een standaardmotivering.

Een nadeel van de hierboven beschreven bezwaarschriftprocedure is dat het de machtspositie van de officier van justitie tegenover de verdachte niet opheft. Weliswaar wordt hij gedwongen een besluit, dat formeel van hem afkomstig is maar dat doorgaans door de administratie is afgehandeld, te herzien en te motiveren, maar hij kan dit geheel zelfstandig doen. Daarin verschilt de beslissing op het bezwaar niet van het oorspronkelijk besluit. Om hieraan tegemoet te komen zal er toch een beroep op de rechter ingevoerd dienen te worden, dat plaatsvindt na de hier voorgestelde bezwaarschriftprocedure. In het bestuursrecht is dit overigens het normale stramien.

Is de betrokkene het niet eens met de beslissing van het $O M$ op het bezwaar genomen, dan is voor hem de weg vrij voor het beroep op de administratieve rechter. Sinds de uitbreiding van de rechtbank met een bestuursrechtelijke sector behoort dit tot de mogelijkheden.

De inmenging van de rechter betekent een versterking voor de rechtspositie van de verdachte die een reëel bezwaar heeft tegen het transactievoorstel. De verdachte kan bij de rechter in beroep gaan ter zake van de beslissing van de officier van justitie op zijn bezwaar genomen. In bestuursrechtelijk jargon: een beroep tegen een uitspraak op bezwaar.

De Awb kent behandeling door een enkelvoudige en een meervoudige kamer, afdeling 8.1.2. Alle zaken worden in eerste instantie bij de enkelvoudige kamer aanhangig gemaakt, art. 8:10 lid $1 \mathrm{Awb}$. Deze enkelvoudige kamer kan volgens het tweede lid van art. 8:10 Awb verwijzen naar een meervoudige kamer.

Voor de verdere procedure wordt verwezen naar de Awb, hoofdstuk 8.

Zoals hierboven reeds vermeld zou ik willen voorstellen een mogelijkheid te creëren voor hoger beroep.

754 Sinds de invoering van het zg. COMPAS-systeem, waarbij de afhandeling van de transactie geautomatiseerd geschiedt, blijft een inhoudelijke beoordeling van de strafzaak veelal achterwege, zie Hoofdstuk 3, §5. 
Voor de executie van de administratieve boete zou ik willen verwijzen naar de regeling zoals de WAHV die thans kent.

Een te verwachten commentaar op het invoeren van deze bezwaar- c.q. beroepsprocedure is, dat het de werkdruk van het $O M$ zal verhogen. In een tijd waarin stroomlijning en efficiency leidraad lijken voor de strafrechtspleging ligt een dergelijk bezwaar voor de hand. Of dit systeem inderdaad tot werkdrukverhoging zal leiden is nog maar de vraag. Als het systeem goed werkt, zal het in ieder geval zittingsvoorbereiding- en zittingstijd voorkomen. Wellicht zijn mensen die in bezwaar en/of beroep de gelegenheid hebben gehad hun bezwaren naar voren te brengen of ten aanzien van wie de transactievoorwaarde is verlicht, eerder bereid aan hun verplichting te voldoen. Wellicht scheelt het ook tijd in de executiefase, omdat mensen die de gelegenheid hebben gehad hun bezwaren aan het OM kenbaar te maken, ook al worden die afgewezen, ecrder tot betaling bereid zijn.

Overigens ben ik van mening dat het niet altijd de eerste prioriteit moet hebben het strafproces zo efficiënt mogelijk in te richten, maar dat ook voorrang gegeven kan worden aan eisen van rechtvaardigheid. De invoering van de verruimde transactiemogelijkheid in 1983, door de Cie. Vermogensstraffen overigens op andere gronden geïnitieerd, beoogde en betekende zo'n enorme doelmatigheidsverbetering dat daar, in mijn ogen, best wat compensatie in de vorm van een lichte werkdrukverzwaring tegenover zou mogen staan. ${ }^{75 s}$

De conclusie van dit alles moet zijn dat het transactiebesluit beschouwd kan worden als een bestuursbesluit in de zin van de Awb.

Aanbeveling: De uitzondering, zoals art. 1:6 onder a. Awb die maakt ten aanzien van vervolging van strafbare feiten, dient voor wat betreft de buitengerechtelijke afdoening door het $\mathrm{OM}$ te worden opgeheven.

3 Toetsing van de administratiefrechtelijke handhaving van verkeersovertredingen aan de Algemene wet bestuursrecht

\subsection{Inleiding}

De afdoening van een aantal verkeersvoorschriften vindt, na invoering van de WAHV, op een administratiefrechtelijke wijze plaats. In hoofdstuk 6 betoogde ik reeds dat het $\mathrm{OM}$ in principe beschouwd moet worden als een bestuursorgaan. In de toelichting

755 Dat het OM sinds 1974 zelf zijn werkdruk heeft verhoogd en een "opportunistisch" gebruik heell gemaakt van de transactieverruiming, blijkt uit het feit dat het bereik van deze afdoeningsmethoden verruimd heeft tot die gevallen waarin voorheen volstaan werd met een onvoorwaardelijk sepot. Zie mijn bijdrage: Justitie miskent uitgangspunten transactiebevoegdheid, NJB 1990, pag. 1281-1282 
bij art. 1:6 Awb worden opsporingsambtenaren, OM en minister van Justitie uitdrukkelijk als bestuursorgaan gekwalificeerd. ${ }^{756}$ Dit impliceert dat de procedure ter administratieve afdoening van de WAHV, gezien de unificatiegedachte achter de Awb, in beginsel moet voldoen aan de voorschriften die de Awb aan een administratief proces (besluitvorming en afdoening) stelt. Immers, de uitzonderingen van art. 1:6 Awb raken de vereenvoudigde afdoening van verkeersvoorschriften niet. Tevens dient de (voortaan) administratieve rechter de toetsingsgronden te hanteren die voor het overige bestuursrecht gelden. De vraag is of hieraan wordt voldaan. ${ }^{75}$ In hoofdstuk $4 \S 10$ meldde ik reeds dat door aanpassingswetten de WAHV op een groot aantal punten is aangepast aan de Awb, een aanpassing die, gezien de unificatiedoelstelling van de Awb, een logisch gevolg is. Op die plaats constateerde ik ook dat een aantal verschillen tussen de WAHV en de Awb bleef bestaan.

In het navolgende zal nog even kort bekeken worden welke aanpassingen zijn doorgevoerd. Daarna komen de resterende verschillen aan de orde, waarbij de vraag moet worden gesteld of specifieke kenmerken op het gebied van de afdoening van lichte verkeersvoorschriften het maken van een uitzondering rechtvaardigen.

Alvorens hiermee de beginnen vergelijk ik eerst de begrippenkaders van de Awb en de WAHV. Bij een vergelijking is het immers noodzakelijk dat de inhoud van de begrippen hetzelfde is.

De Awb geeft in Hoofdstuk 1 definities van de kernbegrippen van de wet. In art. 1:1 Awb wordt onder een bestuursorgaan verstaan:

a. een orgaan van een rechtspersoon die krachtens publiekrecht is ingesteld; of b. een ander persoon of college, met enig openbaar gezag bekleed. ${ }^{738}$

Volgens de MvT betekent dit dat het moet gaan om een orgaan met een publiekrechtelijke bevoegdheid tot het bepalen van de rechtspositie (de rechten en/of verplichtingen) van andere rechtssubjecten ${ }^{799}$ Door de invoeging van onderdeel a. komen er ook organen onder te vallen die weliswaar niet met openbaar gezag zijn bekleed, maar die wel een publieke taak vervullen. ${ }^{700}$ De WAHV verleent de politie een publiekrechtelijke bevoegdheid. Dat de politie hierdoor zeggenschap heeft over de

756 MvT Awb 21221, pag. 42.

757 Deze vraag stelde ik mij, voor wat de procedurc betreft, in mijn bijdrage Toetsing van de Wet administratiefrechtelijke handhaving verkeersvoorschriften aan het wetsvoorstel Algemene wet bestuursrecht, NTB 1990/afl. 5, pag. 139-145. Zie voor de toetsing door de adminisiraticve rechler: D. Allewijn, De bestuursrechtelijke toetsing in de Wet Mulder, in: De Wet Mulder in perspectief: van strafrecht naar bestuursrecht/ red. H. de Doelder, L.J.J. Rogier, P.M. van Russen Groen, Arnhcm 1990, pag. 67-76; Hugo Pennarts, Lex Mulder: van strafrecht naar bestuursrecht, Rechtshulp 1990 , no. 6/7, pag. 11-14.

758 Onderdeel a. is ingevoegd bij de Nota van Wijziging, TK 19(x)-1(x)1, 21221, nr. 6, pag. 1.

759 MvT Awb 21221, pag. 27.

760 Nota van Wijziging, TK 1990-1991, 21221, nr. 6, pag. 5. 
rechtspositie van de burger moge duidelijk zijn. De politie is dus een 'bestuursorgaan' zoals art. 1:1 Awb dit begrip omschrijft. In de toelichting bij art. 1:6 Awb worden opsporingsambtenaren overigensuitdrukkelijk als bestuursorgaan gekwalificeerd. ${ }^{\text {ne }}$ De beslissing van de opsporingsambtenaar tot het opleggen van de verplichting tot betaling van een bepaald geldbedrag wordt door de WAHV in art. 4 als een beschikking bestempeld. Ter zake van een geconstateerde verkeersovertreding wordt door een opsporingsambtenaar aan degene die de overtreding begaat (in de WAHV, ter vermijding van de term 'verdachte', 'betrokkene' genoemd) bij een gedagtekende beschikking een administratieve sanctie opgelegd. Daar er voldaan wordt aan de componenten van een beschikking (beslissing van een bestuursorgaan die een publiekrechtelijke rechtshandeling tot inhoud heeft, niet zijnde van algemene strekking), kunnen we hier dus spreken van een beschikking in de zin van art. 1:3 Awb (het vereiste van schriftelijkheid is bij aanpassingswet vervallen).

Bijzondere aandacht verdient art. 1:4. Hierin wordt namelijk uiteengezet wat onder een administratieve rechter in de zin van de Awb verstaan moet worden. Volgens het eerste lid is dat 'een onafhankelijk, bij wet ingesteld orgaan dat met administratieve rechtspraak is belast'. In lid 2 werd aanvankelijk bepaald dat een orgaan als bedoeld in art. 1 RO slechts wordt aangemerkt als een administratieve rechter voor zover de Wet administratieve rechtspraak belastingzaken van toepassing is. Art. 1:4 lid $2 \mathrm{Awb}$ is in de tweede tranche van de Awb aangevuld ${ }^{762}$, in die zin dat ook de kantonrechter, rechtsprekende in de WAHV, als administratieve rechter wordt aangemerkt.

Deze tweede tranche heeft vooralsnog geen gevolgen voor de WAHV in die zin dat de rechtbank de bevoegde instantie zou worden. ${ }^{70}$ Volgens de MvT bij deze wet is dat uiteindelijk, na integratie van kantongerechten en rechtbanken, wel de bedoeling. ${ }^{\text {tot }}$

De WAHV kent de betrokkene twee achtereenvolgende beroepsmogelijkheden toe, namelijk het beroep op een hoger bestuursorgaan, de officier van justitie, en het beroep op de administratieve rechter, de kantonrechter. In de terminologie van de Awb is er in eerste instantie sprake van administratief beroep: het gebruik maken van de ingevolge een wettelijk voorschrift bestaande bevoegdheid, voorziening tegen een besluit te vragen bij een ander bestuursorgaan dan hetwelk het besluit heeft genomen (art. 1:5 onder $2 \mathrm{Awb}$ ). Hierop zijn de hoofdstukken 6 en 7 van toepassing. In tweede instantie is er sprake van administratieve rechtspraak: het instellen van beroep op een administratieve rechter (art. 1:5 onder 3 jo. art. 1:4 lid 1 Awb). Hierop is Hoofdstuk 7 van de Awb (Bijzondere bepalingen over bezwaar en administratief beroep) niet van toepassing, maar wel Hoofdstuk 8 dat bijzondere bepalingen over het beroep bij de rechtbank bevat.

761 MvT Awb 21221, pag. 42.

762 Awb tweede tranche, 22495.

$763 \mathrm{Zie}$ art. 8:5 Awb en Bijlage bij de Awb, onderdecl A.2.

764 MvT Awb, TK 1991-1992, 22495, nr. 3, pag. 13. 
3.2.1 Voorbereiding van de beschikking

De Awb maakt een onderscheid tussen de beschikking die door een burger is aangevraagd (bijvoorbeeld een vergunning) en de beschikking die niet is aangevraagd, maar ambtshalve gegeven. Het moge duidelijk zijn dat het in de WAHV gaat om een beschikking van het laatstgenoemde soort.

De Awb geeft in art. 4:8 aan hoe de voorbereiding van een dergelijke beslissing er minstens uit ziet:

1. Voordat een bestuursorgaan een beschikking geeft waartegen een belanghebbende die de beschikking niet heeft aangevraagd naar verwachting bedenkingen zal hebben, stelt het die belanghebbende in de gelegenheid zijn zienswijze naar voren te brengen indien:

a. de beschikking zou steunen op gegevens over feiten en belangen die de belanghebbende betreffen, en

b. die gegevens niet door de belanghebbende zelf ter zake zijn verstrekt.

2. Het eerste lid geldt niet indien de belanghebbende niet heeft voldaan aan de wettelijke verplichting gegevens te verstrekken.

In de artikelen 4:9 en 4:10 wordt vervolgens aangegeven hoe de belanghebbende in de gelegenheid moet worden gesteld zijn zienswijze kenbaar te maken. Vervolgens geeft art. 4:11 een drietal uitzonderingen op de hoorplicht van art. 4:8, nl. indien er sprake is van spoed, indien de belanghebbende reeds in een eerder stadium in de gelegenheid is gesteld te worden gehoord en indien de beschikking effect zou missen als de belanghebbende daarvan vooraf op de hoogte is. Deze uitzonderingen doen zich met betrekking tot de WAHV-beschikking niet voor.

Van groot belang is echter art. 4:12: Het bestuursorgaan kan toepassing van de artikelen 4:7 en 4:8 voorts achterwege laten bij een beschikking die strekt tot het vaststellen van een financiële verplichting of aanspraak indien:

a. tegen die beschikking bezwaar kan worden gemaakt of administratief beroep kan worden ingesteld en de hoofdstukken 6 en 7 van toepassing zijn, en

b. de nadelige gevolgen na bezwaar en beroep volledig ongedaan kunnen worden gemaakt.

In het voorontwerp ontbrak een dergelijke uitzondering. Deze bepaling is alsnog opgenomen om tegemoet te komen aan bezwaren die bestonden tegen de werkzdamheden die de hoorregeling bij financiële beschikkingen met zich mee zou brengen. Met name werd hier gedacht aan beschikkingen op het terrein van belastingen, scciale 
verzekeringen en subsidieregelingen. ${ }^{75}$ Hoewel niet met name genoemd, moeten we er vanuit gaan dat, op grond van dit artikel, ten aanzien van de WAHV-beschikking de hoorplicht niet geldt. Het is een beschikking die een financiële verplichting van de betrokkene ten opzichte van de staat vaststelt, er staat administratief beroep open (art. 6 WAHV) en de nadelige gevolgen kunnen worden teruggedraaid (terugbetaling van het geldbedrag).

Op dit punt wijkt de WAHV dus niet (meer) af van de Awb.

Door de aanpassingswet geschiedt de aankondiging en de bekendmaking van de WAHV-beschikking volgens de regels van de Awb.

\subsubsection{Administratief beroep}

De Awb geeft in hoofdstuk 6 algemene bepalingen betreffende bezwaar en beroep. ${ }^{2 \infty}$ Onder beroep moeten we hier dus begrijpen administratief beroep en beroep op een rechter (art. 1:5 lid 3). Hoofdstuk 7 Awb bevat bijzondere bepalingen over administratief beroep, dat wil zeggen beroep op een hoger bestuursorgaan.

Door invoering van de Awb zijn regels voor administratief beroep van de Awb ook voor de WAHV gaan gelden. De Awb bevat algemene regels voor het administratief beroep, zoals bijvoorbeeld voor het horen van de belanghebbende (art. 7:16 - 7:23), de gevolgen van gehele of gedeeltelijke vernietiging (art. 7:25), de motivering van de uitspraak (art. 7:26 lid 1 en 2), de bekendmaking van de uitspraak (art. 7:26 lid 4), de vermelding van de rechtsmiddelen (art. 7:29 lid 5) waardoor veel regels van de oorspronkelijke WAHV (artt. 6-7) konden vervallen. Zo zijn ook de beroepsgronden (art. 7 lid 2 WAHV) geschrapt ${ }^{767}$, zodat de belanghebbende vrij is in het aanvoeren van argumenten, op grond waarvan de sanctie onterecht zou zijn opgelegd.

In aanvulling op art. 6:5 Awb moet het beroepschrift uit de WAHV onder meer bevatten de geboortedatum, de geboorteplaats, het geboortejaar, alsmede zijn bankof girorekeningnummer. ${ }^{\gamma / 8}$ Dit laatste houdt ongetwijfeld verband met de executie van de sanctie. Bij het niet voldoen biedt de WAHV de mogelijkheid dat beslag wordt gelegd op goederen en inkomsten van betrokkene.

765 MvT Awb 21221, pag. 102-103.

766 Hierna zal nog slechts van beroep gesproken worden, omdat de WAHV geen bezwaarprocedure kent. Indien tegen een besluit slechts beroep op een administratieve rechter ingesteld kan worden, moet de betrokkene eerst bezwaar maken bij het bestuursorgaan dat het besluit genomen heeft, art. 7:1. Hicr is met name uitzondering a. van lid 1 van belang. Aangezien de WAHV rechtstrecks beroep openstelt bij de officier van justitie, behocft de betrokkene niet ecrst bezwaar te maken.

767 Aanpassingswet I, art. 11. Stb. 1992, 422.

768 Aanpassingswet 1, art. 11. Stb. 1992, 422. 
Met betrekking tot het horen van de belanghebbende impliceert aanpassing aan de Awb dat degenen, van wie te verwachten is dat zij bezwaar zullen hebben tegen de al dan niet inwilliging van het beroep (in lid 2 van art. 7:16 worden de indiener van het beroep en het bestuursorgaan dat het besluit nam met name genoemd) door het bestuursorgaan op de hoogte moeten worden gesteld van de mogelijkheid te worden gehoord. Het initiatief ligt hier dus bij het beroepsorgaan. De WAHV ging er vanuit dat het initiatief moest uitgaan van degene die het beroep had ingesteld. ${ }^{70}$ Lid 2 van art. 7:16 noemt ook 'de belanghebbende' die eventueel in de gelegenheid wordt gesteld te worden gehoord. In afwijking hiervan wordt in aanpassingswet III ${ }^{70}$ uitdrukkelijk gesteld dat de officier van justitie slechts de indiener van het beroepschrift in de gelegenheid stelt te worden gehoord (art. 7).

In de Awb worden termijnen gesteld voor de behandeling van beroepschriften. ${ }^{{ }_{11}}$ Artikel 7:24 luidt (voor zover hier van belang):

1. Het beroepsorgaan beslist binnen zestien weken na ontvangst van het beroepschrift.

4. Het beroepsorgaan kan de beslissing voor ten hoogste acht weken verdagen.

6. Van de verdaging wordt schriftelijk mededeling gedaan.

7. Verder uitstel is mogelijk voor zover de indiener daarmee instemt en andere belanghebbenden daardoor niet in hun belangen kunnen worden geschaad of ermee instemmen.

Volgens deze bepaling moet de officier van justitie als beroepsorgaan in de WAHV in beginsel binnen zestien weken na ontvangst van het beroepschrift een beslissing nemen. De Awb biedt op dit punt geen uitzonderingsmogelijkheid. ${ }^{m 2}$

De WAHV bindt de officier van justitie, ook na invoering van de aanpassingswetten, bij het nemen van zijn beslissing op het beroep niet aan een vaste termijn, maar bepaalt in art. 7 dat de officier van justitie 'zo spoedig mogelijk' op het beroep beslist."

Ik ben van mening dat deze afwijking moet worden opgeheven. ${ }^{\text {na }}$ De WAHV wil een korte efficiënte procedure scheppen voor de afdoening van verkeersovertredingen. Het stellen van een termijn voor de beslissing in beroep beantwoordt aan deze doel-

769 Vgl. MvA WAHV, TK 1987-1988, 20329, nr. 6, pag. 5.

770 Sib. 1993,690 .

771 Deze zijn alleen van toepassing op het administratief beroep.

772 Zie over uitzonderingsmogelijkheden: MVT Aanpassingswet I, TK 1990-1991, 22061, nr. 3, pag. 9; I.C. van der Vlies, De reikwijdte van de Algemene wet bestuursrecht, NJB 1994, pag. 9-11, m.n. pag. 10.

773 Zie daarover MvT Aanpassingswet I, TK 1990-1991, 22061, nr. 3, pag. 47.

774 Zo ook L.J.J. Rogier in zijn commentaar bij art. 7 WÂH, a.w., pag. 65. 
stelling. Een gedeelte van het parket kan mijns inziens vrijgemaakt worden voor de behandeling van deze zaken, namelijk het gedeelte dat zich tot nu toe met de strafrechtelijke handhaving van deze verkeersvoorschriften bezighoudt, i.c. de verkeersschouten. Wanneer er helemaal geen termijn wordt gesteld is volgens mij de neiging groot, "niets menselijks is ook het openbaar ministerie vreemd"7s, de zaak te laten liggen. Bovendien biedt art. 7:24 Awb het beroepsorgaan de mogelijkheid de termijn te verlengen.

Ook de onderzoeksresultaten uit het Eindrapport geven aanleiding tot opheffing van deze afwijking. In praktijk blijkt de officier van justitie gemiddeld vier weken nodig te hebben om tot een beslissing te komen. In een klein aantal gevallen bleek de officier van justitie meer tijd nodig te hebben, wat kon oplopen tot $41 \% 2$ á 5 maanden.

Aanbeveling: De beslistermijn voor de officier van justitie op beroep dient, overeenkomstig de Awb, 16 weken te bedragen, met de daar voorziene mogelijkheid voor het beroepsorgaan de termijn te verlengen.

Met betrekking tot het beroep op de kantonrechter bepaalde de WAHV in art. 9 dat de betrokkene tegen de beslissing van de officier van justitie binnen dertig dagen na de dag van verzending van deze beslissing, dit beroep kon instellen. Deze bepaling is in Aanpassingswet I gewijzigd in die zin dat hiervoor nu de uniforme termijn van zes weken (art. 6:7) Awb geldt. Ook voor het beroep in cassatie (art. 14 WAHV) is, ingevolge art. 6:24 Awb, deze termijn van zes weken gaan gelden.

Een belangrijke discrepantie tussen de WAHV en de Awb blijft het vereiste van zckerheidstelling. Hoewel art. 11 WAHV aangepast is in die zin dat, overeenkomstig art. 6:6 Awb, bij het niet stellen van zekerheid een hersteltermijn is ingevoerd, blijft het stellen van zekerheid op zich een vreemd iets. Ondanks het feit dat jurisprudentie van de Hoge Raad en aanpassingswetgeving dit vereiste sterk hebben genuanceerd, ben ik van mening dat dit dient te verdwijnen (zie hierover Hoofdstuk 4 § 12.2).

\subsubsection{Beroep bij de rechtbank}

Hoewel het mij in dit onderzoek te doen is om de positie van het bestuursorgaan, het $\mathrm{OM}$, mogen enkele opmerkingen ter vergelijking van het beroep op rechter in de WAHV met bepalingen omtrent het beroep op de rechtbank in de Awb, zoals kort omschrcven in het vorige hoofdstuk, $\S 4$, niet ontbreken.

$775 \mathrm{Vgl}$. de minister van Justitie (weliswaar in een ander verband) tijdens de openbare behandeling van de WAHV in de Tweede Kamer, 15 februari 1989, TK 49, 49-4953. 
Het eerste in het oog lopende verschil ligt in de absolute competentie. De Awb heeft deze voor bestuursrechtelijke geschillen gelegd bij de rechtbank. In de discussie over de WAHV (zie hoofdstuk 4 \$ 8.2) werd aanvankelijk ook gedacht aan de rechtbank, maar is later toch besloten de kantonrechter te laten beslissen, omdat dit het best zou aansluiten bij de tot dan bestaande praktijk. Zoals reeds vaker vermeld is het de bedoeling dat binnen enkele jaren ook in de WAHV de absolute competentie zal komen liggen bij de rechtbank (in de genoemde paragraaf is reeds gewezen op de slechte coördinatie binnen één departement).

Volgens art. 8:10 Awb worden zaken in beginsel in behandeling genomen door een enkelvoudige kamer. Dit heeft als achtergrond dat een bestuursrechtelijk geschil in twee instanties kan worden behandeld, waardoor de zaak in hoger beroep toch bij een meervoudige kamer komt. De WAHV kent een behandeling in twee instanties niet, waardoor dit argument voor de WAHV niet opgaat.

Gelijkstelling van de WAHV aan de Awb zou betekenen dat ook de regeling van het griffierecht (art. 8:41 Awb) voor de afdoening van verkeersovertredingen zou gaan gelden. Gezien de hoogte daarvan, voor de WAHV zou dit variëren van $f 50$,tot $f 200,-$, zou ik dit niet toejuichen.

De gerechtelijke procedure van de Awb kent de mogelijkheid van een tamelijk uitgebreid vooronderzoek (art. 8:42 e.v.). Daaronder vallen onder andere het geven van repliek en dupliek (art. 8:43), het in persoon geven van inlichtingen door partijen (art. 8:44), het schriftelijk geven van inlichtingen door partijen en anderen (art. 8:45), het oproepen en horen van getuigen (art. 8:46), het benoemen van deskundigen voor het instellen van een onderzoek (art. 8:47), het instellen van een onderzoek ter plaatse (art. 8:50 en 8:51). Gezien de zaken waar het bij de handhaving van verkeersovertredingen doorgaans om zal gaan lijkt mij een dergelijke zware voorbereiding niet noodzakelijk.

In tegenstelling tot de kantonrechter in de WAHV heeft de rechtbank ingevolge art. 8:72 Awb de mogelijkheid na gegrondbevinding van het beroep en na vernietiging van de beslissing op het bezwaarschrift zelf een nieuwe beslissing te nemen.

In een zaak waarin de kantonrechter van oordeel was dat de officier van justitie niet inhoudelijk was ingegaan op het verweer van betrokkene (gedraging niet verricht), maar had volstaan met een standaardmotivering, waardoor, ofschoon art. 7 lid 3 hierop geen sanctie stelt, de beslissing op grond van algemene beginselen van behoorlijk bestuur volgens de kantonrechter niet in stand kon blijven, oordeelde de Hoge Raad dat de kantonrechter dit onderzoek alsnog zelf had moeten verrichten, HR 8 juni 1993, NJB-katern 1993, pag. 401-402, nr. 175.

Als laatste vind $\mathrm{ik}$ het van belang te wijzen op twee bepalingen, namelijk een met betrekking tot een schadevergoedingsregeling en een voor de regeling van de proceskosten. De eerste is neergelegd in art. 8:73 Awb. Bij gegrondverklaring van het beroep kan de rechtbank, op verzoek van een partij de door haar aangewezen rechtspersoon veroordelen tot vergoeding van de schade die die partij leed. De proceskostenregeling is te vinden in art. 8:75 Awb: de rechtbank is bij uitsluiting bevoegd een partij te 
veroordelen in de kosten die een andere partij in verband met de behandeling van het beroep bij de rechtbank redelijkerwijs heeft moeten maken.

\section{Conclusie}

In dit hoofdstuk is de vraag onderzocht of en in hoeverre de methoden tot afdoening van strafzaken door het $\mathrm{OM}$ buiten het geding samenvielen met bestuursrechtelijke normen die gelden voor een bestuursbesluit. We konden zien dat dit deels het geval was, deels niet. Op het gebied van de materiële beginselen van behoorlijk bestuur (bijv. het vertrouwensbeginsel, het gelijkheidsbeginsel en het verbod van willekeur) bleek in grote mate overeenstemming te bestaan. Afwijkingen kwamen met name voor op het gebied van procedureregels, bijvoorbeeld met betrekking tot termijnen en beroepsmogelijkheden. Opheffing van deze afwijkingen en verandering analoog aan de regels van het bestuursrecht, zoals geformuleerd in de probleemstelling, zijn waar nodig in de vorm van een aanbeveling neergelegd.

Met name waar het gaat om een afdoening door het OM waarbij voorwaarden worden gesteld is naar mijn mening dringend een goede wettelijke regeling nodig, waarvoor ik aansluiting heb gezocht bij de administratiefrechtelijke procedure.

De onderbouwing daarvan sluit aan bij beantwoording van de in de probleemstelling gestelde vraag of de uitzondering van art. 1:6 met betrekking tot de besluiten van vervolging terecht is gemaakt of dat dit soort vervolgingsbesluiten uitgesloten dienen te worden van de uitzondering van art. 1:6.

De vervolgingsbeslissing (beslissing om te vervolgen, niet te vervolgen, voorwaardelijk niet te vervolgen, te transigeren) laat zich wat betreft de vorm vergelijken met een bestuursbesluit afkomstig van een bestuursorgaan. De vraag is of je ze als categorie van de werking van art. 1:6 kunt uitsluiten. Ik heb getracht aan te tonen dat dit inderdaad mogelijk is. Door het afzien van vervolging door het OM namelijk is er geen sprake meer van 'strafvordering'. Daarvan wordt juist afgezien. De zaak wordt buiten de rechter, de enige instantie die bevoegd is tot oplegging van straffen, afgedaan.

In wezen is de positie van het $\mathrm{OM}$, volgens toelichting bij de Awb te beschouwen als een bestuursorgaan, niet anders dan elk ander bestuursorgaan. Deze vergelijking wordt sterker indien ook andere bestuursorgaan zich bedienen van sanctionering die zich laat vergelijken met de afdoening buiten het strafgeding. Hier wordt gedoeld op de administratieve boete. De positie van het OM in de WAHV onderbouwt deze stelling.

De motivering voor uitsluiting van de vervolgingsbeslissing van het $O M$ van de werking van art. 1:6, namelijk dat er een vermenging van rechtssferen zou ontstaan, gaat bij een beslissing tot niet-vervolging niet op. Er is geen sprake (meer) van strafvordering. 
Conclusie: het besluit van of vanwege het $O M$ tot buitengerechtelijke afdoening van een strafzaak is een bestuursbesluit en dient te vallen onder de werking van de Awb. Daartoe dient de uitzondering die art. 1:6 Awb maakt ten aanzien van opsporing en vervolging van strafbare feiten te worden beperkt in die zin dat de beslissing tot buitengerechtelijke afdoening onder de Awb valt.

In het volgende hoofdstuk worden, ter afsluiting, alle aanbevelingen en voorgestelde wijzigingen nog eens op een rij gezet. 
1060)

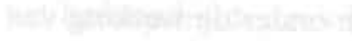

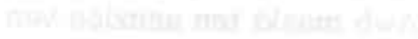

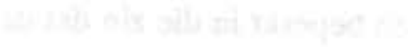

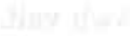




\section{Slotbeschouwing en voorstellen ter verbetering}

\section{Toedeling van gedragingen aan strafrecht of administratief recht}

Het vorige hoofdstuk eindigde met de conclusie dat het besluit van het OM tot buitengerechtelijke afdoening van een strafbare gedraging in feite een bestuursbesluit is, waarop bestuursrechtelijke regels van toepassing zouden moeten zijn. Voor alle duidelijkheid: de gedragingen blijven tot het strafrecht behoren, maar wanneer besloten wordt tot buitenstrafrechtelijke afdoening, treedt het bestuursrecht in werking. De vorige zin lezende kom ik tot de slotsom dat aan de door mij gehanteerde probleemstelling eigenlijk een andere vraag voorafgaat, namelijk, zoals ook in Hoofdstuk 4 aan de orde gesteld, of alle gedragingen die nu in een strafwet strafbaar zijn gesteld dat eigenlijk wel dienen te blijven. Met andere woorden: moet het strafrecht niet gereserveerd blijven (of worden) voor "echte" delicten, en niet "misbruikt" worden voor allerlei regelingen die ordening van de maatschappij beogen en waarop dan, als sluitstuk, als middel tot handhaving, strafbedreiging wordt gesteld? Deze vragen klemmen des te meer als bedacht wordt dat ook het bestuursrecht zich meer gaat bedienen van sancties die niet slechts reparatoir maar punitief ${ }^{77}$ bedoeld zijn en waarvan ook de vorm, betaling van een geldbedrag, overeenkomst met het strafrecht vertoont. Het moge duidelijk zijn dat we hier praten over de administratieve boete. Het lijkt mij toe dat we, ter oplossing van de verstopping in het strafrechtelijk systeem, zeker ook in deze richting moeten denken. In hoofdstuk 4 kon worden vastgesteld dat deze gedachte vrij actueel is, gezien het feit dat reeds voorstellen in die richting zijn gedaan (overtredingen van quota in de visserij, overtredingen van de Meststoffenwet). Het ontwerp van de vierde tranche van de Awb zal naar alle waarschijnlijkheid een regeling ter zake van de administratieve boete gaan bevatten.

Met behulp van het in Hoofdstuk 4 weergegeven schema van De Roos zou verder gestudeerd kunnen worden op het opschonen van het strafrecht van deze regelingen. Voor deze overtredingen, voortaan dan te noemen gedragingen, zou dan een procedure gecreëerd kunnen worden overeenkomstig de (verbeterde) WAHV. Hierbij dient in het oog te worden gehouden dat de handhaving van deze gedragingen de toets met internationaalrechtelijke overeenkomsten moet kunnen doorstaan. Zij mogen

76 Zie H.D. van Wijk, Hoofdstukken van administratief recht, bewerkt door W. Konijnenbelt en R.M. van Male, achtste druk, Utrecht 1993 , pag. 487-4k8. 
derhalve niet, naar de normen der internationaalrechtelijke overeenkomsten, met straf worden bedreigd.

\section{Voorstellen ter verbetering}

In deze paragraaf zal ik aangeven op welke wijze de wettelijke bepalingen omtrent de afdoening van strafzaken buiten het geding door het $O M$ moeten worden aangepast c.q. verbeterd. Ik zal eerst een voorstel geven tot wetswijziging, die daarna voorzien zal worden van een toelichting.

\subsection{Voorstel tot wetswijziging}

art. $242 S v$

lid 1

Indien naar aanleiding van het ingestelde opsporingsonderzoek respectievelijk het voorbereidend onderzoek het openbaar ministerie van oordeel is dat vervolging respectievelijk verdere vervolging moet plaatshebben, gaat het daartoe zo spoedig mogelijk over.

lid 2

Van vervolging respectievelijk verdere vervolging kan worden afgezien op gronden aan het algemeen belang ontleend.

\section{art. $242 a S v$}

lid 1

Wordt van vervolging afgezien na het opsporingsonderzoek en is de verdachte op de hoogte van een tegen hem bestaande verdenking, dan doet de officier van justitie de verdachte uiterlijk binnen twee jaren nadat door justitiële autoriteiten een daad is verricht waardoor de verdachte kennis nam van het ontstaan van die verdenking, kennisgeven dat hij hem ter zake van het feit waarop het opsporingsonderzoek betrekking had, niet zal vervolgen.

lid 2

Het besluit tot afzien van vervolging wordt aan de betrokkene bekendgemaakt door middel van toezending of uitreiking van een kennisgeving van niet vervolging.

art. $243 \mathrm{~Sv}$

In geval van de mededeling genoemd in art. 237 , eerste lid, doet de officier van justitie den verdachte onverwijld, doch uiterlijk binnen acht weken nadat de beschikking tot sluiting van het gerechtelijk vooronderzoek voor de verdachte onherroepelijk is geworden, kennis geven dat hij hem ter zake van het feit waarop het gerechtelijk vooronderzoek betrekking had, niet verder zal vervolgen. 
lid 1

Indien een gerechtelijk vooronderzoek heeft plaatsgehad, doet de officier van justitie, buiten het geval van het voorgaande artikel, uiterlijk binnen acht weken nadat de beschikking tot sluiting daarvan voor de verdachte onherroepelijk is geworden, hetzij deze kennis geven dat hij hem ter zake van het feit waarop dat onderzoek betrekking had, niet verder zal vervolgen, of dat in verband met dat onderzoek tot verdere vervolging van enig bepaald omschreven feit zal worden overgegaan, hetzij hem dagvaarden ter terechtzitting.

lid 2 en lid 3 blijven ongewijzigd.

art. $245 \mathrm{~Sv}$

lid 1

Indien een gerechtelijk vooronderzoek niet heeft plaatsgehad, doch voorlopige hechtenis is toegepast, doet de officier van justitie, zodra de zaak tot klaarheid is gebracht, doch binnen acht weken nadat de zaak tot klaarheid is gebracht, hetzij de verdachte kennis geven dat hij hem ter zake van het feit, waarvoor de voorlopige hechtenis is toegepast, niet verder zal vervolgen, of dat tot verdere vervolging van enig bepaald omschreven feit zal worden overgegaan, hetzij hem dagvaarden ter terechtzitting. lid 2 , lid 3 , lid 4 en lid 5 blijven ongewijzigd.

art. $247 \mathrm{~Sv}$

lid 1

Indien de zaak niet wordt vervolgd respectievelijk niet verder wordt vervolgd op grond van:

a. vereniging met een strafbaar feit welk reeds in onderzoek is;

b. niet-ontvankelijkheid van de officier van justitie;

c. niet-strafbaarheid van het feit of van de verdachte;

d. onvoldoende aanwijzing van schuld;

e. andere redenen,

wordt van die grond in de kennisgeving melding gemaakt.

art. $247 a S v$

lid 1

De officier van justitie kan, al dan niet op verzoek van de verdachte, voor de aanvang van de terechtzitting, doch uiterlijk binnen twee jaren nadat door justitiële autoriteiten een daad is verricht waardoor bij de verdachte kennis van het bestaan van een verdenking ontstond, of, indien de vervolging was aangevangen, binnen de in het eerste lid van artikel 244 genoemde termijn, een of meer voorwaarden stellen ter voorkoming van de strafvervolging wegens een overtreding. 
De volgende voorwaarden kunnen worden gesteld:

a. betaling van een geldsom, te bepalen op ten minste vijf gulden en ten hoogste het maximum van de geldboete die voor het feit kan worden opgelegd;

b. afstand van voorwerpen die in beslag zijn genomen en vatbaar zijn voor verbeurdverklaring of onttrekking aan het verkeer;

c. uitlevering, of voldoening aan de staat van de geschatte waarde, van voorwerpen die vathaar zijn voor verbeurdverklaring;

d. voldoening aan de staat van een geldbedrag gelijk aan of lager dan het geschatte voordeel -met inbegrip van besparing van kosten-, door de verdachte verkregen door middel van of uit het strafbare feit;

e. gehele of gedeeltelijke vergoeding van de door het strafbare feit veroorzaakte schade;

f. een voorwaarde betreffende de persoon van de verdachte, welke niet is gericht op vrijheidsheneming.

lid 3

De te stellen voorwaarde dient in redelijke verhouding te staan tot de zwaarte van het door verdachte geschonden belang en de beoogde werking van de op te leggen voorwaarde.

lid 4

Indien de officier van justitie overweegt een voorwaarde betreffende de persoon te stellen, wordt de verdachte daarover vooraf gehoord. Overweegt de officier van justitie een andere voorwaarde op te leggen, dan wordt degene die de wens daartoe heeft te kennen gegeven, gehoord, althans daartoe behoorlijk opgeroepen.

lid 5

Het besluit tot afzien van vervolging wordt alan de betrokkene bekendgemaakt door middel van toezending of uitreiking.

lid 6

Door voldoening van de voorwaarde eindigt de zaak.

\section{lid 7}

Betreft de voorwaarde de betaling van een geldsom, dan is de officier van justitie bevoegd te bepalen dat het geldbedrag in gedeelten kan worden betaald. lid 8

Het voorstel ter afdoening onder voorwaarde bevat de mededeling dat degene tot wie het voorstel is gericht, hiertegen bezwaar kan maken, alsmede waar en binnen welke termijn een bezwaarschrift kan worden ingediend.

\section{art. $247 b S v$}

a. Het besluit van de officier van justitie tot afdoening van een strafzaak buiten het geding, al dan niet onder het stellen van in het vorige artikel genoemde voorwaarden, is een hestuursbesluit in de zin van de Algemene wet bestuursrecht. 
Bepalingen betreffende bezwaar en beroep tegen een bestuursbesluit van de Algemene wet bestuursrecht zijn, voor zover niet uitgesloten, van toepassing. b. Tegen de uitspraak van de rechter in beroep genomen staat hoger beroep en beroep in cassatie open.

\section{art. $247 c S v$}

In tegenstelling tot het bepaalde in art. 6:16 Awb schorst het instellen van bezwaar of beroep tegen het besluit tot afdoening onder voorwaarden de werking van dit besluit.

\section{art. 1:6 Awb (voor zover van belang)}

Deze wet is niet van toepassing op:

a. besluiten ten aanzien van opsporing van strafbare feiten;

b. besluiten ten aanzien van de vervolging van strafbare feiten, met uitzondering van die besluiten, waarbij, onder het stellen van voorwaarden, van vervolging wordt afgezien;

c. besluiten betreffende de tenuitvoerlegging van strafrechtelijke beslissingen;

(onderdelen $b$, $c$ en $d$ worden vernummerd tot $d$, e en $f$ )

\section{Toelichting bij het voorstel tot wetswijziging}

\subsubsection{Buitengerechtelijke afdoening in eén titel}

De regelingen betreffende de buitengerechtelijke afdoening door het $\mathrm{OM}$ (betreffende commune delicten) staan nu verspreid over de strafrechtelijke wetboeken. Zo is de transactie te vinden in het Wetboek van Strafrecht, de beslissing omtrent vervolging na het opsporingsonderzoek in art. $167 \mathrm{~Sv}$ en de beslissingen omtrent verdere vervolging in art. 242 e.v. Sv. Het informeel voorwaardelijk sepot heeft geen wettelijke basis.

lkstel voor deze afdoeningsalternatieven in eén gemeenschappelijke regeling onder te brengen. Hiervoor zijn een aantal argumenten aan te voeren. (1) Ilet lijkt mij dat een aantal van de bepalingen omtrent de afdoeningsalternatieven gemeenschappelijk zijn, dat wil zeggen dat zij voor alle methoden kunnen gelden. Dit is zeker het geval wanneer het voorwaardelijk sepot en de transactie in één gemeenschappelijke regeling komen (zie hierna: de afdoening onder voorwaarde(n)). (2) Bij het nemen van zijn vervolgingsbeslissing heeft het $O M$ niet slechts het alternatief over de uitersten wel of niet vervolgen, maar kiest het uit een "scala" van mogelijkheden: sepot, berisping, voorwaardelijk sepot, transactie, vervolging en bij alle mogelijkheden geldt dat deze zowel informeel (zonder voorlopige hechtenis of gerechtelijk vooronderzoek) als formeel kunnen worden gehanteerd. (3) Het bevordert de overzichtelijkheid. 
(4) In een tijd waarin herziening van het Wetboek van Strafvordering actueel is ${ }^{m}$, lijkt mij deze overweging de moeite waard. (5) Sinds het bestaan van het Wetboek van Strafvordering is er met betrekking tot deze materie het een en ander veranderd. Het wetboek is hier niet in 'meegegroeid'.

De vraag is waar, in welke titel van welk wethoek, een dergelijke gemeenschappelijke regeling geplaatst zou kunnen worden.

Ik stel voor hiervoor titel IV, beslissingen omtrent verdere vervolging, te gebruiken als uitgangspunt en daarvoor aan te passen. Deze titel kan gezien worden als sluitstuk van het voorbereidend onderzoek in strafzaken, waarbij ik dan onder voorbereidend onderzoek zowel het opsporings- als het gerechtelijk vooronderzoek versta. Deze titel zou ik willen noemen: "beslissingen omtrent vervolging respectievelijk verdere vervolging".

Als uitgangspunt wordt genomen de huidige inhoud van titel IV. Een aantal bepalingen wordt toegevoegd, andere gewijzigd.

\subsubsection{Beslistermijnen}

De beslistermijnen in de artikelen 243, 244 en 245 Sv zijn gewijzigd overeenkomstig de danbevelingen uit het vorig hoofdstuk, ontleend aan de Awb. Voor een toelichting wil ik dan ook naar het vorig hoofdstuk verwijzen.

2.2.3 Gemeenschappelijke regeling transactie en voorwaardelijk sepot

\subsubsection{Inleiding}

Hiervóór is al meerdere keren betoogd, dat getracht moet worden te komen tot één regeling ten aanzien van het voorwaardelijk sepot en de transactie. In het navolgende zal gesproken worden over buitengerechtelijke 'afdoening onder voorwaarden'.

De huidige transactie heeft wettelijke regeling in het Wetboek van Strafrecht (art. 74), terwijl de wettelijke bepaling waarop het voorwaardelijk sepot (naar mijn mening overigens ten onrechte) gebaseerd wordt, te vinden is in het Wetboek van Strafvordering (art. 244 lid 3). Als gekomen wordt tot eén regeling, zal gekozen dienen te worden voor één wetboek. Ik denk dat het Wetboek van Strafvordering hiervoor in aanmerking komt, zoals dat ook de plaats was waar de 'voorloper ' van de transac-

777 Zie onder andere het Rapport van de Commissic Moons, Herziening van het gerechtelijk vooronderzoek, Arnhem $1990 \mathrm{en}$ de als gevolg daarvan verschenen gröte stroom van literatuur; D.R. Doorenbos en R.J. Verweij, Hercodificatie Wetboek van Strafvordering, Nijmegen 1991; G.J.M. Corstens en D.R. Doorenbos, Hercodificatic van strafprocesrecht? NJB 1991, pag. 1613-1618. 
tie, de submissie, voor 1886 was geregeld. In 1886 (invoering nieuw WvSr) werd de regeling daarnaar overgebracht, met als argument dat de vraag of strafvordering kon worden ingesteld of dat dit recht was vervallen (bijvoorbeeld door een transactie), een vraag van materieel recht was. Dit mag zo zijn, de feitelijke toepassing van de transactie is een formeelrechtelijke kwestie en hoort in het Wetboek van Strafvordering thuis. De transactieprocedure vindt plaats tijdens het vooronderzoek en kan worden gezien als onderdeel van de afweging die de officier van justitie maakt met betrekking tot zijn vervolgingsbeslissing. Vanuit het oogpunt van wetssystematiek is het wenselijk de transactieregeling daar in de wet op te nemen, waar ook de andere regels met betrekking tot het nemen van de beslissing tot (niet) (verdere) vervolging staan, namelijk in het Wetboek van Strafvordering.

Hieronder worden de argumenten voor een gemeenschappelijke regeling van het voorwaardelijk sepot en de transactie nog eens kort vermeld.

De transactie heeft een uitgebreide regeling in art. $74 \mathrm{Sr}$. Het voorwaardelijk sepot daarentegen komt er, voor wat de wettelijke regeling betreft, beduidend bekaaider af. Ten aanzien van het informeel voorwaardelijk sepot (het voorwaardelijk sepot na enkel een opsporingsonderzoek) ontbreekt enige wettelijke voorziening, terwijl de regeling die doorgaans wordt genoemd als wettelijke basis voor het formeel voorwaardelijk sepot (voorwaardelijk sepot na een gerechtelijk vooronderzoek en/of na toepassing van voorlopige hechtenis), art. $244 \mathrm{~Sv}$, niet als een dergelijk basis gezien kan worden. Bovendien ontbreken bepalingen omtrent de te volgen procedure en zijn de rechtsgevolgen van het voorwaardelijk sepot niet geheel duidelijk. De theoretische achtergrond van de transactie en van het voorwaardelijk sepot zijn verschillend. Aan de transactie liggen meer proceseconomische overwegingen ten grondslag: meer strafbare feiten kunnen op een snellere manier worden afgedaan. De aanleiding voor een voorwaardelijk sepot lag meer in de persoonlijkheid van de verdachte. In de praktijk blijken deze afdoeningsmethoden vaak niet wezenlijk van elkaar te verschillen: ter voorkoming van strafvervolging voldoet de verdachte aan een voorwaarde, die gesteld is door het $\mathrm{OM}$. Deze vonrwaarde kan zowel zijn vermogen als zijn persoon betreffen. Voor beide regelingen zou de mogelijkheid dienen te bestaan dat de verdachte zelf een voorstel ter voorkoming van strafvervolging doet.

Door het (voormalig) voorwaardelijk sepot te integreren in de (voormalige) transactieregeling, komt er een einde aan de gebrekkige wettelijke basis van het formeel voorwaardelijk sepot. Tegelijkertijd impliceert het dat het informeel voorwaardelijk sepot een wettelijke regeling krijgt, hetgeen tot nu toe niet het geval was. 
2.2.3.2 Feiten die door middel van afdoening onder voorwaarden kunnen worden afgedaan

In de wettelijke regeling inzake de transactie is een beperking aangebracht met betrekking tot de delicten, die door middel van transactie kunnen worden afgedaan. De transactie is beperkt tot misdrijven waarop niet meer dan zes jaar gevangenisstraf staat. Het voorwaardelijk sepot kende tot nu toe een dergelijke beperking niet. De vraag is of een dergelijke beperking in een nieuwe gemeenschappelijke regeling van de transactie en het voorwaardelijk sepot gehandhaafd moet en kan blijven of, ruimer gesteld: moeten er ten aanzien van de (groep) delicten, welke aanleiding kunnen zijn voor een afdoening onder voorwaarden beperkingen worden aangebracht? Hierbij zijn verschillende opties mogelijk:

- onbeperkte toepassing bij alle delicten (zoals de Cie. Vermogenssancties voorstelde ten aanzien van de transactie);

- indeling naar soorten delicten (zoals in de WAHV het geval is);

- indeling naar bedreigde straf (huidige transactie);

- indeling naar ernst van het gepleegd feit.

Vooraf moet de opmerking worden gemaakt dat de discussie over het toepassingsgebied van de voorwaardelijke afdoening niet los gezien kan worden van de op te nemen voorwaarden. Vooruitlopend op § 2.2.3.3 meen ik dat geen voorwaarden mogen worden opgelegd die een inbreuk maken op grondrechten, waarbij ik in dit kader met name denk aan het recht op persoonlijke vrijheid. Deze inbreuk kan slechts worden gemaakt door een rechterlijke uitspraak.

Verder moet in het oog worden gehouden dat de vraag welke feiten door middel van afdoening onder voorwaarden door het $O M$ kunnen worden afgedaan samenhangt met het leerstuk van bestuursrechtelijke handhaving. In dat kader immers werd door mij deze wijze van afdoen gezet. Gezien de discussie die nog gevoerd wordt over de beperkingen die art. 6 EVRM zou stellen aan het opleggen van bestuurlijke boeten, met name over de aard van de overtredingen die bestuurlijk zouden kunnen worden afgedaan, ligt het in de lijn der verwachtingen dat niet alle overtredingen van (straf)bepalingen daarvoor in aanmerking komen. ${ }^{78}$

De eerste optie, ongelimiteerde toepassing, is aantrekkelijk. Grenzen trekken is moeilijk. De uitersten zijn veelal wel duidelijk, maar naar mate men het grensgebied nadert, worden de afwegingsproblemen groter.

Men zou kunnen redeneren: indien de rechtsgang van de voorwaardelijke afdoening met voldoende rechtswaarborgen is omringd, is er weinig op tegen deze op uitgebreide

778 In het Öztürk-arrest sprak het EHRM over 'minor offences' (dit zegt dus niets over de hoogte van de boete); In het Lutz-arrest werd hicraan toegevoegd: 'which are not so discreditable thal the offenders deserve the stigma of a criminal penalty', zie Hoofdstuk 4. 
schaal toepasbaar te maken en onbeperkte toepassing bij alle delicten mogelijk te doen zijn. Ik wijs deze optie toch af, omdat dat het risico in zich draagt dat de gerechtelijke procedure ook bij de zwaardere strafbare feiten eerder uitzondering dan regel wordt, met als gevolg dat het $\mathrm{OM}$ ook de ernstige strafbare feiten kan gaan afdoen. lk ben van mening dat deze categorie delicten door de rechter dient te worden berecht, met het oog op zowel de belangen van de verdachte als het belang van het slachtoffer en de samenleving als geheel bij een openbare berechting van de verdachte van een ernstig strafbaar feit. Een meer fundamenteel argument tegen algemene toepassing van de transactie vinden we in de historie van deze afdoeningsmethode. Tot 1983 (uitbreiding transactie) is men er steeds van uitgegaan dat terughoudend moest worden omgesprongen met de transactie. Deze bleef steeds beperkt tot lichtere strafbare feiten, zelfs gedurende de crisis in de jaren dertig (zie hoofdstuk 3). Met andere woorden: de transactie was geen instrument voor proces-economische politiek. Indien het toepassingsgebied van de transactie ongelimiteerd zou zijn, wordt dit naar mijn mening wel in de hand gewerkt.

Een laatste argument tegen een onbeperkte toepassing ligt in de jurisprudentie van het EHRM, die dit niet toelaat.

Hoewel het leggen van een grens als nadeel heeft dat er een zekere starheid optreedt (de grens ligt vast) en willekeur met zich meebrengt (deze delicten wel, deze niet), denk ik dat hieraan niet valt te ontkomen.

Een limitatieve opsomming van delicten die in aanmerking komen voor een eventuele transactie, zoals dat ook met betrekking tot de administratiefrechtelijke handhaving gebeurt, is erg aantrekkelijk en wellicht het ideaalbeeld, maar stuit, vanwege het groot aantal feiten dat hiervoor in aanmerking komt, op praktische problemen.

Hoewel ik me realiseer dat elke grens willekeurig is en kan leiden tot onrechtvaardigheden (zie hoofdstuk 3 \$ 2.4 ) moet naar mijn gevoel het criterium voor een onderscheid toch gezocht worden ergens in de sfeer van 'ernst van het feit' of 'zwaarte van het delict'.

Een mogelijke indeling van de bevoegdheid tot aldoening onder voorwaarden is aansluiting te zoeken bij de indeling naar misdrijven en overtredingen. Deze indeling ligt er nu eenmaal. Een beperking tot slechts overtredingen lijkt mij in de huidige strafrechtelijke realiteit niet meer te handhaven. Dit wordt echter anders indien deze indeling tussen misdrijven en overtredingen wordt bijgesteld en bepaalde (lichte) vormen van misdrijven naar de overtredingen-categorie zouden verhuizen (of andersom). Hiervan zou ik voorstander zijn. Indien blijkt dat een bepaald delict of een verschijningsvorm ervan ten onrechte wel of niet in de regeling van de afdoening onder voorwaarden valt, is het de taak van de wetgever dit door middel van een wetswijziging op te lossen. Voor zware verschijningsvormen van een bepaald delict zouden bijvoorbeeld aparte delictsomschrijvingen geformuleerd kunnen worden, 
zodat deze dan uitgesloten kunnen worden van de buitengerechtelijke afdoening. Op deze manier zou gekomen kunnen worden tot buitengerechtelijke afdoening van overtredingen (als bestuursbesluit), die naar de normen van internationaal recht voor bestuursrechtelijke handhaving in aanmerking komen.

Conclusie: de afdoening onder voorwaarden (transactie en voorwaardelijk sepot) is toepasbaar bij overtredingen die volgens internationaalrechtelijke normen daarvoor in aanmerking komen.

\subsubsection{Voorwaarden}

De huidige voorwaarden zoals die gelden voor de transactie kunnen wat mij betreft gehandhaafd blijven. In de nieuwe regeling met betrekking tot de afdoening onder voorwaarden dient één voorwaarde te worden toegevoegd: een voorwaarde betreffende de persoon (in tegenstelling tot het vermogen) van de verdachte. Het lijkt mij niet verstandig een limitatieve opsomming van de op de persoon gerichte voorwaarden op te nemen, om zo ruimte te laten voor flexibiliteit en inventiviteit van de officier van justitie en van de verdachte.

Van belang is dat de op te leggen voorwaarde in redelijke verhouding staat met het nadeel dat door het strafwaardig gedrag van de verdachte is veroorzaakt. Voor een meer uitgebreide toelichting bij dit evenredigheidsbeginsel wil ik verwijzen naar het vorige hoofdstuk.

In de nieuwe regeling van de afdoening onder voorwaarden wordt een bepaling opgenomen wclke inhoudt dat, indien de officier van justitie overweegt een voonwarde op te leggen, de verdachte in de gelegenheid wordt gesteld te worden gehoord. Immers, het door mij ingenomen standpunt dat een besluit tot buitengerechtelijke afdoening een bestuursbesluit is heeft als consequentie dat de Awb toegepast wordt. Artikel $4: 8$ bevat een bepaling met betrekking tot het horen van een belanghebbende die de beschikking niet had aangevraagd." Moet dit horen ter zake van alle op te leggen voorwaarden het geval zijn? Afgezien van de omstandigheid dat dit ondoenlijk is, is het ook niet echt noodzakelijk. Mij lijkt deze hoormogelijkheid vooral van belang en op zijn plaats wanneer er overwogen wordt een voorwaarde met betrekking

779 De volledige tekst van deze bepaling luidt:

1. Voordat een bestuurșorgaan cen beschikking geeft waartegen een belanghebbende die de beschikking niet hecft aangevraagd naar verwachting bedenkingen zal hebben, stelt het die belanghebbende in de gelegenheid zijn zienswijze naar voren te brengen indien:

a. de beschikking zou steunen op gegevens over feiten en belangen die de belanghebbende betreffen, en b. die gegevens niet door de belanghebbende zelf zijn verstrekt.

2. Het eerste lid geldt niet indien de belanghebbende niet heeft voldaan aan een wettelijke verplichting gegevens te verstrekken. 
tot de persoon op te leggen. De verdachte moet de voorwaarde uitvoeren en het animo hiertoe zal groter zijn als hij al in een vroeg stadium erbij wordt betrokken en de gelegenheid heeft zijn mening erover kenbaar te maken. Dit zal ertoe bijdragen dat mislukkingen worden voorkomen.

Dit horen van de verdachte met betrekking tot de te stellen voorwaarde moet uitdrukkelijk onderscheiden worden van het verhoren van de verdachte ter zake van zijn betrokkenheid bij het gepleegde strafbare feit.

\subsubsection{Rechtsgevolg}

Door de afdoening onder voorwaarden op te nemen in de titel omtrent de beslissing tot (verdere) vervolging, krijgt deze modaliteit hetzelfde rechtsgevolg dan een beslissing tot niet (verdere) vervolging, namelijk, na voldoening van de voorwaarde, beëindiging van de zaak (art. 246 lid $1 \mathrm{~Sv}$ ). Omdat de verdachte aan een voorwaarde heeft voldaan, met andere woorden: hij heeft een prestatie geleverd, moet zijn zaak hiermee beëindigd zijn. Is het een voorwaarde betreffende zijn persoon, dan is deze bovendien moeilijk terug te draaien.

Voorgaande is een voorwaarde die ik stelde ten aanzien van de keuze voor een bestuursrechtelijke afdoening. Conform het una via-beginsel ${ }^{750}$ kan slechts eenmaal tegen een bepaalde overtreding worden opgetreden. Kiest het $\mathrm{OM}$ de buitengerechtelijke weg, dan is de strafrechtelijke daarmee afgesloten.

\subsubsection{Rechtsmiddelen tegen de afdoening onder voorwaarden}

Betaalt de verdachte in de huidige transactieregeling het transactiebedrag niet of voldoet hij niet aan een andere gestelde voorwaarde, dan wordt hij in de meeste gevallen ter terechtzitting gedagvaard. We zagen reeds dat de verdachte in een dwangpositie kan komen te verkeren, omdat hij, door het transactie-aanbod te weigeren vanwege een zwak bewijs of het ontbreken van schuld zijnerzijds, ter terechtzitting een hogere boete of een andere straf riskeert. Ook het in het openbaar terechtstaan kan voor menig verdachte, met name voor een bepaalde groep namelijk bedrijven of andere rechtspersonen (bijvoorbeeld in de kwestie van advocaat Wladimiroff, zie vorig hoofdstuk) reden zijn aan de transactievoorwaarde(n) te voldoen. Het in het openbaar terechtstaan, met de daaraan gekoppelde publiciteit kan het bedrijfsbelang te zeer schaden en een stigmatiserende werking hebben.. Daarnaast kan het voorkomen dat de verdachte een transactie-aanbod niet wil accepteren, niet vanwege een van de vragen die door de rechter ter zitting worden behandeld over bewijs en schuld, maar bijvoorbeeld omdat hij het niet eens is met de hoogte van het transactiebedrag, de gestelde voorwaarde of van mening is dat de officier van justitie door het aanbieden van een transactie ten onrechte van het gevoerde beleid ter zake van

780 Zie hicrover: LJJ. Rogier, Strafsancties, administratieve sancties en het una via-beginsel, dissertatie EUR, Arnhem 1992. 
een bepaald delict is afgeweken. Deze belangen om een transactiebesluit aan controle te onderwerpen betreffen voornamelijk de verdachte. Daarnaast kunnen er nog andere, meer 'algemene' belangen zijn om het besluit in de openbaarheid te brengen, bijvoorbeeld wanneer het gaat om transacties met (grote) ondernemingen inzake belastingfraude of milieudelicten.

In het vorige hoofdstuk heb ik gepleit voor toepasselijkheid van de Awb op het besluit tot buitengerechtelijke afdoening, met name de afdoening onder voorwaarden. Dit standpunt impliceert dat de bezwaar- en beroepsmogelijkheid die de Awb kent (hoofd stukken 6 en 7), dan ook voor de afdoening onder voorwaarden mogelijk zijn. De Awb biedt deze bezwaar- en beroepsgang ook aan anderen dan de direct betrokkene door de hantering van het begrip 'belanghebbende'.

De termijn voor indiening van een bezwaarschrift bedraagt, zoals ook de Awb bepaalt in art. 6:7 0 weken. De termijn vangt aan met ingang van de dag na die waarop de betrokkene het voorstel tot afdoening onder voorwaarden heeft ontvangen (vgl. art. 6:8 Awb). De officier van justitie overweegt het gehele besluit, waarna hij, bij afwijzing van het bezwaar, een met redenen omklede beslissing neemt, binnen de termijn zoals de Awb die stelt (in beginsel zes weken na ontvangst van het bezwaarschrift, art. 7:10). De officier van justitie verklaart het bezwaar gegrond of ongegrond. In het eerste geval betekent dit dat van een voorwaarde wordt afgezien. In het laatste geval heeft de betrokkene twee alternatieven: hij voldoet aan de voorwaarde of hij gaat tegen de beslissing van de officier van justitie in beroep (zie hierna).

Overigens is deze bezwaarschriftprocedure ten aanzien van een afdoening onder voorwaarden niet zo nieuw als het misschien lijkt. Het is de formalisering van de in de praktijk voorkomende situatie dat de verdachte of diens raadsman het initiatief neemt om schriftelijk of telefonisch contact op te nemen met het $O M$ over de voorgestelde transactie. Door formalisering zou deze mogelijkheid voor iedere verdachte gaan bestaan (de verdachte wordt op de mogelijkheid om bezwaar aan te tekenen gewezen), hetgeen betekent een grotere rechtsgelijkheid.

Indien de betrokkene het met de beslissing op zijn bezwaar niet eens is, kan hij daartegen in beroep gaan bij de bestuurskamer van de rechtbank. Behandeling zal doorgaans plaatsvinden door een enkelvoudige kamer (art. 8:10 Awb). Het beroepschrift moet worden ingediend binnen zes weken. Daarin zal de verdachte gronden moeten aangeven ter onderbouwing van zijn stelling dat de officier van justitie het betrokken voorstel ter afdoening onder voonwaarde ten onrechte aan de verdachte heeft gedaan. Er vindt een rechtmatigheidstoetsing door de rechter plaats.

Op de uitspraak van de rechtbank is afd. 8.2.6 Awb van toepassing.

Tegen de uitspraak van de rechtbank is hoger beroep en beroep in cassatie mogelijk.

Administratief bezwaar of administratief beroep schorst niet de werking van het besluit waartegen het is gericht, tenzij bij of krachtens wettelijk voorschrift anders is bepaald, aldus art. 6:16 Awb. In beginsel is er dus geen schorsende werking, maar 
dit kan voor een aparte wet wel uitdrukkelijk worden ingevoerd. De vraag is of dat ten aanzien van de buitengerechtelijke afdoening onder voorwaarden het geval zou moeten zijn. Ik ben van mening dat, overeenkomstig de WAHV, in dit geval na het instellen van bezwaar en beroep de werking het besluit geschorst dient te worden. Hiervoor zijn de volgende argumenten aan te voeren:

1. Indien na bezwaar en beroep aan de werking van het besluit geen schorsende werking zou worden toegekend, zouden de verdachten die 'normaal' vervolgd worden door het $\mathrm{OM}$ in het voordeel zijn ten opzichte van degenen wiens zaak bestuursrechtelijk wordt afgedaan. Immers, voor eerst genoemden geldt ontstaat de eventuele betalingsplicht pas na uitspraak van de strafrechter;

2. Het ontbreken van schorsende werking is gepast ten opzichte van betrokkenen die aanvoeren dat zij de betreffende gedraging niet verricht hebben of dat de gedraging hen niet verweten kan worden.

\subsection{Voorstellen tot wijziging van de WAHV}

\section{art. 7 AHV}

lid 1

De officier van justitie beslist zo spoedig mogelijk, doch uiterlijk binnen 16 weken na ontvangst van het beroepschrift op het beroep. De officier van justitie kan de beslissing voor ten hoogste acht weken verlengen. Van deze verlenging wordt schriftelijk mededeling gedaan.

De zekerheidstelling van art. 11 WAHV dient te verdwijnen. 



\section{Samenvatting}

Sinds de invoering van het Wetboek van Strafvordering in 1926 is de rol van het Openbaar Ministerie (OM) veranderd. Oorspronkelijk had het de taak leiding te geven aan de opsporing van strafbare feiten en deze te vervolgen. Ten aanzien van vrijwel ieder opgespoord strafbaar feit betekende dit, dat de verdachte werd gedagvaard, teneinde te worden berecht door de onafhankelijke strafrechter na een openbare terechtzitting. Heden ten dage is het $O M$, veel meer dan louter een vervolgend orgaan, een beleidvoerend orgaan. Niet ieder opgespoord delict wordt meer vervolgd. Integendeel, ten aanzien van het overgrote deel van de opgespoorde strafbare feiten wordt door het $\mathrm{OM}$ of de politie van vervolging afgezien en de zaak zelf afgedaan. Tot vervolging wordt slechts overgegaan indien daar redenen voor zijn. De afdoening van strafbare feiten door middel van een strafrechtelijke geding voor een onafhankelijke strafrechter is daarmee uitzondering geworden.

Wanneer het OM een strafzaak buiten het geding afdoet, heeft het de keuze tussen verschillende afdoeningsmethoden. Het kan de zaak onvoorwaardelijk seponeren, waarbij de verdachte geen sanctie wordt opgelegd. Ook kan het een voorwaardelijk sepot toepassen, waarbij de verdachte, ter voorkoming van vervolging, een voorwaarde moet vervullen. Een belangrijke afdoeningsmethode wordt gevormd door de transactie, waartoe ook de politie een zelfstandige bevoegdheid heeft. Een afdoeningsmethode die tussen sepot en vervolging ligt is de voeging ad informandum. De handhaving van een grote groep verkeersvoorschriften is overgegaan van het strafrecht naar het bestuursrecht. Daarbij speelt de officier van justitie de rol van beroepsinstantie. De verwachting is dat in de toekomst meer strafzaken door het $O M$ en de politie zullen worden afgedaan, bij voorkeur door middel van een methode waarbij een sanctie wordt opgelegd. In het Jaarverslag OM 1992 wordt gesproken over het streven in 1995 een derde van de vervolgbare strafzaken door transactie af te doen. Verder wordt uitbreiding overwogen van bestuursrechtelijke handhaving.

$\mathrm{Nu}$ de buitengerechtelijke afdoening van strafbare feiten zulk een belangrijke plaats is gaan innemen, is het belangrijk aandacht te schenken aan de normering ervan. Geconstateerd kan worden dat deze op een aantal punten tekort schiet, bijvoorbeeld omdat er geen of een gebrekkige wettelijke grondslag is, omdat de rechtsgevolgen niet goed zijn geregeld, omdat te weinig rechtsbescherming wordt geboden of omdat toepassing ervan leidt tot rechtsongelijkheid. Doel van deze studie is te komen tot 
een verbetering van de normering van de buitengerechtelijke afdoening door het OM. Hiertie wordt. vanwege een zestal redenen, aansluiting gezocht bij het bestuursrecht. De vragen die kunnen worden opgeworpen zijn, of het OM kan worden beschouwd als een bestuursorgaan en of, dientengevolge, het besluit tot buitengerechtelijke afdoening kan worden beoordeeld als een bestuursbesluit. De consequentie van een positieve beantwoording van deze vragen is dat de uitsluiting die de Algemene wet bestuursrecht (Awb) momenteel in art. 1:6 maakt ten aanzien van de vervolging van strafbare feiten, voor besluiten tot buitengerechtelijke afdoening zal dienen te vervallen, althans indien de reden die de Memorie van Toelichting voor deze uitzondering geeft voor deze afdoening niet opgaat. Hierdoor zullen de bestuursrechtelijke bepalingen van de Awb ook voor de buitengerechtelijke afdoening gelden. Ter zake van de buitengerechtelijke afdoening die aan een voorwaarde is verbonden, wordt hier aangehaakt bij het vraagstuk van de administratieve buete.

In het eerste deel van dit onderzoek (hoofdstukken 2 tot en met 6) worden de verschillende methoden tot buitengerechtelijke afdoening bekeken. Daarbij wordt onder meer aandacht geschonken aan de historische ontwikkeling, de wettelijke grondslag, termijnen die in acht dienen te worden genomen en het rechtsgevolg. De beantwoording en uitwerking van de gestelde vragen vindt plaats in het tweede deel (hoofdstukken 7 tot en met 11).

Hoofdstuk 2 handelt over het sepot, het niet vervolgen van een strafbare gedraging. De officier van justitie kan verschillende redenen hebben om onvoorwaardelijk van vervolging af te zien: hij acht de kans groot dat de zaak niet tot een veroordeling zal leiden (technisch of haalbaarheidssepot) of hanteert beleidsmatige overwegingen (beleidssepot). Dit beleidssepot heeft als grondslag het opportuniteitsbeginsel, zoals dat is neergelegd in art. 167 lid 2 Sv en art. 242 lid 2 Sv. Een beleidssepot kan zich voordoen in twee vormen: onvoorwaardelijk en voorwaardelijk. Vooruitlopend op het beleid van het $\mathrm{OM}$ neemt de politie in voorkomende gevallen reeds de sepotbeslissing, het zogenaamde politiesepot.

Het opportuniteitsbeginsel kreeg wettelijke grondslag in 1926. Hoewel de redactie van de wettelijke bepaling sindsdien niet is gewijzigd, is de hantering ervan wezenlijk veranderd, namelijk van "vervolgen, tenzij ..." naar "niet vervolgen, tenzij ...". Hiervoor zijn meerdere oorzaken aan te wijzen. Het gegeven dat een bepaalde gedraging een strafbaar feit oplevert is onvoldoende legitimatie om tot vervolging over te gaan. Daarnaast is aantal strafbepalingen flink toegenomen, evenals het aantal overtredingen van strafhepalingen.

In verschillende stadia van het vooronderzoek kan de sepotbeslissing worden genomen. Als nog geen vervolging was aangevangen wordt gesproken van een informeel sepot, na een begin van vervolging van een formeel sepot. Niet altijd bindt de wet de officier van justitie aan een duidelijke termijn bij het nemen van zijn vervolgingsbeslissing. 
Ten aanzien van een technisch sepot verplicht de wet in art. $247 \mathrm{~Sv}$ tot motivering van de beslissing, in tegenstelling tot een beleidssepot.

Het politiesepot kent geen uitdrukkelijke wettelijke grondslag. Dat is ook niet nodig, indien de mandaatfiguur uit het bestuursrecht op de verhouding tussen OM-sepot en politiesepot wordt gelegd.

Het informeel voorwaardelijk sepot heeft geen wettelijke basis. Die van het formeel voorwaardelijk sepot (art. 244 lid 3) is niet helemaal duidelijk. De vraag wordt opgeworpen of er een principieel verschil bestaat tussen het voorwaardelijke sepot en de transactie.

Waar het rechtsgevolg van een sepotbeslissing niet wettelijk vaststaat, komt aanvulling van het vertrouwensbeginsel. De vraag is of hiermee kan worden volstaan.

In hoofdstuk 3 volgt bespreking van de transactie. Uit de historie van dit instituut blijkt dat het steeds met een zekere argwaan is bekeken, omdat misbruik en rechtsongelijkheid het gevolg konden zijn. De vraag was of er wel of niet een rechter bij betrokken moest worden. Uitbreiding van de transactieregeling was vrijwel steeds gebaseerd op proces-economische overwegingen, waarbij valt waar te nemen dat bepaalde toepassingsvoorwaarden die de wetgever bij een uitbreiding stelde vrij snel na de inwerkingtreding werden verlaten. De oorspronkelijke gedachte van vereenvoudiging van het strafproces ten aanzien van lichte overtredingen is veranderd in het zo snel mogelijk afdoen van de meerderheid van misdrijven.

Kritiek op de transactieregeling betreft voornamelijke de machtige positie van het $\mathrm{OM}$ in verhouding tot de dwangpositie van de verdachte.

Teneinde bij de uitvoering van de transactie een zo groot mogelijke rechtsgelijkheid te bereiken, zijn ten aanzien van een aantal misdrijven richtlijnen vastgesteld door de procureurs-generaal.

Ook de politie heeft een transactiebevoegdheid. Aanvankelijk beperkte deze zich tot bepaalde overtredingen, met name verkeersovertredingen. In 1993 is de politietransactie voor een aantal eenvoudige misdrijven ingevoerd.

Een belangrijke plaats in dit onderzoek is ingeruimd voor de administratiefrechtelijke handhaving van verkeersvoorschriften, zoals blijkt uit Hoofdstuk 4. Overbelasting van het justitiële apparaat lag aan de ontwikkeling hiervan ten grondslag. De tot dan toe bestaande afdoeningsmethoden buiten de rechter om waren te zeer afhankelijk van de medewerking van de verdachte. Een belangrijk verschil met de transactie is dan ook dat degene die het met de aan hem opgelegde sanctie (boete) niet eens is zelf daartegen in beroep moet gaan en niet kan wachten tot hij gedagvaard wordt. Wordt geen beroep ingesteld dan wordt de boete executabel.

De belangrijkste thema's bij de totstandkoming van de WAHV en in de eerste jurisprudentie betreffen de zekerheidstelling als ontvankelijkheidsvoorwaarde bij het beroep op de kantonrechter en de vraag of deze bestuursrechtelijke handhaving van verkeersvoorschriften niet in strijd komt met internationaalrechtelijke bepalingen, te weten art. 6 EVRM en art. 14 IVBP. Wat dit laatste betreft kan worden aangeslo- 
ten bij het vraagstuk van de administratieve boete (bijvoorbeeld de fiscale boete) en art. 6 EVRM. Naarmate enerzijds het bestuursrecht gebruik gaat maken van sancties die vallen onder het begrip 'criminal charge' van art. 6 EVRM en anderzijds het voornemen bestaat dat ook andere strafrechtelijke gedragingen worden overgeheveld naar het bestuursrecht, wordt de vraag van belang waar de grens behoort te liggen tussen strafrechtelijke en bestuursrechtelijke handhaving.

$\mathrm{Na}$ de invoering van de WAHV werden door de invoering van de Algemene wet bestuursrecht verschillende aanpassingen noodzakelijk. Ook jurisprudentie van de Hoge Raad heeft inmiddels geleid tot wetswijziging.

Hoewel de dienstverlening na wettelijke invoering in 1989 niet meer voorkomt als afdoeningsmethode voor het OM maar als werkstraf die uitsluitend door de rechter kan worden opgelegd, wordt hieraan in Hoofdstuk 5 toch aandacht geschonken. Ten aanzien van de dienstverlening is namelijk de concrete afweging gemaakt tussen afdoening door de rechter of door het OM. Aanvankelijk lag de nadruk op het officiersmodel (toepassing door het $\mathrm{OM}$ ), met als argument dat de termijn tussen het plegen van het delict en de dienstverlening zo beperkt mogelijk te houden. Ook de minister van Justitie opteerde voor afdoening door het OM, daar dienstverlening in zijn ogen geen straf was. Uiteindelijk wordt toch gekozen voor het rechtersmodel: dienstverlening wordt opgenomen als hoofdstraf in art. 9 jo. $22 \mathrm{~b}$ Sr. De rechter kan dienstverlening opleggen in plaats van een onvoorwaardelijke vrijheidsstraf van niet meer dan zes maanden. In tegenstelling tot eerdere uitspraken wordt de dienstverlening nu gekwalificeerd als een straf, omdat het de vrijheid van de verdachte aanzienlijk beperkt.

In Hoofdstuk 6 komt de voeging ad informandum aan de orde. Bij deze voeging ad informandum worden een verdachte die een reeks van strafbare feiten heeft gepleegd, niet al deze feiten tenlaste gelegd, maar ter informatie gevoegd, waarbij de officier van justitie de rechter verzoekt bij de strafbepaling ermee rekening te houden.

Belangrijke thema's rond de voeging ad informandum zijn de rechtsgrond en het rechtsgevolg. De voeging ad informandum heeft geen wettelijke basis. Vaak wordt als rechtsgrond het opportuniteitsbeginsel genoemd, omdat dat de officier van justitie de mogelijkheid geeft van vervolging af te zien. Hiermee stem ik niet in, omdat feitelijk wel wordt vervolgd. Uit vroegere jurisprudentie van de Hoge Raad kon worden opgemaakt dat voeging ad informandum niet in de weg stond van (nieuwe) vervolging. Dit standpunt is inmiddels achterhaald ter zake van door de verdachte bekende feiten die tot een veroordeling hebben geleid. De vraag is of vervolging nog is tuegestaan indien de hoofdzaak geëindigd is met vrijspraak of ontslag van rechtsvervolging.

Om te voorkomen dat van de voeging ad informandum vanwege redenen van efficientie te veelvuldig gebruik wordt gemaakt, moet de toepassing ervan aan een aantal voorwaarden worden verbonden. 
Aparte aandacht verdient het slachtoffer van het ad informandum gevoegde feit.

Vanaf hoofdstuk 7 wordt teruggekeerd naar de in de inleiding gestelde vraag of art. 1:6 Awb moet worden aangepast voor wat betreft de beslissing tot buitengerechtelijke afdoening.

In hoofdstuk 7 staat de vraag centraal of het OM beschouwd moet worden als onderdeel van de rechterlijke macht of als een bestuursorgaan. Deze vraag wordt behandeld aan de hand van een drietal aandachtspunten: de Grondwet, inhoudelijke kenmerken en de uitleg van administratiefrechtelijke bepalingen.

De Grondwet rekent slechts die gerechtelijke instanties tot de rechterlijke macht die door de wetgever worden aangewezen. Een formele wet die het OM als zodanig kwalificeert, ontbreekt.

$\mathrm{Na}$ bespreking van inhoudelijke kenmerken (zelfstandigheid, onafhankelijkheid, objectiviteit en beslissingsbevoegdheid) wordt geconstateerd dat het $\mathrm{OM}$ in deze niet wezenlijk anders functioneert dan andere bestuursorganen.

Administratiefrechtelijke bepalingen tenslotte beschouwen het $\mathrm{OM}$ als een bestuursorgaan.

In het vervolg hierop behandelt Hoofdstuk 8 het karakter van de OM-beslissing. De vraag is of deze valt onder de omschrijving van 'bestuursbesluit' in de zin van art. 1:3 lid 1 Awb. Eerst wordt uiteengezet wat in het bestuursrecht wordt versta: onder 'besluit', waarna geconstateerd wordt dat de OM-beslissing in beginsel an de beschrijving voldoet. Echter, de beslissingen inzake vervolging worden in de Awb in art. 1:6 Awb uitgesloten. Op grond van een drietal argumenten pleit ik ervoor de besluiten van het $O M$ tot buitengerechtelijke afdoening niet bij voorbaat van de werking van de Awb uit te sluiten, maar deze te beschouwen als bestuursbesluiten waarop bestuursrechtelijke bepalingen van toepassing zouden kunnen zijn.

Voorgaande leidt tot de centrale vraag in hoeverre de voorschriften van de Awb, welke gelden voor een bestuursorgaan bij het nemen van een (discretionaire) beslissing, zich lenen voor de afdoening buiten het strafgeding door het OM.

Om dit te kunnen beoordelen, wordt in Hoofdstuk 9 uiteengezet welke normen er gelden ten aanzien van een bestuursrechtelijk besluit. Uitgangspunt is de Awb. Onder meer komen aan de orde regels met betrekking tot de totstandkoming van een besluit, de algemene beginselen van behoorlijk bestuur en regels ten aanzien van bezwaar en beroep.

De bedoeling van Hoofdstuk 10 is te bezien in hoeverre de besluiten tot buitengerechtelijke afdoening verlopen volgens de in het vorig hoofdstuk beschreven normen en op welke punten afwijkingen bestaan. Indien blijkt dat er van afwijking sprake is wordt bezien of bijstelling of wijziging nodig is in de vorm van aanpassing aan de algemene bestuursrechtelijke norm. 
Ook hierbij wordt ruim aandacht geschonken aan de algemene beginselen van behoorlijk bestuur, waarbij gesteld kan worden dat in het algemeen de werking van deze beginselen bij het nemen van de vervolgingsbeslissing niet wezenlijk afwijkt van de werking in het bestuursrecht.

Als er afwijkingen worden geconstateerd (bijvoorbeeld ten aanzien van motiveringsvoorschriften of bepaalde termijnen), wordt wijziging voorgesteld in de vorm van een aanbeveling.

Een aanzienlijke discrepantie tussen normen van bestuursrecht en de normen voor buitengerechtelijke afdoening wordt gevormd door de omstandigheid dat de verdachte, ten aanzien van wie onder voorwaarde van vervolging wordt afgezien, geen reële beroepsmogelijkheid heeft. Met name hier wordt rechterlijke controle gemist. Door het besluit tot voorwaardelijke buitengerechtelijke afdoening te beschouwen als een bestuursorgaan en de uitzondering die art. 1:6 Awb ten aanzien van vervolgingsbesluiten maakt te schrappen, wordt een dergelijk sanctiebesluit vatbaar voor bezwaar en beroep volgens de bestuursrechtelijke procedure.

Een dergelijke procedure is het bestuursrecht niet vreemd, want zij bestaat al in de vorm van de regeling van administratieve sancties, met name de administratieve boete. De theorievorming rond deze administratieve boete is nog niet geheel uitgekristalliseerd. Een belangrijk discussiepunt is de verenigbaarheid met mensenrechtenbepalingen. Bij deze discussie zou de voorgestelde regeling van buitengerechtelijke afdoening moeten aansluiten.

Door de handhaving van een groep verkeersvoorschriften over te dragen naar het bestuursrecht, moet de regeling in beginsel volgens bestuursrechtelijke normen verlopen. In de laatste paragraaf van dit hoofdstuk wordt de WAHV afzonderlijk getoetst aan de Awb. Afwijking bestaat op het punt van de beslissing op het beroep. Deze dient te worden opgeheven.

In Hoofdstuk 11 tenslotte volgen een slotbeschouwing en voorstellen ter verbetering. Alvorens toe te komen aan de vraag of handhaving van strafbare feiten via het bestuursrecht zou kunnen verlopen, moet de toedeling van gedragingen aan het strafrecht of administratief recht heroverwogen worden.

De voorstellen ter verbetering omtrent de wettelijke bepalingen van de buitengerechtelijke afuoening worden samengevat in de vorm van een voorstel tot wetswijziging en voorzien van een toelichting.

Voorgesteld wordt de buitengerechtelijke in één titel op te nemen. Enkele beslistermijnen worden aangepast. Voor de transactie en het voorwaardelijk sepot wordt een gemeenschappelijke regeling voorgesteld. Vanaf het moment dat besloten wordt tot afdoening onder voorwaarden is de Awb van toepassing. De grens tussen feiten die wel of niet door middel van deze afdoening onder voorwaarden kunnen worden afgedaan moet worden getrokken aan de hand van de ernst van het feit. De huidige indeling in misdrijven en overtredingen voldoet daartoe niet meer en moet worden aangepast. Kiest de officier van justitie voor de afdoening onder voorwaarden, dan 
is dat definitief. Hij kan niet later alsnog voor strafrechtelijke afdoening kiezen. Door het besluit tot afdoening onder voorwaarden als een bestuursbesluit te beschouwen wordt dit besluit vatbaar voor bezwaar en beroep conform de Awb.

Ten aanzien van de WAHV wordt voorgesteld art. 7 zodanig te wijzigen dat de officier van justitie bij het nemen van zijn beslissing op het beroep aan een termijn wordt gebonden. Deze termijn zal 16 weken bedragen, met de mogelijk van verlenging met 8 weken. De zekerheidstelling als ontvankelijkheidsvoorwaarde bij het beroep op de kantonrechter dient te verdwijnen. 


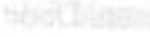

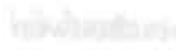

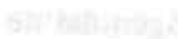

an wit| || || 


\section{Summary}

Since the introduction of the Dutch Code of Criminal Procedure (DCCP) in 1926, the role of the Public Prosecutors' Office (openbaar ministerie, $O M$ ) has changed. Originally, the $O M$ was charged with heading the investigation and prosecution of criminal offenses. This meant that for virtually every criminal act detected, the alleged offender was summoned to court in order to be judged in public criminal proceedings by an independent judge. Today, the $O M$ is a policy-directed body rather than a prosecuting body. Not all offenses detected lead to prosecution. The reverse is true, the majority of detected criminal offenses are not brought before the judge, because the $O M$ or the police waive the right to prosecute and deal directly with the case in a final settlement. Prosecution only takes place if there are specific grounds for it.Consequently, disposing of criminal offenses through criminal proceedings before an independent judge has become an exception.

If the $O M$ disposes of a criminal case out of court, it can do so by various methods. It can waive its rights unconditionally, in which case no punishment is imposed on the alleged offender. Another option is to waive the right to prosecute conditionally, in which case the alleged offender must meet a condition in order to avoid prosecution. A frequently used form for out-of court settlement of criminal cases is a 'transaction', which also falls within the competence of the police. Another form halfway between waiver and criminal prosecution is the joinder ad informandum.

A large number of traffic offenses that were governed by criminal law are now regulated by administrative law. In these cases, appeal lies with the public prosecutor. It is expected that in future the number of criminal offenses that are disposed of by the $O M$ or the police will increase, preferably using a method involving the imposition of a sanction. The OMS 1992 Annual Report speaks of an effort to dispose of one third of all prosecutable cases by transaction. In addition, enforcement under administrative law is being contemplated.

Since out-of-court disposition of criminal cases has gained such a prominent place, attention must be paid to its normative framework. On a number of points deficiencies can be found, for example, because there is no statutory basis or a defective statutory basis, the legal effects are not properly regulated, the alleged offender does not enjoy adequate protection under the law or the choice of out-of-court disposition leads to inequality under the law. 
The purpose of this dissertation is to achieve better standards for $O M$-decisions to dispose of criminal cases out of court. There are six reasons for seeking a connection with administrative law. Relevant questions are whether the $O M$ should be considered an administrative body and, if so, whether the decision to dispose of a case out of court can be seen as an administrative decision to be scrutinized under administrative law. The consequence of an affirmative answer to these two questions is that the exception pursuant to article 1:6 of the Algemene wet bestuursrecht (Act regulating Administrative Action) for decisions relating to the investigation and prosecution of criminal offenses, must be repealed, providing the reasons offered for the exception in the Explanatory Memorandum to the $A w b$ did not apply to dispositions out of court. If the exception were repealed, the provisions of administrative law laid down in the Awb would also be applicable to out-of-court dispositions of criminal cases. The author deals with conditional out-of-court disposition in the context of the problem of administrative penalties.

In the first part (Chapters 2 through 6) of this study, the different methods of out-ofcourt disposition are examined. Among the matters discussed are its historical development, its statutory basis, the time-limits to be observed and its legal effect. In the second part (Chapters 7 through 11), an elaborate answer is worked out to the two questions posed above.

Chapter 2 deals with sepot (i.e. waiving the right to prosecute criminal offenses). The public prosecutor may have various reasons for unconditionally waiving his right to prosecute: he may fear that a conviction is unlikely (haalbaarheids-sepot, waiver on technical grounds), or he may act on considerations of policy (beleids-sepot). The legal basis for a waiver on policy grounds is the expediency principle (opportuniteitsbeginsel) as laid down in articles 167 (2) and 242 (2) DCCP. It is either conditional or absolute. In anticipation of the policy adopted by the $O M$, the police in effect take the decision on such sepot (politie-sepot).

The principle of expediency was enacted in 1926. Although the text of the provision remains unchanged, its interpretation has undergone a fundamental change, from 'prosecution, unless...' to 'no prosecution, unless....' This has many reasons. The fact that certain conduct constitutes a criminal act in itself does not legitimize prosecution. Moreover, the number of criminal provisions has increased considerably, as has the incidence of violations.

The decision not to prosecute may be taken in different stages of the preliminary investigation. Where prosecution has not been initiated, the sepot is an 'informal sepot'; after prosecution has been initiated, the decision not to prosecute is a 'formal s'pot.' The law does not in all cases oblige public prosecutors to decide on prosecution within a specific time-limit.

As for the sepot decided on technical grounds, article 247 DCCP prescribes a statement of the reasons for the decision. There is no such duty in case of sepot decided 
on policy grounds (beleidssepot). Decisions not to prosecute taken by the police (police sepot) are not expressly regulated by statute. This is not required, if a 'mandate', as conceived under administrative law, is applied to the relation between $O M$-sepot and police sepot.

The informal conditional sepot has no statutory basis. The position of the formal conditional sepot (art. 244 (3) DCCP) is not very clear. The author raises the question of whether the difference between conditional sepot and a 'transaction' is fundamental.

Where the legal effect of a decision of sepot is not based on a statutory provision, the principle of legitimate expectation can help out. The question is, however, whether this is a sufficient remedy.

In Chapter 3 'transaction' is discussed. Throughout its history, this legal institution has been looked upon somewhat warily, because abuse and inequality under the law could be its result. The issue was whether the judge should be involved in settling criminal cases by transaction. Extension of the transaction arrangement was almost always based on considerations of procedural efficiency and it is revealed that some of the conditions for employing transaction, imposed by the legislator when extending the rule, were abandoned shortly after they came into effect. The original motive for simplifying criminal procedure in cases of minor offenses has been substituted by the need to dispose of the majority of criminal cases in the speediest possible way.

Criticism of the transaction regulation principally concerns the powerful position of the $O M$ as opposed to the compulsory choice the alleged offender is presented with.

In order to obtain the greatest possible equality under the law when employing a 'transaction', the Prosecutors-General have drafted guidelines with regard to a number of serious criminal offenses.

The police are also authorized to employ transactions. At first, this was restricted to specific lesser offenses, particularly traffic offenses. In 1993, police transaction was introduced for a number of simple serious offenses.

In this study, administrative enforcement of traffic regulations has been given an important place, as is demonstrated in Chapter 4 . The development of dealing with offenses through administrative law was prompted by the excessive work load for the prosecution system. The methods of out-of-court disposition of criminal offenses previously used depended too much on the cooperation of the alleged offender. An important distinction between administrative sanctions and transactions under the criminal law is therefore that the person upon whom an administrative sanction (i.e. fines) is imposed, must lodge an appeal if he objects to the fine and does not have the option of awaiting criminal proceedings. If he does not appeal against the decision to impose a fine, it will be final and enforceable. 
The major issues in the legal history of the Administrative Enforcement of Traffic Regulations Act and the early decided cases concern the alleged offender having to pay a sum of money to secure locus standi in review proceedings before the Cantonal Court judge and the question of whether enforcement under administrative law of traffic regulations violates international law, more particularly the provisions of articles 6 ECHR and 14 ICCPR. As to the second question, a comparison can be made with the question of administrative fines (for instance fiscal penalties) and article 6 ECHR. The more administrative law uses sanctions that fall within the scope of 'criminal charge' of article $6 \mathrm{ECHR}$ and the more it contemplates bringing other criminal acts within the scope of administrative law, the more pressing becomes the question of where the line dividing enforcement under criminal law and administrative enforcement must be drawn.

The introduction of the $A w b$ has necessitated several amendments to the Administrative Enforcement of Traffic Regulations Act (WAHV). The case law developed by Netherlands Supreme Court on this matter has also led to amendments of the latter Act.

In spite of the fact that community service, which was made a principal penalty in 1989 only to be imposed by the judge, is no longer used by the $O M$ as a method of disposition, it is discussed, however, in Chapter 5, because a concrete assessment was made in the past of whether these cases should be dealt with by the judge or by the $O M$. Originally, the emphasis was on the prosecutor model (imposition by the $O M$ ). As the reason for this the government mentioned the desirability of limiting the time between commission of the offense and the offenders actually doing community service to the shortest possible period. The then Minister of Justice also opted for disposition by the $O M$, since he did not conceive of community service as punishment. Eventually, the judge model was opted for: community service was introduced as a principal penalty in articles 9 and $22 \mathrm{~b} \mathrm{ff}$. DPC. The judge may impose community service in lieu of an unconditional custodial sentence of not more than six months. In contradistinction to earlier judgments, community service these days is regarded as punishment, because it considerably curtails the offender's freedom.

In Chapter 6, the author discusses the joinder ad informandum. In case of a joinder ad informandum, the person suspected of a series of criminal offenses, is charged with only one or some of the offenses. The remainder is included in the case file on the principal offense(s) for the judge's information and the public prosecutor will request the judge to take these into account in sentencing.

Important issues relating to the joinder ad informandum are legal basis and legal effects. The joinder ad informandum has no statutory basis. Often the expediency principle is cited as its legal basis, because this principle allows public prosecutors to waive their right to prosecute. The author does not concur with this view, because, in effect, prosecution does take place. From earlier case law developed by the Netherlands Supreme Court, it can be inferred that joining ad informandum does not bar 
(a new) prosecution. This point of view is outdated for acts admitted by the defendant that have resulted in his conviction. The question is whether prosecution is still allowed if the defendant has been acquitted in the principal case or if the case has been dismissed on the grounds of absence of criminal liability.

To avoid a too frequent use of joining ad informandum on the grounds of efficiency, a number of conditions should be set with regard to its application.

Special consideration should be given to the victim of an act that was joined ad informandum.

Starting with Chapter 7, the author's returns to question posed in the introduction: whether article 1:6 Awb should be amended to suit out-of-court disposition of criminal cases.

The main question discussed in Chapter 7 is whether the $O M$ must be regarded as belonging to the judiciary or as an administrative body (bestuursorgaan) as defined by article 1:1 Awb. Discussion of this question is based on three focal points: the Netherlands Constitution, the material make up of administrative bodies and the interpretation of administrative rules.

Under the Constitution, only those institutions belonging to the judiciary that are expressly so designated by the legislature. There is no statute qualifying the $O M$ as judiciary.

After a discussion of the material elements: independence, objectivity and discretion the author concludes that the $O M$ 's functioning does not fundamentally differ from that of other administrative bodies. And finally, in administrative law the $O M$ is regarded as an administrative body.

In Chapter 8 , the nature of $O M$-decisions is discussed. The question here is whether such decisions fall within the definition of 'bestuursbesluit' (administrative decision) of article 1:3 $A w b$. First, the meaning of the term 'besluit' (decision) in administrative law is explained and it is thereupon concluded that the characteristics of $O M$-decisions satisfy the definition. However, pursuant to article 1:6 Awb, decisions on prosecution do not fall within the definition. The author submits three arguments against placing the $O M$-decisions on out-of-court disposition a priori outside the scope of the $A w b$ and for considering them administrative decisions to which the provisions of administrative law may be applicable.

The above leads to the central question of whether the statutory requirements, laid down in the $A w b$, applicable to discretionary decisions of administrative bodies, would be suitable in regulating $O M$-decisions to dispose of criminal cases, out of court. To facilitate that assessment, Chapter 9 is dedicated to the norms that govern administrative decisions. Point of departure is the $A w b$. Among those treated are the rules for decision-making, the general principles of proper administration and the rules governing administrative appeal and administrative review. 
The objective of Chapter 10 is to discover whether decisions to dispose of criminal cases out of court are taken according to the norms described in the preceding chapter and to establish the extent of possible deviations. Where a deviation from the norm is found, the author determines whether amendment is needed in the form of an adaptation to the general norm in administrative law.

The general principles of proper administration are also thoroughly discussed in this connection. The author's general conclusion is that these principles with regard to decisions on prosecution do not operate in a substantially different manner from when they are applied to administrative law.

If deviations are discovered (for instance, as regards the requirement to state the reasons for the decision or the observance of time-limits), the author proposes amendments in the form of a recommendation.

The considerable discrepancy between the norms operative in administrative law and those for out-of-court disposition is caused by the fact that the alleged offender whose case is settled out of court subject to a condition, does not have a means of appeal against such a decision. In this area especially, the need is felt for judicial control. By regarding the decision to dispose of a criminal case out of court as an administrative decision and by abolishing the exception provided in article 1:6 Awb, the administrative procedure of appeal against and review of such a punitive decision is made possible.

This is not foreign to administrative law, because a similar procedure already exists in the form of rules for administrative sanctions, in particular administrative fines. The legal-theoretical framework for administrative penalties is still under development. An important subject that needs to be discussed in this context is compatibility with human rights provisions. This discussion should serve as the basis for the proposed regulation of out-of-court dispositions.

By transferring the enforcement of a set of traffic regulations to administrative law. the enforcement should in principle be governed by administrative norms. In the final section of this chapter, the $W A H V$ is separately compared with the $A w b$. There are variations where appellate decisions are concerned. These variations should be eliminated.

Chapter 11 , finally, contains a summary conclusion and suggestions for improventent. Before the question of whether criminal offenses should be dealt with by administrative law can be resolved, a reassessment should be made of the acts which are to fall within the scope of administrative law.

Suggestions for improving the statutory provisions on out-of-court dispositions are summarized and commented upon in a proposal for legislative change.

The author proposes organizing all forms of out-of-court disposition in one legislative title. Some of the time-limits for decision-making are adapted. Common rules are proposed for 'transaction' and conditional sepot. The $A w b$ is applicable from the moment a conditional decision not to prosecute is taken. Whether an act is dealt 
with by out-of-court disposition is determined by the gravity of the offense. The present classification of misdrijven (serious offenses) and overtredingen (lesser offenses) cannot be maintained and must be changed. If the public prosecutor opts for conditional out-of-court disposition, this is a final decision. He is not allowed to opt at a later date for criminal proceedings. If the decision for conditional out-of-court disposition is seen as an administrative decision, it is open to appeal and review pursuant to the $A w b$.

As to the $W A H V$, the author proposes amending article 7 so that the public prosecutor, in taking a decision on an appeal against a police decision, is bound to a timelimit. This time-limit is to be sixteen weeks, with a possible extension of eight weeks. The alleged offender's duty to pay of a sum of money to secure locus standi in review proceedings before the Cantonal Court judge must be abolished.

Translated by Louise Rayar 



\section{Lijst van de geraadpleegde en verkort aangehaalde literatuur}

Alkema, E.A. - Het arrest Öztürk en de vereenvoudigde afdoening van (verkeers-) overtredingen, VR november 1984, pag. 241-244.

Alkema, E.A. - Het arrest Öztürk en de vereenvoudigde afdoening van (verkeers-) overtredingen, Trema november 1984, pag. 267-275.

Allewijn, D. - De bestuursrechtelijke toetsing in de Wet Mulder, uit: De wet Mulder in perspectief: van strafrecht naar bestuursrecht (red. H. de Doelder, L.J.J. Rogier en P.M. van Russen Groen), Arnhem 1990, pag. 67-76.

Angeren, J.A.M. van (red.) - Kracht van wet, Zwolle 1984.

Asscher, B.J. - Alternatieve straffen of anders, Proces 1976, pag. 151-160.

Asscher, B.J. - De officier van justitie door het oog van een rechter, of: de derivatieve uitvoering van originaire bevoegdheden, uit: T.M. Schalken e.a. (red.), Magistraat met beleid: de officier van justitie en zijn omgeving, Arnhem 1992, pag. 145-153.

Baauw, P.J. - Afdoening van verkeersovertredingen: afrekening met het strafrecht, NJB 1985, pag. 1225-1227.

Beaufort, L.A.R.J. de - Tien jaar op weg naar een wettelijke regeling van de executoir verklaring van transacties, Trema 1978, pag. 167-170.

Beaufort, L.A.R.J. de - Strafbevel of strafvoorstel? Een onderzoek naar een vereenvoudigde strafrechtspleging. Preadvies voor de Vereniging voor de vergelijkende studie van het recht van België en Nederland, 's-Gravenhage 1979.

Beleidsplan Samenleving en Criminaliteit, TK 1984-1985, 18995.

Beleidsplan Recht in beweging, TK 1990-1991, 21829. 
Beleidsplan Strafrecht met beleid, beleidsplan openbaar ministerie 1990-1995, OM 1990.

Belinfante, A.D. - Strafrechtelijke en administratiefrechtelijke sancties, Geschrift VAR, nr. XXXVI 1957.

Belinfante, A.D. - Kort begrip van het administratieve recht, Alphen aan den Rijn 1981.

Belinfante, A.D.; Reede, J.L. - Beginselen van Nederlands staatsrecht, Alphen aan den Rijn, 1987.

Bemmelen, J.M. van - De positie van de beledigde partij in het strafproces, TvS 1942, pag. 1-25 en 115-138.

Bemmelen, J.M. van - Het politiesepot, DD 1976, pag. 524-527.

Bemmelen, J.M. van - Ons strafrecht, deel II sanctierecht, bewerkt door Th.W. van Veen en J.P. Balkema, Alphen aan den Rijn 1990.

Bemmelen, J.M. van - Ons strafrecht, deel IV strafprocesrecht, bewerkt door Th.W. van Veen, Alphen aan den Rijn 1986.

Berge, J.B.J.M. ten; Stroink, F.A.M. - AROB in vogelvlucht, AJphen aan den Rijn 1982.

Berge, J.B.J.M. ten; Tak, A.Q.C. - Nederlands administratief procesrecht, deel 1, Zwolle 1983.

Beuker-Tilstra, A. - Jurisprudentie Centrale Raad van Beroep in ambtenarenzaken 1988-1989, Bestuurswetenschappen 1990, pag. 219-220.

Biggelaar, G.J.M. van den - Toetsing van de Wet administratiefrechtelijke handhaving verkeersvoorschriften aan het wetsvoorstel Algemene wet bestuursrecht, NTB 1990/5, pag. 139-145.

Biggelaar, G.J.M. van den - Justitie miskent uitgangspunten transactiebevoegdheid, NJB 1990, pag. 1281-1282.

Bins, A.J. e.a. (red.) - Beginselen, Arnhem 1981. 
Blad, John - (Voorwaardelijk) seponeren als conflictoplossende activiteit buiten de rechter om, uit: H.J. Snijders e.a. (red.), Overheidsrechter gepasseerd, Amhem 1988, pag. 297-312.

Blok, A.J.; Besier, L.Ch. - Het Nederlands strafproces, deel I, II en III, Haarlem 1925.

Bol, M.; Overwater, J. - Dienstverlening, vervanging van de vrijheidsstraf in het strafrecht voor volwassenen, deel 1, 2 en 3, WODC 's-Gravenhage 1983.

Bol, M.; Overwater, J. - Dienstverlening. Eindrapport van het onderzoek naar de vervanging van de vrijheidsstraf in het strafrecht voor volwassenen, WODC's-Gravenhage 1984.

Borman, J.A. - Openbaar Ministerie en beginselen van behoorlijk bestuur, Trema 1981, pag. 103-112.

Bos, P.A.H. - Voeging ad informandum. Uit: Naar eer en geweten, Arnhem 1987, pag. 47-58.

Bosch, A.G. - De ontwikkeling van het openbaar ministerie. Uit: T.M. Schalken e.a. (red.), Magistraat met beleid: de officier van justitie en zijn omgeving, Arnhem 1992, pag. 15-31.

Bosch Kemper J.MJ. de - Het Wetboek van Strafvordering, Amsterdam 18.38.

Bovens, M.A.P., Derksen, W. en Witteveen W.J. (red.) - Rechtsstiat en sturing, Zwolle 1987.

Brants, C. - Slavenburg: een geslaagde transactie? R en K 1987, pag. 7-30.

Breda, H. van - De rechter in het zicht van het jaar 2000, NJB 1989, pag. 1081-1084.

Brederode, R.F.W. - De rechten van de mens in het belastingrecht, WFR 1987, pag. $749-760$.

Brenninkmeijer, A.F.M. - De plaats van de rechter in onze constitutionele rechtsorde. Uit: Dynamiek in de trias. Verschuivingen in de verhouding regelgeving, bestuur en rechtspraak. Lochem 1987.

Brenninkmeijer, A.F.M.; Zoomers, Y.D.M. - De rechterlijke toetsing van sancties in het bestuursrecht, NTB 1988/2, pag. 49-56. 
Broekman, J.M.; Hart, A.C. 't - Normverleggend gedrag en justitieel beleid, Leuven 1980.

Bröring, H.E. - Richtlijnen, dissertatie RUG, Deventer 1993.

Bruijn, R. de - De Officier van Justitie als rechterlijk ambtenaar? AA 1989, pag. 973-979.

Bunt, H.G. van de - Officieren van justitie; verslag van een participerend observatieonderzoek, dissertatie RUU, Zwolle 1985.

Bunt, H.G. van de; Jonge, G. de (red.) - De macht van het OM, Nijmegen 1983 ,

Bunt, H.G. van de; Roording, J.F.L.; Verpalen, M.J.M. (red.) - Richtlijnen van het Openbaar Ministerie, Nijmegen 1993.

Burg, F.H. van der - Mandaat en delegatie, NTB 1992/8, pag. 268-275.

Burg, F.H. van der; Cartigny, G.J.M.; Overkleeft-Verburg, M. - Rechtsbescherming tegen de overheid, 1985.

Buruma, Y. - De strafrechtelijke handhaving van bestuurswetten, dissertatie RUL, Arnhem 1993.

Cleiren, C.P.M. - Beginselen van een goede procesorde, disseratie RUL, Arnhem 1989.

Cleiren, C.P.M. - Identiteit van behoorlijke strafrechtspleging en beginselen van behoorlijk bestuur? DD 1990, pag. 497-514.

Commissie inzake algemene bepalingen van administratief recht - Rapport Algemene bepalingen van Administratief recht, Alphen aan den Rijn 1984.

Commissie herijking Wetboek van Strafvordering - Herziening van het gerechtelijk vooronderzoek, Arnhem 1990.

Commissie vereenvoudigde afdoening lichte overtredingen van verkeersvoorschriften (Cie. Mulder) - Rapport van de Commissie vereenvoudigde afdoening lichte overtredingen van verkeersvoorschriften, 's-Gravenhage 1985.

Commissie Vermogensstraffen - Interimrapport, 's-Gravenhage 1969.

Commissie Vermogensstraffen - Eindrapport, 's-Gravenhage 1972. 
Corstens, G.J.M. - Waarborgen rondom het vervolgingsbeleid, dissertatie UvA, IJmuiden 1974.

Corstens, G.J.M. - De verhouding rechter-openbaar ministerie; een LAT-relatie in het strafrecht, oratie KUN, Arnhem 1983.

Corstens, G.J.M. - Civielrechtelijke, administratiefrechtelijke of strafrechtelijke rechtshandhaving, Preadvies NJV 1984.

Corstens, G.J.M. - Beginselen van behoorlijk procesrecht, Trema 1985, pag. 173-191.

Corstens G.J.M. (red.) - Administratieve afdoening verkeersovertredingen, Zwolle 1986.

Corstens, G.J.M. - Richtlijnen: recht in de zin van art. 99 RO, DD 1991, pag. 1-6. Corstens, G.J.M. - Transactie bij misdrijven. Uit: G.J.M. Corstens, G.E. Mulder, H. Singer-Dekker en P.C. Vegter (red.), Straffen in gerechtigheid, Arnhem 1987.

Corstens, G.J.M. - Briefwisseling met de minister van Justitie, NJB 1988, pag. 226 e.v. en 324 e.v.

Corstens, G.J.M. - Het Nederlands strafprocesrecht, Arnhem 1993.

Corstens, G.J.M. - Consensualiteit, DD 1994, pag. 4-8.

Corstens, G.J.M.; Tak, P.J.P. - Het openbaar ministerie, Zwolle 1982.

Corstens, G.J.M.; Mulder, G.E.; Singer-Dekker H.; Vegter P.C. (red.), Straffen in gerechtigheid, Arnhem 1987.

Corstens, G.J.M.; Frielink, P.M. - De Hoge Raad en de fiscale boete: twee maal in de pas, eenmaal uit de pas, WFR 1989, pag. 216-224.

Corstens, G.J.M.; Doorenbos, D.R. - Hercodificatie van strafprocesrecht? NJB 1991, pag. 1613-1618.

Cozijn, C. - De executie van de geldboete, Een onderzoek onder wanbetalers, WODC 's-Gravenhage 1987.

Crébolder, L.E.G.W. - De wet Mulder, Trema 1992, pag. 15-20. 
Crébolder, L.E.G.W. - De wet Mulder, paper voor het symposium De Wet Mulder in bedrijf, Erasmus Universiteit Rotterdam, 1 september 1992.

Daalder, E.J. - Het Openbaar Ministerie: magistraat of bestuursambtenaar?, Trema 1991, pag. 88-92.

Doelder, H. de - Het OM in positie, oratie EUR, Arnhem 1988.

Doelder, H. de - De ministeriële verantwoordelijkheid voor het OM, Trema 1988, pag. 374-377.

Doelder, H. de - Van strafrecht naar administratief recht. Uit: H. de Doelder, L.J.J. Rogier en P.van Russen Groen (red.), De Wet Mulder in perspectief: van strafrecht naar bestuursrecht, Arnhem 1990, pag. 85-94.

Doelder, H. de; Hart, A.C. 't - Verbaliseringsbeleid en opportuniteitsbeginsel, DD 1976, pag. 204- 211.

Doelder, H. de; Rogier, L.J.J.; Russen Groen, P. van (red.) - De Wet Mulder in perspectief: van strafrecht naar bestuursrecht, Arnhem 1990.

Donner, A.M. - Nederlands bestuursrecht, algemeen deel, Alphen aan den Rijn 1987.

Doorenbos, D.R.; Verweij, R.J. - Hercodificatie Wetboek van Strafvordering, Nijmegen 1991.

Duisterwinkel, G. - Enige facetten van de taak van het openbaar ministerie naar Nederlands recht, Deventer 1965.

Duisterwinkel, G. - Vereisen de functies van het Openbaar Ministerie nieuwe wettelijke voorzieningen? Preadvies NJV 1968, Handelingen NJV 1968, deel 1.

Duk, W. - Tanden van het recht, Zwolle 1973.

Duk, W. - Malatstaven voor de beoordeling van sancties, AA 1981, pag. 231-238.

Duk, W. - Handhaving van bestuursrecht, Capita Selecta, NTB 1988/4, pag. 105-110.

Dijk, P. van - Massaliteit van verkeersovertredingen en het recht op behandeling door de rechter, Trema 1982, pag. 3-13.

Dijk P. van - Het doolhof van art. 6(1) ECRM; nieuwe openingen of doodlopende paden? NJCM-bulletin 1987, pag. 128-138. 
Dijk, P. van; Hoof, G.J.H. van - De Europese Conventie in theorie en praktijk, AA Libri, Nijmegen 1982, pag. 274-281.

Elzinga, D.J. - Een volle ministeriële verantwoordelijkheid voor het Openbaar Ministerie - maar geen ongebreidelde sturing van het OM, NJB 1994, pag. 529-537.

Eschen, S.; Kommer, M. - Evaluatie invoering Wet Mulder; interimrapportage, 'sGravenhage 1991, Ministerie van Justitie/CDWO.

Eijkern, W.J. van - Aanzet tot een evaluatie van onze strafvordering. Uit: P. Nicolaï e.a. (red.), Recht op scherp, Zwolle 1984.

Faber, S. - OM-richtlijnen, geen nieuw verschijnsel. Uit: H.G. van de Bunt, J.F.L. Roording en M.J.M. Verpalen (red.), Richtlijnen van het Openbaar Ministerie, Nijmegen 1993.

Feteris, M.W.C. - Belastingen en mensenrechten, NJCM-bulletin 1993, pag. 755-771.

Feteris, M.W.C. - Fiscale administratieve sancties en het recht op een behoorlijk proces, dissertatie UvA, Deventer 1993.

Feteris, M.W.C. - Het derde wetsvoorstel tot aanpassing van de fiscale administratieve boetes, WFR 1994, pag. 43-59.

Ficq, C.R.L.R.M. - De officier van justitie, magistraat (of bestuursambtenaar?), Trema 1991, pag. 158-166.

Franken, A.A. - Voeging ad informandum in strafzaken, dissertatie KUB, Arnhem 1993.

Frielink, P.M. - Voorwaarden ter voeging ad informandum, AA 1984, pag. 245-251

Frielink, P.M. - De positie van het slachtoffer in ad informandum gevoegde strafzaken, NJB 1985, pag. 777-779.

Frielink, P.M. - Inleiding fiscaal strafrecht, Zwolle 1991.

Fijnaut, C. - De magistratelijke rol van de politie. Uit: H.J. Snijders e.a. (red.), Overheidsrechter gepasseerd, Arnhem 1988, pag. 321-330.

Fijnaut, C.; Nuijten-Edelbroek, E.G.M.; Spickenheuer, J.L.P. - Politiële misdaadbestrijding, 's-Gravenhage 1985. 
Garé, D.M.H.R. - Het onmiddellijkheidsbeginsel in het Nederlandse strafproces, dissertatie RL, Arnhem 1994.

Goede, B. de; Brink, H. van den - Beeld van het Nederlands Bestuursrecht, 's-Gravenhage 1986 .

Goorden, C.PJ. - Beleidsregels bij mandaat en delegatie, NTB 1992/5, pag. 163-168.

Goorden, C.P.J. e.a. - Kroniek van het bestuursrecht, Zwolle 1993.

Groenhuijsen, M.S. - Criterium van strafbaarstelling, DD 1993, pag. 1-6.

Groenhuijsen, M.S.; Kalmthout, A.M. van - De wet vermogenssancties en de kwaliteit van de rechtsbedeling, DD 1983, pag. 8-13.

Groenhuijsen, M.S.; Kalmthout, A.M. van - Transactie en voorwaardelijk sepot: lood OM oud ijzer? DD 1983, pag. 474-483.

Groenhuijsen, M.S.; Kalmthout, A.M. van - Commentaar op het Rapport van de werkgroep justitieel beleid en slachtoffers, DD 1984, pag. 836-851.

Haak, W.E. - De sanctie op overschrijding van de redelijke termijn. Uit: Naar eer en geweten, Arnhem 1987, pag. 151 e.v.

Hart, A.C. 't - Strafrecht en beleid, Leuven 1983.

Hart, A.C. 't - Criminal law policy in the Netherlands. Uit: Criminal law in action (red. J. van Dijk e.a.), Arnhem 1986, pag. 73-99.

Hart, A.C. 't - Instrumentalisme en strafrechtelijk beleid. Uit: M.A.P. Bovens, W. Derksen en W.J. Witteveen (red.), Rechtsstaat en sturing, Zwolle 1987, pag. 39-45.

Harteveld, A.E. - Inverzekeringstelling en art. 5 EVRM, NJB 1989, pag. 109-111.

Harteveld, A.E. - Het Wetboek van Strafvordering en het (gerechtelijk) vooronderzoek. Uit: D.R. Doorenbos en R.J. Verweij (red.), Hercodificatie Wetboek van Strafvordering, Nijmegen 1991.

Harteveld, A.E. - Het stelsel van strafvordering en het rapport van de Commissie Moons, DD 1991, pag. 565-591.

Hartog, J.D. den - Artikel 6 EVRM: grenzen aan het streven de straf eerder op de daad te doen volgen, dissertatie RUG, Antwerpen-Apeldoorn 1992. 
Hazewinkel-Suringa, D. - Inleiding tot de studie van het Nederlandse strafrecht, bewerkt door J. Remmelink, Alphen aan den Rijn 1991.

Heringa, A.W.; Verheij, N. - Publiekrechtelijke bewegingen, Deventer 1990.

Hirsch Ballin, E.M.H. - De officier van justitie, magistraat of bestuursambtenaar? Trema 1991, pag. 196-197.

Hirsch Ballin, E.M.H.; Moor-van Vugt, A.J.C. de - Doel en middel in het bestuursrecht, AA 1986, pag. 783-789.

Hoekema, A.J. - Opsporings- en vervolgingsrichtlijnen, een rechtssociologisch onderzoek, DD 1978, pag. 443-487.

Hoekstra, RJ. - Ministeriële verantwoordelijkheid. Uit: Gegeven de grondwet, Deventer 1988, pag. 100 e.v.

Hoogenboom, $\mathrm{T}$. - De macht van het Openbaar Ministerie en de grenzen van het bestuursrecht. Uit: H.G. van de Bunt en G. de Jonge (red.), De macht van het OM, Nijmegen 1983.

Horst, W, van der - De Wet Mulder - vluchten kan nog wel (over de verzet- en beroepsprocedure), De rechtsstrijd 1992, nr. 2, pag. 178-180.

Huisman, R.A. - De toekomstige dienstverlening, Proces 1983, pag. 142-155.

Hullu, J. de - Opvattingen over dienstverlening, WODC 's-Gravenhage 1981.

Ingelse, P. - Dading in plaats van strafrecht, NJB 1991, pag. 963-967.

Jaarverslagen Openbaar Ministerie 1970 tot en met 1992 - Jaarverslagen 1970-1985 zijn gepubliceerd als bijlage bij de jaarlijkse begroting van het ministerie van Justitie; alle volgende jaarverslagen zijn zelfstandig gepubliceerd.

s'Jacob, P. - Geschiedenis, theorie en practijk van artikel 74 Wetboek van Strafrecht, dissertatie RUL, 's-Gravenhage 1936.

Janssens, A.L.J. - De botte bijl gewet? Uit: J.L.M. Boek e.a., Grensoverschrijdend strafrecht, 1990.

Jong, D.H. de - Rechtsbescherming in een beslissende fase, oratie RUG, Arnhem 1985. 
Jong, D.H. de - De afdoening van strafzaken buiten proces, Preadvies voor de Vereniging voor de vergelijkende studie van het recht van België en Nederland 1985.

Jong, D.H. de - Het rapport van de commissie-Mulder: een noodzakelijke wijziging? Uit: G.J.M. Corstens (red.), Administratieve afdoening verkeersovertredingen, Zwolle 1986.

Jong, D.H. de - Undue delay: lagere straf in plaats van niet-ontvankelijkheid OM, AA 1987, pag. 628-634.

Jong, D.H. de - Opzoek naar de ware eenvoud bij afdoening van lichte verkeersovertredingen, DD 1988, pag. 316-325.

Jonkers, W.H.A. e.a. - Het penitentiair recht, losbladig, Arnhem.

Jonkers, W.H.A. - Gedwongen tewerkstelling als sanctie? Proces 1972, pag. 151-152.

Jörg, N. - Administratiefrechtelijke afdoening van lichte verkeersovertredingen, Trema december 1985, pag. 1-36.

Kalmthout, A.M. van - Het wettelijk kader voor de dienstverlening, JV 6/1984, pag. 72 e.v.

Kalmthout, A.M. van; Quint, H. - Met het systeemperspectief blijven we altijd zitten, AA 1974, pag. 259-266.

Keijzer, N. - Enkele opmerkingen over de presumptio innocentiae in strafzaken. Uit: Naar eer en geweten - Liber Amicorum J. Remmelink, Arnhem 1987, pag. 235253.

Kleijs-Wijnnobel, C.J. - Bestuurs- en strafsancties; een LAT-relatie. Uit: C.P.J. Goorden e.a., Kroniek van het bestuursrecht, Zwolle 1993.

Koeman, N.S.J. - Hoofdstuk 6 Handhaving $\S 1$ Handhaving in de Awb en $\S 4$ Dwangsom. Uit: W. Konijnenbelt (red.), De derde tranche, Alphen aan den Rijn 1992, pag. 103-110 en 131-134.

Kommer, M. - Mulder vs Murphy, paper voor het symposium De Wet Mulder in bedrijf, Rotterdam 1 september 1992.

Kommer, M.M.; Essers, J.J.A.; Damen, W.A.F. - De transactie in misdrijfzaken: Een beleidsevaluatie, 's-Gravenhage 1986 (WODC-reeks nr. 68). 
Kommer, M.; Eschen, S.; Heijden, E. van der - Eindrapport evaluatie invoering Wet Mulder, 's-Gravenhage 1991, Ministerie van Justitie/CDWO.

Konijnenbelt, W. - Rechtsverwerking door het bestuur: het vertrouwensbeginsel in het administratieve recht, Preadvies VAR LXXIV 1975.

Konijnenbelt, W. - Openingsrede VAR-congres 25 april 1986, VAR XCV (1986).

Konijnenbelt, W. - Hoofdstuk 2 Attributie, delegatie en mandaat in de Algemene wet bestuursrecht. Uit: W. Konijnenbelt (red.) De derde tranche, Alphen aan den Rijn 1992, pag. 6-22.

Konijnenbelt, W. (red.) - De derde tranche, Alphen aan den Rijn 1992.

Koolen, L.J.M.; Wiebrens, C.J; Berg, E.A.I.M. van den - Geschikt of niet geschikt? Een evaluatie van de lik-op-stuk experimenten, WODC, 's-Gravenhage 1989.

Kors, A. - Administratiefrechtelijke handhaving: toekomstperspectief. Uit: H. de Doelder, L.J.J. Rogier en P. van Russen Groen (red.), De Wet Mulder in perspectief: van strafrecht naar bestuursrecht, Arnhem 1990, pag. 77-84.

Korthals Altes, F. - De verhouding tussen minister van justitie en het openbaar ministerie, Trema 1988, pag. 367-373.

Kortmann, C.A.J.M. - De grondwetsherzieningen 1983 en 1987, Deventer 1987.

Kosto, A. - De Wet Mulder in perspectief. Uit: H. de Doelder, L.J.J. Rogier en P. van Russen Groen (red.), De Wet Mulder in perspectief: van strafrecht naar bestuursrecht, Arnhem 1990, pag. 141-145.

Kreveld, J.H. - Beleidsregels in het recht, dissertatie RUG, Deventer 1983.

Kuyper, J.R.H. - Rechtshandhaving en het Openbaar Ministerie. Uit: T.M. Schalken e.a. (red.), Magistraat met beleid: de officier van justitie en zijn omgeving, Arnhem 1992, pag. 53-63.

Laan, P.H. van der - Alternatieve sancties voor jeugdigen, dissertatie VU, Arnhem 1991.

Langbroek, P.M. - Machtenscheiding en Decentralisatie, Enschedé 1988.

Lensing, J.A.W. - Het verhoor van de verdachte in strafzaken, dissertatie KUN, Arnhem 1988. 
Lensing, J.A.W. - De Hoge Raad en de beginselen van behoorlijk strafprocesrecht, DD 1988, pag. $960-978$.

Lensing, J.A.W. - Aspecten van de invloed van art. 6 EVRM op onderdelen van het strafproces in Nederland. Preadvies voor de vereniging voor de vergelijkende studie van het recht van België en Nederland, 1988.

Lensing, J.A.W. - Uitspraak Europees Hof in Britse zaak noopt tot bezinning op Nederlandse rechtspraktijk inverzekeringstelling, Trema 1989, pag. 14 e.v.

Lensing, J.A.W. - De Hoge Raad en de presumptie van onschuld: een motiveringsklacht, NJB 1989, pag. 84-86.

Leijten, J.C.M. - De bloemlezing in de dagvaarding, NJB 1956, pag. 488-490.

Leijten, J.C.M. - De strafmaat in verband met niet tenlastegelegde feiten, NJB 1964, pag. 36-43.

Lubberdink, De betekenis van de ministeriële verantwoordelijkheid voor de organisatie van het openbaar bestuur, dissertatie RUG, Deventer 1982.

Maarseveen, H.ThJ.F. van - Ministeriële verantwoordelijkheid en Openbaar Ministerie na 1976, NJB 1977, pag. 209-215.

Male, R.M. van - Onvoltooid recht, oratie EUR, Zwolle 1993.

Manen, N.F. van - Automatisering binnen het openbaar ministerie, JV 1992, nr. 5, pag. 39-54.

Martens van Sevenhoven, A.H. - De justitiële colleges in de steden en op het platteland van Holland 1795-1811, dissertatie RUU 1912.

Melai, A.L. c.s. - Het Wetboek van Strafvordering. losbladig. Arnhem.

Meulen, Bernd van der e.a. - Bestuursbevoegdheid als bron van recht, NTB 1991/5, pag. 133-141.

Michiels, F.C.M.A. - De Arob-beschikking, dissertatie KUN, 's-Gravenhage 1987.

Michiels, F.C..M.A. - De boete in opmars? Oratie VU, Zwolle 1994. 
Ministerie van justitie - Samenleving en criminaliteit; een beleidsplan voor de komende jaren, TK 1984-1985, 18995, nr.

$1-2$.

Ministerie van justitie - Recht in beweging; een beleidsplan voor justitie in de komende jaren, 's-Gravenhage 1990.

Minkenhof, A. - De Nederlandse strafvordering, bewerkt door J. Reijntjes, zesde herziene druk, Arnhem 1993.

Molen-Maesen, P.M.H. van der - OM en politiesepot, TvdP 1984, pag. 1-4.

Mols, G.P.M.F. - Staande de zitting: een beschouwing over het onmiddellijkheidsbeginsel, oratie RL, Arnhem 1989.

Moons, J.M.A.V. - Het opportuniteitsbeginsel. Enige notities over zijn inhoud en omvang, NJB 1969, pag. 491-495 en 521-529.

Moor-van Vugt, A.J.C. de - Algemene beginselen van behoorlijk bestuur en buitenlandse equivalenten, Zwolle 1987.

Moor-van Vugt, A.J.C. - Symbiose van evenredigheidstoetsen? NTB 1993/1, pag. 26-37.

Mostert, P. - Vereisen de functies van het Openbaar Ministerie nieuwe wettelijke voorzieningen? Preadvies NJV 1968.

Mulder, A. - De verhouding van administratieve sancties en straffen, geschrift VAR XXXVI 1957.

Mulder, A. - Strafrechtspolitiek, DD 1980, pag. 331-341.

Mulder, A. - De functie van het strafrecht in de verzorgingsstaat, AA 1981, pag. 225-231.

Mulder, A. - Overvraging van rechtsbescherming. Uit: Th.W. van Veen e.a. (red.), Strafrechtspleging onder spanning, Arnhem 1981, pag. 53-72.

Mulder, A. - De massaliteit van verkeersovertredingen, VR 1982, pag. 25-28.

Mulder, A. - Naar een nieuwe structuur van de rechterlijke macht, NJB 1989, pag. 1073-1080. 
Mulder, A. - De bestuurlijke boete als middel tot bestrijding van economische delicten, SEW 1994, pag. 219-235.

Mulder G.E.; Schootstra H. - De voorwaardelijke veroordeling, Preadvies NJV 1974.

Myjer, E. - De verdachte in het geding - ter informatie, DD 1974, pag. 244-247.

Myjer, E. - Bijdrage in de rubriek Strafrecht en Mensenrechten, NJCM-bulletin 1989, pag. 194-195.

Nicolaï, P. e.a. (red.) - Recht op scherp, Zwolle 1984.

Nicolaï, P. - Beginselen van behoorlijk bestuur, dissertatie UvA, Deventer 1990.

Nicolaï, P. - Hoofdstuk 5 Beleidsregels. Uit: W. Konijnenbelt (red.), De derde tranche, Alphen aan den Rijn 1992, pag. 82-102.

NJCM-commentaar op het rapport "Vereenvoudigde afdoening van lichte overtredingen van verkeersvoorschriften", NJCM-bulletin 1986, pag. 385.

Noyon, T.J. - Het Wetboek van Strafrecht, 1926.

Nijboer, J.F. - De doolhof van de Nederlandse strafwetgeving, Groningen 1987.

Oomen, C.P.Chr.M. - Werken in plaats van zitten: een gewenste nieuwe ontwikkeling in de strafrechtspraak? NJB 1972, pag. 257-267.

Oortmerssen, A. van - De dienstverlening in het officiersmodel, Trema 1986, pag. 67 e.v.

Oostenbrink, J.J. - Administratieve sancties, dissertatie RUU, 1967.

Osinga, P. - Transactie in strafzaken, dissertatie KUB, Arnhem 1992.

Osinga P. - Politietransactie bij misdrijven, DD 1993, pag. 399-413.

Patijn, A. - De strafrechtelijke handhaving van de wetgeving. Uit: J.A.M. van Angeren (red.), Kracht van wet, Zwolle 1984, pag. 147-164.

Pennarts, H. - Lex Mulder: van strafrecht naar bestuursrecht, Rechtshulp 1990, nr. 6/7, pag. 11-14.

Peijster, C.N. - Het politiële sepot, TvdP 1964, pag. 97-101. 
Pieterman, R. - De plaats van de rechter in Nederland, 1813-1920, dissertatie RUU, Arnhem 1990.

Prechal, S. en Heukels, T. - Algemene beginselen in het Nederlandse recht en het Europees recht: rechtsvergelijking en interactie, SEW 1986, pag. 287-331.

Pompe, W.P.J. - Handboek van het Nederlandse strafrecht, Zwolle 1959 (vijfde druk).

Pompe, W.P.J. - Vooronderzoek of eindonderzoek beslissend? Uit: Vijf opstellen van Willem Pompe, Zwolle (zonder jaartal), pag. 15-32. Tevens in: TvS 1959, pag. 141-151.

Pront-van Bommel, S. - Hoofdstuk 6 Handhaving $\$ 2$ Toezicht. Uit: W. Konijnenbelt (red.), De derde tranche, Alphen aan den Rijn 1992, pag. 111-124.

Pront-van Bommel, S. - Afstand van beroep op de administratieve rechter, NTB 1993, pag. 182-189.

Ras, H.E. - De onafhankelijkheid van de rechterlijke macht, NJB 1989, pag. 12721274.

Remmelink, J. - Het openbaar ministerie ter discussie, VR 1968, pag. 169-174 en 193-197.

Remmelink, J. - De plaats en taak van het Openbaar Ministerie bij de Hoge Raad in strafzaken. Uit: A.J. Bins e.a. (red.), Beginselen, Arnhem 1981.

Remmelink, J. - De officier van justitie, magistraat of bestuursambtenaar? Trema 1991, pag. 167-179.

Reijntjes, J. - Voorwaardelijk sepot. Uit: Liber Amicorum Th.W. van Veen, Arnhem 1985, pag. 295-316.

Robertson, A.H. - De internationale bescherming van de rechten van de mens (Nederlandse bewerking: H.C. Dirkse-Bresters), Groningen 1974.

Rogier, L.J.J. - Administratiefrechtelijk beroep op de kantonrechter, NJB 1990, pag. 452-455.

Rogier, L.J.J. - De wet Mulder, artikelgewijs commentaar op de Wet administratiefrechtelijke handhaving verkeersvoorschriften, Arnhem 1990 (eerste druk), 1992 (tweede druk). 
Rogier, LJJJ - Strafsancties, administratieve sancties en het una via-beginsel, dissertatie EUR, Arnhem 1992.

Rogier, L.J.J. - Recente jurisprudentie op grond van de Wet Mulder, NJB 1994, pag. 425-432.

Rogier, L.J.J.; Hartmann, A. - Verschillen en overeenkomsten tussen strafrecht en bestuursrecht, DD 1993, pag. 1043-1058.

Rogier, L.J.J.; Dane, N.M. - De uitoefening van bevoegdheden in het dwangtraject van de Wet Mulder, Trema februari 1994.

Roon, R. de - Beoordeling van politie en OM door de Nationale Ombudsman, DD 1991, pag. 134-150.

Roos, Th.A. de - Strafbaarstelling van economische delicten, dissertatie RUU. Arnhem 1987.

Roos, Th.A. de; Serrarens, J. - De zaak-Wladimiroff. Uit: L. van Almelo, Crimineel Jaarboek 1993, pag. 178-184.

Rooyen-de Wit, C.M. van - Het politiesepot, afstudeerscriptie RUU, 1986.

Rooyen-de Wit, C.M. van - Wie is er eigenlijk bang voor het politiesepot? TvdP 1987, pag. 6-13.

Ruiter, D.W.P. - Het ongrijpbare gelijkheidsbeginsel, Preadvies VAR 1985.

Russen Groen, P.M. van - Eindrapport van het juridisch deelonderzoek van het Evaluatierapport Wet Mulder, deel I en II, Erasmus Universiteit Rotterdam, 1992.

Rijn, J.H.C. van - Politiesepot: een uitkomst voor het Openbaar Ministerie of voor de politie? TvdP 1983, pag. 621-625.

Schaffmeister, D. - Politiële en justitiële delicten, Preadvies Nederlandse Juristenvereniging 1984.

Schaffmeister, D. - Afzonderlijk straf-en strafprocesrecht voor de veelvoorkomende criminaliteit, JV 1990, pag. 8-28.

Schalken, T.M. - Het politiesepot en de mandaatsverhouding tussen openbaar ministerie en politie, Trema 1984, pag. 3-13. 
Schalken, T.M. - HR en politiesepot: De carrière van een parkeerwachter, NJB 1989, pag. 917-918.

Schalken, T.M. - Het postmoderne OM; management in toga, NJB 1990, pag. 14351436.

Schalken, T.M. - Het taboe van art. 5 RO, Trema 1991, pag. 179-193.

Schalken, T.M. e.a. (red.) - Magistraat met beleid: de officier van justitie en zijn omgeving, Arnhem 1992.

Schalken, T.M. - Een nieuwe cultuur binnen het openbaar ministerie? NJB 1992, pag. 813-818.

Scheltema, M. - De rechtsstaat. Uit: J.W.M. Engels e.a. (red.), Zwolle 1989, pag. 11-25.

Schorlesheim, M. - Dossiers ad informandum, NJB 1930, pag. 216-221.

Sectie bestuursrecht Rijksuniversiteit Limburg - Beleidsregels: gebruiksaanwijzing van bestuursbevoegdheid, Regelmaat 1993, pag. 54-60.

Singer-Dekker, H. - Alternatieve sancties, DD 1977, pag. 219-224.

Singer-Dekker, H. - Dienstverlening, Arnhem 1984.

Sluijs, M.J. - Administratieve sancties in een strafrechtelijke context, NJB 1988, pag. $522-528$.

Snijders H.J. e.a. (red.) - Overheidsrechter gepasseerd, Arnhem 1988.

Spill, F.W. ter; Tak, A.Q.C. - Onwetmatig bestuur, Preadvies VAR 1981.

Spronken, T. - Presumptie van onschuld: De Salabiaku zalak, NJCM-bulletin 1989, pag. 495-503.

Steenbeek, J.G. - Het beroep tegen administratieve beschikkingen, 's-Gravenhage 1965.

Steenbeek, J.G. - Wet administratieve rechtspraak overheidsbeschikkingen, 's-Gravenhage 1979 . 
Steenbeek, J.G.; Stroink, F.A.M. - Wet Administratieve rechtspraak overheidsbeschikkingen, 's-Gravenhage 1988.

Steenbrink, J. - Het Openbaar Ministerie en de beginselen van een behoorlijke procesorde, AA 1984, pag. 593-601.

Stolwijk, S.A.M. - Voeging ad informandum, DD 1984, pag. 519-527.

Stolwijk, S.A.M. - De minister van justitie, het Openbaar Ministerie en artikel 5 RO. Uit: T.M. Schalken e.a. (red.) Magistraat met beleid: de officier van justitie en zijn omgeving, Arnhem 1992, pag. 53-63.

Stroink, F.A.M. - Het leerstuk der deconcentratie, dissertatie RUU, 's-Gravenhage 1978.

Stroink, F.A.M. - De plaats van de rechter in het staatsbestel, oratie RL, Zwolle 1990.

Stroink, F.A.M.; Waard, B.W.N. de - Het specialiteitsbeginsel. Uit: Burger en overheid (Steenbeekbundel) 1984.

Tak, A.Q.C. - Overheidsbestuur en privaatrecht, 1978.

Tak, A.Q.C. - Bevoegdheidsafbakening van de AROB-rechter; kunstig of gekunsteld? oratie RL, Deventer 1984.

Tak, A.Q.C. - De Algemene wet bestuursrecht (het nieuwe bestuursprocesrecht), Zwolle 1993.

Tak, A.Q.C. - Kleine lapsus in de Awb, NTB 1993, pag. 190.

Tak, A.Q.C.; Bakker, R.E. - De centrale rol van het willekeursverbod bij de toetsing van overheidshandelen. Uit: A.W. Heringa en N. Verheij (red.), Publiekrechtelijke bewegingen, Deventer 1990, pag. 205-218.

Tak, P.J.P. - Einige Aspekte des Opportunitätsprinzips bei der Strafvervolgung nach niederländischem Strafprozessrecht, ZGStW 1972, pag. 220-253.

Tak, P.J.P. - Voorstellen rond de voeging ad informandum, DD 1978, pag. 79-87.

Tak, P.J.P. - Strafbefehls- en Bussgeldverfahren; wijzen van afdoening van verkeersmisdrijven en verkeersordnungswidrigkeiten. Ministerie van Justitie, 's-Gravenhage 1980. 
Tak, P.J.P. - The legal scope of non-prosecution in Europe, Helsinki Institute for crime prevention and control affiliated with the United Nations, Helsinki Finland 1986.

Valkenburg, W.E.C.A. - Het bezwaarschrift tegen de dagvaarding, dissertatie KUB, Arnhem 1993.

Veen, Th.W. van - De geldboete op de helling, NJB 1978, pag. 915-921.

Veen, Th.W. van e.a. (red.) - Strafrechtspleging onder spanning, Arnhem 1981.

Veen, Th.W. van - Het nieuwe art. 74 Sr, een aardverschuiving, DD 1983, pag. 539543.

Veen, Th.W. van - Anders dan strafrechtelijk afdoen, VR 1985, pag. 359-362.

Veen, Th.W.van - Iets over de geldboete, redactionele kanttekeningen, RM Themis 1991, pag. 313-314.

Veld, J. in 't en Koeman, N.S.J. - Beginselen van behoorlijk bestuur, Zwolle 1985.

Velzen, A.H.W. van - Het rapport van de commissie Mulder: een vereenvoudiging voor de praktijk? uit: G.J.M. Corstens (red.), Administratieve afdoening verkeersovertredingen, Zwolle 1986, pag. 65-89.

Vlies, I.C. van der - De reikwijdte van de Algemene wet bestuursrecht, NJB 1994, pag. 9-11.

Walther, S.R.B. - Een wettelijke regeling van het politiesepot, TvdP 1987, pag. 264270.

Wattel, H.L. - Inverzekeringstelling en rechterlijke toetsing, DD 1989, pag. 846 e.v.

Wattèl, P.J. - Fiscaal straf- en strafprocesrecht, Deventer 1989.

Wennekers, N.; Quint, H.; Kalmthout, A.M. van - Wie niet zitten wil mag ook niet werken, AA 1973, pag. 115-132.

Wiarda, G.J. - Algemene beginselen van behoorlijk bestuur, preadvies VAR XXIV, Haarlem 1952.

Wiewel, P.G. - De beslissing tot vervolging is bestuur, DD 1991, pag. 10-14. 
Wilde, L. de - Het strafbevel, Preadvies voor de Vereniging voor de vergelijkende studie van het recht van België en Nederland, 's-Gravenhage 1979.

Wladimiroff, M. - Niets bijzonders, oratie RUU, Deventer 1989.

Wijk, H.D. van - Hoofdstukken van administratief recht, bewerkt door W. Konijnenbelt, Culemborg 1988 (6e druk), bewerkt door W. Konijnenbelt en R.M. van Male, Utrecht 1993, (8e druk). 


\section{Jurisprudentieregister}

\section{Europese Hof voor de Rechten van de Mens}

EHRM 17 januari 1970, Publ. ECHR Series A, vol. 11 (Delcourt).

EHRM 16 juli 1971, Publ. ECHR Series A, vol. 13 (Ringeisen).

EHRM 8 juni 1976, Publ. ECHR Series A, vol. 22 (Engel).

EHRM 28 juni 1978, Publ. ECHR Series A, vol. 27 (König).

EHRM 21 februari 1975, Publ. ECHR Series A, vol. 18 (Golder).

EHRM 4 december 1979, Publ. EC.HR Series A, vol. 34; NJ 1980, 547 m.nt.

Alkema (Schiesser).

EHRM 27 februari 1980, Publ. ECHR Series A, vol. 35 (Deweer).

EHRM 23 juni 1981, Publ. ECHR Series A, vol. 43 (Le Compte,

Van Leuven en De Meyere).

EHRM 2 oktober 1984, Publ. ECHR Series A, vol. 83 (Skoogström).

EHRM 23 oktober 1983, Publ. ECHR Series A, vol. 97; NJ 1986, 2 m.nt.

Alkema; AB 1986, 1 m.nt. Hirsch Ballin (Benthem).

EHRM 21 februari 1984, Publ. ECHR Series A, vol. 73; NJ 1988, 973

m.nt. EAA. (Öztürk).

EHRM 22 mei 1984, Publ. ECHR Series A, nr. 77, 78 en 79; NJ 1986, 507

m.nt. EEA (De Jong, Baljet en Van den Brink/ Van der Sluis, Zuiderveld en KJappe/Duinhof en Duijf).

EHRM 29 mei 1986, Publ. ECHR Series A, vol. 99; NJCM-bulletin 1986, pag. 452 e.v. (Feldbrugge).

EHRM 25 augustus 1987, Pub]. ECHR Series A, vol. 123-A; NJ 1988, 938 m.nt. EAA (Lutz).

EHRM 7 oktober 1988, Publ. ECRM Series A, vol. 141-A (Salabiaku). EHRM 29 november 1988, Publ. ECHR Series A, vol. 145-B (Brogan).

HR 25 februari 1992, Publ. ECHR Series A, vol. 227 (Pfeifer en Plankl).

Europese Commissie voor de rechten van de Mens

ECRM 10 december 1990, FED 1993/326 m.nt. F.W.C. Feteris (Bendenoun).

\section{Hof van Justitie}

Hof van Justitie 20 september 1990, AB 1993, 143 m.nt. FHudB (Alutech). 


\section{Hoge Raad}

HR 10 oktober 1927, NJ 1927, pag. 1433.

HR 27 juni 1932, NJ 1933, pag. 27.

HR 25 februari 1949, NJ 1949, 558.

HR 31 januari 1950, NJ 1950, 668 m.nt. WP.

HR 20 december 1960, NJ 1961, 211 m.nt. Röling.

HR 6 juni 1961, NJ 1962, 17 m.nt. WP.

HR 2 februari 1964, NJ 1964, 419.

HR 1 maart 1966, NJ 1966, 375.

HR 3 oktober 1972, NJ 1973, 18.

HR 31 oktober 1972, NJ 1973, 44 m.nt. ThWvV.

HR 22 oktober 1974, NJ 1975, 39 m.nt. ThWvV.

HR 26 november 1974, NJ 1976, 36 m.nt. ALM.

HR 18 oktober 1977, NJ 1978, 128 m.nt. GEM.

HR 12 april 1978, NJ 1979, 533 m.nt. MS.

HR 29 mei 1978, NJ 1978, 358 m.nt. ThWvV.

HR 13 februari 1979, NJ 1979, 243 m.nt. ThWvV.

HR 13 maart 1979, NJ 1979, 269 m.nt. ThWvV.

HR 27 maart 1979, NJ 1979, 431.

HR 22 mei 1979, NJ 1979, 301 m.nt. GEM.

HR 24 juni 1980, NJ 1981, 659 m.nt. JAB.

HR 23 september 1980, NJ 1981, 116 m.nt. GEM.

HR 23 februari 1982, NJ 1982, 647 m.nt. ALM.

HR 9 maart 1982, NJ 1982, 409 m.nt. ALM.

HR 15 juni 1982, NJ 1983, 216.

HR 22 juni 1982, NJ 1983, 73.

HR 28 juni 1983, NJ 1984, 77.

HR 13 september 1983, NJ 1984, 151.

HR 29 november 1983, NJ 1984, 277.

HR 28 maart 1984, BNB 1984/253 m.nt. J.P. Scheltens.

HR 26 juni 1984, NJ 1985, 41.

HR 25 september 1984, NJ 1985, 317.

HR 23 oktober 1984, NJ 1986, 8 m.nt. N. Keijzer.

HR 19 februari 1985, NJ 1985, 581 m.nt. ThWvV.

HR 19 juni 1985, BNB 1986/29 m.nt. J.P. Scheltens; NJ 1986, 104.

HR 27 augustus 1985, BNB 1986/269.

HR 11 oktober 1985, NJ 1986, 322.

HR 10 november 1985, NJ 1986, 494 m.nt. 'tH.

HR 12 november 1985, NJ 1986, 421.

HR 4 december 1985, BNB 1986/159 m.nt. van Brunschot.

HR 17 december 1985, NJ 1986, 591 m.nt. ThWvV.

HR 21 januari 1986, NJ 1987, 663.

HR 6 mei 1986, NJ 1987, 26. 
HR 20 mei 1986, NJ 1987, 192.

HR 27 mei 1986, NJ 1987, 29.

HR 10 februari 1987, NJ 1987, 950.

HR 17 februari 1987, NJ 1987, 951.

HR 3 maart 1987, NJ 1988, 298 m.nt. C.

HR 17 maart 1987, DD 87.377.

HR 7 april 1987, NJ 1987, 587 m.nt. ThWvW.

HR 8 april 1987, BNB 1987/191 m.nt. Hofstra.

HR 19 mei 1987, NJ 1988, 218.

HR 19 mei 1987, DD 87.470.

HR 26 mei 1987, NJ 1988, 175.

HR 2 juni 1987, NJ 1988, 180.

HR 2 juni 1987, NJ 1988, 266.

HR 16 juni 1987, NJ 1988, 220.

HR 19 juni 1987, NJ 1988, 583.

HR 23 juni 1987, DD 87.494.

HR 23 juni 1987, DD 87.501.

HR 23 juni 1987, NJ 1988, 353.

HR 22 september 1987, DD 88.039.

HR 20 oktober 1987, NJ 1988, 473.

HR 24 november 1987, NJ 1988, 563.

HR 14 oktober 1987, BNB 1988/115 m.nt. H.J. Hofstra.

HR 24 november 1987, NJ 1988, 617.

HR 26 januari 1988, NJ 1988, 817.

HR 15 maart 1988, DD 88.336.

HR 22 maart 1988, NJ 1988, 861.

HR 19 april 1988, NJ 1988, 879.

HR 26 april 1988, NJ 1989, 37.

HR 21 juni 1988, NJ 1988, 1021 m.nt. 'tH.

HR 22 juni 1988, BNB 1988/292

HR 15 juli 1988, BNB 1988/270 m.nt. Van Dijck; FED 1988/708

m.nt. P.J. Wattèl.

HR 7 september 1988, FED 1988/715 m.nt. P.J. Wattèl.

HR 13 september 1988, NJ 1989, 282 m.nt. ALM.

HR 13 september 1988, NJ 1989, 403.

HR 19 september 1988, NJ 1989, 379.

HR 4 oktober 1988, NJ 1989, 392 m.nt. ThWvV.

HR 12 oktober 1988, BNB 1989/333.

HR 26 oktober 1988, NJB 1988, pag. 1454

HR 8 november 1988, NJ 1989, 368.

HR 23 november 1988, BNB 1989/29.

HR 25 april 1989, NJ 1989, 705.

HR 6 juni 1989, NJ 1990, 117. 
HR 19 september 1989, NJ 1989, 379.

HR 28 maart 1990, NJ 1991, 118 m.nt. MS; AB 1990, 306.

HR 19 juni 1990, NJ 1991, 119 m.nt. ThWvV en MS.

HR 5 maart 1991, NJ 1991, 694 m.nt. C.

HR 22 oktober 1991, NJ 1992, 282 m.nt. 'tH.

HR 26 mei 1992, NJ 1992, 697.

HR 11 februari 1992, NJ 1992, 692 m.nt. C.

HR 11 februari 1992, NJ 1992, 693 m.nt. C. (onder NJ 1992, 692).

HR 25 februari 1992, NJ 1992, 694 m.nt. C. (onder NJ 1992, 692).

HR 26 mei 1992, NJ 1992, 697 m.nt. C. (onder NJ 1992, 692).

HR 3 maart 1992, NJ 1992, 696 m.nt. C (onder NJ 1992, 692).

HR 8 juli 1992, NJ 1993, 180 m.nt. MS; RvdW 1992, 191.

HR 29 september 1992, NJ 1993, 31.

HR 29 september 1992, NJ 1993, 32.

HR 10 november 1992, NJ 1993, 181 m.nt. MS; RvdW 1992, 251.

HR 2 februari 1993, NJB-katern 1993, pag. 179, nr. 71.

HR 9 februari 1993, NJB-katern 1993, pag. 179, nr. 72.

HR 2 maart 1993, NJB-katern 1993, pag. 248, nr. 98.

HR 16 maart 1993, NJB-katern 1993, pag. 279-280, nr. 116.

HR 16 maart 1993, NJB-katern 1993, pag. 288, nr. 119.

HR 20 april 1993, NJB-katern 1993, pag. 326, nr. 145.

HR 20 april 1993, NJB-katern 1993, pag. 326, nr. 146.

HR 18 mei 1993, NJB-katern 1993, pag. 358, nr. 158.

HR 18 mei 1993, NJB-katern 1993, pag. 359, nr. 159.

HR 18 mei 1993, NJ 1993, 698.

HR 18 mei 1993, NJB-katern 1993, pag. 418, nr. 180.

HR 18 mei 1993, NJ 1994, 1.

HR 25 mei 1993, NJB-katern 1993, pag. 376, nr. 162.

HR 1 juni 1993, NJB-katern 1993, pag. 388-389, nr. 166.

HR 8 juni 1993, NJB-katern 1993, pag. 401-402, nr. 175.

HR 15 juli 1993, NJB-katern 1994, pag. 50, nr. 8.

HR 15 juli 1993, NJB-katern 1994, pag. 75-76, nr. 16.

HR 15 juli 1993, DD 94.002.

HR 26 oktober 1993, DD 94.074.

HR 26 oktober 1993, NJB-katern 1994, pag. 76, nr. 17.

HR 26 oktober 1993, NJB-katern 1994, pag. 76-77, nr. 18.

HR 26 oktober 1993, NJB-katern 1994, pag. 77, nr. 20.

HR 26 oktober 1993, NJB-katern 1994, pag. 97, nr. 33.

HR 2 november 1993, NJB-katern 1994, pag. 97, nr. 34.

HR 9 november 1993, NJB-katern 1994, pag. 97-98, nr. 35.

\section{Gerechtshof}

Hof Arnhem 27 mei 1930, W. 12414. 
Hof 's-Hertogenbosch 16 januari 1974, NJ 1974, 229 m.nt. ThWvV. Hof Arnhem 25 augustus 1982, NJCM-bulletin 1983, pag. 44.

Hof 's-Hertogenbosch 2 december 1982, NJ 1983, 168.

Hof 's-Gravenhage 25 januari 1983, BNB 1984/120.

Hof 's-Gravenhage 25 januari 1983, BNB 1984/121.

Hof Amsterdam 21 maart 1983, NJ 1983, 301.

Hof 's-Gravenhage 17 september 1986, BNB 1988/20.

Hof 's-Gravenhage 23 december 1988, BNB 1990/28.

Hof Amsterdam 17 juni 1991, NJ 1991, 583.

Hof 's-Hertogenbosch 18 december 1991, NJ 1993, 60.

Hof Amsterdam 10 februari 1993, NJ 1993, 355.

\section{Rechtbank}

Rb. Zutphen 1 juli 1987, NJ 1987, 942.

Rb. Rotterdam 11 november 1987, NJ 1988, 616.

Rb. Dordrecht 27 februari 1981, NJ 1981, 609.

Rb. Amsterdam 12 januari 1982, NJ 1982, 395.

Rb. Alkmaar 16 december 1986, NJ 1987, 397.

Rb. Dordrecht 28 juli 1988, NJ 1989, 94 m.nt. ThWvV.

\section{Kantongerechten}

Ktr. Zwolle 1 april 1992, NJ 1992, 807.

\section{Koninklijk Besluit}

KB 15 augustus 1970, AB 1971, 170.

(Voorzitter) Afdeling Geschillen van Bestuur van de Raad van State Vz. AGRvS 2 september 1988, AB-TwK 1988, 507 m.nt. FO.

AGRvS 20 februari 1989, M en R 1990, 10.

AGRvS 15 september 1989, AB 1990, 239 m.nt. G.T.J.M. Jurgens.

AGRvS 22 april 1993, AB 1993, 387.

(Voorzitter) Afdeling Rechtspraak van de Raad van State ARRvS 20 december 1976, AB 1979, 70.

Vz. ARRvS 14 augustus 1978, tB/S V, pag. 341, nr. 97.

ARRvS 30 januari 1979, tB/S III, pag. 571, nr. 109.

ARRvS 24 februari 1983, tB/S VIII, pag. 280, nr. 75.

ARRvS 25 januari 1985, AB 1986, 62.

ARRvS 1 juli 1985, AB 1986, 91.

ARRvS 15 maart 1989, Gem.st. 1989, 6878; AB 1991, 3/4.

ARRvS 24 september 1992, AB 1993, 61 m.nt. RMvM. 


\section{Centrale Raad van Beroep}

CRvB 17 november 1988, TAR 1989, 8.

CRvB 8 december 1988, TAR 1989, 29.

CRvB 15 december 1988, TAR 1989, 46.

CRvB 22 december 1988, TAR 1989, 51.

CRvB 21 februari 1989, TAR 1989, 91.

CRvB 9 maart 1989, TAR 1989, 99.

CRvB 23 maart 1989, TAR 1989, 116.

CRvB 6 april 1989, TAR 1989, 120.

CRvB 18 mei 1989, TAR 1989, 144.

CRvB 11 juli 1989, TAR 1989, 188.

CRvB 19 oktober 1989, TAR 1990, 242.

CRvB 7 november 1989, TAR 1990, 7.

CRvB 7 november 1989, TAR 1990, 8.

CRvB 12 december 1989, TAR 1990. 29.

CRvB 21 december 1989, TAR 1990, 37.

CRvB 2 januari 1990, TAR 1990, 52.

CRvB 9 januari 1990, TAR 1990, 54.

CRvB 11 januari 1990, TAR 1990, 55.

CRvB 1 februari 1990, TAR 1990, 78.

CRvB 31 juli 1990, AB 1991, 3.

CRvB 14 augustus 1990, AB 1991, 4.

\section{Nationale Ombudsman}

NO 28 februari 1989, AB 1989, 222.

NO 10 maart 1989, AB 1989, 241.

NO 24 april 1989, AB 1989, 274.

NO 28 juni 1989, AB 1989, 459.

NO 29 september 1989, AB 1989, 559.

NO 4 oktober 1989, AB 1989, 560.

NO 8 november 1989, AB 1990, 64.

NO 13 november 1989, AB 1990, 565.

NO 16 november 1989, AB 1990, 138.

NO 25 november 1989, AB 1989, 147.

NO 28 februari 1990, AB 1990, 333.

NO 20 december 1990, AB 1991, 158.

NO 4 september 1992, AB 1992, 620 m.nt. PJS.

NO 7 december 1992, AB 1993, 84 m.nt. PJS. 


\section{Trefwoordenregister}

de nummers verwijzen naar de betreffende pagina's

aangiftebclasting 145,146

aanhouding $25,86,134,142,205$

aankondiging 174,380

aanmaning $90,139,145,150,166$

aanpassingswet $106,173-177,341,378$, 380-382

aanslagbelasting 145

aanvraag $279,282,290,293,303,314-320$, $322,323,363,364$

aanwijzingen $39,42,43,48,75,249,253$, $255,256,260,261,309,330$

accusatoir proces 12

administratief beroep $142,158,170,174$, $175,177,226,227,273,292,293$, $301,316,317-319,321,324$, 378-381, 398

administratieve boete $112,122,123,146$, $147,150,151,170,180,183,184$, $188,192,194,269,317,373,374$, $376,384,387$

administratieve handhaving $4,122,173$, 193,271

administratieve sanctie $6,98,104,136$, $138,141,142,151,156,159,162$, $165,166,178,180,181,269,295$, $299,303,304,378$

adviescommissie $150,322-324$

afdoening buiten het geding $3,4,9$ afdoeningsmethode $3,5,48,53,58,82,98$, $212,329,334,339,362,395$

afdoeningsmodalitciten $3,5,7,9,196$ algemeen belang $2,15-20,22,23,32,233$, $239,244,246,261,265,267,268$, $271,300,332,342,353,388$

algemeen verbindende voorschriften 308 , 326,357 algemene beginselen van behoorlijk bestuur $6,55,179,215,227,274$, $290,291,295,298,299,301$, $309-311,330,332,333,355-357$, 383

algemene beginselen van behoorlijke strafrechtspleging 7,330

Algemene wet bestuursrecht $7,9,10,42$, $105,106,159,164,172-174,176$, $177,274,288-292,325,376,377$, $381,390,391$

alternatieve sanctie $3,63,268,333$

Bataafse omwenteling 13

beginselen van behoorlijk bestuur 6,55 , $170,179,215,227,253,274,288$, $290,291,292,295,298,299,301$, $305,307,309-311,330-333,341$, 355-357, 383, 384

beginselen van behoorlijk procesrecht 60 , $86,161,330$

beginselen van een beboorlijk vervolgingsbeleid 330

beginselen van een behoorlijke procesvoering 330

beginselen van een behoorlijke strafrechtsbedeling 330

beginselen van een deugdelijkc procesvoering 330

beginselen van een goede procesorde 61 , $65,216,330,333,350$

bekendmaking $33,174,175,288,293,305$, $309-311,320,323,335,346,380$

beklag over niet vervolgen 64

beklagregeling $15,64,65$

belastingrechter 145,289

beledigde partij 12, 221 
beleid $4,6,12,16,19,21,22,36-38,47$, $61,75,112,178,179,221,223,231$, $234,235,237,240,241,244,247$, $250-254,258,261,262,266,301$, $304,307,308,309,313,314,322$, $323,325,333,345,350,354,355$, $354,355,357,358,361,362,397$

beleidsafspraken $37,85,359$

Beleidsplan Samenleving en Criminaliteit 21

Beleidsplan Strafrecht met beleid 4, 21, 424

belcidsregels $6,7,44,106,282,288,292$, 293, 295, 304, 307-311, 313, 314, $326,354,355,358-360$

beleidswijriging 314

berechting $1,2,12,13,15,24,70,73,87$, $106,122,123,129,135,141,200$, $201,211,213,215,219-222,227$, $238,242,267,367,368,395$

berisping ten parkette 12, 56, 269

beroepschrift 123, 136-138, 158, 160, 162, $175,177,318-321,324,327,344$, $380,381,398,399$

beroepsgronden $156,164,175,177,380$ beroepsorgaan $6,174-176,190,191,320$, $324,325,381,382$

beroepstermijn $28,112,154,157-159,165$, 174

beschikking $5,6,23,27,28,30,31,36,40$, $65,96,104,120,122,133,136-141$, $145,148,149,153-157,163-165$, $167-170,174-176,190,193,198$, $269,270,272,279-282,284,290$, $292,293,295,296,301-303,305$, $306,310,312,314,315-317,323$, $331,356,3601,362-366,378-380$, $388,389,396$

beslissingsbevoegdheid $4,258,260,312$ besluit $5,7-9,49,74,93-96,99,100,102$, $118,133,145,155,159,164,174$, $175,180,227,279-282,284$, 292-296, 298, 299, 301-306, $309-311,314,315,317,318$, $319-321,323-325,327-329,331$, $332,334,335,342-345,347,367$, $370,372,374,375,378,380,381$, $385,387,388,390,391,396,398$, 399 bestuursbesluit 7-10, 277, 279-281, 305, $315,318,329,331,333,334,346$, $359,372,376,384,385,387,390$, 391,396

bestuurscompensatie 300

bestuursdwang $269,300,317$

bestuursorgaan $6,7,9,42,96,114,156$, $159,168,171,172,174,178,179$, $181,225,22 b-228,231,248,249$, $258,263,267,269-271,274-277$, $279,280,282,285,287-289$, 291-208, 301-312, 314-324, 327-332, $335,338,340,341,343,354,363$, $364,370,376-382,384,396$

bestuursprocesrecht $7,159,164,172,288$, $289,292,325,374$

bestuursstrafrecht $185,191,235$

bestuurswetten 6

betalingsbevel 109, 112, 126

betekening $28,33,113,170,346$

bewaring $25,249,258,260,266,279,355$ bezwaarschrift tegen de dagvaarding 86 , 219,370

bezwaarschriftprocedure $32,145,159,321$, $323-325,369,370,374,375,398$

boete $4,5,57,68-74,76,79,80,84,85,88$, $92,103,109,112,113,119,120$, $122,123,126,128,132,133,135$, $137,138,141,146-151,153,166$, $167,170,180,183,184,188$, 192-194, 210, 269, 288, 289, 299, $317,336,339,340,369,372-374$, $376,384,387,394,397$

buitengebruikstelling 104, 122, 139

buitengerechtelijke afdoening $3-5,7-10$, 104, 210, 212, 244, 268, 274, $284-286,305,329-336,346,372$, $373,376,385,387,391,396,398$, 399

buitenvervolgingstelling 32

Bussgeldprocedure 112

capaciteit $19,121,187,208$

cassatie $25,104,114,115,120,122,138$, $146,148,163,177,308,309,318$, $320,321,325,357,361,382,391$, 398

Cie. Moons 29-31, 33, 214

CJIB 104, 152-155, 163, 165, 166, 168, 191

Code d'Instruction Criminelle 13

codificatie 172, 217, 274, 291, 295 
Compas 91, 371, 375

compositie $67-69$

coördinatie 36,383

correctieprocedure 154

criminal charge $25,123-125,127,129,147$, 180

criminaliteitsbestrijding $20,250,262$

dading 3

dagvaarding $23,25,31-33,59,75,79,86$, $88,91,110,117,206,211,214,216$, $218,219-221,255,266,315,370$

decriminalisering $82,121,123,133,186$

delegatie $42,44,106,242,256,263,274$, 288,309

depenalisering 133

determination of civil rights and obligations 125,127

deurwaarder 166-168, 170

dienstverlening $8,57,63,195-210,269$, 333,355

officiersmodel $3,195,196,200$, 202, 206-210, 268, 333

rechtersmodel $3,8,195,196$, 202-20-4, 206-209

disciplinaire straffen 289

discretionaire bevoegdheid 19, 154, 301, $331,333,342$

discriminatieverbod 313

dispositievereiste 313

dividendbelasting 145

driehoeksoverleg $36,37,46$

dwangarbeid 196, 200

dwangbevel 139, 157, 166-171

dwangmiddelen $1,104,122,139,142,157$, $171,187,220,336,363$

dwangpositie $5,83,85,88,159,206,348$, 397

dwangsom $183,269,289,300,304,305$, 317

eenvoudige belediging $44,46,86$

eenvoudige diefstal $44,45,86,97$

eindonderzoek 1,2,153

equality of arms 129

evenredigheid 116, 159, 187, 298, 299, 339, 340

evenredigheidsbeginsel 291, 295, 298-300, 339-341, 396 exccutie $92,103,107,111,113,126,141$, $152,153,165-168,171,192,279$. $283,284,376,380$

fair hearing 129

fair play $291,294,295,335$

first-offender 44,46

fiscaal procesrecht 144,148

fiscale boete $149,188,288,289,404,427$ gedogen 307

gelijkheidsbeginsel $270,300,307,309$, $311-314,342,343,345,354,356$, $357,360,361,362,363,384$

gerechtelijk vooronderzoek 11, 15, 18, 23-25, 27-33, 48-51, 53, 220, 238, $239,281,335,338,365-368,388$, $389,391-393$

gerechtvaardigd vertrouwen $306,350,352$, 361

gewekte verwachtingen $262,306,312,349$, 353

gijzeling 104, 118, 123, 139

grifficrecht $158,161,170,171,178,324$, 326,383

grundrechten 55, 183, 394

grondwetsherzicning 228

HALT-aanpak 8

handhaving verkeerswoorschriften 103 , $136,155,173,288,377$

hardheidsclausule 168, 174

heling $45,97,216,371$

hersteltermijn 161, 177, 382

hoger beroep $28,103,148,196,198,207$, $216,318,320,326,374,375,383$, 391,398

hoor en wederhoor 73, 297, 296, 297

hoorplicht 256, 257, 304, 316, 321, 324, $363,364,379,380$

hoorzitting 322

huisvredebreuk 44-46

incassokosten $167,170,171,193$

inkomstenbelasting 145

inlichtingen $307,354,383$

inneming van het rijbewijs 139

inquisitoir proces 12,13

instructie $14,255,356$

inverzekeringstelling $25,45,101,255$, $257-259,267$

invorderingskosten 170

inzagerecht 137

Jaarverslag Openbaar Ministeric 248 
kansspelbulasting 145

kantongerecht $104,117,137,138,158,160$, $162,163,165,170,171,191$

kennisgeving van niet verdere vervolging $27,32-34,60,64,199,214,344$, $346,347,349,365$

kentekenregister $136,167,172$

kwijtscheldingsbesluit 145,146

legaliteitsbeginsel $1,11,18,40,113,187$. 252

Lex Mulder 136, 173, 288, 377

loonbclasting 145, 147

machtenscheiding 225

mandaat $42,44,63,92,95,106,246,253$, $288,309,312$

marginale toetsing 301

matigingsrecht 141,156

mishandeling 44-46, 86, 98, 213

modalitciten $4,5,201-206,208,333,334$

motivering $18,33,49,51,52,129,149$, $175,186,188,193,197,204,209$, $216,231,288,293,296,297,303$, $304,310,314,318,323,324$, 343-346, 357, 364, 373, 380, 384,

moliveringsbeginsel $291,298,302-304,344$, 347

motiveringsplicht $34,295,313,311,344$

motorrijtuigenbelasting 141), 145, 147

naheffingsaanslag 146,149

navorderingsaanslag 145, 149

niet-ontvankelijkheid $23,27,34,60), 62,86$, $158,161,163,164,169,174,176$, $178,191,216,219,220,327,332$, $341,342,344,347,351,352,359$, $360,368,369,389$

normering 4,5

omzetbelasting 145

onbetaalde arbeid 195, 208, 209

onbevoegdheid $34,327,344$

onmiddellijkheidsbeginsel 2

onredelijke belangenafweging 170, 298

openbaarheid $47,75,82,84,146,322,371$, 372, 398

opportuniteitsheginsel $2,3,11,12,15-20$, $22,23,38,41,42,47,48,52,113$, $210,212,213,214,235,239,243$, $252,261,264,271,331,342,355$, 356

negatieve uitleg 18,22

positieve uitleg 17, 18, 20 opsporing $1,7,13,20,21,37,38,40,41$, $43,92-94,101,119,122,243,247$, $259,263,266,283,284,337,354$, $356,385,391$

opsporingsambtenaar $24,40,41,92,94$, $96,99,133,134,139,141,142,266$, $352,353,378$

opsporingscapaciteit 36

opsporingsdiensten 37

opsporingsonderzoek $18,23,30,31,38-40$, $44,45,239,256,261,266,338,388$, 391,393

ordeningsrecht $6,118,119,188$

Ordnungswidrigkeiten 113, 114

overbelasting $21,26,119,121,179$

overleg $6,20,21,36,37,46,89,97,101$. $107,205,236,237,240,252,254$, $266,364,370$

politiedwang $263,305,306,305,306$

politieverhoor 25

Politiewet 37, 43, 44, 252

presumptio innocentiae 123, $130,148,18$ ? proceseconomic 364

proceskosten 383

pscudo-wetgeving 307,313

rechter-commissaris $1,15,27-30,218,236$, $258,266,331,333$

rechtsbescherming $4,5,7,16,20,21,77$, $81,84,114,134,140,141,153,154$, $160,183,271,279,292,297,320$, $326,327,371$

rechtsbijstand $53,54,83,91,132,294,335$ rechtsgelijkheid $87,88,398$ rechtsgevolgen $5,29,60,62,63,65,166$, $217,247,305,332,393$

rechtshandhaving $5,119,121,148,185$, $245,252,253,300$

rechtsingang 14,268

rechtsmiddelen $26,175,306,323,380,397$

rechisongelijkheid $5,36,46,76,77,107$, 347

rechtsstuat $130,140,141,252,253,261$, 264,265

rechtszekerheid $5,62,63,65,216,217$, $280,281,311,317-320,328,344$, $345,347,348,364,365,368$

rechtszekerheidsbeginsel $265,305,306$, 357

reclassering $48,56,57,198,199,201,204$ redelijke belangenafweging 267,268 
redelijke termijn $24-26,60,70,129,147$,

$175,220,317,329,364,367-369$

reformatio in peius $141,151,159,327$

retributicve sanctie 182

richtlijnen $6,15,37,46,76,85-88,94,102$, $145,155,222,245,270,287,307$, $340,345,354,355,354,355,354$, $356-358,361,362,375$

Rijksdienst voor het Wegverkeer 94, 167, 169

sanctie $3-6,28,32,33,55,57,58,63,82$, $96,98,104,105,109,114-116,119$, $121,122,127-129,136-138,141$, 142 . 151, 154-156, 158-160, $162-172,175,178,179,180-183$, $187,189,190,192,193,197,199$, $206,207,222,268,269,287,289$, 295, 298, 299, 303, 304, 315, 331, $333,339-341,367,378,380,383$

schadebriefje 56,57

schadevergoeding $57,80,87,100,221-223$, 302

schenkingsrechten 145

schikking $68,78,83,84,89,119,151,210$, 359,371

schikkingsvoorstel $84,108-110,371$

schorsende werking $120,178,320,398$, 399

schriftelijkhcid 174, 280, 281, 334, 378

sepot $2-4,8,11,12,15,17,21-24,33-36$,

$38,41,44-61,63-65,74,88,91$, 113, 196, 198-200, 202-205, 207, $208,210,212,214,215,218,254$, $281,284,285,334,335,339$, $343-350,352,364,365,368-372$, $376,391-394,396$

beleidssepot $2,11,12,17,34,43$, $47,345,352,365$

formeel sepot $11,60,334,344$, 345,349

haalbaarheidssepot 11

informeel sepot $24,33,47,49$, $60,63,215,344-346$, 368,369

onvoorwaardelijk scpot $3,12,15$, $36,49,52,58,63$, $200,202,203,334$, $335,345,376$ politiesepot $8,12,37-47,52,62$, 351,352

technisch sepot $2,11,17,33,54$, $91,218,345,371$

voorwaardelijk sepot $3,4,8,12$, 21-23, 47-56, 58, 59, $63,113,196$, 198-200, 203, 204, $205,210,285,334$, $339,346-349,364$, $369,370,372$, $391-394,396$

sepotbeleid $34,46,88$

sepotbesluit 8,367

sepotgronden $17,34,35,45,46$

sepotmededeling $16,24,33,47,60-62,65$, $215,347,349-353,368$

slachtoffer $12,17,23,55,64,98,221-223$, $336,342,395$

sociaalrechtelijke boete 5

specialiteitsbeginsel 297

staande magistratuur 20, 225, 232, 233, 241,243

straf $1,3,8,27,49,58,63,67-73,79,92$, $101,112-114,116,117,124,127$, $128,132,178-182,185,187,192$, 195-200, 202-206, 2(18-211, 213, $216,219,222,266,268,269,279$. $284,298,314,338-341,355,367$, $373,388,394,397$

strafbaarstelling 6, 185-188

Strafbefehl $109,112,113$

strafbevel 108, 111, 112

straftoemetingsbeleid $76,83,340$

strafvervolging $14,18,19,24-26,40,57$, $62,69-72,77,82,87,92,96,106$, $108,110,118,119,127,128,140$, $146,147,151,198,199,232,239$, $248,273,285,286-288,338,348$, $350,355,367,374,389,393$

strafvordering $1,2,8,11,13-16,18,22$, $28-30,41,48,52,54-56,59,63,68$, $69,71,72,75,78,82,93,97,106$, $107,115,116,179,213,217,237$, $238,257,261,266,270,271,276$, $283,329-331,337,349,354,356$, $368,373,384,392,393$

submissic $67-69,75,79,393$ subsidiariteitsbeginsel $52,186,1 \mathrm{kx}$ successie 145 
Termijnenwet $28,30,33,346,365$

toetsing $6,62,77,106,113,119,124,131$, $140,162,164,173,174,179,192$, $235,237,255,257,279,280,284$, $288,289,295,297,298,301,302$, $323,325,327,329-331,333,338$, $342,343,348,357-362,369,376$, 377,379

toezegging $61,62,116,168,216,220,307$, $311,312,349-351,367$

toezending $33,138,168,305,323,346$, 388,390

toczicht $15,47,73,93,99,100,125,126$, $130,141,173,178,179,200.225$, $265,266,273,288,317$

transacticbeleid $75,85,89$

transactiebesluit $3.32,339,341,345,362$ $369,370,372,374,370,398$

transactierichtlijnen $21,86,270,362$

triasverdeling 1

uitreiking $33,305,323,346,388,390$

uitstel $26,90,119,122,146,199-203,205$, $236,323,364,381$

unificatie $7,9,172,325$

uniformiteit $34,41,105,317,355,356$

vennootschapsbelasting 145

verbalisering 38

verbeurdverklaring $68-70,72,80,109,113$, $114,116,126,281,390$

verbod van détournement de pouvoir 291, $295,297,338,348$

verbod van willekeur $267,291,295$, 299-302, 309, 314, 341-343, 345, $354,356,361,384$

verdenking $24,32,33,68,130,132,240$, $335,344,347,353,367-369,388$, 389

verdere vervolging $2,8,11,15,18,27$, $31-34,50,60,62-64,84,86,199$, $202,214,239,261,344,346,347$, $349,351,365,366,370,388,389$, 391,392

verduistering 45

vereenvoudigde afdoening $5,105,117$, $118,120,126,129,131,372,377$

vereenvoudigde behandeling 327

vereenvoudiging $8,44,70-73,105,106$, $111,112,117,121,205$

vergiijpboete 150 verhaal $104,107,110,111,122,126,135$, $139,141-143,152,153,157,166$, $170,171,190,371$

verhoor $134,256-258,363$

verkeersovertredingen $6,7,92,94,95,102$, $103,105,107,111,113-116,118$, $119,121,122,126,129,131,133$, $135,136,139,142-144,158,160$, $176,184,189,270,271,287,288$, $334,376,381,383$

verkeersvoorschriften $6,8,95,103$, 119-121, 126, 131, 136, 143, 148, $155,171,172,173,174,176,187$, $188,288,315,325,376,377,382$

vermogensbelasting 145

vernieling $44-46,86,95,98$

vernietiging $113,156,175,320,325,328$, 380,383

versnelde procedure 327

verstek $103,113,121,193,218$

verloogschrift 138

vertrouwensbeginsel $24,61-63,86,101$, $217,220,306,307,309-313,343$, $345,347,348,349,353-356,361$, 384

vervangende hechtenis $107-110,116-118$, $122,141,167$

vervolging $1-4,7,8,11-24,26,27,31-37$, $45,47-50,52-54,57-65,67-69,71$, $73,77,78,84,86,92,101,111$, $113,122,127,128,195,199,202$, $212-217,219,220,225,227,229$, $232,238,239,243,247,250,255$, $257,259,261,263,264,270,271$, $283,284,330,332,333,337,338$, $342,344-347,349-351,353,354$, $355,354-357,359-362,365-368$, $370,374,376,384,385,388-390$, 391-393, 397

vervolgingsbeleid $6,15,36-38,85,107$, $179,210,235,237,247,250,252$ $261,330,331,333,343-345,351$, 362,427

vervolgingsbeslissing $9,10,15,17,19$, $22-24,27,30-33,39,48-50,57,58$, $92,101,102,200,203,210,234$, $249,256,260,264,266,268,271$, $293,315,331,333,335,338$, $342-345,347,353,357,359-362$, $364-367,369,384,391,393$ 
vervolgingsmonopolie $11,15,23,249,264$, 341

vervolgingsrecht $11,12,14-16,36,37,47$, $107,264,265$

verzet $86,112,113,118,139,157,159$, $167-171,178,280,320,323$

verzetschrift 171,177

verzuimboete 150

voeging ter berechting 211

voorbereidingsprocedure 293, 304, 363, 374

voorlopige hechtenis $11,15,23,24,30,32$, $33,48,50,51,53,101,117,195$, $204,220,281,335,365-368,389$, 391,393

voorondcrzock $1,2,11,15,18,23-25$, 27-33, 48-51, 53, 220, 238, 239, $271,281,327,335,337,338$, $363-368,383,388,389,391-393$

voorwaardelijke veroordeling $49,55,56$, $196,197,200,203-205$

vormvoorschriften 29

vrijhcidsstraf $57,74,81,83,89,109,128$, 195-197, 199, 200, 202, 205, 207-209, 220, 341

waarborgfunctie 1 waarhcidsvinding 1

waarschuwing $12,23,39,57,58,110.113$. 141

werkdruk $2,38,268,376$

werkvourwaarde $1 \% 6,197$

Wet Vermogenssanctics $53,58,59,78-80$, $82,85,89,270$

wcttclijke regcling $5,10,15,24,42,43,47$, $49,57,62-64,74,78,81,1108,118$, $119,120,132,208,210,214,217$, $228,269,287,207,317,318,348$. $355,365,372,3 \times 4,392-394$

willekeur $11,16,36,54,61,68,72,92$, 267, 291, 295, 299-302, 309, 314 . $341,342,343,345,350,353,354$, $356,361,384,395$

winkeldiefstal $46,86,95,97,99$

zekerheidstclling $123,132,135,137,138$, $140,141,144,158-163,165,172$, $176,177,178,191,192,318,382$, 399

zorgvuldige belangenafweging 338

zorguldighcidsheginscl 291,2$) 5,2 \%, 299$, $302,336,338$

zwaarwichtiger belangen $23,61,215,350$ 



\section{Curriculum Vitae}

G.J.M. van den Biggelaar werd op 30 januari 1960 geboren te Helmond. In 1978 behaalde zij het V.W.O.-diploma aan het Dr. Knippenbergcollege te Helmond. Het doctoraal examen Nederlands recht behaalde zij in 1985 aan de Katholieke Universiteit Brabant, waarna zij tot 1991 werkzaam was bij de vakgroep Strafrecht en Criminologie van de Rijksuniversiteit Limburg. 
Een groot deel van alle opgespoorde strafbare feiten wordt door het openbaar ministerie zelfstandig afgedaan.

In het eerste deel van dit boek beschrifft de auteur de verschillende methoden die het openbaar ministerie kan hanteren voor de afdoening buiten het geding. waarbij veel aandacht wordt geschonken aan het sepot en de transactie.

Een belangrijke plaats wordt ingeruimd voor de administratiefrechtelijke handhaving van verkeersvoorschriften, waarbij de officier van justitie een rol speelt als orgaan voor administratief beroep.

$\mathrm{Na}$ de beschrijving van de methoden van buitengerechtelijke afdoening constateert de auteur dat de wettelijke normering ervan op sommige punten tekortschiet of ontbreekt. Ter verbetering van deze normering zoekt zij, vanwege een zestal redenen, aansluiting bij het bestuursrecht. De centrale vraag hierbij is of het besluit van het openbaar ministerie tot buitengerechtelijke afdoening beschouwd kan worden als een bestuursbesluit in de zin van de Algemene wet bestuursrecht. Positieve beantwoording van deze vraag heeft als consequentie dat de uitsluiting die de Awb momenteel in art. 1:6 maakt ten aanzien van de vervolging van strafbare feiten voor besluiten tot buitengerechtelijke afdoening zal dienen te vervallen, met als gevolg dat de bestuursrechtelijke bepalingen van de Awb ook voor de buitengerechtelijke afdoening zullen gelden.

Door de buitengerechtelijke afdoening te plaatsen in bestuursrechtelijk perspectief wordt aangehaakt bij het actuele vraagstuk van sanctionering in het bestuursrecht, met name de administratieve boete. 